PP-1 is

\section{0 歳以上の弁膜症手術の適応}

北里大学 心臓血管外科

$\begin{array}{ccccc}\text { 入澤 } & \text { 友輔、北村 } & \text { 律、林 } & \text { 秀憲、 } \\ \text { 友保 } & \text { 貴博、華山 } & \text { 直二、井上 } & \text { 崇道、 } \\ \text { 柴田 } & \text { 深雪、岡 } & \text { 徳彦、鳥井 } & \text { 晋三、 } \\ \text { 宮地 } & \text { 鑑 } & & & \end{array}$

【目的】近年、高齢化社会に伴い 80 歳以上の高齢者の 弁膜症患者に出会う機会は少なくない。特に基礎疾 患を多く抱えた患者では手術を無事に終えることが できても、術後に ADL 低下をきたす例も多く認めら れる。【目的】Japan SCOREをもとに、高齢者の弁膜 症患者における手術の危険性と有益性の検討を retrospectiveに施行した。【対象と方法】1971年から 2012 年 7 月の間に当科で行われた成人弁膜症手術 1006 例のうち、80 歳以上の 29 症例を対象とした。 男性 8 例、女性 21 例で、平均年齢は 83.1 \pm 3.1 歳 (80-91 歳)であった。手術術式の内訳は AVR 単独：18 例、 $\mathrm{AVR}+\mathrm{CABG}: 6$ 例、MVR/MVP $\pm \mathrm{TAP}: 4$ 例、 DVR+TAP : 1 例であった。各症例の Japan SCORE を計算し、手術成績 - 合併症、術前後の NYHA 及び ADL、及び遠隔成績を検討した。【結果】全 29 症例の Japan SCORE の予測 30 日死亡率の平均值は $6.5 \pm$ $5.7 \% 、 30$ 日死亡率 + 合併症発生率は $22.3 \pm 9.4 \%$ で あった。実際の 30 日死亡率は 1 例 (3.4\%) で、Japan SCOREよりも低かった。また合併症は 3 例 (10.3\%) に認め、創感染 : 1 例、透析導入 $: 1$ 例、肺胞出血： 1 例で、脳血管障害は認めなかった。術後観察期間 は平均 3.1 年(24 日 -8.4 年) で、Kaplan-Meier 法によ る累積生存率は1、3、5 年でそれぞれ $96.6 \%$ 、 90.1\%、83.2\%であった。術前の NYHA は平均 3 で あったが、術後は 2 と改善を認めていた。また術前 に歩行補助器具を使用していた 7 症例を含む全 29 例 中、術前と同等の ADL を達成できなかった症例は 3 例 $(10.3 \%)$ のみでった。【結語】当科における 80 歳 以上の弁膜症手術の成績はほぼ満足できるもので、 30 日死亡率はJapan SCOREによる予測值を下回っ ていた。周術期に脳神経系合併症はなく、遠隔成績 も良好であった。手術によるADLの低下も少なく、 特に術前の歩行能力の良好な症例では、術後 ADL が低下する可能性は低いことが示された。年齢が 80 歳以上であることは弁膜症手術の適応を考慮する上 で、問題とはならないものと考える。

\section{PP-2 2 \\ 80 才以上の弁膜症手術の検討}

\section{久留米大学病院 外科}

\author{
有永 康一、友枝博、赤須 晃治、 \\ 小須賀智一、飛永覚、税所 宏幸、 \\ 平田雄一郎、和田久美子、高木 数実、 \\ 古野 哲慎、明石 英俊、田中 啓之
}

【目的】今回、 80 才以上の弁膜症の開心術症例につい て、80才未満の症例と比較し、高齢者における開心 術の問題点について検討を行った。【対象と方法】 2009 年 1 月より 2012 年 3 月までに当科で行った弁膜 症手術 284 例を対象とした。主な術式は AVR144 例、 AVR+MVP23 例、MVP76 例、MVR32 例、DVR6 例、 その他 3 例で同時 CABG 施行例は 33 例であった。 今回大動脈基部置換術や大血管合併手術は除外した。 これらの症例を 80 才以上の群 (O 群 : 38 例) と未満の 群(Y 群 : 246 例)に分けて以下の項目について比較検 討した。術前状態 (性別、BMI、BMI18 以下、喫煙、 DM、HL、COPD、CVA、eGFR、CKD3 以上、心機 能、収縮期、PA 圧、ショックの有無、緊急手術の有 無など)、術中因子(術式、人工心肺時間、大動脈遮 断時間、最低直腸温、手術時間、輸血など)、術後因 子 (人工呼吸器時間、 72 時間以上長期人工呼吸器、 ICU 滞在期間、7 日間以上の長期滞在、再挿管、病 院死亡、脳合併症、再開胸、心房細動) とした。【結果】 80 才以上症例は 38 例で全体の $13.4 \%$ であった。術前 因子は $\mathrm{BMI}(\mathrm{O}$ 群 21.3、Y 群 22.4)、BMI18 以下 $(\mathrm{O}$ 群 6 例 /Y 群 18 例)、sPA (P 群 $29.4 \mathrm{mmHg} 、 \mathrm{Y}$ 群 $34.2 \mathrm{mmHg}$ )、EF (O 群 $60.4 \% 、 \mathrm{Y}$ 群 $61.3 \%$ )、緊急手 術 $(\mathrm{O}$ 群 2 例、 $\mathrm{N}$ 群 16 例)、その他、術前ショック、 NYHA3 以上、性別、COPD、DM、HL、契煙など に有意差は認めなかった。有意差を認めた術前因子 は eGFR (O 群 54.0、Y 群 64.5)、CKD3 以上 $(\mathrm{O}$ 群 23 例、Y 群 90 例) であった。術中因子は手術時間 $(\mathrm{O}$ 群 323、N 群 347)、術式や CABG 合併手術に有意差は 認めなかったが、大動脈遮断時間 $(\mathrm{O}$ 群 118 分、 $\mathrm{Y}$ 群 135 分)、人工心肺時間 (O 群 152 分、 $\mathrm{Y}$ 群 176 分)、 輸血(O 群 32 例、Y 群 138 例) に有意差を認めた。術 後因子は人工呼吸器装着時間 $(\mathrm{O}$ 群 31.6 時間、Y 群 31.5 時間)、 ICU 滞在期間 (O 群 3.8 日、Y 群 4.5 日)、 長期呼吸器管理 (O 群 1 例、Y 群 14 例)、長期 ICU 滞在 $(\mathrm{O}$ 群 3 例、 $\mathrm{Y}$ 群 18 例)、再扦管 $(\mathrm{O}$ 群 3 例、 $\mathrm{Y}$ 群 6 例) 有意差は認めなかった。術後合併症は $(\mathrm{O}$ 群 12 例、Y 群 79 例) で脳合併症、術後出血、術後 $\mathrm{AF}$ 等に有意差は認めなかった。病院死亡は 6 例 $(2.1 \%)$ で $(\mathrm{O}$ 群 1 例、 $\mathrm{Y}$ 群 5 例 $)$ と有意差は認めなかった。 【結語】今回の検討では 80 才以上の高齢者について周 術期の経過と急性期成績に関しては 80 才未満の症例 と同等の結果であった。 


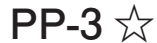 \\ 超高齢者(80 歳以上)の大動脈弁狭窄症に対 する弁置換術の予後規定因子についての検 討}

\author{
独立行政法人 国立病院機構 呉医療センター心 \\ 臓血管外科
}

関谷 直純、中里 太郎、仲村 輝也

【目的】超高齢者は年々増加の傾向にあり、心臓血管 外科手術をうける患者の高齢化はいまだ持続してい る。当院における高齢化は特に顕著であり、超高齢 者に対する手術適応をより明確にする必要性がある と考えられる。今回、最近 8 年間に経験した大動脈 弁狭窄症 $(\mathrm{AS})$ 症例の手術成績を、80 歳以上の高龃群 (O 群) と 80 歳未満の非高齢群(Y 群)の 2 群に分けて 比較検討した。【対象】対象は 2004 年 1 月から 2012 年 7 月までに AS に対して大動脈弁置換術 (AVR)を 施行した 116 例(男 43 例、女 73 例)。O 群は 48 例 (41.4\%) で平均 $83.6 \pm 3.2$ 歳。Y 群は 68 例 (58.6\%) で 平均 $70.6 \pm 7.9$ 歳。全体での Isolated AVR は 59 例 (50.9\%)であり、術後平均観察期間は 36 ヶ月 (0-100 ヶ 月)であった。【結果】両群間 (O 群 vs Y 群)の比較で、 術前 NYHA (2.6 \pm 0.7 vs $2.4 \pm 0.6 、 \mathrm{P}=0.001)$ は有意に O 群が高值であったが、弁口面積 $(0.62 \pm 0.23$ vs 0.67 $\left.\pm 0.27 \mathrm{~cm}^{2}\right)$ 、圧較差 $(87.9 \pm 40.0$ vs $79.1 \pm 31.4 \mathrm{mmHg})$ 、 体外循環時間 $(145 \pm 37$ vs $147 \pm 44 \mathrm{~min})$ 、大動脈遮 断時間 $(113 \pm 28$ vs $117 \pm 32 \mathrm{~min}$ )、術後在院日数 (24.5 \pm 17.3 vs $22.0 \pm 12.6$ 日)において有意差を認めなかっ た。また、心臓超音波検査での術前 $\operatorname{LVEF}(63.5 \pm 12$ vs $67.2 \pm 8.0 、 \mathrm{P}=0.05)$ は Y 群が高值の傾向にあり、術 前 $\operatorname{LVMI}\left(177 \pm 50\right.$ vs $\left.151 \pm 50 \mathrm{~g} / \mathrm{m}^{2} 、 \mathrm{P}=0.01\right)$ は O 群 が有意に高值であったが、術後 LVMI $(135 \pm 34$ vs $\left.124 \pm 28 \mathrm{~g} / \mathrm{m}^{2} 、 \mathrm{P}=0.07\right)$ では有意差を認めなかった。 観察期間内中の死亡は $\mathrm{O}$ 群 9 例 (18.8\%)、Y 群 11 例 (16.2\%) で Kaplan-Meier 法を用いた 3 年生存率は O 群 $83.5 \%$ 、Y 群 $85.5 \%$ 、5 年生存率は O 群 $64.0 \% 、 Y$ 群 $80.3 \%$ で 2 群間に有意差を認めなかった。次に比 例ハザードモデルを用いてＯ群単独における予後因 子について単変量解析を行ったところ、術後エコー での経大動脈弁最大血流速度值 (peak V、m/sec) が リスク因子 $(\mathrm{P}=0.04 、 H R$ 4.99) であった。さらに術前 LVDd、Ds、体外循環時間、大動脈遮断時間を加え て多変量解析を行ったが、術前および術中での因子 について有意差はなく、術後 peak V のみが唯一の予 後規定因子であった。【結語】超高齢者 AS に対する AVR では、80歳未満に比して術前の症状、心筋肥 大は重度であったが、術中因子、手術成績では有意 差を認めなかった。また、術前での子後因子の同定 は困難であったが、術後の圧較差を少しでも軽減さ せることが予後改善のための方法であることが示唆 された。

\section{PP-4 尔 \\ 80 歳以上の超高齢者大動脈弁狭窄症に対す る大動脈弁置換術の検討}

\section{島根大学 心臓血管外科}

\author{
花田 智樹、横山 真雄、金築 一摩、 \\ 清水 弘治、今井 健介、未廣 章一、 \\ 織田 禎二
}

【背景】近年高齢化の進展に伴い、超高齢者に対する 心臓手術が増加傾向にある。本県は全国でも $1 、 2$ を 争う高齢県であり、特に高齢者の大動脈弁狭窄症は 増加傾向にある。今回当院における超高齢者 $(80$ 歳以 上) 大動脈弁狭窄症に対する大動脈弁置換術について 検討した。【対象と方法】2006 年 12 月から 2012 年 6 月の間に大動脈弁狭窄症に対して大動脈弁置換術を 行なった 94 例を対象とし、これを 80 歳以上の $\mathrm{O}$ 群 45 例 (80 歳〜 90 歳: 平均 84.0 歳、男 18 例、女 27 例)、 80 歳未満の $Y$ 群 49 例 (41 歳〜 79 歳: 平均 71.6 歳、 男 27 例、女 22 例) に分けて比較検討した。【結果】手 術症例数に対する $\mathrm{O}$ 群の割合は 2007 年に $18 \%$ で あったが、以後 38\%、44\%、53\%、55\%、と増加し、 2012 年は $80 \%$ が 80 歳以上であった。同時に行った 手術では O 群で CABG: 12 例、MVR: 3 例、TAP: 3 例など、Y 群では Maze: 7 例、CABG: 6 例、MVR: 5 例、TAP: 5 例、上行大動脈置換: 5 例などであり、 $\mathrm{O}$ 群では CABG の同時手術が多かった。上行大動脈 高度石灰化例 (O 群 1 例、Y 群 2 例) では低体温循環 停止下に大動脈を切開し、直視下に大動脈を遮断し た。両群とも弁輪拡大を行った症例はなく、O 群で は生体弁を 38 例、機械弁を 7 例に使用した。在院死 亡は $\mathrm{O}$ 群 4 例 : 8.9\% (肺炎、PVE、敗血症、MOF)、 Y 群 2 例 : 4.1\%(縦隔炎、PMI)であり、Japan Score による予測值 (O 群 : 6.8\%、Y 群 : 4.5\%) に近い值で あった。主要合併症 (再手術 (再開胸)、透析 $(\mathrm{CHDF}) 、$ 縦隔炎、脳梗塞、長期人工呼吸 (24h 以上))の発生率 は O 群 $42 \% 、 Y$ 群 $20 \%$ で、有意 $(\mathrm{P}=0.02)$ に 群で 高率であり、再手術、透析、長期人工呼吸で $\mathrm{O}$ 群が 高かった。遠隔期死亡は $\mathrm{O}$ 群 4 例 (癌 2 例、突然死 1 例、不明 1 例)、Y 群 2 例 (肺炎 1 例、不明 1 例) で、 耐術例の生存率(Kaplan-Meier 法) は O 群で 3 年 $85 \% 、 5$ 年 $57 \% 、 \mathrm{Y}$ 群で 3 年 $95 \% 、 5$ 年 $87 \%$ であり、 両群とも生命表から求めた期待生存率 $(\mathrm{O}$ 群 : 3 年 $80 \% 、 5$ 年 $65 \% 、 \mathrm{Y}$ 群 : 3 年 $95 \% 、 5$ 年 $90 \%)$ と概ね 一致した。【結語】超高歯者では CABG 合併手術が多 かった。また、周術期合併症の頻度が高く、慎重な 術後管理が必要である。耐術例の予後は良好であり、 超高齢者の大動脈弁狭窄症に対する積極的な外科治 療は妥当であると考えられた。 
PP -5 尔

\section{高齢者 (80 歳以上) 大動脈弁狭窄症のリスク 評価と手術成績}

\author{
東京慈恵会医科大学 心臓外科 \\ 坂本 吉正、儀武 路雄、松村 洋高、 \\ 木ノ内勝士、成瀬瞳、中尾 充貴、 \\ 橋本 和弘
}

【目的】高齢者重症大動脈弁膜症は増加傾向にあり外 科治療を施行しないと予後不良である。今回、80歳 以上の大動脈弁置換術 (AVR)のリスク評価の妥当性 と手術成績、治療戦略について考察した。【対象と方 法】対象 2002 年 1 月〜 2011 年 3 月に 80 歳以上の ASに対しAVRを含む手術を施行した 20 例(ASに 対してAVRを施行した症例全体の $12 \%$ )、年齢 82 $\pm 2(80$ ～87) 歳、男女比 $7: 13$ 、身長 $151 \pm 10 \mathrm{~cm}$ 、体 重 $52 \pm 12 \mathrm{Kg}$ 、BSA1.45 $\pm 0.18 \mathrm{~m}^{2}$ 。施行手術単独 AVR14 例、AVR+ 冠動脈バイパス術 4 例、その他 の同時手術は MVP 2 例、MVR、TAP が各 1 例。心 エコー検查 弁口面積 : $0.7 \pm 0.3 \mathrm{~cm}^{2} 、 \mathrm{LVEF}: 60 \pm$ 11\%、 $\mathrm{pPG} / \mathrm{mPG}: 98 \pm 26 / 59 \pm 16 \mathrm{mmHg}$ 。これら重症 AS に対し手術成績、予測死亡率(Japan score、logisticEuroSCORE、STS score)、遠隔成績を検討した。 【結果】手術及び術後経過冠動脈バイパス術をともな う緊急手術が 1 例、透析中の生体弁機能不全(術後 5 年目)に対する再手術 1 例を含み、手術時間は $333 \pm$ 88 分、大動脈遮断時間は $122 \pm 22$ 分、術後在院日数 は 30 $31(15$ ～154) 日。在院死亡は呼吸不全による 1 例 $(5.9 \%$ )、脳合併症はなかった。予測死亡率 Japan $\operatorname{score}(n=20) ; 5.6 \pm 4.7(1.6 \sim 15.6)$ \%、logistic EuroSCORE $(\mathrm{n}=20) ; 9.9 \pm 5.5(5 \sim 23) \%$ 、STS score $(\mathrm{n}=17) ; 5.8 \pm 3.9(3 \sim 20) \%$ 。人工弁選択 65 歳以上 は生体弁を第一選択とし、弁輪拡大は積極的に施行 せず狭小弁輪に対し小口径機械弁を選択する方針。 その結果、生体弁 15 例 (CEP5 例、CEPMagna2 例、 Mosaic4 例、Mosaic ultra 4 例)、機械弁 5 例 (SJMRegent2 例、CM1 例、ATSAP360 2 例)、サイズは $19 \pm 1 \mathrm{~mm}(16 \mathrm{~mm} 3$ 例、 $17 \mathrm{~mm} 2$ 例、 $19 \mathrm{~mm} 11$ 例、 $21 \mathrm{~mm} 4$ 例)。遠隔成績完全追跡率 $94.1 \%$ で、肺癌、 脳出血による遠隔死亡 2 例(10\%)。Kaplan-Meier 法 を用いた 5 年生存率は $77 \pm 15 \%$ 。現在、外来通院中 14 例 (70\%、平均 86 歳、最高齢は 94 歳)、訪問診療 1 例 (認知症)。心エコー検查 術後 2 年以上経過し た 5 例について LVEF : $72 \pm 11 \%$, pPG/mPG: $53 \pm$ $20 / 26 \pm 19 \mathrm{mmHg}$ 、EOAI : $0.88 \pm 0.35 \mathrm{~cm}^{2} / \mathrm{m}^{2}$ 。【結語】 機械弁使用症例が比較的多かったが現時点では外科 治療は良好な成績がえられている。High risk 症例は 現状では $10 \%$ 程度であるが、今後さらなる重症高齢 者が増加することが予想され年齢によらず統合的な 病態把握や早期診断にもとづいた待機手術が積極的 に選択できる環境を内科医とともに整備しておく必 要がある。

\section{PP-6 宛 \\ 超高齢者(80 歳以上)の大動脈弁狭窄症に対 する大動脈弁置換術の治療成績}

\section{山口大学 大学院器官病態外科学 心臓外科}

$\begin{array}{lrll}\text { 鈴木 } & \text { 亮、美甘 } & \text { 章仁、河村 } & \text { 大智、 } \\ \text { 田中 } & \text { 裕也、工藤 } & \text { 智明、藏澄 } & \text { 宏之、 } \\ \text { 高橋 } & \text { 雅弥、白澤 } & \text { 文吾、濱野 } & \text { 公一 }\end{array}$

【背景】社会の高齢化に伴い、80 歳以上の超高齢者に おける大動脈弁狭窄症 $(\mathrm{AS})$ 症例数は増加の一途をた どっている。一般的に高齢者に対する大動脈弁置換 術(AVR) は手術リスクが高くなるが、 activity of daily life(ADL)が保たれていれば積極的に外科的治 療が行われている。【目的】当院における超高齢者 AS に対する AVR の手術成績ならびに遠隔期成績を retrospective に検討すること。【対象と方法】対象は 2002 年 4 月〜 2012 年 3 月までの 10 年間で、大動脈 疾患合併例を除く $\mathrm{AS}$ 症例 159 例を対象とした。80 歳以上の 26 例 $(\mathrm{O}$ 群) と同時期に行なわれた 80 歳未 満の 133 例 (Y 群)を 2 群に分け比較検討した。評価 項目は合併症発生の有無を含めた手術成績、および 遠隔成績とした。合併症は日本心臓血管外科デー夕 ベースが定義している再手術、新規の透析、縦隔洞炎、 脳梗塞、長期挿管とした。【結果】平均年齢は $\mathrm{O}$ 群 $82.6 \pm 2.4$ 歳(80-88)、Y 群 $70.7 \pm 7.1$ 歳(41-79)、男女 比は O 群 7: 19、Y 群 51: 82 であった。日本心臓血管 外科データベースの Japan SCOREにおける予測手 術死亡率はO群 4.50\% (1.1-26.6)、Y 群 4.75\% (0.921.6)で、両群間に有意差を認めなかった $(\mathrm{p}=0.47)$ 。 併施手術を 57 例 $(35.8 \%$ ) に施行した。16例の透析患 者を含め慢性腎不全患者は 21 例 (13.2\%)であった。 再手術症例は 6 例で、AVR 術後が 1 例、僧帽弁置換 術後が 1 例、冠動脈バイパス術後が 4 例であった。 冠動脈バイパス術後 2 例および食道癌術後 1 例の石 灰化大動脈症例 3 例に対して apico-aortic valved conduit 行った。全症例 159 例中、在院死亡は Y 群の 1 例 $(0.6 \%)$ のみで、術後に間質性肺炎の急性増 悪により失った。術後入院期間は O 群 20.6 日、Y 群 23.2 日であった。合併症は $\mathrm{O}$ 群 2 例、Y 群 11 例に発 生し、再開胸 $(\mathrm{O}$ 群: 2 例、 $\mathrm{Y}$ 群: 4 例)、縦隔洞炎 $(\mathrm{O}$ 群 :

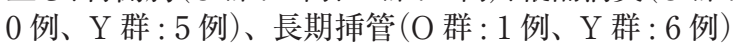
であった(重複例含む)。新規の透析、脳梗塞は両群 とも発生せず、合併症の全ての項目において発生率に 両群間で有意差を認めなかった。全症例の累積生存 率は 3 年 $92.8 \%$ 、 5 年 $88.3 \%$ で、O 群は 3 年 $95.5 \%$ 、 5 年 $83.5 \%$ 、Y 群は 3 年 $92.3 \% 、 5$ 年 $89.0 \%$ であった。 $\mathrm{O}$ 群の累積生存率は予測生存率 $(3$ 年 $83.7 \%$ 、 5 年 $69.8 \%$ ) と比較し、有意差を認めないものの良好であっ た $(\mathrm{p}=0.18)$ 。【結語】当院の超高齢者を含めた ASに 対する手術成績および遠隔成績は良好であった。現 在の成績であれば今後も ADL が保たれた超高齢者 の AS 症例に対して積極的に手術を考慮すべきであ ると考えられた。 
PP-7 $\downarrow$

85 歳以上の超々高齢者に対する大動脈弁置 換術の手術成績

高知大学 外科2

西森 秀明、山本 正樹、福冨 敬、

割石精一郎、木原 一樹、近藤 庸夫、

田代 未和、渡橋 和政

目的)いまや 80 歳代でも当たり前のように心臓手術 が行われているが、平均寿命を過ぎた 85 歳以上でも 行うかどうかについては議論もある。85 歳以上の大 動脈弁置換術 (AVR) 症例においてその手術成績を検 討することによりその正当性を検討した。対象と方 法) 2006 年 4 月から 2012 年 7 月までの間に 80 才以 上でAVRを行った症例は 37 例で、うち 12 例が 85 才以上であった。年令は $85 \sim 91$ 才(平均 86.8 才) で、 男性 7 例、女性 5 例であった。原疾患は AS が 11 例、 $\mathrm{AR}$ が 1 例であった。ユーロスコアは $2.63 \sim 37.83$ (中 央值 4.17) であった。全例で生体弁 (Mosaic)による AVRが行われた。人工弁サイズは $19 \mathrm{~mm}: 7$ 例、 $21 \mathrm{~mm}: 3$ 例、 $23 \mathrm{~mm}: 1$ 例、 $25 \mathrm{~mm}: 1$ 例であった。 3 例では $\mathrm{CABG}$ が同時に施行された。結果) 入院中死 亡例はなかった。術後合併症として再開胸 2 例、一 時的透析 1 例(術前 $\mathrm{Ccr} 11 \mathrm{ml} / \mathrm{min}$ の症例)、PAf 4 例を認めた。術後エコーによる $19 \mathrm{~mm}$ 弁の大動脈弁 流速はピークで $2.7 \sim 3.1 \mathrm{~m} / \mathrm{s}$ 、平均 $2.97 \mathrm{~m} / \mathrm{s}$ 、平均圧 較差は $17.5 \mathrm{mmHg}$ であった。術後入院日数は平均 29 日（長期入院となった 2 例を除く）で、2 例がリハビリ 目的で転院となった以外は全員自宅へ退院可能で あった。最長 5 年 5 ケ月のフォロー期間中に 1 例が 術後 1 年 10 ケ月めに死亡した以外は全例生存してお り、また自宅生活が可能であった。考察) ユーロスコ アをみると低〜中リスクの症例が手術適応と判断さ れていることが多く手術成績は良好であった。人工 弁は半数以上が $19 \mathrm{~mm}$ であったが左室 -大動脈間の 圧較差は許容範囲内であり日常生活への支障はない ものと思われた。結語) 85 歳以上でもAVRの手術成 績は良好であり、選ばれた患者に行うことは正当で ある。

\section{PP-8 2 s \\ 大動脈弁置換術における人工弁のサイズ選 択は術前心臓超音波検査で予測できるか?}

\section{滋賀医科大学 心臓血管外科}

$\begin{array}{llrr}\text { 早川 } & \text { 真人、木下 } & \text { 武、内藤 } & \text { 志歩、 } \\ \text { 高島 } & \text { 範之、畔柳 } & \text { 智司、乃田 } & \text { 浩光、 } \\ \text { 鈴木 } & \text { 友彰、浅井 } & \text { 徹 } & \end{array}$

【目的】大動脈弁狭窄症に対する大動脈弁置換術にお いて人工弁のサイズ選択は重要である。今回われわ れは術前の心臓超音波検査により選択すべきサイズ を予測できないかどうかを検討した。【対象、方法】 2011 年 1 月から 2011 年 12 月まで当院へ入院した大 動脈弁狭窄症患者のうち、生体弁を用いて大動脈弁 置換術を行った 60 例を対象とした。合併手術として は冠動脈バイパス術：18 例 (30.0\%)、上行置換術 : 7 例 (11.7\%)、僧帽弁形成術- 置換術： 5 例 (8.3\%)、三 尖弁形成術：4 例 (6.7\%)であった。術前に安静時経 胸壁的心臓超音波検査を行い、大動脈弁輪径、Valsalva 洞 径、Sino-tubular junction 径 (以下 ST junction 径)を計測し、これらの数值と実際に置換した生 体弁のサイズとの関係を統計学的に検討した。【結 果】平均年齢は $74.6 \pm 6.1$ 歳、女性が 21 例 (35.0\%)、 平均身長 : $157.4 \pm 8.7 \mathrm{~cm}$ 、平均体重 : $56.2 \pm 10.0 \mathrm{~kg}$ 、 平均体表面積 : $1.55 \pm 0.16 \mathrm{~m}^{2}$ であった。術前の心臓 超音波検查で得られた大動脈弁輪径、Valsalva 洞径、 ST junction 径の平均值はそれぞれ $20.7 \pm 2.8 \mathrm{~mm}$ 、 $32.0 \pm 4.3 \mathrm{~mm} 、 25.8 \pm 4.1 \mathrm{~mm}$ であった。術中に使用 した人工弁の平均サイズは $22.9 \pm 1.9 \mathrm{~mm}$ 、有効弁口 面積係数 (弁口面積 / 体表面積)の平均は $1.20 \pm 0.16$ $\mathrm{cm}^{2} / \mathrm{m}^{2}$ であった。使用した人工弁サイズを従属変数 として、年齢、身長、体重、大動脈弁輪径、Valsalva 洞径、ST junction 径を含んだ多変量線形回帰分析を 行ったところ、大動脈弁輪径においてのみ有意な正 の相関がみられた(標準化回帰係数：0.224(95\%信頼 区間 : $0.054-0.395) 、 p=0.011)$ 【結語】本研究より 大動脈弁置換術における人工弁サイズは術前の心臓 超音波検查により予測可能と考えられ、特に大動脈 弁輪径を知ることが重要である。術前の心臓超音波 検査にて大動脈弁輪径が $19.0 \mathrm{~mm}$ 以上の症例では全 例 $21 \mathrm{~mm}$ 以上の生体弁に置換することができている。 また大動脈弁輪径は独立した因子であり、術前に心 臓超音波で計測することが有用であると考えられる。 
PP-9 눈

CEP Magna 弁装着後実測有効弁口面積指 数の早期成績に及ぼす影響

\section{千葉大学医学部 心臓血管外科}

$\begin{array}{llr}\text { 石田 } & \text { 敬一、石坂 } & \text { 透、黄野 皓木、 } \\ \text { 田村 } & \text { 友作、渡邊 } & \text { 倫子、阿部真一郎、 } \\ \text { 焼田 康紀、若林 } & \text { 豊、松宮 護郎 }\end{array}$

【背景】CEP Magna 弁はカフが薄く外径に対してより 大きな $\mathrm{EOAi}$ が確保され PPM の回避に有用な弁で ある。術前予測 EOAi で PPM を避ける弁を選択した にもかかわらず、術後 UCG にて PPM を指摘される ことがある。今回 CEP Magna 弁における実測 EOAi による PPM の頻度および術後早期成績における心機 能への影響を検討した。【対象】2008 年 1 月から 2012 年 8 月までに当科で CEP Magna 弁を用いて AVR を 施行した症例 88 例中、術後 UCGにて EOAi を測定 し得た 76 例を対象とした。年齢は $72.3 \pm 8.4$ 歳。単独 AVR は 26 例で、合併手術は CABG：24 例、大動脈 手術 : 6 例、僧帽弁形成・置換 : 11 例、メイズ : 14 例。 AS : 50 例、ASR : 17 例、AR : 9 例。使用した弁の サイズは $19 \mathrm{~mm}: 41$ 例、 $21 \mathrm{~mm}: 25$ 例、 $23 \mathrm{~mm}: 9$ 例、 $25 \mathrm{~mm}$ : 1 例。PPM は術後 3 ヶ月以内の UCG にて連 続の式で評価し、 $\mathrm{EOAi}<0.85 \mathrm{~cm}^{2} / \mathrm{m}^{2}$ を $\mathrm{PPM}(+)$ とした。【結果】術前予測 EOAi では PPM となる症例

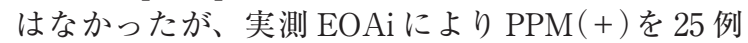
(33\%) に認め、mild $\operatorname{PPM}\left(0.75 \leqq<0.85 \mathrm{~cm}^{2} / \mathrm{m}^{2}\right)$ : 13 例、 moderate $\operatorname{PPM}\left(0.65 \leqq<0.75 \mathrm{~cm}^{2} / \mathrm{m}^{2}\right): 7$ 例、 severe $\operatorname{PPM}\left(<0.65 \mathrm{~cm}^{2} / \mathrm{m}^{2}\right): 5$ 例に認めた。Size 別では、19mm：14例(34\%)、21mm：9例(36\%)、 $23 \mathrm{~mm}: 2$ 例 $(22 \%) 、 25 \mathrm{~mm}: 0$ 例であった。PPM (+) 群は $\mathrm{PPM}(-)$ 群と比べ $\mathrm{BSA}(1.62 \pm 0.18$ vs $1.53 \pm 0.18$ $\left.\mathrm{m}^{2} 、 \mathrm{p}=0.06\right) 、 \operatorname{BMI}\left(24.1 \pm 4.0\right.$ vs $22.4 \pm 3.4 \mathrm{~kg} / \mathrm{m}^{2}$ 、 $\mathrm{p}=0.06)$ 、体重 $(61.5 \pm 12.4$ vs $54.8 \pm 11.2 \mathrm{~kg} 、 \mathrm{p}=0.02)$ が大きかった。術後の UCGで、mean APGに差は なく $(\operatorname{PPM}(+)$ 群 : $15.1 \pm 5.4$ vs $\operatorname{PPM}(-)$ 群 : $13.5 \pm 5.7$ mmHg、p $=0.25) 、$ mean $\mathrm{APG}>20 \mathrm{mmHg}$ を $\mathrm{PPM}(+)$ 群で $3 / 25$ 例 $(12 \%) 、 \operatorname{PPM}(-)$ 群で 6/45(13\%) と同 程度に認めた。LV mass indexは両群とも術後減少 していたが、群間での差は認めなかった(術前; PPM (+) 群 vs PPM ( - 群 : $144.2 \pm 56.0$ vs $153.8 \pm 52.9 \mathrm{~g} /$ $\mathrm{m}^{2} 、 \mathrm{p}=0.47$ 、術後; $120.9 \pm 58.3$ vs $123.8 \pm 41.0 \mathrm{~g} / \mathrm{m}^{2}$ 、 $\mathrm{p}=0.80)$ 。一方、 $\mathrm{EF}$ は術前後で群間に差を認めなかっ たが $\mathrm{PPM}(+)$ 群では EFが低下していた(術前; $\operatorname{PPM}(+)$ 群 vs $\operatorname{PPM}(-)$ 群 : $59.6 \pm 10.8$ vs $58.6 \pm$ $14.6 \% 、 \mathrm{p}=0.76$ 、術 後; $54.6 \pm 11.4$ vs $58.6 \pm 11.5 \%$ 、 $\mathrm{p}=0.17)$ 。【結語】CEP Magna 弁による AVRにおい て、術後早期の実測 EOAi 測定により $33 \%$ にPM を認めた。しかし両群間で術後 mean APGに差を認 めず LV mass regressionでも差を認めなかった。 $\operatorname{PPM}(+)$ 群では術後 EF が低下しており、遠隔期成 績への影響を検討する必要がある。

\section{PP-10 咨 \\ SJM Epic 弁による AVR の早期成績の検討}

\author{
独立行政法人国立病院機構災害医療センター 心臓 \\ 血管外科
}

\section{新野 哲也、宇野澤 聡、木村 玄}

【目的】高齢化社会に伴い生体弁の使用頻度も高く なっているが、狭小弁輪や大動脈基部の石灰化など により、人工弁の植え込みが困難な症例も少なくな い。SJM Epic 生体弁は 2011 年 5 月から日本でも臨 床使用が可能となった生体弁である。ブ夕心臓弁か ら作製されたステント付生体弁で、ステントエッジ にはウシ心膜をカバーすることで耐久性と植え込み 時の操作性の向上が期待されており、大動脈弁用と して Supra(Aortic) Model と Aortic Model がある。 今回、SJM Epic 弁を用いた AVR 症例の早期成績と 弁機能評価について検討した。【対象と方法】2011 年 6 月から大動脈弁位に SJM Epic 弁を用いた手術症例 17 例を対象とした。男性 6 例、女性 11 例、平均年 齢 77.1 $\pm 3.6(69$ 85) 才。術前診断は AS 7 例、ASR 4 例、AR 6 例であった。術前 BSA は $1.47 \pm 0.16$ であっ

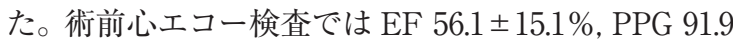
$\pm 27.6 \mathrm{mmHg}, \mathrm{MPG} 42.9 \pm 11.3 \mathrm{mmHg}$, Vmax $4.3 \pm$ $1.2 \mathrm{~m} / \mathrm{sec} 、$ EOA $0.7 \pm 0.3 \mathrm{~cm} 2$, LVDd $53.3 \pm 10.4 \mathrm{~mm}$ 、 LVDs $37.5 \pm 11.4 \mathrm{~mm}$ 、PWT $11.6 \pm 2.7 \mathrm{~mm}$ 、IVST $12.2 \pm 1.9 \mathrm{~mm}$ であった。術後 1 か月に経胸壁心エコー 検査による評価を行った。【結果】術式は単独の AVR 4 例、同時施行手術は大動脈基部パッチ拡大術 3 例、MVR 2 例、Bentall 2 例、CABG 5 例、TAP 5 例、再手術 1 例であった。使用した人工弁サイズは $19 \mathrm{~mm} 10$ 例、 $21 \mathrm{~mm} 4$ 例、 $23 \mathrm{~mm} 3$ 例であった。手 術時間 $284 \pm 70.4$ 分、ECCT $179.7 \pm 43.6$ 分、ACCT $105.5 \pm 23.9$ 分であった。病院死亡は 1 例で MRSA 敗 血症により失った。術後心エコー検査では EF 58.1 15.3\%、PPG 27.6 ะ7.2mmHg, MPG $13.2 \pm 3.6 \mathrm{mmHg}$ 、 Vmax $2.6 \pm 0.3 \mathrm{~m} / \mathrm{sec} 、$ EOA $1.27 \pm 0.16 \mathrm{~cm} 2 、 \mathrm{LVDd}$ $44.9 \pm 9.4 \mathrm{~mm}$ 、LVDs $31.3 \pm 11.0 \mathrm{~mm}$ 、PWT $11.5 \pm$ $2.3 \mathrm{~mm} 、$ IVST $10.8 \pm 2.4 \mathrm{~mm}$ であった。Perivalvular lekage と transvalv ular leakage はともに認めな かった。【結語】もっとも小さい $19 \mathrm{~mm}$ の使用が多 かったが、SJM Epic 弁による AVRの早期成績は満 足できるものであった。術中の操作性についても、 リンス時間が 1 回 10 秒を 2 回で完了するため、弁輪 への糸かけ後にサイズを決定してもストレスがない。 また、ロープロファイルデザインかつ弁葉のコアプ テーションポイントが低いため、植え込み時の操作 性も満足できるものであった。今後も症例を重称て 検討していきたい。 


\section{PP-11}

TrifectaTM の超急性期成績と有用性の検討

\section{埼玉医科大学国際医療センター 心臓血管外科}

$\begin{array}{lrr}\text { 道本 } & \text { 智、森田 } & \text { 耕三、小池 裕之、 } \\ \text { 神戸 } & \text { 将、高橋 } & \text { 研、池田 昌弘、 } \\ \text { 岡田 } & \text { 至弘、高澤 } & \text { 晃利、林 祐次郎、 } \\ \text { 井口 } & \text { 篤志、朝倉 } & \text { 利久、中嶋 博之、 } \\ \text { 上部 } & \text { 一彦、新浪 } & \text { 博 }\end{array}$

【背景】TrifectaTM(St Jude Medical)は本年 4 月に日 本に導入され、当科では導入当初から使用している。 前回われわれの検討では、圧較差 $(\mathrm{PG})$ 、有効弁口面 積 $(\mathrm{EOA})$ に関する超急性期成績は優れている可能性 が示唆された。今回は更なる検討と PG、EOA に関 して従来の生体弁と比較検討した。【対象と方法】 2012 年 4 月から当科で施行した AVR 症例のうち TrifectaTM を使用した 21 例(男 15 例、女 6 例) を対 象とした。平均年齢は $74.3 \pm 6.9$ 歳、体表面積は 1.51 $\pm 0.13 \mathrm{~m} 2$ であった。手術適応となった大動脈弁疾患 は AS 13 例、AR 8 例であり、使用した弁のサイズは $19 \mathrm{~mm} 6$ 例、 $21 \mathrm{~mm} 8$ 例、 $23 \mathrm{~mm} 7$ 例であった。合 併手術は MVR 2 例、MVP 5 例、CABG 2 例、TAP 3 例、MAZE 手術 4 例、myectomy (Morrow 手術) 2 例、VSD 閉鎖術 1 例であった。術後 7 日目に心臓超 音波検査を施行した。また、 $19 \mathrm{~mm}$ サイズで同一患者 背景の Perimount Magna (Carpentier Edwards)、Mosaic Ultra(Medtronic) とそれぞれ 2 群間比較検討し た。【結果】19 mm 使用例は peak PG 22.6 $\pm 7.9 \mathrm{mmHg}$ 、 mean PG $11.9 \pm 4.3 \mathrm{mmHg}$ 、EOA $1.48 \pm 0.25 \mathrm{~cm} 2$ 、 EOAI $1.01 \pm 0.18 \mathrm{~cm} 2 / \mathrm{m} 2 、 21 \mathrm{~mm}$ 使用例では peak PG $18.9 \pm 6.5 \mathrm{mmHg}$ 、mean PG $19.3 \pm 6.6 \mathrm{mmHg}$ 、 EOA $1.65 \pm 0.40 \mathrm{~cm} 2$ 、EOAI $1.12 \pm 0.26 \mathrm{~cm} 2 / \mathrm{m} 2 、 23$ $\mathrm{mm}$ 使用例では peak PG $15.8 \pm 5.6 \mathrm{mmHg}$ 、 mean PG $8.3 \pm 2.4 \mathrm{mmHg}$ 、EOA $2.22 \pm 0.65 \mathrm{~cm} 2$ 、EOAI $1.42 \pm$ $0.49 \mathrm{~cm} 2 / \mathrm{m} 2$ であった。2 21 例全例で EOAI $\geqq 0.85$ $\mathrm{cm} 2 / \mathrm{m} 2$ であり、 patient-prosthesis mismatch(PPM) を生じなかった。Magna 使用例では peak PG 31.0土 $6.4 \mathrm{mmHg}$ 、mean PG $17.2 \pm 3.0 \mathrm{mmHg}$ 、EOA $1.10 \pm 0.21$ $\mathrm{cm} 2 、$ EOAI $0.80 \pm 0.13 \mathrm{~cm} 2 / \mathrm{m} 2$ であり、TrifectaTM で $\mathrm{EOA}(\mathrm{p}=0.016)$ は有意に大きく、mean $\mathrm{PG}(\mathrm{p}=0.037)$ は有意に低かった。また、Mosaic 使用例では peak PG $37.6 \pm 10.1 \mathrm{mmHg}$ 、mean PG $18.8 \pm 7.9 \mathrm{mmHg}$ 、 EOA $1.18 \pm 0.28 \mathrm{~cm} 2$ 、EOAI $0.92 \pm 0.26 \mathrm{~cm} 2 / \mathrm{m} 2$ で あり、TrifectaTM で peak $\mathrm{PG}(\mathrm{p}=0.043)$ は有意に低 かった。考案】超急性期の TrifectaTM の成績は良 好で、従来の弁と比較しても有用である可能性が示 唆された。しかしながら症例数がまだ少なく、また 生体弁としては耐久性が大きな問題となるので、今 後もさらなる評価が必要と考える。
PP-12

AS に対する AVR における Trifecta valve の 術後早期弁機能

\author{
1明石医療センター 心臓血管外科 \\ 2高槻病院 心臓血管外科
}

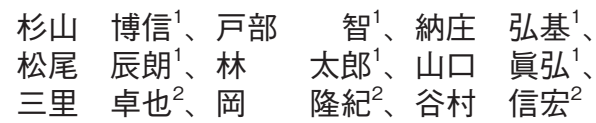

Background : Trifecta valve は他の valve に比べ有 効弁口面積が大きく低い圧較差が期待されている。 そのため当院での ASに対する AVRにおける Trifecta valve (T)、Carpentier Edwards Perimount valve $(\mathrm{C}) 、$ Mosaic valve $(\mathrm{M})$ の術後早期弁機能つい て比較検討した。Methods：2002 年 1 月から 2012 年 8 月までに当科で施行した ASに対する AVR137 例 (T：9例、C：33 例、M : 95 例)を対象とした。これ らの症例に対して術直後に経胸壁心エコーを施行し 弁機能を評価した。Results：患者の平均年齢は $\mathrm{T}$ ： $73.5 \pm 7.2$ 歳、 $\mathrm{C}: 74 \pm 6.8$ 歳、 $M: 77 \pm 6.7$ 歳で術前の 心エコーでは、最大大動脈弁圧較差( $\mathrm{T}: 74.5 \pm$ $26.9 \mathrm{mmHg} 、 \mathrm{C}: 87.9 \pm 30.5 \mathrm{mmHg} 、 \mathrm{M}: 78.4 \pm$ $27.3 \mathrm{mmHg})$ 、左室拡張末期径 $(\mathrm{T}: 45.9 \pm 5.5 \mathrm{~mm} 、 \mathrm{C}$ : $49.1 \pm 7.09 \mathrm{~mm} 、 \mathrm{M}: 46.8 \pm 6.51 \mathrm{~mm})$ 、左室心笳重量係 数 $(\mathrm{T}: 129.2 \pm 16.6 \mathrm{~g} / \mathrm{m} 2 、 \mathrm{C}: 157.7 \pm 45.5 \mathrm{~g} / \mathrm{m} 2 、 \mathrm{M}$ : $153.3 \pm 51.5 \mathrm{~g} / \mathrm{m} 2)$ 、左室駆出率 ( $\mathrm{T}: 71.5 \pm 8.0 \% 、 \mathrm{C}:$ $59.4 \pm 12.8 \% 、 \mathrm{M}: 63.2 \pm 14.5 \%)$ に有意差は無かった。 并口面積 $(\mathrm{T}: 0.97 \pm 0.12 \mathrm{~cm} 2 、 \mathrm{C}: 0.71 \pm 0.26 \mathrm{~cm} 2 、 \mathrm{M}$ : $0.7 \pm 0.2 \mathrm{~cm} 2(\mathrm{p}$ 值 $<0.01)$ に扔いては Trifecta が有意 に大きかった。術後の心エコーにおいては大動脈弁 圧較差 $(\mathrm{T}: 14.4 \pm 5.9 \mathrm{mmHg} 、 \mathrm{C}: 23.7 \pm 7.0 \mathrm{mmHg} 、 \mathrm{M}$ : $31.9 \pm 10.4 \mathrm{mmHg}(\mathrm{p}$ 值 $<0.000001))$ と弁口面積 $(\mathrm{T}: 2.1$ $\pm 0.4 \mathrm{~cm} 2 、 C: 1.52 \pm 0.33 \mathrm{~cm} 2 、 \mathrm{M}: 1.46 \pm 0.3 \mathrm{~cm} 2(\mathrm{p}$ 值 $<0.005)$ に拈いて Trifecta が有意に改善してい た。Conclusion：ASに対する生体弁での AVRにお いて Trifecta は弁口面積が大きく最大大動脈弁圧較 差も低い傾向にあるため有用であると考えられた。 
PP-13 文

PPM の有無が大動脈弃置換術後の左室収縮 能、拡張能に与える影響

\author{
和歌山県立医科大学 第一外科 \\ 本田賢太朗、岡村 吉隆、西村 好晴、 \\ 打田 俊司、湯崎充、國本 秀樹、 \\ 舩橋 亮輔
}

【はじめに】大動脈弁狭窄症 (AS) に対する大動脈弁置 換術 $(\mathrm{AVR})$ 後の左室収縮能に関する報告は多いが、 拡張能に関する報告は少ない。今回 Prosthesis-patient mismatch (PPM)の有無が AVR 後の左室収縮 能および拡張能に与える影響について検討を行った。 【対象および方法】2012 年 4 月までの 10 年間に ASに 対してAVRを施行した 233 例のうち、手術前後で 心機能の詳細が得られた 95 例を対象とした。95例 において使用した弁のサイズが $19 \mathrm{~mm}$ 以下の症例は 56 例 (59\%) で、機械弁の使用は 4 例だった。左室収 縮能の評価としては Ejection fraction $(\mathrm{EF})$ を、拡張 能の評価としては左室弛緩の指標である E’と、左室 充満圧の指標である $\mathrm{E} / \mathrm{E}$ をを、また Left ventricular mass index (LVMI)に関しても評価を行った。エコー 評価は術前、術後 1 週間、 3 力月、 6 か月、 1 年、 2 年の期間をおいて施行した。またPPM は Effective orifice area index $(\mathrm{EOAi})$ が $0.85 \mathrm{~cm} 2 / \mathrm{m} 2$ 未満と定義 し、これら 95 症例を $\mathrm{EOAi} \geqq 0.85$ の C 群 (75 例) と、 $\mathrm{EOAi}<0.85$ のP 群 $(20$ 例 $)$ に分け各項目について比 較検討を行った。平均年齢は C 群 75.3 歳、 $\mathrm{P}$ 群 76.5 歳で両群間に有意差は認めなかった。【結果】C 群で $\mathrm{EF} \%$ は(術前、術後 1 週間、6 月月、2 年)において (54.9、54.9、61.2、62.3) と徐々に改善を認め、P 群で も EF は (56.8、56.7、59.7、64.8) と改善を認めた。左 室弛緩の指標である E' は C 群で $4.3 、 5.9 、 5.5 、 7.0)$ と改善傾向を認め、P 群でも (4.4、5.3、6.5、6.7) と改 善傾向を認めた。左室充満圧の指標である $\mathrm{E} / \mathrm{E}$ ’ $\mathrm{C}$ 群で(21.9、16.8、19.0、13.8) と改善し、P群でも(18.7、 16.0、15.3、13.8) と改善傾向を認めた。Left ventricular mass index (LVMI g/m2) \& C 群(144.9、126.0、112.8、 105.8) と改善し、P群でも同様に(151.9、131.6、 121.6、106.7)改善を認めた。【まとめ】 PPM の有無 にかかわらず、左室収縮能はAVR 術後改善を認め た。拡張能の指標である E'、E/E’ や、LVMI も術後 2 年の follow で術前と比較して有意に改善を認めた。 PPM は左室収縮、拡張機能のいずれにも大きな影響 は与えないと考えられた。

\section{PP-14 高齢者の狭小大動脈弁輪に対する弁輪拡大 術}

立川綜合病院 心臓血管外科

$\begin{array}{llrl}\text { 岡本 } & \text { 祐樹、山本 } & \text { 和男、杉本 } & \text { 努、 } \\ \text { 若林 } & \text { 貴志、加藤 } & \text { 香、三村 慎也、 } \\ \text { 吉井 新平 } & & \end{array}$

【背景と目的】狭小大動脈弁輪に対する弁置換術後の Patient-Prosthesis Mismatch (PPM) は軽度・中等度 であれば手術・遠隔成績に影響を及ぼさないという 報告が散見され、特に高齢者では弁輪拡大を行わな い傾向にある。しかし $19 \mathrm{~mm}$ 生体弁の移植も困難な 症例が少なくないため、我々は必要があれば弁輪拡 大術を行うが、高齢者に対する手術・遠隔成績につ いての報告は非常に少ない。今回我々の手術成績を 検討し報告する。【対象と方法】2004 年 1 月から 2012 月 7 月までに、高齢者 (75 歳以上) に対し弁輪拡大を 行った大動脈弁置換術 (AVR) 24 例 (O 群)を検討。適 応は患者の全身状態・背景を考慮するが、最小サイ ズの機械弁や $19 \mathrm{~mm}$ 生体弁が移植不可である、生体 弁が有利な患者に適切なサイズが移植できない、移 植できるサイズでは高度 PPM が発生する場合など。 弁輪拡大は全例 Nicks 法(パッチには二重ウマまたは ウシ心膜を使用) を施行。男性 3 例、女性 21 例、平 均年齢 79.9 歳。8 0 歳以上の超高齢者は 15 例 $(63 \%)$ 。 術前心エコーでは平均 EF $62 \%$ 、左室 - 大動脈最大圧 較差平均 $94 \mathrm{mmHg}$ 。 $\mathrm{O}$ 群の手術・遠隔成績を検討し、 同時期に行った 75 歳未満で弁輪拡大を要した AVR15 例 (Y 群) と比較して、年齢が手術・遠隔成績 に影響を与えるか解析した。【結果】代用弁は機械弁 5 例 ( $16 \mathrm{~mm} 1$ 例、 $17 \mathrm{~mm} 2$ 例、 $18 \mathrm{~mm} 2$ 例)、生体弁 19 例 $(19 \mathrm{~mm} 12$ 例、 $21 \mathrm{~mm} 5$ 例、 $23 \mathrm{~mm} 2$ 例)。併施 手技は TAP3 例、CABG2 例、MAZE1 例、PVisolation3 例、上行置換 1 例。病院死亡は 1 例 (4\%)で、 術後 18 日目に敗血症で失った。術後早期合併症は一 過性心房細動 10 例、脳梗塞 1 例、縦隔炎 1 例、敗血 症 1 例。遠隔期平均観察期間は 35 ヶ月で、死亡 3 例 (心臓関連死なし)。弁輪拡大パッチ部位の瘤化は認 めず、1、3、5 年の心事故回避率は $95 \%$ 、95\%、 95\%であった。Y 群と比較して O 群は、糖尿病の既 往が少ないが $(\mathrm{p}=0.018)$ 、手術時間、入院期間、早期 死亡、術後合併症に差はなく、年齢(高齢)が早期・ 遠隔期の死亡、心事故の危険因子にならなかった。 また術後 PPM の存在が死亡、心事故発生の危険因 子とはならなかった。【結論】高齢者で弁輪拡大を 行ったAVRの手術・遠隔成績は良好であった。二 重ウマまたはウシ心膜は強度が十分でハンドリング も良く、比較的簡便に Nicks 法を行うことができる。 術後 PPM の存在が遠隔期に与える影響は大きくはな いが、弁輪拡大は高齢者でも過大侵襲とは言えず、 適応があれば考慮すべきである。 
PP-15 公

血液透析患者における大動脈弁手術におい て、透析期間は成績に影響を与えるか

\author{
名古屋第二赤十字病院 心臓血管外科 \\ 宗像 寿祥、田嶋 一喜、秋田 翔、 \\ 内田健一郎、日尾野 誠、藤井恵、 \\ 加藤 亙、高味 良行、酒井 喜正
}

【はじめに】血液透析患者の大動脈弁狭窄症は全身性 に生じた異所性血管石灰化の部分症候であり、大動 脈置換術患者は全身性に動脈硬化症が進行している 場合が多い。血液透析年数が ASに対するAVRに おいて短期成績に及ぼす影響を検討した。【方法】 2001 年から 2011 年にかけて当院で施行した血液透 析患者の大動脈弁狭窄症に対する大動脈弁置換術は 95 例であった。血液透析期間によって S 群 76 例 : 血液透析期間 19 年以下と L 群 17 例 : 血液透析期間 20 年以上と振り分け診療記録を元に retrospective に各群の術前因子、手術成績について比較検討した。 【結果】術前因子として糖尿病合併は S 群に多い傾向 があったが、有意差はみられなかった $(\mathrm{S}$ 群 : 21 例、 $\mathrm{L}$ 群 : 2 例、 $\mathrm{P}=0.17)$ 。手術成績 : 合併手術は $\mathrm{S}$ 群に て $\mathrm{CABG}(\mathrm{S}$ 群 : 30 例、 L 群 : 2 例、 $\mathrm{P}=0.03)$ が多かっ たが、僧帽弁手術 ( $\mathrm{S}$ 群 : 13 例、 L 群 : 3 例、 $\mathrm{P}=0.95$ )、 不整脈手術 $(\mathrm{S}$ 群 : 5 例、 $\mathrm{L}$ 群 : 2 例、 $\mathrm{P}=0.46)$ は同等 であった。手術死亡は 4 例 (S 群 : 4 例、L 群 : 0 例、 $\mathrm{P}=0.33)$ 。術後合併症は出血再開胸 5 例 $(\mathrm{S}$ 群 : 5 例、 $\mathrm{L}$ 群 : 0 例、 $\mathrm{P}=0.27$ )、脳梗塞 3 例 ( $\mathrm{S}$ 群 : 4 例、 $\mathrm{L}$ 群 : 0 例、 $\mathrm{P}=0.49$ )、長期人工呼吸器使用 ( $\mathrm{S}$ 群 : 4 例、 $\mathrm{L}$ 群 : 0 例、 $\mathrm{P}=0.58)$ であり両群の間に差は見られなかった。 遠隔期成績では 1 年生存率 $(\mathrm{S}$ 群 $87 \%$ 、 L 群 $88 \%$ 、 $z=0.014) 、 5$ 年生存率 $(S$ 群 $59 \% 、 \mathrm{~L}$ 群 $81 \% 、 z=1.718)$ にて有意差は見られなかったが L 群が生存率が高い 傾向にあった。心事故、再心臓手術、主要出血事故、 死亡をエンドポイントとした事故回避率は 1 年 $(\mathrm{S}$ 群 $79 \% 、 \mathrm{~L}$ 群 $81 \% 、 z=0.233) 、 5$ 年 $(\mathrm{S}$ 群 $38 \%$ 、L 群 $39 \% 、 Z=0.078)$ ともに差を認めなかった。【結論】20 年以上の血液透析歴を有する患者は血液透析歴が 20 年以下の患者と比べて早期・遠隔期成績ともに差が みられなかった。血液透析期間が長期であることは 手術成績に対して不利な影響を与えない。

\section{PP-16 的 \\ 透析患者の大動脈弁狭窄症に対する人工弁 置換術の検討}

\section{福山循環器病院 心臓血管外科}

\author{
平岡 俊文、向井 省吾、尾畑 昇悟、 \\ 森元 博信、打田 裕明、山根 吉貴
}

【目的】透析患者に対する生体弁の使用は構造的劣化 率が非常に高いとの理由で非有用とされている。し かし機械弁は脳梗塞などの血栓塞栓症や出血の合併 症が問題となり生体弁の使用を推奨する意見も多く、 人工弁選択に関して一定の見解が得られていないの が現状である。そこで当院で施行した透析患者の大 動脈弁狭窄症に対する人工弁選択の検討をした。【対 象と方法】2000 年 4 月から 2012 年 3 月までに当科で 透析患者の大動脈弁狭窄症に対して大動脈弁置換術 を施行した 23 例 $(72.4 \pm 7.8$ 歳)を対象とし、術後累積 生存率、術後弁関連イベント (心臓死、塞栓症、出血、 人工弁感染および劣化による再手術) 回避率を算出 し、機械弁と生体弁間で比較した。さらに術後定期 的に心エコー検査評価をし、最大圧較差 $(\mathrm{PG})$ 、左室 心筋重量径数 $(\mathrm{LVMI}) 、$ 左室駆出率 $(\mathrm{EF})$ に関して、 pre (術前) 、 post (術後 1 力月以内) 、 early (術後 1 年 以内)、 $\operatorname{mid}$ (術後 3 年以内) 、 long (術後 3 年以上) に 分けて評価した。手術術式は、単独 AVR10 例、複 合手術 13 例であった。機械弁は 7 例 (71.6 47.2 歳)、 生体弁は 16 例 $(72.8 \pm 8.3$ 歳)であった。【結果】術後累 積生存率は 1 年 $69.6 \% 、 2$ 年 $59.6 \% 、 4$ 年 $42.6 \%$ であっ た。機械弁 1 年 $57.1 \% 、 2$ 年 $42.9 \% 、 4$ 年 $28.6 \%$ 、生 体弁 1 年 $75.0 \% 、 2$ 年 $67.5 \% 、 4$ 年 $50.6 \%$ であり、両 者間で有意差は認めなかった。人工弁劣化による再 手術は認めなかったが、術後弁関連イベント回避率 は、 1 年 $76.7 \% 、 2$ 年 $76.7 \% 、 4$ 年 $54.8 \%$ であった。 機械弁 1 年 $51.4 \% 、 2$ 年 $51.4 \% 、 4$ 年 $34.3 \%$ 、生体弁 1 年 $87.5 \% 、 2$ 年 $87.5 \% 、 4$ 年 $65.6 \%$ であり、両者間 で有意差は認めなかった。心エコー検査の経時的評 価では、EFは著変を認めなかったが、PG と LVMI は改善傾向を示した。【結語】当院での透析患者の大 動脈弁狭窄症に対する人工弁選択に関して、累積生 存率、術後弁関連イベント回避率は両者間で有意差 は認めなかったが、生体弁使用例の PG と LVMI は 改善傾向を示しており、今のところ弁劣化の可能性 は少ないと考えられ、透析患者に生体弁の積極的な 使用は考慮され得ると考える。生存例の追跡期間が 短く、今後の調査が必要である。 


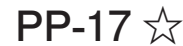

\section{慢性透析患者大動脈弁置換術における BNP の予後予測因子としての有用性の検討}

\author{
${ }^{1}$ 大阪大学 心臓血管外科 \\ ${ }^{2}$ OSCAR group \\ ${ }^{3}$ 大阪大学 低侵襲循環器医療学講座
}

\begin{tabular}{|c|c|c|c|c|c|}
\hline |木 & ${\mid \Phi^{1}}^{1}$ & 戸田 & 宏一 & 宮川 & \\
\hline 叀 & 宏之 1 & 吉川 & 泰司 ${ }^{1}$ & 福 & 五月 \\
\hline 谷口 & 和博 ${ }^{2}$ & 笱野 & 弘志 ${ }^{2}$ & 公江 & \\
\hline 18 & 高義 ${ }^{1}$ & & & & 芳樹 \\
\hline
\end{tabular}

[背景］脳性ナトリウム利尿性ペプチド (BNP) は左室 壁応力上昇に伴い主に心室から分泌され、心不全の 診断、予後判定などに有用である。しかし、そのク リアランスに腎機能が影響するため、慢性腎不全あ るいは慢性透析 (HD) 患者においては BNP 高值の解 釈を複雑にしている。近年の研究では透析患者にお いても左室肥大の程度、心機能の評価や心血管イベ ントの予測に BNP が有用とする報告があるが、心蔵 手術に関連した報告はない。今回、我々は HD 患者 大動脈弁置換術 (AVR)における BNP の有用性を検 討した。[対象と方法]対象は当院および 3 関連施設 にて術前にBNPを測定し、かつ AVRを施行された HD 患者 72 例 (2003-2011 年、年齢 $68.8 \pm 7.3$ 歳、男性 37 例 $(51 \%))$ 。大動脈弁の病変は AS 58 例、ASR14 例、CABG 併施 25 例。HD の原因は糖尿病性腎症 17 例。術前 EF63 $011 \%$ 、術前左室心筋重量係数 (LVMI、

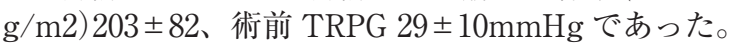
これらにおける BNP と心機能、左室肥大との相関関 係を調べ、かつ ROC 分析を行った。また、術後早期 成績と中期成績を求め、BNP が危険因子となりうる か多变量解析を行った。[結果]術前平均 BNP は 933 $\pm 1150 \mathrm{pg} / \mathrm{ml}$ であった。BNP との相関関係は $\mathrm{EF}$ $(\mathrm{r}=0.34 、 \mathrm{P}<0.01) 、 \mathrm{LVMI}(\mathrm{r}=0.24 、 \mathrm{P}<0.05)$ 、 TRPG ( $\mathrm{r}=0.28 、 \mathrm{P}<0.05)$ であった。BNP の ROC 解 析では、 $\mathrm{EF} 40 \%$ 未満 $(\mathrm{AUC}=0.74)$ 、高度左室肥大 $($ LVMI 男性 $>184$ 、女性 $>172)($ AUC $=0.80) 、 T R P G$ $>40$ 以上 $(\mathrm{AUC}=0.72)$ であった。病院死亡は 8 例 (11.1\%) であった。多変量解析の結果、末梢動脈疾患 の合併 $(\mathrm{OR}=31.7 、 \mathrm{P}<0.01) 、 \mathrm{BNP}(\mathrm{OR}=1.0008 、 \mathrm{P}<$ 0.05) が独立危険因子であった。弁関連死亡の中期成 績は 1 年 $88 \% 、 3$ 年 $86 \% 、 5$ 年 $66 \%$ であった。多変 量解析の結果、糖尿病性腎症 (HR4.7、P $<0.05)$ 、 $\operatorname{BNP}(\mathrm{HR}=1.0006 、 \mathrm{P}<0.05)$ が独立危険因子であっ た。[結語]術前 BNP は HD 患者 AVR の早期および 中期成績においても独立危険因子であり、予後予測 因子となる可能性が示唆された。また、HD 患者にお いて術前 BNP と術前 EF、TRPG、LVMI は弱い相 関関係であり、EF40\%以下、高度左室肥大、TRPG $>40$ 以上の予測では、BNP は中等度の正確性を示 した。腎機能、透析の影響が考えられるものの、HD 患者においても BNP は術前心機能の評価に使用でき る可能性が示唆された。しかし、予後予測および心 機能評価のためのカットオフ值の設定などには症例 数を増やした更なる検討が必要と考えられた。

\section{PP-18 高齢者に対する冠動脈血行再建を伴う大動 脈弁置換術}

\section{立川綜合病院 心臓血管外科}

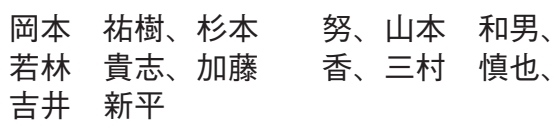

【背景と目的】大動脈弁置換 (AVR) と冠動脈バイパス (CABG) 同時手術では、高度冠動脈狭窄と心肥大の ため、不完全な心筋保護の可能性や長時間の心筋虚 血により、特に高齢者では手術リスクを増大させ、 術後心機能障害を招くことも少なくない。当院では 極力 $\mathrm{CABG}$ を心拍動下で行うことや、心筋保護に関 しては順行性に加えて逆行性冠灌流を併用すること で、術中の安定した心筋保護や虚血時間の短縮に努 めている。今回我々の手術成績、治療戦略の妥当性 を検討した。【対象と方法】2003 年 11 月から 2012 月 4 月までに大動脈弁狭窄症と冠動脈疾患の合併に対 してAVRと CABG を同時施行した 83 例。平均年齢 75 歳(48～89)、男性 52 例 (63\%)、NYHAIIIorIV59 例 $(72 \%) 、$ LMT 病変 20 例 $(63 \%)$ 、不安定狭心症 9 例、 手術成績・遠隔成績を検討し、80 歳以上の高齢者群 を $\mathrm{O}$ 群 (23 例)、80 歳未満を $\mathrm{Y}$ 群 $(60$ 例) として比較 した。【結果】術前 IABP 使用 7 例、緊急手術 3 例。 AVR は機械弁使用 34 例 (41\%)、CABG は off pump または on pump beating が 62 例 $(76 \%)$ 、平均吻合数 2.1 本、使用したグラフトは LITA63 例、RITA6 例、 GEA10 例、RA1 例、SVG59 例。併施手技は MVR4 例、 MAP3 例、MVP1 例、 TAP1 例、MAZE4 例、PV isolation3 例、上行置換 4 例、ASD 閉鎖 1 例、Myectomy 1 例、ペースメーカー植え込み 1 例、弁輪拡大 2 例。平均大動脈遮断時間 98 分。病院死亡は 1 例 $(1.2 \%)$ で、術後 64 日目に間質性肺炎で失った。術後 早期合併症は一過性心房細動 32 例、出血再開胸 3 例、 間質性肺炎 1 例、原因不明血小板減少症 1 例。O 群 はY 群と比較して入院期間がやや長い傾向にあった が(31 日 vs 25 日、p=0.037)、手術時間、バイパス吻 合本数、ICU 滞在期間、早期死亡、術後合併症で差 はなかった。遠隔期平均観察期間 39 ヶ月で、死亡 9 例(心臓関連死はなし)。心臓関連の合併症は心不全 3 例、心筋梗塞 1 例、弁周囲逆流 1 例で $1 、 3 、 5$ 年 の心血管事故回避率は 100\%、100\%、79\%であった。 CABG に関して心停止下では、心拍動下に比べバイ パス本数が少ない傾向にあり(平均 1.3 本 vs 1.9 本、 $\mathrm{p}=0.076$ )、大動脈遮断時間が延長したが (135 分 vs 87 分、 $\mathrm{p}=0.002$ )、入院期間、早期 - 遠隔期死亡、心 事故発生で差は認めなかった。【結論】高齢者に対す るAVR と CABG の同時手術の成績は良好であり、 積極的な治療が予後を改善する可能性がある。バイ パス本数が少ない場合、遮断時間延長は許容されそ うだが、多枝バイパスが必要な症例が増加している ため、心拍動下での CABG は重要な option である。 


\section{PP-19 出 \\ 後期高齢者の重症 AS に対する単独 AVR 手 術とAVR + CABG 複合手術における手術 成績の比較}

\author{
岩手医科大学循環器医療センター \\ 熊谷 和也、岩瀬 友幸、菅野 勝義、 \\ 満永 義乃、小泉 淳一、鎌田武、 \\ 坪井 潤一、金一、向井田昌之、 \\ 猪飼秋夫、岡林均
}

【背景】近年、高齢者の AS に対する手術症例は増加 傾向にあり、冠動脈疾患 $(\mathrm{CAD})$ を合併している症例 も稀ではない。一般的に CABG 同時手術の成績は不 良とされているが、当センターでは CAD 合併症例に 対して積極的に CABG を施行いる。過去 5 年間にお ける当センターでの単独 AVR 手術と AVR + CABG 複合手術との成績を比較検討した。【対象】2006 年 11 月から 2011 年 12 月までに施行した単独 AVR 手術 症例 (A 群) と AVR + CABG 複合手術症例 (AC 群) の 89 例を対象とした。A 群は 60 例、年齢は 75 84 歳 (平均 78.6 歳)、男性 18 例、女性 42 例。 AC 群 は 29 例、年齢は $75 \sim 86$ 歳(平均 78.7 歳)、男性 14 例、 女性 15 例。術前 NYHA は A 群 $2.0 \pm 0.6$ 、AC 群 2.4 土0.7であり有意差はみられなかった。また、両群間 において術前の高血圧症、高脂血症、糖尿病などの 基礎疾患に差はなく、 $\mathrm{Hb}$ 值は $\mathrm{A}$ 群 $11.6 \pm 1.8 \mathrm{mg} / \mathrm{dL}$ 、 $\mathrm{AC}$ 群 $12.0 \pm 1.7 \mathrm{mg} / \mathrm{dL} 、 \mathrm{CRE}$ 值は A 群 $0.9 \pm 1.1 \mathrm{mg} /$ $\mathrm{dLAC}$ 群 $1.2 \pm 1.4 \mathrm{mg} / \mathrm{dL}$ であり有意差はなかった。 使用した人工弁は全て生体弁であり、A 群では Mosaic 弁 3 例、CEP 弁 39 例、CEP MAGNA 弁 17 例、 CEP MAGNA EASE弁 1 例に対して、AC群で $\mathrm{CEP}$ 弁 5 例、CEP MAGNA 弁 23 例、CEP MAGNA EASE 弁 1 例であった。人工弁のサイズは $\mathrm{A}$ 群 $20.4 \pm 2.3 \mathrm{~mm} 、 \mathrm{AC}$ 群 $20.9 \pm 2.6 \mathrm{~mm}$ で差はなかっ た。【結果】手術時間は A 群 $221.6 \pm 49.1$ 時間、 AC 群 334.8 時間、体外循環時間に関しては A 群 $89.7 \pm 20.8$ 時間、 AC 群 $130.4 \pm 31.4$ 時間と AC 群で有意に延長 していたが、大動脈遮断時間は A 群 $58.8 \pm 16.8$ 時間、 $\mathrm{AC}$ 群 $65.4 \pm 25.0$ 時間で有意差は認められなかった (当センターでは on-pump beating CABGを施行)。 術後の合併症は A 群で不整脈 29 例 (48.3\%)、心囊液 貯留 2 例 (3.3\%)、腎不全 1 例 $(1.7 \%) 、$ 虚血性腸炎 1 例 (1.7\%)であり、AC 群では不整脈 14 例 (48.2\%)、

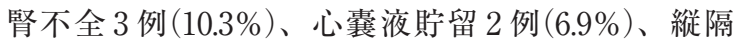
洞炎 1 例 (3.4\%) であり、術後合併症の発生率には差 がなかった。入院日数は A 群 $23.7 \pm 13$ 日、AC群 $34.7 \pm 34.4$ 日で有意差はみられなかった。病院内死亡 は A 群において 1 例あり、腹部大動脈瘤の破裂が原 因であった。遠隔死亡は心蔵関連死が A 群で 2 例で あった。また、Kaplan - Meier 法を用いた遠隔期生 存率に関して、両群間において有意差はなかった。 【結果】AVR + CABG 複合手術の成績は良好で、 $\mathrm{CAD}$ 合併症例に対して積極的に CABG を行う治療 方針は妥当であると思われる。

\section{PP-20 公 大動脈弁、僧帽弁形成術の現状と展望}

\author{
聖路加国際病院 心血管センター \\ 阿部 恒平、川副浩平、渡邊直、 \\ 山崎学、桑内慎太郎、伊藤 丈二
}

僧帽弁形成術の遠隔成績は弁置換術に比しはるかに 優れることが知られるようになり、広く積極的に行 われるようになって来た。一方で大動脈弁形成術に 関しては、弁置換術との対比においてその評価が未 だ明らかでなく、世界的にも限られた施設でのみ行 われているのが現状である。近年当院では積極的に 大動脈弁を含めた弁形成術を行っているので、僧帽 弁形成術と比較しながら、現時点での問題点と今後 の展望を述べる。

【対象および方法】1996年から 2012 年までに弁閉鎖 不全症に対して当院で行われた大動脈弁形成術 33 例 （1 尖弁 2 例、 2 尖弁 13 例、 3 尖弁 17 例、4 尖弁 1 例） と僧帽弁形成術 132 例 (TypeI22 例、TypeII89 例〈前 尖逸脱 23 例、後尖逸脱 53 例、前後尖逸脱 13 例〉、 TypeIIIa1 例、TypeIIIb18 例、TypeII+IIIb2 例)。 大動脈弁手術は、バルサルバ洞の拡大を伴う弁輪拡 大に対しては基部置換術、正常バルサルバ洞の弁輪 拡大に対しては subvalvular circular annuloplasty 若 しくは commissuroplastyを施行。2 尖弁に対しては 2 尖弁化若しくは 3 尖弁化、逸脱弁尖に対しては adjustable suspension 法もしくは central plication 法 を用いた。

僧帽弁手術では、TypeI 病変に対してはリングによ る弁輪縫縮術、前尖逸脱に対しては人工腱索、後尖 逸脱に対しては切除、TypeIIIb 病変に対しては弁輪 縫縮に加えて tethering heightに応じて弁下部手術 を主体として行った。Kaplan-Meier 法を用いてイべ ント解析を行った。

【結果】大動脈弁形成術では入院死亡及び遠隔期死を 認めなかった。 III ${ }^{\circ} \mathrm{AR}$ 回避率 1 年 $100.0 \% 、 3$ 年 $83.6 \%$ 、大動脈弁再手術回避率 1 年 $100.0 \%$ 、3 年 $95.0 \%$ であった。僧帽弁形成術では、入院死亡 2 例 (1.5\% )、遠隔期死亡 7 例 (心臓死 6 例、非心臓死 1 例) を認めた。 III ${ }^{\circ} \mathrm{MR}$ 回避率 1 年 $99.2 \% 、 3$ 年 $97.9 \%$ 、 5 年 $97.9 \%$ 、10 年 $97.9 \%$ 、僧帽弁再手術回避率 1 年 $97.6 \% 、 3$ 年 $96.2 \% 、 5$ 年 $96.2 \% 、 10$ 年 $96.2 \%$ であった。 大動脈弁において、基部置換を行った症例で III ${ }^{\circ} \mathrm{AR}$ 回避率が 100\%(12/12) に対して基部置換を行わな

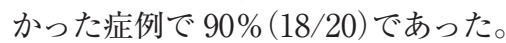

【考察】僧帽弁閉鎖不全症に対する形成術は極めて良 好であった。大動脈弁閉鎖不全症に関しては追跡期 間は短いが、再手術回避率は僧帽弁形成術とほぼ同 等であり、患者の QOL の改善は明らかであった。し かし比較的早期に逆流再発症例が見られるため、形 成に適した病変の再検討と形成手技のさらなる工夫 を要すると考えている。 
PP-21年

僧帽弁形成術における逆行性心筋保護下心 拍動逆流試験の確実性

\author{
札幌医科大学 外科学第二講座 \\ 橘一俊、宮木 靖子、中島 智博、 \\ 安田 尚美、高木 伸之、樋上 哲哉
}

【目的】僧帽弁形成術 (MVP)の長期遠隔成績を向上さ せる必須条件は、手術直後の逆流を限りなくゼロと することにある。MVPにおいて術中水試験と心拍再 開後の経食道エコー評価に差があることが術後 MR の残存につながる。これは術中水試験が生理的状態 にない事に起因している。これらの点を考慮し我々 は、大動脈遮断下にて心拍動を再開させ、直視下に 逆流評価をする逆行性心筋保護下心拍動逆流試験 (Retrograde cardioprotective beating test ; RCBT) を施行し症例を重ねてきた。これにより生理的収縮 期の閉鎖状態により近い僧帽弁を直視下に観察する 事ができ、minor leakの部位および成因をより明確 に認識することにより、有効な追加手技が可能となっ た。これらの症例をもとに大動脈遮断下心拍動の利 点およびその注意点に関し報告する。【方法】2010 年 1 月より 2012 年 8 月までに RCBT を施行した MVP 症例 59 例を対象とした。【結果】対象症例中 RCBT をもとに、追加手技を加え minor leak を制御した症 例は 16 例 $(28.0 \%)$ であった。これら全例で形成術が 完遂でき、病院死亡は 0 例であった。早期成績は、 MR ゼロもしくは Trace(エコー上の逆流面積 $1 \mathrm{~cm} 2$ 以下) が 55 例、 trivial(エコー上の逆流面積 $2 \mathrm{~cm} 2$ 以 下)が 4 例、 mild 以上の MR は 0 と極めて良好であっ た。中期成績は、 trivial 以下が 54 例、 mild となった 症例は 5 例であり、その内訳は TypeIIIa(non-prolapse type) 2 例、成人先天性 2 例、TypeI1 例であっ た。再手術症例 0 例、遠隔死亡は 0 例であった。術 中心筋梗塞発症例は 0 例であり、カテコラミン開始 後、SAM を呈し術中再弁形成を要した 1 例を除き 2nd-Runを要した症例は認めなかった。術後経食道 心エコーと RCBT の逆流評価に相違を認めた症例は 0 例であった。【考察】RCBT は、心内圧 $70 \mathrm{mmHg}$ 以 上での等容性収縮の観察を主とするより生理的で確 実な術中評価法である。この評価法開始により術中 所見と術後エコー評価の差はなくなり形成術の完成 度は確実に向上した。しかながら、カテコラミン使 用時に明らかとなる SAM に対する対応は要する可 能性はある。【結語】RCBT 法により、より確実な僧 房弁形成術が可能となる期待される。

\section{PP-22 虚血性僧帽弁閉鎖不全に対する早期外科介 入の功罪}

\author{
兵庫県立姫路循環器病センター 心臓血管外科 \\ 森本 直人、松島 峻介、邊見宗一郎、 \\ 青木 正哉、西岡 成知、村上 博久、 \\ 本多祐、中桐啓太郎、吉田正人、 \\ 向原 伸彦
}

【目的】当センターでは 2000 年以来、CABG 施行時に 2 度 以上の虚血性僧帽弁閉鎖不全 $(\mathrm{IMR})$ を有するに対し積極 的に外科的介入を行ってきた。早期外科的介入の功罪を 検討する。【方法および対象】2000 年から 2008 年まで IMR 合併 $\mathrm{CABG}$ 症例 289 例 (CABG の み 104 例、 $\mathrm{CABG}+$ 僧 帽弁形成術 165 例、CABG+ 僧帽弁置換術 20 例)のうち、 2 度の IMR を有する症例は $\mathrm{CABG}$ の み 66 例 (CABG 群：年齢 $72 \pm 8$ 才、女性 $30 \% 、 \mathrm{EF} 37 \pm 8 \%$ 、LVESVI79 $\pm 28 \mathrm{ml} / \mathrm{m} 2$ 、緊急 $18 \%$ )、CABG + 僧帽弁形成術 118 例 $(\mathrm{CABG}+\mathrm{M}$ 群：年齢 $69 \pm 9$ 才、女性 $23 \%$ 、 $\mathrm{EF} 33 \pm 7 \%$ 、 LVESVI90 $\pm 23 \mathrm{ml} / \mathrm{m} 2$ 、緊急 $25 \%$ ) であった（除外基準： recent MI、再手術、大動脈弁手術併施)。これらを propensity score matchingにより比較検討した。CABG 群 では 34 例 $(52 \%)$ で OPCAB を施行。僧帽弁形成術では total ringによる undersized annuloplasty を基本とした。 【成績】病院死亡は CABG 群 0\%、CABG+M 群 11\% (緊 急 : $27 \%$ 、待機 $6 \%$ ) と、緊急では $\mathrm{CABG}+\mathrm{M}$ 群が有意 に高かった $(\mathrm{p}=0.04)$ 。平均観察期間 $4.1 \pm 2.8$ 年での遠隔 死亡は 2 群ともに 26 例で、8 年生存率では CABG 群 43 $\pm 8 \% 、 \mathrm{CABG}+\mathrm{M}$ 群 $62 \pm 6 \%(\mathrm{p}=0.32)$ で、 $\mathrm{CABG}+\mathrm{M}$ 群 では術後早期死亡多く、遠隔死亡が少ない傾向にあった。 待機緊急別のサブグループ解析では、 $\mathrm{CABG}+\mathrm{M}$ 群緊 急例の術後早期の生存率低下が顕著であった。Matching (両群とも EF35\%、LVESVI82ml $/ \mathrm{m} 2$ ) 後の病院死亡は両 群で $0 \% 、 6$ 年生存率も CABG 群 $30 \pm 8 \%$ に比べ、 $\mathrm{CABG}+\mathrm{M}$ 群 $86 \pm 6 \%$ と有意に良好であった $(\mathrm{p}<0.001)$ 。 $\mathrm{CABG}+\mathrm{M}$ 群でのみ遠隔の $\operatorname{LVESVI}(68 \mathrm{ml} / \mathrm{m} 2, \mathrm{p}=0.01)$ 、 $\mathrm{EF}(42 \%, \mathrm{p}=0.001)$ の有意な改善が得られた。【結論】IMR への早期外科介入は、遠隔の左室容積の縮小、 $\mathrm{EF}$ の上 昇を認め、心機能および生存率を有意に改善する。しかし、 緊急例での病院死亡を含めた早期成績が不良で、他疾患 などの合併により長期生存が期待できない症例では、 IMR への早期外科介入の効果は期待できない。

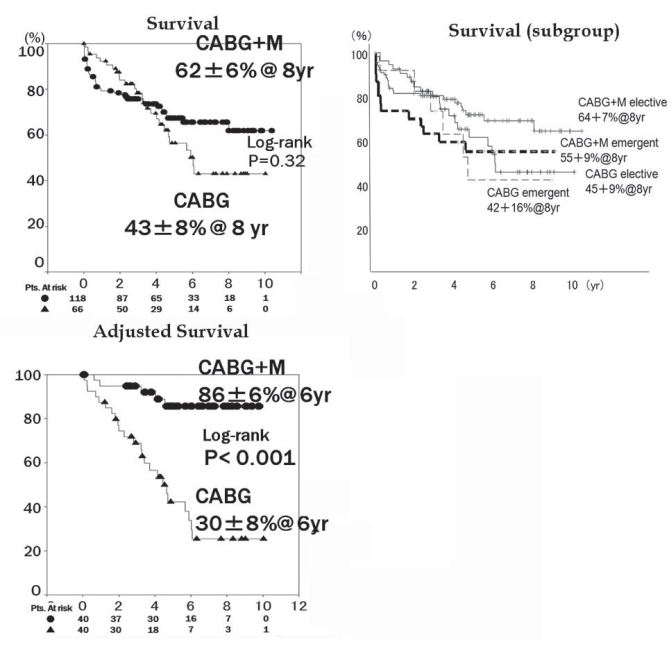


PP-23 눈

心筋症に対する乳頭筋吊り上げ術——糸で 行う心室治療としての効果

\author{
1名古屋ハートセンター 心臓血管外科 \\ 川川崎医科大学付属病院循環器内科
}

北村 英樹 ${ }^{1} 、$ 木村 有成 ${ }^{1} 、$ 深谷 俊介 ${ }^{1} 、$

大川 育秀、尾長谷喜久子 ${ }^{2} 、$ 吉田 清 2 、

米田 正始 1

重症心不全の原因として心筋症がある。拡張型心筋 症 (DCM)、虚血性心筋症 (ICM)、二次性心筋症なと に分類されるが、いずれも機能性僧帽弁逆流 (Functional MR)を発症する。FMRに対して当院では、後 尖 Tethering の改善を目的とし、前尖・後尖の乳頭 筋 Head を併せた後に僧帽弁前尖中央部へ引き上げ る、Papillary Head Optimization 法(PHO 法)を考案、 試用している。今回、各種心筋症に対してPHOを施 行した 22 例を対象に、エコーにて手術前後、中期遠 隔期成績を検討し、心筋症に対する PHO の妥当性を 報告する。対象症例は心筋症 22 例 (女 7 例) で平均年 齢 66 歳。 7 例が拡張型心筋症、8 例が 2 次性拡張型 心筋症、7 例が虚血性心筋症であった。術前エコー では駆出率 $29 \%$ 、左室拡張末期径 (LVDd) $64 \mathrm{~mm}$ 、 MR3.4 度であった。術後 1 週間で施行したエコーで は、EF32\%であったが、LVDdは 58mm、MR は 0.86 と有意に改善した。中期遠隔期 (平均 410 日) エコー では、EF37\%、LVDd52mm と左室機能は術前より 改善し、MRは 1.2 と再発は認めなかった。Etiology 別にみると、DCM群では $\mathrm{EF} は 25 \rightarrow 29 \rightarrow 40 \%$ 、 LVDd は $64 \rightarrow 57 \rightarrow 46 \mathrm{~mm}$ と経時的に改善した。 $2 \mathrm{ndDCM}$ でも EF は $36 \rightarrow 36 \rightarrow 50 \%$ 、LVDd は $64 \rightarrow 57 \rightarrow 46 \mathrm{~mm}$ と左室機能改善がみられた。MRも 両群とも $1.1 、 1.0$ と良好に制御されていた。ICM では $\mathrm{EF}$ は $25 \rightarrow 29 \rightarrow 21 \%$ 、LVDd \& $64 \rightarrow 59 \rightarrow 65 \mathrm{~mm}$ と改善が見られなかった。しかしながら、MRは1.7(術 前 3.4、 $\mathrm{P}=0.0039)$ と制御されており、PHO 法は虚血 性を含めた心筋症の僧帽弁逆流に対して有効な手段 になると考えられた。二次性を含めた DCM に対して は、左室の改善効果が見られたが、虚血性に対して は左室機能改善が認められなかった。完成した虚血 性心筋症に対しては、更なる追加手技が必要な可能 性が残る。
PP-24 幽

重症心不全に対する外科治療戦略

\section{太田西ノ内病院 心臓血管外科}

丹治 雅博、高橋 皇基、山本 晃裕

重症心不全に対する外科治療の最終手段として人工 心臓や心臓移植があるが、その前段階として左室形 成術が考慮される。しかしその術式は左室容積、左 室形態、残存心筋、さらには合併する僧帽弁逆流、 不整脈などにより各症例にあわせて行うオーダーメ イド手術であると考えられる。心不全を合併した虚 血性心筋症 $(\mathrm{ICM})$ 及び拡張型心筋症 (DCM) に対する 外科治療戦略について検討を行った。【対象及び方 法】2008 年 5 月より心不全を合併した ICM : 10 例(年 齢は $50 \sim 84$ : 平均 68.3 歳、全例男性) DCM : 5 例(年 齢は $41 \sim 62$ : 平均 51.2 歳、男 4 例・女性 1 例) に手 術を施行した。術前心エコー検査でLVEF は 12 30 (平均 22.5 ) \%、LVDd は $61 〜 86$ (平均 71.9) $\mathrm{mm}$ で、ICM の 7 例、DCM の全例に moderate 以上の tetheringによる機能性僧帽弁閉鎖不全症 (FMR)を 認めた。ICM に対する左室形成術はSAVE 法を原則 とし、対角枝の走行によってはDor 法を選択した。 DCM に対しては Overlapping 法を選択した。FMR 対 しては乳頭筋接合術(PMA) 及び僧帽弁輪縫縮術 (MAP)を行った。しかし DCM に対する治療方針とし て Overlapping 法の手術成績が不良であること、DCM の心不全に FMR が強く関与していること、PMAにも 多少の左室容積減少効果があることから、最近では左 室心尖部を小切開 $(3 \sim 4 \mathrm{~mm})$ し内視鏡下に PMA/MAP を行った。不整脈に対しては cryoablation や maze 手術、 さらには ICD、CRT-D 植え込み術を施行した。【結果】 ICM に対してはSAVE + CABG + cryo : 3 例、SAVE ま たはDor + PMA/MAP + TAP : 3 例、SAVE + PMA/ $\mathrm{MAP}+\mathrm{TAP}+\mathrm{CABG}: 2$ 例、Dor + PMA/MAP + maze $: 1$ 例、左室小切開 $+\mathrm{PMA} / \mathrm{MAP}+\mathrm{CABG}: 1$ 例を施行した。DCMに対しては Overlapping + $\mathrm{PMA} / \mathrm{MAP}+\mathrm{TAP}: 3$ 例、左室小切開 + PMA/MAP $+\mathrm{TAP}: 1$ 例、左室小切開 + PMA/MAP + TAP + maze: 1 例を施行した。術後 ICD 植え込み術を 5 例に、 CRT-D 植え込み術を 7 例に施行した。15例のうち、 手術死亡 1 例、入院死亡 1 例で、ともにDCM に対す る Overlapping 例であった。生存 13 例の遠隔死亡は なく、術前 NYHA クラス $3 \sim 4$ が 1 ～2 に改善したが、 $\mathrm{MR}$ の再発を認めた 1 例 (Dor + PMA/MAP + TAP) では術後 1 年より NYHA はクラス 3 に悪化した。【結 語】ICM に対する左室形成術及び PMA/MAP は概ね 良好な結果であった。DCM に対する左室心尖部小切 開による PMA/MAP は少ない侵襲で FMR、心不全を 改善する効果的な方法と考えられた。また遠隔期の突 然死及び心不全防止には ICD、CRT-D 植え込み術が 有効と考えられた。 


\section{PP-25} 当院における虚血性心筋症に対する中期遠
隔期手術成績の検討

\author{
明石医療センター 心臓血管外科 \\ 林太郎、戸部 智、杉山 博道、 \\ 納庄 弘基、松尾 辰朗、山口 眞弘
}

【目的】虚血性心筋症 (ICM)に対する外科治療は、完 全血行再建を基本とし、有意な虚血性僧帽弁逆流 (MR) 症例には僧帽弁形成術もしくは置換術を、そし て心拡大著明な症例に対しては左室形成術が追加さ れる。今回当院での ICM に対する中期・遠隔期手術 成績を検討した。【方法】当院開設以来” 01.11 月より’ 12.2 月までに、ICM を 32 例経験した。術式の内訳は 冠動脈バイパス術のみ(CABG 群) が 9 例、僧帽弁形 成術のみを追加したもの (MAP 群)が 12 例、左室形 成術を追加したもの (LVR 群) が 11 例であった。当 院では、虚血性 MR に対して down-size の弁輪形成 を基本術式とし、僧帽弁置換術を行った症例はなかっ た。平均年齢は、CABG 群 : $69 \pm 6.3$ 歳、MAP 群 : $66 \pm 8.2$ 歳、LVR 群 : $63 \pm 10.9$ 歳であり、平均観察期 間は CABG 群: $28.4 \pm 26.9$ 力月 (13日〜 78 力月)、 MAP 群 : $45.1 \pm 34.3$ 力月 (8 113 力月)、LVR 群 : $58.1 \pm 37.7$ カ月 (14 日〜 96 カ月)であった。【結果】経 胸壁心エコーでの Dd 推移は、術前 / 術直後 / 中期 / 遠隔期にて、CABG 群 : 50.4 $7.2 / 48.9 \pm 11.0 \mathrm{~mm} 、 \mathrm{MAP}$ 群 : $61.4 \pm 4.8 / 55.9 \pm 5.5 / 54.8$ $\pm 5.9 / 55.1 \pm 4.4 \mathrm{~mm}$ 、LVR 群 : $65.1 \pm 8.8 / 56.6 \pm$ $10.5 / 57.1 \pm 9.0 / 59.6 \pm 8.7 \mathrm{~mm}$ と、有意差はないが全群 で術前より僅かに縮小傾向であった。同様に FS 推移 は、CABG 群 : $21.4 \pm 15.0 / 24.0 \pm 11.6 / 25.1 \pm 14.8 / 21.2$ $\pm 4.8 \%$ 、MAP 群 : $18.7 \pm 5.3 / 21.5 \pm 5.4 / 20.2 \pm 4.9 / 20.8$ $\pm 4.5 \%$ 、LVR 群 : $19.2 \pm 6.4 / 19.7 \pm 5.1 / 20.7 \pm 6.5 / 18.8$ $\pm 6.5 \%$ と、全群で術直後・中期は改善したが、遠隔 期では再低下傾向であった。MR garde 推移は、 CABG 群 : $1.3 \pm 0.5 / 0.9 \pm 0.6 / 1.4 \pm 0.8 / 0.5 \pm 0.7$ 度、 MAP 群 : $2.7 \pm 0.8 / 0.8 \pm 0.5 / 1.3 \pm 0.8 / 0.6 \pm 0.5$ 度、 LVR 群 : $2 \pm 1 / 0.2 \pm 0.4 / 0.7 \pm 0.7 / 1.1 \pm 1.0$ 度と、遠隔 期まで制御出来ている。各群における 3 年 $/ 5$ 年生存 率は、CABG 群 : $67 \% / 67 \%$ 、MAP 群 : $75 \% / 75 \%$ 、 LVR 群 : $90 \% / 68 \%$ であり、ICM 症例全体では $78 \%$ $/ 67 \%$ あった。【結論】当院での ICM に対する外科 治療手術成績は、ほぼ満足のし得る結果であった。 成績改善には、手術時の心筋虚血の解除と並存する MR を制御が基本となり、術前より存在する重症心 不全に対する対策が術後必要となる。今後症例を積 み重ね、さらなる検討を行っていきたい。

\section{PP-26 文 心筋梗塞を伴わない急性僧帽弁閉鎖不全に 対する手術成績の検討}

\section{済生会熊本病院 心臓血管外科}

高志賢太郎、三隅 寛恭、萩原正一郎、

上杉 英之、出田 一郎、押富 隆、

片山幸広、佐々 利明、村田 英隆、

鈴木 晴郎、宝亀 亮悟、植田ちひろ、

平山 統一

【背景】急性の僧帽弁逆流 (MR)による心不全に対する 外科的治療は、手術の時期、至適な手技などまだ不 明確な点が多い。当科では最近 10 年間に、心筋梗塞 が関与しない急性の僧帽弁逸脱に対する緊急手術を 7 例経験したので、その手術成績を検討した。【対象】 2002 年から 2012 年に当科で急性 MR に対し緊急手 術を行った 7 例を対象とした。【結果】7 例の平均年 齢は $67 \pm 11$ 歳で男女比 $6: 1$ 、症状発現から平均 2 日 で手術に至った。全例気管内挿管が必要な肺水腫を 認め、IABPによる循環補助を必要とした。胸部レン トゲンでは典型的な butterfly shadowを 4 例にみと め、術前の $\mathrm{P} / \mathrm{F}$ ratio は $153 \pm 75$ であった。術前から の炎症所見の上昇を全例で認め、白血球数 $13.3 \pm 6.5$ $\times 10^{3} / \mathrm{mm}^{3} 、 \mathrm{CRP} 11.9 \pm 9.6 \mathrm{mg} / \mathrm{dl}$ と高值を示し、体 温も平均 $38.2^{\circ} \mathrm{C}$ であった。エコー所見上 5 例が $\mathrm{P} 2$ の 広範囲逸脱であった。手術は 4 例に僧帽弁形成術を、 3 例に弁置換術を施行した。いずれの症例も感染性 心内膜炎を示唆する所見は見当たらなかった。術後 に5 例において warm shock 様の血行動態からノル アドレナリンの投与を要し、3 例には敗血症治療に準 じたステロイド投与を行い奏効した。術後の $\mathrm{P} / \mathrm{F}$ ratio は $153 \pm 52$ で 3 例は人工心肺から離脱できず PCPS での呼吸・循環補助を要した。3 日以上の人工 呼吸器管理は 4 例に必要だった。在院死亡は 1 例で、 PCPS 使用によるへパリン化から出血傾向が続き、多 臓器不全で失った。【考察】7 例の JapanSCORE の中 央值は 9.4 であり、実際の死亡率は $14.2 \%$ で症例数が 少ないことから 1 例の死亡が影響するとともに、急 性 MR 症例のリスク評価は JapanSCORE では難しい と考えられた。全例で急性の発症の割には術前の炎 症所見が高く、術前の呼吸不全に僧帽弁逆流以外に 全身性炎症反応症候群 (SIRS) が関与していることが 示唆された。死亡症例は術前 WBC $21000 / \mathrm{mm}^{3}$ 、 CRP $30.3 \mathrm{mg} / \mathrm{dl}$ 、初発症状から手術までが 5 日間で、 炎症の強い時期に手術を行わざるを得なかったこと が、死亡につながった可能性がある。【結論】当科に おける急性 MR に対する手術成績は許容範囲内では あるが、さらなる改善には早期診断、早期治療と SIRS に対する集学的治療が重要と考えられる。 
PP-27 文

機能的 MR に対する前尖パッチ拡大と乳頭 筋吊り上げを併用した小サイズ増帽弁形成術

長崎大学病院 心臟血管外科

$\begin{array}{lrrr}\text { 橋本 } & \text { 亘、橋詰 } & \text { 浩二、久田 } & \text { 洋一、 } \\ \text { 谷川 } & \text { 和好、主浦 } & \text { 崇、尾立 } & \text { 朋大、 } \\ \text { 田崎 } & \text { 雄一、横瀬 } & \text { 昭豪、江石 } & \text { 清行 }\end{array}$

【諸言】拡張型心筋症・虚血性心筋症に合併した機能 的僧帽弁閉鎖不全症 (FMR) に対する小サイズ僧帽弁 輪形成術 (UMAP) は遠隔期の MR 再発の問題が指摘 されている。当院では 23 例の FMR に対しUMAP を施行し、入院死亡 1 例 $(4 \%)$ 、平均観察期間 4 年で MR 再発は 4 例 $(17 \%)$ であった。2012 年 4 月より遠 隔成績の更なる向上のためにUMAP に加え、自己心 膜による前尖パッチ拡大及び両側の乳頭筋吊り上げ 術の併用を開始した。典型例をビデオで供覧し、そ の期待されるメカニズムについて解説する。【症例】 70 歳男性で 26 年前から心筋症と診断され、2012 年 2 月より心不全を繰り返すようになり severe MR、 severe TR 及び moderate AR を指摘された。4 月よ りカテコラミン離脱が不能となり手術適応と判断さ れた。手術は、心停止下に右側左房切開で僧帽弁輪 に2-0 タイクロンで弁輪形成用の糸をかけた後、僧帽 弁前尖弁輪から $3 \mathrm{~mm}$ 離れて前交連から後交連に切 開を加えた。次に前後の乳頭筋基部にそれぞれフエ ルト付ゴアテックス CV-4 を通した後に、僧帽弁前尖 弁輪から左房側に刺入した。自己心膜を幅 $15 \times$ 25mm にトリミングし5-0 プロリンを用いて最初に切 開した前尖 clear zone のパッチ拡大を行った。前尖 の大きさに合わせて Memo3D 30mm で弁輪形成を行 い、前尖弁輪に通しておいた CV-4 を人工リングに通 して乳頭筋吊り上げを行った。CV-4の長さ調節は、 水試験を行いながら弁尖がやや浮き上がる位置で CV-4 を固定した。大動脈弁は CEP Magna 21mm で 置換し、三尖弁は MC3 26mm で弁輪形成を行い手 術を終了した。僧帽弁・三尖弁とも遺残逆流はなく 術後経過は良好であった。【考察】FMRに対する UMAP 後にリモデリングの進行と共に心不全が再発 し、その結果として MR が再発する症例が確かに少 なからず存在する。リモデリングが進行した場合で も MR 再発を防ぐために、前尖 clear zone にパッチ を当てて前尖弁尖の高さを延長し、更に両側乳頭筋 基部を前尖弁輪に吊り上げることで遠隔期において も両尖の tethering を予防できることが期待される。

\section{PP-28 公 器質的僧帽弁閉鎖不全症に対する乳頭筋 Sandwich 形成法併用の有用性}

\section{東京都立墨東病院 胸部心臓血管外科}

$\begin{array}{llr}\text { 石川 } & \text { 進、片山 } & \text { 康、三島 秀樹、 } \\ \text { 伊藤 淳、江花 } & \text { 弘基 }\end{array}$

【目的】乳頭筋 Sandwich 形成法は、前尖 - 後尖の腱 索間の距離を短縮することで弁尖の接合 (coaptation) を改善させる効果があり、機能的僧帽弁閉鎖不全症 (MR)に対して用いてられてきた。今回、本法を器質 的 MR に対する僧帽弁形成術に併施し、その有用性 を検討した。【対象と方法】対象は 5 例で、年齢は平 均 63(39-78) 歳、男女比は 3 対 2 であった。主病変は MR が 3 例、大動脈弁狭窄を伴う連合弁膜症が 2 例 で、MR は severe が 3 例、 moderate が 2 例であった。 僧帽弁の器質的変化は、腱索断裂による逸脱が 3 例、 硬化および石灰化(中等度)が 2 例であった。術前の 左室駆出率 $(\mathrm{LVEF})$ は平均 $61 \pm 5 \%$ 、拡張期径 (LVDd) は $51 \pm 3 \mathrm{~mm}$ 、左房径は $44 \pm 1 \mathrm{~mm}$ であった。 Sandwich 形成法では、前・後乳頭筋それぞれの腱索 付着部(乳頭筋頭)に Teflon-pledget 付 3-0 タイクロ ン糸をかけ、前尖・後尖の腱索付着部をマットレス 固定した。【結果】1)手術：僧帽弁逸脱症の 3 例では、 後尖の部分切除後に Sandwich 形成を行い、次いで 弁尖縫合と人工弁輪縫着を行った。大動脈弁症例で は、弁切除後に大動脈弁輪口より Sandwich 形成を 行い、大動脈弁置換術を施行した。Sandwich 形成に 要した時間は、経左房が平均 10 分、経大動脈弁輪が 20 分であった。手術終了時、経食道超音波検査での MR は、全例で non-trivial であった。2)術後超音波 検査所見: 残存 MR は non-trivial が 4 例、 mild が 1 例であった。僧帽弁の tenting heightは、術前の $10.2 \pm 0.3 \mathrm{~mm}$ から $6 \pm 0.5 \mathrm{~mm}$ 一と有意に $(\mathrm{p}<0.01)$ 減 少した。僧帽弁の弁口面積は $4.3 \pm 0.1 \mathrm{~cm} 2$ であり、狭 窄をきたした症例はなかった。左室流入血流の圧較 差 $(\max )$ は、術前の $7 \pm 2 \mathrm{mmHg}$ から $2 \pm 0.6 \mathrm{mmHg}$ へと低下した。LVDd は術後に有意に $(\mathrm{p}<0.05)$ 縮小 したが $(51 \pm 3 \rightarrow 43 \pm 3 \mathrm{~mm}) 、 L V E F 、 L A D$ には変化 がなかった。3)術後中期成績: 術後平均 6 ケ月の現 在、残存 MR の増加はない。血清 BNP 值は $110 \pm$ $29 \mathrm{pg} / \mathrm{ml}$ LDH $240 \pm 11 \mathrm{U} / \mathrm{L}$ であり、心不全の増 悪や溶血はなかった。【考察およびまとめ】1)器質的 僧帽弁閉鎖不全症においても弁尖の可動性がある場 合に本法により coaptationの改善が得られる。2)適 応症例や長期成績に関しては今後の検討を要する。 
PP-29 눈

Marfan 症候群の機能的僧帽弁両尖逸脱に対 する前尖温存弁形成術

\section{平塚市民病院 心臓血管外科}

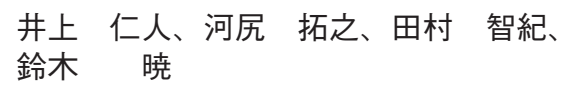

【目的】僧帽弁形成術の目的は良好な弁尖の coaptationを再構築することである。Barlow 症候群や Marfan 症候群の両尖高度逸脱症例では、過剩弁組織 による弁形成後の収縮期前方運動 (SAM) が起こり易 く、左室流出路閉塞や僧帽弁逆流の原因となる。そ のため、両尖逸脱部の余㮃組織の切除による形成術 が行われて来ている。しかし、弁尖端が弁輪の水準 を乗り越える腱策断裂による弁尖逸脱とは異なり、 Barlow 症候群や Marfan 症候群では機能的逸脱に起 因した逆流を来している症例がある。即ち、収縮期 に大きな弁腹が左房側へ突出し牽引されることで coaptation zone の減少を来たして僧帽弁閉鎖不全を生 じる。その結果、腱策の延長や断裂が誘発されて逆 流が進行し、さらに収縮期に弁輪が外下方へ偏位す ることにより生じる弁尖の機能的逸脱が逆流の増悪 を来たす。こういった僧帽弁閉鎖不全に対し、前尖 組織を切除せず、大きめの annuloplasty ring を用い て弁輪を安定化することで機能的逸脱の矯正が可能 と考え、その手技を動画で供覧する。

【方法】当院で 1992 年〜 2012 年に 77 症例に対して僧 帽弁閉鎖不全症に対して弁形成術を施行した。腱策 断裂に伴う弁尖逸脱に対しては、後尖逸脱症例は弁 尖切除と弁輪形成術、前尖逸脱症例には loop technique と弁輪形成術施行。Marfan 症例の機能的僧帽 弁尖逸脱症例に対しては、前尖温存し弁輪形成を施 行した。方法は、1) 後尖過剩組織の横方向の修正 : P2 small qudrangular resection $(10 \mathrm{~mm}) 。 2$ ) 後尖過 剩弁組織の縦方向の調整：P1-2, P2-3 cleft closure に より後尖を単尖弁化し、後尖高 $15 \mathrm{~mm}$ になるように sliding plasty 施行。3) 機能的逸脱修正のための大き めの人工弁輪縫着(Physio II $36 \mathrm{~mm}$ )。

【結果】Marfan 症候群の機能的僧帽弁両尖逸脱症例に 対し、後尖の切除縫合と弁輪形成術のみ施行した結 果、逆流は完全に消失し、SAM を認めず、充分な弁 尖接合面の再構築が得られた。外来経過観察中も再 発を認めなかった。

【結論】Marfan 症候群では前尖の機能的逸脱を生じて おり、大きめの人工弁輪縫着により弁輪の動きを安 定化することで逆流の制御が可能であると考えられ た。

\section{PP-30 㲾 \\ Mitral prolapse に対する僧房弁形成術にお ける ring size の検討}

\author{
国立循環器病研究センター 心臓血管外科 \\ 川本 尚紀、藤田 知之、秦広樹、 \\ 島原 佑介、佐藤 俊輔、齋藤 正博、 \\ 深澤 万歓、松本 順彦、山下 築、 \\ 小林 順二郎
}

【目的】当センターにおける mitral prolapse に対する 僧房弁形成術 mitral valvulo-plasty (MVP)の成績を検 討し、術後の心機能と、ring size の関係を PPM の観 点から検討した。【対象および方法】当センターにおけ る、2006 年 1 月から 2012 年 4 月までの、僧帽弁疾患 に対して mitral prolapseによる mitral regurgitation (MR)を有する症例に対し弁形成術を行った 228 例を 対象とした。平均年齢 59 12 歳、男女比 148: 80 であっ た。MVPは、resection and sutureを 167 例 (73\%)、 chordae replacement 62 例 (27\%) 施行した。使用 した人工弁輪の種類は Cosgrove band 83 例、Physio ring 55 例、 Physio II 32 例、Tailor ring 28 例、Duran 15 例、その他 15 例であった。術前・術後・follow-up の計 3 回心エコー検査を施行し、心機能を評 価した。【結果】手術死亡または病院死亡は認めな かった。MVP 症例の再手術は 5 例 $(1.7 \%) に$ 行い、再 手術の原因は MR 再発が 3 例、溶血が 1 例、感染性 心内膜炎が 1 例であった。術後 3 度以上の MR 再発 は 2 例 (0.8\%)であった。LVDd は術前 $58 \pm 7 \mathrm{~mm}$ から 術後 $49 \pm 7 \mathrm{~mm}$ へ有意 $(\mathrm{p}<0.0001)$ に減少 し、left ventricular mass index (LVMI) も術前 $166 \pm 50 \mathrm{~g} / \mathrm{m}^{2}$ から術後 $125 \pm 34 \mathrm{~g} / \mathrm{m}^{2}$ へ有意 $(\mathrm{p}<0.0001)$ に減少し た。また、 peak tricuspid regurgitant pressure gra$\operatorname{dient}(\mathrm{TRPG}$ ) $33 \pm 14 \mathrm{mmHg}$ から $20 \pm 6 \mathrm{mmHg}$ に有 意 $(\mathrm{p}<0.0001)$ に減少した。Edwards lifesciences 社 製 (cosgrove、Physio、Physio2)の人工弁輪を使用し た患者を対象にBSA、Ring size と術後心機能を比較 したところ size $26 \mathrm{~mm}$ を使用した患者の BSA は 1.53 $\pm 0.03 \mathrm{~m} 2$ と他のサイズと比べて有意に低かった $(28 \mathrm{~mm} \mathrm{p}=0.015 、 30 \mathrm{~mm} \mathrm{p}=0.0004)$ 。 $\mathrm{mPG}$ は $26 \mathrm{~mm}$ : $3.87 \pm 1.12 \mathrm{mmHg}(\mathrm{n}=35) 、 28 \mathrm{~mm}: 2.88 \pm 1.06 \mathrm{mmHg}$ $(\mathrm{n}=63) 、 30 \mathrm{~mm}: 2.58 \pm 1.05 \mathrm{mmHg}(\mathrm{n}=38)$ と size $26 \mathrm{~mm}$ の患者で有意に $\mathrm{mPG}$ は高值 $(\mathrm{p}<0.0001)$ となった が、術後と follow-up の心エコー検査にて、TRPG・ LVMI の推移には ring size による有意差は認められ なかった。【結語】Mitral prolapse による MRに対す る resection and suture、chordae replacementを用 いた修復術は術後の心機能の改善を促し、良好な成 績を示した。 ring sizeによる mPGの比較からは、 $26 \mathrm{~mm}$ を選択した場合、他の ring size と比べて、有 意に術後 $\mathrm{mPG}$ が高くなる傾向があるが 1 、その後の 心機能の変化は他の ring size と有意な違いは認めら れなかった。今後、長期の心機能の推移をみる必要 があると考えられた。 


\section{PP-31 放 \\ 僧帽弁逸脱に対する僧帽弁形成術の長期遠 隔成績}

佐賀大学 胸部・ 心臟血管外科

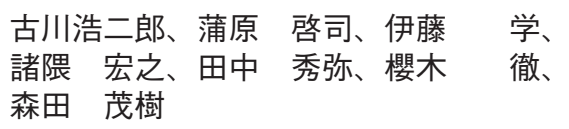

【背景】現在、僧帽弁閉鎖不全症 $(M R)$ にたいする形成 術(MVP) は一般的なものとなったが、未だに種々の 術式が提唱されており、普遍的なものはない。われ われは、これまで病変部位に対し一定の術式にて対 応してきた(後尖 $\rightarrow$ 切除縫合、交連 $\rightarrow$ edge to edge、 前尖 $\rightarrow$ 人腱索)。【目的】これまでの MVP の長期遠 隔成績の結果より、われわれの方針の妥当性を検討 した。【対象と方法】1986 年 8 月より 2012 年 5 月まで に僧帽弁逸脱による MR に対して上記の方針に則っ てMVPを行った 148 例を対象とした。年齢 $64 \pm 12$ (31 ～88) 歳、男性 / 女性 84/64 例、緊急 2 例であっ た。弁輪形成術は、134 例 (91\%)に行った。同時手術 は、TAP 30 例、CABG 10 例、不整脈手術 32 例、 AVR 7 例、Bentall 手術 1 例、上行大動脈置換 2 例、 上行弓部大動脈置換 1 例であった。遠隔期に心エコー にて MR の程度 $(1$ ～4)、弁口面積などを測定した。 生存・再手術に関する follow up は 100\%、心エコー の follow up は 88\%であった。平均観察期間は、89 土67(2 262) ケ月であった。全症例および切除縫 合 群(RS 群: 83 例)、edge to edge 群( $\mathrm{E}$ 群: 31 例)、 人工腱索群 (AC 群: 34 例) に分けて Kaplan-Meier 法 にて生存率、再手術回避率、 $\mathrm{MR}$ 再発 (3 度以上) 回避 率などを比較した(病変が複数個所にわたる場合は、 主病変に対する術式に分類した)。【結果】1. 手術死亡 はなく入院死亡は 1 例 $(0.6 \%)$ であった。全体の生存 率 $(5$ 年 $/ 10$ 年 $/ 15$ 年) $93 \% / 83 \% / 77 \%$ 、再手術回避 率 5 年 $/ 10$ 年 $/ 15$ 年) $97 \% / 96 \% / 96 \%$ 、MR 再発回避 率 $(5$ 年 $/ 10$ 年 $/ 15$ 年) $95 \% / 88 \% / 79 \%$ であった。 2. $\mathrm{RS}$ 群での生存率 $(5$ 年 $/ 10$ 年 $/ 15$ 年) $95 \% / 87 \%$ $/ 82 \%$ 、再手術回避率 $(5$ 年 $/ 10$ 年 $/ 15$ 年) $98 \% / 95 \%$ $/ 95 \% 、 M R$ 再発回避率(5 年 $/ 10$ 年 $/ 15$ 年) $95 \% / 91 \%$ $/ 83 \%$ であった。E群での生存率 (5 年 $/ 10$ 年) $89 \%$ $/ 67 \%$ 、再手術回避率 (5 年 $/ 10$ 年) $100 \% / 100 \%$ 、MR 再発回避率 $(5$ 年 $/ 10$ 年) $94 \% / 94 \%$ であった。AC 群 での生存率 $(5$ 年 $/ 10$ 年 $/ 15$ 年) $90 \% / 80 \% / 73 \%$ 、再 手術回避率 $(5$ 年 $/ 10$ 年 $/ 15$ 年) $93 \% / 93 \% / 93 \%$ 、MR 再発回避率 $(5$ 年 $/ 10$ 年 $/ 15$ 年) $97 \% / 83 \% / 74 \%$ で あった。生存率・再手術回避率・MR 再発回避率す べてにおいて各群間で有意差はなかった。3. RS 群 / $\mathrm{E}$ 群 / $\mathrm{AC}$ 群での弁口面積はそれぞれ 2.8/2.7/3.0 cm2 であった。【結論】1.われわれの僧帽弁逸脱に対する MVP の長期遠隔期成績は満足できるものであった。 2. 病変部位によるシンプルな手術戦略を用いること により再現性のある、durability の高い手術を達成で きる。

\section{PP-32 춘 Sphericity index と僧帽弁手術後の心機能}

\author{
名古屋大学 心臟外科 \\ 蒔苗永、大島 英揮、荒木 善盛、 \\ 成田 裕司、六鹿 雅登、徳田 順之、 \\ 薦田さつき、野中 利通、岡田 典隆、 \\ 藤田山、碓水 章彦
}

【目的】僧帽弁閉鎖不全症の至適手術時期を評価する ために、左室形態の指標である sphericity index(SI) と術後の心機能との関連を調べた。【方法】僧帽弁閉 鎖不全症に対して僧帽弁形成術または僧帽弁置換術 を施行し、術後に再燃のない 14 例。平均年齢 $61.4 \pm$ 12.1 歳、男性: 女性 $=6: 8$ 、において、術前と術後 1 年の心エコー所見を比較した。さらに、術前の LVEF が 60\% 未満の群 (group L) と60\% 以上の群 (group H)に分けて検討した。group L は 8 例で平均 年齢 $61.5 \pm 13.9$ 歳、group $\mathrm{H}$ は 6 例で平均年齢 61.3 土 10.4 歳であった。術前に中等度以上の僧帽弁狭窄 症または大動脈弁疾患のある症例と、冠動脈バイパ 又術と左室形成術を施行した症例は除外した。【結 果】group Lでは、術前の LVEF $38.0 \pm 13.6 \%$ 、術 後 $34.9 \pm 15.7 \%(\mathrm{P}=0.35)$ 、相関係数 $0.83(\mathrm{P}=0.01)$ 。 手術前後の LVEF そのものの変化に有意差はない が、術前の LVEF が良いほど術後も保たれる傾向が みられた。術前のSI $1.49 \pm 0.13$ 、術後 $1.51 \pm 0.15$ $(\mathrm{P}=0.75)$ 、相関係数 $0.65(\mathrm{P}=0.08)$ 。SI は手術前後で 有意な変化はないが、術前と正の相関があった。 LVEF の増減(術後 LVEF/ 術前 LVEF) と術前の SI の相関係数は $-0.04(\mathrm{P}=0.93)$ で、SI は手術前後の LVEF の増減との相関がみられなかった。group $\mathrm{H}$ では、術前の LVEF $70.0 \pm 4.7 \%$ 、術後 $57.0 \pm 7.5 \%$ $(\mathrm{P}=0.04)$ 、相関係数 $-0.75(\mathrm{P}=0.09)$ 。手術前後の LVEF の変化に有意差があり、術前の LVEF に対し て有意な負の相関がみられた。術前の体表面積当た りの左房容積 $(\mathrm{LAvol} / \mathrm{BSA}) 51.2 \pm 24.5$ 、術後 $31.0 \pm$ 13.9 $(\mathrm{P}=0.09)$ 、相関係数 $0.38(\mathrm{P}=0.45)$ で、手術前後で 有意に改善し、術前の LAvol/BSA に対しては有意 ではないが弱い正の相関がみられた。術前の SI 1.54 \pm 0.16 、術後 $1.70 \pm 0.27(\mathrm{P}=0.05)$ 、相関係数 0.88 $(\mathrm{P}=0.02)$ 。手術前後で SI は有意に改善し、かつ術前 のSIに有意な強い相関がみられた。LVEF の増減と 術前の SI の相関係数は 0.36 $(\mathrm{P}=0.49)$ で、有意ではな いものの SI は LVEF の増減に弱い正の相関がみられ た。【まとめ】group H では術後の左房容積と SI の有 意な改善がみられており、いずれもより軽症である 方が術後も良好である傾向が示唆された。術前の LVEF が 60\% 以上の症例では、SI が低くならないう ちに手術をした方が心機能の改善を期待できる可能 性が示唆された。 
PP-33 公

僧帽弁形成術中直接計測した coaptation length と術後 TEE で計測した値との関連性

\author{
川崎医科大学 心臓血管外科
}

$\begin{array}{llrl}\text { 山澤 } & \text { 隆彦、本田 } & \text { 威、三村 } & \text { 太亮、 } \\ \text { 滝内 } & \text { 宏樹、古川 } & \text { 博史、渡部 } & \text { 芳子、 } \\ \text { 柚木 } & \text { 靖弘、田淵 } & \text { 篤、正木 久男、 } \\ \text { 種本 和雄 } & & & \end{array}$

【緒言】僧帽弁形成術は、今や僧帽弁閉鎖不全症 $(M R)$ に対する gold standard となっているが、一部で慢性 期に逆流が再発し、溶血・心不全などで再手術を余 儀なくされる症例がわずかながら存在する。このよ うな逆流再発をきたさない quality の高い僧帽弁形成 術を行うことが求められるところである。一方、僧 帽弁形成術の出来上がりを心停止下に評価する方法 としては、生理食塩水による逆流テストが一般的に 行われているが、逆流テストで完璧に逆流が制御さ れていると判断しても、術後に逆流が残るケースも あるとされている。我々は大動脈遮断下に行う逆流 テストに ink testを併用し、それによって coaptation length と術後に経食道心エコー図で計測する coaptation lengthの相関を検討し、それが慢性期の逆流再 発に与える影響について検討しているので報告する。 【対象と方法】術中 ink test とは、僧帽弁形成が終了 した時点で逆流テストにより、僧帽弁が閉鎖してい る時点で、coaptation line にサージカルマーキングペ ンで色を付け、ラインから僧帽弁自由縁までの距離 を直接測定することによって接合部の深さをセク ションごとに計測し、それを術中に測定した coaptation length $(\mathrm{CL})$ とする。1 症例で $\mathrm{A} 1^{\sim} \mathrm{A} 3, \mathrm{P} 1^{\sim} \mathrm{P} 3$ の 6 セグメントに分けたデータを収集した。25例におい て術中に測定した coaptation length と、術後経食道 心エコー図(TEE)で測定した coaptation length の相 関を分析検討した。術中直接計測した值はセグメン トごとに、A1: 4 7mm 平均 $4.5 \mathrm{~mm} 、 \mathrm{~A} 2: 4 \% 9 \mathrm{~mm}$ 平均 $5.2 \mathrm{~mm} 、 \mathrm{~A} 3: 3 \sim \mathrm{mm}$ 平均 $4.9 \mathrm{~mm} 、 \mathrm{P} 1: 4 \sim 12 \mathrm{~mm}$ 平均 $6.1 \mathrm{~mm} 、 \mathrm{P} 2: 5^{\sim} 20$ 平 均 $9.3 \mathrm{~mm} 、 \mathrm{P} 3: 4^{\sim} 12 \mathrm{~mm}$ 平 均 $6.0 \mathrm{~mm}$ で術後経食道心エコー図との計測と ink test の結果とに強い相関があった。【考察】術後の残存・ 再発 MR と coaptation length の関係についての検討 は未だ不十分であるが、今後症例数を蓄積し明らか にしていくとともに、十分な coaptation lengthを得 るための術式・術中の追加手技を判断する上で、術 中 ink testによる coaptation length 測定は重要な指 標となる可能性がある。この coaptation lengthの小 さい症例で術後の僧帽弁逆流の残存、再発が多いと いう結論が得られれば、そのような症例に対して術 中に coaptation lengthを増加させる手技 (commissure stitch, leaflet augmentation など)を追加する必 要を判断する重要な指標となると考えている。

\section{PP-34} 心内膜床欠損症に対する僧帽弁形成術の工 夫

\author{
札幌医科大学 外科学第二講座 \\ 宮木 靖子、橘一俊、中島 智博、 \\ 高木 伸之、樋上 哲哉
}

当科では僧帽弁前尖形成術式として「新しい coaptation zone の作成」を目的とした rough zone trimming 法(RZT)を主体として形成を行っている。RZT とは、腱索間を rough-zoneに限った帯状に trimming し縫合することで本来の coaptation line を左室 側に引き込み、新しく深い coaptation zone を作成す るというコンセプトに基づいた術式である。今回は この方法を応用した心内膜床欠損症 (ECD)の弁形成 術を紹介する。症例 166 歳女性。40 歳時に不完全 型心内膜床欠損症と診断され ASD 閉鎖と mitral cleft 縫合を行った。その後、僧帽弁閉鎖不全症の増 悪による心不全の症状強く、手術となった。手術は 上行大動脈送血・上下大静脈脱血により体外循環を 開始し、心停止下に行った。僧帽弁逆流は、mitral cleft 切痕部の硬化による接合不全が原因であった。 cleft 下端の弁硬化部とその周囲の腱索を観察し、腱 索を残す形で両側の硬化弁尖の trimming を行った。 腱索を寄せるように弁尖を結節縫合し、若干の弁尖 の引き込みにより新たな coaptation line が作成され、 僧帽弁逆流も消失した。症例 231 歳男性。生後 6 カ月で完全型 ECD の診断で根治術を施行されてい る。30 歳ごろより重症僧帽弁閉鎖不全症による心不 全症状を認め、手術となった。手術は型のごとく体 外循環・心停止下に施行した。僧帽弁を観察すると、 逆流の主な原因は A1 の腱索断裂であった。RZTに て形成を施行。逆流を確認すると、少量の cleft から の残存逆流も認めており、症例 1 と同様に cleft 雨端 の硬化病変を trimming し、腱索を寄せるように縫合 し、逆流は完全に消失した。症例 356 歳男性。検 診にて心雑音を指摘され、精査したところ不完全型 ECD の診断で手術となった。手術は型のごとく体外 循環・心停止下に施行した。30mm 程度の VSD を閉 鎖した後に僧帽弁を観察すると、2 時方向の弁輪まで 到達する cleft を認めた。弁輪部より cleftの端 $5 \mathrm{~mm}$ 手前まで結節縫合で閉鎖をしたのち、 $1 \cdot 2$ と同様の 手順で cleft 両端の処理を行い、僧帽弁逆流は消失し た。ECDに対する僧帽弁逆流に対する再手術は成人 期に時折経験する。逆流の主体はほぼ cleft 切痕の硬 化による接合不全が原因となっており、これは RZT の応用で確実に逆流を消失できる。症例 $1 \cdot 2$ におい ては術後 5 年の経過観察にて MR0 を維持している。 $\mathrm{ECD}$ に対する我々の RZT の応用は有用な術式と考 えられた。 


\section{PP-35 $\lesssim$ \\ 成人期における心房中隔欠損修復術後の僧 帽弁閉鎖不全症についての検討}

\author{
福井心臓血圧センター 福井循環器病院 心臓血管 \\ 外科 \\ $\begin{array}{llll}\text { 吉田 } & \text { 昇平、堤 } & \text { 泰史、門田 治、 } \\ \text { 沼田 } & \text { 智、山崎 } & \text { 祥子、瀬尾 浩之、 }\end{array}$ \\ 佐村 高明、大橋 博和
}

【はじめに】心房中隔欠損 $(\mathrm{ASD})$ 修復術後に僧帽弁閉 鎖不全症 $(M R)$ が新たに出現または増悪する報告が散 見される。J.Park らは $29 \%$ の患者で ASD 修復術後 に MR が出現または増悪し、6.3\%の患者では MR が 2 度以上増悪したと報告している。今回当院で成人期 に ASD 修復術を施行後にMRが出現または増悪し た症例を検討し、その危険因子について調査した。 【対象、方法】1998 年〜 2011 年のうち当院にて施行し た 18 歳以上の ASD 修復術は 75 例。そのうち大動脈 弁置換術、冠動脈バイパス術、大動脈手術を同時に 施行した 9 例、また術前より MR を認め僧帽弁形成 術を同時に施行した 8 例を除いた 58 例を対象とし た。5 8 例の患者背景は平均年齢 49.9 歳、男性 25 例、 NYHA 分類 I 度 41 例、II 度 17 例、高 血圧 13 例、 脂質代謝異常 4 例、糖尿病 5 例。心房細動 19 例。ま た ASD 以外の先天性奇形の合併としては肺動脈狭 窄症を 3 例、単冠動脈症を 1 例、Holt-Oram 症候群 を 1 例に認めた。 58 例のうち 15 例に三尖弁形成術、 8 例に MAZE 手術を同時に施行した。MR は術前術 後ともに経胸壁心臓超音波検査にて評価した。MR の出現または増悪の危険因子としては術前の NYHA 分類、心臓超音波検査、心臓カテーテル検査、心電図、 および術中所見を検討した。【結果】平均観察期間は 75.6 か月であり $25.9 \%(15 / 58)$ で MR の出現また増悪 を認め $12.1 \%(7 / 58)$ で MR2 度以上の増悪を認めた。 ASD 術後の MR についての再手術は $6.9 \%$ (4/58)で 施行された。MR 増悪の危険因子を検討したところ、 単変量解析では高齢、左房径 $35 \mathrm{~mm}$ 以上、心房細動 の存在、NYHA 分類 II 度、収縮期肺動脈圧 $40 \mathrm{mmHg}$ 以上、収縮期右室圧 $40 \mathrm{mmHg}$ 以上、右房 圧 $10 \mathrm{mmHg}$ 以上が危険因子であると解析されたが、 多変量解析では有意な結果は認めなかった。ただし ASD 修復術後に MR が 2 度以上増悪した症例は、術 前心房細動を認めた症例では 31.6\% (6/19) と高率で あるのに対して術前心房細動を認めない症例では 2.6\%(1/39) と低率であった。術後も心房細動が継続 して認めた症例では $41.7 \%(5 / 12) に M R 2$ 度以上の増 悪を認めた。【結語】ASD 修復術前に心房細動を認め る症例では ASD 修復術と同時に僧帽弁形成術を積 極的に考慮すべきと考えられた。

\section{PP-36 文 高齢者の胸部大動脈瘤に対する TEVAR の 検討}

天理よろづ相談所病院 心臓血管外科

$\begin{array}{lll}\text { 仁科 } & \text { 健、中塚 大介、安水 } & \text { 大介、 } \\ \text { 堀 } & \text { 裕貴、五十嵐 仁、広瀬 圭一、 } \\ \text { 金光 } & \text { 尚樹、山中 一朗、上田 } & \text { 裕一 }\end{array}$

Thoracic Endovascular Aortic Repair(TEVAR) の 普及とともに高齢者の胸部大動脈瘤症例も増加傾向 にある。80 歳以上の高齢者に対する TEVAR 治療の 検討を行った。【対象と方法】2007年 7 月から 2012 年 7 月までの胸部大動脈瘤治療症例は 142 例で、平 均年齢 $74 \pm 11$ 歳 (男性 97 : 女性 45)。このうち緊急 症例は 27 例、待機症例は 115 例であった。TEVAR 導入以降は、Zone3よりも末梢の動脈瘤は、TEVAR を治療の第 1 選択としてきた。そしてZone2 にステ ントグラフトの中枢 Landing が可能な症例は、左鎖 骨下動脈の Debranching を追加した。80 歳以上の 症例数は 43 例 (平均年齢 $84 \pm 4$ 歳、男性 31 例：女性 12 例)、最高年齢は 95 歳であった。 80 歳未満の症例 は 99 例 (平均年齢 $70 \pm 8$ 歳、男性 66 例：女性 33 例)。 TEVAR はカテ室にて局所麻酔下を基本とした。 80 歳以上の Old patient 群( $\mathrm{OP}$ 群) と未満の Young Patient 群 (YP 群) 間での比較検討を行った。【結果】動 脈瘤の形態から $\mathrm{OP}$ 群の大動脈解離関連症例は 5 例 (12\%)であったのに対して、YP 群は 35 例 (35\%) と 有意にYP群に多かった $(\mathrm{p}<0.005)$ 。緊急症例は OP 群 14 例 (32\%) に対してYP 群 13 例 (13\%) と YP 群に多かった $(\mathrm{p}<0.01)$ 。死亡率および合併症の比較 では $\mathrm{OP}$ 群の死亡例は 5 例 $(11 \%)$ 、緊急症例 2 例 (DIC)・待機症例 2 例(感染症)で、ステント関連は 1 例であった。YP群は 4 例 (4\%)で OP 群に多い傾向 にあり、緊急症例 3 例中ステント関連は Shower emboly の 1 例で、待機症例は 1 例(脳出血)であった。 ステント関連合併症は OP 群 7 例 (16\%) に対して YP 群 15 例 (15\%) と有意差なかった。内訳はYP群 : Paraplegia2 例、脳梗塞 2 例、血管損傷 1 例、リーク による追加治療 2 例であった。YP 群 : Paraplegia4 例、脳梗塞 4 例、血栓症 1 例、リークによる追加治 療 4 例、創部離開 1 例、塞栓症 1 例であった。術後 の在院日数に関しては両群間にて有意差は見られな かった。【結語】1. 高齢者のZone3 より末梢の胸部大 動脈瘤に対する第 1 選択治療として TEVAR は有用 である。2. 高齢者では緊急症例が多い傾向にあり、 TEVAR 後に年齢による差はなく積極的な対応を行 うべきである。 
PP-37 文

80 歳以上の高齢者における胸部大動脈瘤に 対するステントグラフト内挿術の検討

\author{
1 国立国際医療研究センター \\ 2 島田総合病院

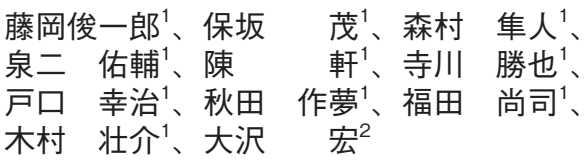

【はじめに】近年、血管外科領域では治療の低侵襲化 に伴い、以前は治療が困難であった 80 歳以上の高齢 者においても積極的に治療が行われるようになって きている。当科では debranch や塞栓予防の左鎖骨下 動脈バルーン閉塞を併用しながら、胸部大動脈瘤に 対する TEVAR を行っている。当院にて TEVARを 施行した高齢者の症例について検討したので報告す る。【対象】 2009 年 1 月から 2012 年 8 月まで、当院に て施行したTEVAR(分枝再建症例含む) 50 症例につ いて、80 歳以上の 14 症例 $(28 \%)$ と 80 歳未満 36 症 例 $(72 \%)$ について比較検討した。【結果】患者の平均 年齢は $83.1 \pm 2.6$ 歳 $/ 70.4 \pm 7.6$ 歳、動脈瘤の最大短径 は $63.1 \pm 10.5 \mathrm{~mm} / 52.8 \pm 10.1 \mathrm{~mm}$ であった。術式は TEVAR が 7 例 (50\%)/21 例 (58\%)、de-branch 群 5 例 (36\%)/13 例 (36\%)、ほかの手術との合併手術例が 6 例あった。 80 歳以上で 3 例の破裂例を含み、 1 例 は大動脈食道瘻を合併していた。80歳未満の患者で は気管に穿破した症例を 1 例認めた。手術時間は TEVAR 群 $121 \pm 36.6$ 分/136 \pm 79 分、de-branch 群 $329.6 \pm 50.6$ 分 $/ 253 \pm 111$ 分であった。また出血量は TEVAR 群 $48.0 \pm 53.4 \mathrm{ml} / 102 \pm 135 \mathrm{ml}$ 、de-branch 群 $442 \pm 224 \mathrm{ml} / 474 \pm 571 \mathrm{ml}$ であった。全例で初期成功 が得られた。 80 歳以上では大動脈食道瘻を合併した 1 症例 $(7.1 \%)$ は在院死となったが、他 13 例は軽快退 院となった。 80 歳未満では死亡症例を認めなかった。 また脳梗塞は 80 歳以上、以下ともにの de-branch 群 に 1 例 $(7.1 \%: 2.8 \%$ 、 $\mathrm{p}=0.52)$ 、対麻瘏は 80 歳以上 の de-branch 群と 80 歳以下の TEVAR 群に 1 例ず つ認め $(7.1 \%: 2.8 \% 、 \mathrm{p}=0.52)$ 、有意差は認めなかった。 その他に大きな合併症は認めなかった。【結語】80 歳 以上の高齢者においても、TEVAR を用いることで 胸部大動脈瘤に対する治療が安全に行えることが示 唆された。高齢であっても、本人、家族の希望があ れば積極的に手術を考慮すべきと考えられた。

\section{PP-38 咨 \\ 併存疾患のある高齢者胸部大動脈瘤破裂に 対する TEVAR の有用性}

\author{
1筑波記念病院 心臓血管外科 \\ 2東京大学医学部附属病院 心臓外科 \\ $\begin{array}{lrr}\text { 河田 } & \text { 光弘 }{ }^{1} \text { 、竹谷 } & \text { 剛 }^{2} \text { 、古屋 舞 }{ }^{1} 、 \\ \text { 森住 } & \text { 誠 }{ }^{1} \text { 末松 } & \text { 義弘 }\end{array}$
}

【目的】最近市販ステントグラフトの普及が進んでき ているが、併存疾患のある高齢者胸部大動脈瘤破裂 に対する TEAVR の有用性について当院の経験をも とに報告する。【背景】併存疾患のある高齢者が胸部 大動脈瘤破裂で搬送されてきた場合、年齢やその併 存疾患により conventional な人工心肺、低体温を用 いた手術に耐術不可能と判断される事もあり、また 救命のために手術を施行した場合でも満足のいく結 果が得られない事もある。2012 年 4 月から 2012 年 8 月の期間、当院にて胸部大動脈瘤破裂に対する準緊 急 TEAVR を 4 例経験し全例救命できた。その中で、 3 例が併存疾患のある高齢者 $(75$ 才以上) であり呈示 する。【症例 1】93 歳女性。背部痛にて救急搬送され、 $\mathrm{Hb} 5.7 \mathrm{~g} / \mathrm{dl}$ 、TAAA (Crawford V 型) 破裂と訬断。全 身状態改善させた後、準緊急 visceral debranching (Celiac a., SMA) TEVAR施行。15POD独歩退院。 【症例 2】75 歳男性。既往として CABG (LITA-LAD、 SVG-OM が開存)、TEVAR (for TAA (distal arch))、 脳梗塞。多量な喀血にて救急搬送。ステントグラフ 卜 dislodgement、同部位 TAA 囊状 $80 \mathrm{~mm}$ と急速拡 大、破裂と診断し、準緊急 debranching (LtCCA, LtSCA) TEVAR 施行。17POD 独歩退院。【症例 3】 87 歳男性。20 年前より TAA (descending) は指摘され ていた。1 か月前より食道通過障害による嘔吐、誤嚥 性肺炎を繰り返し、精査にてTAA 襄状 $90 \mathrm{~mm}$ 、切 迫破裂の診断で他院より緊急転院。準緊急 TEVAR 施行。2POD り立位、歩行。3POD に内視鏡的に ED-tube を十二指腸まで挿入し、経管栄養開始。現在、 食道通過障害に対する治療を計画中。【成績】高齢者 3 例とも無事救命でき ADL も保たれている。【結論】 併存疾患のある高齢者胸部大動脈瘤破裂に対して、 救命目的に施行した準緊急 TEVAR は非常に有用で あった。今後も慎重な follow up を続けてゆく予定で ある。

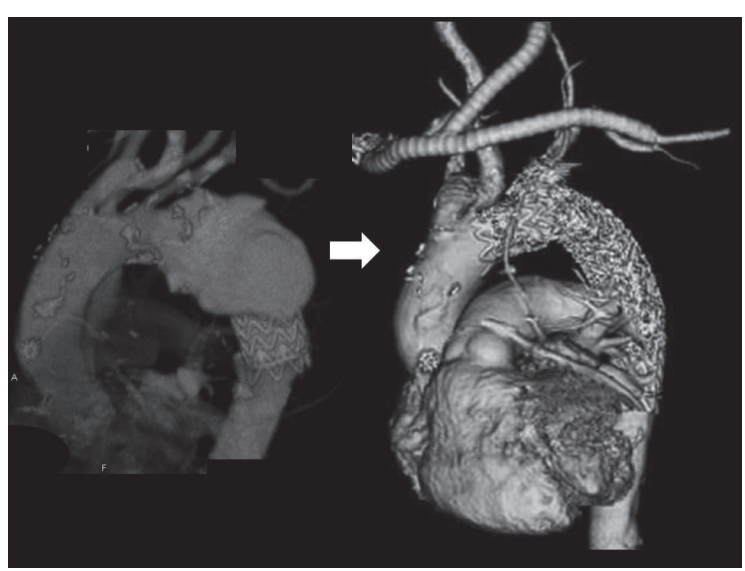


PP-39 尔

腎障害 TEVAR の早期遠隔期成績の検討

1宮崎大学 第二外科

2宮崎県立延岡病院 心臓血管外科

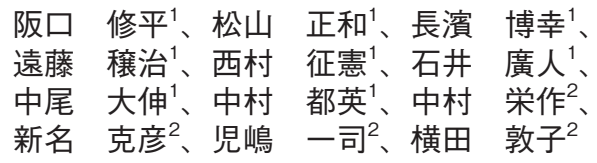

【はじめに】腎障害例における TEVARの早期および 遠隔期成績を健常例と比較し、妥当性と問題点を検 討した。【対象と方法】2000 年 4 月から当科㧍よび関 連施設で施行されたTEVAR連続 106 例のうち、 eGFR 30 未満の 11 例を腎障害群 (A 群) とし、それ以 外の 95 例を健常群 (B 群) として、周術期因子、早期 及び遠隔期成績を比較検討した。2 群間の検討には、 $\chi$ 二乗検定 (Fisher 正確検討)、Mann-Whitney 検定、 Log-rank 検定を用いた。観察期間は最長 152 ヶ月、 平均 52 ケ月であった。【結果】平均年齢 (A 群: 68.9 歳 vs B 群: 72.7 歳; $\mathrm{p}=0.236$ )、性別(女性 $27.3 \%$ vs $33.7 \%$; $=1$ )、解離例 $(45.5 \%$ vs $27.4 \%$; $\mathrm{p}=0.29$ )、平 均瘤径 $(64.0 \mathrm{~mm}$ vs $58.8 \mathrm{~mm} ; \mathrm{p}=0.34)$ 、平均ランディ ングゾーン (LZ) 長 $(40.4 \mathrm{~mm}$ vs $28.7 \mathrm{~mm}$; $\mathrm{p}=0.21$ )、平 均 LZ 径 (31.0mm vs $31.5 \mathrm{~mm}$; $\mathrm{p}=0.68$ ) に有意差を認 めなかった。呼吸器疾患、循環器疾患などの併存疾 患も差を認めなかった。在院死亡を両群に認めず、平 均手術時間 (227min vs $232 \mathrm{~min}$; $\mathrm{p}=0.88$ )、平均出血量 $(242 \mathrm{ml}$ vs $312 \mathrm{ml}$; $\mathrm{p}=0.48)$ 、血管損傷発生 ( 0 vs $5.3 \%$; $\mathrm{p}=1$ )、脳梗塞発症 ( 0 vs $1.1 \% ; \mathrm{p}=1)$ 、脊䯣障害発生 $(0$ vs $4.2 \%$ )に有意差を認めなかった。しかしながら遠隔 成績は、エンドリーク発生 $(81.8 \%$ vs $17.9 \%$; $<<$ 0.0001 )、追加 TEVAR 例 (54.5\% vs $6.3 \%$; $\mathrm{p}=0.0002)$ 、 開胸転換例 $(18.2 \%$ vs $5.3 \% ; \mathrm{p}=0.15)$ と A 群の成績が 有意に不良であった。遠隔期生存率は 5 年 $(42.4 \%$ vs $68.0 \%) 、 10$ 年 ( $21.2 \%$ vs $42.1 \% \quad \mathrm{p}=0.05)$ 、大動脈関 連死亡回避率は 5 年 $(60.6 \%$ vs $90.8 \%) 、 10$ 年 $(30.3 \%$ vs $86.3 \% / 10$ 年; $\mathrm{p}=0.0005)$ と有意に $\mathrm{A}$ 群が不良で あった。【結語】腎障害の有無で早期成績には差を認 めなかったが、遠隔成績は有意に腎障害例が不良で あった。腎障害例ではランデイングゾーンの脆弱性 によるエンドリーク発生増加の危険性が示唆された。 腎障害例に対する TEVAR が適切か否かを慎重に検 討する必要があると考えられた。
PP-40

演題取り下げ 


\section{PP-41}

\section{当院における B 型大動脈解離に対する血管 内治療の経験}

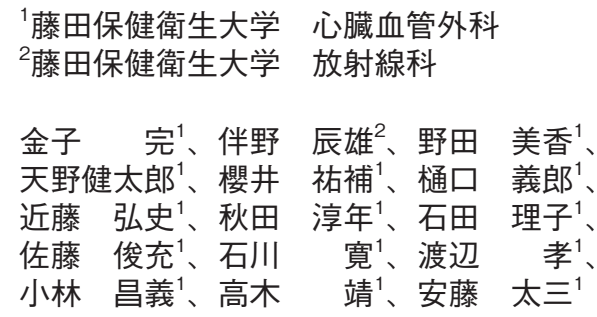

【はじめに】B 型大動脈解離は様々な病態を呈するた め、症例に応じて手術のタイミングや術式を選択す る必要がある。近年ステントグラフトを含めた血管 内治療が普及してきて打り、その適応も拡大しつつ ある。今回、当院で経験した B 型大動脈解離に対す る血管内治療の経験を報告する。【対症】2008 年 11 月から 2012 年 7 月までの間に B 型大動脈解離に対し て血管内治療を行った症例は 8 例であった。全例男 性で、平均年齢は 63 歳 $(46-81$ 歳)。病態の内訳は 急性 $\mathrm{B}$ 型解離 3 例 (带急性 1 例)、外傷性 B 型解離 1 例、慢性 B 解離 3 例、慢性 B 型解離術後の臟器虚血 1 例であった。慢性 B 型解離術後の臟器虚血症例は、 胸部下行大動脈の偽腔拡大に対する下行置換術後に、 末梢側の偽腔血流増加に伴う腹部分枝及び下肢の虚 血を生じた症例であった。手術は、緊急手術 4 例、 待機手術 4 例であった。緊急手術の 4 例は、臟器虚 血に対して entry 閉鎖目的にTEVAR(Gore 社 $\mathrm{TAG}$ )を行った 1 例、上腸間膜動脈 (SMA) 灌流障害 に対してSMA にステント留置を行った 1 例、外傷 性大動脈解離に対する TEVAR (Gore 社 TAG) 1 例、 下行置換術後の臟器虚血に対して真腔の拡大目的に 自作大動脈ステント留置を行った 1 例であった。待 機手術の 4 例は、B 型解離発症 1 ケ月後の亜急性期 に entry 閉鎖目的に TEVAR(自作ステントグラフ 卜)を行った 1 例、慢性 B 型の下行大動脈拡大に対し て entry 閉鎖目的に TEVAR (Gore 社 TAG)を行っ た 2 例 (発症 4 年目と 17 年目)、慢性 B 型の腹腔動脈 起始部の限局性偽腔拡大に対して entry 閉鎖目的に 腹腔動脈に $10 \mathrm{~mm}$ カバードステント留置を行った 1 例であった。【結果】手術、病院死亡はなく、全例軽 快退院した。臟器虚血を呈した症例は全例で治療後 直ちに虚血の改善を認めた。ステントグラフト症例 に打いてエンドリークは認めなかったが、慢性 B 型 解離に対してTEVARを行った 2 例では、1 例で偽 腔の血栓化を全長にわたって認めたが、1 例は re-entry からの血流が残存し、その後瘤径の拡大を認めた。 その他、自作ステントグラフトを用いた症例で、末 梢側の新たな解離所見を認めた。【結語】B 型大動脈 解離に対する血管内治療は比較的安全で有効な治療 法であった。特に急性期の臟器虚血に対する血管内 治療では、侵襲も少なく、速やかに虚血を解除する ことができた。慢性期の entry 閉鎖を行った症例で は re-entry 部からの偽腔への血流が残存する症例が あり、今後 re-entry に対する処置が課題と思われた。

\section{PP-42 2 非急性期 Stanford B 型大動脈解離に対する ステントグラフト治療}

\author{
北里大学 心臓血管外科
}

$\begin{array}{llll}\text { 北村 律、井上 } & \text { 崇道、林 } & \text { 秀憲、 } \\ \text { 榊 健司朗、柴田 } & \text { 深雪、入澤 } & \text { 友輔、 } \\ \text { 友保 貴博、岡 } & \text { 徳彦、華山 } & \text { 直二、 } \\ \text { 鳥井 晋三、宮地 } & \text { 鑑 } & & \end{array}$

【目的】近年、ステントグラフト治療の適応は大動脈 真性瘤のみならず、大動脈解離にまで拡大されつつ ある。当院では Stanford B 型大動脈解離に対して積 極的にステントグラフト治療を行ってきた。しかし ながら、非急性期症例に対するステントグラフト治 療の有効性に関しては未だに明らかではない。そこ で今回、その治療成績を後視方的に検討した。【対象 と方法】1998 年から 2012 年 7 月の間に当院で行われ た大動脈ステントグラフト手術 145 例のうち、B型 解離は 82 例であった。そのうち発症後 14 日以内の 急性期症例と破裂および藏器灌流障害症例を除く非 急性期症例 53 例を対象とした。手術時年齢は平均 $55 \pm 13$ 歳 (23-79 歳)であった。ステントグラフト治療 後の再手術例が 11 例、透析症例が 4 例であった。偽 腔開存症例が 34 例、ULP(ulcer-like projection) が 19 例で、大動脈解離発症から手術までの期間は平均 523 日(15-5678 日)であった。アプローチは腹部大動 脈 1 例、外腸骨動脈 2 例、その他は大腿動脈であった。 ステントグラフトに先行して腸骨動脈にPTAを行っ た症例が 4 例あった。当院における非急性期 B 型大 動脈解離に対するステントグラフト治療の成績を入 院・外来記録をもとに検討した。【成績】周術期死亡 はなく、周術期合併症は 6 例 $(11.3 \%)$ で、脳梗塞 2 例、 Migration 1 例、透析 - 長期呼吸器管理 1 例、大腿動 静脈瘻 1 例、鼠径血腫 1 例であった。偽腔開存症例 34 例のうち術後初回 CT において偽腔の閉塞を認め たものは 4 例(12\%)であった。ULP 症例 19 例のうち 術後初回 CT において ULP 消失かつ新出 ULPを認 めなかったのは 17 例 (89\%)であった。観察期間は平 均 7.2 年で、初回治療後の生存率は 1 年 $100 \% 、 5$ 年 $86 \%$ 、10 年 $62 \%$ 、術後大動脈手術回避率は 1 年 $87 \% 、 5$ 年 $73 \% 、 10$ 年 $59 \%$ であった。偽腔開存例の 術後大動脈手術回避率は 1 年 $81 \% 、 5$ 年 $65 \% 、 10$ 年 $52 \%$ であった。遠隔期死亡 15 例のうち 2 例が大動脈 破裂、2 例が大動脈手術時の周術期死亡であった。 偽腔開存 34 例の非再発率は 1 年 $12 \% 、 5$ 年 $9 \%$ で、 ULP 19 例の非再発率は 1 年 $75 \% 、 5$ 年 $65 \%$ であっ た。【結論】非急性期 B 型大動脈解離に対するステン トグラフト治療の中長期成績は必ずしも良好ではな いことが示された。特に偽腔開存症例対するステン トグラフト治療には限界があると考えられる。 
PP-43 公

B 型大動脈解離に対するステントグラフト内 挿術の早期成績

${ }^{1}$ いわき市立総合般城共立病院 心臓血管外科

2福島県立医科大学付属病院 心臓血管外科

高野 智弘 $^{1}$ 、中村 健 $^{1}$ 、六角 丘 $^{1}$ 、

[はじめに]B 型大動脈解離に対する治療は未だに議 論の余地があるが、最近のステントグラフトの趨勢 から、多くの施設で B 型大動脈解離に対する血管内 治療を積極的に介入してきている。当科でも、2009 年から B 型大動脈解離に対してステントグラフト治 療を施行してきた。[対象]当施設で 2009 年から 2012 年 6 月までにB 型大動脈解離に対してステント グラフト内插術を行った 22 例を対象とした。平均年 齢 $65 \pm 15.3$ 歳 $(21-81$ )、男 $77 \%$ 、急性期 7 例 (発症 後手術移行平均日数: $7 \pm 6$ 日)、慢性期 15 例 (発症後 手術移行平均月数 $32.2 \pm 52.6$ 月) であった。使用した デバイスは TAG: 12 例、TX-2: 9 例、TALENT: 1 例 であった。急性期の治療目的は早期エントリー閉鎖 目的が 2 例、外傷によるものが 2 例、早期瘤拡大が 2 例、破裂が 1 例であった。一方、慢性期症例の治 療目的は、瘤拡大によるものが 11 例、エントリー閉 鎖目的が 2 例、ULP の拡大によるものが 1 例、真腔 狭小化が 1 例であった。ステントグラフトの留置部 位は zone 1 が 1 例、zone 2 が 9 例、zone 3 が 12 例 であった。また、腋窩 - 腋窩動脈バイパスと腋窩 - 左 総頸 - 腋窩バイパスを各 1 例行った。追跡期間は平 均 $14.3 \pm 6.4$ 月であった。[結果]手術死亡、入院死亡 はそれぞれ認めなかった。遠隔死亡は 1 例認めたが、 大動脈解離と無関係であった。大動脈関連合併症は 1 例で、術後に A 型大動脈解離を発症した症例であっ た。エンドリークは 3 例で認めたが、追加手術を行っ た症例は今のところない。解離腔の消失または瘤の 縮小を認めた症例は 15 例 (68\%)であった。[結語]B 型大動脈解離に対するステントグラフト治療は、早 期遠隔成績は良好であった。しかし、解離腔の残存 している症例については今後も慎重な追跡調査が必 要である。

\section{PP-44 文 \\ 腹腔内動脈レベルまで挿入を必要とした胸腹 部大動脈瘤のステントグラフト手術}

\author{
${ }^{1}$ 札幌医科大学 第2外科 \\ ${ }^{2}$ 札幌医科大学 救急救命センター
}

【目的】胸腹部大動脈瘤もしくはそれに準じる大動脈 瘤に対して open surgery ではなくステントグラフト 治療を選択せざるを得ない症例を経験することがあ る。当科での基本方針は人工血管置換術を行ってき たが、それには耐えられないような患者に対しては 血管内治療を行ってきた。そのなかでも腹部分枝動 脈レベルまで landing しなければならないステントグ ラフト治療をまとめて報告する。【方法】2001 年 1 月 から 2008 年 11 月まで当科で施行した胸部領域に対 するステントグラフト治療症例は 438 例であった。 そのうち腹部分枝動脈レベルまで landing しなけれ ばならなかったステントグラフト治療 15 例について 検討した。平均年齢 67.7 歳、男性 10 例、女性 5 例 であり、解離症例は 3 例、非解離症例は 12 例、 15 例のうち緊急手術は切迫破裂の 3 例であった。【結 果】腹部分枝動脈の温存方法は、人工血管もしくは自 家静脈で bypass した debranch 法が 7 例であり、ス テントグラフトに開空を作成して行った fenestration 法が 5 例、腹腔動脈単純閉塞 3 例であった。ステン トグラフトを挿入した範囲を Crawford 分類に当ては めると、 1 型 5 例、 2 型 3 例、 3 型 2 例、 5 型 3 例であっ た。病院死亡は 3 例 (20\%)であり、7 例は遠隔死亡 (肝癌、残存瘤破裂、脳梗塞、消化管出血、急性心筋 梗塞)している。【結語】企業ステントが汎用されてい る現在、胸腹部大動脈瘤に対する血管内治療も行わ れるようになった。当科では open surgeryに耐えら れない患者を選択しているために、本研究での成績 は良好で満足できるものとは言えない。したがって 現時点での治療方針は、胸腹部大動脈瘤に対しての ステントグラフト治療は通常の人工血管置換術に耐 えられない合併症を有する患者に対してのみ選択す るべきと考える。 
PP -45 尔

胸部大動脈疾患におけるパラダイムシフト

${ }^{1}$ 横浜市立大学附属 市民総合医療センター 心臓 血管センター

${ }^{2}$ 横浜市立大学 外科治療学

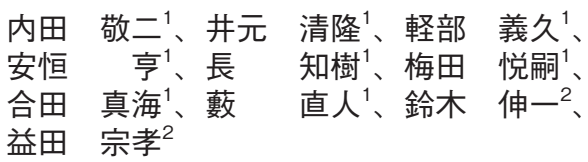

【背景】企業製デバイスの進化とともに TEVAR の適 応は拡大し、その良好な成績が報告されている。し かし TEVAR の適応症例には開胸手術も可能なもの、 開胸手術ほぼ不可能なもの、瘤破裂に対する緊急症 例、合併症を有する B 型解離に対する緊急・準緊急 TEVAR など様々な病態があり、その病態別に成績 を検討する必要がある。【目的】胸部大動脈疾患外科 治療におけるステントグラフトの成績を、適応となっ た病態別に検討することにより、今後の展望につい て考察する。【TEVAR 適応の分類】1.Less invasive (LI) 群：開胸手術も可能だが低侵襲を目指して TEVAR を施行した群。2.Challenge $(\mathrm{CH})$ 群 : risk が 高く待期的には開胸手術の適応とし難いが TEVAR なら可能という、いわば手術適応拡大群。今回の検 討では術前の Risk factor (80 歳以上、再手術、心疾患、 COPD、脳梗塞既往、HD) を 2 個以上有する症例を CH 群とした。3.Lifesaving(LS) 群：緊急または準緊 急で救命的に行われる群、すなわち大動脈瘤破裂や 合併症を有する B 型解離に対する TEVAR 群であ る。【対象及び方法】2007 年以降当センターで TEVARを施行した 142 例をLI、CH、LS の 3 群に 分類し、その成績を retrospective に検討した。死亡 には入院死亡を含め、退院時麻疩の残る脳梗塞や脊 髄梗塞を重篤な合併症と定義した。【結果】LI 群は 73 例 $51 \%$ 平均年齢 74.3 歳で、屈曲開空型を 60 例、 TAG 8 例、その他のデバイスを 5 例で使用した。 手術死亡は 1 例 $1.4 \%$ 、死亡 + 重篤合併症は 3 例 $4.1 \%$ であった。CH 群は 21 例 15\%平均年齢 79.9 歳で、屈 曲開空型 15 例、TAG 4 例、TX2 2 例を使用した。 死亡、死亡＋重篤合併症とも 6 例 29\%であった。LS 群は 48 例 $34 \%$ 平均年齢 70.8 歳で、TAG 31 例、 屈曲開空型を 9 例、その他を 8 例で使用した。死亡 は 6 例 $13 \%$ 、死亡+重篤合併症は 10 例 $21 \%$ であっ た。【考察】LI群の手術成績は良好であり、今後の長 期成績によっては解剖学的難易度を考慮の上で TEVAR が待機手術の第 1 選択となり得る。CH 群、 LS 群の成績は未だ満足できるものではないが、 $\mathrm{CH}$ 群においては開胸困難な患者に手術の可能性をひろ げ、LS 群においてはこの病態に対する開胸手術に比 し成績は改善している。TEVARの適応はさらに拡 大していくと思われる。
PP-46 文

当院における胸部大動脈外科治療へのステ ントグラフト内挿術の影響

\section{小倉記念病院 心臓血管外科}

新井 善雄、羽生 道弥、長澤 淳、

御欴 彰義、瀧本 真也、中根武一郎、

寺西宏王、渡邊隼、辻崇、

宗像 緩宣

【目的】当院における胸部大動脈外科治療へのステン トグラフト内挿術(TEVAR)の影響を検討したので報 告する。【対象と方法】1998 年 1 月以降 2012 年 7 月 までの胸部大動脈瘤に対し手術を行った 1106 例を対 象とし、2008 年 10 月のステントグラフト内挿術導入 前の Pre 群と導入後の Post 群との 2 群に分け、上行 大動脈瘤、弓部大動脈瘤、下行大動脈瘤、胸腹部大 動脈瘤、大動脈解離 Stanford A, Stanford B の各領 域における手術転帰を比較検討した。なお、弓部大 動脈瘤を含む広範囲動脈瘤は弓部大動脈瘤に含め、 TEVARの弓部大動脈瘤の定義は中枢側 landing zone が弓部 3 分枝ないしは上行大動脈に及ぶものと し、当初より GR+TEVAR の Hybrid 手術を予定施 行した症例は除外した。【結果】真性大動脈瘤はPre 群 425 例、Post 群 276 例で、大動脈解離はPre 群 268 例、Post 群 127 例であった。上行大動脈瘤と StanfordA 大動脈解離以外にはステントグラフト内 挿術での治療が行われた。手術転帰結果は表参照。 【結論】領域によってはステントグラフト導入にて胸 部大動脈外科治療にパラダイムシフトが起こりつつ ある。今後のデバイスの進歩によりシフトする傾向 は強まるものと考える。

\begin{tabular}{|c|c|c|c|}
\hline 誩断頖城 & $\begin{array}{c}\text { Pre } \\
\text { 1998.1 2008.9 }\end{array}$ & $\begin{array}{c}\text { Post } \\
\text { 2008.10 2012.7 }\end{array}$ & $\mathrm{P}$ 值 \\
\hline 上行大動脈溜 & $\begin{array}{l}\text { GR } 103 \text { 例 } \\
\text { Mortality } 4.9 \%\end{array}$ & $\begin{array}{c}\text { GR } 77 \text { 例: TEVAR 0 例 } \\
\text { Mortality } 3.9 \%\end{array}$ & $P=$ N.S. \\
\hline 弓部大動脈福 & $\begin{array}{l}\text { GR } 250 \text { 例 } \\
\text { Mortality } 4.4 \%\end{array}$ & $\begin{array}{c}\text { GR } 57 \text { 例 : TEVAR } 69 \text { 例 } \\
\text { Mortality } 3.2 \%\end{array}$ & $\mathrm{P}=\mathrm{N} . \mathrm{S}$. \\
\hline 下行大動脈癣 & $\begin{array}{c}\text { GR } 52 \text { 例 } \\
\text { Mortality } 9.6 \%\end{array}$ & $\begin{array}{c}\text { GR } 1 \text { 例 : TEVAR } 58 \text { 例 } \\
\text { Mortality } 1.7 \%\end{array}$ & $P=$ N.S. \\
\hline 胸腹部大動脈癉 & $\begin{array}{l}\text { GR } 20 \text { 例 } \\
\text { Mortality } 15 \%\end{array}$ & $\begin{array}{c}\text { GR 1 例: TEVAR 13 例 } \\
\text { Mortality } 0 \%\end{array}$ & $\mathrm{P}=$ N.S. \\
\hline 真性大動脈㾇全体 & $\begin{array}{l}\text { GR } \quad 425 \text { 例 } \\
\text { Mortality } 5.6 \%\end{array}$ & $\begin{array}{c}\text { GR } 136 \text { 例: TEVAR } 140 \text { 例 } \\
\text { Mortality } 3.2 \%\end{array}$ & $\mathrm{P}=0.12$ \\
\hline $\begin{array}{l}\text { 大軼脈解離 } \\
\text { Stanford A }\end{array}$ & $\begin{array}{c}\text { GR } 229 \text { 例 } \\
\text { Mortality } 8.7 \%\end{array}$ & $\begin{array}{c}\text { GR } 93 \text { 例 : TEVAR } 0 \text { 例 } \\
\text { Mortality } 4.3 \%\end{array}$ & $\mathrm{P}=$ N.S. \\
\hline $\begin{array}{l}\text { 大動脈解離 } \\
\text { Stanford B }\end{array}$ & $\begin{array}{c}\text { GR } 39 \text { 例 } \\
\text { Mortality } 15.4 \%\end{array}$ & $\begin{array}{c}\text { GR } 10 \text { 例 : TEVAR } 24 \text { 例 } \\
\text { Mortality } 2.9 \%\end{array}$ & $\mathrm{P}=0.04$ \\
\hline 大野脈解離全体 & $\begin{array}{l}\text { GR } 268 \text { 例 } \\
\text { Mortality } 9.7 \%\end{array}$ & $\begin{array}{c}\text { GR } 103 \text { 例 : TEVAR } 24 \text { 例 } \\
\text { Mortality } 3.9 \%\end{array}$ & $\mathrm{P}=0.07$ \\
\hline
\end{tabular}




\section{PP-47 文 \\ オープンステントグラフト挿入時の大動脈内 イベント}

1高知大学医学部外科学 心臓血管外科

${ }^{2}$ 広島大学病院 心臓血管外科

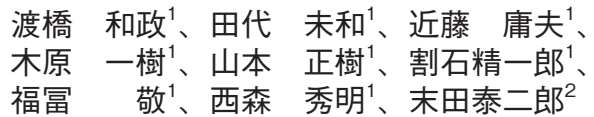

【目的】オープンステントグラフト (OSG) 内挿術では シースカテやガイドワイヤを用いてグラフトを下行 大動脈内に挿入するが、その操作が㑶腫に及ぼす影 響は必ずしも明らかでない。またグラフト留置の評 価は術後となることも多い。我々は経食道心エコー (TEE) モニター下にシースカテで挿入してきたが、 その際の大動脈内イベントや術中グラフト評価を報 告する。【方法】対象は 1997 年以降 OSG を行い TEE 記録を解析し得た遠位弓部大動脈瘤、大動脈解離 47 例 (男性 39 例、平均 71。1 歳。うち 7 例解離)。人工 血管(Intervascular, UB Dacron) にZステント (30mm または $40 \mathrm{~mm}) 2$ 連を縫着したグラフトを径 $10 \mathrm{~mm}$ のシースカテに充填し、大動脈切開部から下 行大動脈に挿入し TEEガイド下にdeployした。 VTR 記録から deploy 部の性状(啉腫の厚さなど)、 カテと大動脈の角度、挿入時、 deploy 後のグラフト の状態などを検討した。【成績】真性瘤症例ではカテ 先端付近の濑腫の厚さが $1.3 \mathrm{~mm} \sim 13.1 \mathrm{~mm}$ (平均 $5.6 \mathrm{~mm})$ で、半数以上が $5 \mathrm{~mm}$ 以上、 5 例では $10 \mathrm{~mm}$ 以上であった。挿入時にはカテ先端が大動脈後壁に 接触し、解離症例ではフラップを圧排していた。カ テと大動脈の角度は deploy 直前に最小で $12 \sim 60^{\circ}$ (平均 $34^{\circ}$ ) であった。大動脈壁や内膜フラップの破 断はなかったが、術後脳梗塞や対麻痺(不全対麻瘏を 含む)を初期の 4 例で認めた。うち 3 例は濑腫が $10 \mathrm{~mm}$ 以上で、カテが籷腫の一部を破壊していた。 その後 TEEガイド下に弪腫を回避しつつカテを進 め、グラフトで张腫を被覆することも可能となった。 再灌流時に非ステント部のグラフトが屈曲し内腔が 狭小化する所見が見られたが、有意狭窄をきたした 症例はなかった。体外循環離脱後、ステント部分の 中枢側への migration 2 例で認めた。いずれも大 弯側に突出する大動脈瘤で、血流が尾側に方向を変 える際にグラフトにかかる力が末梢側のグラフトを 星引したためと考えられた。いずれも術中にはステ ント 1 連で固定された状態で維持されエンドリーク は認めず、術後早期に瘤腔が血栓閉塞し数力月内に 瘤が縮小し、それ以上の migration は回避できた。 【結論】OSGでは見えない部分で合併症に関連しうる 事象が起こるが、透視でリアルタイムに評価するこ とは容易でなく、TEEのメリットと考えられる。ま た外側に突出する瘤では、グラフトの migration に 注意が必要である。

\section{$\mathrm{PP}-48$ 公 当科における企業製 TEVAR の治療成績}

\section{岸和田徳洲会病院心臓血管外科}

$\begin{array}{llll}\text { 薦岡 } & \text { 成年、東上 } & \text { 震一、頓田 } & \text { 央、 } \\ \text { 松林 } & \text { 景二、川平 } & \text { 敏博、東 } & \text { 修平、 } \\ \text { 平松 範彦、降矢 } & \text { 温一 } & \end{array}$

【背景】胸部大動脈瘤手術はステントグラフト(以下 SG)の登場で大きく変化し、特にZone 2 以下では TEVAR が第一選択の治療となりつつあり全国的に 普及し始めている。また病態では真性瘤から解離へ の応用が進んでいるのが現状である。【対象】当科で は 2003 年 12 月の自作 SG に始まり、2010 年 12 月か ら企業製 SGによる TEVAR を施行している。2012 年 7 月までに計 137 例施行し、内訳は自作 : 85 例、 TX2 : 38 例、TAG : 11 例、TALENT : 3 例であった。 今回企業製 SG による TEVAR 52 例について検討し た。尚、自作 SG ではZ Zone 3 以下の適応のみだった が、企業製 SG 導入以後は Zone 0 まで適応を広げて いる。【結果】男性 39 例 - 女性 13 例、平均年齢 74.4 \pm 9.4 歳。病態では真性瘤 34 例、解離関連 18 例であっ た。解離関連では、A 型解離への人工血管置換術後 の施行例が 3 例、その他 15 例は $\mathrm{B}$ 型解離(偽腔開存 9 例、発症から手術まで平均 440 日)への適応であっ た。全体の平均瘤径は $56 \pm 11 \mathrm{~mm}$ 。破裂や切迫破裂 での緊急例を 9 例認めた。開腹下の 2 例以外は全て 大腿動脈アプローチで施行した。SG 留置部位では、 Zone 0 が 1 例、Zone 1 が 3 例、Zone 2 が 15 例、 Zone 3 以下が 33 例であった。SG 留置部位がZone 2 以上の症例では debranch 法として、鎖骨下動脈間 バイパス 18 例、鎖骨下動脈 - 左総頚動脈バイパス 2 例、大動脈 - 左総頚動脈 - 左腋窩動脈バイパス 1 例、 大動脈 - 腕頭動脈 - 左総頚動脈バイパス 1 例を行っ た。その他合併手術として、OPCAB、EVAR、腹部 大動脈人工血管置換、左総腸骨動脈 - 上腸管膜動脈 総肝動脈バイパス、大腿動脈間バイパス、内シャン 卜造設を各々 1 例ずつ行った。平均手術時間 $128 \pm 82$ 分。平均 ICU 入室期間 $2.3 \pm 1.5$ 日、平均術後入院期 間 $21.1 \pm 11.3$ 日であった。術後合併症としては脳梗 塞 2 例、不全対麻痺 2 例を認めたが、術死・病院死 は認めなかった。術後 endoleak は type Iを 2 例、 type II 4 例に認めた。【結語】企業製 SG 導入以後 の自験例の成績は概ね良好と考えられたが、脳梗塞 や対麻痺に関しては今後も課題であると考える。一 方で deviceの発達に伴い、弓部例や解離例への適応. 術式は依然として議論があり、今後の更なる検討が 必要と考える。 
PP-49 尔

胸部下行疾患のステントグラフト導入後の治 療法のパラダイムシフト

神戸大学大学院医学研究科 外科学講座心臓血管外 科

$\begin{array}{llll}\text { 野村 } & \text { 佳克、後竹 } & \text { 康子、木下 } & \text { 史子、 } \\ \text { 小原 } & \text { 大見、中井 } & \text { 秀和、山中 } & \text { 勝弘、 } \\ \text { 宮原 } & \text { 俊介、白坂 } & \text { 知識、竹歳 } & \text { 秀人、 } \\ \text { 坂本 } & \text { 敏仁、大村 } & \text { 篤史、井上 } & \text { 武、 } \\ \text { 南 } & \text { 一司、岡田 } & \text { 健次、大北 } & \text { 裕 }\end{array}$

【背景と目的】ステントグラフトの保険償還により大 動脈瘤の治療の変遷について、当院における胸部大 動脈瘤の手術術式から検討した。【方法】胸部ステン トグラフト保険償還 (2008 年 7 月) 前後で 1999 年 10 月から 2012 年 7 月 31 日までの症例を検討した。当 院ではZone2より中枢の弓部大動脈瘤は Open repair を第一術式としているため除外した。Open surgery (OS) 群、TEVAR 群で評価を行った。TEVAR 群は企業製 (commercial available: CA 群)、自作・ オーダーメイド(Custom+Order made : CO 群)に分 類した。【結果】対象症例は下行大動脈疾患症例 294 例 (OS 133 例、CA 78 例、CO 83 例) とした。症例の 推移は 2008 年以降で TEVAR の増加を認めた。疾 患の内訳 (OS、CA、CO 順) は真性瘤 41.3\%、66.7\%、 $61.4 \%$ 、解離 $48.1 \% 、 17.9 \% 、 22.9 \%$ (OS vs CA、CO $\mathrm{p}<0.01$ ) であった。破裂は OS $18.8 \%$ 、CA 25.6\%、 CO 28.9\%であった。病因死亡は OS 7.5\%、CA 4\%、 CO 3.6\%であった。TEVARの初期成功(瘤の Excludion) はCA 93.6\%、CO 85.5\% であった $(\mathrm{p}=0.06) 。$ 合併症は対麻痺 OS 3 例 $(2.3 \%) 、$ CA 2 例 $(2.6 \%)$ 、 CO 1 例 $(1.2 \%)$ 、不全対麻痖 OS 3 例 $(2.3 \%) 、$ CA 1 例 $(1.2 \%) 、 C O 2$ 例 $(2.4 \%)$ 、脳梗塞 OS 8 例 (6.0\%)、 CA 2 例 (2.6\%)、CO 4 例 $(4.8 \%)$ で、神経合併症は各 群で有意差は認めなかった。遠隔期破裂を CA 0 例、 CO 6 例 $(7.2 \%)$ で認めた $(\mathrm{p}=0.01)$ 。 endoleak は CA 1 例 $(1.2 \%) 、 \mathrm{CO} 18$ 例 $(21.7 \%)$ で認めた $(\mathrm{p}<0.001)$ 。 遠隔期の大動脈関連イベント回避率は OS 1 年 $96.1 \pm$ $1.9 \% 、 3$ 年 $94.8 \pm 2.3 \% 、 5$ 年 $88.9 \pm 4.0 \% 、 \mathrm{CA} 1,3$ 年 $90.6 \pm$ 年 $3.7 \% 、 \mathrm{CO} 89.4 \pm 3.5 \% 、 3$ 年 $74.6 \pm 5.2 \% 、 5$ 年 $60.3 \pm 6.5 \%$ であった。OS、CO 間でのみ有意差を 認めた $(\mathrm{p}<0.001)$ 【結語】CO 群は遠隔期の瘤破裂、 endoleak 認め、企業製ステントグラフと有意差を 認めた。大動脈イベント回避率でも優位差を認めた。 企業製ステントグラフトにより胸部下行大動脈疾患 ではパラダイムシフトが起こった。

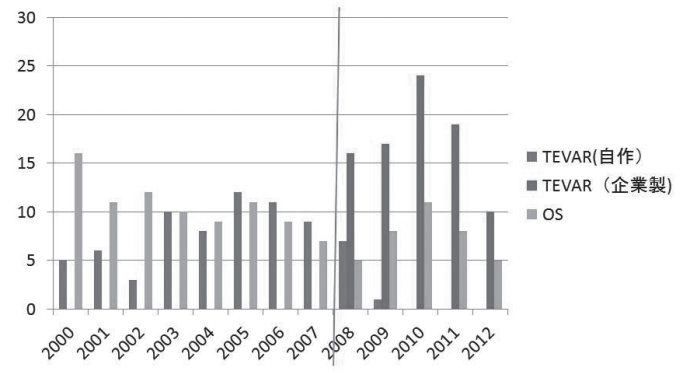

\section{PP-50 年 \\ 超高齢者急性 $A$ 型大動脈解離に対する手術 成績の検討と向上に向けて}

\section{福山循環器病院 心臓血管外科}

\author{
森元 博信、向井 省吾、尾畑 昇悟、 \\ 平岡 俊文、打田 裕明、山根 吉貴
}

【目的】高齢化社会に伴い、高齢者の急性大動脈解離 に直面する機会も増加傾向にある。今回我々は超高 齢者 $\mathrm{A}$ 型急性大動脈解離に対する手術成績と成績向 上に向けての課題について検討した。【対象】2006 年 1 月から 2012 年 7 月に急性 $\mathrm{A}$ 型大動脈解離で緊急手 術を施行した 73 例を対象とした。対象の内 80 歳以 上を $\mathrm{O}$ 群 (14 例)、80 歳未満を $\mathrm{Y}$ 群(59 例) として比 較検討した。平均年齢は $\mathrm{O}$ 群 $83.5 \pm 2.5$ 歳、Y 群 65.8 \pm 9.6 歳。男女比は $\mathrm{O}$ 群 2: $12 、 \mathrm{Y}$ 群 35: 24 であった。 【結果】術前の心囊ドレナージ施行症例や意識障害は 両群間で有意差を認めなかったが、DeBakeyII 型は $\mathrm{O}$ 群 7 例 (50\%)、Y 群 7 例 (11.9\%) と O 群で有意に 多かった。上行〜部分弓部置換は O 群 11 例 (78.6\%)、 $\mathrm{Y}$ 群 13 例 $(22.0 \%)$ と O 群で有意に多く、全弓部置換 は O 群 3 例 (21.4\%)、Y 群 46 例 $(78.0 \%)$ と Y 群で有 意に多かった。メイン送血が順行性の症例は $\mathrm{O}$ 群 7 例 (50\%)、Y 群 43 例 (72.9\%) と有意差は認めなかっ た。手術時間、体外循環時間は $\mathrm{O}$ 群 $347.4 \pm 79.0$ 分、 $201 \pm 39.6$ 分、Y 群 $399.1 \pm 84.5$ 分、241.8 458.0 分と $\mathrm{O}$ 群で有意 $(\mathrm{P}=0.04 、 \mathrm{P}=0.004)$ に短かったが、循環停 止時間は $\mathrm{O}$ 群 $35.7 \pm 17.7$ 分、 $\mathrm{Y}$ 群 $45.4 \pm 14.9$ 分と有 意差 $(\mathrm{P}=0.08)$ は認めなかった。周術期死亡は $\mathrm{O}$ 群 0 例 $/ \mathrm{Y}$ 群 3 例 (5\%)、長期挿管 (72 時間以上) は $\mathrm{O}$ 群 3 例 $(21.4 \%) / \mathrm{Y}$ 群 16 例 $(27.1 \%)$ 、平均在院日数は $\mathrm{O}$ 群 $28.4 \pm 12.9$ 日 $/ \mathrm{Y}$ 群 $27.7 \pm 13.9$ 日とそれぞれ両 群間で有意差を認めなかったが、生存者の自宅退院 率は $\mathrm{O}$ 群 8/14 例 (57.1\%)、Y 群 50/56 例 (89.2\%) と $\mathrm{O}$ 群で有意 $(\mathrm{P}=0.01)$ に低かった。術後合併症は、出 血再開胸 $\mathrm{O} / \mathrm{Y}: 0 / 3$ 例、縦隔炎 $\mathrm{O} / \mathrm{Y}: 0 / 1$ 例、脳梗 塞 $\mathrm{O} / \mathrm{Y}: 0 / 5$ 例であった。 5 年生存率は $\mathrm{O}$ 群 $83.5 \pm$ $11 \% 、 Y$ 群 $88.6 \pm 4.5 \%$ と有意差は認めなかった。【考 察】高齢者群では entry 切除を目的とした上行〜部分 弓部置換術の比率が高かった。このため手術時間や 体外循環時間が有意に短く、術後成績は若年者群と 有意差を認めなかった。自宅退院率が低い原因は、 呼吸不全やリハビリ目的によるもので、早期自宅退 院に向けPTによる呼吸理学療法やリハビリを積極 的計画的に介入させる必要があると思われた。 


\section{PP-51 尔 \\ 超高齢者 (80 歳以上)の急性 $A$ 型解離症例に 対する手術成績}

\author{
自治医科大学附属さいたま医療センター \\ 外科 \\ 木村 直行、武部学、吉崎 隆道、 \\ 中野 光規、佐藤 哲也、西 智史、 \\ 野中崇夫、堀 大治郎、田村敦、 \\ 木村知恵里、安達 晃一、由利 康一、 \\ 松本 晴信、山口 敦司、安達 秀雄
}

【目的】患者年齢の高歯化に伴い、急性 $\mathrm{A}$ 型解離にお いても 80 歳以上の症例は増加している。近年の IRAD 研究で、80 歳以上の急性 A 型解離では、内科 的治療と比較した外科的治療による在院死亡率の減 少が報告され、手術治療の有効性が示唆されている。 今回、我々は、当施設での 80 歳以上の超高齢の急性 $\mathrm{A}$ 型解離症例の手術成績を解析した。【対象・方法】 1991 年 1 月から 2011 年 1 月までに緊急手術を行った 急性 A 型解離 443 例 (男 232 例、平均年齢 $62.2 \pm 12.1$ 才(23-92 歳)を、A 群(超高齢者群 ; 80 歳以上、 $\mathrm{n}=30$ 、 平均年齢 $83.2 \pm 2.8$ 才) と B 群 (非超高齢者群; 80 歳 未満、 $n=413 、 61.7 \pm 11.3$ 才) に分類し、併存疾患 · 術前状態、術式、早期成績、遠隔成績を比較した。 平均追跡期間は $5.8 \pm 4.4$ 年であった。【結果】男性比 率 は、A 群 $30 \%(9 / 30) 、 B$ 群 54\% (223/413) で、A 群で有意に低く $(\mathrm{P}=0.01) 、 \mathrm{~B}$ 群のみ Marfan 症候群 (3\%) と二尖弁 $(1 \%)$ を認めたが有意差なく、併存疾 患(高血圧、糖尿病、COPD など) と術前状態 (ショッ ク、意識障害、臓器潅流障害)も、両群間に有意差は 認めなかった。術式は、リング付グラフト；A 群 7\% (2/30)、B 群 3\% (14/413)、上行置換 ; A 群 $83 \%$ (25/30)、B 群 $81 \%(335 / 413)$ 、上行弓部置換 ; A 群 10\% (3/30)、B 群 16\% (64/413) で、手術時間 · 人工 心肺時間・送血部位・エントリー切除率を含め、両 群間に有意差は認めなかった。在院死亡率・ICU 滞 在日数はA 群 $10 \%(3 / 30) 、 B$ 群 $9.7 \%(40 / 413) 、 A$ 群 $6.5 \pm 4.4$ 日、B 群 $7.3 \pm 6.6$ 日で差異なく、合併症発 生率(出血再開胸、気管切開など) も有意差を認めかっ た。生存例の 5 年累積生存率は、A 群 $66 \%$ 、B 群 $86 \%$ と A 群で低く $(\mathrm{P}<0.05)$ 、遠隔死因は A 群; 心 不全 5 例、肺炎 4 例、癌 1 例、脳血管疾患 1 例、他 1 例、 B 群; 癌 20 例、心不全 18 例、大動脈破裂 15 例、 脳血管疾患 10 例、肺炎 6 例、他 6 例で、肺炎での死 亡が A 群で高かった $(\mathrm{P}<0.05)$ 。結語】超高齢者に 対する急性 A 型解離の早期治療成績は良好で、遠隔 期も超高齢者群で大動脈関連死は認めなかった。 80 歳以上の高齢者の手術適応には慎重な検討を要する が、手術治療により予後の改善が期待できると思わ れた。

\section{PP-52 公 超高齢者に対する急性 $A$ 型大動脈解離緊急 手術の検討}

\author{
埼玉医科大学 国際医療センター 心臓血管外科
}

$\begin{array}{lrrrr}\text { 神戸 } & \text { 将、林 } & \text { 祐次郎、高澤 } & \text { 晃利、 } \\ \text { 岡田 } & \text { 至弘、道本 } & \text { 智、池田 } & \text { 昌弘、 } \\ \text { 高橋 } & \text { 研、森田 } & \text { 耕三、小池 } & \text { 裕之、 } \\ \text { 中嶋 } & \text { 博之、上部 } & \text { 一彦、朝倉 } & \text { 利光、 } \\ \text { 井口 } & \text { 篤志、新浪 } & \text { 博 } & & \end{array}$

【目的】近年、社会の高齢化や医学の進歩などにより、 80 歳を越える超高齢者に対しても積極的に心大血管 手術が行われるようになってきたが、その成績は確 立されていない。我々は超高齢者に対しても積極的 に心大血管手術を行っている。今回、超高齢者に施 行したStanord A 型急性大動脈解離に対する緊急手 術の成績を検証した。【方法】2007 年 4 月から 2012 年 3 月までの 5 年間で、Stanford A 型急性大動脈解 離に対し 161 例の緊急手術が施行された。そのうち 80 歳以上の症例は 21 例あった。男女比は男 5 例、 女 16 例で、80 歳未満に比較し有意に女性が多かっ た。大動脈解離の型は、80 歳未満で血栓閉塞型が 48 例、偽腔開存型が 92 例であったのに対して、80 歳 以上では血栓閉塞型が 12 例、偽腔開存型が 9 例で あった。 80 歳以上では術前に心房細動を合併してい る割合が $14.2 \%$ (3/21 例) と、80 歳未満の $2.9 \%$ (4/140 例)に対して有意に高かった。基本方針は年齢にかか わらずエントリー切除である。エントリーが上行大 動脈にある場合は上行(部分弓部) 置換術を行い、DeBakey I 型の場合はステントグラフト内挿術(遠位弓 部)を追加する。エントリーが弓部にある場合は全弓 部置換術を行っている。【成績】在院死亡は 80 歳以上 が 1 例 $(4.8 \%)$ であり、80 歳未満の 7 例 $(5.0 \%)$ と比較 して有意差を認めなかった。ICU 滞在日数は 80 歳以 上が 13.4 日に対して 80 歳未満が 10.1 日と差を認め なかった。挿管日数は 80 歳以上が 8.3 日に対して 80 歳未満が 5.9 日であり有意差はなかった。在院日数も 80 歳以上が 43 日に対して 80 歳未満は 30 日と有意 差を認めなかった。その他、脳梗塞や心大血管合併 症、腎機能障害などの発生に両群間で有意差は認め なかった。【結論】80 歳以上の超高齢者に施行した Stanford A 型急性大動脈解離に対する緊急手術の成 績は、80 歳未満と比べて遜色ないものであった。我々 の急性大動脈解離に対する治療方針は超高齢者に対 しても安全に行え得るもので、妥当と考えられた。 
PP-53 文

80 歳以上の超高齢者の A 型急性大動脈解離 に対する手術成績

\author{
川崎幸病院 大動脈センター \\ 藤川 拓也、関根 裕司、大島 \\ 増山 慎二、小野畺、山本晋、 \\ 笹栗 志朗
}

[背景]高齢者の増加に伴い、80 歳以上でStanford A 型急性大動脈解離を発症する患者も増加傾向にある。 手術のリスクを考慮し、保存的治療が選択される場 合も少なくないが、その場合の予後は極めて不良で ある。当施設では積極的に超高齢者の A 型解離に対 する手術に取り組んでいる。我々が経験した超高齢 者の $\mathrm{A}$ 型解離の手術成績について報告するとともに 退院時の ADL についても検証する。[方法]2008 年 1 月から 2012 年 7 月までの間に当院で施行された胸骨 正中切開による胸部大動脈手術 608 例のうち、80 歳 以上の高齢者に対する手術は 110 例であり、そのう ち A 型解離に対する手術 19 例を対象とした。なお 同期間に、患者および家族の手術希望があるにもか かわらず非手術となった症例はなかった。これらの 症例の術後の ADL について、退院時の病歴から、厚 生労働省に寄る日常生活自立度判定基準に基づき活 動性を 8 段階に分類し、評価した。[結果］19例の平 均年齢は 83 歳、最高は 90 歳であった。そのうち 10 例が男性であった。DHCA/RCP で行ったのが 14 例、 DHCA/RCP/SCP で行ったのが 5 例であった。全弓 部置換術を行ったのが 4 例、部分弓部置換術を行っ たのが 15 例であった。併施手術は基部置換 1 例、 Aorto-bifemoral bypass1 例であった。手術死亡は 4 例で、 malperfusion3 例、肺炎 1 例であった。手術死 亡 4 例を除く 15 例の退院時 ADL は 8 例が J1 または J2 に保たれた。[結語] 80 歳以上の高齢者の Stanford $\mathrm{A}$ 型急性大動脈解離であっても、緊急手術を行い、 救命することは十分に可能である。また術後 ADL も 比較的良好に維持されており、本年齢層に対する積 極的治療を支持するものである。

\section{PP-54 \\ 解離性大動脈瘤 (Stanford type A) に対する 手術の遠隔成績}

\author{
市立四日市病院心臓血管外科
}

爲西 顕則、松村 泰基、岡本 浩

目的】近年、解離性大動脈瘤 (Stanford type A)の手 術成績は向上し、救命率も改善している。今回私達 は解離性大動脈瘤に対する外科手術の遠隔成績を検 討したので報告する。【方法】対象は 1991 年 10 月か ら 2011 年 6 月までに、当施設にて施行した解離性大 動脈瘤(Stanford type A) に対する手術 99 症例であ る。遠隔期生存率を Kaplan-Meier 法で算出し、それ に寄与する因子を Log rank 検定、Cox ハザードモデ ルにて検討した。また、心臓関連 event 回避率、血 管関連 event 回避率、及び re-operation 回避率も同 様に算出し、検討した。【成績】年齢 $62.7 \pm 12.0$ 歳、 男女比は 54: 45 であった。術式としては上行置換が 90 例、弓部置換が 9 例であった。遠隔期死亡は 18 例で、心血管関連は胸部大動脈瘤破裂 2 例、心不全 1 例、VSP 1 例であった。 5 年、10 年、15 年生存率は、 89.8\%、78.3\%、64.4\%であった。単変量解析では 75 歳以上 $(p=0.0256)$ 、男性 $(p=0.0102)$ 、腎不全 $(p=0.0205)$ 、 糖尿病 $(\mathrm{p}=0.0261)$ 、契煙 $(\mathrm{p}=0.0139)$ が有意な因子で あったが、多変量解析では有意な因子はなかった。 心臓関連 event は心不全 10 例、弁膜症増悪 4 例、 AMI 1 例、ペースメーカー移植 1 例であり、5 年、 10 年、15 年回避率は $91.6 \% 、 57.7 \% 、 49.5 \%$ であった。 多変量解析では女性 $(\mathrm{p}=0.0428)$ 、術後呼吸不全 ( $p=0.0288)$ が有意な因子であった。血管関連 event は大動脈解離 (Stanford type B) 4 例、弓部大動脈瘤 3 例、下行大動脈瘤 3 例、脳出血 3 例であり、 5 年、 10 年、 15 年回避率は $87.6 \% 、 67.3 \% 、 52.9 \%$ であった。 多变量解析では 75 歳以上 $(\mathrm{p}=0.0500)$ が有意な因子で あった。Re-operation は弓部置換 2 例、弓部下行置 換 1 例、Bentall 1 例、弓部置換 + AVR 1 例、上行置 換 + AVR 1 例、AVR 4 例であった。 5 年、10 年、15 年回避率は $91.4 \% 、 71.6 \% 、 59.7 \%$ であった。単変量 解析では Marfan 症候群 $(\mathrm{p}=0.0120)$ が有意な因子で あったが、多変量解析では有意な因子は認めなかっ た。それぞれの統計的解析では、いずれも術式は有 意な因子とはならなかった。【結論】解離性大動脈瘤 (Stanford type A) に対する手術の遠隔成績を検討し た。遠隔期心血管関連死亡は 4 例のみであったが、 術式などによる有意な因子は認めなかった。 


\section{PP-55 \\ Stanford A 型急性大動脈解離術後遠隔期に 再手術を要した症例の検討}

\author{
麻生飯塚病院 心臓血管外科 \\ 松山翔、谷口賢一郎、松元崇、 \\ 内田 孝之、安藤 廣美、福村 文雄、 \\ 田中 二郎
}

【目的】Stanford A 型急性大動脈解離術後遠隔期に大 動脈に対し再度外科的介入を必要とした症例につい て検討する。【対象】1996 年 1 月から 2012 年 3 月まで に当院で急性大動脈解離に対する初回手術を施行し た症例は 133 例で、初回手術の際の手術脂肪は 3 例、 30 日死亡は 21 例および院内死亡例は 9 例であった。 残りの 100 例のうち再度大血管手術を必要とした症 例は 9 例であった。100 例中男性 39 例、女性 61 例 であり、術後の CT で偽腔開存を認めた症例は 35 例 であった。再手術を必要とした 9 例のうち男性 5 例、 女性 4 例であった。再手術を要した 9 例の初回手術 の内容は上行大動脈置換術が 2 例、条項大動脈置換 +大動脈弁つり上げ術が 1 例、弓部大動脈置換術が 3 例、弓部大動脈置換術 +大動脈弁つり上げ術が 1 例、Bentall 手術が 1 例、Bentall 手術 $+\mathrm{CABG}$ が 1 例であった。再手術時の年齢は 42 歳から 82 歳 (中央 值 65 歳)で、初回手術から再手術までの期間は 80 日 から 4250 日(中央值 889 日)であった。9 例中 2 例が マルファン症候群であり、9 例うち 5 例に初回手術後 に造影 CT にて偽腔開存を認めた。9 例中 8 例に初回 手術でGRF glue が使用されていた。再手術を必要 とした原因としては、吻合部仮性瘤が 2 例、人工血 管吻合部遠位側の解離性大動脈瘤の拡大が 4 例、人 工血管近位側瘤の拡大もしくは解離が 2 例、大動脈 弁閉鎖不全症および溶血性貧血を 1 例に認めた。再 手術としては上行大動脈置換術が 1 例、再上行大動 脈置換術が 2 例、再上行大動脈置換術 + 大動脈弁置 換術が 1 例、弓部大動脈置換術が 1 例、下行大動脈 置換術が 1 例、胸腹部大動脈置換術が 2 例、大動脈 弁置換術が 1 例であった。2 例を術後LOS、ARDS にて失ったが、7 例は生存退院した。男女比、GRF glue の使用の有無、偽腔開存の有無、マルファン症 候群の有無についてオッズ比を測定したところ、偽 腔開存(オッズ比: 2.54)、マルファン症候群の有無 (オッズ比: 25.71) が有意な危険因子であった。今回 の結果からは GRF glue は再手術の危険因子とは言 えなかった。【考察および結語】急性大動脈解離術後 の再手術率は $9 \%$ であり妥当と考えられた。マルファ ン症候群、偽腔開存は急性大動脈解離術後再手術の リスクファクターと考えられたが、GRF glue の使用 はリスクファクターとは言えなかった。マルファン症 候群、偽腔開存例については慎重な経過観察が必要 と考えられた。GRF glue および Bio glueについて の今後の検討が望まれる。

\section{PP-56 定 \\ 急性 $\mathrm{A}$ 型大動脈解離の遠隔期成績(再建方 法と偽腔開存、再手術との関連)}

\author{
名古屋第二赤十字病院 循環器センター外科 \\ 加藤 瓦、内田健一郎、宗像 寿祥、 \\ 日尾野 誠、藤井恵、高味 良行、 \\ 酒井 喜正、田嶋 一喜
}

【背景】急性大動脈解離の遠隔期成績の報告は多く存 在するが、慢性期の大動脈の変化は報告により異な る。当院における急性大動脈解離の手術症例をもと に再建方法と遠隔期成績の関連を検討した。【対象と 方法】当科で 2000 年 1 月から 2011 年 12 月までに 行った急性 A 型大動脈解離 131 例を対象にした。男 性 76 例、女性 55 例、平均年齢は $64.4 \pm 13$ 歳であった。 手術は、右腋窩動脈と左右どちらかの大腿動脈送血、 右房脱血で人工肺を確立し、膀胱温 $25^{\circ} \mathrm{C}$ で選択的 脳灌流を併用するのを基本とし entry closure を第一 として置換範囲を決定している。IIIb 逆行解離の場 合は患者の年齢、基礎疾患などを考慮して弓部大動 脈全置換か上行大動脈置換術を選択している。2004 年までは GRF glue を用いたが、それ以降は外膜翻 転かフェルトを用いて断端形成を行っている。2011 年よりバイオグルーを断端形成時に偽腔に用いてい る。【結果】入院死亡は 16 例 (12.2\%)であった。観察 期間中 7 例の遠隔死亡があり内訳は瘤破裂 2 例、 stroke3 例、癌死 1 例、肺炎 1 例であった。転院によ る CT 追跡困難が 12 例あった。大動脈径が胸腹部レ ベルまでで $55 \mathrm{~mm}$ を超えた例は 12 例であった。再手 術は 5 例(瘤拡大 4 例、graft 感染 1 例)に施行した。 弓部全置換術を行うと遠位弓部の偽腔の開存、拡大 は有意に少なくなったが胸腹部レベルで偽腔の開存、 拡大を生ずることが比較的多かった。【考察】GRFを 用いた時期の症例も含まれるが GRF が原因と推測さ れるような問題は認めず適正な使用方法であったと 思われる。置換範囲の選択についても、遠隔期の再 手術が少ないことから当科の戦略は妥当と考える。 しかし大動脈径の拡大がありながら高齢や合併疾患 により再手術を躊躇している例や適応外とした症例 術後 10 年を経過した症例に散見されるため、さらな る長期遠隔期の検討を必要とする。2011 年からバイ オグルーを使用しているが偽腔開存の有無に現在の ところ大きな差は認めない。 
PP-57 is

$\mathrm{A}$ 型急性大動脈解離血栓閉塞型に対する初 期保存的加療の妥当性

小倉記念病院心臓血管外科

$\begin{array}{lrll}\text { 渡邊 } & \text { 隼、羽生 } & \text { 道弥、新井 善雄、 } \\ \text { 長澤 } & \text { 淳、御厨 } & \text { 彰義、中根武一郎、 } \\ \text { 瀧本 } & \text { 真也、寺西 } & \text { 宏王、过 } & \text { 崇 }\end{array}$

【背景】A 型急性大動脈解離血栓閉塞型に対して早期 に外科的に介入するか、保存的に加療するかは未だ に議論の残るところである。【対象と方法】2004 年 3 月から 2012 年 3 月までに当科で保存的に加療した A 型急性大動脈解離血栓閉塞型 (上行大動脈が血栓閉塞 している症例 $) 50$ 症例を研究対象とした造影 CT での フォローを入院翌日に施行、その後 1 週間おきに造 影 CT でフォローした、4 週間経過をみて退院、その 後は一ヶ月、 3 ヶ月、半年以後 1 年おきにCT フォロー を行った。生存率、大動脈関連死亡回避生存率、大 動脈関連イベント (再解離、再疎通、破裂、潰瘍様突 出像(ULP) 拡大、大動脈拡大、大動脈関連手術) 回避 生存率を Kaplan-Meier 法で検討した。フォローアッ プ期間は $24.2 \pm 18.3$ ヶ月、フォローアップ率は $100 \%$ であった。【結果】平均年龃は $71.9 \pm 10.1$ 歳、男性 32 例、 50 例中 15 例は入院時の CT で ULPを認めた。 2 年間での全死亡回避率は $93.8 \%$ 、大動脈関連死亡 回避率は $96 \%$ 、大動脈関連イベント回避生存率は $54.6 \%$ であった。経過中に再疎通を 11 例、ULP 拡大 を 11 例に認め、その 22 例中 12 例に待機的に手術を 行った。手術までの平均期間は $37.4 \pm 25.6$ 日であっ た。全例生存退院し、平均術後入院日数は $26.1 \pm 16.1$ 日であった。大動脈関連死亡症例は 2 例で発症 13 日 目に大動脈破裂し手術を進めたが拒否された症例と 発症 65 日目に再解離した症例であった。【考察】A 型 急性大動脈解離血栓閉塞型は解離発症後 1 ケ月程度 で再疎通および再解離を呈する症例が半数程度みら れたが、それらの症例に対する手術成績は良好であっ た。短期における大動脈関連死亡回避率も良好な成 績であった。今回の結果では初期保存的加療は有効 な治療戦略となりうると考えられた。

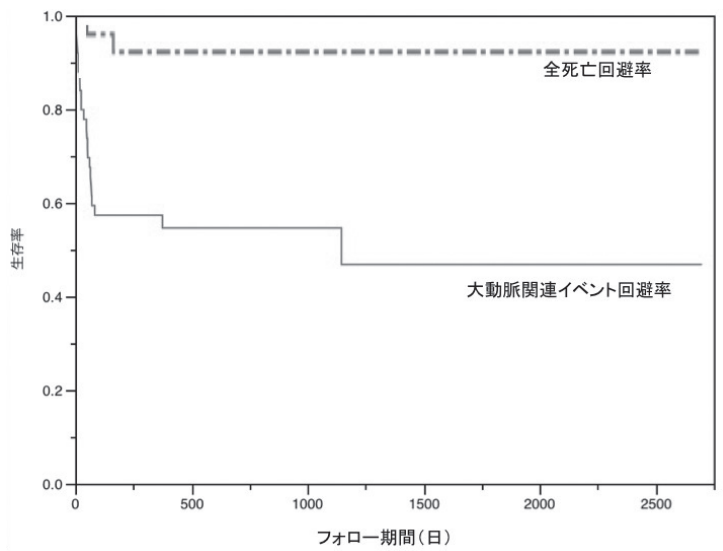

PP-58 年

術前拡張能は冠動脈バイパス術後遠隔期心 イベントに対して影響を及ぼすか?

\section{榊原記念病院 心臓血管外科}

林祥子、福井 寿啓、田端実、
高梨秀一郎

【背景】虚血性心疾患に対して CABGを施行した低心 機能 (収縮能) 患者の予後は不良とされているが、拡 張能を指標とした検討は少ない。Off-pump CABG 患 者を術前拡張能の正常群と異常群に分けて予後につ いて比較検討した。【対象・方法】2008 年から 2010 年 に Off-pump CABG を行った症例のうち、術前超音 波検査を施行した 508 例を対象とした。Primary endpoint を心イベント (心不全入院、入院治療を要す る不整脈、心関連死亡、心筋梗塞) とし、術後 1 年の 追跡期間で検討した。拡張能指標としては、E/e を 用い、15 未満を正常群 ( $\mathrm{N}$ 群 366 例)、15 以上を異常 群 (A 群 142 例) と定義した。これらの術前・術後の 因子を比較検討した。【結果】術前背景として、年齢 は A 群が高く( $\mathrm{N}$ 群 $67.1 \pm 10.1$ 対 $\mathrm{A}$ 群 $71.2 \pm 8.4$ 歳、 $\mathrm{p}<0.01) 、$ 性別は A 群で女性が多かった $(\mathrm{N}$ 群女性 48 例 $13 \%$ 対 A 群 31 例 29\%、p < 0.01)。陳旧性心 筋梗塞例は両群で差を認めなかった $(\mathrm{N}$ 群 152 例 $41 \%$ 対 A 群 70 例 $49 \% 、 \mathrm{p}=0.11)$ 。糖尿病患者は A 群で多かった (N 群 150 例 40\%対 A 群 77 例 54\%、p $<0.01)$ 。術前超音波検査に関して、左室駆出率は $\mathrm{A}$ 群で低く( $\mathrm{N}$ 群 $57.2 \pm 9.6 \%$ 対 $\mathrm{A}$ 群 $52.2 \pm 12.8 \%$ 、p $<0.01)$ 、左房径は $\mathrm{A}$ 群で拡大していた $(\mathrm{N}$ 群 $36.0 \pm$ $4.9 \mathrm{~mm}$ 対 A 群 $38.6 \pm 5.2 \mathrm{~mm} 、 \mathrm{p}<0.01)$ 。Mild 以上 の僧帽弁逆流は $\mathrm{A}$ 群で多く認めた $(\mathrm{N}$ 群 16 例 4\% 対 A 群 19 例 13\%、p < 0.01)。手術因子として、末梢 側吻合数は両群間で差を認めなかった $(\mathrm{N}$ 群 $4.2 \pm 1.2$ 対 A 群 4.1 $\pm 1.1 、 \mathrm{p}=0.56)$ 。心イベントは 1 年回避率 で $\mathrm{N}$ 群 $95.9 \pm 4.1 \%$ 、 $\mathrm{A}$ 群 $88.6 \pm 11.4 \%$ であり $(\mathrm{p}<$ 0.01)、N 群で良好であった。心イベントの危険因子 は多変量解析にて、術前 $\mathrm{E} / \mathrm{e}$ ' 15 以上(オッズ比 2.483、95\%信頼区間 1.066_5.782、p = 0.04)のみであっ た。【結語】off-pump CABG 患者において、術前拡張 能低下例は心イベントを起こしやすいと考えられた。 それゆえ、術前拡張能もリスク評価の一つとして考 えるべきである。 


\section{PP-59 $\lesssim$ \\ 低心機能虚血性心疾患に対する単独冠動脈 バイパス手術}

\author{
三井記念病院 心臓血管外科 \\ 楠原 隆義、大野 貴之、李 洋伸、 \\ 三浦 純男、福田 幸人、宮入 剛、 \\ 高本 眞一
}

【緒言・目的】低心機能を伴う虚血性心疾患患者に対 する治療としては積極的薬物治療、冠動脈バイパス 手術 $(\mathrm{CABG}) 、$ 左室形成術といった選択肢がある。 現代の積極的薬物治療下でも低心機能患者に対する CABG は心血管死 2 次予防効果が大きいことがわ かっている[エビデンスレベル B]。しかし低心機能 患者に対するCABG はリスクが高く、慎重な手術手 技と周術期管理が必要である。当院での CABG 成績 を示すとともに低心機能虚血性心疾患患者に対する 治療戦略について考察したため報告する。【対象・方 法】2011 年 1 月から 2012 年 7 月の間に単独 CABG 施 行した連続 134 人を $\mathrm{EF} \leqq 35 \%$ 群(16 例) と $\mathrm{EF}>$ $35 \%$ 群(118 例)に分け比較した。両群の患者背景は平 均年齢 67.1 歳 vs. 66.9 歳、平均 EF $26.8 \%$ vs. $60.5 \%$ 、 緊急手術 2 例 (13\%)vs. 19 例 (16\%) であった。【結 果】オフポンプ率は $63 \%$ vs. $97 \%(\mathrm{P}$ 值 < 0.01)、平均 吻合数 3.8 本 vs. 3.5 本 (P 值 0.32 )、両側内胸動脈使 用率 $38 \%$ vs. $62 \%$ (P 值 0.064 )、IABP 使用率は $13 \%$ vs. $5 \%$ (P 值 0.24 )、手術場抜管率 $38 \%$ vs. $69 \%$ (P 值 $0.015) 、$ 平均術後入院期間 36 日 vs. 18 日 (P 值 0.061) であった。病院死はともに急性心筋梗塞症例での 1 人ずつ、脳梗塞はゼロであった。縦隔炎は低心機能・ 糖尿病患者 1 人であった。【考察】低心機能患者群に おいてオフポンプ率、手術場抜管率は低く、術後入 院期間の延長を認めた。しかし両群とも急性心筋梗 塞の緊急症例を除いて病院死はなく、成績は良好で あった。当院では低心機能患者に対しては左室形成 術の治療効果よりも積極的に吻合数を多くすること により CABG 単独の心臓死 2 次予防効果を期待して いる。また手術死亡率、脳梗塞率を極力低くするた めにオフポンプ手技を第一選択とし、術前に安静と 利尿薬によって適正体重まで心不全をコントロール した後に CABG 施行している。心拡大著明な患者で は安全のために on pump beating CABG を採用して いるが、心不全が十分にコントロールできていれば EF20\%以下の超低心機能症例でもオフポンプ CABG は可能であった。【結語】低心機能に対する CABG は 手術手技・管理に工夫が必要であるが、成績は良好 であった。

\section{PP-60 2 s \\ 細径冠動脈に対する 4 点結節側々吻合の有 用性}

\author{
自治医科大学 心臓血管外科学
}

$\begin{array}{lrrr}\text { 村岡 } & \text { 新、川人 } & \text { 宏次、楜澤 } & \text { 壮樹、 } \\ \text { 高澤 } & \text { 一平、佐藤 弘隆、相澤 } & \text { 啓、 } \\ \text { 坂野 } & \text { 康人、上西祐一朗、大本 } & \text { 伸一、 } \\ \text { 齊藤 } & \text { 力、小西 宏明、三澤 } & \text { 吉雄 }\end{array}$

(はじめに)

近年、虚血性心疾患に対するカテーテル治療の進歩 で冠動脈バイパス術の適応となる症例は重症化して おり、内径が小さく、性状の悪い冠動脈への吻合が 求められることが多くなっている。われわれは、径 $1.0 \mathrm{~mm}$ 前後の細径冠動脈に対して、吻合の quality を上げるため、田代ら、田邊らが報告した 4 点結節 の側々吻合を行っているので、その有用性を検討し た。

(方法)

2010 年 3 月から 2012 年 7 月までに施行された冠動 脈バイパス術で 4 点結節側々吻合を行なった症例は 38 症例 (47 吻合)であった。症例の内訳は、男 26 例、 女 12 例、平均年齢 66 9 歳であった。吻合は 8-0 ポ リプロピレン糸を用いて、4 箇所の結節縫合で側々吻 合を行い、leakがあった場合は適宜、外膜に糸かけ して縫合を追加した。

(結果)

術式の内訳は、cardioplegic arrest：37 吻合 $(28$ 例)、 on pump beating 3 吻合 (3 例)、off pump が 8 吻合 $(7$ 例)であった。冠動脈吻合箇所は LAD : 3 吻合、D1： 20 吻合、D2:3 吻合、HL : 3 吻合、OM : 4 吻合、 $\mathrm{PL}: 6$ 吻合、4PD：5吻合、4AV：2吻合であった。 ほとんどが sequential 吻合の中枢側(44吻合)で、末 梢側は 3 吻合であった。使用グラフトはLITA 17 吻 合、RITA 5 吻 合、RGEA 2 吻 合、RA 1 吻 合、SV 22 吻合であった。吻合形態は diamond 型 38 吻合、 parallel 型 9 吻合であった。術後早期(術後 10 日〜 3 週間)の冠動脈造影施行例は $43 / 47$ 吻合 $(91 \%)$ であっ た。早期グラフト開存率は $100 \%$ で、吻合形態に問題 がある症例はなかった。動脈グラフトの場合は細い 血管同士なので吻合口のミスマッチはなかったが、 静脈グラフトでは、細い冠動脈に合わせるため、静 脈グラフト径に比較し吻合口が小さくなる傾向が あった。

(結語)

4 点結節側々冠動脈吻合は、グラフト種類、冠動脈の 性状に関係なく、確実な吻合が可能で良好な早期開 存率を示した。本法は細い動脈グラフトの sequential 吻合において有用であったが、静脈グラフトでは吻 合口が小さくなる傾向があり、遠隔成績を検討する 必要がある。 


\section{超高齢者に対する冠動脈バイパス術の治療 成績}

筑波大学 心臓血管外科

坂本 裕昭、徳永 千穂、相川 志都、

榎本 佳治、佐藤 藤夫、平松 祐司、

榊原謙

【目的】WHO が 2012 年に発表した国別平均寿命は日 本が男女平均 83 歳で世界第 1 位であり、今後も超高 齢者に対する心臓血管手術は益々増加していくこと が予想される。超高齢者に対する手術では特に低侵 襲化が必要と考えられ、当院でも近年は OPCABを 第一選択にして低侵襲化に努めている。今回我々は 80 歳以上の超高齢者に対する心臓血管手術のうち特 に冠動脈バイパス術に関する治療成績を検討した。 【方法】2003 年 1 月から 2012 年 7 月までに当院で施 行した単独 $\mathrm{CABG}$ の 365 例を対象とした。 80 歳以上 を超高齢者群 $(\mathrm{E}$ 群)、80 歳未満を非超高齢者群 $(\mathrm{Y}$ 群) として術前、術中、術後因子について retrospectiveに検討した。【結果】E 群(平均年齢 82 歳) 16 例、 $\mathrm{Y}$ 群(平均 65 歳) 349 例。 $\mathrm{E}$ 群と $\mathrm{Y}$ 群を比較すると術 前因子に関しては女性 38\% vs 19\%、高脂血症 31\% vs $55 \%$ 、腎機能障害 $14 \%$ vs $26 \%$ 、喫煙 $36 \%$ vs $62 \%$ 、COPD $0 \%$ vs $5 \%$ 、脳血管障害 $50 \%$ vs $26 \%$ 、 術前 EF 59\% vs 64\%、不安定狭心症 38\% vs 37\%、 LMT 病変 $50 \%$ vs $34 \%$ 、病変枝数 2.7 本 vs 2.5 本、 であり各々有意差なし。一方、高血圧 $100 \%$ vs $69 \%$ 、糖尿病 $14 \%$ vs $54 \%$ であり各々 p < 0.05 。術 中因子に関しては緊急・準緊急手術 $56 \%$ vs 34\%、 OPCAB 率 $81 \%$ vs $54 \%$ 、吻合数 2.3 vs 2.8 ケ所であ り各々有意差なし。術後因子に関してはLOS 0\% vs $3 \%$ 、縦隔炎 $0 \%$ vs $1 \%$ 、脳梗塞 $6 \%$ vs $1 \%$ 、早期グ ラフト開存率 $100 \%$ vs $96 \%$ 、術後在院日数 18 日 vs 23 日、術後 30 日死亡 $0 \%$ vs $1 \%$ 、入院死亡 $6 \%$ vs $2 \%$ であり各々有意差なし。尚、 $\mathrm{E}$ 群に認めた入院死 亡は 1 例のみで、83 歳の LMT+LAD 病変による不 安定狭心症に対し IABP 補助下に緊急 OPCAB を施 行したが術後肺炎を契機に敗血症となり 39PODに死 亡した。【結語】当院における 80 歳以上の超高齢者に 対する冠動脈バイパス術の治療成績は 80 歳未満の患 者群と同様に良好である。しかし入院死亡した 1 例 のように合併症発生が生命予後に大きく関与するた め、合併症発生を予防する手術戦略および周術期管 理が必須である。 


\section{PP-63 六}

\section{超高齢者(80 歳以上)の弓部大動脈瘤に対す る当科の治療方針}

\section{東北大学医学部 心臓血管外科}

\author{
神田 桂輔、本吉 直孝、片平晋太郎、 \\ 高橋 悟朗、秋山 正年、川本 俊輔、 \\ 齋木 佳克
}

【背景】高齢者の増加に伴い、80 歳以上の胸部大動脈 瘤患者が増加している。高齢者の手術は術前から諸 臓器の予備能の低下が予測されるため、保存的な治 療を選択される症例もあるが、近年胸部血管外科治 療の進歩で手術成績の向上が報告され、高齢者に対 する手術適応は拡大している。【対象】2002 年 1 月〜 2011 年 12 月までに当科で施行した、80 歳以上の弓 部大動脈瘤に対する全弓部置換術 (TAR) 7 例および debranching TEVAR7 例、計 14 例を対象とした。 男性 11 例、女性 3例。80-86(平均 81.4) 歳。疾患は真 性瘤 13 例、慢性解離 1 例、術前リスク評価が不十分 な症例は除いた。術前合併症に脳梗塞後遺症 1 例、 COPD6 例、軽度腎機能低下 4 例、糖尿病 4 例があっ た。Japan SCORE は平均 8.2\% (2.6-33.6\%)、TAR 群 で平均 $5.3 \%$ 、TEVAR 群で平均 $11.0 \%$ であった。当 科における TAR は正中アプローチ、低体温下での 順行性脳灌流下に、Open distal 法にて末梢吻合を 行った後、頸部分枝再建、近位側吻合を行っている。 TAR 群での併施手術はCABG3 例、AVR1 例、 AVP1 例であった。TEVAR 群では debranching 後 に TEVAR を施行した二期的手術例が 2 例ある他は 一期的に施行し、全例で逆行性にステントグラフト を留置した。【結果】術後 30 日死亡はなし。在院死亡 は TEVAR 群で 2 例あり、いずれも感染が原因であっ た。それぞれ COPD 及び慢性腎不全と糖尿病の合併 症があった。TAR 群と TEVAR 群の平均挿管時間 はそれぞれ $7.1 \pm 10.0$ 日 vs $3.2 \pm 4.5$ 日、平均 ICU 滞在 日数は $12.9 \pm 13.3$ 日 vs $12.7 \pm 13.7$ 日であった。遠隔成 績で大動脈関連死はなく、TAR 群では術後 1 年で全 例生存し、術後 5 年で累積生存率 $100 \%$ であった。 TEVAR 群では震災後追跡不能 2 例の他、死亡例は なかった。【まとめ】現在当科では 80 歳以上の弓部大 動脈瘤に対しては重篤な合併症のない症例では TAR、合併症を有する例で TEVAR を選択している。 当科において debranching TEVARはJapan SCORE が TAR より高値になる傾向があるが、TAR と同等の術後経過で、高齢者にとって大きな利点と 考える。一方で TAR は術後侵襲は大きいが、早期 成績、遠隔成績ともに良好で、術前リスクを算出し て適応を判断すれば高齢者にも有用な手術と考えら れる。

\section{PP-64 2 s 80 歳以上高齢者における胸部大動脈瘤に対 する治療戦略の検討}

\section{慶應義熟大学 医学部 外科（心臓血管）}

$\begin{array}{lllr}\text { 吉武 } & \text { 明弘、志水 } & \text { 秀行、川口 } & \text { 聡、 } \\ \text { 川口 } & \text { 新治、高木 } & \text { 秀暢、伊藤 } & \text { 隆仁、 } \\ \text { 灰田 } & \text { 周史、平野 } & \text { 暁教、四津 } & \text { 良平 }\end{array}$

【目的】近年社会の高齢化に伴い、高齢者に対する手 術は増加傾向にあり、TEVAR あるいはハイブリッ ド手術など治療の選択肢が増えている。今回当院で 行われた 80 歳以上の高齢者に対する胸部大動脈疾患 に対する手術成績を検討する。【方法】対象は 2005 年 8 月から 2012 年 7 月までの間に当院にて行った胸部 大動脈疾患 (上行大動脈〜下行大動脈) に対する手術 のうち、待機手術を行った 80 歳以上の高齢者の患者 57 例。術式により Open surgery 群 (O 群) 24 例(平 均年齢 81.5 歳、男 15 -女 9 例)、TEVAR 群 ( $\mathrm{T}$ 群) 25 例 (平均年齢 83.0 歳、男 $21 \cdot$ 女 4 例)、頸部分枝 再建併用の debranching TEVAR 群(D 群) 8 例(平均 年齢 82.9 歳、男 7 .女 1 例) の 3 群にわけて比較検討 した。術式は $O$ 群では全弓部置換術 19 例、部分弓 部置換術 2 例、下行置換術 4 例で 4 例に CABG, 1 例 に AVRを同時施行した。T 群ではステントグラフト 16 例、開空型ステントグラフト 6 例、1 分枝付き自 作ステントグラフト 3 例。D 群では total debranch 3 例、左総頸動脈左鎖骨下動脈 debranch5 例であった。 術前合併症としてＯ群では冠動脈疾患 11 例 (46\%)、 COPD3 例 (13\%)、腎不全 1 例 $(4 \%)$ 、脳梗塞 6 例 (25\%) であり、T群では冠動脈疾患 11 例 (44\%)、 COPD5 例 (20\%)、腎不全 2 例 $(8 \%)$ 、脳梗塞 2 例 (8\%)、D 群では冠動脈疾患 3 例 (38\%)、COPD1 例 (13\%)であった。Japan score では各群間での有為差 はなかった。成績】在院死亡は認めなかった。入院 期 間(中央值) は $\mathrm{O}$ 群 31 日（17-148日）、 $\mathrm{T}$ 群 15 日 (7-76 日)、D 群 27 日 (13-134 日)で、O 群 $\mathrm{T}$ 群間では 有意差を認めたが、O 群 D 群間では有意差を認めな かった。術後合併症は $\mathrm{O}$ 群で気管切開 1 例、脳梗塞 1 例、縦隔炎 1 例、D 群で脳梗塞 3 例、気管切開 1 例などであり、脳梗塞発生頻度は有意に D 群が高 かった。【結論】全ての群で比較的良好な結果を得ら れた。超高齢者に対するDebranch TEVARに関し、 Open と比較しての優位性は認めず今後の課題である と思われた。80歳以上の高齢者であってもそれぞれ の症例に適した術式を選択することで比較的安全な 治療を行うことができると考えられた。 


\section{PP-65 玄 \\ 80 歳以上の超高齢者に対する long elephant trunk を用いた弓部大動脈瘤手術の成績}

大阪労災病院

$\begin{array}{lll}\text { 近藤 } & \text { 晴彦、舩津 } & \text { 俊宏、栘田 浩禎、 } \\ \text { 三宅 } & \text { 啓介、谷口 } & \text { 和博 }\end{array}$

80 歳以上の弓部大動脈症例に対しては、若年者に比 べ諸臟器の予備能の低下もあることから、低侵襲か つ合併症を軽減できる治療法が望まれる。弓部大動 脈瘤の治療は、Stent Graft の登場以来、より多彩な 治療術式が選択可能となってきたが、当科では末梢 側吻合を上行大動脈の遠位部レベルで行う Long Elephant Trunk(LET) を用いた Total Arch Replacement(TARLET 手術)を行っている。本術式の利点 は、胸骨正中切開で施行可能で、弓部、下行大動脈 の剥離操作が一切不要なため神経障害も回避でき、 両側腋窩動脈、左総頸動脈の 3 本送血による順行性 脳分離下に末梢側吻合も容易 (25 度の低体温下に平 均約 25 分の open distal 法) である点で、術後の morbidity、mortality を改善すると報告してきた。80歳 以上の高齢者に対する本術式の早期・遠隔成績を検 討した。【対象と方法】1998 年 10 月以降の弓部大動 脈瘤に対する TARLET 手術 136 例のうち手術時年 齢が 80 歳以上の 12 例 (A 群: 平均 82 歳) を対象と し、79 歳以下の 124 例 (B 群: 平均 68 歳)を比較対照 とした。両群間で年齢以外に術前状態に差があった のは、瘤の最大短径 $(\mathrm{A}$ 群: $64 \pm 14 \mathrm{~mm} 、 \mathrm{~B}$ 群: $57 \pm$ $11 \mathrm{~mm}$ )、EuroScore (A 群: $12 \pm 1$ 点、B 群: $9 \pm 2$ 点)、 冠動脈疾患 (A 群: なし、B 群 : 32 例 $(26 \%)$ ) でその他 (男女比、解離 - 緊急手術率、脳・肺合併症、未梢血 管病変、腎障害等)に差は認めなかった。AVRや $\mathrm{CABG}$ 等の同時手術は (A 群: 2 例 $(17 \%$ )、B 群: 46 例 $(37 \%))$ であった。両群間で術後早期・遠隔成績を 比較した(平均追跡期間: A 群 50 ケ月、B 群 51 ケ月)。 【結果】A 群では、二期手術例 (4 例) も含め手術死な く、全例 3 日以内に抜管。術後に脳梗塞、対麻瘏、 腎不全はいずれもなく、縦隔炎 1 例、二期手術後の 肺炎を 1 例に認め、この 2 例は病院死となった。一方、 $\mathrm{B}$ 群では、手術死は 2 例 (1.6\%; TAAA 破裂)で、術 後に脳梗塞 4 例 $(3.2 \%$ )、永久対麻瘏 4 例 $(3.2 \%)$ 、 VSP 1 例 (0.8\%) 等を認め、二期手術例 (23 例) も含め、 病院死は 6 例 $(4.8 \%$; (縦隔炎 1 、肺炎 1 、 $\mathrm{AEF} 1$ 、 TAAA 破裂 1、MOF 1、Sepsis 1)) であった。入院期 間 (中央值) は、A 群: 37 日、B 群: 26 日であり A 群 で長期入院となった。A 群は病院死例を除く 10 例で 独歩退院し、1、5、7 年生存率 (Kaplan Meier 法) はそ れぞれ 83、75、75\%で、B 群 $(1 、 5 、 7$ 年生存率 : 90 、 $79 、 75 \%)$ と比較し、有意差は認めなかった。【まとめ】 80 歳以上の超高齢者に対して、TARLET 手術は、 術後の感染症が致命的となったが、脳合併症等認め ず、成績は概ね良好であり、open surgery であるが、 妥当な術式と思われた。

\section{PP-66 穴 超高齢者に対する全弓部置換術の検証}

\author{
独立行政法人 国立病院機構 帯広病院 心臟血管 \\ 外科 \\ 木村 文昭、菊池 洋一、椎久 哉良、
熱田 義顕
}

【背景】近年超高齢者弓部大動脈疾患の増加に伴い、 全弓部置換 $(\mathrm{TAR})$ の手術適応に苦虑する機会も増加 しつつある。【目的】TARの手術成績並びに術後 ADL から、超高齢者に抢ける手術適応の妥当性を検 証する。【対象】過去 22 年間に施行した TAR 連続 206 例を対象。平均年齢 $70.5 \pm 7.2$ 歳、男女比 145 ： 61、緊急手術 30\%。弓部大動脈疾患の成因は、急性 A 型解離： $22 \%$ 、慢性解離性瘤： $12 \%$ 、真性瘤： $66 \%$ 。手術は全例 SCP による脳保護下に 4 分枝付き 人工血管を使用。術後追跡率 $96 \%$ 、平均観察期間 4.4 \pm 3.7 年。超高齢者の手術適応は、術前 ADL が自立し、 重度の認知症、重度の呼吸機能障害(一秒率 $40 \%$ 以 下、一秒量 $700 \mathrm{ml}$ 以下)、低心機能 (観血的治療によ る心機能改善の見込みがない EF $30 \%$ 以下)がない症 例とした。【方法】対象を 80 歳以上 $(\mathrm{O}$ 群) と 80 歳未 満 (C 群)の 2 群に分け比較検討。術後 ADL は厚生 労働省の日常生活自立度判定基準から、活動性を 4 段階に分類。待機症例に対し、術前、退院時、外来 受診時に評価。早期死亡、中遠隔期死亡、ADL 低下 危険因子につき、多重ロジスティック回帰分析及び Cox 回帰分析による多変量解析を施行。【結果】O 群 30 例：C 群 176 例、平均年齢 $\mathrm{O}$ 群 82.7 歳：C 群 68.4 歳。O 群に COPD 併存が有意に多かった。 $(\mathrm{p}=0.001)$ Japan SCORE (Mortality)；O 群 9.6\%：C 群 7.9\%、 Japan SCORE(Mortality+ 主要合併症); O 群 32.1\%： $\mathrm{C}$ 群 $29.4 \%$ 。手術成績 ( $\mathrm{O}$ 群 : C 群) は、周術期死亡 $(6.7 \%: 5.7 \%)$ 、在院死亡 $(6 \%: 7.4 \%)$ 、主要合併症発 症率 $(46.7 \%: 25.6 \%)$ 、平均在院日数 (61 日：55日)で、 $\mathrm{O}$ 群で有意に主要合併症が多いが $(\mathrm{p}=0.018)$ 、死亡や 在院日数に有意差なし。 $(\mathrm{p}=0.59)$ 累積生存率 $(1$ 年 : 3 年 : 5 年) は、 $\mathrm{O}$ 群 $(75.7 \%: 67.3 \%: 33.7 \%) 、 \mathrm{C}$ 群 $(81.2 \%$ : $76.9 \%: 72.3 \%)$ で有意差なし。 $(\mathrm{p}=0.05)$ 早期死亡の オッズ比 $(95 \% \mathrm{CI})$ は、主要合併症発症: $5.57(1.59-19.4)$ 。 中遠隔期死亡のリスク比 $(95 \%$ CI は、虚血性心疾患の 既往 : 1.95(1.13-3.37)、COPD の 既往: 2.11(1.26-3.51)。 術後 ADL 低下のリスク比 (95\%CI) は、超高齢 : 4.11 (1.52-11.1)、術前腎機能障害 $(\mathrm{Cr} 1.5 \mathrm{mg} / \mathrm{dl} \uparrow): 4.95$ (1.71-14.3)、主要合併症発症 : 4.35(1.65-11.4)。【結論】 超高齢者に対する TAR は、非高齢者と比較し安全に 施行可能であるが、術後 ADL 低下の危険性を念頭 に置き、慎重な適応決定が必要であると考えられた。 


\section{PP-67 攵 \\ 80 歳以上超高齢者の胸部大動脈瘤に対する 人工血管置換術の成績とその検証}

\author{
和歌山県立医科大学 第一外科 \\ 西村 好晴、本田賢太朗、湯崎 充、 \\ 國本 秀樹、舩橋 亮輔、打田 俊司、 \\ 岡村 吉隆
}

【はじめに】胸部大動脈瘤に対する TEVARは device の問題や解剖学的な制限、supra aortic bypass の遠 隔期成績など今なお問題が多い。我々は周術期合併 症を乗り切ることにより人工血管置換術による確実 な成績が得られるとの考えから上行および弓部大動 脈瘤に対して 80 歳以上という歴年齢に関係なく低体 温循環停止法による人工血管置換術を行ってきた。 【目的】今回我々は 80 歳以上超高齢者の上行および弓 部大動脈瘤に対する人工血管置換術の成績を 80 歳未 満の症例と比較することで 80 歳以上という歴年齢に 対する人工血管置換術の妥当性を検証した。【対象お よび方法】2002 年 1 月〜 2012 年 7 月までに上行およ び弓部置換を行った 275 例中、 80 歳以上の症例は 42 例であった。 80 歳以上 $(\mathrm{O}$ 群) と 80 歳未満 $(\mathrm{Y}$ 群 233 例)に分けて乎術成績を比較した。我々は超高齢者の 手術成績を向上させるために術後呼吸器合併症を回 避する対策として子防的なミニトラックの使用、経 口摂取開始前の鱟下造影による評価、嚥下訓練を行つ ている。【結果】O 群(平均年齢 83 歳)の疾患は急性大 動脈解離 (AAD) 30 例、真性大動脈瘤 (TAA) 8 例、 $\mathrm{TAA}$ 破裂 4 例であり、Y 群 (平均年齢 65 歳) に比較 し AAD の占める頻度が高かった。O 群の術式は弓 部全置換 19 例、上行置換 18 例、 hemiarch5 例であり、 両群間で術式の差は認めなかった。平均手術時間、 体外循環時間には差を認めなかった。ICU 滞在日は $\mathrm{O}$ 群 3 日、 $\mathrm{Y}$ 群 2 日、人工呼吸時間は $\mathrm{O}$ 群 33 時間、 $\mathrm{Y}$ 群 19 時間、在院日数は $\mathrm{O}$ 群 37 日、Y 群 30 日(い ずれも中央值)であり $\mathrm{O}$ 群で有意に長かった。在院死 亡は O 群 2 例 (5\%、いずれも AAD)、Y 群 12 例 (5\%、 AAD9、TAA 破裂 2、TAA 1) で差を認めなかった。 術後合併症として脳梗塞は $\mathrm{O}$ 群 3 例、 $\mathrm{Y}$ 群 12 例で 差を認めなかった。ミニトラックを含む気管切開は $\mathrm{O}$ 群で有意に多かった。遠隔期成績として O 群の 5 年生存率は $70 \%$ 、Y 群は $80 \%$ で、両群間に有意差を 認めなかった。【まとめ】 80 歳以上超高齢者の上行、 弓部大動瘤に対する人工血管置換術の手術成績は呼 吸器合併症の予防に重点を置いた術後管理を行うこ とにより、80 歳未満の症例と比較し遜色なく、遠隔 期成績も良好であった。歴年歯にかかわらず超高齢 者に対しても積極的な人工血管置換術は妥当である と思われた。

\section{PP-68 2 々 大動脈弓部置換術後の長期成績}

\section{福井循環器病院 心臓血管外科}

$\begin{array}{llll}\text { 沼田 } & \text { 智、堤 } & \text { 泰史、門田 } & \text { 治、 } \\ \text { 山崎 } & \text { 祥子、瀬尾 } & \text { 浩之、吉田 } & \text { 昇平、 } \\ \text { 佐村 } & \text { 高明、大橋 } & \text { 博和 } & \end{array}$

目的分枝付き人工血管を用い、順行性脳灌流、低体 温循環停止にて弓部大動脈手術を施行した症例の長 期成績を検討した。方法 1992 年から 2012 年までに 当院で施行した 263 例の弓部大動脈手術を対象とし た。男性 144 例 (55\%)。平均年齢は $68 \pm 12$ 才。部分 弓部置換を 37 例 (14\%) に施行し、弓部全置換術を 226 例 (86\%) に行った。125 例(47.5\%) が緊急手術で あり、134 例 (51\%) が大動脈解離であった。18\%の症 例が術前ショック状態であった。結果 30 日死亡は 19 例 $7.2 \%$ 。術後 30 日以内の Permanent neurological deficit は 8.4\%であった。平均フォローアップ期間は $2.9 \pm 3.4(0-19.8)$ 年であった。病院死亡と有意に関連 する因子は多変量解析では年齢 $(\mathrm{p}=0.0003)$ 、術前 ショック状態 $(\mathrm{p}=0.023)$ 、体外循環時間 $(\mathrm{p}=0.0011)$ が 有意に関連していた。解離症例と非解離症例に分け、 生存分析を行うと中長期には解離症例が生存率が高 い傾向にあり、解離症例で有意に生存期間が長かっ た（ログランク法 $\mathrm{p}=0.008$ ）（図 1)。遠隔期死亡は 36 例に見られた。原因は肺炎 6 例、大動脈瘤破裂 3 例、 癌 3 例、脳梗塞 4 例、末梢血管疾患 2 例、敗血症 1 例、 人工血管感染 1 例、不明 16 例であった。 21 例の症 例が $1.2 \pm 1.9(0-7.5)$ 年後に新たな部位の大動脈手術を 必要とした。6 例の患者が退院後に脳梗塞を発症し た。1例で人工血管分枝の閉塞が認められた。結語 術後遠隔期の脳梗塞は低く抑える事が出来、分枝付 graft の patency も良好であった。非解離例は解離症 例と比べ手術時年齢が有意に高く $(71 \pm 11$ vs $64 \pm 12$ 才) 生存曲線に影響した可能性がある。また非解離例 の主な中長期の死因は脳梗塞 4 例、肺炎 4 例、瘤破 裂 2 例等であり、遠隔期には呼吸器疾患、脳血管疾患、 残存動脈瘤に特に留意する必要がある。

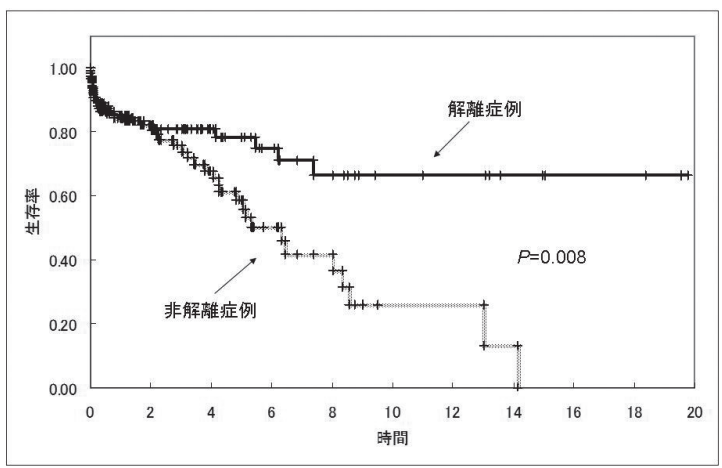




\section{PP-69 六 広範囲弓部大動脈瘤に対する術式別治療成 績}

${ }^{1}$ 広島市立安佐市民病院 心臓血管外科
${ }^{2}$ 日本心臓血管外科データベース機構
${ }^{3}$ 広島大学大学院医歯薬保健学研究院 応用生命科学
部門外科学

片山暁、宮田 裕章 $2 、$ 本村昇 ${ }^{2} 、$

内田 直里 ${ }^{3}$ 、小澤 優道 ${ }^{1} 、$ 須藤 三和 ${ }^{1} 、$

高本 眞一 ${ }^{2}$

【背景】弓部から胸部下行大動脈に至る広範囲胸部大 動脈瘤に対する治療戦略は、TEVAR 時代を迎えて 様々なストラテジーが論議されている。今回我々は TEVAR 導入以前の本邦の広範囲弓部大動脈瘤に対 する手術において、JACVSD に登録されたデー夕を もとに術式別の治療成績に検討を加えたので報告す る。【方法】本邦で 2008 年 2009 年に施行された弓部 大動脈瘤に対する人工血管置換術のうち、JACVSD に登録された 3965 例を対象とした。これらの症例を 下行大動脈に及ばない弓部大動脈置換術群 (TAR 群) 3325 例、弓部および下行大動脈置換術群 (DA 群) 388 例、オープン型ステントグラフトを用いた弓部およ び下行大動脈置換術群 (OS 群) 252 例に分けて術前因 子、手術成績を検討した。【結果】術前因子の検討で は、性別、高血圧、糖尿病、腎機能障害、肺機能障害、 術前 Japan score に 3 群間で差はなかったが、年齢 は(TAR：68.0、DA：66.8、OS：70.7) で OS 群が有 意に高く、頭頸部病変の合併率 $(\mathrm{TAR}: 14.4 \%$ 、DA : 12.6\%、OS：19.0\%）も OS 群で有意に高かった。術 中因子では冠動脈バイパス術、弁膜症の同時手術の 割合が OS 群で有意に高かったが、手術時間(分) (TAR : 477.5、DA : 545.7、OS : 436.4)、人工心肺時 間(分) (TAR：246.6、DA：256.1、OS：221.8) は有意 に短かった。(手術時間 : vs TAR : p $<0.001 、 v s$ DA : p $<0.001$ ) (人工心肺時間 : vs TAR : p $<0.001$ 、 vs DA : p < 0.001) 手術死亡は TAR 群 6.0\%、DA 群 $9.3 \%$ 、OS 群 $9.9 \%$ と TAR 群が有意に低く $(\mathrm{p}=0.012)$ 、 脳合併症も TAR 群 $8.2 \%$ 、DA 群 $11.3 \% 、 14.7 \%$ と TAR 群が有意に低かった $(\mathrm{p}=0.003)$ 。いずれも DA 群とOS 群の間には差はなかった。平均人工呼吸時 間(時 間) は TAR 群 103、DA 群 187、OS 群 112 と DA 群が有意に高く $(p=0.039)$ 、肺炎の合併頻度も TAR 群 $8.0 \%$ 、DA 群 $13.0 \%$ 、OS 群 $8.3 \%$ とA 群で 有意に高くなっていた $(\mathrm{p}=0.05)$ 。考察】広範囲瘤の 治療において左開胸を加えた下行および弓部大動脈 置換術は有意に死亡率、術後合併症が高く有効な治 療戦略ではないと考えられた。今後の治療選択とし ては弓部置換術 + TEVAR が一般的になると思われ るが、オープン型ステントグラフトを用いた弓部〜 下行大動脈置換術では高齢者や脳血管病変の合併頻 度が高く死亡率や脳合併症の頻度が高かったものの 通常の弓部置換術と比して手術侵襲はむしろ低く、 一期的治療を行う際は有効なオプション手術と考え られた。

\section{PP-70 出 弓部真性大動脈瘤に対する弓部置換での脳 合併症の予防}

\author{
東京慈恵会医科大学 心臓外科 \\ 松村 洋高、儀武 路雄、木ノ内勝士、 \\ 成瀬 瞳、中尾 充貴、坂本 吉正、 \\ 橋本 和弘
}

[緒言]当院では塞栓症のリスクの高い Bad aortaの 症例は患者のステント治療の強い希望がない限り、 弓部置換手術の適応としている。弓部置換の際、上 行大動脈の性状が造影 CT・術中エコー上良好ならば 上行送血、不良ならば右腋窩送血 $(\mathrm{Ax})$ を第一選択と し、2008 年 9 月より、直腸温 $25^{\circ} \mathrm{C}$ で上行大動脈を遮 断後、順行性に心筋保護にて心停止を得、予め逆行 性心筋保護用カテーテルを SVC より頭側へ挿入して おき、循環停止後にSVCを occlusion、心筋保護装 置ポンプにて約 $300 \mathrm{ml} / \mathrm{min}$ で逆行性脳還流 (RCP)を 開始し、RCP 下に十分な backflow 確認して選択 的順行性脳還流 (SCP) 用カテーテルを挿入。空気塞 栓、debrisによる脳梗塞を予防しながら SCP に移行 している。ただし、AX 経由の送血例でフローを下げ て送血を継続することで弓部分枝よりのバックフ ローが得られる症例では RCP は行っていない。この 脳還流の 3 方法にて脳合併症発生率を比較検討した。 [対象] 2007 年 3 月〜 2012 年 8 月の真性瘤に対し弓 部置換を施行した連続 43 例を対象とした。S 群：上 行送血下循環停止後大動脈を切開し SCP のみを施行 した 11 例。年齢 $70.5 \pm 9.1$ 歳、抗リン脂質抗体症候 1 例(脳梗塞発生)、Shaggy aorta1 例(脳梗塞発生)で あった。AX \& S 群 : 右腋窩送血下循環停止後、大 動脈を切開し SCP へ移行した 8 例。年齢 $69.8 \pm 7.5$ 歳、Kommerel 憩室瘤 1 例、Shaggy aorta1 例(脳梗 塞発生)であった。 R \& S 群：上行送血下循環停止直 後より $\mathrm{RCP}$ を開始し大動脈切開後 SCP へ移行した 24 例で年齢 $71.0 \pm 5.8$ 歳、コレステロール塞栓症 1 例、 Shaggy aorta5 例 (うち脳梗塞発生 2 例、このうち 1 例が術前脳梗塞合併症例)であった。なお、3 群の全 症例にて大腿動脈送血による末梢側吻合後に debris の逆行性フラッシュは行った。[手術成績]全群で手 術、入院死亡は認めなかった。3 群間において循環停 止時間には有意差を認めなかった。術後脳梗塞の発症 は S 群 2/11 例 (18.18\%)、AX \& S 群 1/8 例 (12.5\%)、 $\mathrm{R} \& \mathrm{~S}$ 群 $2 / 24$ 例 $(8.33 \%$ ) であった。[結 語]1) Bad aorta に対するステント治療は不適切であるが、弓部 置換もリスクが高いという結果であった。2)SCPに おける cannulation の際、十分な backflow がある状 況で行うことは脳合併症予防に重要であり、他の 2 群に比べ R \& S 群では良好な結果であった。当院で 施行している RCP 方式の併用は安全かつ簡便で効果 が十分に期待できること、操作も簡単で体外循環技 師の負担も軽減できることから推奨される方法と思 われる。 
PP-71 攵

大動脈瘤破裂に対する緊急手術の手術成績 および中期遠隔成績

\section{${ }^{1}$ 東北大学医学系研究科 大動脈疾患治療開発学寄 附講座}

2東北大学 心臟血管外科

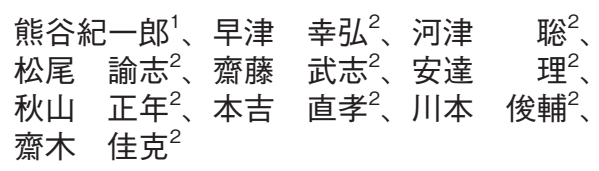

目的)大動脈瘤破裂に対する緊急手術の手術成績と術 後の 5 年以内の遠隔成績を評価し、術式および危険 因子による比較を行う。対象) 2007 年 1 月から 2011 年 12 月までに大動脈瘤破裂、切迫破裂に対して当科 にて緊急手術を行った症例 48 例を対象とした。原疾 患は、胸部、胸腹部領域の真性瘤、術後仮性瘤、慢 性解離、外傷によるものとした。結果) 48 例の平均年 齢は 69.1 歳 $(19$ ～88 歳)で男女比 35: 13 であった。 術式は、弓部置換術が 11 例、下行置換術が 5 例、胸 腹部置換術が 15 例、TEVAR が 17 例であった。入 院死亡は全体で $10.4 \%(5 / 48)$ であり、術後合併症は、 脳梗塞が 2 例、対麻痺が 4 例、術後腎不全が 6 例、 敗血症、肺炎などの感染が 8 例、消化器系合併症が 6 例にみられた。耐術例の遠隔期フォローアップ期間 は 1 〜 63 ヶ月で、この間の全死亡は $23.8 \%(10 / 42$ : 1 例重複)であったが、大動脈関連死亡は $11.9 \%$ (5/42) であり、その内訳は残存瘤の破裂が 2 例、再手術後 の死亡が 3 例であった。他病死は 5 例でみられた。 また、全症例中の再手術も含めた大動脈関連イベン トは 25\% (12/48)に発生しており、大動脈関連イベン トもエンドポイントとして含む Kaplan-Meier 生存分 析は表のとおりである。全体の 1 年、 3 年の大動脈 ベントフリー生存率はそれぞれ 0.76、0.58であった。 単変量解析では、年齢 80 歳以上 $(n=11)$ が有意な $(\mathrm{P}=0.003)$ 危険因子と抽出されたほか、TEVAR 群が 開胸手術群と比較して、他病死を含む死亡または再 手術率が有意に $(\mathrm{P}=0.012)$ 高かった。その他の危険因 子では差がみられなかった。多変量解析結果では明 らかな有意差を認めなかった。考察) 大動脈瘤破裂に 対する緊急手術の手術成績は入院死亡 $10.4 \%$ と良好 であり、短〜中期遠隔期の成績も概ね良好であった。 年齢による術後成績の差がみられたほか、TEVAR 群の大動脈イベントフリー生存率が低かった。 TEVAR 群の平均年齝が開胸手術群より高く(75 歳)、 合併症も多いことが原因と考えられる。

Aortic-Event Free Survival

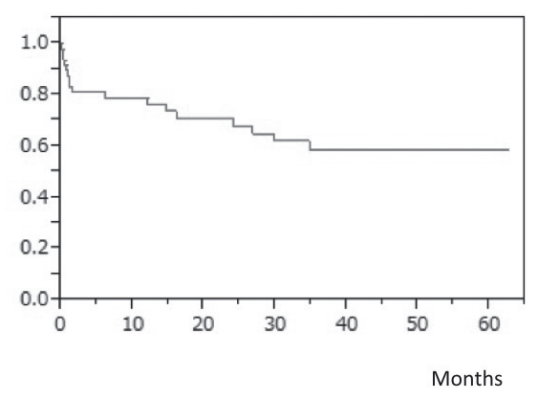

PP-72 公

大動脈病変に伴う虚血性脊䯣障害に対する 緊急脳脊髄液ドレナージの有効性

\author{
東海大学 医学部 外科学系 心臓血管外科学 \\ 志村信一郎、岡田 公章、古屋 秀和、 \\ 田中 千陽、小田桐重人、秋顕、 \\ 長 泰則、上田 敏彦
}

【目的】脳脊髄液ドレナージ (CSFD) は下行及び胸腹部 大動脈の待機手術時に脊髄保護を目的に施行されて いる。我々は大動脈緊急症発症時や胸部大動脈瘤術 後に発生した虚血性脊髄障害発症時に対しても緊急 CSFD を施行しており、その有用性について検討し た。【対象と方法】2010 年 5 月から 2012 年 7 月までに 大動脈緊急症もしくは手術に伴い発生した虚血性脊 髄障害 6 例に対し緊急 CSFD を行った。年齢は 49 〜 75 歳 $(59 \pm 8.9)$ で全て男性だった。春髄障害の発 生様式は、症例 1 は胸腹部置換後 5 日目に発症した 遅発性対麻痺。症例 2 は急性 $\mathrm{A}$ 型解離に対する上行 置換術後 1 日。症例 3 は対麻痺を初発症状として発 症した A 型解離に対する緊急手術術前。症例 4 は急 性 B 型解離に対する降圧治療開始後に完全対麻痺発 症。症例 5 は慢性 $\mathrm{A}$ 型解離に対する胸腹部置換後に 発生。症例 6 は上部下行大動脈瘤に対するステント グラフト留置術後に発生した不全対麻瘏であった。 CSFD は対麻痺確診後にカテーテルを留置し、右房 基点 $12 \mathrm{cmH} 2 \mathrm{O}$ でドレナージを開始、治療効果を観 察しつつ 48 時間ないし 72 時間を目安に抜去した。 対麻瘏の程度は膝関節における徒手筋力テスト (MMT)により CSFD 前後で評価した。【結果】 4 例で CSFD 後に MMT の改善を認め最終的に歩行可能と なった(表)。対麻痺発生後 13 時間、19 時間経過後 に開始した症例でも有効と考えられたものがあった。 【結論】これまでの経験では、大動脈緊急症や手術に 伴う虚血性脊髄障害では、緊急 CSFD が奏効する症 例は少なくないと考えられ、脊髄虚血の原因や恒久 性によってその有効性は異なる可能性がある。

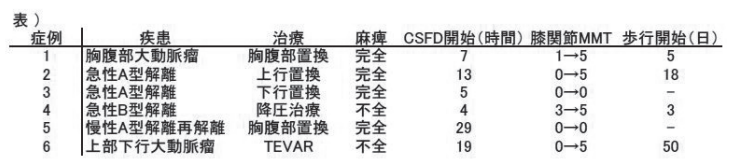


PP-73 公

大動脈石灰化例における上行大動脈遮断の リスク評価一術後脳合併症への影響一

\section{神戸大学 心臓血管外科}

$\begin{array}{lrll}\text { 井上 } & \text { 武、木下 } & \text { 史子、後竹 } & \text { 康子、 } \\ \text { 中井 } & \text { 秀和、小原 } & \text { 大見、竹歳 } & \text { 秀人、 } \\ \text { 山中 } & \text { 勝弘、白坂 } & \text { 知識、野村 } & \text { 佳克、 } \\ \text { 坂本 } & \text { 敏仁、大村 } & \text { 篤史、南 } & \text { 一司、 } \\ \text { 岡田 } & \text { 健次、大北 } & \text { 裕 } & \end{array}$

【目的】上行大動脈遮断と術後脳神経合併症との関係 を上行、弓部大動脈の石灰化スコアにより検討した。 【対象】 2007 年 1 月から 2011 年 12 月の間で上行大動 脈遮断を行った開心術のうち上行大動脈の人工血管 置換を行わず、かつ術前に胸部 CT が評価できた 325 例を対象とした。IE や超低体温循環停止の症例は除 外。平均年齢 $67.0 \pm 12.7$ 歳 ( $20 \sim 92$ 歳)、男性 162 例 (53.1\%)、維持透析 $(\mathrm{HD}) 16$ 例 $(5.2 \%)$ 。主な術式は AVR119、MVP82、MVR34、DVR15 例。【方法】術 前単純胸部 CT 再検討し 3 つのレベル(上行大動 脈、近位弓部、弓部)の石灰化の有無をそれぞれ 0 4 点としてスコア化した。また大動脈の動脈硬化率を 大動脈壁厚から算出しプラーク率として検討した。 【結果】全例の Ca スコア平均は $2.4 \pm 2.2(0 \sim 11)$ 。術 前背景では 80 歳以上 $(4.4 \mathrm{vs} 2.1 ; \mathrm{p}<.0001) 、 \mathrm{HD}$ 症例 (4.4vs2.3; $\mathrm{p}=0.001$ )、高血圧(3.1vs1.9; $\mathrm{p}<0.0001$ )、 頸動脈病変 (4.5vs2.2; p < 0.0001)で有意にスコアが高 かった。術後脳梗塞 (stroke) 7 例 $(2.3 \%)$ 、一過性 脳神経障害を 17 例 (5.6\%)に認めた。脳梗塞発生に対 するリスク解析では年齢、脳梗塞既往、高血圧、頸 動脈狭窄などは有意な因子とはならなかった。石灰 化スコアは上行大動脈中央 (stroke あり : なし $=1.1 \pm$ $1.6: 0.3 \pm 1.0 、 \mathrm{p}=0.03)$ 、近位弓部 $(1.0 \pm 1.4: 0.5 \pm 1.2$ 、 $\mathrm{p}=0.26)$ 、弓部 $(1.6 \pm 0.9: 1.7 \pm 1.0 、 \mathrm{p}=0.96)$ であり stroke 症例で大動脈遮断部位の石灰化が強い傾向に あった。さらに多変量解析では上行大動脈中央石灰 化のみが脳梗塞の有意な危険因子となった (OR 2.7、

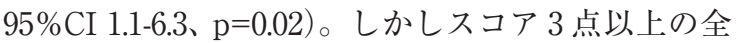
周に近い石灰化症例 17 例のうち stroke は 1 例のみ であった。プラーク率では上行大動脈中央(stroke あ り：なし $=22.1 \pm 6.9: 18.2 \pm 7.3)$ 、近位弓部 $(23.7 \pm 9.0$ ： $18.4 \pm 2.8)$ 、弓部 $(21.3 \pm 5.4: 23.3 \pm 6.7)$ で脳梗塞発生 との相関はなかった。【結語】上行大動脈石灰化を有 する症例での大動脈遮断は術後脳梗塞に注意を要す るが、全周性の石灰化大動脈に脳梗塞を多く認める 傾向はなくむしろ散在性の石灰化に注意を要するこ とが示唆された。

\section{PP-74 文 \\ 左開胸, 腋窩送血, 低体温循環停止を用い た解離性胸部および胸腹部大動脈瘤の治療 成績}

\author{
${ }^{1}$ 札幌医科大学 第 2 外科 \\ ${ }^{2}$ 札幌医科大学 医学部 救急集中治療医学
}

伊藤 寿朗 ${ }^{1} 、 川$ 原田修義 ${ }^{1}$ 、小柳 哲也 ${ }^{1}$ 、 奈良岡秀一 ${ }^{1}$ 、萩原 敬之 ${ }^{1}$ 、栗本 義彦 ${ }^{2} 、$ 樋上 哲哉 1

【はじめに】ステントグラフト治療の普及によって、胸 部および胸腹部大動脈瘤に対する人工血管置換術の 症例数が減少傾向にある反面、ステントグラフトで は治療困難な解離性胸部および胸腹部大動脈瘤に対 する人工血管置換術の重要性が増してきている。左 開胸による低体温循環停止法は大動脈を遮断せず中 枢吻合が行える有効な方法で、当院では左鎖骨下動 脈の末梢で大動脈遮断が困難な解離性胸部および胸 腹部大動脈瘤に対して、これらの方法を用いて手術 を施行している。今回は、待機的に当院で手術を施 行した左開胸、腋窩送血、低体温循環停止を用いた 解離性胸部および胸腹部大動脈瘤の治療成績を検討 した。【対象および方法】2006 年 12 月から 2012 年 7 月まで、待機的に当院で手術を施行した解離性胸部 および胸腹部大動脈瘤に対して、左開胸で低体温循 環停止を用いた人工血管置換術 19 例を対象とした。 平均年齢 $56 \pm 11$ 歳、女性 4 例 (21\%) でマルファン症 候群が 4 例 $(21 \%)$ であった。手術の内訳は胸部大動 脈人工血管置換術が 11 例 $(57.9 \%)$ 、胸腹部大動脈人 工血管置換術が 8 例 $(42.1 \%)$ であった。手術は腋窩動 脈と大腿動脈送血にて直腸温を $20^{\circ} \mathrm{C}$ まで冷却し循環 停止とした後、open proximal anastomosisにて中枢 側を吻合した。心筋保護は使用せず、冷却にて心室 細動になった心臓を、加温後除細動にて心拍動を再 開させた。体外循環時間は $213 \pm 11$ 分、循環停止時 間は $35 \pm 11$ 分 $(10 \sim 62$ 分)、循環停止時直腸温 20.9 $\pm 3.1^{\circ} \mathrm{C}$ で術中の最低直腸温は $19.2 \pm 2.1^{\circ} \mathrm{C}$ であった。 【結果】術後 ICU 滞在期間 $4.3 \pm 3.9$ 日、気管挿管時間 $63 \pm 92$ 時間であった。術後の合併症は脳梗塞 1 例 $(5.2 \%)$ 、対麻疩 2 例 (10.5\%)、左反回神経麻痺 4 例 $(21.0 \%)$ 、呼吸不全 $(72$ 時間以上の扱管管理 $) 7$ 例 (36.8\%)、肺塞栓症 1 例 (5.2\%)、乳び胸 2 例 (10.5\%) であった。術後心不全を合併した症例はなく、病院 死も認めなかった。【考察】術後長期扱管管理が必要 な症例や、左反回神経麻痺を合併する症例が多かっ たものの、脳梗塞の合併は低值で心不全の発症もな く、成績は許容できるものであった。 
$\mathrm{PP}-75$ 公

$28^{\circ} \mathrm{C}$ での循環停止による弓部大動脈全置換 術の手術成績

1小倉記念病院 心臓血管外科
2岩手医科大学 心蔵血管外科

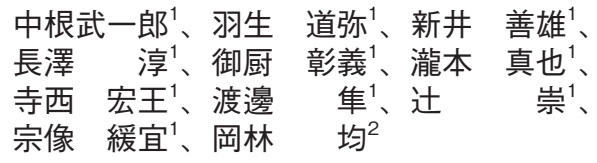

【目的】弓部大動脈全置換術 (TAR)における循環停止 時の至適温度については依然議論の余地がある。当 科では選択的脳潅流 (SCP) 併用下の $28^{\circ} \mathrm{C}$ での循環停 止による open distal anastomosis 法を採用しており、 臓器保護や出血傾向等の観点からその妥当性を検討 した。【方法】当科では TAR は、送血温 28 度で 30 分全身冷却後に循環停止、大動脈切開し SCP 開始、 末梢側吻合後に下半身循環再開、中枢側吻合後に心 拍再開、最後に弓部分枝再建の順で施行している。 同術式を採用した 1998 年 1 月から 2009 年 12 月まで に胸骨正中切開のみの開胸で施行した TARの待機 的手術例で、弁膜症手術併施例は除く 170 例を対象 とした。年齢 $72.0 \pm 6.0$ 歳で男女比 $112: 58$ 。真性瘤 142 例、慢性解離性瘤 28 例。既往歴は虚血性心疾患 $38 \%$ 、高血圧 $84 \%$ 、脂質異常症 $38 \%$ 、糖尿病 $11 \%$ 、 脳血管障害 $24 \%$ 、未梢動脈疾患 $5.9 \%$ 、慢性腎臓病 (CKD) $11 \%$ 、慢性閉塞性肺疾患 (COPD) $13 \%$ で冠動 脈バイパス術 $(\mathrm{CABG})$ を 43 例に併施した。【結果】術 中最低膀胱温は $28.5 \pm 0.7$ 度で心停止 $83 \pm 23$ 分、 SCP $102 \pm 20$ 分、下半身循環停止 $52 \pm 10$ 分、体外循 環 $159 \pm 31$ 分で手術時間 $354 \pm 90$ 分だった。術中濃 厚赤血球輸血量は $330 \pm 522 \mathrm{ml}$ で無輸血は 61 例 (36\%) だった。術後の覚醒、人工呼吸、強心剂使用 の時間はそれぞれ $5.3 \pm 3.4 、 26 \pm 28 、 48 \pm 51$ 時間で、 入院日数は $27 \pm 17$ 日だった。術後 30 日以内の死亡 は 2 例で肺炎(術後 6 日) 、縦隔洞炎(術後 14 日) で死 亡した。術後の一過性脳障害 9 例 $(5.3 \%$ ) (せん妄 8 例)、恒久的脳障害 5 例 $(2.9 \%)$ で脊髄障害 1 例 (0.6\%)。CK-MB 最高值は $41.3 \pm 25.7 \mathrm{IU} / \mathrm{L}$ で周術期 心筋梗塞は無かった。他に出血再開胸 3 例 (1.8\%)、 新規透析 1 例 $(0.6 \%)$ 、消化管合併症 7 例 $(4.1 \%)$ 、呼 吸器合併症 (48 時間以上の人工呼吸、肺炎) 7 例 $(12 \%)$ 、縦隔洞炎 2 例 $(1.2 \%)$ 。採血結果は術前、術 後最高值、退院時で CRE: $1.03 \pm 0.56 、 1.30 \pm 0.77 、 1.02$ $\pm 0.56(\mathrm{mg} / \mathrm{dl}) 、$ AST: $20.1 \pm 8.1 、 85.9 \pm 84.3 、 18.1 \pm 8.0$ (IU/L)、ALT: $17.2 \pm 9.3 、 53.5 \pm 51.8 、 19.8 \pm 15.1$ (IU/ L)、T-Bil: $0.51 \pm 0.24 、 1.30 \pm 0.73 、 0.55 \pm 0.32(\mathrm{mg} / \mathrm{dl})$ で 1 週間以内に peak out し正常化した。多変量解析 にて手術死亡の有意な危険因子は無く、呼吸器合併 症は COPD、CABG 併施、輸血は年齢、女性、手術 時間、解離性瘤、CKD が有意な危険因子で他の合併 症に有意な因子は無かった。【結語】28 度での循環停 止は術後の覚醒や心肺機能回復が良好で諸蔵器の合 併症が少なく、輸血量も少なく、安全で妥当な方法 と考えられた。

\section{PP-76 \\ 動脈硬化性胸部大動脈瘤待機手術患者にお ける Multisite Artery Disease の評価}

\author{
船橋市立医療センター 心臓血管外科 \\ 榎本 吉倫、茂木 健司、松浦馨、 \\ 櫻井学、川村 知紀、高原 善治
}

[目的]動脈硬化病変は全身の血管に認められ多様な 病態を示す。胸部大動脈瘤手術においては、これら の病変は手術成績に大きく影響を与えている。そこ で術前の Multisite Artery Disease(MAD)の合併率 と手術成績に与える影響について検討した。［対象 と方法 2000 年 1 月から 2011 年 6 月までの期間に動 脈硬化性胸部大動脈瘤待機手術を施行した(上行置 換：45 例、弓部置換：103 例、下行置換: 39 例、胸 腹部置換: 14 例) 連続 201 例を対象とした。術前 MAD の評価として頸動脈及び椎骨動脈の評価を MRI、冠動脈病変を CAG、MDCT、シンチグラム、 下肢動脈の評価を $\mathrm{ABI}(<0.9)$ 、腹部大動脈瘤評価を CT で行った。これらの動脈病変に対しては侵襲的治 療適応のある病変に対しては胸部大動脈瘤手術と同 時もしくは二期的に治療を行った。合併病変の有無 により手術成績、遠隔成績を比較検討した。［結果］ 頸動脈及び椎骨動脈病変の合併は 19 例 $(9.5 \%) 、$ 冠 動脈病変は 55 例 $(27.4 \%)$ 、下肢動脈病変は 16 例 (8.0\%)、腹部大動脈瘤は 35 例 $(17.3 \%)$ に認めた。胸 部大動脈瘤単独 113 例を $\mathrm{A}$ 群、一病変以上の合併を 認めた MAD 合併 88 例を $\mathrm{B}$ 群とした。糖尿病及び 高脂血症の合併率は B 群で有意に高く、腎機能 $(\mathrm{e}-$ GFR) も B 群で有意に低かった。術前 EuroSCORE2 は A 群 B 群それぞれ $2.17 \pm 1.47 \% 、 3.79 \pm 2.04 \%$ で有 意差を認めた $(\mathrm{P}=0.0001)$ 。入院死亡率は $0.9 \% 、 5.7 \%$ $(\mathrm{P}=0.047)$ であった。術後 96 か月での生存率は 70.9

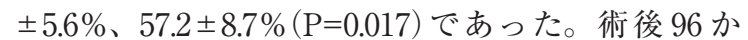
月での大動脈イベント回避率は $76.0 \pm 5.7 \% 、 68.7 \pm$ $6.1 \%(\mathrm{P}=0.0079)$ 、冠動脈イベント回避率は $93.1 \pm$ $3.7 \% 、 84.1 \pm 9.4 \%(\mathrm{P}=0.28)$ 、脳血管イベント回避率 は $90.6 \pm 3.6 \% 、 80.3 \pm 7.5 \%(\mathrm{P}=0.09)$ であった。［結論］ 動脈硬化性胸部大動脈瘤患者における $\mathrm{MAD}$ の合併 率は 43.8\%であった。EuroSCORE2、入院死亡率は MAD 合併患者において有意に高かった。術後遠隔 期においては生存率、大動脈イベント回避率は MAD 合併患者において有意に低かったが、冠動脈イベン 卜及び脳血管イベント回避率には有意差は認めな かった。 
PP-77 尔

\section{再手術として施行した大動脈基部置換術 21 例の検討}

\section{千葉西総合病院 心臓血管外科}

金森 太郎、三輪 快之、井上 武彦、

坂口 秀仁、市原 哲也

【目的】再手術として施行した大動脈基部置換術 21 症 例の治療内容、成績について検討した。【対象】2008 年 1 月から 2012 年 7 月までに、当院で再手術(胸骨 再正中切開) として大動脈基置換術を施行した 21 例 を対象とした。平均年齢 60.3 歳、男 15 例女 6 例であっ た。前回手術は大動脈弁置換 8 例 (+上行大動脈置換 1 例、+ 僧帽弁置換 2 例)、大動脈基部置換 6 例、上 行 ( 弓部) 大動脈置換 5 例、僧帽弁置換 1 例、その 他 1 例であった。前回手術からの期間は平均 4 年 4 か月 (最短 49 日、最長 23 年)であった。待機症例は 9 例、緊急症例は 12 例であった。手術適応は急性大動 脈解離 6 例(いずれも動脈瘤を伴う)、動脈瘤径拡大 6 例 (うち大動脈弁逆流を伴うもの 4 例) 、仮性瘤形成 9 例(感染性 6 例、非感染性 3 例)であった。術式は 全例基部(再) 置換を施行した。同時手術として上行 (弓部) 置換を 14 例に施行した。人工弁温存 7 例、左 室流出路再建 7 例、右室切開 5 例であった。冠動脈 再建法は左右 Carrel patch 法 15 例 (うち 2 例は右の み SV バイパス)、Piehler 法 6 例(うち 2 例は右のみ $\mathrm{SV}$ バイパス)であった。全例、大腿動脈送血、経大 腿静脈右房脱血、低体温循環停止下に胸骨再正中切 開を行った。必要に応じて LV ベント、上大静脈脱 血を追加した。9 例は上行大動脈（人工血管を含む） 遮断が可能であった。平均手術時間、体外循環時間、 大動脈遮断時間、循環停止時間はそれぞれ、381、 326、211、33 分であった。【成績】在院死亡率は待機 手術では 0\%、緊急手術では 33\%（4 例：術前からの 敗血症 2 例、術前ショックからの LOS1 例、術後感 染 1 例)であった。緊急症例で術後脳梗塞を 1 例に認 めた。術後追跡期間は平均 13.6 ケ月 (最短 1 日〜最長 55 ヶ月)で、全体の 1 年生存率は $81 \%$ 、死亡含めた 1 年大動脈イベント回避率は $64 \%$ 、待機手術、緊急 手術別の 1 年生存率はそれぞれ 100\%、68\%であっ た。【結論】低体温循環停止を基本とした再手術にお ける大動脈基部置換術の待機手術成績は概ね良好で あり、術式として妥当と考えられた。
PP-78

\section{外傷性胸部大動脈損傷・救命 20 例の検討}

\author{
1筑波メディカルセンター病院 心臓血管外科 \\ 2筑波メティィカルセンター病院 救急救急センター \\ 松崎寛二1、塚田 亨 ${ }^{1} 、$ 池田 晃彦 1 、 \\ 小西 泰介 ${ }^{1}$ 、河野 元嗣 2 、軸屋 智昭 1
}

【対象と方法】1990 年〜 2012 年 3 月に当院救命救急 センターにて経験した胸部大動脈損傷のうち救命し た 20 例を対象とした。その受傷機転、来院時バイ夕 儿、損傷部位、検査所見、合併外傷、治療戦略、補 助手段、手術所見、術後合併症を分析した。【結果】 15 例が交通事故、2 例が転落事故、その他 3 例であり、 来院時に 10 例がショック状態 4 例が意識混濁を伴っ ていた。受傷から手術までの時間は 24 時間以内が 8 例、 1 週間以内が 2 例、それ以降が 10 例であった。 損傷部位は下行大動脈狭部が 17 例と多数であり、多 くが仮性瘤や縦隔血腫の CT 所見で診断された。2例 が delayed ruptureを起こした。合併外傷は血気胸 17 例、肺挫傷 9 例、腹部臓器損傷 6 例、脊䯣損傷 3 例、 脳合併症 2 例、熱傷 1 例であり、骨折を 18 例に認め た。術式は 15 例に左開胸下の胸部下行置換術あるい は直接縫合術を行った。その補助手段は部分体外循 環が 9 例、低体温循環停止が 3 例、単純遮断が 2 例、 一時バイパスが 1 例であった。2004 年以降、5 例に ステントグラフト治療を適応して良好な結果を得て いる。他蔵器損傷に対する先行手術が 1 例に、同時 手術が 5 例に、追加手術が 5 例に行われた。術後合 併症として対麻痺 3 例、高次脳機能障害 2 例、乳び胸、 胆囊炎、創部感染を各 1 例に認めた。【考察】受傷 24 時間以内に手術した症例のうち肺や脳、腹部実質臓 器の損傷例は 8 例中 3 例であった。一方、24 時間以 降の手術例においては 12 例中 10 例とその割合が高 かった。すなわち他蔵器損傷を伴う場合は、できる だけ緊急手術を避けるべきである。肺挫傷の合併例 において大動脈手術そのものは順調であったにも関 わらず、肺出血や急性肺障害の併発から失った経験 が少なくない。そのため的確な診断を基に、まずは 集中治療による循環動態の安定に全力を注ぐべきで ある。そして他臓器の止血安定を待って大動脈損傷 の修復に臨むことができれば勝算が高くなる。それ が困難であれば緊急手術もやむを得ないが、侵襲の 少ないステントグラフト治療が望ましい。開胸下に 補助循環を用いる大動脈手術は最終手段である。【結 語】外傷性胸部大動脈損傷に対しては合併外傷の重症 度を的確に判断して治療戦略を練る必要がある。損 傷部位の多くが下行大動脈狭部であるためステント グラフト治療の有効性が高く、特に他臓器損傷を有 する場合には第一に検討すべきである。 


\section{PP-79 文 \\ 膝窩動脈瘤に対する sequential sural artery bypass}

${ }^{1}$ 自治医科大学付属さいたま医療センター心葴血 管外科

2埼玉医科大学総合医療センター 血管外科

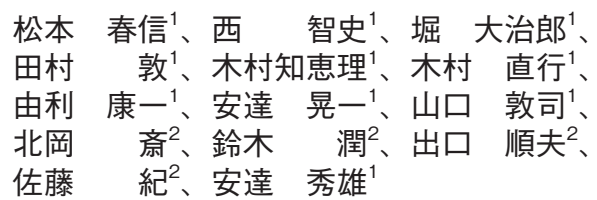

(はじめに) 膝窩動脈瘤に対する標準術式は、置換術 または瘤空置+バイパス術である。いずれの術式に おいても、膝周囲の側副血行への血行再建は通常行 われていない。しかし、膝窩動脈瘤においては、こ れら側副血行がしばしば発達している。腓腹動脈 (sural artery) は下腿へ血流を供給する膝周囲の重要 な側副血行路であり、腓腹動脈バイパスにより救肢 し得た重症虚血肢の報告もある。今回われわれは、 発達した腓腹動脈を認める膝窩動脈瘤に対し、膝周 囲の側副血行の温存を目的として、瘤空置＋下腿動 脈バイパスに腓腹動脈バイパスを追加した sequential sural artery bypass の 2 例を経験したので報告 する。(症例 1) 80 歳女性。足趾潰瘍の既往あり。 CT、血管撮影では滕窩動脈瘤の血栓塞栓症による広 範な下腿動脈閉塞と、発達した腓腹動脈および足関 節部前脛骨動脈以下の開存が確認された。瘤空置+ 浅大腿一前脛骨動脈バイパス術に腓腹動脈バイパス を追加した。（症例 2) 75 歳女性。虚血症状はなし。 末梢塞栓症を伴う膝窩動脈瘤を認め、瘤空置 + 浅大 腿一脛骨腓骨動脈幹ならびに腓骨動脈バイパスを施 行した。腓腹動脈が太く発達しており、腓腹動脈バ イパスも追加した。(結果)いずれの症例も、内側到 達法でバイパスを施行した。症例 1 では、通常のバ イパスでは、腓腹部への血行がそしく、術後の創治 癒遷延や腓腹部の虚血症状の残存が懸念されたため に、腓腹動脈バイパスを施行した。症例 2 では、通 常のバイパスでも腓腹部の血流は温存されるが、腓 腹動脈が太く発達しており、バイパスの長期開存や さらなる下腿血流の確保を目的として腓腹動脈バイ パスを追加した。いずれの症例も、術後下肢浮腫を 認めたほかに合併症は認めず、独歩退院となった。 (考察・結語)腓腹動脈バイパスの報告は少なく、そ の適応となる症例は限られる。膝窩動脈瘤では、し ばしば腓腹動脈が発達しており、腓腹動脈を経由し た血行再建によって、下腿血流増加による肢機能温 存やバイパス開存の面での効果が期待される。腓腹 動脈バイパスの効果の評価方法や長期成績など、今 後検討すべき問題はあるものの、症例を選択すれば、 sequential sural artery bypass は、膝窩動脈瘤に対 する有効な術式の一つであると考える。

\section{PP-80 ¿s 下肢動脈バイパス術後の静脈グラフト狭窄 に対する血管内治療の有用性}

\author{
国立病院機構金沢医療センター 心臓血管外科 \\ 笠島 史成、山本 宜孝、川上 健吾、 \\ 松本 康、遠藤 將光
}

【目的】重症虚血肢に対する膝下以下へのバイパス術 の代用血管として自家静脈グラフトが有用であるが、 $20 \%$ 余の頻度で進行性内膜肥厚によるグラフト狭窄 が生じるとされ、長期開存の上での問題となる。対 処として従来からの外科的修復術の他、最近では血 管内治療の報告もみられるようになってきたが、そ の有用性は十分に検討されていない。今回、当科に おける静脈グラフト狭窄に対する血管内治療の成績 を評価し検討を加えた。【方法】2006 年から 2011 年に 閉塞性動脈硬化症に対するバイパス術後の静脈グラ フト狭窄に対して血管内治療を行った 11 症例 (15 病 変)を対象とした。年齢は $60 \sim 87$ 歳で、男性 9 例、 女性 2 例であった。併存症として 10 例に糖尿病、9 例に高血圧が認められた。先行して施行したバイパ ス術式は、大腿 - 滕下㯟窩動脈バイパス 4 例、大腿 後脛骨動脈バイパス 4 例、膝窩 - 後脛骨動脈バイパ ス 2 例等であった。大伏在静脈グラフトを 8 例で in situ、3 例で reversed として使用していた。バイパ ス術からグラフト狭窄に対する治療までの期間は、1 〜 38 ヶ月(平均 12 ケ月)であった。狭窄部位はグラ フト近位側 7 病変、遠位側 5 病変、中央部 3 病変で あった(中枢及び末梢側吻合部近傍各 2 病変含む)。 血管内治療手技は同側の総大腿動脈順行性穿刺で行 い、ガイドワイヤーをグラフト内に誘導し、参照血 管径にあわせた 1.5 ～ $4 \mathrm{~mm}$ 径バルーンカテーテルに て血管形成術を施行した。最近の 3 例では peripheral cutting balloon (PCB)を使用した。【結果】全例 で狭窄部の良好な拡張が得られ、合併症を認めなかっ た。平均 25 ケ月の経過観察中、6 例 (7 病変)に再狭 窄が認められ(通常バルーン 5 例、PCB 1 例)、5 例 に再度の血管形成術を施行した。その後は概ね良好 であったが、 1 例のみ 3 年後に再々狭窄が生じ、以後、 約 3 ヶ月ごとに狭窄を繰り返し、計 5 回の血管形成 術を行った。一次開存率は 1 年 $64 \% 、 2-4$ 年 $38 \%$ で、 二次開存率は 1 年 $100 \% 、 2-4$ 年 $83 \%$ であった。経過 中、壊死進行による大切断が 3 例に施行されたが、 2 例でグラフトの開存は保たれていた。【結語】下肢動 脈バイパス術後の静脈グラフト狭窄に対する血管内 治療の初期成績は良好であったが、一次開存率は中 期以降不良であった。しかしながら二次開存率は良 好であり、再治療が可能なこと、低侵襲性と手技の 容易さを考慮すれば、有用な術式であると考えられ る。ただし晚期には再狭窄を繰り返す可能性もあり、 慎重な観察が必要である。 


\section{PP-81 is \\ 下肢血行再建術後バイパスグラフト開存のま ま肢大切断となった症例の検討}

\author{
名寄市立総合病院 心臓血管外科 \\ 眞岸 克明、和泉 裕一、清水 紀之
}

<対象・方法＞1997 年 1 月以降、当科で行った下肢 末梢バイパス術症例のうち、バイパスグラフトが開 存していたが肢切断となった 5 症例を対象とした。 同時期におこなった静脈グラフトによる下肢バイパ ス術症例の $4.2 \%$ であった。術前から足部以上の壊死 で当初から下腿切断以上となる症例とグラフト閉塞 により切断に至った症例を除外した。男性 2 例、女 性 3 例で、平均年齢は 69.4+/-8.6(58-79) 才であった。 虚血重症度は、Fontaine III 2 例、IV 3 例であっ た。急性増悪で緊急/準緊急的にバイパス術を行っ たのは 3 例であった。足趾のみの乾性壊死が 2 例、 足趾と踵部の乾性壊死 1 例であった。全例糖尿病を 合併しておりインスリンを使用していた。血液透析 は 3 例であった。バイパス術は、大腿一前脛骨動脈 $1 、$ 大腿一後脛骨動脈 3、大腿一腓骨動脈バイパス 1 で、 大腿 - 腓骨動脈バイパス症例は、二期的に前脛骨動 脈へのバイパスを追加した。いずれも自家静脈を insitu 3、reversed 2 で用いた。術中グラフト血流は、 $42-270 \mathrm{ml} / \mathrm{min}$ であった。急性増悪の 2 例では筋膜切 開術を追加した。切断に至る前の創の治療は、壊死 部のデブリードメンと創部の洗浄を基本とし、持続 吸引療法を併用したのは 1 例であった。<結果＞切

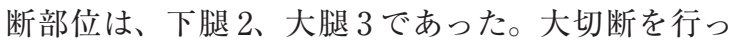
た時期は、バイパス術後 $2-8$ 週であった。大切断 となった理由は、先行する切断創からの感染拡大 1 、 筋膜切開創の感染 2 、足趾切断後創治癒不全と同部 の感染 1 、手術創治癒不良で持続的な疼痛 1 であっ た。感染巣の起因菌は、MRSA 2、緑膿菌1、enterococcus faecalis 1 であった。在院死亡は 1 例で透 析困難で失った。<考察>下肢バイパス術後、グラ フト開存のまま肢切断となるのは 3-59\% と報告され ており、対象患者背景によりその頻度は大きく異な るといわれている。特に糖尿病、血液透析合併はグ ラフト開存でも肢切断となる割合が増えるとされて いる。本検討でも、いずれもインスリン療法の糖尿 病患者で $60 \%$ は血液透析患者であった。急性増悪症 例では筋膜切開を施したがのちに感染が波及した。 肢切断の主原因は 4 例で感染であるが、そのうち 3 例は乾性壊死症であった。乾性壊死では感染が広が る恐れが少ないとされているが、糖尿病を背景とす る易感染性患者では、感染拡大には特に注意を要す ると思われた。

\section{PP-82 \\ 重症虚血肢に対する末梢血単核球細胞移植 療法の治療成績と問題点}

\author{
${ }^{1}$ 慶應義塾大学 外科 \\ 慶應義塾大学 輸血・細胞療法部
}

\begin{abstract}
関本 康人 1 、尾原 秀明 ${ }^{1} 、$ 田中 克典 ${ }^{1} 、$

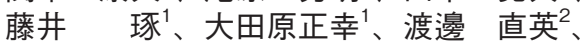
半田 誠、北川 雄光 ${ }^{1}$
\end{abstract}

【目的】当科における重症虚血肢に対する標準治療は、 バイパス術をはじめとした外科的血行再建術および 血管内治療である。一方、血行再建が不可能、もし くは適応外となるような重症虚血肢については従来、 下肢切断術が余儀なくされることも少なくなかった が、当科ではそのような症例に対して、2003 年 11 月 より末梢血単核球細胞移植療法を導入し、救肢を試 みている。そこで、細胞移植療法導入後 9 年間の治 療成績を検討し、本治療法の有効性や問題点を明ら かにする。【対象と方法】閉塞性動脈硬化症 (ASO) ま たは Buerger 病による重症虚血肢患者で、血行再建 の適応外と判断された 12 例に自家末梢血単核球細胞 移植療法をのべ 20 回施行した。 5 例に複数回の治療 を施行した。男性 9 名、女性 3 名、平均年齢 56 歳 (28-73 歳)であった。原疾患は AS06 例、Buerger 病 6 例であった。Fontaine 分類は III 度が 3 例、IV 度 が 9 例であった。ASO 症例の 6 例中 3 例に糖尿病を みとめ、4 例は透析患者であった。移植後の効果判 定は、主に臨床症状、足関節上腕血圧比 (ABI) で評 価した。2008 年以降は治療前後で皮膚灌流圧 $(\mathrm{SPP})$ の測定を行った。【結果】12 例中 9 例に疼痛の改善や 潰瘍の縮小など、何らかの臨床症状の改善を認めた。 SPP 值の測定が可能であった 4 例 (ASO 2 例、 Buerger 病 2 例) のうち 3 例で、臨床症状の改善とと もにSPP 值の改善を認めた。しかしながら、急性増 悪期の ASO 症例 2 例は全く治療効果が得られず、う ち 1 例はハイリスク症例であったが足底動脈へのバ イパス術を施行し救肢を得た。また、Buerger 病の 1 例は臨床症状、SPP 值のいずれも改善を認めなかっ た。全例で有害事情を認めなかった。【考察】自家末 梢血単核球細胞移植療法は、わずか 12 例であるが比 較的良好な成績が得られ、安全に施行できた。しか しながら、治療効果の全く得られない症例も存在し、 治療効果の予測や施行時期、適応可能な病態の範囲、 そして治療機序の解明など解決すべき問題点が多数 あるのが現状である。現在、G-CSF 動員自家末梢血 単核球細胞移植治療に関する他施設共同 RCT (IMPACT study)が進行中であり、結果が待たれる。現 時点では、Buerger 病あるいは感染や疼痛の control が比較的良好な ASO 症例で有効であることが示唆さ れた。 


\section{PP-83 行 \\ 末梢血単核球細胞移植遠隔成績の患者背景 による比較}

\author{
1神奈川県立病院機構 神奈川県立循環器呼吸器病 \\ センター 心臓血管外科 \\ 2横浜グリーンクリニック \\ ${ }^{3}$ 横浜市立大学 外科治療学 心臓血管外科 \\ 安田 章沢 ${ }^{1}$ 、徳永 滋彦 ${ }^{1}$ 、松木 佑介 ${ }^{1}$ 、 \\ 岡本 浩直 1 、市川由紀夫 ${ }^{2} 、$ 益田 宗孝 ${ }^{3}$
}

【背景】当科では重症虚血肢 (CLI) に対する G-CSF 動 員末梢血単核球移植を 2003 年より導入しているが、 特にBurger 病を原疾患とした症例が多い。今回患 者背景毎の成績について比較検討しその効果を検証 した。【対象】 2003 年 2 月より 2011 年 9 月まで当科で 施行した 40 例 (再治療 3 例を含む) 78 肢を対象とし た。平均年齢は $55.9 \pm 16.0$ 歳、男性 29 名、女性 11 名であった。閉塞性動脈硬化症 ASO (A 群) は 14 例 (35\%)、Burger 病 (B 群) は 26 例 (65\%)であった。A 群に強皮症の合併を 1 例、維持透析を 2 例に認めた。 喫煙者はB 群に多かったが $(50 \% v s 88 \%, P<0.01) 、$ 生活習慣病合併の比率は A 群で有意に多かった。16 例 (40\%)に患肢に対する前治療の既往があり、PTA4 例、外科的血行再建 4 例、末梢血単核球細胞移植 3 例、 交感神経ブロック 3 例、LDL 吸着療法 2 例、高圧酸 素療法 1 例であった。治療部位は下肢のみ 30 例 $(75 \%)$ 、上肢のみ 4 例 $(10 \%)$ 、四肢 6 例 $(15 \%)$ であっ た。【結果】術前のアフェレーシスにより平均 $71.2 \pm$ $26.7 \mathrm{ml}(32-113)$ の単核球細胞液を採取することが出来 た。CD34 陽性細胞数は平均 $8.37 \pm 10.3 \times 107$ 個と個 人差が大きかった。Follow up 期間は平均 $845 \pm 845$ 日(12-2872 日)であった。治療後、Fontaine 分類は 3.25 \pm 0.14 より $2.22 \pm 0.14$ へ $(\mathrm{P}<0.01)$ 、Rutherford 分類 は $3.92 \pm 0.24$ より $2.42 \pm 0.27$ へ $(\mathrm{P}<0.01)$ といずれも 改善を認め、群毎の比較でも改善を認めた。Follow up 期間中 6 例 (15\%, A 群 4 例 B 群 2 例) が増悪を来 し、A 群の 4 例は大切断となったが B 群の 2 例は再 度の単核球移植を施行し現時点で救肢出来ている。 増悪患者の背景に $\mathrm{A}$ 群で透析患者 2 例、強皮症合併 1 例を認め、B 群 2 例はいずれも喫煙の再開及び念薬 により治療が中止されていた。全症例の 2 年大切断 回避率は $89.3 \%$ と良好であったが $\mathrm{A}$ 群のみを検討す ると $70.1 \%$ に低下していた。又、A 群の中でも切断 症例での CD34 陽性細胞採取数は非切断症例に比較 して少ない傾向 $(\mathrm{P}=0.069)$ にあった。【結語】末梢血単 核球移植は四肢の大切断回避に有効であったが特に Burger 群での成績が良好であった。維持透析や膠原 病を合併した閉塞性動脈硬化症症例では得られる細 胞数も少なく、効果は不十分である。これらの症例 に対する治療は今後の課題と思われる。

\section{PP.84 2 \\ 重症下肢虚血に対する BK angioplasty}

\section{東京医科大学 心臓血管外科}

$\begin{array}{ccc}\text { 西部 } & \text { 俊哉、丸野 } & \text { 恵太、高橋 聡、 } \\ \text { 戸口 } & \text { 佳代、飯田 泰功、岩橋 徹、 } \\ \text { 岩崎 } & \text { 倫明、山本希誉人、小泉 信達、 } \\ \text { 佐藤 } & \text { 雅人、松山 克彦、杭ノ瀬昌彦、 } \\ \text { 荻野 } & \text { 均 }\end{array}$

【背景】膝下動脈病変は糖尿病や透析患者に多く、全 身状態が不良であったり血管の性状が悪かったりし て、バイパス手術が困難であることが少なくない。 Below-the-knee angioplasty (BK angioplasty) はその 低侵襲性から、重症虚血肢に対する first-line therapy として推奨するエビデンスが増加している。【方 法】膝下以下の病変を有する重症虚血肢に対して BK angioplasty first で治療を行った 34 例 39 肢を対象と した。平均年齢 73 歳、男性 32 肢・女性 7 肢であり、 Fontaine 3 度 1 肢、 4 度 38 肢であった。高血圧 $(85 \%)$ 、脂質異常症 $(41 \%) 、$ 糖尿病 $(74 \%)$ 、維持透 析 $(72 \%) 、$ 脳血管疾患 $(69 \%) 、$ 虚血性心疾患 $(54 \%) 、$ 喫煙歴 $(85 \%)$ などの危険因子を高率に併存していた。 BK angioplasty は足関節以下の動脈まで one straight line を形成するようにして、Plain Old Balloon Angioplasty(POBA)で行った。Angiosome conceptに基づて前脛骨動脈か後脛骨動脈を治療した が、それが不可能なときは腓骨動脈を治療した。また、 腸骨動脈ステント留置術を 4 肢、浅大腿動脈・膝窩 動脈 POBA を 2 肢、浅大腿動脈・膝窩動脈ステント 留置術を 7 肢で併施した。【結果】平均観察期間は 313 日（5～903 日)であった。BK angioplasty は膝下 膝窩動脈 7 肢、前脛骨動脈 29 肢、後脛骨動脈 5 肢、 腓骨動脈 5 肢に行い(重複あり)、初期成功率は 95\% であった。臨床的成功率を趾切断や中足骨切断が行 われて治癒した場合や虚血性潰瘍が治癒したか著明 に改善した場合と定義すると、3 か月以上経過観察し た症例で 74\%であった。重症虚血肢の治療効果の判 定に最も良いとされる大切断回避生存率 (Amputation Free Survival, AFS) は 6 か $87 \% 、 12$ か 69\%であった。透析肢で AFS が不良な傾向があった が有意差はなかった。その内訳をみると、救肢率は 6 か月 $95 \% 、 12$ か月 $86 \%$ であり、生存率は 6 か月 87\%、12 か月 73\%であった。死因は心筋梗塞などの 心疾患 7 肢 $(47 \%$ )、敗血症 5 肢 $(33 \%$ )、癌 2 肢 $(13 \%)$ などであった。【結論】BK angioplasty は下肢救済の 目的を達して、QOL を保つことが可能であった。し かし、良好な救肢率にも関わらず生存率が不良であ り、とくに心疾患への積極的な治療介入が必要であ ることが示唆された。 
PP-85 文

閉塞性動脈硬化症と血清エイコサペンタエン 酸 / ラキドン酸 比の関係

\footnotetext{
1'国立国際医療研究センター戸山病院

2 国立国際医療研究センター研究所
}

\begin{tabular}{|c|c|c|c|c|}
\hline & 勝也 ${ }^{1}$ & 福田 & 尚司 ${ }^{1} 、$ & 藤岡 \\
\hline 保坂 & & 秋田 & 作夢 ${ }^{1} 、$ & 木村 \\
\hline & 佳代 2 & 溝上 & 哲也 ${ }^{2} 、$ & 有村 \\
\hline & 軒 ${ }^{1}$ & - & 佑輔 ${ }^{1}$ 、 & 森村 \\
\hline
\end{tabular}

Purpose: A low ratio of serum eicosapentaenoic acid to arachidonic acid(EPA/AA) has been associated with coronary artery disease. We retrospectively examined serum concentrations of polyunsaturated fatty acids in patients with arteriosclerosis obliterans (ASO) and in non-atherosclerotic patients. Methods: From April 2011 to March 2012, serum EPA/AA was retrospectively examined in 33 consecutive outpatients with ASO complicated by intermittent claudication and 21 outpatients with hypercholesterolemia without ASO as controls. The Student's t-test was used for continuous variables and Chi-square test for categorical variables, with analysis of covariance adjusting for age, sex, body mass index, smoking, alcohol, and diabetes.

Results: The ASO group were significantly different with regard to mean age (71.5 vs. 63.9 year-old, $\mathrm{p}=0.03)$, body mass index $\left(21.3\right.$ vs. $24.1 \mathrm{~kg} / \mathrm{m}^{2}, \mathrm{p}=$ 0.002 ) and morbidity of diabetes mellitus ( 51.5 vs. $4.8 \%, \mathrm{p}=0.0004)$. Serum EPA/AA was significantly decreased in ASO(0.36 vs. 0.61, p = 0.03), when adjusted for age, sex, body mass index, smoking status and alcohol drinking, but was not statistically significant when adjusted for diabetes.

Conclusion: Patients with ASO were more likely to have a low EPA/AA ratio and non-diabetic patients with ASO had a significantly reduced EPA/AA.
PP-86 光

Surgical Site Infection 根絶を目指して：長 野県立こども病院の取り組み

\author{
長野県立こども病院 \\ 小坂 由道、坂本 貴彦、㴊上 泰、 \\ 島田 勝利、原田 順和
}

【背景と目的】小児におけるSSI 予防ガイドラインは 示されていないが、未熟性、チアノーゼ、染色体異 常とそれに伴う免疫応答障害、多段階的手術、人工 補填物の使用はいずれも risk factor になりうる。我々 は 2009 年上半期に SSI の outbreak $(9.2 \%)$ を経験し、 それを契機として新しいSSI 対策を導入した。この 対策の効果を検証することを研究目的とした。【対象 と方法】導入前後の 5 年間 (2007 年 1 月から 2011 年 12 月)に当科で手術を施行した 1023 件を対象とし SSI 発生率を比較検討した。【対策の変更】術前皮膚 消毒方法は単回消毒(10\%ポピドンヨード)を、3 段階

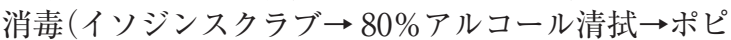
ドンヨード)に変更。予防的抗生剂の投与量を変更 $(\mathrm{CEZ}: 30 \mathrm{mg} / \mathrm{kg} / \mathrm{q} 6 \mathrm{hr} \rightarrow 50 \mathrm{mg} / \mathrm{kg} / \mathrm{q} 6 \mathrm{hr})$ ) MRSA 保菌または感染既往患者には従来どおりバンコマイ シン (VCM、20mg $/ \mathrm{kg} /$ dose) を使用した。閉創時、 皮下脂肪層が厚い症例では皮下ドレーンを留置し融 解脂肪を吸引排除した。創閉鎖方法を連続縫合から 単結節縫合に変更した。筋層は連続縫合で、真皮を 最低 $10 \mathrm{~mm}$ 以上の間隔をあけた単結節縫合で閉鎖。 創面接合不良の場合はモノフィラメント糸による垂 直マットレス縫合で合わせ、4 日後に抜糸。再切開創 ではさらに血流保全を心がけ、筋層もすべて単結節 で閉鎖。漏斗胸など胸郭変形合併例では形成外科と ともに胸郭形成術 (Kirschner wire)を行い、創にスト レスがかからないよう心がけた。長期ドレーン留置 が予想されるフォンタン手術症例では、刺入部にカ デックスを塗布。吸湿バッドを巻きつけて浸出液を 除去。創部は保湿吸収性被覆材で保護し、72 時間後 に開放、水道水洗浄を開始した。【結果】 2007 年から 2009 年まで 6.4-8.2\% で推移していた SSI 発生率は 2010 年に $4.2 \%$ 、そして 2011 年には $1.6 \%$ にまで減少 した。【まとめ】SSI 対策を見直すことで発生率は大幅 に減少した。

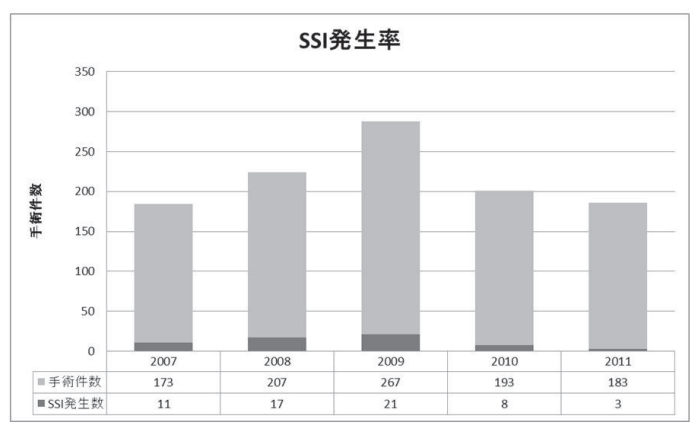




\section{PP-87 公 当科における開心術後縦隔洞炎の予防のた めの工夫}

\author{
東京女子医科大学東医療センター 心臓血管外科 \\ 浅野 竜太、中野 清治、小寺孝治郎、 \\ 佐藤 敦彦、片岡 豪、立石渉
}

背景と目的：開心術後の縦隔洞炎は 1 〜 $2 \%$ に起こる との報告が多く、発症すると治療に難渋し重篤な状 態に陥る。当科では 2007 年 4 月以降、現在まで開心 術後の縦隔洞炎の発症がない。そこでわれわれの行っ ている周術期の感染予防対策について報告する。対 象と方法：2007 年 4 月から 2012 年 5 月までにおこ なった胸骨正中切開による開心術は 473 例だった。 男 / 女 300/173、年齢 $65 \pm 12$ 歳、術式は弁膜症手術 247 例 (52\%)、胸部大動脈瘤手術 28 例 (6\%)、OPCAB172 例 (36\%)、その他 26 例 (6\%)であった。緊 急手術は 29 例 (6\%)であった。また OPCABにおい て両側 ITA 使用は 115 例 (67\%)であった。感染対策 としては、(1)接触感染の機会を減らすため、機械台 のドレーピングの工夫ならびに手術の参加人数制限 をおこなう。(2)皮膚からの細菌混入を防ぐため、手 術前日のシャワー浴を徹底し、術中は縫合系を皮膚 にかけない、皮膚にかけた糸はほかに接触しないよ うにする。（3）落下細菌の混入予防のため術中胸骨接 合面を露出させないようにする、可及的に骨蛹を除 去する。(4)術後胸骨周囲の血腫を予防するため胸骨 の動摇が少ないワイヤー固定をおこなう。(5)洗浄は 胸骨をワイヤーで閉鎖する前後に入念に温生食で行 い、さら閉創時に筋創および皮下組織の縫合を終 えた後、再度温生食で創を洗浄したのち真皮綘合を おこなう。術後創部は $3 P O D$ まで閉鎖して管理する。 結果：術後の縦隔洞炎の発症は 1 例もなかった。考 察: 開心術後の縦隔洞炎は手術中の接触感染および 術後の創部からの逆行性感染によると考えられる。 また、落下細菌の混入もあり、われわれの過去の研 究では、術中の回収血において 60 ～80\%の細菌混 入を認めた(Surg Today(2006)36: 504-507)。結語： いくつもの感染予防対策の積み重ねにより開心術連 続 473 例において周術期の縦隔洞炎の発症を認めな かった。
PP-88 2

開心術における予防的抗生剂投与に関する 検討

大隅鹿屋病院 心臓血管外科
川崎
$\begin{aligned} & \text { 裕満、中山 義博、里 学、 } \\ & \text { 洋輔 }\end{aligned}$

【背景】開心術後の感染症対策として、手術時抗生剂 投与の有用性は広く知られているが、術後抗生剂投 与の有用性は未だ確立していない。当院の症例を対 象に術後抗生剂投与期間と術後感染症の関連を検討 した。

【対象と方法】2011 年 6 月〜 2012 年 6 月までに行った 開心術定期症例のうち術前から感染症を起こしてい たものを除外した 90 例を、術当日のみ抗生剂を投与 した群 (A 群 41 例) と術後 3 日間投与した群 (B 群 49 例)に分け、術後感染の有無や死亡率等を比較検討し た。連続変数の検定は $\mathrm{t}$ 検定を用い、比率の検定は $\chi 2$ 乗検定を用い、 $\mathrm{p}$ 值 0.05 以下を有意とした。

【感染対策】術前検査として鼻腔内 MRSA 保菌の有無 をチェック。陽性の場合、除菌および手術日にバン コマイシンの点滴を併用。術前日シャワー浴。術前 30 分前にセファゾリン $1 \mathrm{~g}$ 点滴。3 時間ごとに追加投 与。イソジン消毒、ドレープ貼付。術後創保護はドレッ シング材貼付。

【結果】術前状態として、年齢 $(\mathrm{A}$ 群 $72.0 \pm 10.0 、 \mathrm{~B}$ 群 69.1 $\pm 10.9 、 \mathrm{p}=0.19$ )、男性比率 (A 群 $58.5 \%$ 、B 群 $67.8 \% 、 \mathrm{p}=0.33)$ に有意差はみられなかった。高血圧、 高脂血症、糖尿病、慢性腎臓病 $(\mathrm{Cr} \geqq 2 \mathrm{mg} / \mathrm{dl})$ の有 病率、鼻腔内 MRSA 保菌率、術前 $\mathrm{EF}$ に有意差は見 られなかったが、契煙の既往はB群で多かった (34.1\%vs58.3\%、p=0.02)。 Japan Score (mortality) に有意差はみられなかった $(3.6 \pm 4.7 \mathrm{vs} 2.4 \pm 2.7$ 、 $\mathrm{p}=0.15)$ 。術式はA 群で単独 CABG21 例、valve (+CABG) 17 例、 $\operatorname{aorta}$ (複合手術含む) 4 例、その他 1 例、B 群 で単独 CABG14 例、valve $(+\mathrm{CABG}) 29$ 例、 $\operatorname{aorta}$ (複合手術含む) 4 例、その他 2 例で両群間に有 意差は見られなかった。手術時間に有意差は見られな かったが、術後挿管時間 $(6.1 \pm 7.7 \mathrm{vs} 12.0 \pm 14.0$ 、 $\mathrm{P}=0.02) 、 \mathrm{ICU}$ 滞在日数 $(2.1 \pm 0.5 \mathrm{vs} 4.0 \pm 4.9 、 \mathrm{p}=0.01)$ は A 群で短かった。術後感染は A 群で 6 例 $(14.6 \%) 、 B$ 群で 8 例 $(16.3 \%)$ で有意差は認めなかった $(\mathrm{p}=0.83)$ 。 感染の内訳は A 群で SSI1 例、尿路感染 4 例、腸炎 1 例、B 群で SSI3 例、尿路感染 3 例、肺炎 1 例、血流 感染 1 例であった。手術死亡は A 群 1 例 $(2.4 \%) 、 B$ 群 2 例 (4.1\%)で有意差を認めなかった。

【結論】術後抗生剂投与日数の差により感染症の発症 率に差はなく、術翌日以降の抗生剂投与は不要であ ることが示唆された。 


\section{PP-89 交 \\ 心臓血管手術におけるSSI に対する我々の 取り組み}

\author{
公益財団法人 天理よろづ相談所病院 心臓血管外 \\ 科 \\ 安水 大介、山中 一朗、仁科 健、
金光 尚樹、廣瀬 圭一、中塚 大介、 \\ 五十嵐 仁、堀裕貴、上田裕一
}

【目的】心臓血管手術における手術部位感染 (surgical site infection : SSI) は、長期入院、医療費増大、予後 を左右する重篤な合併症にもなり得る。また手術手 技の進歩により高齢で基礎疾患を多く合併した症例 に対しても手術適応が拡大し、SSI の予防はさらに重 要な課題となっている。当院では 2011 年末より SSI が増加し、早急な感染対策を迫られた。そこで心臓 血管手術症例に対して 2012 年 2 月より SSI 対策とし て ICT と協力し、医療チームとして対策を講じ、SSI 数の減少を達成したのでその詳細を報告する。【対象 と方法】対象は 2011 年 8 月から 2012 年 7 月まで同一 手術チームによって施行された開心術 200 例。手術 は CARD : 心臓の弁または中隔に対する開胸手術(冠 動脈バイパスグラフト、血管の手術、心臓移植、ペー スメーカー植え込み手術を含まない) CBGB: 胸部とグ ラフト採取部位の切開を伴う冠動脈バイパスグラフ 卜(足などから適した静脈を採取することを含む) CBGC : 胸部切開のみの冠動脈バイパスグラフト TAA: 胸部血管手術に分類。CARD91 例、CBGB43 例、 CBGC4 例、TAA62 例。年齢 $60.0 \pm 24.27$ 歳、男性 124 例女性 76 例。方法は 2011 年 8 月から 2012 年 1 月までの前期群 99 例 (年齢 $61.38 \pm 25.72$ 歳、男性 66 例、女性 33 例) (CARD48 例、CBGB20 例、CBGC2 例、 TAA29 例) と 2012 年 2 月から 2012 年 7 月までの後 期 群 101 例 (年齢 $59 \pm 23$ 歳、男 58 例、女性 43 例) (CARD43 例、CBGB23 例、CBGC2 例、TAA33 例) に分け、SSI の発生数を比較した。後期群では 1) 夕 イムアウトによる抗生剂の術前投与の徹底 2) 2 重手 袋の徹底と頻回の手袋交換 (ドレーピング終了後、術 中 3 時間毎、閉創前)3) 創部洗浄 4) 胸骨正中切開創 の閉創法の工夫 (深筋膜・浅筋膜 - 真皮のそれぞれの 創をモノフィラメント合成吸収糸を用いて結節縫合 により寄せ、深筋膜と浅筋膜の間には SB チューブを 留置する筋膜 / 皮下縫合法による閉創) といった一連 の取り組みを実施した。術式、SSI の危険因子(糖尿 病、腎機能障害、高血圧症、喫煙歴、低栄養状態、 ステロイド使用)に両群で優位差は認めず。SSI の定 義は CDC ガイドラインに準拠した。【結果】SSI の発 生は、前期群では 7 例 (深層 SSI4 例、浅層 SSI3 例、 培養結果より MRSA2 例、MSSA1 例、Corynebacterium2 例が検出)、後期群では 2 例 (浅層 SSI 2 例) と 減少した。【結論】SSI 予防のための一連の取り組み により、SSI の発生件数を抑えることができた。取り 組みを通じて各部署間の意思疎通やチーム内の SSI への意識の変化も現れ、このことも SSI の減少に寄 与したと考えられる。

\section{PP-90 咨 心臓血管外科における周術期感染制御シス テムの構築とその効果に関する検討}

\author{
秋田大学 心臟血管外科
}

$\begin{array}{ll}\text { 石橋 } & \text { 和幸、山本 文雄、山浦 玄武、 } \\ \text { 佐藤 } & \text { 央、本川真美加、白戸 圭介、 } \\ \text { 張 春鵬、山本 浩史 } & \end{array}$

【緒言】心臓血管外科手術は、体外循環による免疫能 の低下や人工材料の使用により、他の外科手術より 易感染状態にあり、一度感染した場合には致死的と なることも多い。当科では、2004 年に MRSA 集団感 染を経験し、その後その解決のため、様々な感染予 防対策を構築してきた。今回その対策の有効性につ いて見当を加えたので報告する。【対象と方法】2004 年 6 月より 2012 年 7 月までの開心術 982 例を対象と した。症例は先天性 281 例、虚血性 181 例、弁膜症 319 例、胸部大血管 179 例、その他 22 例であった。 感染対策としてすべての部署、スタッフにスタンダー ドプレコーションを徹底すると同時に、術前には全 例監視培養を行い、MRSA 保菌の場合には除菌に努 めた。MRSA が検出された場合には、患者のベッド 配置や清掃方法などの環境対策にも留意した。また、

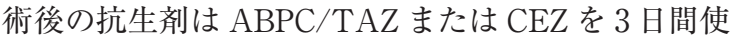
用した。術後、感染が疑われた場合には、培養を採 取すると同時に deescalation 的に抗生剂を使用した。 【結果】術前の監視培養で MRSA が検出されたのは 8 例 $(0.8 \%)$ であり、その内 4 例は除菌後に手術を施行 した。術後の SSI 発症率は $1.3 \%$ (13 例：縦隔炎 5 例、 膿胸 3 例、表層感染症 5 例) であり、起因菌は MRSA5 例 (38\%)、MSSA4 例 (30\%)、緑膿菌と Enterobactor が 2 例ずつであった。多変量解析におい て、深部 SSI を発症する危険因子は、緊急手術と大 動脈疾患であった。また、血流感染を 17 例 $(1.7 \%) に$ 認めた。起因菌は MRSA6 例 (35\%)、MSSA(E) 3 例 (18\%)、Enterobactor2 例 $(12 \%)$ と Klebsiella2 例 $(12 \%) 、 そ の$ 他 4 例であった。危険因子は大動脈疾患、 緊急手術、術前の MRSA 保菌であった。術後の MRSA 肺炎を 10 例 (1\%)、緑膿菌肺炎を 5 例 $(0.5 \%)$ に認めた。その内 10 例 (67\%) が大動脈瘤緊急手術と 有意に多く認めた。感染関連死亡は 6 例 $(0.6 \%)$ であ り、縦隔炎 2 例、sepsis 3 例、感染性脳動脈瘤破裂 1 例であった。起因菌は 6 例中 4 例が MRSA であった。 術後における MRSA 保菌率は 27 例 $(2.7 \%)$ であり、 その内 20 例 $(74 \%)$ が大血管症例であり、次いで 4 例 (15\%) が弁膜症症例であった。また当科におけるこ の 1 年間の MRSA prevalence rate は平均で 4.0 5.0 を推移していた。【結語】周術期感染制御システム の構築、実践することにより、心臓血管手術後の感 染は減少しているものの完全に 0 にすることはでき なかった。今後も、特に大血管緊急手術などにおいて、 更なる周術期感染管理が必要と考えられた。 


\section{PP-91 文 術後縦隔炎に対する陰圧閉鎖療法の治療経 験}

JA長野厚生連佐久総合病院

津田 泰利、濱元拓、新津 宏和、 白鳥一明、竹村 隆広

術後縦隔炎は、依然死亡率が高く治療に難渋する合 併症である。我々は 2009 年から術後縦隔炎に対して 陰圧閉鎖療法を導入し良好な成績を得たので報告す る。【対象】 2009 年から 2012 年 1 月までに当科で 治療した術後縦隔炎 12 例。【方法】術後の全身状態、 創部の視診触診、血液検査所見、および胸部 CT 等 の画像所見において縦隔炎が強く疑われる場合は直 ちに再開胸を行い胸骨周囲の洗浄と不良肉芽のデブ リードマンを施行し陰圧閉鎖療法を開始した。陰圧 閉鎖療法について保険償還される VAC システムが あるが保険償還される治療期間が 2 週間に限られて いるため、主にイソジンドレープ・19FrBLAKEDO$\mathrm{RAIN}$ ・電気式低圧持続吸引器等を用いた自作のシス テムを使用した。術後は一般病棟で管理した。陰圧 閉鎖療法システムは麻薬性鎮痛剂使用下に一週間に $2-3$ 回交換を行いその際創部洗浄・デブリードマン を行った。縦隔内体液の細菌培養が連続して陰性と なり、良好な肉芽が増生した時点で形成外科スタッ フとともに筋皮弁等を併用し閉創した。【結果】男性 11 例 女性 1 例。先行手術は CABG: 6 例、CABG+LVAD 装着 1 例、TVR: 1 例、 total arch replacement 2 例、心 室中隔穿孔閉鎖術 1 例、心囊ドレナージ術 (非開心術) 1 例で、開心術後の縦隔炎発症率は $2.1 \%$ であった。 死亡例は 3 例でこのうち感染症関連死亡は 1 例 (VAD 植え込み症例) あった。生存例のうち 3 例は瘦 孔を形成し長期間排膿したが、医療機関における定 期的処置は必要としない状態に改善した。【考察】術 後縦隔炎に対する㓌圧閉鎖療法はきわめて有効な治 療法であると考えられた。また、従来の開放洗浄療 法と比較すると処置の頻度が減少し、胸郭の動摇も 低減されるため治療中の QOL を高く保つことが可能 であると考えられた。

\section{PP-92 文 心臓血管手術後創部トラブルに対する VAC 療法導入の治療効果}

\author{
千葉大学医学部附属病院 心臓血管外科 \\ 焼田 康紀、石坂透、黄野 皓木、 \\ 石田 敬一、田村 友作、渡邊 倫子、 \\ 阿部真一郎、若林豊、松宮 護郎
}

手術創の離解・感染は術後入院期間の延長の一因と なる。局所陰圧閉鎖療法は持続的な陰圧によって肉 芽を創床から引き出し肉芽形成を促進する。また、 感染性老廃物や過剩な浸出液を除去し創部血流を改 善することで創傷治癒を促進する環境を作り出す。 $\mathrm{KCI}$ 社の VAC システムは小型の㓌圧維持管理装置 により連続的な陰圧環境を得られ、患者の移動の妨 げにならないため術後リハビリと同時の施行が可能 であり、早期退院の一助となる。当院では創傷発生 から早期にVAC 療法を導入して治癒期間の短縮を 図っている。[対象と方法] 2010 年 10 月から 2012 年 7 月まで心臓血管手術後の創部離解・感染に対して VAC 療法を施行した症例を検討した。治療陰圧は $-125 \mathrm{mmHg}$ の持続吸引に設定し、グラニューフォー ムは 2 日ないし 3 日に一度の交換とし培養を提出し て感染監視を行った。症例数は 17 例で年齢は 22 歳 から 83 歳まで平均 64.5 歳、男性 10 名、女性 7 名。 心臓手術後の胸部正中創感染への使用は 8 例で SSI が 7 例、縦隔炎が 1 例であった。ペースメーカー感 染の抜去部への使用が 1 例、腋窩 - 大腿動脈バイパ スの人工血管感染の抜去部に 1 例、F-F バイパスの 人工血管感染に 1 例、SVG 採取部が 2 例、PCPS 抜 去後の鼠径部感染が 2 例、その他の創部 SSI が 2 例 であった。VAC 開始時の創部培養は 16 例で陽性で あり、検出菌は MSSA7 例、MRSA4 例、その他表皮 ブドウ球菌、緑膿菌、マルトフィリア、CNS 等が見 られた。全例で同時期に抗生剂投与を併用した。創 傷治癒に関与する合併症として糖尿病が 3 例、透析 2 例、ステロイド内服が 1 例であった。[結果]正中創 SSI は 6 例で良好な肉芽形成を得られ、退院後外来 にて創閉鎖を確認している。1 例は他の手術合併症に より失った。 VAC 施行期間は $12.5 \pm 7.6$ 日間、 VAC 終了時に 4 例で創部培養は陰性となった。縦隔炎へ の使用は第一選択としていないが、全身状態不良で 大網充填等の手術適応にならない症例に施行した。 F-F バイパスの人工血管感染に対しての使用では、 20 日間の使用である程度の肉芽形成と感染コント ロールを得たのち、人工血管抜去、腋窩 - 大腿バイ パス追加、筋皮弁移植により創閉鎖した。その他の 8 例の創部使用でも全例良好な肉芽形成を得ており、 $\mathrm{VAC}$ 施行期間は $22.6 \pm 10.3$ 日間、6 例で創部培養は 陰性となった。[結語]術後創感染に対してVAC 療 法を用いた創傷管理は肉芽形成の促進に有用であり、 また局所感染のコントロールにも有効に働き、入院 期間の短縮の一助となった。 
PP-93 \{

Nasal High Flow 利用による心臓外科術後の 呼吸不全回避

\author{
1東京女子医科大学東医療センター 心臓血管外科 \\ 2東京女子医科大学東医療センター ME室

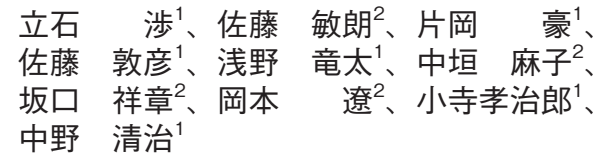

【目的】Nasal high flow (NHF) は酸素と空気をブレン ドし高度加湿を加え鼻腔から高流量で流すデバイス である。通常の酸素カニューラより死腔が wash out されることで確実な $\mathrm{FiO}_{2}$ 実現と $\mathrm{CO}_{2}$ 再吸収回避を 可能にしている。また軽度の positive airway pressure をかけることも可能である。 Nasal High Flow の利用が心臟外科術後の呼吸不全の回避に有用であ るか検討した。【方法と結果】2012 年から当科で手術 した心臓外科症例 60 例を対象とした。年齢は $70 \pm 7$ 歳、男/女 42/18 例。扦管中は全例で術後 Dräger 社のEvita $($ を使用。SmartCareにより呼吸状態を 評価し抜管としている。NHF 装着の適応は、従来の 当科での NPPV の装着の適応基準と同じく、(1) 入 室時に Low Flow PV Loop を用い肺胞が膨張し始め る最低の圧が $5 \mathrm{cmH}_{2} \mathrm{O}$ 以上要する場合、(2) 抜管時 $\mathrm{FiO}_{2}>0.5$ を要する酸素化が不良な場合、(3)抜管後 に 12L 酸素にて酸素化が不良な場合、とした。NHF 装着した症例は 20 例 (33\%)であった。NHF の設定 は、適切な $\mathrm{PaO}_{2}$ を確保する $\mathrm{FiO}_{2}$ と、抜管前の自発 呼吸の flow と同等かそれよりも 10L 程多い flow の 設定とした。ほぼ全例で良好な $\mathrm{PaO}_{2}$ 確保、呼吸回数 安定、触診で胸郭の拡大を得ることができた。NPPV に conversion した症例は 1 例で、NHF 使用による 呼吸不全回避 (NPPV 使用回避)率は全体で $98.3 \%$ で あった。NHFによる合併症発生はなかった。また従 来の NPPV と比べ、食事や会話が可能・十分な口腔 ケア実施可能、NG-tube 不要、装着不快感が軽度で あるなどメリットが非常に多かった。また医療者側 のメリットとして、デバイスの構造が簡素化されて おり組立も容易に行うことができた。【結論】NHF 使 用による呼吸不全回避率は $98.3 \%$ と非常に高く、心 蔵外科術後の呼吸不全に対してこれまでNPPV 使用 としていた症例は、ほほNHF のみで管理可能であっ た。また従来の NPPV と比べ、患者の QOL をはじ めとした満足度が高いこと、医療者側の管理面でも メリットがあることを考慮すると、心蔵外科術後の 呼吸不全に対してNHF を第一選択とすることが好ま しいと考える。

\section{PP-94 公 当科における小開胸心臓手術(MICS)の経験}

大分大学 医学部 心臓血管外科

$\begin{array}{llll}\text { 濱本 } & \text { 浩嗣、廣田 } & \text { 潤、和田 } \text { 朋之、 } \\ \text { 首藤 } & \text { 敬史、佐藤 } & \text { 愛子、川野まどか、 } \\ \text { 穴井 } & \text { 博文、宮本 } & \text { 伸二 }\end{array}$

心蔵手術の成績の安定化に伴い、近年その低侵襲化 が望まれている。われわれは2009年から右小開胸心 臓手術 (Minimally Invasive Cardiac Surgery; MICS) を導入した。今回、当施設での MICS に対する取り 組みを紹介し、そのメリットおよび限界について検 討したので報告する。【対象】2009 年 1 月から 2012 年 8 月までに当科で右小開胸による心臓手術を受け た全症例。詳細は ASD 7 例、僧帽弁閉鎖不全 2 例、 大動脈弁閉鎖不全 1 例の計 10 例。年齢は 16 歳から 69 歳、平均年齢 $40.0 \pm 17.1$ 歳、男女比は $3: 7$ と女性 が多かった。【成績】いずれの症例も右小開胸からの アプローチで完遂し、Conventional な胸骨正中切開 にConvertした症例はなかった。全例送血は大腿動 脈から行い、脱血は上下大静脈からとした。上行大 動脈を遮断し、Aortic root から順行性に Cold blood cardioplagia を注入して心停止を得た。ASD は Patch 閉鎖を基本とし、MR 例に対してはは弁形成を、 AR 例には AVR を行った。全症例の平均手術時間は $270 \pm 55$ 分、体外循環時間は $115.6 \pm 50$ 分、大動脈遮 断時間は $87.0 \pm 48$ 分であった。 MICS のメリットを 検討するために MICS ASD7 例 (M 群) と 2009 年以 前に行われた胸骨小切開による ASD 根治術 14 例 (PS 群) とを比較検討した。M 群 vs. PS 群において 平均手術時間は $252 \pm 43$ 分 vs. $228 \pm 36$ 分、平均体外 循環時間は $92 \pm 26$ 分 vs. $79.5 \pm 23$ 分 $(\mathrm{p}<0.05)$ 、平 均大動脈遮断時間は $63 \pm 17$ 分 vs. $60 \pm 17$ 分であっ た。手術時間、体外循環時間、心停止時間いずれも 長い傾向があった。ただし出血量は $66 \pm 25 \mathrm{~mL}$ vs.151 $\pm 78 \mathrm{~mL}(\mathrm{p}<0.05)$ と有意に少なかった。【結論】2009 年から MICS 手術を導入して、良好な結果を得た。 手術時間、体外循環時間等は長い傾向があったが、 出血量は有意に少なく、適応疾患に関しては今後も MICS 手術を積極的に適応する意義があると考えら れた。 
PP-95 is

\section{Septal superior approach の合併症の検討}

\section{社会医療法人敬和会大分岡病院 心臟血管外科}

高山 哲志、迫 秀則、森田 雅人、

岡敬二、葉玉 哲生

【はじめに】僧帽弁手術において僧帽弁へのアプロー チする方法としては右側左房切開法や経中隔切開法 などが一般的であるが、当院では特に僧帽弁形成術 時には視野の確保において優れている点で Septal superior approach (以下 SSA)を用いて手術を行ってい る。しかし、SSA では洞結節動脈の損傷による術後 心房性不整脈や房室伝導障害発生の懸念があると言 われている。今回 SSA による術後不整脈の発生につ いて検討した。【方法】症例は、2006 年 7 月から 2012 年 6 月までのSSA で行った連続した 110 症例。 Maze 手術を同時施行した 20 例と術前より完全房室 ブロックを呈した 1 例、ペースメーカー植え込み後 の (DDD3 例 VVI2 例) 5 例は今回の検討からは除外 し、最終的には 84 症例で検討を行った。評価には術 前後の心電図所見を用いて評価を行った。【結果】 84 例中術前洞調律は 55 例、術前心房細動は 29 例であっ た。全 84 例中術後に 1 度房室ブロックを呈した症例 を 25 例 (29.7\%) 認めた。2 度以上のペースメーカー 植え达み術を必要とする房室ブロックを呈した症例 は認めなかった。1 度房室ブロックを呈した症例のう ち 9 例 (36\%) ではその後房室ブロックは消失した。 そのうち房室ブロックが消失するまでの期間は術後 1 ヶ月以内が最も多く 5 例 (55.5\%)であり、2 ケ月以 内が 1 例 $(11.1 \%) 、 6$ ケ月上が 3 例 $(33.3 \%)$ であっ た。また洞停止を 3 例 (3.6\%)に認めたが、シロス夕 ゾール内服により心拍数上昇を得られたため、ペー スメーカー植え达み術は必要としなかった。その内 2 例は内服中止することができた。【まとめ】今回我々 の検討では、術後 1 度房室ブロックを 25 例 (29.7\%) に認めたが、ペースメーカー植え込みを必要とする 2 度以上の房室ブロックを呈した症例は認めなかった。 その内 9 例では術後経過で房室ブロックは消失して いる。また洞停止を 3 例 $(3.6 \%)$ 認めたが、ペースメー カー植え込み術を必要としなかった。【結語】SSA は 右側左房切開に比べて極めて良好な視野が得られる ので、複雑な僧帽弁の手技を行なうのには適したア プローチである。しかし、洞結節動脈の損傷による と考えられる洞停止が $3.6 \%$ 発生する。また 1 度房室 ブロックは $29.7 \%$ に発生するが、経過とともにその 約 4 割は回復する。

\section{PP-96 六 \\ ROTEM を用いた止血管理 : 手術時間短縮と 再開胸減少への挑戦}

\section{弘前大学医学部 胸部心臓血管外科}

小笠原尚志、皆川 正仁、千代谷真理、

服部薰、齊藤 良明、野村 阿南、

福田和歌子、渡辺 健一、近藤 慎浩、

谷口哲、大徳 和之、福井康三、

鈴木 保之、福田 幾夫

【目 的】Rotational thromboelastometry (ROTEM)の 使用は周術期の止血管理に有用であるが止血時間や 再開胸減少をもたらすかどうか検討した。【方法】対 象は成人人工肺使用症例とした。2011 年 1 月から 12 月末までの 121 例中 PCPS 症例を除外した 117 例; C 群と以降の ROTEM 使用症例 2012 年 7 月ま での 68 例中 PCPS 症例を除外した 66 例 ; R 群につ いて検討を行った。輸血管理について ROTEM の測 定結果による介入を行った。全血検体を用いたフィ ブリノゲン測定を中心に置き新鮮凍結血漿(FFP)に よるフイブリノゲンの補充を行い FIBTEM A10 值が $10 \mathrm{~mm}$ 以上を目指した(正常值 $7 \sim 23 \mathrm{~mm}$ 、測定 10 分後の血餅硬度でフィブリノゲン值と相関がある)。 止血時間：人工心肺終了後から手術終了と術後 24 時 間での再開胸止血術の件数を測定した。【結果】術前 因子では女性の割合 ; n $(\%)$ の有意差が認められた $(\mathrm{P}=0.018)$ 。術中術後因子では大動脈遮断時間 $(\mathrm{min})$; mean $\pm \mathrm{SD}$ に有意差を認めた $(\mathrm{P}=0.047)$ 。 $\mathrm{R}$ 群の術中 最終 FIBTEM 值 $(\mathrm{A} 10)$ は $12.2 \pm 4.8 \mathrm{~mm}$ であった。止 血時間 (min) は R 群で減少を認めたが有意差は認め られなかった (C 群 $125 \pm 73 、 \mathrm{R}$ 群 $113 \pm 56$; $\mathrm{P}=0.25) 。$ 術後 24 時間での再開胸止血術(件)についても減少は 認めたが有意差は認められなかった ( 群 10/117 件、 $8.55 \%$ 、 $\mathrm{R}$ 群 $2 / 66$ 件、 $2.99 \% ； \mathrm{P}=0.14)$ 。ただし、止 血時間に関してはヒストグラム (各時間帯の件数を\% 表示)からわかるように長時間の止血を要する症例の 減少が認められた。161 分以上の止血を要した症例 は C 群と R 群で $10 \%$ 差が認められた (C 群 $22.2 \%$ 、 $\mathrm{R}$ 群 $12.1 \%$ )。【結語】今後も症例を重ねる必要はある が ROTEM の導入は術中の止血時間短縮と再開胸止 血術の減少をもたらす可能性がある。

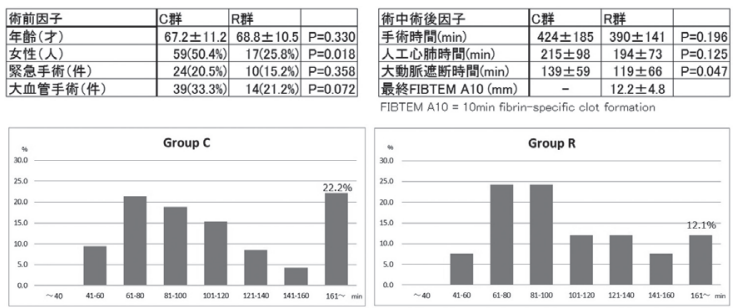


PP-97 文

慢性血液透析症例の開心術における術後合 併症と除水の関連性

\author{
東京女子医科大学東医療センター 心臓血管外科 \\ 佐藤 敦彦、浅野 竜太、片岡 豪、 \\ 立石 渉、小寺孝治郎、中野 清治
}

【目的】慢性血液透析症例における開心術では、術後 の除水量とドライウェイトの決定は難しい。術後の 除水量に関連した合併症の報告もある。今回、慢性 血液透析症例の開心術における術中バランス、術後 除水量、体重変化と術後合併症の関係性について検 討した。【方法】2003 年 1 月から 2012 年 3 月までの慢 性血液透析症例の開心術 66 例 (男 46 ：女 20、65 歳) (OPCAB 39 例、AVR 12 例、MVR 2 例、DVR 2 例、その他 11 例)。術後合併症は死亡、脳障害、心 房細動、消化器障害、シャントトラブルとし、術後 合併症のある群 ( $\mathrm{C}$ 群)、無い群 $(\mathrm{N}$ 群)の 2 群に分け、 術式、術後除水量、体重変化を比較。術中バランス に関しては各群で人工心肺使用例 ( $\mathrm{P}$ 群)、非使用例 $(\mathrm{O}$ 群)に分け比較検討した。【結果】C 群 21 例(男 10 : 女 11、66 7 歳)、 $\mathrm{N}$ 群 45 例 (男 36: 女9、64 10 歳) であり $\mathrm{N}$ 群で男性が有意に多かった $(\mathrm{p}=0.02)$ が年齢 に有意差は認めなかった。人工心肺使用例は C 群 15 例 (CP 群)、 $\mathrm{N}$ 群 12 例 (NP 群)、非使用例は $\mathrm{C}$ 群 6 例 (CO 群)、N 群 33 例 (NO 群) であり、C 群で有意 に人工心肺使用例が多かった $(\mathrm{p}=0.0015)$ 。手術時間 は CP 群 : $289 \pm 104$ 分 v.s NP 群 : $226 \pm 47$ 分 ( $\mathrm{p}=0.58) 、 \mathrm{CO}$ 群 : $240 \pm 82$ 分 v.s NO 群 : $242 \pm 65$ 分 $(\mathrm{p}=0.93)$ であり、人工心肺使用、非使用例ともに有 意差を認めなかった。術中の水分バランスは CP 群 : $3088 \pm 1490 \mathrm{ml}$ v.s NP 群 : $2251 \pm 726 \mathrm{ml}(\mathrm{p}=0.10) 、 \mathrm{CO}$ 群 : $2328 \pm 1050 \mathrm{ml}$ v. s NO 群 : $1942 \pm 948 \mathrm{ml}(\mathrm{p}=0.37)$ 、 出血は CP 群 : $650 \pm 320 \mathrm{ml}$ v.s NP 群 : $481 \pm 197 \mathrm{ml}$ $\mathrm{p}=0.26$ )、CO 群 : $1020 \pm 710 \mathrm{ml}$ v.s NO 群 : $939 \pm$ $449 \mathrm{ml}(\mathrm{p}=0.71)$ であり、人工心肺使用、非使用例とも に有意差を認めなかった。また、術後 1 日目の除水 量 は C 群 : $1339 \pm 704 \mathrm{ml} 、 \mathrm{~N}$ 群 : $1098 \mathrm{ml} \pm 669 \mathrm{ml}$ $(\mathrm{p}=0.53)$ と有意差は認めなかった。術後 3 日目の術 前 DW に対する体重変化は C 群 : $3.3 \pm 1.8 \mathrm{~kg} 、 \mathrm{~N}$ 群 : $2.8 \pm 2.1 \mathrm{~kg}(\mathrm{p}=0.74)$ 、術後 7 日目ではC群: $1.4 \pm$ $1.4 \mathrm{~kg} 、 \mathrm{~N}$ 群 : $1.4 \pm 1.0 \mathrm{~kg}$ ( $\mathrm{p}=0.99)$ であり、どちらも有 意差は認めなかった。術後在院日数は C 群 : $26 \pm 14$ 日、 $\mathrm{N}$ 群 : $15 \pm 8$ 日であり、C 群で有意に在院日数が 長かった $(\mathrm{p}=0.001)$ 【【結論】術後合併症は人工心肺 使用例に多く、在院日数も長かった。しかし、術中 バランス、出血量、術後の除水量、体重変化には有 意差を認めなかった。術後合併症は除水量の管理だ けでは回避困難であると考えられるとともに、当科 での術後水分管理の方法は適切であったと考える。

\section{PP-98 咨 心臓血管外科領域における Tolvaptan 投与 効果の検討}

\author{
日本医科大学 心臓血管外科 \\ 藤井 正大、上田 仁美、芝田 匡史、 \\ 鈴木 大悟、栗田 二郎、渡邊 嘉之、 \\ 坂本俊一郎、大森 裕也、新田隆、 \\ 落雅美
}

【目的】Tolvaptan(バソプレシン V2-受容体拮抗剤)は 強い利尿作用を有することから体液貯留が著しい心 不全患者の治療に使用されるが、心臓血管外科領域 における Tolvaptanの報告は未だ少ない。今回われ われは、周術期に Tolvaptan の内服加療を実施した 症例について効果を検討した。【方法】対象は術後に 一般病棟で Tolvaptan を使用した 7 例。平均年齢 78.1 歳(72-82 歳)、男/女：4/3。症例の内訳は、開 心術後 5 例、腹部大動脈瘤術後 1 例、閉塞性動脈硬 化症 1 例。Tolvaptan は 7.5mg/日の量を内服投与し、 フロセミド $(20-40 \mathrm{mg})$ もしくスピロノラクトン $(0-$ $50 \mathrm{mg}$ )を併用。尿量、水分バランス、体重、血清 Cre 值、血清 $\mathrm{Na}$ 值、血清 $\mathrm{K}$ 值を投与前後で比較検 討した。【結果】平均投与開始時期は 15.9 病日 $(3-47$ 病日)で、平均投与期間は7.1日(2-19日)であった。 尿量は、投与前 $1174 \pm 485(\mathrm{~mL} /$ 日) に対し投与後 $2301 \pm 930(\mathrm{~mL} /$ 日) と有意に増加 $(\mathrm{p}=0.011)$ した。水 分バランスは、投与前 $+41 \pm 902(\mathrm{~mL} /$ 日)に対し投 与後 $-1156 \pm 1423(\mathrm{~mL} /$ 日) と有意に減少 $(\mathrm{p}=0.001)$ した。術前体重を基準とした体重変化量は、投与前 $+2.6 \pm 4.7(\mathrm{~kg})$ に対し投与後 $-2.2 \pm 5.7(\mathrm{~kg})$ と有意に 改善 $(p=0.0041)$ した。血清 Cre 值は、投与前 $0.9 \pm 0.4$ $(\mathrm{mg} / \mathrm{dL})$ に対し投与後 $0.9 \pm 0.3(\mathrm{mg} / \mathrm{dL})$ と有意差な く、血清 $\mathrm{K}$ 值も投与前 $4.2 \pm 0.7(\mathrm{mEq} / \mathrm{L})$ に対し投与 後 $4.1 \pm 0.4(\mathrm{mEq} / \mathrm{L})$ と有意な変化はなかった。血清 $\mathrm{Na}$ 值は、投与前 $132 \pm 9(\mathrm{mEq} / \mathrm{L})$ に対し投与後 140 $\pm 4(\mathrm{mEq} / \mathrm{L})$ と有意に改善 $(\mathrm{p}=0.0065)$ した。【考察】 Tolvaptan は、腎臓の集合管に存在するバソプレシ ン V2-受容体に対する拮抗作用によりアクアポリン -2 の発現を抑制し、水の再吸収を抑制することで利 尿効果を発揮し電解質を低下させず選択的に水を排 泄する。Tolvaptanを使用する場合に高 $\mathrm{Na}$ 血症の発 生が危惧されるが、今回の検討では低容量の内服を 行い使用期間も 1 週間程度であったため高齢者で あっても有害事象は回避できた。また、今回の対象 症例が利尿を必要とすると同時に血清 $\mathrm{Na}$ 值が低め であったため Tolvaptan の導入とともに速やかな改 善が得られたが、欧米において Tolvaptan は低 Na 血症の改善薬として普及していることと合致する。 【結語】心臓血管外科領域の周術期において Tolvap$\tan$ の低容量 $(7.5 \mathrm{mg} /$ 日) の内服は腎機能に影響を与 えずに尿量を増加させ、水分バランス管理に有効で あった。 


\section{PP-99 文 \\ 開心術後急性期および亜急性期におけるト ルバプタンの使用経験：カルペリチドとの比 較}

\section{KKR札幌医療センター 心臓血管外科}

阿部 慎司、上田 秀樹、大畑 俊裕

【背景】トルバプタンは腎臟集合管 V2 レセプター拮抗 薬で、カルペリチド (hANP)に代表される $\mathrm{Na}$ 利尿薬 と異なり水利尿作用がメインの利尿薬である。慢性 心不全症例に対する本薬の使用報告は散見されるが、 開心術後急性期の使用報告例は少数である。今回、 開心術後急性期および亜急性期に使用したトルバプ タンの臨床的有用性について検討した。【対象および 方法】2011 年 4 月以降に施行した開心術後にトルバ プタンを投与した 9 例 ( $\mathrm{T}$ 群 : 亜急性期使用群 ST: 5 例、急性期使用群 AT: 4 例) と、カルペリチドを投与 した 22 例 (H 群)を対象とした。トルバプタンは術後 第 1 病日、若しくは亜急性期よりループ利尿剂と併 用投与、カルペリチドは術後第 1 病日より経静脈投 与した。投与後 2 日間の積算尿量、反応尿量 (投与後 2 日間平均尿量 - 投与前尿量)、Response ratio (RR: 投与後 2 日間平均尿量 / 投与前尿量)、周術期 PA、 CVP、C.I、尿比重、血清 $\mathrm{Na}$ 変化率 (投与後值 / 前值) を比較した。RRは 1.5 以上で responder とした。ま た低左心機能症例 $(\mathrm{EF}<30 \%)$ の各パラメーターも 比較検討した。【結果】1)積算尿量はST 群 vs.AT 群 vs.H 群 $=3440$ vs. 4968 vs. $5070 \mathrm{ml}$ 、反応尿量は 439 vs. 1184 vs. $1346 \mathrm{ml}$ であった。平均 RR は 1.9 vs. 1.7 vs. 3.2、平均 CVP は 5.2 vs. 9.1 vs. $7.5 \mathrm{mmHg}$ 、C.I. は 3.2 vs. 3.6 vs. $2.9 \mathrm{~L} /$ 分 $/ \mathrm{m}^{2}$ であった。平均 $\mathrm{Na}$ 変化率 は 1.0 vs. 0.96 vs. 0.95 で投与前後で有意な変化を認 めず、尿比重についても同様であった。2) responder 症例は H 群で $86 \%$ であったが、ST 群で $20 \%$ 、AT 群で $75 \%$ と、ST 群に non responder 症例を多く認 めた。3)低左心機能症例における RR は T 群 vs. H 群 $=2.8$ vs. 2.9 と差を認めなかったが、非低左心機能 症例では 1.3 vs. 3.4 と、T 群は低左心機能症例でより 利尿効果が大きかった。【まとめ】開心術後急性期お よび亜急性期におけるトルバプタンとカルペリチド の臨床的有用性を比較検討した。利尿効果は概して $\mathrm{H}$ 群が ST 群、AT 群に比し優れていた。AT 群は投 与時の CVP が高值であり、トルバプタンは前負荷が 高い状態においてより効果的である可能性が示唆さ れた。また H 群は心機能にかかわらず RR は良好だっ たが、T群では低左心機能症例で RR 高值であり、 トルバプタンは低左心機能症例の開心術後急性期使 用にてより効果が期待できる可能性が示唆された。

\section{PP-100 究 \\ 血管ベーチェット病の 3 例}

\section{自治医科大学附属さいたま医療センター 心臓血管 外科}

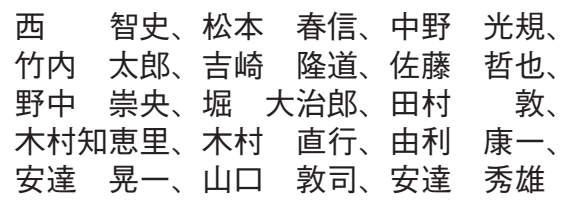

【はじめに】血管ベーチェット病はまれな疾患で、動 脈瘤破裂は致死的であり迅速な対応が必要であるが 治療が確立されていないのが現状である。今回我々 は血管ベーチェット病の 3 例を経験したので報告す る。【症例 1】47 歳男性。30 歳で不全型ベーチェット 病と診断される。腹痛にて近医を受診し CT で $3 \mathrm{~cm}$ 大の腹部大動脈瘤を認め経過観察となっていたが、 3 力月後腹痛増悪し CT にて瘤径が $12 \mathrm{~cm}$ と拡大し、 切迫破裂の診断で当科紹介となった。緊急で仮性瘤 切除およびパッチ閉鎖術を施行した。術後 8 カ月の 造影 CT にてパッチ部位からの造影剤の漏出を認め たため、ステントグラフト内挿術を施行し術後 11 日 目退院となった。術後 2 年 10 力月仮性瘤の再発、新 たな病変を認めない。【症例 2】34 歳男性。6 歳時より 口腔内潰瘍を繰り返していた。1 カ月前に左鼠径部の 疼痛を自覚し疼痛が持続するため前医整形外科を受 診し MRIにて血腫形成性腫瘍が疑われ当センター整 形外科へ紹介となった。造影 CT にて $7 \mathrm{~cm}$ 大の左大 腿深動脈仮性瘤および $1.5 \mathrm{~cm}$ 大の左膝窩動脈瘤、深 部静脈血栓症を認め、血管ベーチェット病が疑われ た。左大腿深動脈仮性瘤に対し仮性瘤切除術を施行 した。術後 13 日目内科へ転科、この時に肛門部潰瘍 を認め、不全型の血管ベーチェット病と診断されス テロイド、ワーファリンの内服を開始した。またスク リーニング目的の MRIにて左総頚動脈分岐部の瘤を 認めた。術後 4 力月仮性瘤の再発、既存の動脈瘤の 拡大、新たな病変は認めない。【症例 3】38 歳男性。 28 歳時より口内炎を繰り返していた。2 か月前より 右下肢の疼痛を自覚し近医受診した。エコー検査に て右下肢深部静脈血栓症と診断され抗凝固療法が行 われた。この頃より右脛骨外側の疼痛および拍動性 腫瘤を自覚し、造影 CT にて右足関節頭側に約 $3 \mathrm{~cm}$ の右前脛骨動脈仮性瘤を認め当科紹介となった。準 緊急で右前脛骨動脈仮性瘤切除術を施行した。不全 型の血管ベーチェット病と診断し術後 10 日目よりス テロイドとコルヒチンの内服が開始された。術後 2 カ 月仮性瘤の再発や新たな病変は認めない。【まとめ】 血管べーチェット病の術後合併症では吻合部仮性瘤、 吻合部狭窄、グラフト閉塞が問題となるため、症例 ごとに治療方針を吟味する必要がある。ステントグ ラフトによる長期成績は不明であるが今後は選択肢 になりうると考える。いずれの治療を選択しても厳 重な経過観察が必要である。 


\section{PP-101攵 原発性肺動脈肉腫の一例}

\author{
${ }^{1}$ 横浜南共済病院 心臓血管外科 \\ ${ }^{2}$ 横浜市立大学 外科治療学
}

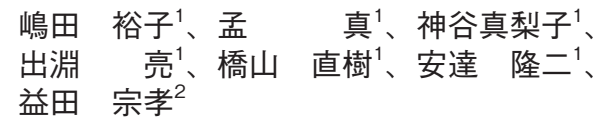

症例は 65 歳女性。平成 $\mathrm{x}$ 年 11 月頃より感冒症状つ づくため近医受診し、胸部 X 線で異常侩影指摘され、 平成 $x+1$ 年 1 月に持続する呼吸困難で他院を受診し た。造影 CT で肺血栓塞栓症による右肺動脈血栓閉 塞の診断で、IVCフィルター留置、抗凝固療法で加 療されていた。しかし、徐々に呼吸器症状は増悪し、 4 月 25 日当科紹介受診。6 6 月で $13 \mathrm{~kg}$ 体重減少、 4 月の造影 CT で右肺動脈内中枢〜末梢にかけて腫瘤 性病変を認め、腫瘤が 2 月時点では認めなかった左 肺動脈内にも進展し肺動脈内に突出していることか ら肺動脈肉腫を疑い、症状緩和・精査加療目的で 5 月 9 日入院となった。術前に行った体幹部造影 CT では右肺に多発塊状の腫瘤認め、右肺動脈末梢から 左肺動脈上葉枝分岐部まで完全閉塞を認めていた。 他の全身検索で転移なく、気管支鏡検査でも気管支 への直接浸潤は認めなった。心蔵超音波検査では TR2/4-3/4 (PG48mmHg、推定 SRVP53mmHg)、PR (EDPG7 mmHg) と肺高血圧症を呈した。左肺動脈内 へ突出する腫瘍による肺動脈閉塞、突然死を防ぐた めに 5 月 14 日手術となった。胸骨正中切開アプロー チ、常温人工心肺下に左肺動脈切開。左肺動脈内の 腫瘍は浮遊し、術中迅速病理診断で Sarcoma と診断 した。右、主幹部肺動脈切除、左肺動脈部分切除・ 肺動脈腫瘤切除、自己心膜による左肺動脈形成、右 肺全摘を施行した。術後の循環動態、酸素化良好で POD1 抜管、POD2に ICU 退室した。術後の心臓超 音波検査では肺高血圧は消失し、経過良好にて 6 月 10 日退院。病理診断は Pulmonary artery sarcoma、 intimal sarcoma、右肺内転移認め、左肺動脈断端陽 性であったが、追加療法行わず術後 3 か月時点で造 影 CT 上も再発の兆候はない。きわめて稀な原発性 肺動脈肉腫を経験したので若干の文献的考察を加え て報告する。

\section{PP-102 㫕 当院における心臓腫瘍 34 例の外科治療経験}

\author{
1長崎大学病院 心臓血管外科 \\ ${ }^{2}$ 長崎大学病院 循環器内科 \\ ${ }^{3}$ 長崎大学病院 病理部
}

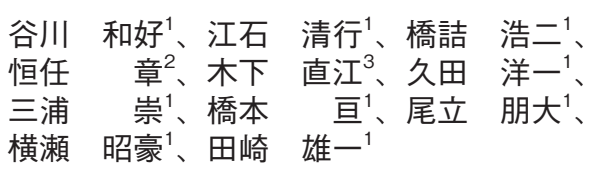

【目的】心臓腫瘍は非常にまれな疾患で、特に悪性腫 瘍では満足できる治療成績はえられていない。今回 我々は心臓原発血管肉腫症例に手術治療を行い、補 助療法を行わずに再発を認めていない 1 症例を経験 しているが治療方針に苦慮するものであった。当院 における 34 例の心臓腫瘍の経験について検証する。 【方法】当院にて 1999 年 4 月から 2012 年 6 月までに ついて経験した心臓腫瘍に対して手術治療を行った 34 例について術前状態、治療法、病理診断、予後な どについて検討する。【成績】原発性腫瘍は良性腫瘍 25 例 (全て myxoma)、悪性腫瘍は 4 例 (leiomyosarcoma、myofibroblastic sarcoma、 osteosarcoma angiosarcoma それぞれ 1 例)、転移性腫瘍 5 例(腎細胞 癌 4 例、肝細胞癌 1 例)であった。myxomaについ て局在は左房 24 例、右室 1 例。すべて切除可能であっ た。追跡期間 (期間、平均土標準偏差 $<$ 単位は月 $>)(0$ ～120、39.4 442.6)において弓部置換との同時手術後 のARDSにより 1 例を術後急性期に失ったが、他再 発、腫瘍死はみられなかった。悪性腫瘍について局 在は左房 3 例、心膜 1 例。いずれも病理学的完全摘 除は不可能であった。追跡期間 $(5 〜 25 、 14.5 \pm 11.6)$ において leiomyosarcoma、myofibroblastic sarcoma、 osteosarcoma のそれぞれに補助療法を行ったものの 局所再発・遠隔転移により死亡した(それぞれの術後 死亡時期は24 か月、25 か、 4 か月)。 angiosarcoma の 1 例は補助療法施行せず術後 6 ケ月が経過し たが再発・遠隔転移はみられていない。転移性腫瘍 について局在は右房 4 例、左房 1 例。すべて切除可 能であったが、追跡期間 $(1$ 〜 $75 、 34.4 \pm 32.3)$ におい て肝細胞癌の 1 例、腎細胞癌(左房転移)の 1 例が早 期に遠隔転移により死亡、腎細胞癌(右房進展)の 1 例が交通事故死を認めたが、腎細胞癌(右房進展)の 2 例は遠隔転移を認めながらも術後 51 か月、75 ケ月 の生存をえている。【結論】諸家の報告のように粘液 腫については切除可能であれば良好な再発回避・長 期生存がえることができた。しかし原発性悪性心臓 腫瘍については遠隔期に再発・転移が出現し予後不 良であった。しかし比較的長期生存がえられている 症例もあり今後の術後補助療法について検討を行 なっていく必要がある。転移性悪性腫瘍については 遠隔転移による心臓腫瘍の予後は不良だが、腎細胞 癌伸展による心臓腫瘍は長期生存が期待できるため 積極的切除術が望まれる。 
PP-103 市

当院で手術を施行した心臓腫瘍の検討

\section{山梨大学 第 2 外科}

神原 賢士、松本 雅彦、武居 祐紀、

本田 義博、神谷健太郎、加賀重亜喜、

鈴木 章司

【はじめに】剖検例による心臓腫瘍の発生頻度は 0.001\%～0.1\%と報告されており、非常にまれな疾患 である。今回、当院で経験した心臓腫瘍症例につい て検討したので報告する。

【対象】1985 年から 2011 年の 27 年間、当院で心蔵腫 瘍と診断し手術を施行した症例は 29 例であった。平 均年齢は $56.9 \pm 20.9$ 歳 $(0 \sim 84$ 歳)、男性 :9 例、女性 : 20 例であった。主訴は脳塞栓 2 例、未梢動脈塞栓 2 例、他疾患精査中 7 例、心雑音 3 例、一過性心房細 動 4 例、心不全症状 7 例、胸痛 4 例であった。心臓 腫瘍と診断となった検査は心臓エコー 25 例、CT4 例 であった。手術は緊急または準緊急で施行した。

【結果】病理組織型は粘液腫 21 例、静脈瘤 3 例、乳頭 状線維弾性腫 3 例、横紋筋腫 2 例であった。術前、 粘液腫の症例 10 例の IL-6 を測定しており $5.93 \pm 2.35$ $\mathrm{pg} / \mathrm{ml}$ (正常值 $4 \mathrm{pg} / \mathrm{ml}$ 以下) と高值の傾向にあった。 手術術式：粘液腫に対しては腫瘍切除、心房中隔再 建を行い、僧帽弁逆流を認めた 1 例に対して弁形成 術を施行した。術後、AVブロックのため 3 症例に 対してペースメーカー挿入した。静脈瘤に対しては 腫瘍切除を行い、狭心症を合併した 1 症例に対して は CABG を同時に行った。乳頭状線維弾性腫に関し ては大動脈弁に腫瘍を認めた 2 例に対して腫瘍切除、 僧帽弁に腫瘍を認めた 1 例に対して腫瘍切除と人工 腱索による再建を行った。横紋筋腫の 2 例は、それ ぞれ左室流出路、右室流出路に腫瘍による狭窄があ り腫瘍切除、流出路の形成術を行った。術後、在院 死亡は認めず、全例退院可能であった。手術症例 29 例中再発のため再手術を施行した症例は 2 例であり、 組織型は粘液腫であった (手術後 1 年、 3 年)。

【考察】当院で経験した心臓腫瘍はすべて良性腫瘍で あった。心臓腫瘍により嵌頓、腫瘍塞栓を起こすこ とがあり、致命的な経過になることもあるため、緊急、 準緊急に手術を施行し経過良好であった。今回、心 臓粘液腫症例の 2 例に再発を認めたが、再発時、早 期診断のため定期的に心臓エコーでフォローが必要 と思われた。

\section{PP-104 خ \\ 低体温ラットにおける心筋組織のプロテオミ クス解析}

\section{島根大学 循環器呼吸器外科}

\author{
清水 弘治、清水 弘治、横山 真雄、 \\ 金築 一摩、今井 健介、末廣 章一、 \\ 花田 智樹、織田 禎二
}

【背景】心臓血管外科領域、特に大血管手術において 臓器保護のため低体温法を用いている。その主要な メカニズムは代謝の抑制であるが、その詳細な分子 生物学的機序は解明されていない。プロテオミクス 解析は生体反応におけるたんぱく質の変化を網羅的 に解析する手法である。【方法】ラットを無作為に常 温コントロール群 $\left(37^{\circ} \mathrm{C} 、 \mathrm{n}=6\right)$ と低体温群 $\left(23^{\circ} \mathrm{C} 、 \mathrm{n}\right.$ =6）とに分けた。低体温群では心筋保護装置を用い た表面冷却法にて目標体温である $23^{\circ} \mathrm{C}$ を 3 時間維 持。また常温コントロール群においても同様の方法 にて体温 $37^{\circ} \mathrm{C}$ を 3 時間維持した。その後心筋組織を 採取し、2 次元電気泳動 (蛍光標識二次元ディファレ ンスゲル電気泳動解析システム(2D-DIGE))を行い、 2 群間で有意差のあるスポットを同定した。そしてそ れぞれの質量分析 (MALDI-TOF/TOF)を行い、その タンパクを同定した。【結果】2D-DIGEにより同定さ れたスポットは2490、そのうち低体温により有意に 1.5 倍以上増加したスポットは 66、減少したスポット は 238 であり、そのうちたんぱくが同定されたもの は計 22 スポットであった。同定されたたんぱくに関 してデータベース解析を行ったところ、酸化的リン 酸化、ATP 産生経路におけるたんぱくの減少、また 心筋収縮におけるたんぱくの減少を認めた。【考察】 低体温によりATP 産生が抑制され、また心筋収縮が 抑制されていると考えられた。【結語】低体温モデル ラットは低体温研究に有用であり、また2D-DIG、 MALDI-TOF/TOFを用いたプロテオミクス解析は 生体内現象を解明するのに有用な手法と考える。今 後さらに他の手法も併せて用いることにより、さら に詳細な解析が行えると考える。

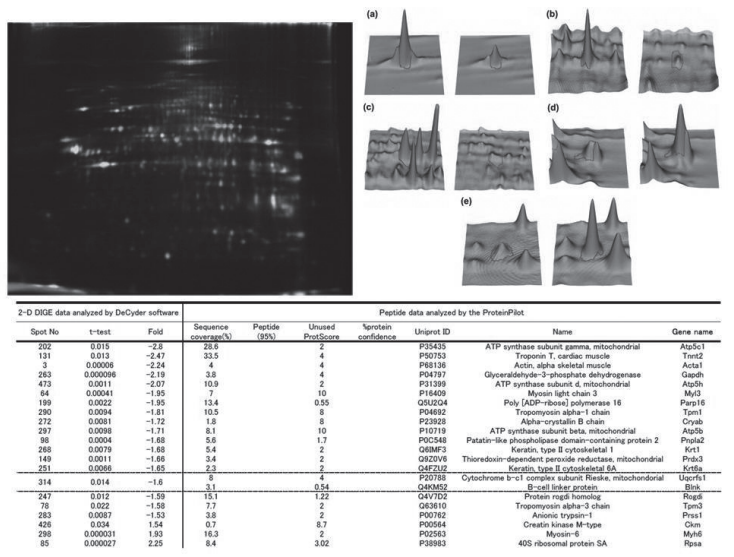


PP-105 宛

ワーファリン内服患者のためのビタミン Kオ フ納豆風味大豆食品の開発研究一第一報

\author{
1筑波大学 \\ 2筑波大学 医学医療系 小児科 \\ 筑波大学 生命環境系 食品バイオマス工学 \\ 平松 祐司 ${ }^{1} 、$ 北村 豊 ${ }^{3} 、$ 田中 麻理 ${ }^{3} 、$ \\ 堀米 仁志、榊原謙 ${ }^{1}$
}

【目的】ワーファリンは、ビタミン $\mathrm{K}$ に拮抗して肝臓 でのビタミン K 依存凝固因子 II、VII、IX、X の合成 を阻害する。納豆は納豆菌が産出するビタミン K2 (menaquinone-7) の含有量が多く、菌は腸内でも MK-7 を産生するため、ワーファリン内服時には一般 に摂食が禁じられる。我々は、患者の嗜好に応え、 日本の伝統的食品文化を保護する観点から、「MK-7 を含まない納豆風味大豆食品」の開発を企図した。 【対象と方法】発酵納豆から曳糸性の粘性物質を浄水 に溶出して粘質液を作成し、非加熱殺菌法でありビ 夕ミン K 分解作用が証明されている紫外線照射を用 いて納豆菌の殺菌と MK-7 分解を同時に試みた。U 字型紫外線殺菌ランプを用い、液深 $1 \mathrm{~mm}$ の粘質液 に対して照度・時間を変えながら紫外線を照射した。 得られた試料を $37^{\circ} \mathrm{C}$ で 18 時間培養後、コロニー計数 法により生残曲線を描き、殺菌に必要な照射量を求 めた。照射後の液を $60^{\circ} \mathrm{C} て ゙ 20$ 時間乾燥させて粉末 とし、この粘質液粉末の還元液の糸引き長をレオメー ターにより計測した。また、粘質液粉末を添加した 蒸煮大豆食品について、匂い、風味、系引き、硬さ、 苦み、甘味、総合評価の 7 点において市販の発酵納 豆と比較した。【結果と考察】芽胞の存在により、照 射開始から 500 秒までは粘質液中の菌数減少は緩徐 であったが、600 秒以降は10-8 まで急速に減少した。 照射総量は $32.8 \mathrm{~mJ} / \mathrm{cm} 2$ で、照射前 $236 \mu \mathrm{g} / 100 \mathrm{~g}$ で あった MK-7 含有量は照射後 0 となった。加熱殺菌 を試みた従来の研究と比較して、粘質液粉末還元液 の全ての濃度において本研究では糸引き長が長く保 持された。全ての官能評価項目で市販の納豆に劣っ たが、加熱殺菌した従来法の粉末と比べると糸引き と香りの評価が高かった。【結論】紫外線照射によっ て納豆菌を殺菌しビタミン $\mathrm{K}$ をオフとしながら、系 引き性能を含む食品特性を保持した納豆風味大豆食 品を作成し得た。今後は風味等の改良を行いつつ、 ワーファリン内服患者抢よびボランティアによる性 能試験を実施する予定である。

\section{PP-106 \\ 胸部大動脈手術におけるクリオプレシピテー トの有効性について}

\author{
国立循環器病研究センター 心臓血管外科
}

猪野崇、佐々木啓明、湊谷 謙司、
松田均、田中 裕史、伊庭 裕、
小林順二郎

【目的】術中の大量出血時には循環血液量の維持や赤 血球輸血が重要であるのは言うまでもないが、希釈 性凝固生涯が引き起こす、止血不全に対する治療が 大量出血を未然に防ぐ重要な役割を果たしている。 希釈性凝固障害の主因は低フィブリノーゲン血症に よるものと考え、それが予想される症例に関し、ク リオプレシピテート(新鮮凍結血漿濃厚液)を術中に 使用している。今回、胸部大動脈手術におけるクリ オプレシピテートの使用経験を報告する。【方法】当 院で行われた、2011 年 1 月から 2012 年 4 月までの胸 部大動脈瘤のうち、希釈性凝固性障害、低フィブリ ノーゲン血症を引き起こす、あるいはすでに陥って いると予想させる症例に関しクリオプレシピテート (新鮮凍結血漿濃厚液)を術中に使用した。【結果】ク リオプレシピテートを用いた胸部大動脈の手術を待 機例 (14 例)、緊急例 (16 例)、破裂例 (6 例)であった。 待機例、緊急例、破裂例の 3 つにわけ、クリオプレ シピテート使用量、 $\mathrm{RCC}$ (赤血球濃厚液)、 $\mathrm{FFP}$ (新鮮 凍結血漿)PLT(血小板) 使用量に関し集計を行った。 待機例ではクリオプレシピテート使用量 : $3 \pm 0$ [単 位]、 $\mathrm{RCC}$ (赤血球濃厚液) : $34 \pm 19$ [単位]、 $\mathrm{FFP}$ (新 鮮凍結血漿) : $36 \pm 35$ [単位]、PLT (血小板) :53 28 [単 位]であった。緊急例では、クリオプレシピテート使 用量 : $2.9 \pm 0.3$ [単位]、RCC (赤血球濃厚液) $: 37 \pm 20$ [単 位］ＦFP(新鮮凍結血漿) : $32 \pm 13$ [単位]、PLT(血 小板) :54 20 [単位] 破裂例では、クリオプレシピテー 卜使用量 : $2.8 \pm 0.4$ [単位]、RCC(赤血球濃厚液) : 34 \pm 10 [単位]、 $\mathrm{FFP}($ 新鮮凍結血漿) : $37 \pm 20$ [単位]、 PLT(血小板) : 40土11[単位]であり、クリオプレシ ピテート、RCC、FFP、PLT の使用量に違いは認め なかった。また、緊急症例中の 7 症例に関し、フィ ブリノーゲン濃度と出血量の詳細を術中測定すると、 プロタミン投与直前の平均出血量は $36.7 \mathrm{ml} / \mathrm{min}$ 、フィ ブリノーゲン濃度は $312 \mathrm{mg} / \mathrm{dl}$ 、直後は $36.2 、 143.3 、$ 5 分後 30.5、145.5、10 分後 18.8、155.3、その後止血 が進み、40 分後には 11.0、198.0 となりほぼ閉胸出来 る状態となった。【考察】クリオプレシピテートは FFP から作成するため、作成するための手数がか かってしまうことが難点であるが、術中の大量出血 が予想される場合等においては、容量が少ないため、 投与する時間が FFPよりも短く、早く効果が出現す ることが期待され、有効な方法と考えられた。 


\section{PP-107 六 \\ 大動脈縮窄症、大動脈離断症に対する大動 脈弓再建術の成績}

福岡市立こども病院

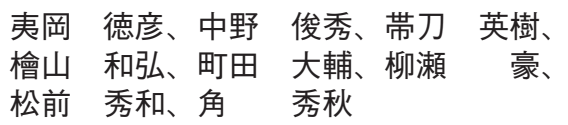

【背景と目的】CoA、IAA に対する術式として、2003 年頃より extended aortic arch anastomosis(EAAA 法)に加えて end to side anastomosis(ESA 法)を用 い始め、現在ではほぼ全例 ESA 法を行っている。両 術式の最近 10 年間の成績を検討する。【対象】対象は 2003 年 1 月から 2012 年 9 月までにCoA、IAA に対 して施行したESA法 120 例と EAAA 法 40 例。 ESA 群は CoA が 81 例、IAA が 39 例で、併存心疾 患は ASD/VSD が 73 例、TGA/DORV が 19 例、そ の他の複雑心奇形が 5 例、単心室が 23 例であった。 EAAA 群 は CoA が 33 例、IAA が 7 例 で、ASD/ VSD が 33 例、TGA/DORV が 4 例、単心室が 3 例 であった。手術は全例胸骨正中切開、人工心肺下で 行った。ESA 群で 1 例、EAAA 群で 6 例の下行大 動脈単純遮断を行っている以外は、全例下行大動脈 送血を併用している。【結果】平均観察期間は ESA 群 が $36 \pm 31$ ケ月、EAAA 群が $64 \pm 33$ ケ月であった。 ESA 群で 2 例の在院死と 5 例の遠隔期死亡を認め、 EAAA 群では 2 例の遠隔期死亡を認めた。10 年生存 率はそれぞれ 92\%、94\%であった。re-CoA に対する 再介入は、カテーテル治療を ESA 群で 2 例 $(1.7 \%) 、$ EAAA 群で 2 例 $(5 \%)$ 認めた。 5 年インターベンショ ン回避率はそれぞれ 98\%、97\%であった。術後造影 を行った症例の aortic arch angle は、ESA 群 $(\mathrm{n}=44)$ が $73.5 \pm 11$ 度、EAAA 群 $(\mathrm{n}=11)$ が $72.5 \pm 12.7$ 度で あった。コントロール群 $(\mathrm{n}=20)$ は $69.4 \pm 8.0$ であり、 3 群間の有意差は認めなかった。CoA index ( arch 最 小径/下行大動脈径) は、ESA 群が $1.08 \pm 0.21$ 、 EAAA 群が $0.84 \pm 0.15$ で、ESA 群が有意に大きかっ た $(\mathrm{p}<0.005)$ 。吻合部前後の圧較差は、ESA 群が 4 $\pm 10 \mathrm{mmHg}$ EAAA 群が $6 \pm 10 \mathrm{mmHg}$ であった。【ま とめ】Aortic arch angleは両群に差は無かったが、 CoA index は ESA 群で有意に大きかった。re-CoA に対するインターベンションの頻度は EAAA 群で高 い傾向にあった。以上の結果より ESA 法は妥当な術 式と考える。

\section{PP-108 文 \\ 側方開胸によるIAA/CoA に対する大動脈再 建の適応と限界}

\author{
1徳島大学大学院 ヘルスバイオサイエンス研究部 \\ 心臟血管外科学 \\ 2徳島大学大学院 ヘルスバイオサイエンス研究部 \\ 小児医学
}

\begin{tabular}{|c|c|c|c|c|c|}
\hline 北市 & 隆 ${ }^{1} 、$ & 菅野 & 幹雄 ${ }^{1}$ 、 & 藤本 & 鋭貴1 \\
\hline 由 & 保 ${ }^{1}$ 、 & 木下 & 肇 ${ }^{1}$ 、 & 中山 & 泰介 ${ }^{1}$ 、 \\
\hline & 美穂 ${ }^{2} 、$ & 早渕 & 康信 2 & 北川 & 哲也 ${ }^{1}$ \\
\hline
\end{tabular}

【背景と目的】近年の人工心肺や周術期管理の向上に 伴い IAA/CoA with VSD に対しては一期的修復を 目的とした胸骨正中切開による人工心肺下大動脈再 建が主流となりつつある。一方、我々は二期的修復 にて安定した成績が得られていることから新生児期 の人工心肺使用を避けた側方開胸による大動脈再建 を第一選択として行ってきた。今回、側方開胸によ り大動脈再建を行った新生児期 IAA/CoA with/ without VSDの治療成績とその問題点を検討した。 【対象】1990.4-2012.4に外科的介入を行った IAA/CoA complex 27 例、 simple CoA 5 例のうち新生児期に側 方開胸による大動脈再建を行った IAA/CoA with/ without VSD (CAVSD) の 19 例。IAA (A) 2 例、IAA (B) 1 例、CoA 16 例で、合併心内奇形は、無し 3 例、 VSD 14 例、CAVSD 2 例。手術時日齢 $14 \pm 8$ 日、体 重 $2.8 \pm 0.6 \mathrm{~kg}$ 、再建術式は、拡大大動脈弓吻合を基 本とするが 4 例に subclavian flap 法、2 例に end-toend吻合が行われた。【方法】術後経過中、大動脈再 建部に $20 \mathrm{mmHg}$ 以上の圧較差や形態上明らかな再狭 窄を生じた症例 $(\mathrm{RS}$ 群) と生じなかった症例 (NS 群) を、手術因子として体重、右腕頭動脈 - 左総頚動脈 間の大動脈弓径 (Arch 径)、再建直後圧較差 $(\mathrm{PG})$ 、 吻合中枢側端の位置等について検討した。【結果】術 前ショック状態の 1 例と $1785 \mathrm{~g}$ の低出生体重児 1 例 が手術死亡した。7 例 (37\%)に $25 \pm 8 \mathrm{mmHg}$ の再狭 窄を認めたが、全例経皮的血管形成にて狭窄は解除 され根治術が完遂された。手術時体重: RS 群 $2.9 \pm 0.6$ $\mathrm{kg}$ 、NS 群 $2.8 \pm 0.5 \mathrm{~kg}$ 、Arch 径 : RS 群 $4.4 \pm 0.9 \mathrm{~mm}$ 、 NS 群 $5.8 \pm 0.8 \mathrm{~mm}(\mathrm{p}<0.05) 、 \mathrm{PG}: \mathrm{RS}$ 群 $16 \pm 7$ $\mathrm{mmHg} 、 \mathrm{NS}$ 群 $8 \pm 8 \mathrm{mmHg}(\mathrm{p}<0.05)$ 、右腕頭動脈 起始部〜上行大動脈まで吻合口作成を要した 9 例中 4 例に再狭窄を来したが残り 5 例は再狭窄を来さず 経過した。【考察】側方開胸による大動脈再建も再狭 窄率は高いものの第 1 期手術として容認できる成績 であった。再狭窄に関しては、吻合口を上行大動脈 近くまで伸ばすこと自体は危険因子とはならず、大 動脈弓径 $4 \sim 5 \mathrm{~mm}$ 以下の hypoplastic arch 症例が 再狭窄を来す要因と考えられた。このような症例に ついては正中アプローチによる人工心肺下の再建を 考慮した治療戦略をたてる必要があると考えられた。 
PP-109 尔

僧帽弁狭窄を伴った大動脈縮窄・離断複合 に対する 2 心室修復の成績

\author{
大阪府立母子保健総合医療センター \\ 山内 早苗、川田 博昭、盤井 成光、 \\ 上仲 永純、荒木 幹太、岸本 英文
}

【背景】大動脈縮窄 $(\mathrm{CoA})$ / 離断 (IAA) 複合の僧帽弁 狭窄 (MS) 合併例は、2 心室修復 (BVR) 後の左心系の 成長がそしく、成績不良とされている。

【目的】BVRを行った CoA/IAA 複合のうち、MS 合 併例の術後成績とその影響因子の検討。

【対象と方法】94 年 -12 年の BVR 施行 CoA/IAA 複 合 67 例中、術前の心カテもしくは心エコー検査で MS (弁輪径正常比 $100 \%$ 未満もしくは形態異常) 合併 の 10 例を対象とした。

僧帽弁形態は、狭小弁輪 6 例、パラシュート様僧帽 弁 4 例。合併心内奇形はVSD10 例、ASD8 例。大動 脈弁下狭窄は 4 例で、うち 2 例は二尖大動脈弁であっ た。

初回手術時年歯令は中央值 22 日 (9 日 - 1 歳 3 ヶ月)、体 重 3.0(2.2-6.8) kg。初回術式は一期的根治術 6 例、 Arch repair+PAB 2 例（いずれも ductal shockによる 搬送例)、Arch repair のみ 2 例。Arch repair+PAB 例は、各々 7 ヶ月、 1 年 2 ケ月後に心内修復術を行い、 Arch repairのみの VSD は自然閉鎖した。Arch repair は Extended direct anostomosis 9 例、subclavian flap1 例。全例、僧帽弁に対する手術は行わなかった。 心カテ検査による僧帽弁輪径(MVD)正常比、左室拡 張末期容量 (LVEDV) 正常比、大動脈弁輪径 (AVD) 正常比、左房圧、左室駆出率 (LVEF)、心係数 $(\mathrm{CI})$ を初回手術前と BVR 術後 1.1 年(4 ケ月 - 1.6 年) で比 較し、さらにこれらと ASD 径、VSD 径、 $\mathrm{Qp} / \mathrm{Qs}$ と の相関関係を検討した。

【結果】術後観察期間は 6.5 年 $(6$ ケ月 -16.9 年)。死亡 例なし。reCoA に対するバルーン拡張術を 2 例に計 4 回要した。術前後で、MVD 94(63-123) - 104(73154) \%、LVEDV $110(79-203) \rightarrow 104(61-142) \%$ 、 AVD 88(77-93) $\rightarrow$ 103(80-120) \%、左房圧 8(1-17) $\rightarrow 7(4-10) \mathrm{mmHg}$ 、LVEF 60(47-68) $\rightarrow$ 60(53-67) \%、 CI 3.4 (2.4-3.9) $\rightarrow 4.6(3.3-5.8) \mathrm{L} / \mathrm{min} / \mathrm{m}^{2}$ といずれも有 意な変化はなかった。

$\mathrm{ASD}$ 径は術後 MVD と負の相関を示し $(\mathrm{p}=0.012 、 \mathrm{r}=$ -0.87)、VSD 径は術前 AVD と負の相関を示したが $(\mathrm{p}=0.048 、 \mathrm{r}=-0.82) 、 \mathrm{Qp} / \mathrm{Qs}$ はいずれにも相関せず、 LVEDV、左房圧、LVEF、CI に影響する因子は見出 せなかった。

直近の心エコーによる僧帽弁流入速度は 1.2(0.94-2.2) $\mathrm{m} / \mathrm{s}$ で 1 例を除き MS は顕著化せず、心機能も保た れている。Large ASD+ small VSD、術 前 MVD 88\%、LVEDV 79\%、AVD 93\% の Kabuki make-up 症候群の 1 例のみ、術後 MS が顕著化し、管理に難 渋している。

【まとめ】MS 合併の CoA/IAA 複合の二心室修復術 後は、僧帽弁輪径、左室容量は変化しないが 10 例中 9 例は MS が顕著化せず、成績は良好であった。し かし、術前大きな ASD が存在する場合は 2 心室修復 後 MS が顕著化することがあり注意が必要である。

\section{PP-110 文 \\ Modified BT shunt 術後の感染性仮性動脈瘤 に対する治療の工夫}

\author{
名古屋市立大学 心臓血管外科 \\ 中井 洋佑、鵜飼 知彦、野村 則和、 \\ 浅野 實樹、三島 晃
}

\section{【背景】}

チアノーゼ性先天性心疾患において人工血管を用い る Modified Blalock-Taussig(mBT) shunt 術は準備 手術として広く用いられている。 mBT shunt 術後の 人工血管感染は稀な合併症ではあるが、shunt 閉塞 によって酸素化不良を来したり、shunt 血管の再感染 を生じ、予後不良な合併症の一つである。今回、 mBT shunt 術後に人工血管感染、感染性仮性動脈瘤 を来した 2 例に対して外科的治療を行い、ICT と連 携して抗菌薬のプロトコールを実施して良好な結果 を得られたので報告する。

【症例】

症例 1: 3 歳男児。ファロー四徵症、肺動脈閉鎖症の 診断で日歯 19 に左 BT shunt術、2歳時に右 BT shunt 術を施行した。今回、3 歳時に持続する発熱を 認め、CT で右 BT shunt-腕頭動脈との吻合部に感 染性仮性動脈瘤を指摘された。抗菌薬治療を行うも 感染が持続していたため、人工心肺・循環停止下に 感染人工血管抜去および RV-PA 導管形成術を施行 した。術後は抗菌薬治療を継続し、感染の再燃を認 めず、4 歳時に最終手術 (Rastelli 手術)に到達した。

症例 2: 3 ケ月男児。右室型単心室症、肺動脈狭窄症 の診断にて日齢 8 に右 BT shunt 術、2 2 ケ月時に左 BT shunt 術を施行した。今回、3 月月時に酸素化不 良を契機に CT で左 BT shunt- 鎖骨下動脈吻合部に 感染性仮性動脈瘤を指摘されたため、人工心肺・循 環停止下に感染人工血管抜去および central shunt 術 を施行した。本症例も術後、抗菌薬治療を継続し、 感染の再燃を認めず、8 月月時に両方向性 Glenn 手 術を施行した。現在、最終手術待機中である。

術後抗菌薬のプロトコールは 1) 1 週間毎に血液培養 を採取して 3 週連続の陰性を確認、2) 血液検査で CRP 陰性化の 1 週間継続、3) 抗菌薬終了後、48 時間 以降に再度血液培養の陰性を確認することで抗菌薬 の終了の指標とした。上記の方法により文献上、通 常 $6 \sim 8$ 週間必要とされる加療期間を約 4 週間に短 縮し、良好な結果が得られた。

【結語】

複雑心奇形における全ての過程で、人工血管感染の 治療では感染巣の完全な外科的抜去と術後の感染制 御が重要であり、術後 ICT と連携して治療にあたり 抗菌薬治療期間を短縮できることが示唆された。 


\section{PP-111 is \\ Modified Blalock-Taussig shunt における至 適人工血管径の検討}

$\begin{array}{llll}\text { 北里大学医学部 } & \text { 心臓血管外科 } & \\ & & & \\ \text { 柴田 } & \text { 深雪、岡 } & \text { 徳彦、吉井 } & \text { 剛、 } \\ \text { 福西 } & \text { 琢真、井上 } & \text { 崇道、鳥井 } & \text { 晋造、 } \\ \text { 柴田 講、北村 } & \text { 律、華山 } & \text { 直二、 } \\ \text { 井上 信幸、友保 } & \text { 貴博、入澤 } & \text { 友輔、 } \\ \text { 榊 健司朗、林 } & \text { 秀憲、宮地 } & \text { 鑑 }\end{array}$

【目的】Blalock-Taussig shunt(BTS) は小児心臓外科 領域で重要な姑息手術の一つである。新生児、乳児 早期の BTS は肺血流過多や shunt 不全による手術死 亡・合併症は少なくないのが現状である。我々は BTSにおける至適人工血管径を検討した。【対象と 方法】当院で BTS を施行した二心室修復症例 22 例を 対象とし、 $3 \mathrm{~mm}$ 径人工血管を使用した 9 例 (A 群) と $3.5 \mathrm{~mm}$ 径を使用した 13 例 (B 群)に分け両群を比較検 討した。日齢は平均 46 日 $(8 \sim 134$ 日)、体重は平均 $3.3 \mathrm{~kg}(2.5 \sim 4.5 \mathrm{~kg})$ で両群間に差はなかった。疾患は DORV12 例、TOF6 例、TGA4 例であり、BTS は全 例胸骨正中切開アプローチで施行、肺動脈形成を同 時施行した 1 例を含む 5 例 $(22.7 \%)$ に人工心肺を使用 した。【結果】病院死亡や shunt 不全は両群共に認め なかった。肺血流過多による循環不全を B 群の 2 例 (15.4\%)に認めた。術後カテコラミン index は B 群が A 群に比し有意に高かった (A 群 : $4.4 \pm 1.0$ vs B 群 : 7 土4.2、 $\mathrm{p}=0.05)$ 。BTS 術後から根治術までの体重増 加率(BWG) は $\mathrm{A}$ 群は B 群に比し高かった(A 群 : $20.6 \pm 4.1 、 B$ 群 : $11.5 \pm 4.7 \mathrm{~g} /$ day、 $\mathrm{P}=0.001)$ 。根治術 時の体重は両群間に差はなく、BTS 術後から根治術 施行時までの日数も $\mathrm{A}$ 群は B 群に比し有意に短かっ た(A 群: $150 \pm 25 、 B$ 群: $244 \pm 98$ 日、 $\mathrm{P}=0.008)$ 。人 工血管断面積を体表面積で除した值 (人工血管係数) と BWGは負の相関を認めた $(\mathrm{R}=0.63 、 \mathrm{P}<0.01$ 、図 $1)$ 。総括】小口径 $(3.0 \mathrm{~mm})$ 人工血管の使用で shunt 不全を認めず、安定した血行動態と順調な体重増加 を得た。体格に至適の人工血管を選択する事が重要 でその選択の幅を広げる意味で、小口径人工血管の 使用は有効であると思われる。

\section{人工血管係数と体重増加率の相関関係}

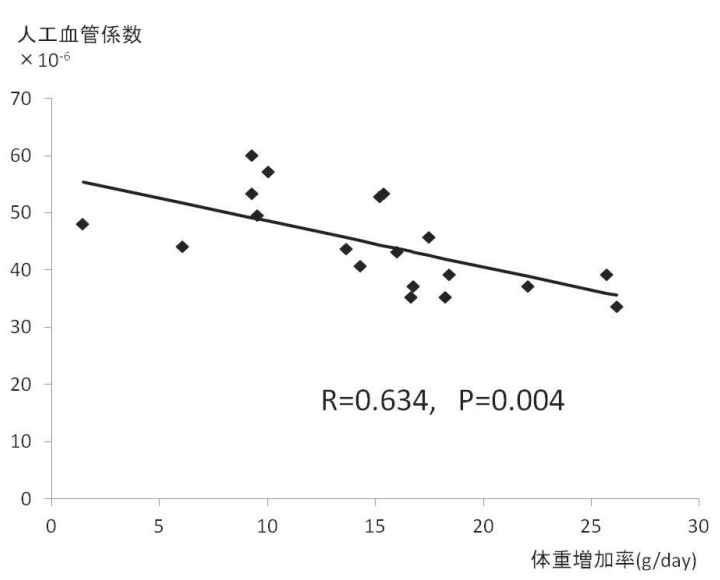

\section{PP-112 宛 新生児開心根治術の周術期管理に関する検 討}

\author{
岩手医科大学 心臓血管外科
}

$\begin{array}{lccc}\text { 岩瀬 } & \text { 友幸、猪飼 } & \text { 秋夫、小泉 } & \text { 淳一、 } \\ \text { 菅野 勝義、熊谷 } & \text { 和也、満永 } & \text { 義乃、 } \\ \text { 鎌田 武、坪井 } & \text { 潤一、金 } & \text { 一、 } \\ \text { 向井田昌之、岡林 } & \text { 均 } & \end{array}$

【背景】新生児開心根治術の成績向上は著しいが術後 状態の安定には、今尚、利尿、出血、capillary leakage を含めた水分管理が重要である。【目的】新生児 期開心術において、術後の水分管理を容易にするた め術前にステロイド、Antithrombin(AT)III 製剤を 投与し、術後出血軽減目的に modified ultrafiltration (MUF) 施行時に濃厚血小板 $(\mathrm{PC})$ 、新鮮凍結血漿 (FFP)の大量急速輸血を行い、その効果を検討した。 【方法】2007 年以降二心室修復を行った新生児開心術 に対して、デキサメサゾン $(0.25 \mathrm{mg} / \mathrm{kg})$ および AT III 製剂 500 単位を術前入室前に可能であれば投与 し、術中 MUF15 分間施行時に終了前 5 分間のみ、 PC および FFPを除水しつつ急速輸血した。術後経 過および合併症に関して検討した。【結果】対象は 36 例。完全大血管転位 (TGA) 13 例、大動脈縮窄 /大動 脈離断複合 (CoA/IAA complex) 13 例、総肺静脈還 流異常 (TAPVC) 8 例、TGAを合併した IAA 1 例、 Taussig-Bing 奇形 1 例。投与前の AT III 值 56.1\% $(n=28)$ 、投与後は全例 $130 \%$ 以上であった。手術時 体重 $2.9 \mathrm{~kg} \pm 0.5 \mathrm{~kg}$ 、体表面積 $0.20 \pm 0.03 \mathrm{~m}^{2}$ 、手術時間 $314.2 \pm 58.0$ 分、人工心肺時間 $149.7 \pm 42.3$ 分、大動脈 遮断時間 $79.5 \pm 25.6$ 分、最低直腸温 $29.7 \pm 2.7^{\circ} \mathrm{C}$ で、 MUF 時 PC 平均 $70 \mathrm{ml} 、 \mathrm{FFP} 100 \mathrm{ml}$ を輸血。周術期 死亡はなく、遠隔期に腸管穿孔で 1 例死亡。二期的 胸骨閉鎖を要した症例は 5 例。ICU 帰室直後の血小 板数、フィブリノゲン、APTT-R は $19.3 \pm 10.9 \times 10^{4}$ / $\mu \mathrm{l} 、 182.7 \pm 50.4 \mathrm{mg} / \mathrm{dl} 、 1.64 \pm 0.42$ 。術後 3 時間、3-24 時間、24-48 時間の出血量 $(\mathrm{ml} / \mathrm{kg} / \mathrm{h})$ はそれぞれ 2.1 $\pm 2.0 、 0.7 \pm 0.6 、 0.3 \pm 0.2$ 。挿管時間は $83.6 \pm 45.6$ 時間、 一酸化窒素吸入を要した症例は 6 例 (CoA/IAA complex 3 例、TAPVC 3 例)。術後 6 時間、6-24 時間、 24-48 時間の尿量 $(\mathrm{ml} / \mathrm{kg} / \mathrm{h})$ はそれぞれ $5.2 \pm 2.5 、 3.5$ $\pm 1.5 、 4.3 \pm 1.1$ 。Pediatric modified RIFLE 分類では Injury 群は CoA complex 1 例、Risk 群は 7 例 (TGA 3 例、CoA/IAA complex 3 例、TAPVC 1 例)であっ たが、全例で腹膜透析は行わず経過。ICU 滞在日数 は $8.4 \pm 4.1$ 日で、 12 日以上の症例は二期的胸骨閉鎖 例の内 3 例、長期扦管 $(\geqq 120$ 時間) 5 例であるが、腎 機能障害の有無に相関はなかった。術後合併症は、 縦隔洞炎 2 例 (5.6\%)、表層創感染 3 例 (8.3\%)、乳び 胸 1 例であった。【考察】術前の AT III 製剤、ステロ イド投与と、MUF 中の血小板、新鮮凍結血漿輸血を 併用することで、出血量と術後腎機能障害を軽減し、 術後管理を容易にする可能性が示唆された。 
PP-113 它

\section{心房細動に対する治療成績の検討〜 10 年以 上の心房細動歴を持つ症例への適応}

\section{舞鶴共済病院 心臓血管外科}

林田 恭子、松下 努、増田 慎介

当院での心房細動に対する手術適応・術後薬物療法 と成績について検討した。【対象】2008年 1 月から 2012 年 7 月までに施行した、持続性および発作性心 房細動に対する肺静脈隔離術ならびに maze 手術施 行例 71 例のうち、デー夕抽出が可能であった 69 例 (平均年齢 ; $71.6 \pm 8.7$ 歳、平均観察期間 $9.3 \pm 12.0$ ケ月) を対象とした。【結果】持続性心房細動群 48 例に対す る手術は、full maze 37 例、肺静脈隔離術 (PVI) 6 例、 左房 maze 3 例、PVI + 右房 maze 2 例であった。発 作性心房細動 21 例に対しては、full maze 1 例、PVI 12 例、左房 maze 7 例、右房 maze 1 例であった。併 施手術は、大動脈弁手術 23 例、僧帽弁手術 42 例、 冠動脈バイパス術 3 例、心房中隔欠損修復術 3 例、 基部置換術 3 例、弓部大動脈置換術 2 例、上行大動 脈置換術 1 例、永久ペースメーカー植込久術 2 例で あった。術後の薬物療法は、45 例にカルベジロール を使用した。心房細動再発例には低用量(1日 $100 \mathrm{mg}$ )のベプリジルの投与を基本とした。全症例の 術直後の除細動率は $79.7 \%$ であった。頻拍に対して、 2 例は入院中に、1 例は遠隔期にカテーテルアブレー ションを追加した。退院時の除細動率は $71.0 \%$ 、遠 隔期除細動率は $78.3 \%$ でった。中でも、発作性心 房細動では、術直後、退院時、遠隔期いずれにおい ても、心房細動を来した症例はなかった。持続性心 房 細 動 48 例 (V1 誘 導での f 波高; 平均 $0.10 \pm$ $0.06 \mathrm{mV}$ 、術前 CTR； $60.0 \pm 6.3 \%$ 、左房径 ; 平均 53.4 $\pm 6.7 \mathrm{~mm})$ のうち、心房細動歴が追跡できた 29 例に ついて検討した。10 年以上の心房細動歴をもつ症例 においては、術直後除細動率 $75.0 \%$ 、退院時除細動 率 $62.5 \%$ であったが、経過観察中に洞調律に復帰し た症例があり、遠隔期除細動率は $87.5 \%$ であった。 除細動できた症例群と、できなかった症例群での比 較検討では、術直後では術前 CTR 值 (除細動 (+) 群; $58.5 \pm 5.3 \%$ 、除細動 $(-)$ 群; $65.3 \pm 7.0 \%$ ， p=0.004)、 遠隔期では術前左房径(除細動 (+) 群; $51.9 \pm 6.6 \mathrm{~mm}$ 、 除細動 ( - 群; $56.0 \pm 6.0 \mathrm{~mm} 、 \mathrm{p}=0.021)$ において、両 群に有意差を認めた。【結語】発作性心房細動に対す るPVIならびに maze 手術の治療成績は良好であっ た。持続性心房細動では、退院時除細動率が低下す る傾向にあったが、外来での経過観察中に洞調律に 復帰する例もあり、10 年以上の心房細動歴をもつ症 例においても、比較的良好な除細動率を得られた。

\section{PP-114 \\ 心房細動手術における GP アブレーションの 周術期心房細動予防に関する比較検討}

\author{
日本医科大学 心臓血管外科 \\ 上田 仁美、坂本俊一郎、芝田 匡史、 \\ 鈴木 大悟、栗田 二郎、渡邊 嘉之、 \\ 大森裕也、藤井正大、新田隆、 \\ 落雅美
}

【目的】心房細動手術後の周術期心房性細動(POAF) の発症はめずらしくなく、管理に難渋し、入院期間 が長くなる場合もある。近年、 maze 手術に GP(心臓 神経叢)アブレーションが併用され、心房細動手術の 治療成績向上が期待されているが、この GP アブレー ション $(\mathrm{GPA})$ の除神経効果および POAF の発症率を maze 手術単独と比較した報告は少ない。【方法】我々 は 2010 年 1 月から 2012 年 2 月までに計 77 例の心房 細動手術を施行している。このうち弁膜症疾患に合 併する心房細動 36 例 (慢性心房細動 28 例、持続性心 房細動 2 例、発作性心房細動 6 例)へと施行した full Maze 手術 (Radial 手術もしくは Maze 手術)を対象に した。GPA 施行群 $(\mathrm{N}=18)$ と未施行群 $(\mathrm{N}=18)$ につい てホルター心電図による各種心拍変動パラメーター から自律神経機能を調べ、またPOAF 発症率、退院 時調律を比較検討した。GP アブレーションのうち 16 症例は高頻度刺激を GP マッピングを行い active GP を同定した後、連続刺激焼灼法を用いてアブレーショ ンを施行した。その他 2 例はそれまでの active GP の局在情報をもとに高頻度刺激を行わず、解剖学的 GP 部へのアブレーションを施行している。【結果】active GP は計 69 箇所同定 $(4.2 \pm 2.1$ 箇所 / 症例 $)$ され、 95\%が局所心外膜アブレーションで焼灼しえた。 POAF の発症は GPA 施行群 10 名 $(55 \%)$ 、未施行群 11 名 $(61 \%)$ と有意差を認めなかった。退院時の洞調 律維持率は GPA 施行群 94\%、未施行群 $88 \%$ と良好 であった。両群における術後の各種心拍変動パラメー ター（HF、LF、rMSSD、SDNN）を比較したところ、 いずれも有意差をみとめなかった。一方、すべての 対象患者で POAF の発症有無で分け、心拍変動を比 較したところ、発症群に比べて洞調律維持群で HF と LH ともに有意に低下していた。（HF 28.9 25.6 vs. $254.2 \pm 242.6 \mathrm{P}<0.05)(\mathrm{LF} 18.5 \pm 23.5$ vs. $254.4 \pm$ $222.7 \mathrm{P}<0.05$ 【結論】GP アブレーションの併用は 除神経効果、POAF 発症率および退院時洞調律維持 率に関して full maze 手術単独と明らかな差は得られ なかった。また GP アブレーションの併用有無に限ら ず、POAF 発症予防に関して除神経効果が関与して いる可能性が示唆された。 


\section{PP-115 \\ 低心機能患者に対する Maze 手術の安全性 と有効性の検討}

\author{
新東京病院 心臓血管外科 \\ 糸原 孝明、山口 裕己、中尾 達也、 \\ 大島祐、徳永 宜之、依田 真隆、 \\ 浅見 冬樹、中村 裕昌、門脇 輔、 \\ 植野 恭平
}

【目的】心房細動に対する Maze 手術の有用性は十分 に認識されている。当院では従来より心房細動を有 するすべての開心術患者に除外基準を設けずに Maze 手術を行ってきた。今回我々は低心機能患者 (EF40\%未満)に対する Maze 手術の安全性と有効性 について検討した。【対象】2009 年 5 月から 2012 年 3 月まで当院における Maze 手術について検討した。 この間に 235 例の Maze 手術を施行した。男性 126 人、女性 109 人。年齢 $69.9 \pm 9.9$ 歳。発作性心房細動： 59 例 慢性心房細動: 176 例。手術の内容はFull Maze 手 術(Biatrial Maze) 195 例、Mini-Maze 手術 32 例、LA Maze 手術 2 例、PV isolation6 例であった。 基本的に慢性心房細動に対してはBiatrial Maze (Mini Maze+右房側 Maze を付加)また発作性心房 細動に対しては Mini Maze(PV isolation+ 左右 isthmus ablation+ 左心耳切除) を行っている。同時手術 は大動脈弁置換術 72 例、大動脈弁形成術 2 例、僧帽 弁置換術 33 例、僧帽弁形成術 146 例、冠動脈バイパ 又術 53 例、三尖弁形成術 180 例その他である。再手 術は 16 例あった。巨大左房に対しては左房縫縮術を 42 例で施行した。これらを $\mathrm{EF} 40 \%$ 以上の群( $\mathrm{A}$ 群): 210 例と EF40\%未満の群(B 群): 25 例に分けた。【結 果】年齢は $\mathrm{A}$ 群年齢 $70.1 \pm 9.9$ 歳、B 群 $69.0 \pm 11.3$ 歳。 A 群 は Paf: 55 例 Caf: 155 例。B 群 は Paf: 4 例 Caf: 21 例であった。手術の内容は Biatrial Maze 手術 (A 群 173 例、B 群 22 例) Mini-Maze 手 術 (A 群 29 例、 $\mathrm{B}$ 群 3 例)、PV isolation 手術 A 群 の 26 例。 LA Maze 手術 A 群のみ 2 例であった。左房径は $\mathrm{A}$ 群 $50.9 \pm 12.1 \mathrm{~mm} 、 \mathrm{~B}$ 群 $45.6 \pm 2.1 \mathrm{~mm}$ 。駆出率はA 群 $59.0 \pm 8.3 \%$ 、 B 群 $31.3 \pm 2.8 \%$ 。院内死亡A群 5 例 $(2.3 \%) 、 B$ 群 1 例 $(4 \%)(\mathrm{p}=0.85)$ 。死因は呼吸不全 1 例、MOF 1 例、SAH1 例、脳出血 1 例、敗血症 1 例、 虚血性腸炎 1 例であった。遠隔死亡は A 群にのみ 4 例 (ARDS1 例、不明 1 例、薬物中毒 1 例、敗血症 1 例) であった。退院時の除細動率は A 群 $67.1 \% 、 B$ 群 $80 \%(\mathrm{p}=0.12)$ 。最終外来時除細動率は A 群 $82.1 \%$ 、 $\mathrm{B}$ 群 $85 \%(\mathrm{p}=0.43)$ 。ペースメーカーの植え込みは $\mathrm{A}$ 群 33 例 (15.7\%、SSS30 例、CABV2 例、ICD1 例) で B 群 は 7 例 (28\% SSS1 例、CAVB1 例、CRTD3 例、 ICD2 例) であった。【結語】今回の検討で低心機能症 例に対する Maze 手術は院内死亡を上げることなく、 安全であり、かつ正常な心機能と同等の除細動率を 達成できる有効性が明らかとなった。今後更なる症 例を重ね、遠隔期における有効性、意義を検討する 必要があると考えている。

\section{PP-116 尓 \\ 周術期におけるランジオロール塩酸塩の Af 予防効果について}

\author{
岸和田徳洲会病院 心臓血管外科 \\ 頓田央、東上 震一、松林 景二、 \\ 川平 敏博、東修平、薦岡 成年、 \\ 平松 範彦、降矢 温一
}

冠動脈バイパス術後の心房細動 (Af)の発生率は約 20 〜 30\%と言われ、脳梗塞や下肢動脈塞栓症などのリ スクを増大させる。 $\beta$ 遮断薬は生体内の交感神経 $\beta$ 受容体に拮抗して交感神経の興奮を抑え、心拍数お よび心収縮を低下させ、心筋酸素消費量の増加を抑 える。また心拍数の減少に伴い、心拡張周期を延長 することにより、冠血流の増大をもたらし虚血性心 疾患の進展を抑制する。今回我々は、冠動脈バイパ 又術時、麻酔導入時より塩酸ランジオロール(短時間 作用型 $\beta 1$ 選択的遮断薬) を低用量で持続投与し、術 中・術後における心房細動の予防効果、循環動態に 及ぼす影響を検討した。対象；2011 年 9 月から 2012 年 2 月までに当院で施行した冠動脈バイパス症例は 125 例。当該期間に塩酸ランジオロールを使用。2011 年 1 月から 8 月までの冠動脈バイパス症例は 155 例。 心原性ショック、安静時(導入時) $50 / \mathrm{min}$ 以下の徐脈、 2 度以上の AV ブロック、甲状腺機能低下症または 充進症を有する症例、DHCA 症例は除外した。ラン ジオロール使用群 (L 群) は 113 例、コントロール群 (C 群) は 134 例。麻酔導入後より塩酸ランジオロール(オ ノアクト)を $1 \mu \mathrm{g} / \mathrm{kg} / \mathrm{min}$ で開始し、循環動態に応じ $0 \sim 10 \mu \mathrm{g} / \mathrm{kg} / \mathrm{min}$ の範囲で適宜増減を行いつつ、 2POD まで持続静注投与した。心拍数、血圧、CKMB、トロポニン -I を術前、ICU 帰室時、6 時間後、 12 時間後、1、2、3POD で測定した。また BNPを術 前、帰室時、1、2、4、7、14POD で測定した。結果・ 結語; 術後 48 時間の心房細動発生率は L 群 7.6\%、 C 群 $13.3 \%$ で有意差はないがランジオロール群で抑 制傾向が見られた。術後覚醒から抜管時のストレス においても血圧・脈拍を変化させず、頻脈発生を予 防する傾向にあった。心筋障害マーカー (CK-MB、ト ロポニン I)についても、ランジオロール群で低い傾 向となった。塩酸ランジオロールは開心術後の循環 動態に悪影響を与えず、頻脈性不整脈、特に心房細 動の予防に有用であると思われた。 
PP-117 文

\section{心外膜用アブレーションデバイスの有効性と 循環血流の与える影響}

\author{
${ }^{1}$ 日本医科大学附属病院 外科 心臓血管外科 \\ ${ }^{2}$ ワシントン大学 心臓外科
}

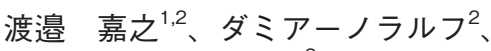 \\ シュスラーリチャード、落雅美 ${ }^{1} 、$ 新田隆 ${ }^{1} 、$ \\ 清水 一雄 ${ }^{1}$
}

【背景】心房細動に対する外科的アブレーションデバ イスの中でラジオ波を用いたクランプデバイスは確 実なブロックラインを形成できると考えられている。 そのデバイスも改良され、近年心外膜側からのアブ レーション可能となった。ワシントン大学において その一つである Atricure Coolrail(AtriCure, Inc.) を用いて動物に対しテストされたが、結果は満足の いくものではなかった。特に右房から上・下大静脈 (SVC/IVC)にかけてのアブレーション作成率 (48\%) は左房自由壁(LA)に比べ低かった $(92 \% 、 \mathrm{P}<0.01)$ 。 原因としてアブレーションが単回施行であったこと、 循環血流がデバイスエネルギーを障害していると考 えられた。今回の研究ではアブレーションの反復施 行(研究 1)、両上大静脈の血流を遮断しアブレーショ ンを施行 (研究 2) し、その影響を検討した。【方法】ア ブレーションは Coolrail デバイスを用いて行われた。 アブレーション組織は 1\% 2,3,5-triphenyltetrazolium chloride で染色後、短軸方向に $5 \mathrm{~mm}$ ごとに切り出し 貫壁性を評価した。研究 1：ブタ 6 匹に対し心拍動 下に心外膜アブレーションを行った。アブレーショ ンはLA、右房自由壁 (RA) と SVC/IVCに各 40 秒で 2 回ずつ施行。研究 $2:$ ブタ 6 匹を使用し、RA から $\mathrm{SVC} / \mathrm{IVC}$ にかけての領域への心拍動下にアブレー ション施行。両大静脈の遮断もしくは非遮断のもと 各 1 回ずつ 40 秒施行した。【結果】研究 1 : 組織の厚 さは平均 $2.74 \pm 1.95 \mathrm{~mm}$ (範囲: 0.49-12.1mm)。組織 切片中のアブレーション貫壁率は $76 \%(160 / 211)$ 。ア ブレーション範囲全体の貫壁率は $54 \%(19 / 35)$ 。各領 域の貫壁率は SVC/IVC 領域が 48\%で (33/69) で他の 領域より優位に低值であった (LA 92\%: p < 0.01、 RA 86\%: p < 0.01)。アブレーションの反復施行では LA 領域のみが有意に貫壁率が改善した(単回施行: $71 \% 、 2$ 回施行 : $92 \%, \mathrm{p}<0.05)$ 。血流遮断群は非遮 断群に比べ優位に貫壁率が高かった $81 \% \mathrm{vs} 24 \%$ 、p < 0.01)。【結論】Coolrail デバイスによる反復アブ レーションはLA 領域のみ貫壁率が改善した。循環 血流はSVC/IVC 領域におけるアブレーションパ フォーマンスを低下させていると考えられた。

\section{PP-118 2 خ 血管手術症例における術前冠動脈評価}

奈良県立医科大学 胸部 - 心臟血管外科

廣瀬 友亮、多林 伸起、吉川 義朗、

阿部 毅寿、早田 義宏、山下 慶悟、

谷口 繁樹

【目的】腹部大動脈瘤 $(\mathrm{AAA}) 、 末$ 、梢動脈疾患 $(\mathrm{PAD})$ は 冠動脈病変の合併が多く、周術期予後に影響を与え る。当科では AAA、PADの術前冠動脈病変の評価 として、薬物負荷心筋シンチ $(\mathrm{RI})$ を行っている。虚 血性変化を認めた場合には CAG を施行し治療方針 を決定している。その妥当性について検討した。【対 象と方法】対象は 2007 年 1 月から 2012 年 6 月に施行 したAAA、PAD 待機手術症例 241 例中、術前に RI を施行した 201 例。 RI は薬物 (ジピリダモール、アデ ノシン)負荷を行い、99mTc-MIBI もしくは $201 \mathrm{TlCl}$ を静注した。基本方針は、3 枝病変、LMT 病変症例 には CABG を先行もしくは同時手術、2 枝病変、 1 枝病変でも LAD 病変を有する症例ではPCIを、 LAD 病変以外の症例では血管病変に対する外科治療 を先行した。しかし、内胸動脈が下肢の血管病変の 側副血行路となっている場合には、下肢バイパス術 を先行するか $\mathrm{CABG}$ を同時に行った。術後は、(1) 心筋梗塞、(2) 不安定狭心症、(3) うっ血性心不全、 (4)心室頻拍・心室細動を心合併症とした。【結果】RI を施行した 201 例中 27 例 (13.4\%) に虚血性変化を認 め、26 例に CAG、1 例に心臓 CT を施行した。その 結果、有意狭窄と判断したものは 16 例 (1 枝病変 : 6 例、 2 枝病変 : 7 例、 3 枝病変 3 例) であった。 3 枝病 変の 3 例と 2 枝病変の 2 例に CABG を施行した。そ のうち 2 例は Leriche 症候群 (内胸動脈が下肢への側 副血行路)で、1例は同時手術を行い、もう 1 例は下 肢バイパス術を先行した。2 枝病変の 5 例と 1 枝病 変の 1 例で PCI を先行した。1 枝病変の他の 5 例は $\mathrm{LAD}$ 病変ではなく、1 例は $\mathrm{AAA}$ が径 $8 \mathrm{~cm}$ であった ため血管手術を先行し、1 カ月後にPCIを施行した。 それ以外の 4 例は灌流域が小さかったため薬物療法 とした。入院死亡は 2 例 (1 例 : MOF、 1 例 : 肺炎)で、 non-sustained VTを 1 例認めた以外に心合併症は認 めなかった。【結語】冠動脈病変の評価として、薬物 負荷心筋シンチでスクリーニングを行い、虚血を認 める症例には CAG を行い、積極的に冠状動脈血行再 建することで周術期の心合併症を予防し得た。 


\section{PP-119 公 心房細動は ICU 滞在期間, 入院期間を延長 させない}

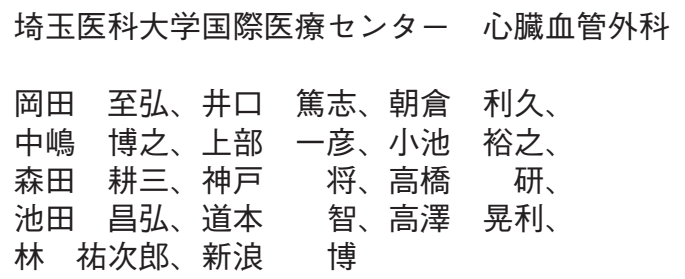

【はじめに】心臓大血管術後に心房細動を発症した場 合に入院期間が延長することが報告されている。急 性大動脈解離 (Stanford typeA)の術後に心房細動を 発症した症例は、積極的に治療をした場合でも、集 中治療室 $(\mathrm{ICU})$ 滞在期間、入院期間を延長するか検 討した。

【対象と方法】 2007 年 4 月から 2012 年 3 月に急性大 動脈解離に対して手術を施行した 161 例(男 100 例、 女 61 例)のうち、入院時に心房細動であった 7 例、 手術死亡 8 例抒よび、重度脳障害 3 例を除く 143 例 (男 90 例、女 53 例)を対象とした。年齢は 33 歳から 86 歳(平均 63 歳)であった。入院期間中の診療録を 後乃向きに調查し、入院期間中、経過表に記載され たすべての心房細動を対象とした。心房細動が確認 された時点で、マグネシウム、抗不整脈剂(ピルジカ イニド、アミオダロンなど)を投与し、効果がない場 合は電気的除細動を施行した。心房細動が遷延した 場合は抗凝固療法を開始した。

【結果】術後心房細動を発症したのは 61 例 (42.66\%)で あり、心房細動発症時期は、㨂管期間中 33 例 (54.01\%)、ICU 滞在期間中 19 例 (31.15\%)、ICU 退 室後 9 例 $(14.75 \%)$ であった。心房細動発症症例の平 均年齢は 67.2 歳、平均挿管期間は 7.2 日、平均 ICU 滞在期間は 11.5 日、平均入院期間は 32.5 日、洞調律 維持症例の平均年齢は 60.2 歳、平均挿管期間は 5.3 日、平均 ICU 滞在期間は 9.1 日、平均入院期間は 29.6 日だった。平均年齢: $\mathrm{p}=0.0011$ 、平均挿管期間 : $\mathrm{p}=0.017$ 、平均 ICU 滞在期間 $: \mathrm{p}=0.027$ 、平均入院期 間 $\mathrm{p}=0.22$ で、心房細動発症症例では、高年齢であり、 平均挿管期間、平均 ICU 滞在期間が有意に長かった。 年齢別に見た心房細動発症の頻度は、30-39歳で 5 例 中 1 例 $(20.0 \%) 、 40-49$ 歳 で 24 例 中 6 例 $(25.0 \%)$ 、 50-59 歳で 23 例中 10 例 (43.5\%)、60-69 歳で 36 例中 13 例 (36.1\%)、70-79 歳 で 39 例 中 19 例 $(48.7 \%) 、 80$ 歳以上で 16 例中 12 例 $(75.0 \%)$ だった。年齢の層別解 析による、50-79歳の 98 例 (男 59 例、女 39 例) の検 討では、心房細動発症症例の平均年齢は 66.7 歳、平 均挿管期間は 6.31 日、平均 ICU 滞在期間は 10.95 日、 平均入院期間は 29.3 日であり、洞調律維持症例の平 均年齢は 64.7 歳、平均挿管期間は 5.38 日、平均 ICU 滞在期間は 9.35 日、平均入院期間は 30.4 日だった。 平均年齢 : $p=0.74$ 、平均挿管期間 : $p=0.86$ 、平均 $\mathrm{ICU}$ 滞在期間 : $\mathrm{p}=0.96$ 、平均入院期間 $\mathrm{p}=0.83$ で、有意差 はなかった。

【結語】術後心房細動は適切に治療することにより、 ICU 滞在期間、入院期間に影響を与えなかった。

\section{PP-120 宛 \\ 人工心肺を用いた小児開心術における周術 期の補体值変動について}

\author{
群馬県立小児医療センター 心臓血管外科
}

乾 明敏、吉井 剛、宮本 隆司

【背景】補体は生体防御において重要な役割を担って おり、炎症の急性期には産生が方進する結果上昇す る。一方、肝硬変やネフローゼ症候群といった血清 補体価が低下する病態も各種認められている。しか し、小児開心術前後での補体価の変化は、手術侵襲 による炎症の結果増加するのか、人工心肺使用によ る消耗の結果減少するのかは不明である。また、小 児開心術後の稀な合併症である capillary leak syndrome の発症に補体が関与しているとの報告もある。 以上より、人工心肺前後での補体值の比較を行うこ ととした。【方法】2010 年 4 月より 2012 年 8 月におけ る当院での心臓血管外科手術 (人工心肺使用例)のう ち、人工心肺使用前後に補体值 $(\mathrm{Clq}$ 、血清補体価、 C1 inactivator 活性、C3、C4)を測定した 96 例が対象。 人工心肺前後での補体值変化について分析した。【結 果】人工肺前後での補体值の変化率を調べたとこ ろ、C1q、血清補体価、C1 inactivator 活性、C3、C4 はそれぞれ $29.7 \pm 18.8 \% 、 36.5 \pm 20.6 \% 、 27.1 \pm 13.5 \%$ 、 $25.7 \pm 38.4 \%$ 、29.0 $\pm 69.4 \%$ 減少しており、増加した項 目は1つも認めなかった。また、Basic Aristotle Score (BAS) に注目して 8 以上を $\mathrm{H} 1$ 群 (54 例)、8未 満を L1 群(42 例) として両群の比較を行ったところ、 C4 の減少率は H1 群が $39.9 \pm 18.2 \%$ L1 群は $14.9 \pm$ $101.8 \%$ であり、H1 群で有意に大きかった $(\mathrm{p}=0.04)$ 。 $\mathrm{C} 3$ については $\mathrm{p}=0.13$ で、 $\mathrm{H} 1$ 群で減少率が大きい傾 向であった。一方、人工心肺時間 (CPB time) に注目 して 200 以上を $\mathrm{H} 2$ 群 (41 例)、200未満を L2 群(55 例) として両群の比較を行ったところ、全ての項目に 関して減少率に有意差は認めなかった。【考察】人工 心肺使用により補体值は減少することが判明した。 また、BAS が高ければより減少する傾向が示唆され た。しかし、CPB time は減少の程度には無関係であっ た。今後も引き続き症例を積み重ね、補体值減少に 影響する因子を同定したい。 
PP-121 公

感染性大動脈瘤に対する当科でのリファンピ シン浸漬グラフトの使用成績

\section{慶應義塾大学病院 心臓血管外科}

灰田 周史、志水 秀行、吉武 明弘、

川口新治、高木 秀暢、伊藤 隆仁、

平野 暁教、川口聡、四津 良平

【目的】感染性大動脈瘤は全大動脈瘤のうち 0.5 $1.3 \%$ と比較的まれであるが、死亡率は $23.5 \sim 37 \%$ と 極めて高く、予後不良な疾患である。われわれの施 設における感染性大動脈瘤に対する基本方針は、ま ず抗生剤治療を行い、その後、リファンピシン浸漬 グラフトを用いて人工血管置換術 (in-situ)を行うもの である。今回、感染性大動脈瘤に対する外科治療成 績を報告する。【対象】2008 年から 2012 年 6 月まで に当科で感染性大動脈瘤に対しリファンピシン浸漬 グラフトを使用した 8 例 (年齢 $41 \sim 73$ 歳、男性 6 . 女性 2 例)。病変は基部 上行 3 例、下行 1 例、胸腹 部 2 例、腹部 2 例であった。 8 例中 5 例が再手術で、 うち 1 例が腹部ステントグラフト内挿術後だった。 全例で発熱と炎症反応の克進を認め、CT で感染性 大動脈瘤に矛盾しない結果を確認した。5例が術前 血液培養陽性例で、残り 3 例の血液培養陰性例中 2 例で術中採取した組織培養結果が陽性であった。起 因菌は MRSA 3 例、MRSE 2 例、ほか P. aeruginosa、 E.coli、Candida 各 1 例であった。緊急 1 例、準緊急 3 例、待機手術 4 例であり、待機的手術可能だった 4 例は、抗生剂投与により血液培養陰性化した後に手 術を施行した。術式は、Bentall 手術 3 例、下行置換 術 1 例、胸腹部置換術 2 例、腹部大動脈置換術 2 例 であり、全症例でリファンピシン浸漬グラフトを用 いて in-situ 人工血管置換術を行った。【結果】術後平 均在院日数は 35 日で、全例生存退院した。平均 2 年 の観察期間で 1 例他因子 (脳出血)を認めたが、その 他の症例では明らかな感染の再発を認めていない。 【結論】少ない経験数ではあるが、リファンピシン浸 漬グラフトを用いた人工血管置換術は感染性大動脈 瘤に対してきわめて有効な治療法であると考えられ た。

\section{PP-122 㫕 \\ 大伏在静脈採取部におけるJVACを用いた 創傷管理}

\author{
大和成和病院 心臓血管外科 \\ 鈴木耕太郎、遠藤 由樹、菊地 慶太、 \\ 小坂 眞一、倉田篤
}

当院では、冠動脈バイパス術において使用する大伏 在静脈を、下腿を基本として採取している。近年糖 尿病患者、透析患者のバイパス症例が増加し、創傷 治癒遅延のリスクが高まっている。当科では、JVAC system を使用した除圧療法を用いて創傷治癒 を促進する試みを行い、良好な経過を得られている ので報告する。方法 : 大伏在静脈採取後、創部の止 血を十分に行う。採取部が下腿の場合は滕から、大 腿に及ぶ場合は膝、鼠径部の 2 箇所から、10Fr の JVAC brake drain を挿入する。皮下は縫合せず、皮 膚を 4 - OPDS 連続マットレスで埋没縫合し、足関 節から大腿まで弾性包帯で圧迫する。結果：2011 年 11 月から、連続 21 例の CABG 症例に対して、25 箇 所から大伏在静脈を採取し、上記方法で創閉鎖を行 なった。全例で創離開や創感染はなく、創傷治癒は 良好であった。平均のドレーン挿入日数は 4.7 日、ド レーン排液量は、一日平均 $30 \mathrm{~g}$ であった。創に関す るトラブルは、1 例で血腫残存にて血腫除去を要した が縫合不全はなかった。この症例は、ドレーン抜去 時の排液が血性で量も多く、手術時の止血とドレー ン抜去のタイミングに問題があったと考えられた。 また、3 例、術直後のドレーン排液量が多かった症例 で、ドレーン抜去後、ドレーンホールからの浸出液 を認めたが、弾性包帯装着によりいずれも問題なく 治癒した。大伏在静脈採取創に対する J-VACによる 陰圧療法は、創傷治癒に対して有効であると考えら れた。皮下縫合を行わない分、㓌圧療法を行うこと で皮下の dead space をなくし、綺麗な創面にするこ とが可能であった。ただし、当然のことではあるが、 閉創時の確実な止血、また適切なドレーン抜去の夕 イミングが重要であると考えられた。 
PP-123 公

両側多発性腎囊胞腎不全患者の心臓・血管 手術

群馬県立心臟血管センター 心臓血管外科

\author{
滝原瞳、金子 達夫、江連 雅彦、 \\ 佐藤 泰史、長谷川 豊、岡田 修一、 \\ 小此木修一、伊達 数馬
}

(はじめに) 常染色体優性遺伝型多発性囊胞腎に患者 において冠動脈疾患、大動脈疾患の合併の報告は稀 である。今回、多発性囊胞腎を伴う心臓・血管手術 を 5 例経験したので報告する。<症例 $1>64$ 歳男性。 突然ショック状態となり、心エコー・CT で大動脈解 離(Stanford A 型)を認めた。尿流出なく、Cre 3.0、 $\mathrm{K}$ 值 6.8 と高值で、 $\mathrm{CHDF} \cdot \mathrm{G}-\mathrm{I}$ 療法施行し、上行置 換術施行。術後は利尿剂持続投与にて管理。Cre 2.4 で術後 33 日目に退院。<症例 2>54 歳女性。多発 性囊胞腎による慢性腎不全にて 2 年前より透析導入。 その際の follow up CT にて慢性大動脈解離(Stanford A 型) 認め、上行弓部全置換術施行。術後は 酸素化不良、胸水貯留したが $\mathrm{CHDF} \cdot \mathrm{HD}$ での除水 により、酸素化・胸水貯留改善。術後 34 日目に退院。 <症例 $3>56$ 歳男性。多発性腎囊胞による慢性腎不 全にて 5 年前より透析導入。労作時胸痛あり、CAG にて 3 枝病変を認めたため、人工心肺下に冠動脈バ イパス術施行。術中 HD・術後 CHDF 施行。術後 11 時間後に血圧低下、電解質異常などから VT となり PCPS、IABP を挿入。その後改善し、術後48 日目 に独歩退院。<症例 $4>56$ 歳女性。多発性囊胞腎に よる慢性腎不全にて維持透析を行っていた。前䅡部 と胸部に疼痛を認め、かかりつけ医受診。心電図上 の変化はないため透析施行したが血圧低下あり 1 時 間で終了。夕方に再度胸痛出現し。心エコーで心夕 ンポナーデの所見あり当院緊急搬送。CT で大動脈解 離(Stanford A 型)の所見を認めた。意識レベル低下、 ショック状態となり、心囊ドレナージ施行後、上行 置換術施行。術中 HD - 術後 CHDF 施行。酸素化不 良であったが術後 6 日目抜管し、CHDF 終了。循環 動態は安定。術後 18 日目、加療目的に透析病院へ転 院。<症例 $5>77$ 歳男性。多発性囊胞腎による慢性 腎不全あり。4 年前より腹部大動脈瘤を指摘され、フォ ローされていた。瘤径拡大し、Cre 3.30でYgrafting+IMA 再建術施行。術後 Cre 4.72 まで上昇 したが補液負荷を行い、透析を回避した。術後 18 日 目に退院。(まとめ)電解質異常で治療に難渋した多 発性囊胞腎患者の術後経過を含め、文献・考察を加 え報告する。

\section{PP-124 宛 \\ 初診時に無症候性の血栓閉塞型 A 型解離と 診断された炎症性上行大動脈瘤の 1 例}

\author{
砂川市立病院 心臓血管外科
}

橋口 仁喜、鈴木 崇史、佐々木昭彦

【はじめに】炎症性大動脈瘤は腹部大動脈瘤の約 5\% に認め、しばしば目にする疾患である。しかしなが ら炎症性胸部大動脈瘤に関しては報告が少なく、特 に上行大動脈に関してはほとんど報告がない。今回 我々は、初診時に A 型解離を疑われた炎症性上行大 動脈瘤の 1 例を経験したため報告する。【症例】60 代 男性。約 2 週間前より嗄声と夜間の脂汗を自覚し改 善しないため近医を受診。悪性リンパ腫を疑われ胸 部 CT を確認したところ上行大動脈に大動脈解離を 疑う所見を認め、当院紹介入院となった。2 週間前よ り嗄声と夜間の脂汗が出現していることから、発症 後 2 週間経過した慢性 A 型大動脈解離と診断した が、血栓化した偽腔が $11 \mathrm{~mm}$ と厚く、ASはないも のの二尖弁およびバルサルバ洞の軽度拡大を認めた ため、手術適応と判断し、準緊急的に大動脈基部置 換術を行う予定とした。胸骨正中切開にて縦隔にア プローチすると、無名静脈および上行大動脈周囲に 強固な癒着を認め、上行大動脈は大動脈壁が石灰化 したように硬くなっており、炎症性大動脈瘤の所見 であったため、手術は行わずに閉胸した。術後造影 MRI にて、上行大動脈壁の著明な肥厚を認め炎症性 上行大動脈瘤と診断。上行大動脈径は $45 \mathrm{~mm}$ であり、 嗄声以外はほぼ無症状のため、ステロイド投与など も行わずに外来経過観察とした。【考察】炎症性上行 大動脈瘤は報告がほとんどなく、マントルサインを 認めても、早期血栓閉塞型 $\mathrm{A}$ 型解離と非常に類似し た CT 像となるため、CT 画像のみから判断すること ができない。炎症性腹部大動脈瘤の場合と異なり、 炎症による痛み症状が出現しにくいことから、痛み 症状のない無症候性慢性 A 型解離を認めた場合には 炎症性大動脈瘤の可能性も考慮し、慎重に画像診断 を進めることが必要だと考えられた。 
PP-125 公

\section{0 歳以上の弁膜症症例における Japan SCORE と手術成績の相関の解析}

\author{
東北大学医学部 心臓血管外科 \\ 鈴木 智之、川本 俊輔、本吉 直孝、 \\ 熊谷紀一郎、秋山 正年、安達 理、 \\ 齋藤 武志、河津 聡、齋木 佳克
}

【目的】 80 歳以上の弁膜症症例に対する手術治療にお いては、術前リスク評価・予後の検討が不可欠である。 今回、術前リスク評価の指標である Japan SCORE と実際の術後経過との相関について検討した。【対 象】2001 年から 2011 年までの 10 年間の弁膜症手術 症例 419 名(男性 233 名、女性 186 名) を対象とした。 80 歳未満 389 例 (A 群)、80 歳以上 30 名 (B 群) とし、 それぞれの平均年齢は 62.4 ( \pm 13.4$)$ 歳、 $82.5( \pm 2.2)$ 歳 であった。背景として脳血管疾患の既往があるもの

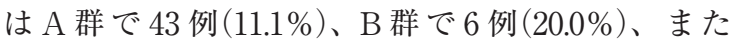
心臓手術歴のあるものは A 群で 115 例 $(29.6 \%) 、 B$ 群で 3 例 $(10.0 \%)$ と有意差がみられた $(\mathrm{P}=0.02) 。 \mathrm{~A}$ 群、 $\mathrm{B}$ 群の術前の $\mathrm{EF}$ の平均はそれぞれ62.8(14.0) \%、 61.4( \pm 13.4$) \%$ 、心不全の割合は $32.9 \% 、 30.0 \%$ と差は なく、B群の Japan SCORE の平均は 6.52( \pm 6.2$) \%$ であった。手術の内訳は大動脈弁手術が A 群で 223 例 (57.3\%)、B 群で 24 例 $(80.0 \%)(\mathrm{P}=0.02)$ 、僧帽弁手 術が A 群で 213 例 (54.8\%)、B 群で 6 例 (20\%) ( $\mathrm{P}<$ 0.01)行われており、大動脈弁および僧帽弁の両弁手 術が行われたものは A 群で 60 例 $(15.4 \%)$ に対し B 群 で 0 例であった $(\mathrm{P}=0.01)$ 。 群の大動脈手術はすべ て大動脈弁置換術であり、CABG を併施したものは $\mathrm{A}$ 群で 23 例 (5.9\%)、B 群で 6 例 $(20.0 \%)$ であった $(\mathrm{P}=0.01)$ 。両群の術中遮断時間は $\mathrm{A}$ 群 184.2 分、 $\mathrm{B}$ 群 153.7 分と $\mathrm{B}$ 群が短く $(\mathrm{P}=0.04)$ 、人工心肺時間に は差がなかった。【結果】術後挿管時間、ICU 滞在日 数は A 群、B 群で差はなかった。IABPを要したも のは $\mathrm{A}$ 群で 28 例 $(7.2 \%) 、 \mathrm{~B}$ 群で 3 例 (10\%)、術前 後にPCPSを必要としたのはA 群 8 例 $(2.1 \%)$ に対し $\mathrm{B}$ 群で 0 例であった。術後全合併症の割合は $\mathrm{A}$ 群で 200 例 (51.4\%)、B 群で 13 例 (43.3\%)、そのうち脳卒 中の数は $\mathrm{A}$ 群 9 例 $(2.3 \%) 、 \mathrm{~B}$ 群 1 例 $(3.3 \%)$ 、透析は $\mathrm{A}$ 群 28 例 $(7.2 \%) 、 \mathrm{~B}$ 群 1 例 (3.3\%)、肺炎は A 群 18 例 (4.6\%)、B 群 1 例 (3.3\%) であった。30 日後死亡は $\mathrm{A}$ 群で 8 例 $(2.1 \%) 、 \mathrm{~B}$ 群で 0 例、退院時死亡は A 群 で 20 例 $(5.1 \%) 、 B$ 群で 0 例であった。【考察】80歳 以上の弁膜症手術症例の術後経過は 80 歳未満の群に 劣らず、30 例中の術後死亡率は $0 \%$ であり、Japan SCOREによる予測と乘離がみられた。術式が比較的 簡易であった等の要素が考えられるが、超高齢者で も条件が悪くなければ術後の生存の見込みは低くな いことが示唆された。

\section{PP-126 々 گ 超高齢者に対する大動脈弁置換術の手術成 績〜日本における TAVI 適応について〜}

\author{
高知医療センター 心臓血管外科 \\ 田中 哲文、岡部学、三宅陽一郎、 \\ 旗厚、大上 賢祐
}

\section{【目的】}

近年、80 歳以上の超高齢者における大動脈弁疾患が 増加しているが、特に高齢者は虚血性心疾患や慢性 腎不全などの合併症も多く手術のリスクは高いもの と考えられており、外来で経過観察となっている症 例も多い。当院における 80 歳以上の超高齢者に対す る大動脈弁置換術 (AVR)の手術成績を検討した。

\section{【対象と方法】}

2005 年 3 月から 2012 年 4 月までに当科で施行した 80 歳以上の AVR 78 例のうち、待機症例 68 例 $(87 \%)$ を対象とした。平均年齢 $82.6 \pm 3.2$ 歳、最高齢は 93 歳。 男性 18 例、女性 50 例。術前診断は AS 65 例 (96\%)、 AR 3 例 (4\%)。術前合併症としては、虚血性心疾患 21 例 (31\%)、慢性腎不全 6 例 (9\%)、COPD 3 例 (4\%)、 脳梗塞 1 例 $(2 \%)$ 、低心機能 4 例 (6\%)を認めた。

【結果】

使用した人工弁は生体弁 66 例 (97\%)、機械弁 2 例 (3\%)であった。人工弁サイズは $16 \mathrm{~mm}$ が 2 例 $(3 \%) 、$ $19 \mathrm{~mm}$ が 35 例 (51\%)、21mm が 21 例 (32\%)、23mm が 7 例 (10\%)、25mm が 3 例 (4\%)であった。同時手 術は、冠動脈バイパス術 21 例 (31\%)、僧帽弁手術 5 例 (7\%)、上行大動脈置換術 4 例 (6\%) を行った。手 術時間 $305 \pm 77$ 分、体外循環時間 $179 \pm 46$ 分、大動 脈遮断時間 $110 \pm 34$ 分であった。手術死亡は認めな かった。合併症は術後出血 5 例、呼吸不全 6 例、術 後脳梗塞 1 例、縦隔洞炎 1 例、SSI 1 例、バルサルバ 洞破裂を 1 例に認めたが修復可能であった。平均在 院日数は合併症のない症例は $29.9 \pm 9.5$ 日、合併症を 認めた症例は $112 〜 215$ 日と長期になった。平均観 察期間 2.1 年、不明 2 例。遠隔期死亡は非心臓関連 死 2 例であった。

【結語】

80 歳以上の超高齢者は多様な合併症を伴っていたに も関わらず、待機的な AVRの成績は良好なもので あった。 
PP-127 is

Japan Score に基づいたハイリスク AS に対 する外科治療成績の検討

静岡市立静岡病院 ハートセンター 心臓血管外科

野村 亮太、三浦友二郎、島本 光臣、

山崎 文郎、中井 真尚、岡田 達治、

糸永 竜也、寺井 恭彦、村田 由祐、

宮野 雄太

【背景】高齢化によりハイリスク AS 患者は増加の一 途である。2012 年 3 月の ASCVTS (Bali)で報告した 通り、75歳以上の AS 患者に対する AVR148 例の病 院死亡 $2.7 \%$ で Japan Score(J-Score) の予測死亡率 $4.1 \%$ よ低く、高齢だけではリスクとはならない。 今後 TAVR を施行するにあたり real world でのリス ク評価と適切な患者選択が重要となる。J-Score の弁

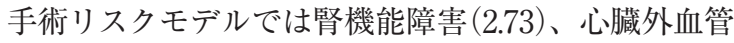
病変 (1.92)、低左室機能 (3.29)、再手術 (2.85) の Odds ratio が特に高く、これら危険性の高い症例を検討し た。【方法】 2005 年 1 月から 2012 年 5 月また、ASに 対する AVR350 例を対象とした。僧帽弁合併と大動 脈弁閉鎖不全症は除外。平均年齢 71 歳 (28～89 歳)、 男性 48\%。透析症例 18 例 (5\%)、 $\mathrm{EF}<30 \% 8$ 例 (2.4\%)。76\%の患者が生体弁を選択、3 例に弁輪拡 大を施行。 350 例中 40 例 (11\%) が再手術で、開存グ ラフトのある CABG 後再手術は 15 例。手術は全例 胸骨正中切開アプローチ、20\%にCABG 、37 例 (10\%)に上行または弓部大動脈手術を併施。また、 上行大動脈粥状硬化により低体温循環停止下に大動 脈切開、内腔観察後大動脈遮断、AVR 施行は 18 例。 高度石灰化と粇腫により大動脈遮断回避した CRCP 下AVR が 5 例。更に J-Score で特に危険度の高い とされる予測病院死亡率 $\geqq 10 \%$ (かつ合併症発生率 $>30 \%$ : 以下高危険群) は 16 例。高危険群の平均予 測死亡率 $24 \%$ 、平均合併症発生率は $46 \%$ 。【結果】病 院死亡は 7 例 $(2 \%)$ で、Stroke は 0.9\%であった。病 院死亡を危険度別にみると透析症例は 1 例 $(5.6 \%$ 、感 染)、 $\mathrm{EF}<30 \% 1$ 例 (13\%、LOS) と高率であったが、 再手術例では死亡 1 例 (2.5\%、CABG 後は死亡0)。 病的大動脈による上行または弓部置換併施例では死 亡 1 例 $(2.8 \%) 、 \mathrm{CRCP}$ 下 AVR、内腔観察後大動脈遮 断例何れも死亡 $0 \%$ と標準的 AVR $(2.1 \%)$ と有意差は なかった。また Strokeでも CRCP 下 AVR と内腔観 察後大動脈遮断例では $0 \%$ 。大動脈置換併施群は 1 例 $(2.8 \%)$ で通常 $\operatorname{AVR}(0.7 \%)$ と有意差を認めなかっ た。16 例の高危険群の死亡は 1 例 $(6.3 \%)$ であった。 死亡に関して有意差はなかったが、合併症の発生率 に有意差を認めた。（ $\mathrm{p}=0.0095 ） 【$ 結論】ハイリスク AS-AVR の早期治療成績は概ね満足のゆくものであ るが、心機能低下例など回復困難症例もある。AS は 大動脈浰状硬化合併も多く、人工心肺や大動脈遮断 について症例毎の治療戦略により重篤な合併症を回 避しTAVRが導入されつつある本邦でも治療の Golden standard である。

\section{PP-128 宛 \\ 術前 EF 低下を伴う大動脈弁狭窄に対する AVR 施行例の検討}

\author{
千葉大学医学部 心臟血管外科
}

\author{
石坂透、黄野 皓木、石田 敬一、 \\ 渡邊 倫子、田村 友作、阿部真一郎、 \\ 若林豊、焼田 康紀、松宮 護郎
}

【目的】術前 EF 低下を伴う AS に対する AVR の手術 成績、心機能の推移を検討した。

【対象】2007 年 8 月以降の ASに対するAVR47 例を 対象とした。二弁手術は除外、CABG：14、MAZE： 9、大動脈手術：10 同時手術は対象。術前 EF50\%未 満の 9 例 $(\mathrm{EF} 17 \sim 47$ 平均 $38 \pm 9 \%)$ について、 $\mathrm{EF} 50 \%$ 以上の 38 例 $(51 \sim 75$ 平均 $64 \pm 8 \%)$ と比較検 討した(低下群 vs 対照群)。年齢は $68 \pm 9$ vs73 56 歳 $(\mathrm{p}=0.05)$ 。機械弁 : 生体弁は低下群 $1: 8$ 、対照群 $11: 27(\mathrm{NS})$ 。術 前 NYHA は $3.3 \pm 0.9$ vs $2.4 \pm 0.8$ : $\mathrm{p}=0.001$ 、BNP 值は 287 vs $185 \mathrm{pg} / \mathrm{dl}$ と低下群で心 不全傾向。術前 LVDd／LVDs は低下群が高值(62/53 vs 48/31)であったが、LVMI は 205 vs 181 は有意差 認めず。弁口面積に有意差ないが $(0.70$ vs $0.72 \mathrm{~cm} 2)$ 、 peak Ao flow は 4.4 vs $5.0 \mathrm{~m} / \mathrm{s}$ で低下群が低值 $(\mathrm{p}=0.03)$ 。術前 $\mathrm{E} / \mathrm{A}$ は 0.55 vs 0.67 で低下群がより 低值 $(\mathrm{p}=0.02)$ 。

【結果】大動脈遮断(115 vs 114 分)、 $\operatorname{maxCPK(790~vs~}$ $765 \mathrm{IU} / 1)$ は有意差なし。人工心肺 (212 vs 174 分) は 低下群で長かった $(\mathrm{p}=0.05)$ 。退院前心エコーで、EF (45 \pm 12 vs $59 \pm 10: \mathrm{p}=0.0004) 、 \mathrm{LVDd} / \mathrm{Ds}(50 / 39$ vs $45 / 31: p=0.03 / 0.001)$ と、低下群の EF 心拡大は著明 に改善。観察期間平均 2.8 (最長 5.0) 年で、手術死 1 (術 中解離 AMI)、遠隔死 1 (心不全)、心血管イベントに よる再入院を 13 例 (低下群 3 : 内訳は Af 契機心不全 1、Af脳梗塞 2) に認めた。累積生存率は 1 年 89 vs $97 \% 、 3$ 年 89 vs $97 \%(\mathrm{p}=0.26) 、 \mathrm{MACE}$ 回避率 1 年 56 vs $78 \% 、 3$ 年 56 vs $76 \%(\mathrm{p}=0.13)$ でともに有意差 なし。最終 NYHAclass1.4 \pm 0.5 vs $1.3 \pm 0.5$ 、術後 0.5 〜 1.5 年の BNP 值は $113 \mathrm{vs} 114 \mathrm{pg} / \mathrm{dl}$ でともに有意 差なし。術後平均 1.2 年の心エコーでは、 $\mathrm{EF}(54 \pm 6$ vs $64 \pm 6: \mathrm{p}=0.0001)$ と、低下群は対照群に比し低い ものの、全例 $50 \%$ 以上に改善した。LVDd/Ds は (47/33 vs 46/30 : p=0.3/0.03) と、低下群で術前認め

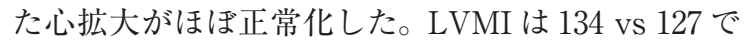
両群ともに術前より減少した。 $\mathrm{E} / \mathrm{A}$ は 0.72 vs 0.92 : $\mathrm{p}=0.05$ と低下群で拡張能低下が遷延した。全例予測 EOAI > 0.85 となる弁選択をしたが、遠隔期実測 EOAI は 6 例(低下群 2) で EOAI 00.85 の PPMを 示した $(\mathrm{EF}$ 值に有意な影響認めず)。

【結語】術前 EF 低下を伴う AS に対する AVR は対照 群との比較においても遜色なく良好な結果であった が、不整脈に伴う MACE の発生例を認め注意深い管 理を要する。術後約 1 年で左室 dimension は著明な 改善を認めたが、 $\mathrm{E} / \mathrm{A}$ に示される拡張能低下はやや 遷延していた。 
PP-129 究

低心機能大動脈弁狭窄症に対する心拍動下 大動脈弁置換術の検討

\author{
青森労災病院 心臓血管外科
}

小野裕逸、棟方護

【はじめに】大動脈弁置換術において、大動脈遮断 ・ 心停止という補助手段は必要欠くべからざるもので あるが、低心機能の場合、心停止後の心不全に難渋 することがある。心拍動を維持できるような冠循環 がもっとも良好な心筋保護であるという立場から、 左室駆出率 $30 \%$ 台の大動脈弁狭窄症の 3 例に、酸素 加血の逆行性持続冠灌流下に大動脈弁置換術を実施 した。【対象と方法】症例は 63 歳〜 75 歳。男性 2 例、 女性 1 例。大動脈弁疾患は、リウマチ性 1 例、動脈 硬化性 2 例。 1 例は、心肺蘇生術の既往あり。術前 左室駆出率は $28.8 \%$ ３5\%、AR は mild 1 例、 mod 2 例、大動脈弁圧較差は 46 ～109mmHg であった。 手術は、aorta 送血、SVC・IVC 脱血とし、冠静脈洞 より逆行性冠灌流カニューレを直視下に留置。上行 大動脈遮断と同時に、酸素加血の逆行性持続冠灌流 を開始。冠灌流条件は流量 $300 \sim 400 \mathrm{ml} / \mathrm{min}$ 、冠静 脈洞圧が $55 \mathrm{mmHg}$ を越えない範囲とした。心電図変 化のないことを確認し大動脈を切開。冠動脈口から の逆流血を吸引しつつ、通常のごとく大動脈弁置換 術を行った。大動脈遮断解除後には左室ベント、大 動脈ベントから十分にエア抜きを行い、non-working beatを経て体外循環より離脱した。【結果】大動脈遮 断時間 $51 \sim 71$ 分、逆行性冠灌流時間 $53 \sim 72$ 分、 体外循環時間 $93 \sim 141$ 分、手術時間 191 ～ 250 分で あった。体外循環離脱時には、ドパミン・ドブタミ ン量にして $3 \sim 7 \gamma$ 程度を使用。全例、術後にLOS を来すことなく経過。術翌日の CK-MB は $41 〜 45$ $\mathrm{U} / \mathrm{L} 、$ 、オシン軽鎖は $3.5 \sim 4.5 \mathrm{ng} / \mathrm{ml}$ と軽度高值で あった。術後の検査では左室駆出率は 30 ～40\% と 依然として低いが、術前にPH を認めた症例の肺動 脈圧は $66 \mathrm{mmHg}$ から $32 \mathrm{mmHg}$ へ改善。術後観察期 間は 2 か月〜 4 年で、NYHA1 度 2 例、 2 度 1 例であ る。【考察】様々な心筋保護法があるものの、心停止 という手段は少なからず心筋障害をともなう。僧帽 弁手術や左室形成術などでは大動脈遮断なしで心拍 動下手術が可能な場合もあるが、大動脈弁手術に関 しては何らかの冠循環手段を構築する必要があり、 その灌流条件も諸家により様々である。自験例はい ずれも良好な経過で、通常の心停止下手術と比して 遜色ない結果であった。大動脈弁への低侵襲治療と してTAVI(経カテーテル大動脈弁置換術)が普及し てくることも予想されるが、弁膜症手術のひとつの option として習熟すべき手段と考えられる。

\section{PP-130 㲾 大動脈弁置換術を必要とした超高齢者大動 脈弁狭窄症例の特徵と成績の検討}

\section{神戸大学 心臓血管外科}

$\begin{array}{lrrr}\text { 井上 } & \text { 武、木下 } & \text { 史子、後竹 } & \text { 康子、 } \\ \text { 中井 } & \text { 秀和、小原 } & \text { 大見、竹歳 } & \text { 秀人、 } \\ \text { 白坂 } & \text { 知識、山中 } & \text { 勝弘、宮原 } & \text { 俊介、 } \\ \text { 大村 } & \text { 篤史、坂本 } & \text { 敏仁、野村 } & \text { 佳克、 } \\ \text { 南 } & \text { 一司、岡田 } & \text { 健次、大扎 } \text { 裕 }\end{array}$

【目的】経カテーテル的大動脈弁植え込み術 (TAVR) が導入されようとする中、その適応を判断する上で 超高齢者 AS に対する手術例の特徴を理解すること は重要であると考える。今回当院での成績をもとに 検討した。【対象と方法】1999 年 10 月から 2012 年 4 月に当院で行われた ASに対する AVR 連続 351 例 を対象とした。 80 歳以上は 65 例(18.5\%)で O 群とし、 79 歳以下 286 例を Y 群として比較検討した。【結果】 年齢 $\mathrm{O}$ 群 $: \mathrm{Y}$ 群 $=83.2 \pm 2.9: 69.3 \pm 8.1$ 歳であった。 術前状態として慢性肺疾患合併 $\mathrm{O}$ 群 : Y 群 (以下同 様 $)=12(18.5 \%): 13(4.5 \%) 、 \mathrm{p}<0.0001 、$ NYHA3 度 以上 $24(36.9 \%): 56(20.3 \%) 、 \mathrm{p}=0.004$ と有意に O 群 で多く、挿管例も $7(10.8 \%): 13(4.5 \%) 、 \mathrm{p}=0.05$ と多 かった。ショック例 4(6.2\%) : 14(4.9\%)、 $\mathrm{p}=0.75$ に 差はなかった。リスクスコアは EuroScore II (10.9土 $15.7: 5.3 \pm 11.0 、 p=0.004)$ 、Japan Score 30 日死亡 $(7.9$ $\pm 11.3: 5.6 \pm 9.9 、 \mathrm{p}=0.13)$ 、Japan Score30 日死亡 + 主要合併症 $(22.6 \pm 15.0: 17.7 \pm 16.4 、 \mathrm{p}=0.04)$ と $\mathrm{O}$ 群 で高かった。術前 $\mathrm{EOAI}(0.45 \pm 0.13: 0.49 \pm 0.17 \mathrm{~cm} 2$ 、 $\mathrm{p}=0.11$ )、最大及び平均圧較差に差はなかった。単独 AVRは 41(63.1\%) : 154(53.8\%)、p=0.17であったが 僧帽弁手術併施は 3(4.6\%) : 50(17.5\%)、p < 0.01 と $\mathrm{Y}$ 群で多かった。在院死亡は O 群 4 例 $(6.2 \%$ 、縦隔 炎 2、腸管壊死 1、PVE1)、Y 群 8 例 (2.8\%、LOS 2、 敗血症 4、低酸素性脳症 1、消化管出血 1) であり $\mathrm{O}$ 群の 1 例、Y 群の 6 例は術前ショック状態であった。 $\mathrm{O}$ 群の他 3 例も慢性呼吸器疾患を合併した挿管例で CABG や MVR の併施例であった。術後合併症とし て再挿管 6(9.2\%): 12(4.5\%)、 $\mathrm{p}=0.04$ 、気管切開 5 $(7.7 \%): 9(3.6 \%) 、 \mathrm{p}=0.04$ と O 群で有意に多かった。 また術後平均在院日数は $37.3 \pm 40.0: 26.8 \pm 19.6$ 日、 $\mathrm{p}$ $<0.01$ 、自宅退院率が $41(63.1 \%): 236(82.5 \%) 、 \mathrm{p}<$ 0.01 であり $\mathrm{O}$ 群は有意に在日数が長く、自宅退院率 が低かった。O 群の遠隔生存率は 3 年 $80.0 \% 、 5$ 年 $55.2 \%$ と 83 歳日本人生存率とほぼ同等であった。【結 語】80 歳以上の AVR 症例は 79 歳以下に比べ慢性肺 疾患を合併し術前状態が悪い症例が多かった。この ような症例が在院死亡や術後呼吸器合併症、さらに 長期入院、ADL 低下につながっており今後 TAVR などのより低侵襲な治療が望まれると思われた。 


\section{PP-131 㲾 \\ 狭小弁輪を伴う高齢者大動脈狭窄症に対す る弁輪拡大術の有用性の検討}

\author{
福井心臓血圧センター 福井循環器病院 心臓血管 \\ 外科
}

$\begin{array}{lllll}\text { 佐村 } & \text { 高明、堤 } & \text { 泰史、門田 } & \text { 治、 } \\ \text { 沼田 } & \text { 智、山崎 } & \text { 祥子、瀬尾 } & \text { 浩之、 } \\ \text { 吉田 } & \text { 昇平、大橋 } & \text { 博和 } & & \end{array}$

【背景】近年、高齢者の大動脈弁狭窄症は増加傾向で ある。高齢者には一般的に生体弁による弁置換術が 行われるが狭小弁輪を伴う症例では patient- prosthesis mismatch の観点から十分なサイズの弁が挿入で きず生体弁の使用に苦慮することがある。その際、 弁輪拡大術の併施が一つの選択肢となるが、高齢者 では弁輪拡大術が過大侵襲とならないかが懸念され る。そこで今回、我々は狭小弁輪を伴った高齢者大 動脈弁狭窄症に対し弁輪拡大術を行った症例の術後 早期成績を検討した。【方法】対象は 2007 年 1 月〜 2012 年 7 月までに当院で施行した、70 歳以上の大動 脈弁狭窄症に対し単独大動脈弁置換術を施行した 55 例。単独大動脈弁置換術を施行した 46 例 (A 群) と大 動脈弁置換術に弁輪拡大術(Nicks 法)を併施した 9 例 (B 群)に分け、術後早期成績 を比較検討した。【結 果】年齢は $78.3 \pm 4.6$ 歳、男性は 22 例、女性は 33 例 であった。術前大動脈弁口面積は $0.85 \pm 0.22 \mathrm{~cm} 2$ 、 最大圧較差は $83.6 \pm 32.0 \mathrm{mmHg}$ であった。使用した 弁は $\mathrm{A}$ 群 が生 体 弁 $19 \mathrm{~mm}: 22$ 例、 $21 \mathrm{~mm}$ : 11 例、 23mm: 6 例、 $25 \mathrm{~mm}: 1$ 例、機 械 弁 $17 \mathrm{~mm}: 2$ 例、 19mm: 1 例、 $20 \mathrm{~mm}: 3$ 例。B 群は生体弁 $19 \mathrm{~mm}: 2$ 例、 21mm: 4 例、 $23 \mathrm{~mm}: 2$ 例、機械弁 $18 \mathrm{~mm}: 1$ 例であっ た。年齢、性別、最大圧較差、大動脈弁口面積、左 室内径短縮率に関し両群間に有意差を認めなかった。 弁輪径はそれぞれ(以下 A 群、B 群の順) $21 \pm$ $2.0 \mathrm{~mm} 、 19.6 \pm 1.6 \mathrm{~mm}$ で B 群が有意に狭小であった。 体外循環時間 $(116.4 \pm 16 、 129 \pm 12$ 分)、大動脈遮断 時間 $(77 \pm 13 、 92 \pm 14$ 分) は B 群が有意に長かったが、 手術時間 $(242.5 \pm 43 、 252 \pm 19$ 分) は有意差はなかっ た。出血量 $(478 \pm 312 、 581 \pm 179 \mathrm{ml})$ 、術後 ICU 滞在 日数 $(3.7 \pm 3.9 、 3.1 \pm 0.9$ 日)、術後退院日数 $(35.9 \pm$ 20.4、39.7 \pm 15.4 日)も両群に有意差はなかった。術後 合併症は完全房室ブロックが A 群で 3 例、 B 群では 認めず、再開胸止血術は $\mathrm{A}$ 群 6 例、B 群は 1 例であっ た。術後心エコーでは両群とも最大圧較差 $(24.5 \pm 9.8$ 、 $23.0 \pm 4.8 \mathrm{mmHg}$ ) は術前と比べ有意に改善し、左室内 径短縮率 $(31.9 \pm 6.7 、 33.6 \pm 2.9 \%)$ は術前後で変化はな く、両群間に有意差はなかった。手術死亡は A 群に 2 例、B 群は 0 例であった。【結語】狭小弁輪を伴う高 齢者大動脈弁狭窄症に対する弁輪拡大術の早期成績 は良好で、高齢者でも安全に手術を行うことができ ると思われた。高齢者でも狭小弁輪を伴う症例では できるだけ十分なサイズの弁を挿入するべく弁輪拡 大術を施行することも必要ではないかと考えられる。

\section{PP-132 㲾 \\ 大動脈二尖弁での上行大動脈拡大の検討 上行大動脈径と下行大動脈径の比による解 析}

\author{
愛媛大学 心臟血管呼吸器・再生外科学 \\ 中村 優貴、泉谷 裕則、大倉 正寛、 \\ 鹿田 文昭、岡崎 幹生、岡村達、 \\ 重松 久之、流鄉 昌裕、佐野 由文、 \\ 八杉巧
}

【目的】大動脈二尖弁 (BAV)は最もありふれた先天性 心疾患であり、その合併症として大動脈弁狭窄症 (AS) や大動脈弁閉鎖不全症 (AR) などの弁膜症以外 に上行大動脈拡大に伴う大動脈瘤や大動脈解離と いった大動脈疾患を併発する可能性がある。臨床で は大動脈弁置換術施行時にどの程度の上行大動脈拡 大があれば上行大動脈置換術も行うべきかについて は現在も議論の余地があるところである。また上行 大動脈拡大の機序についても Post-stenotic aortic dilatation など血行動態的因子や二尖弁に伴う病理組織 学的因子などが指摘されているが未だ解明されてい ない。今回、大動脈弁手術を施行した症例の大動脈 基部径、上行大動脈径、下行大動脈径の計測から、 BAV が大動脈拡大に及ぼす影響について検討した。 【方法】当院で 2009 年 10 月以降に施行された大動脈 弁手術症例で術中所見にて大動脈弁が三尖弁であっ た症例 (TAV 群 $\mathrm{n}=59$ )、二尖弁であった症例 (BAV 群 $\mathrm{n}=17$ )、およびコントロール群として心拍動下冠 動脈バイパス術を施行した症例 (OPCAB 群 $\mathrm{n}=73$ )の 3 群を対象とした。術前の CT 検査で大動脈基部径、 上行大動脈径、下行大動脈径を計測し比較検討した。 【結果】TAV 群、BAV 群、OPCAB 群の平均年齢は それぞれ $77 \pm 7$ 歳、 $70 \pm 7$ 歳、 $68 \pm 9$ 歳で、各群にお ける男性の比率はそれぞれ $52.5 \% 、 70.6 \% 、 84.9 \%$ あっっ た。TAV群では ASが 46 例、AR が 13 例、 BAV 群 では AS が 13 例、AR が 1 例であった。また TAV 群 に大動脈基部置換術合併例が 1 例、BAV 群に上行大 動脈置換術合併例が 3 例あった。術前 CT 検査によ る上行大動脈径と下行大動脈径の比は、TAV 群で $1.318 \pm 0.106$ 、 BAV 群で $1.578 \pm 0.249 、 \mathrm{OPCAB}$ 群で $1.300 \pm 0.118$ であった。BAV 群は、他の群に比して 有意に值が高かった $(\mathrm{p}<0.05)$ 。またTAV 群と $\mathrm{OPCAB}$ 群の間に差はなかった。大動脈基部径と下 行大動脈径の比においても同様で、BAV 群は TAV 群に比し有意に值が高かった。しかし ASとARの 違いによる大動脈径の差はなかった。【結論】BAV 群 の患者は、TAV 群に比して上行大動脈および大動脈 基部の有意な拡大を認めた。上行大動脈拡大には、 大動脈弁狭窄症の存在よりも先天性二尖弁である因 子の方がより強く影響している可能性が示唆された。 今回の結界から上行大動脈径と下行大動脈径の計測 により、先天性二尖弁の存在が推察され臨床上の指 標の一つになりうると考えられた。 


\section{$\mathrm{PP}-133$}

\section{大動脈弁 4 尖弁に対する自己心膜を用いた 3 尖再建術}

${ }^{1}$ 苑田第一病院 心臓血管外科

2東邦大学医療センター 大橋病院 心臓血管外科

\author{
河瀬勇 1,2 尾崎 重之 2 、野澤 幸成 2 \\ 山下 裕正 2 、内田真 2 、松山孝義 ${ }^{1,2}$ 、 \\ 高遠 幹夫 2 萩原 壮 ${ }^{2}$
}

【目的】大動脈弁 4 尖弁は過去の剖検や心エコー調 査で 0.008 ～ $0.013 \%$ の発生率とされる稀な奇形であ る。患者は大動脈弁閉鎖不全症を発症することがあ り大動脈弁置換術が主な治療法とされている。今回、 我々は大動脈閉鎖不全症を呈する大動脈弁 4 尖弁症 例に遭遇し、自己心膜を用いた大動脈弁 3 尖再建術 (尾崎手術)を施行して良好な結果を得たので報告す る。【方法】患者は 80 歳男性で軽度の認知症・左大腿 骨骨折や心筋梗塞の既往もあり車椅子生活であった。 平成 22 年から心不全を繰り返し平成 23 年 2 月には 入院加療を要した。精査にて重症の大動脈弁閉鎖不 全症及び心機能低下が判明し、家族と協議を重ね十 分な同意を得て術後薬物管理の簡素な自己心膜を用 いた大動脈弁 3 尖再建術(尾崎手術)を行う方針と なった。術前 NYHA class4 であり、心エコー検査に て AR 4 度で石灰化を部分的に認める大動脈 4 尖弁 を認め、 $\mathrm{EF}=24.2 \% 、 \mathrm{LVDd} / \mathrm{Ds}=69.6 / 61.5 \mathrm{~mm}$ と左 心機能低下が著明で中等量の心囊液貯留を伴ってい た。大動脈弁は右冠尖の無冠尖寄りにAccessory Cusp を伴う Hurwitz and Roberts 分類 type b の 4 尖弁で部分的に石灰化を伴っていた。弁尖切除後、 右冠尖とAccessory Cusp をまとめる形で慎重に心 膜弁尖の縫合ラインを決定し、尾崎氏オリジナルの サイザーで交連間距離を測定した。オリジナル・テ ンプレートでグルタルアルデヒド処理した自己心膜 から 3 弁尖をトリミングして弁輪に縫着し 3 尖再建 した。【結果】術後合併症はなく、手術翌朝に人工呼 吸器を離脱し $2 \mathrm{POD}$ にICUを退室し 17POD に退院 となった。術後早期の心エコーで経大動脈弁最大圧 較差 $=7.1 \mathrm{mmHg}$ でAR1度と改善を認めたが $\mathrm{EF}=20.5 \%$ と左心機能低下は存在していた。術後 15 ヶ月の心エコーでは、最大圧較差 $=7.1 \mathrm{mmHg}$ 、 trivial AR で $\mathrm{EF}=70.1 \%$ LVDd/Ds=40.2/24.5 mm と著明な心機能改善を認めた。バイアスピリンのみ の内服で NYHA class1 と経過良好である。【結語】大 動脈弁閉鎖不全症を呈する稀な大動脈弁 4 尖弁症例 に対し、自己心膜を用いた大動脈弁 3 尖再建術を施 行し良好な結果を得た。本術式は術後内服薬も少な くて済み、高齢者や認知症を示す患者に有効である と思われた。

\section{PP-134 宛 大動脈弁閉鎖不全症に対する大動脈弁形成 術}

独立行政法人国立病院機構帯広病院 心臓血管外科

熱田 義顕、菊池 洋一、椎久 哉良、 木村 文昭

【目的】大動脈弁形成術は大動脈弁閉鎖不全 $(\mathrm{AR})$ の病 態が明らかになるにつれて、その病態別に弁形成の 手術手技が工夫され、安定した成績が報告されてい る。我々は弁の接合範囲を増加させかつ弁輪の縫縮 にも効果のあるとされる Subcommissural annuloplasty $(\mathrm{SA})$ に着目し行ってきた。またST junction (STJ)の拡大を伴う AR に対してはSTJ 縫縮を追加 している。当院における方法と成績について報告す る。【対象と方法】1999 年 1 月から 2012 年 6 月までの AR 232 例を対象とした。このうち弁温存・弁形成を 施行しえたものは 44 例(19\%)で、交連部の SA を併

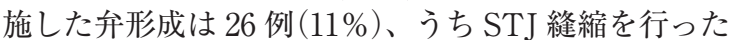
ものは 5 例であった。平均年歯令 64 歳 $(16-85$ 歳)。 男性 17 例、女性 9 例。病因は弁逸脱 : 16 例、STJ 拡大 : 5 例、先天性二尖弁: 3 例、先天性二尖弁 $+\operatorname{VSD}(2$ 型 $): 1$ 例、 $\operatorname{VSD}(1$ 型 $)$ による弁逸脱 $: 1$ 例、 であった。術前の逆流の程度は 2 度 : 6 例、 3 度 : 16 例、 4 度 : 4 例 (4 度はすべて先天性二尖弁)であった。 手術術式は各交連部に弁用プレジェットつきの 3-0 ポ リエステル糸を用い、弁輪に沿うようにマットレス 縫合をおいた。同時に施行した手技は二尖弁に対す る raphe 切除：3例、plication : 1 例、Remodeling : 1 例。三弁の逸脱例で 2 例にCusp plication を併施し た。STJ 形成術は弁輪部の内径とほぼ等しい人工血 管で STJ を縫縮したものが 4 例、人工血管でバンド を作成し STJ 縫縮を行ったもの 1 例であった。同時 手術は大動脈疾患：11例、僧帽弁形成術：6例、僧 帽弁置換術 : 1 例、三尖弁輪縫縮 : 3 例、冠動脈バイ パス術 : 2 例、VSD 閉鎖術 : 2 例、incomplete ECD 閉鎖術 : 1 例、MAZE : 1 例、左室形成術 : 1 例であっ た。これらについて、 5 年の中期成績を検討した。【結 果】手術死亡、在院死亡はなかった。術中弁置換への 移行はなかった。退院時の UCG は 1 度以下：16 例、 2 度: 9 例。 3 度 : 1 例。 3 度の症例(先天性 2 尖弁) は遠隔期に大動脈弁置換となった。他に遠隔期の再 手術はなかった。遠隔期死亡は 4 例で心蔵関連死は なかった。再手術回避率は 5 年 $85.7 \%$ 、生存率は 5 年 $67.2 \%$ であった。【結語】経食道エコー等で大動脈 弁に中心性で中程度以下の AR であれば SA は簡便 で再発も少なく良い方法であった。また動脈瘤など STJ 拡大に伴う AR の場合、SA に加え STJ 縫縮を 付加することで AR を制御できた。 
$\mathrm{PP}-135$ 放

弁輪外固定を併施した Remodeling 法 一従 来法との比較—

榊原記念病院 心臓血管外科

清水 篤、加藤 泰之、田端 実、

福井 寿啓、高梨秀一郎

【目的】当院ではこれまで Reimplantation 法による大 動脈弁温存基部置換術を行ってきたが、より生理的 な再建を目指して、2012 年 6 月より Remodeling 法 を取り入れた。ただし、従来の Remodeling 法では 遠隔期に弁輪再拡大に伴う大動脈弁逆流再発が報告 されているため、弁輪外固定を併施するようにした。 従来の Reimplantation 法の早期成績から Remodeling 法の意義について考察した。【方法】2004 年から 2012 年に当院で施行した Reimplantation 法での大動 脈弁温存基部置換術の再手術回避率や重症大動脈弁 逆流回避率を評価した。また、基部再建後の形態を 心拍同期させた造影 CT で評価し、血行動態を経胸 壁エコーで評価した。尚、当院での Remodeling 法 の特徵は、人工血管を利用したリングを用いて大動 脈弁輪を外側から固定する点(弁輪外固定) と effective height が $9 \mathrm{~mm}$ となるように弁尖形成を追加す ることである。【結果】弁輪外固定を併施した Remodeling 法 (A 群)を 6 例、Reimplantation 法(B 群)を 59 例に施行した。B 群で急性大動脈解離による右室梗 塞により 1 例周術期死亡を認めた。術中、術後の評 価で全例 AR は trivial 以下であった。B 群の再手術 回避率は 5 年で $97.2 \pm 2.2 \%$ 、moderate 以上の大動脈 弁逆流再発回避率は 5 年で $86.8 \pm 8.3 \%$ であった。退 院時エコーでの最大圧較差 $(10.5 \pm 6.3$ vs $13.8 \pm$ $7.0 \mathrm{mmHg} 、 \mathrm{p}=0.27)$ 、最大血流速度 $(1.60 \pm 0.41$ vs 1.82 $\pm 0.43 \mathrm{~m} / \mathrm{s} 、 \mathrm{p}=0.25)$ 、大動脈弁口面積 $(2.28 \pm 0.55 \mathrm{vs}$ $2.23 \pm 0.61 \mathrm{mmHg} 、 \mathrm{p}=0.54$ ) は両群間で有意差はなかっ た。A 群での術後 Sinotubular junction(STJ)、Valsalva 洞 (SN)、Basal ring(BR)レベルでの断面積 (mm2) を拡張期と収縮期で比較すると、STJ $(582 \pm$ 111 vs $590 \pm 103 、 \mathrm{p}=0.76)$ 、 $\mathrm{SN}(902 \pm 185$ vs $924 \pm$ 188、 $\mathrm{p}=0.02) 、 \mathrm{BR}(418 \pm 122$ vs $451 \pm 103 、 \mathrm{p}=0.21)$ であり、SN レベルのみ収縮期に有意に伸展した。拡 張期におけるValsalva 洞と Basal ring の直径比 (SN/BR)は A 群で有意に大きく $(1.50 \pm 0.07$ vs $1.35 \pm$ $0.07(\mathrm{p}=0.02)) 、 \mathrm{~A}$ 群では基部の distensibility がより 良く保持された。【結論】弁輪外固定を併施した Remodeling 法は、Reimplantation 法の良好な遠隔成績 に加え新たにV Valsalva 洞のより良好な distensibility を得ることができ、遠隔成績のさらなる向上が期待 できる方法である。
PP-136 is 右胁間小開胸による大動脈弁置換術の検討

\author{
1 心臓病センター榊原病院 心臓血管外科 \\ 東京医科大学 心臓外科
}

【緒言】近年右胁間開胸による低侵襲心臓手術 (MICS) が再び脚光を浴びている。当初は心房中隔欠損症や 僧帽弁手術が肋間小開胸 MICS の対象疾患であった が、 2008 年本邦第 1 例目の右胁間小開胸による大動 脈弁置換術 (AVR) を当院から報告し (Totsugawa T, et al. Circ J 2008; 72: 674-5)、以降少しずつ MICS AVRの報告がされるようになった。今回我々は、こ れまでの成績をレビューするとともに、今後の展開 も含めて報告する。【対象と方法】2007 年から 2012 年まで 61 例の MICS AVR を施行した。同期間で胸 骨正中切開による一般的な AVRを行った 178 例を 対象とし、両群を比較検討した。【結果】MICS 群の うち 3 例は僧帽弁手術も同時に行った (MVR 1 例、 MAP 2 例)。また、3 例で不整脈手術を追加して施 行した。平均年齢は MICS 群 $55 \pm 14$ 歳、通常群 74 \pm 11 歳と、有意に MICS 群で若かった。大動脈弁疾 患として、MICS 群では大動脈弁狭窄症(AS) 33\%、 大動脈弁閉鎖不全症 $(A R) 67 \%$ であ、通常群では AS79\%、AR21\%と有意に MICS 群ではAR が多く AS が少なかった。手術時間では有意差を認めなかっ たが(MICS 群 $248 \pm 47$ 分、通常群 $237 \pm 49$ 分)、人 工心肺時間 (MICS 群 $137 \pm 33$ 分、通常群 $110 \pm 30$ 分) と大動脈遮断時間 (MICS 群 $95 \pm 24$ 分、通常群 $81 \pm$ 23 分) は MICS 群で有意に長かった。 MICS 群で 1 例 死亡症例を認め、1 例脳梗塞が発症 (HIT 症例) した が、手術死亡率、合併症発生率で有意差を認めなかっ た。ICU 滞在 (MICS 群 $1.4 \pm 0.9$ 日、通常群 $2.5 \pm 1.6$ 日) は有意差がなかったが、術後入院日数 (MICS 群 12.9 土5.7 日、通常群 $19.8 \pm 8.4$ 日) は MICS 群で有意に短 かった。【結語】MICS AVRはこれまでの手術と同等 の安全性を確保しつつ、入院期間の短縮など満足の ゆく成績であった。今後は僧帽弁手術や不整脈手術 を追加して行うことが課題である。 
PP-137 文

Bad aorta に対する片側脳分離、軽度低体温 循環停止法

小牧市民病院 心臓血管外科 弁膜症センター

澤崎優、泊史朗、恒川 智宏、

井澤 直人、立石 直毅

弁膜症手術の際、上行大動脈に動脈硬化性病変を合 併していることがある。このような例では、送血管 刺入、大動脈遮断に伴う桞種の飛散による脳塞栓を 合併する危険がある。今回、片側脳分離循環停止下 に大動脈を横切し、上行から弓部大動脈の内膜を観 察し、病変の除去を行った後、上行大動脈を遮断す る方法を考案した。【対象】2005 年から 2011 年までの 石死化大動脈を伴う弁膜症 17 例 (大動脈弁狭窄症 16 例、僧帽弁閉鎖不全症 1 例) を対象とした。本法 3 例、 単純遮断 14 例であった。【方法】本法は術前 CTに て、bad aorta が疑われた症例に行った。送血部位は 腋窩 +大腿動脈を用いた。 $34^{\circ} \mathrm{C}$ の軽度低体温循環停 止下に、右腋窩動脈から $25^{\circ} \mathrm{C}$ 片側脳分離体外循環法 を行う。脳内組織酸素飽和度(NIRO)のモニターを行 い $40 \%$ を切らないように脳分離の送血量を調節した。 短時間の循環停止下に上行大動脈を横切し、内膜病 変や张腫を CUSA と吸引を用いて除去した後、上行 大動脈を遮断した。【結果】本法を行った 3 例中 2 例 に䐖種が存在し、これを除去した。循環停止時間は $3-3.5$ 分。死亡例、術後の脳障害はなかった。 NIRO の值は右側では軽度の低下に止まったが、左 側は 40-45\%に低下し、脳分離の送血量を $900 \mathrm{ml} / \mathrm{min}$ から $1300 \mathrm{ml} / \mathrm{min}$ まで増やした。単純遮断群では、 入院死亡 2 例 $(14.3 \%) 。$ 。過性構音障害を 1 例 $(7.1 \%)$ に認めた。【考察】Bad aorta を伴う弁膜症手術の脳塞 栓合併対策として、低体温循環停止法、低体温循環 停止下に上行大動脈を置換する方法、バルーン occlusion 法、低体温循環停止下に上行大動脈の内膜摘 除術を行い、その後上行大動脈遮断する方法などが 報告されている。今回の工夫は、低体温にしないた め侵襲が少ないこと、片側であっても脳分離送血を 行うことで脳虚血時間の安全限界を拡げること、脳 内組織酸素飽和度のモニターを行い安全に施行でき ること、大動脈を完全に横切することで弓部大動脈 や上行大動脈前壁内膜の観察、処理が容易で確実と なることである。単純遮断例でも脳塞栓の合併は多 くないが、Epiaortic Echo と触診で確認して送血、 遮断を行ってきたことによる。【結語】短時間の片側 脳分離循環停止法は、Bad aorta を合併する弁膜症 手術の補助手段として有用であった。
PP-138 « گ

Bad Annulus、Bad Aorta - 僧帽弁輪石灰化 を伴う患者に対する DVR 手術への取り組み

\section{名古屋第二赤十字病院 心臓血管外科}

$\begin{array}{llll}\text { 日尾野 } & \text { 誠、田嶋 } & \text { 一喜、秋田 } & \text { 翔、 } \\ \text { 内田健一郎、宗像 } & \text { 寿祥、藤井 } & \text { 恵、 } \\ \text { 加藤 } & \text { 互、高味 } & \text { 良行、酒井 } & \text { 善正 }\end{array}$

【背景】高齢、糖尿病、透析患者の増大を受け、大動 脈弁輪、僧帽弁輪に高度石灰化を呈した End Stage Valvular Disease とも言える末期弁膜症患者への手 術介入なしには今日の心臓手術は語れないものであ る。しかし、本患者群に対しては弁輪脱灰処理の問 題に留まらず、上行大動脈性状不良に対する工夫、 周術期血糖・透析管理等、multi-disciplinary team に よる連携が不可欠である。【目的】当科では大動脈弁 輪、僧帽弁輪の石灰化 (MAC) に対してCUSA を用 いた脱灰処理を行い、上行大動脈性状不良例には送 血部位の調整、循環停止下大動脈遮断を行っている。 その手術手技および周術期管理を示すと共に、レト ロスペクティブに本手術成績の評価を行った。【結 果】1999 年より 2012 年 4 月までに、DVRを施行した 連続する 68 例の内、MACを認めた 24 例の患者を対 象とした。平均年齢は 69.2 才 (57-82 才)、男性 16 例、 透析患者 19 例、平均透析期間 15.3 年、糖尿病 8 例、 僧帽弁病変は狭窄 13 例、逆流 7 例、狭窄兼逆流 4 例 であった。上行大動脈性状不良は 2 例の Porcerain 病変を含めて 11 例あり、3 例で送血部位の変更、9 例で循環停止下遮断を要し、6 例で CUSA を用いた 大動脈石死化病変の脱灰を要した。MAC 病変は後 尖のみ 15 例、後尖優位 4 例、全周性 5 例であった。 CUSA を用いた弁輪石灰化病変の脱灰は大動脈弁輪 20 例、僧帽弁輪 23 例で要した。手術死亡は 3 例に 認め、間質性肺炎、縦隔炎、左室破裂が原因であった。 退院後にPVEを 2 例認め、再手術を要した。中枢神 経合併症は認めなかった。術後平均追跡期間 39.2 ケ 月では、心不全死 1 例、非心蔵死 6 例、死因不明 2 例であり、 1 年生存率 $74.3 \% 、 5$ 年生存率 $45.0 \%$ であっ た。【考察】末期弁膜症患者に対する治療経験の蓄積 により、依然として課題は残るものの比較的満足の いく手術成績が得られている。循環停止下大動脈遮 断、CUSA による大動脈および弁輪の脱灰処理といっ た手技工夫は安全に手術を遂行する上で有用である。 
PP-139 え

当院における冠動脈バイパス術後の弁膜症 手術の検討

\author{
財団法人 倉敷中央病院 心臓血管外科 \\ 伊集院真一、小宮 達彦、坂口 元一、 \\ 島本 健、二神大介、植木 力、 \\ 片山 秀幸、植野剛、西田 秀史、 \\ 古賀 智典、藤本 将人、山中 憲
}

背景：心臓血管手術患者の高齢化、また冠動脈バイ パス術 $(\mathrm{CABG})$ の手術成績向上により再手術症例が 増加している。CABG 術後の開存グラフトを有する 症例は再開胸、剥離操作に慎重を要し、心筋保護法 も検討を要する。当院における CABG 術後の弁膜症 手術についての再開胸、開存グラフトの management、そして心筋保護法の確立について検討を行っ た。方法： 1997 年 1 月から 2012 年 7 月までに当科で 施行したCABG: 1642 例のうち、弁膜症に対して再 手術を施行した 23 例を対象とした。内訳は僧帽弁: 14 例、大動脈弁 : 7 例、僧帽弁 +大動脈弁 : 2 例であっ た。結果：平均観察期間 : $38.2 \pm 29.8$ ヶ月、再手術ま での平均期間 : $69.2 \pm 54.4$ ヶ月、男 : 女 20: 3、再手術 時の平均年齢 : $74.9 \pm 5.5$ 歳であった。併存症は高血 圧: 16 例、糖尿病: 11 例、慢性腎不全(透析導入): 5 例、Euro score: $20.5 \pm 17.3 、 1$ 例のみ 2 回目の再手術 症例であった。初回手術時の使用グラフトはLITA: 22、RITA: 5、RA: 8、SVG: 13、GEA: 2 であった。 再手術時は SVG: 4 例が閉塞、また 2 例に新規病変を 認めており、CABG を併施した。手術は僧帽弁: 14 例 (MVP: 8 MVR: 6)、大動脈弁: 7 例 (全例 AVR)、 僧帽弁＋大動脈弁: 2 例 (DVR: 1 AVR+MVP: 1) で あった(合併手術あり)。カプランマイヤー法による 全生存率 $(5$ 年) は $47.4 \%$ であったが、心臓死回避率 $(5$ 年)では $90 \%$ であった(心不全: 2、術後 LOS: 1)。再 開胸は再胸骨正中切開が 21 例 (91\%)、残りの 2 例は 右胁間開胸を選択した。再開胸時の合併症はグラフ 卜損傷: 3 例、右室損傷 : 1 例であり、何れの症例も 胸骨直下に開存グラフトが走行、また心臓の癒着を 認めていたが、その他の症例も開存グラフトは胸骨 縁を、また胸骨童面の走行を認めていた。術中の心 筋保護法は順行性冠灌流: 12 例、順行性 + 逆行性冠 灌流: 1 例、順行性冠灌流 + 内胸動脈グラフト遮断： 5 例、低体温下: 2 例、その他: 3 例であった。心筋 逸脱酵素として術後の CK の推移は内胸動脈遮断症 例 $(\mathrm{C})$ とそれ以外の症例 $(\mathrm{N})$ で比較したところ、術後 1 日目 C: $596 \pm 225$ vs N: $551 \pm 125$ (P: 0.8363)、術後 2 日目 C: $509 \pm 192$ vs N: $429 \pm 91$ (P: 0.8436)、術後 3 日 目 C: $564 \pm 213$ vs N: $360 \pm 75$ (P: 0.3844) と有意差は認 めなかった。結語：当院における冠動脈バイパス術 後の弁膜症手術の成績は遠隔期の心血管イベントも 少なく良好であり、開存グラフトを有する症例の正 中アプローチも術中トラブルは少なかった。

\section{PP-140 年 \\ CABG 術後の弁膜症に対する到達方法と心 筋保護法の検討}

\author{
管外科

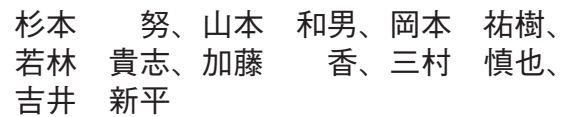

立川メディカルセンター・立川綜合病院 心臓血

【目的】は動脈グラフトの多用などにより、その長期 成績は向上している。しかし CABG 術後の心大血管 手術においてはその開存グラフトが到達方法や心筋 保護の維持に問題になる。今回 $\mathrm{CABG}$ 術後の弁膜症 手術症例について検討した。【方法】2002 年〜2011 年までの期間で当院における $\mathrm{CABG}$ 後の心大血管手 術症例は 32 例であった。その内訳は弁膜症 7 例、大 血管 5 例、狭心症 20 例であった。今回は弁膜症の 7 例を対象とした。平均年齢 $70.0 \pm 6.6$ 歳、男性 4 例 女性 3 例で、大動脈弁疾患 6 例、僧帽弁疾患 1 例で あった。CABG 後経過年数は平均 $8.7 \pm 3.5$ 年であっ た。グラフトの開存は動脈 8 吻合、静脈 4 吻合で開 存率は $85.7 \%$ であった。全例術前 CAG を用いて冠動 脈を精査し、グラフトの走行は $2 \mathrm{D}$ および $3 \mathrm{DCT}$ 検 查を用い検討した。【成績】の走行により心への到達 方法は、胸骨正中切開法、くの字胸骨切開法、右開 胸法を選択した。手術術式はAVR4例、 AVR+CABG1 例、再 AVR1 例、再 MVR+TAP1 例 であった。手術時間は $351.1 \pm 79.8$ 分、人工心肺時間 $148.3 \pm 37.3$ 分、大動脈遮断時間 $93.1 \pm 29.9$ 分、最低 中枢温は $29.4 \pm 1.9^{\circ} \mathrm{C}$ であた。右開胸法の 1 例は、 動脈グラフト 5 枝開存例であり左右内胸動脈は遮断 し胃大網動脈は遮断せずに人工心肺中の systemic の $\mathrm{K}$ 濃度高くし心静止を維持した。手術によるグラフ 卜損傷例はなかった。術後経過は、平均人工呼吸時 間 $33.6 \pm 22.5$ 時間、ICU 日数は $2.7 \pm 1.1$ 日、術 後 CPK 值 は 573.9 5579.8 IU/1、CPK-MB 值 は $42.7 \pm$ 28.7 IU/1 であった。手術死亡及び在院死亡を認めず、 CPK-MB > 100IU/1の 1 例を認めたが心機能に影響 は無かった。【結論】における CABG 後の弁膜症手術 成績は良好であった。開存グラフトの損傷や PMI の 合併が致命的になる場合があり、詳細な到達方法と 心筋保護の戦略の検討が肝要である。 


\section{PP-141方 \\ 冠動脈バイパス術後の大動脈弁手術の治療 戦略と手術成績の検討}

\author{
岸和田徳洲会病院心臓血管外科 \\ 東修平、東上 震一、松林 景二、 \\ 川平 敏博、頓田央、薦岡 成年、 \\ 平松 範彦、降矢 温一、西村 真人
}

【背景】大動脈弁疾患の治療については、大動脈弁置 換術 (AVR) が外科治療として標準術式として安定し ている中、より低侵襲な経カテーテル的大動脈弁植 え达み術(TAVI)が施行されつつある現況において、 冠動脈バイパス術後の大動脈弁疾患の治療について は議論の余地がある。再開胸時の血管損傷による出 血や、開存グラフトの損傷の可能性が高く、再手術 困難症例が多い。今回我々は冠動脈バイパス術後の 大動脈弁置換術における手術成績について検討した。 【対象・方法】1991 年 1 月から 2011 年 12 月までの 20 年間に当院にて施行された大動脈弁手術 741 症例の うち、冠動脈バイパス術後に施行した大動脈弁置換 術 30 例を対象とした。開胸時は全症例において大腿 動脈を剥離し、人工心肺をいつでも使用可能な状態 にして、胸骨正中切開を行うことを原則とした。胸 骨下の癒着組織については電気メスを使用して慎重 な剥離操作を徹底した。遠隔期生存率は KaplanMeier 法で解析し、統計処理は log-rank 検定を用い た。【結果】冠動脈バイパス術後に施行した大動脈弁 置換術 30 例は男性 20 例、女性 10 例、平均年齢 74.0 歳。透析症例は 3 例。全例正中切開で施行。術式に ついては、単独 AVR21 例、AVR + CABG4 例、 AVR + MVP3 例、AVR + 上行大動脈置換 2 例 なった。術中グラフト損傷は 1 例に認めた。手術死 亡症例はなく、病院死亡は 2 例 (肺炎、呼吸不全によ る死亡)に認め、ともに透析症例であった。合併症と 乙て再開胸止血術 1 例 (3.3\%)、術後脳梗塞 1 例 $(3.3 \%)$ を認めた。遠隔期生存率については、3 年生 存率 $84.5 \%$ 、 5 年生存率 $77.5 \% 、 10$ 年生存率 $60.1 \%$ となり、同時期に施行した初回の AVR と比較しても 統計学的な有意差は認めなかった。【考察】冠動脈バ イパス術後の大動脈弁置換術については、癒着剥離 に困難を要するとともに開存グラフトの損傷のリス クがあるが、大腿動脈剥離のもとでいつでも人工心 肺使用可能な状態にして、正中切開を安全に行うこ とができた。手術成績及び合併症は初回のAVR と 比較しても遜色のない結果であった。一方で透析症 例についてはその成績は不良であり、今後これらの 患者に対しての治療戦略を検討する余地がある。

\section{PP-142 文 冠動脈バイパス術後の弁膜症疾患に対する 治療戦略}

\author{
大阪大学大学院医学系研究科 心臓血管外科
}

$\begin{array}{lllll}\text { 齊藤 } & \text { 哲也、戸田 } & \text { 宏二、宮川 } & \text { 繁、 } \\ \text { 西 } & \text { 宏之、吉川 } & \text { 泰司、福嶌 } & \text { 五月、 } \\ \text { 吉岡 } & \text { 大輔、鎌田 } & \text { 創吉、前田 } & \text { 孝一、 } \\ \text { 上野 } & \text { 高義、倉谷 } & \text { 徹、澤 } & \text { 芳樹 }\end{array}$

【はじめに】CABG 術後の再開心術は、ITAを損傷し ないための approach、心停止の心筋保護時に patent ITAの処理など多数の問題点があり、明確な治療戦 略を立てることが重要である。最近、経カテーテル 的大動脈弁置換 (TAVR)の導入により低侵襲による 手術も可能となってきている。そこで今回我々は当 院における $\mathrm{CABG}$ 後の弁膜症手術について、その成 績から CABG 後の再手術に対する治療戦略を検討し た。【対象】2003 年から 2012 年まで、CABG 術後の 弁膜症手術(TAVRを含む) を行った 14 例を対象と した。開心術を行った症例は 9 例で、ASに対する AVR が 1 例、ASに対する Apicoaortic conduit が 1 例、ICM,MR に対する左室形成 + 僧帽弁形成が 3 例、 IE が 3 例 (AVR; 1 例、MVR; 2 例) であった。また TR1例に対し、TVRを施行した。2010年以降 TAVR を 5 例に施行し、全例 AS 症例であった。平 均年齢は $68 \pm 15.8$ 歳、男女比は 9:5、NYHA 3 0.9 、 前回手術からの経過期間は $11 \pm 6.5$ 年、Euroscore は $42 \pm 7.2$ であった。全例術前にCTにて graft の patency を確認した。【結果】開心術 9 例中、正中切開は 8 例、左側開胸は 1 例であった。正中切開の 3 例は 大腿動静脈からカニューレーションを行った。左側 開胸の 1 例はASに対するApicdo-aortic conduit を 行った症例で、FA 送血、FV 脱血の beating 下に行っ た。全例 ITA は patent であり術中にinjuryした症 例は ICM,MR の 1 例で、術後 Nipro-LVAD 装着を余 儀なくされた。心停止を行った症例は 7 例で、2 例は 心拍動下に行った。心停止中にITA を clamp したの は 1 例、低体温もしくは K 投与を行った症例が 2 例 であった。TAVRの 5 例中、EF $40 \%$ 未満の ICM3 症例 (EF $30.3 \pm 4.9 \%$ )に対し、on pump下にTAVR を行った。術後 30 日死亡は開心術の 2 例 $(2 / 9$ pts. $=22.2 \%)$ で、術後肺炎と IEによる sepsisに より失ったが、心筋保護による問題は認めなかった。 TAVRに関しては、30日死亡を認めなかった。【結 語】CABG 術後の再手術は、低左心機能症例が多く術 前リスクの高い症例が多かった。Patent ITAに対し ITA clamp や、低体温や K 投与など工夫を行ったが、 $\mathrm{CABG}$ 術後の再開心術の成績は満足しうるものでは なかった。一方 $\mathrm{CABG}$ 術後の high risk な $\mathrm{AS}$ 症例 に対するTAVRの成績は良好で、今後の治療戦略を 検討する上で、TAVRの選択は重要と考えられた。 


\section{PP-143 文 $\mathrm{CABG}$ 後弁膜症手術症例の問題点とその対 策}

\author{
1神奈川県立病院機構 神奈川県立循環器呼吸器病 \\ センター 心臓血管外科 \\ ${ }^{2}$ 横浜市立大学 外科治療学 心臓血管外科
}

安田 章沢 1 、徳永 滋彦 1 、松木 佑介 ${ }^{1}$ 、

岡本浩直 ${ }^{1}$ 、益田 宗孝 ${ }^{2}$

【背景と目的】近年、心大血管手術症例においても再 手術症例が増加の傾向にあるが、中でも $\mathrm{CABG}$ 後の 再手術は術式や graft の取り扱いに特段の注意を要 する難度の高い手術である。当科における再手術症 例の割合は $21 \%$ と高く多くの knowhow があるが、 $\mathrm{CABG}$ 後の再手術に関して当科の方針を検討する。 【方法】CABG 後の症例の場合、通常の心大血管再手 術の問題点に加え 1.bypass graft の癒着(特に右内胸 動脈の胸骨直下横断症例)、2. 術野の自由度の制限 3. 心筋保護をどうするか、という問題がある。これ らの問題に対し、我々は 1.Harmonic scalpel を用い て癒着剥離を行い、graft を授動しコントロールする、 2. 右腋窩動脈送血と必要に応じた graft の division に より良好な術野を確保する 3 . 逆行性心筋保護を多用 するが、確実な心停止を得ているか毎回心電図を確 認する、という対策を確実に行うことにより安全に 手術を施行している。2010 年 4 月から 2012 年 7 月ま での開心術症例 191 例の内再手術症例を 40 例経験し たが、内 CABG 後の弁膜症症例は 7 例 (17.5\%)であっ た。男女比は 5: 2、平均年齢は $75.0 \pm 4.0$ 歳であった。 既往手術の内、一例は既に graft が閉塞していた。3 例は右内胸動脈の胸骨直下横断症例であった。施行 手術は CABG+MAP1 例、AVR3 例、AVR+MVP2 例、 DVR1 例であった。右内胸動脈が左前下行枝に吻合 されている 2 例は右腋窩送血、右大腿静脈脱血の準 備を行った後胸骨切離を開始した。心筋保護は逆行 性心筋保護を全症例に行い、順行性心筋保護も4例 に併用した。【結果】剥離操作に伴う術中 graft の損 傷は認めなかった。右内胸動脈 - 左前下行枝バイパ ス 2 症例でも丁寧な graft の授動により AVRを問題 なく施行出来た。AVR 症例で 1 例大伏在静脈グラフ 卜と右内胸動脈の division を行い、静脈グラフトの み再建を施行した。1 例で長時間の人工心肺による閉 胸困難を来し二期的胸骨閉鎖を行い、1例で胸骨骨 髄炎による胸骨切除、大網充填を施行したが、在院 死亡はなく全例自宅退院となった。術後の CKMB 值 は $69.0 \pm 25.8 \mathrm{IU} / 1$ であり 100 を超えた症例は人工心 肺が長時間となった 1 例 $(175 \mathrm{IU} / 1)$ のみであった。 【結語】当科の CABG 後再手術症例の手術成績は満足 出来、我々の方法は妥当であると考えられた。CABG 後再手術の場合でも point に注意して臨めば安全に 手術が可能である。

\section{PP-144 乞 当科における僧帽弁置換術後左室破裂症例 の検討}

\author{
久留米大学病院 外科 \\ 赤須 晃治、税所 宏幸、平田雄一郎、 \\ 小須賀智一、友枝博、有永 康一、 \\ 田中 啓之
}

【背景】僧帽弁置換術 (MVR) 後の左室破裂 (LVR)は、 頻度こそ稀ではあるが、合併すると非常に致命率が 高いとされる。そこで現在までに当科で経験した MVR 後のLVRについて検討したので報告する。 【対象と方法】1996 年 1 月から 2012 年 8 月までに当科 で施行した MVR442 例のうち、LVRを合併した 8 例

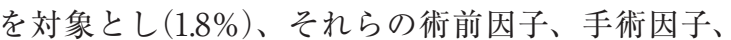
術後因子について検討した。【結果】＼cjkstart術前因子＞平 均年齢は 68 歳 (男: 2 人、女：6) で、平均体表面積 は $1.41 \mathrm{~m} 2$ であった。病因はリウマチ性 MS が 4 例、 変性性 MR が 3 例、感染性心内膜炎による MR が 1 例であった。また、僧帽弁輪周囲石灰化 $(\mathrm{MAC})$ を 4 例に認めた。<手術因子＞全例 MVR であるが、そ のうち術中 MVP からのコンバートを 2 例、MVP術 後遠隔期の遺残 MR に対する MVRを 1 例含んでい た。また、 5 例に心脱転をともなう抗不整脈手術を併 施していた。LVR 発症時期は、術中発症が 5 例、術 翌日が 2 例、術後 3 日目が 1 例であった。LVRの夕 イプは 1 型が 5 例、 3 型が 3 例で、始めの 1 例目以 外は全例心停止下に人工弁を外して修復を行った。 修復方法として 6 例に「心内側からのウマ心膜パッチ +心外側からのテフロンフェルトを用いたマットレ ス縫合フフィブリン製剤」を行った。また「心外から の圧迫のみ」、また「心内外からのテフロンフェルト を用いたマットレス縫合+フィブリン製剤」をそれぞ れ 1 例に行った。<術後因子> 7 例にIABP を用い、 1 例にはPCPS も併用した。6 例は LVR 修復後に閉 胸できず人工皮膚を用いて ICU 管理を行った。4 例 を救命でき、4 例を失った。失った症例の内訳は出血 2 例、縦隔洞炎 1 例、ポンプ離脱困難 1 例であった。 【結語】術翌日、または術後 3 日目の発症例は全て失っ た。術中発症例では救命できる症例も経験したが、 LVRの予後は非常に悪くやはりその発症予防に努め ることが重要であると考える。 
PP-145 公

弁輪部高度石灰化を伴った僧帽弁狭窄症に 対する僧帽弁置換術の手術手技の工夫

山口大学大学院 器官病態外科学 (第一外科)

$\begin{array}{llll}\text { 藏澄 } & \text { 宏之、美甘 } & \text { 章仁、河村 } & \text { 大智、 } \\ \text { 田中 } & \text { 裕也、工藤 } & \text { 智明、鈴木 } & \text { 亮、 } \\ \text { 高橋 } & \text { 雅弥、白澤 } & \text { 文吾、濱野 } & \text { 公一 }\end{array}$

【はじめに】僧帽弁輪の高度石灰化 (mitral annular calcification : MAC) を伴った僧帽弁狭窄症 (MS) に対す る術式として、石灰化病変を完全切除した後の僧帽弁 置換術 (MVR) や弁輪形成後の MVRなど、様々な術 式が報告されている。今回我々は MAC を伴う MSに 対し、石死化病変の切除を最小限に抑えた簡便で安全 な MVRを施行し良好な結果を得たので報告する。 【対象】2006 年 1 月〜 2012 年 7 月までの期間に当院で 経験した MACを伴う MS 症例 15 例。代表的な術前 CT を図 A 〜 C に示す。【手術】胸骨正中切開、右側 左房切開で僧帽弁へ到達する。石灰化病変切除の際に 発生しうる重篤な合併症を回避するため、僧帽弁の前 尖のみを切除する。僧帽弁口を径 $21 \mathrm{~mm}$ の sizer が通 過することで、十分な僧帽弁口の確保を確認する。前 尖側は心室側から左房側に向けて、後尖側は弁尖先端 を貫き心室側から左房に向けて、石灰化した弁輪へ水 平マットレス縫合を置き、人工弁を supraannular position に縫着する(図 D)。【結果】年齢 $69.3 \pm 9.7$ 歳、女 性 12 例。慢性透析患者 6 例 (40.0\%)。Japan SCORE は $6.1 \pm 3.4 \%$ であった。上行大動脈高度石灰化の為、 遮断不可能と判断した 4 例に超低体温逆行性脳灌流 下に上行大動脈置換術を併施した。大動脈弁置換術を 12 例、三尖弁形成術を 3 例、冠動脈バイパス術を 2 例に併施した。手術時間 $493 \pm 126$ 分、人工心肺時間 $294 \pm 69$ 分であった。移植人工弁は SJM 機械弁 11 例 (25mm: 2 例、 $27 \mathrm{~mm}: 8$ 例、 $31 \mathrm{~mm}: 1$ 例)、MOSAIC 生体弁 2 例 (25mm: 2 例)、CEP 生体弁 2 例 ( $27 \mathrm{~mm}: 2$ 例)であった。在院死、周術期脳梗塞、左室破裂を認 めなかった。出血再開胸(非心室出血)、縦隔炎を各 1 例 (6.6\%)に認めた。28.6 21.1(8.1-69.9) ケ月の観察期 間において、心臓死回避率は 5 年 : $100 \%$ であった。 遠隔期の心エコー検査において、stuck valve、弁周 囲逆流、僧帽弁狭窄症、左室瘤の形成を認めなかった。 【結論】MAC 症例に対する我々の方法での MVR は、 周術期の致命的合併症を認めず、遠隔期成績も良好で 積極的に考慮される術式である。
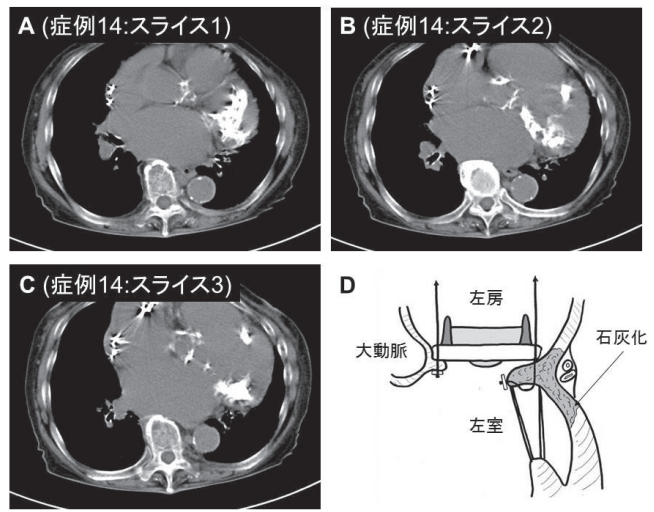

PP-146 它

普遍的で再現性がある僧帽弁形成術をめざ して

\author{
君津中央病院 心臓血管外科
}

飯田 浩司

【背景】本邦の初回僧帽弁手術のうち形成術 (MVP) は $59 \%$ でる。この割合を増やすために変性疾患を確 実に弁形成する方法を検討した。【対象】僧帽弁手術 127 例。【方法】簡便で侵襲を増やさない視野確保法 : 胸骨正中切開で心膜を逆 $\mathrm{T}$ 字に切開し右側心膜の 3 か所を引き上げて固定する。心膜切開の上方を大動 脈右側から SVC 右側を右上肺静脈まで延長する。 IVC と右下肺静脈の間の心膜を切開する。心停止後 上下大静脈脱血管とテーピングを強く左方に引き固 定する。心囊の右側がつり上がり露出した右側左房 を切開し、手術台を左に傾け心房中隔を星引すると 歪みのない視野が得られる。巨大右房 2 例、癒着が 高度な再手術、ASD 合併、粘液腫合併それぞれ 1 例 を除く 122 例に同様の視野展開を行い、出血再開胸、 不整脈の遷延、横隔神経麻痺、縦隔炎は認めなかった。 人工腱索結紮具 : 先端が $\mathrm{Y}$ 型の内筒と、 $\mathrm{T}$ 型の小腕 を有する外筒からなる二重の銁を開発した。ゴアテッ クス糸 $(\mathrm{CV} 5)$ を乳頭筋に固定し他端を弁尖に掛けた 後に、内筒の Y 型部分を乳頭筋の CV5 の結紮部に 当て、外筒の $\mathrm{T}$ 型部分の一方を CV5 を縫着する弁 尖の心室側に、他方を対面の正常弁尖に当てる。両 尖を $\mathrm{T}$ 型銁で同一平面上に置いて内外筒をスライド させて正常腱索が伸展した位置で内外筒を螺子で固 定する。二対の腕が人工腱索のループの中にあるた めに、CV5 が滑って短くなることなく両尖が同じ高 さになるように結紮可能である。複数対を要する場 合も位置に応じた長さでの結紮が可能である。19例 にこの方法を用いて術後の逆流は 2 例で 1 度、 17 例 は trivial 以下であった。Barlow 様の大きな後尖の形 成：prolapse の中央を弁輪まで切開し両側の弁縁に 5-0 糸をかけて横に引いて和服の前合わせのように重 ねて水試験を行い、逆流がない位置で弁尖を重ねて 縫合する。延長した腱索は交差して長さを減じ、そ の両側にある健常な腱索と共に後尖を支持する。5 例 に施行し 1 例に 1 度の逆流が残つたが 4 例では trivial または消失した。【結果】感染性心内膜炎やリュウ マチ性を含めた初回手術 118 例のうち 86 例 (72.9\%)、 エコーで prolapse を認めた変性 62 例では 85 歳の緊 急手術 1 例を除く 61 例 $(98.4 \%)$ で形成術が可能で あった。【考察まとめ】簡便で再現性がある弁形成術 のためにいくつかの方法を考案した。病変に応じて 既存の方法と使い分けることにより形成術成功率は 上昇した。 
$\mathrm{PP}-147$ 公

病態、病変部位および遠隔成績からみた僧 帽弁形成術標準化の是非

\author{
東京慈恵会医科大学 心臓外科 \\ 坂本 吉正、長堀 隆一、儀武 路雄、 \\ 松村 洋高、木ノ内勝士、成瀬瞳、 \\ 中尾 充貴、橋本 和弘
}

【背景】僧帽弁変性疾患における形成術の標準化は後 尖ではほぼ確立されていると考えられるが逸脱部位 の特定や Barlow 病、fibroelastic deficiency (FED)、 不完全型に分類することが治療戦略標準化のメルク マークになる。今回、手術、遠隔成績からみた標準 化の是非について検討した。【方法】1991 年 7 月から 2011 年 12 月に変性疾患 (逸脱病変例のみ)に形成術 を予定し、175 例(男/女：126/49)。年齢は $56 \pm 15$ 歳。Severe MR が 141 例、moderate MR が 34 例、 $\mathrm{EF}$ は $68 \pm 11 \%$ 、後尖 101 例 $(57.7 \%)$ 、前尖 47 例、 前後尖 17 例 $(9.7 \%)$ 、交連 10 例 $(5.7 \%)$ 。術者は延べ 12 名ですべて指導医のもとに施行。前尖は三角切除、 clear zone には切り込まず広範逸脱は人工腱索再建 併用。後尖は三角切除を基本とし単結紮縫合、病的 逸脱部はできる限り切除するがストレス軽減のため 弁輪には切り込まない。交連部は小範囲で edge to edge または広範囲症例では三角切除・縫合。リング は semi-rigid-saddle ring、後尖の高さで band も考 慮。達成率、早期遠隔成績について検討し、KaplanMeier 法により生存率、再手術回避率を算出。【結果】 後尖逸脱 99 例で弁尖切除を施行、2 例で人工腱索再 建 (loop 法) 施行。前尖逸脱 40 例で三角切除、 7 例で 人工腱索再建を併用、人工腱索のみによる再建は 6 例。両尖逸脱は 2 箇所切除が 13 例、3 箇所が 4 例で 人工腱索併用症例は 1 例。交連部病変は edge to edge が多かった。後尖逸脱の $21 \%$ で partial リング を使用、その他は full リング。サイズは $30 \mathrm{~mm}$ が最 も多かった。手術死亡 5 例 (2.9\%)、形成術を予定し 術中、同じ入院中に弁置換術になった症例は 4 例 (Barlow 病が 1 例、縫合部離開 1 例、広範逸脱 1 例、 溶血 1 例)、97.7\%の症例で形成術施行。観察期間 8.7 \pm 5.5 年 (最長 19 年)、追跡率は $91.4 \%$ 、遠隔死亡 9 例で 15 年生存率は $89.2 \pm 3.4 \%$ 。遠隔期再手術は 7 例 $(4.1 \%)$ 、前尖病変を含む不完全型が 5 例、後尖 1 例、 交連部 1 例、原因は溶血 2 例、 IE1 例、逆流増加(再発) 4 例、全例弁置換術を施行。再手術回避率は 15 年で $94.4 \pm 2.1 \%$ で前尖病変、交連部病変で低い傾向にあっ たが有意差は認めなかった。【結語】後尖の単独病変 (FED) では逸脱部位の切除をおこなう術式は標準化 されていると考えられた。前尖病変を含む広範囲逸 脱症例 (Barlow 病、不完全型)で再手術がやや多い傾 向にあり標準化にはさらなる工夫が必要と考えられ た。

\section{PP-148 2 r \\ Trainee が執刀出来る僧帽弁形成術の確立： Folding Mitral Valve Repair Technique}

\author{
東京女子医科大学 心臓血管外科 \\ 津久井宏行、前田 拓也、杉浦 唯久、 \\ 外川 正海、岩朝 静子、梅原 伸大、 \\ 石井光、冨岡 秀行、西中 知博、 \\ 齋藤聡、青見 茂之、山崎 健二
}

【目的】僧帽弁閉鎖不全症(MR) に対する僧帽弁形成術 (MVR)は、技 術的難易度が高いことに加え、ガイドライン上 $\Gamma \mathrm{MR}$ を残すことなく 90\%以上弁形成術が可能である」ことが求められているため、Trainee の執刀機会は限られている。当科では、逸脱弁尖を切除することなく、 左室側に折り畳む Folding Mitral Valve Repair(FMVR)を用いること により、Attending 監督下に Trainee に積極的に執刀機会を与えるこ ととしている。FMVRの有用性について検討した。【方法】2009年 4 月より 2012 年 7 月までに当科にて施行した MVR124 例のうち、 FMVRを用いた 86 例 $69.4 \%$ 、男性 52 例、平均年齢 61.5 歳)を対象 とした。MRの Functional classification は、Type I: 3 例、Type II: 80 例、Type I+II: 3 例であった。術前 MR は moderate: 45 例(52.3\%)、 severe: 36 例(41.9\%)で、感染性心内膜炎(IE)が9例であった(active IE: 3 例)。FMVR の執刀医を Attending 群(A群：5外科医）と Trainee 群( T群：11外科医)の 2 群に分け、比較検討した。結果】 両群とも病院死亡は無かった。Trainee が54例(62.8\%)を執刀した。 T 群は、修復容易な後尖逸脱症例が 50 例 $(75.9 \%)$ であり、A 群は、 難易度の高い前尖や交連部逸脱症例が 21 例(65.6\%)であった。体外 循環時間は $\mathrm{A}$ 群: 148.4 分、 $\mathrm{T}$ 群: 148.1 分、大動脈遮断時間は $\mathrm{A}$ 群： 97.3 分、T群: 99.0 分で有意差を認めなかった。術後 MR は、両群と も None-Trivial(A 群: 24 例、T群: 42 例) ししく Mild(A 群: 8 例、 T群: 12 例)であった。術後遠隔期において、Moderate 以上の MR 再発を 3 例 (A 群: 2 例、 T 群: 1 例)に認めた。考察】FMVR は、逸 脱弁尖を切除しないため、簡便であり、やり直しが可能なため、 MVR の完成度を低下させることなく、Trainee に MVR 執刀機会を 提供できると考えられた。手術成績は満足できるものであると考え られた。今後の長期遠隔成績を注意深く観察する必要がある。

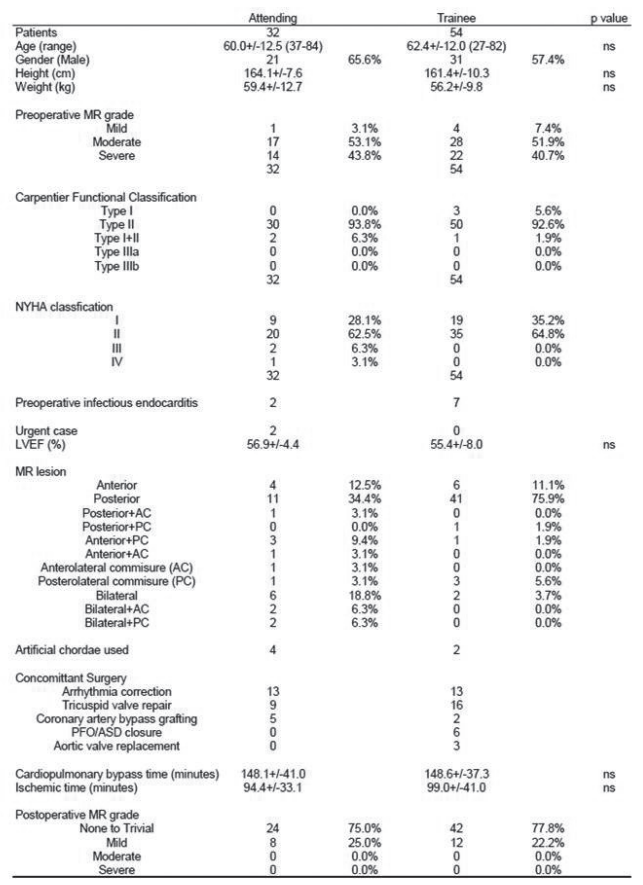


PP-149 눈

\section{人工腱索再建を軸とした僧帽弁形成術を実 現する Loop-in-Loop technique}

\author{
慶應義塾大学 外科（心臓血管）
}

岡本 一真、工藤 樹彦、高木 秀暢、

四津 良平

【目的】僧帽弁形成術の成績向上・普及とともに、複 雑病変に対しても確実に形成することが求められて いる。低侵襲外科治療として右小開胸を僧帽弁形成 の主たるアプローチとしている環境で、僧帽弁形成 戦略は古典的な resection-and-suture 法よりも Looptechnique を用いた複数の人工腱索再建による弁形成 法を採用し 2012 年 8 月までに 203 例に対して採用し 良好な手術成績を実現してきた。さらに僧帽弁形成 の簡便性を高めるために、2011 年 3 月以降は、Looptechnique の変法として primary loop-set と secondary loopからなる Loop-in-Loop technique 用いて いる。本法の妥当性と短期成績について明らかにす る。

【方法】2011 年 3 月から 2012 年 8 月までに施行した僧 帽弁形成術連続 73 例 (右小開胸 65 例)のうち Loopin-Loop technique を用いた 53 例(右小開胸 48 例)に ついて、治療成績を検討した。Loop-in-Loop technique では、乳頭筋と僧帽弁尖との距離を測ることな く ePTFE 糸 $(\mathrm{CV}-5)$ による $5 \mathrm{~mm}$ と短い loop-set $(4$ loops)を乳頭筋に縫着しておき(primary loop-set)、 次に secondary loop として別の ePTFE 糸(CV-5)で loop-setの一つの loop と逸脱弁尖との距離を調節し た。長さの調整においては saline injection testや reference leaflet との比較を参考にし、決定した secondary loop の長さを変えずに正確に ePTFE 糸を結 紮するために、脳動脈瘤用クリップを用いて結紮点 を固定した。

【成績】36 例に前尖病変を認めうち 23 例は両尖の病 変を認めた。平均 3.6 本 $(1-8)$ の人工腱索再建を行っ た。うち 15 例では弁尖の切除と組み合わせて弁形成 を行った。全例でリングによる弁輪形成を行った。 5 例で三尖弁形成術を、1例で大動脈弁置換術を併施 した。6 例で心房細動手術 (PV isolation 3 例、左房 MAZE 3 例)を併施した。周術期・経過観察期間 $(208.2$ 土136.9 日(1-487))を含めて、死亡および脳梗塞など 重篤な合併症を認めず、右小切開アプローチから胸 骨正中切開へのコンバートもなかった。経過中に moderate 以上の逆流を認めたものは 2 例のみで、う ち一例は遷延する溶血のため再弁形成を行ったが、 moderate 以上の僧帽弁逆流回避率は $96.2 \%$ であっ た。

【結論】Loop-in-Loop technique は人工腱索を軸とし た僧帽弁形成を可能とする、簡便性と確実性を持ち 合わせた有用な技法であり、右小切開アプローチの ように視野や作業空間に制限がある設定で安定した 僧帽弁形成を実現するために不可欠な手法である。

\section{PP-150 究 \\ 人工腱索設置における連続縫合によるルー プ法}

\author{
名古屋ハートセンター 心臓血管外科 \\ 米田 正始、木村 有成、深谷 俊介、 \\ 北村 英樹、大川 育秀
}

【目的】僧帽弁形成術において、ゴアテックス糸によ る人工腱索は弁尖を resect せず respectする立場か ら汎用される方向にある。なかでもループ法はその 簡便さと、やり直しが効きやすい安心感から使われ ることが増えている優れた方法である。しかしルー プ法の弱点は弁尖の一か所を支えるために 2 本の PTFE 糸が必要となることである。遠隔期に PTFE が硬化したり石灰化するという報告も散見される中 で、PTFEのダブル使用には懸念がないとは言えな い。我々は僧帽弁形成術において David らの連続縫 合式人工腱索設置術にループ法を加味し、比較的簡 便に弁尖の一か所に一本の PTFE 糸をつける方法を 使用している。【方法】当院で 3 年半の間に施行した 僧帽弁形成術 157 例中、ループ使用の連続縫合式人 工腱索設置術を行った 31 例を検討した。男性 18 名、 女性 13 名、年齢 $51.9 \pm 17.6$ 歳 (平均 $\pm 1 \mathrm{SD}$ ) であった。 【成績】前尖病変は 28 例に、後尖病変は 15 例に認め た。うち両尖病変は 13 例、僧帽弁 Redo 症例は 2 例 であった。これらの病変に対して PTFE 人工腱索は $5.0 \pm 2.7$ 本設置した。全例リングをもちいた MAPを 併用した。病院死はなく、退院時エコーにて moderate MR を一例に認めた他は mild 以下の残存 MR で あった。遺残弁尖逸脱をもつ症例はなく、moderate MR 例の原因は弁尖の硬化と考えられた。術後 3.5 年 までのフォローアップのなかで一例が新規病変発生 のため再手術となったが、他は経過良好である。【結 論】短いフォローアップのなかで本法の有効性を証明 するには至っていないが、多数の人工腱索設置例で は手技の簡便化と虚血時間の短縮そして必要な本数 を問題なく確保でき弁尖の仕上がりがなめらかであ るという利点が見られた。同じ qualityの形成を半数 の PTFE 糸でできるという特長は遠隔期に利点とな る可能性がある。さらなる検討を進めたい。

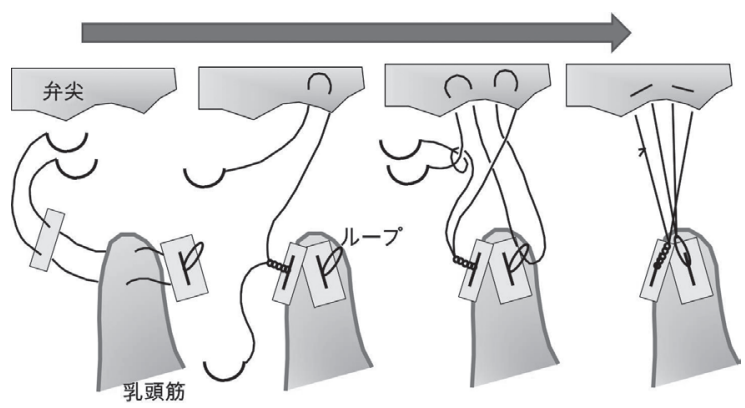




\section{PP-151 文 \\ 僧帽弁形成術における人工腱索の長さを決 定し結紮のするための器具の開発}

\author{
君津中央病院 心臓血管外科
}

飯田 浩司

【目的】人工腱索を用いる僧帽弁形成術(MVP)では、 人工腱索の長さを決める事と滑り易いゴアテックス 糸をその長さで結紮する事が必要である。これらを 再現性を持って同時に解決するための器具を開発し た。【方法】当初は先端が $\mathrm{T}$ 型の銁を用いて対面する 両尖を同時に牽引して高さを合わせた。人工腱索と 対面の健常な腱索の長さを合わせることが可能であ るが、結紮時にゴアテックス糸が滑ると乳頭筋が引 かれて吊り上り人工腱索が短くなる危険があった。 次に市販のノギスの先端を削ったものを作成して対 面の健常腱索の長さを測定し、その幅で固定したノ ギスを乳頭筋と弁尖の間にできた人工腱索のループ の中に入れて結紮した。対面の長さを測定してから 人工腱索側に移動させて使用する必要があり、また ノギスの先端は比較的大きく、左室内への挿入に時 として難渋した。先端がY型の内筒、先端両側に $5 \mathrm{~mm}$ と $8 \mathrm{~mm}$ の非対称な $\mathrm{T}$ 型の腕を有する外筒から なる二腕二重の銁を作成した。人工腱索のループの 中に鈎を入れて、内筒先端の Y 型部分を乳頭筋上の 人工腱索結紮部に当て、外筒の $\mathrm{T}$ 型部分の一方を人 工腱索が弁尖を貫通する部位の心室側に、他方を対 面の正常弁尖の心室側に当てる。両尖を同一平面上 に置いたまま、内外筒をスライドさせて正常腱索を 伸展させた位置で内外筒を螺子で固定一して人工腱 索を結紮すると予定の人工腱索長に結紮することが 可能である。複数対の人工腱索を用いる場合には同 様の手技を繰り返すことによりその位置に合わせた 人工腱索置換が可能である。現在は $\mathrm{Y}$ 型内筒と $\mathrm{T}$ 型 外筒がラチェット機構でつながれて、離れる方向に のみ動く鈎を制作し、内外筒を螺子で固定する際に ずれることが無くなった。【結果】人工腱索を用いた MVP21 例にこの方法を用いて全例で MVP が可能で あり、術後の逆流は 4 例が 1 度、17 例で trivial 以下 であり、最長 7 年経過し再手術を要した症例はない。 【考察・結論】修復した弁尖を対面の正常弁尖と同じ 高さにすることが MVP の要点である。これらの方法 は人工腱索長の決定と結紮時の糸の滑り予防という 人工腱索置換の課題を同時に解決し、糸を鈿子等で 挟んで傷つける事もなく、部位に応じて微調整可能 な簡便で再現可能な方法と考える。

\section{PP-152 穴 \\ 僧帽弁形成術における「切らない形成術」と 「切る形成術」の中期成績の比較}

\author{
財団法人 心臓血管研究所付属病院 心臓血管外科
}

高井 秀明、田邊 大明、門磨 義隆、
山部 剛史

【目的】弁尖切除を行わない形成術が提唱されている。 後尖限局の形成術の切除縫合による形成術と人工腱 策を用いた切除しない形成術の中期成績の比較した。 【対象】2002 年 8 月〜 2012 年 7 月まで、当院での僧帽 弁形成術 287 例のうち、病変部位が後尖に限局した 形成術 98 例を対象とした。100 例のうち、切除縫合 による形成術 (M 群) は 54 例、切除しない人工腱策に よる形成術 $(\mathrm{R}$ 群) は 44 例であった。各群で $\mathrm{M} / \mathrm{R}$ 、 平均年齢 $[62 \pm 12 / 62 \pm 12]$ 、男女比 $[35: 19 / 34: 10]$ 、 術前心房細動合併 $[11 / 12]$ に有意差はなかった。全例 人工弁輪を使用し、使用した人工弁輪は、Physio [M; 45, R; 20]、PhysioII [M; 6, R; 22]、Seguine [M; 1, R; 1]、Taylor $[\mathrm{M} ; 1, \mathrm{R} ; 1]$ 、 Cosgrove $[\mathrm{M} ; 1, \mathrm{R} ; 0]$ であっ た。MRの原因は degenerative [51/42]、healed IE [1/1]、Barlow [0/1]、Tethering [2/0] であった。 併施手術は TAP $(12 / 20) 、 \operatorname{AVR}(5 / 1) 、 \operatorname{Maze}(13 / 15) 、$ $\mathrm{CABG}(2 / 1)$ であった。【結果】全例形成術を完遂、人 工弁輪の大きさは $\mathrm{M}$ 群で平均 $28.7 \pm 2.0 \mathrm{~mm}(24$ 〜 $34 \mathrm{~mm}) 、 \mathrm{R}$ 群で平均 $30.4 \pm 1.7 \mathrm{~mm}(26 \sim 34 \mathrm{~mm})$ で、 有意に $(\mathrm{p}<0.01) \mathrm{M}$ 群で小さかった。大動脈遮断時 間は $130 \pm 37 / 140 \pm 35$ 分で有意差は認めなかった $(\mathrm{p}=0.08)$ 。術後合併症では再開胸、術後脳梗塞、周 術期心筋梗塞、肺炎、消化管出血、縦隔炎、腎不全 で有意差は認めなかった。手術死亡・病院死亡とも に無し、術後 2 年以上経過した症例 (M 群; 47 例 、 $\mathrm{R}$ 群 ; 22 例 )の中期(術後 2 年目)の経胸壁エコーで は $\mathrm{M}$ 群; 0 度 : 37 例、 1 度 : 7 例、 2 度 : 3 例、 $\mathrm{R}$ 群; 0 度: 17 例、 1 度: 2 例、 2 度: 3 例であった。再手 術を要した症例は両群合わせて 0 例、全死亡症例は $\mathrm{M}$ 群で 1 例(術後 20 カ月目に癌死)、 $\mathrm{R}$ 群ではなかっ た。塞栓・出血イベントは両群で認めなかった。術 後 2 年以上経過した症例 ( $\mathrm{M}$ 群 47 例、 $\mathrm{R}$ 群 22 例)を 対象に、MR2 度以上の回避率を Kaplan-Meier 法を 用いて、Logrank 検定行ったが、有意差は認められ なかった。【結語】術後中期において、 $\mathrm{R}$ 群の成績は $\mathrm{M}$ 群のそれと遜色ない結果を示した。今後は遠隔期 においても引き続きフォローしていく必要がある。 
PP-153 败

僧帽弁位人工弁周囲逆流に対する術式の検 討と工夫

\section{聖隷浜松病院 心臓血管外科}

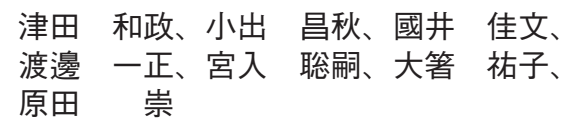

【背景】僧帽弁置換術後遠隔期の人工弁周囲逆流 (PVL) は重大な合併症であり、手術を行っても再発 し治療に難渋する例が少なくない。当院での PVL 発 生状況と修復方法の工夫、手術成績を報告する。【対 象と方法】1993 年以降僧帽弁置換術 (複数弁含む) を 行った 279 例中、 2012 年 7 月までの PVL16 例 (男性： 12、女性：4）に対する手術 19 件を対象とし、術式と 成績を検討した。手術時年齢 $68.6 \pm 6.3$ 歳、先行手術 $2.0 \pm 0.7$ 回(1 回: 3 例、2 回: 9 例、3 回: 4 例)、前回 手術からの期間 $11.5 \pm 6.4$ 年。先行手術使用弁は St. Jude Medical 弁: 14、Carbomedics 弁: 1、BjorkShiley 弁 : 1 であった。【結果】＼cjkstart術前＞全例で術溶血 性貧血を認め、LDH $1709 \pm 8201 \mathrm{IU} / 1$ と高值を示した。 心不全はNYHA II: 3、III: 14、IV: 2 件で、classIV の 2 件は発症から 2 週間以内の準緊急手術を要した。 PVL の原因は石灰化: 13、内膜形成不良: 2、人工弁 感染後: 1、逆流部位は Surgeon's view $11 \sim 1$ 時方 向、5 7 時方向に多かった $10 、 15$ 件、複数箇所の逆 流含む)。<手術>再弁置換 8 件、弁輪修復 11 件で あった。修復は leak 部の直接閉鎖を基本とし、2011 年以降の 4 件では、短冊状にした自己心膜やウマ心 膜で弁輪全周を被覆する補強を追加し再発を予防し た。大動脈弁置換併施例では、Manouguian 法を応 用したパッチ修復や、左室壁と人工弁輪カフを縫合 し leakを抑え込む左室側からの修復などの工夫を 行った。＜成績＞手術死亡なし。術後 LDH 363土 107IU/1、退院後 NYHA は I: 7 件、II: 12 件で、全件 で症状が改善した。遠隔期 PVL 再発による心不全を 5 例に認め、弁輪修復で有意に少なかった(置換： $4 / 8 \mathrm{vs}$ 修復: $1 / 11 、 \mathrm{p}=0.045)$ 。 5 例 中、 2 例 は 90 、 92 ヶ月の心不全死、 1 例は保存的に加療し 32 ヶ月目 生存。残り 2 例は再手術を行うも PVL 再々発症とな り、うち 1 例はさらに追加修復を施行し改善した。 先行手術回数、僧帽弁置換回数 (1 回: 3,2 回 : 12,3 回 : 4)、PVL 発症部位などは、術後 PVL 再発と関連し なかった。修復術のうち 3 例に、1 1 月以内の心エコー 上 PVL mild 以上の再発を認めたが、遠隔期心不全 の発症とは関与しなかった。并輪被覆を行った修復 例では早期再発を認めなかった(被覆 : $0 / 4 \mathrm{vs}$ 非被覆 : 3/7)。【結語】PVLに対する手術は症状を改善し、短 期成績は良好であった。遠隔期 PVL 再発を多く認め ることが課題であり、弁輪修復術は置換術と比べ有 意に再発が少なかった $(\mathrm{p}=0.045)$ 。特に弁輪全周を被 覆する方法は良好な早期成績を示し、PVL 再発防止 に有用な術式であると期待される。

\section{PP-154 幽 術後遠隔期に僧帽弁位人工弁周囲逆流に対 して手術を要した症例の検討}

\author{
兵庫県立尼崎病院 心臓センター 心臓血管外科 \\ 羽室護、夫津木綾乃、吉澤 康祐、 \\ 今井 健太、吉川 英治、大野 暢久、 \\ 藤原 慶一
}

【背景】僧帽弁置換術後の人工弁周囲逆流(PVL) は重 大な合併症の一つであり、術後遠隔期に手術を要す る症例がある。【対象】2000 年から 2012 年に当科で 僧帽弁位人工弁周囲逆流に対して手術を行った症例 は 8 例であった。このうち、人工弁感染に伴う PVL のため術後早期に再手術を要した 1 例を除く、術後 遠隔期手術症例 7 例を対象として、その成因、部位、 修復方法について検討した。【結果】手術時年齢は 59 〜 73 歳(中央值 65 歳) であり、前回手術から今回 PVLに対する手術までの期間は $14 \sim 26$ 年 (中央值 18 年)であった。初診断は MS4 例、MR3 例であり、 先行手術回数は平均 $2.2 \pm 0.4$ 回 (1 回: 1 例、2 回 : 5 例、3 回 : 1 例)、その内訳は閉鎖式交連切開 1 件、 直視下交連切開 1 件、僧帽弁輪形成 1 件、僧帽弁置 換 7 件、僧帽弁再置換 4 件であった。先行再弁置換 4 例の原因は PVL2 例、人工弁機能不全 2 例であっ た。全例が溶血性貧血の出現または進行のため手術 を行った。PVLの部位は、後尖側弁輪部 5 例、前交 連側弁輪部 1 例、後交連側弁輪部 1 例であった。 PVL の原因は、弁輪部石灰化 3 例、弁輪組織断裂 2 例と考えられ、1 例は前回弁置換時に残存した古い sewing cuffに人工弁が縫着されていた。残り1例は 原因を特定できなかった。全例弁置換を行い、4例で 異種心膜による弁輪補強を行った。尚、全例前回弁 置換時より 1 サイズ以上小さい人工弁を選択した。 手術前後で Hb, LDH 值はそれぞれ平均 $7.4 \pm$ $0.8 \rightarrow 11.3 \pm 0.9(\mathrm{~g} / \mathrm{dl}), 1963 \pm 859 \rightarrow 303 \pm 58(\mathrm{IU} / \mathrm{L})$ と 有意に改善を認め、全例生存退院している。【考察】 僧帽弁置換術後遠隔期であっても PVLによる溶血性 貧血の出現や進行のため手術が必要となる場合があ り、先行手術 2 回以上の症例が多かった。(1)著しい 弁輪の石灰化や古い sewing cuff への縫着を認めたこ とから弁置換後の弁輪部内膜新生の障害、(2)後尖側 弁輪部に多く認めたことから生理的に過度なストレ スがかかる部分での弁輪組織断裂などが PVL の原因 である可能性があると考えられた。脆弱な弁輪や石 灰化除去により菲薄化した弁輪に対しては異種心膜 による弁輪補強を行い、再弁置換時には縫合部への 過度なストレスを防ぐように、弁輪径を再評価して 適切なサイズの人工弁を選択することが重要と考え られた。【結語】僧帽弁置換時にはPVL 予防のため に、石灰化組織や古い sewing cuff の徹底的な切除、 脆弱な弁輪に対する異種心膜での補強、適切なサイ ズの人工弁の選択が重要である。 

三尖弁逆流の与える影響

\author{
神戸市立医療センター中央市民病院 心臓血管外科 \\ 福永 直人、岡田 行功、左近慶人、 \\ 小西 康信、中村健、村下 貴志、 \\ 金光ひでお、藤原洋、小山 忠明
}

【目的】開心術後遠隔期に生じる三尖弁逆流に対して は保存的に経過をみることが多く積極的に外科治療 を行ってこなかった。また、外科治療の介入時期、 治療方法に関しても決まった指針はない。再手術に おける三尖弁手術の死亡率、遠隔期生存率が悪いこ とも外科治療介入を踏み留ませる要因であると考え る。以前から我々は、再手術時における三尖弁逆流 に対しても積極的に弁輪縫縮術を行ってきた。再手 術時おける三尖弁逆流の与える影響について検討し た。【方法】1990 年 1 月から 2010 年 12 月までに施行 した僧帽弁・大動脈弁置換術後再手術 181 例を対象 とした。 57 例 (31\%)に中等度以上の三尖弁逆流を認 め、三尖弁輪縫縮術を施行した (A 群)。三尖弁逆流 のみが原因で再手術となった症例は 3 例あった。術 前 NYHA3 度 以上 26 例 (46\%)、心房細動 47 例 (82\%)、肝硬変 7 例 $(12 \%) 、$ 透析 2 例 (3\%) を認めた。 三尖弁縫縮術を施行していない 124 例 (69\%) (B 群) ではNYHA3 度以上 44 例 (35\%)、心房細動 48 例 $(39 \%)$ 、肝硬変 7 例 $(6 \%)$ 、透析 1 例 $(1 \%)$ であった。 【結果】A 群は病院死亡 5 例 (8.8\%) 認めた。多蔵器不 全 2 例、LOS、不整脈、敗血症が 1 例ずつであった。 B 群では 12 例 $(9.6 \%)$ 認め、LOS4 例、多臓器不全、 出血が 3 例ずつ、不整脈が 1 例であった。術後合併 症はA 群では 18 例 (32\%)、B 群では 30 例 (24\%)認 めた。病院死亡率、合併症率共に統計学的には有意 差は認めなかったが術後合併症の頻度が A 群におい て高い傾向にあった。単変量解析では病院死亡の危 険因子は A 群では 4 回目の再手術例、術後合併症の 危険因子は透析症例であった。多変量解析では統計 学的有意差を持った因子は認めなかった。遠隔期生 存率は $\mathrm{A}$ 群では $5 、 10$ 年生存率が $73.3 \pm 6.8 \% 、 60.9$ 土10.2\%であった。B 群では $81.6 \pm 3.7 \% 、 71.0 \pm 5.0 \%$ であった。A 群では遠隔期生存率は低い傾向にはあっ たが、両群間には有意差は認めなかった(Logrank=0.3256)。【結論】A 群では術前併存疾患の頻度 が高くなっており、術後合併症発症に寄与している と考えられる。三尖弁逆流に伴う心臓を含む全身臓 器の不可逆的な変化が起こる前に外科治療を行うこ とで治療成績、遠隔期生存率の改善が期待される。 再手術時における三尖弁逆流の存在・治療介入につ いて再認識する必要がある。 
PP-157 文

遠隔成績からみた重度三先弁閉鎖不全症に 対する三尖弁輪形成術に関する検討

大阪大学大学院医学系研究科 心臓血管外科

$\begin{array}{llll}\text { 溝口 } & \text { 裕規、戸田 } & \text { 宏二、宮川 } & \text { 繁、 } \\ \text { 西 } & \text { 宏之、吉川 } & \text { 泰司、福嶌 } & \text { 五月、 } \\ \text { 吉岡 } & \text { 大輔、斎藤 } & \text { 哲也、上野 } & \text { 高義、 } \\ \text { 倉谷 } & \text { 徹、澤 } & \text { 芳樹 } & \end{array}$

【目的】Functional tricuspid regurgitation(FTR)に対 して、様々な種類の人工弁輪を用いた Tricuspid annuloplasty (TAP)が施行されているが、重度の FTR は遠隔期に TR 再発を起こしやすいことが報告され ており、同病態に対しては遠隔期の確実な TR 制御 が重要である。今回、当院における、重度 FTR に対 する TAP の術後 TR 再発の危険因子について、検討 したので報告する。【対象、方法】2003 年 1 月〜 2012 年 1 月までに当院で施行した TAP 中、術前 TRが grade 3 以上の 94 例 (平均年齢 $63.1 \pm 17.2$ 歳) を対象 とした。術前 TR grade は grade 3(moderate to severe) 43 例、 grade 4 (severe) 51 例、平均 $3.5 \pm 0.5$ で あった。使用人工弁輪は Cosgrove 31 例、MC3 51 例、 Tailor 10 例であり、Cosgrove は前尖から後尖にか けての弁輪形成を、MC3 および Tailor では前尖から 後尖、中隔尖の途中までの弁輪形成を施行した。術 直後残存 TR の危険因子および遠隔期 (平均観察期間 23 ヶ月)における遠隔期 TR 再発の危険因子について 検討した。【結果】術直後 TR の分布は grade0 (zero to trivial) 45 例、 grade1 (mild) 21 例、 grade2 (moderate) 16 例、grade 34 例、grade 41 例 で、平均 TR grade は $0.8 \pm 1.0$ であり、術前に比べて改善していた $(\mathrm{P}<0.05)$ 。術直後 moderate 以上の TRを残存し た 21 例の使用人工弁輪は、Cosgrove 9 例、MC312 例であり、ロジスティック回帰分析では使用人工弁 輪と残存 TR (moderate 以上)に差はみられなかった。 観察期間における遠隔期 TR 再発の危険因子の単変 量解析では、年齢、術前心房細動の合併、術前肺高 血圧症、術前左室拡張末期径 $60 \mathrm{~mm}$ 以上、人工弁輪 サイズに有意差を認めず、有意差を認めたのは Cosgrove 使用 (Hazard Ratio 5.30、P = 0.001) であった。 使用人工弁輪別の遠隔期 TR 再発回避率は Cosgrove、MC3、Tailorの 順 に $71.0 \%$ vs. $91.3 \%$ vs $100 \%$ ( 1 年)、 $51.2 \%$ vs. $78.6 \%$ vs. $85.7 \%$ (2 年) ( $\mathrm{P}=$ 0.003)であった。【結語】重度 FTR に対する人工弁輪 を用いた TAP の術後成績はおおむね良好であった。 Cosgrove 使用例では遠隔期 TR $\geqq$ moderate の再発 を多く認めており、遠隔期 TR 再発を予防するには 中隔尖を充分に含めた弁輪形成が重要であると考え られた。

\section{PP-158 光 三尖弁閉鎖不全症に対する自己心膜パッチ を用いた前尖 augumentation 法}

\author{
新東京病院 心臟血管外科 \\ 徳永 宜之、大島祐、依田 真隆、 \\ 浅見 冬樹、系原 孝明、中村 裕昌、 \\ 門脇輔、植野 恭平、中尾 達也、 \\ 山口裕己
}

【背景】三尖弁閉鎖不全症(TR)に対して、 $\mathrm{MC}^{3}$ ring を用いた三尖弁形成術 (TAP) 後の良好な成績が報告 されつつある。2006 年 9 月から 2011 年 12 月までに、 $\mathrm{MC}^{3}$ ring を用いて 526 例の TAP を施行した。心工 コー上の TR は、術前 $1.8 \pm 0.9$ 度 (Mild = 1、 Moderate $=2$ 、 Severe $=3$ ) 加退院前 $0.2 \pm 0.5$ 度と有意に 改善し、最長 4 年のフォローアップで、TR の増悪は 認めていない。退院時に moderate 以上の TR の残 存を認めた症例は 12 例 $(2.3 \%)$ で、低心機能 4 例、心 房細動残存 3 例、肺高血圧 7 例、外傷性 1 例、redo$\mathrm{TAP} 1$ 例であった。術後 1 年以後の心エコーで、 moderate 以上の TR の残存及び再発を認めた症例は 14 例 $(2.7 \%)$ で、低心機能 6 例、透析 2 例、肺高血圧 10 例、心房細動残存 1 例、外傷性 1 例、redo-TAP 1 例であった。この $\mathrm{MC}^{3}$ ring だけでは制御できない 2 〜 3\%の症例は、TR 発生のメカニズムが三尖弁輪拡 大のみではなく、著明な右室の拡大によって主に前 尖の tethering が著明な症例であることが明らかに なった。これらの TRを制御するためにグルタール アルデヒド処理を行った自己心膜を用いて、前尖の augumentationを施行し、良好な結果が得られるよ うになったので供覧する。【症例】75 歳女性。11 年前 にDCM の診断で CRT-P 植え込みの既往あり。腹部 膨満を主訴に受診され、心エコーで severe TR を認 めたため、半年前に $\mathrm{MC}^{3}$ ring $28 \mathrm{~mm}$ を用いて TAP を施行した。術中心エコーでは mild 〜 moderate に 改善したが、フォローアップ中に severe TR となり、 心不全による 2 度の入院を必要とするようになり、 再手術を施行した。【手術】右大腿動脈送血、大腿静 脈脱血で人工心肺を開始後に、胸骨正中切開を行っ た後、上大静脈に脱血管を追加し、人工心肺を確立 した。順行性心筋保護液注入で心停止を得たのち、 右房を切開し、三尖弁を展開した。前尖の軽度の肥 厚と著明な tethering 認め、TR を制御するには前 尖の大きさが不十分であると判断した。 $\mathrm{MC}^{3}$ ring 除去し、前尖から後尖までを弁輪から切離し、グル タールアルデヒド処理した $2 \times 5 \mathrm{~cm}$ 大の自己心膜を 用いて、6-0 プロリン interrupted suture で前尖及び 後尖の augumentationを施行した。その後、 $\mathrm{MC}^{3}$ ring $30 \mathrm{~mm}$ を縫着し、TAPを施行した。術後の心工 コー上、mild TRまで制御し得た。【結論】 $\mathrm{MC}^{3}$ ring だけでは制御できない著明な右室拡大による前尖の tethering を認める症例に対して、自己心膜を用いた augumentation 法は、有効な手技であることが示唆 された。 


\section{PP-159 㝋 \\ MC3 人工弁輪を用いた三尖弁形成術の早 期・遠隔成績一遠隔 TR 再発のリスクファク ター一}

${ }^{1}$ 財団法人 太田綜合病院附属太田西ノ内病院 心 臓血管外科

2福島県立医科大学 心臓血管外科学講座

$\begin{array}{ll}\text { 五十嵐 } & \text { 崇 }^{1,2} \text { 、丹治 雅博 }{ }^{1} 、 \text { 高橋 皇基、 } \\ \text { 横山 } & \text { 斉 }^{2}\end{array}$

【目的】MC3 人工弁輪を用いた三尖弁形成術 (TAP)の 早期 - 遠隔成績と遠隔 TR 再発の危険因子について 検討した。【対象と方法】2008 年 1 月から 2011 年 12 月までに当科で TAP を受けた 60 例 (平均 $64.8 \pm 14.4$ 歳、男性 36 例)を対象とした。平均フォローアップ期 間 $23.5 \pm 13.8$ ケ月。術前、術直後、遠隔期に心エコー 評価を行った。 MC3 人工弁輪のサイズ選択は、患者 の体表面積 $(\mathrm{BSA})$ が 1.5 以下の場合 $26 \mathrm{~mm}$ を、 1.5 以 上の場合 $28 \mathrm{~mm}$ を選択した。術前診断の内訳は僧帽 弁疾患 34 例 $(57 \%)$ 、大動脈弁疾患 4 例 $(7 \%$ )、A 弁 $+\mathrm{M}$ 弁 11 例 (18\%)、DCM 3 例 (5\%)、ICM 3 例 (5\%)、 ASD 1 例 $(2 \%)$ 、その他 4 例 $(7 \%)$ 。術前 NYHA 3 度 および 4 度 33 例 (55\%)。心房細動合併 40 例 (67\%)。 【結果】病院死亡 2 例 $(3 \%)$ 。在院日数 26 日 (中央值)。 術式は MVP 44 例、MVR 7 例、AVR 16 例、左室形 成 4 例、CABG 8 例、MAZE 手術 31 例であった。選 択リングサイズ毎の平均 BSA は $26 \mathrm{~mm}$ (12 例) $1.45 \pm$ $0.11 、 28 \mathrm{~mm}$ (46 例) $1.60 \pm 0.16$ であった。【TR の推移】 術 前: 0-trace 3 例、mild 10 例、moderate 36 例、severe 6 例であった。術直後：0-trace 44 例、mild 10 例、 moderate 4 例、 severe 0 例と全体の $90 \%$ が mild 以下であった。TS 無し。遠隔期：0-trace 32 例、 mild 19 例、 moderate 8 例、severe 1 例 と全体 の $15 \%$ の症例が moderate 以上の TR を呈した。Moderate 以上の遠隔 TR の危険因子は単変量解析では術 前左房拡大 $(\mathrm{mm})(51.4 \pm 8.7$ vs $61.7 \pm 9.3 、 \mathrm{p}=0.002)$ 、 術前 $\mathrm{EF}(\%)(54.5 \pm 15.1$ vs $37.0 \pm 16.5 、 \mathrm{p}=0.011)$ 、術 前 MR 重症度 $(2.8 \pm 1.0$ vs $3.28 \pm 0.36 、 \mathrm{p}=0.017)$ 、術 前重症 TR $(2.52 \pm 0.63$ vs $3.06 \pm 0.53 、 p=0.021)$ 、術前 肺高血圧の有無 $(p=0.054)$ 、三尖弁輪径 $(\mathrm{mm})$ （四腔像、 $29.9 \pm 5.6$ vs $37.1 \pm 6.3 、 \mathrm{p}=0.003)$ であった。多変量解 析 (Cox 比例ハザード)では術前重症 $\mathrm{TR}(\mathrm{p}=0.027$ 、 hazard ratio 24.3) が有意な因子であった。【考察】 MC3 人工弁輪を用いた TAP により遠隔期でも $85 \%$ の症例は TR を制御可能であり、 rigid-3D ringによ る TAP は長期的な durability が期待できるものと考 えられた。体表面積に応じたリングサイズ選択は術 後 TSを生じず妥当なものと考えられた。一方、遠 隔 TR 再発危険因子は重症 TR、低心機能、左房拡大、 肺高血圧、三尖弁輪拡大であり、これらの症例では 弁輪縫縮のみでの TR 制御が困難な場合があるため、 追加手技の適応を検討していく必要があるものと考 えられた。

\section{PP-160 ¿ 2 \\ Zone 0 TEVAR のための Total debranching with proximal neck reshaping}

\author{
広島大学病院 心臓血管外科 \\ 片山桂次郎、内田 直里、倉岡 正嗣、 \\ Zheko Naychov、渡谷 啓介、高橋 信也、 \\ 高崎 泰一、黒崎 達也、今井 克彦、 \\ 末田泰二郎
}

近年弓部大動脈瘤に対して、従来の弓部置換術と比 べ低侵襲手術である TEVAR が高齢やハイリスク症 例に対して施行されるようになった。特に、上行大 動脈に landingするZone 0 TEVAR は debranching、開空型ステントグラフト、chimney technique など様々な手法が取られている。しかし頸部分枝の 再建が必要な弓部大動脈への TEVAR の手技は確立 させておらず、またその治療成績も不明である。特 に上行大動脈からステントグラストを留置するZ Zone 0 TEVAR に関しては議論の余地が多く残っている。 当科では、高齢者や人工心肺使用の risk のあるハイ リスク症例に対し、上行大動脈から頸部 3 分枝再建 を行う、total debranching を人工肺非使用下で施 行している。術前 CTにより上行大動脈の性状と頸 部再建部位の性状を確認する。特に頸部分枝起始部 の動脈硬化生病変を注意深く観察する。また頭頸部 MRA にて頭蓋内血管の開存の有無を確認する。上行 大動脈直径が $37 \mathrm{~mm}$ 以上ある場合は確実な sealing を得るためにダクロンパッチまたは $\mathrm{ePTFE}$ パッチに よる banding を施行する。アプローチは上行大動脈 の性状が良く、冠動脈バイパスなど追加手術が必要 ないときは、第 4 肋間胸骨上部分切開で行うように している。中枢側吻合は OPCAB 用の上行大動脈 partial clamp を用いて部分遮断を行い、上行大動脈 を吻合口は縦切開後、上下端を大動脈パンチャーで 吻合口を広げる。フェルト帯で補強しながら 3 分枝 管中枢側と 4-0 ポリピレン糸で連続綘合する。頸部分 枝再建は単純遮断下に行うため、近赤外線分光法酸 素モニターでrSO2 のモニタリングを行う。10\%以上 の低下を認める際は、血圧を上昇することにより対 応する。頸部分枝の剥離は吻合部周囲のみで最小限 に止め、中枢側遮断前に末梢側を遮断する。頸部分 枝の再建は分枝を完全離断し5-0 ポリピレン糸を用 いて腕頭動脈、左総頸動脈、左鎖骨下動脈の順に連 続端々吻合を行う。頸部分枝への再建は stroke 予防 のために healthy to healthy, complete isolation およ び distal protection を確実に行えるように心がけて いる。今回頸部分枝バイパス型 TEVAR としてわれ われが施行している上行大動脈から頸部 3 分枝すべ てを再建する total debranch 手術を紹介する。 


\section{PP-161 is \\ 弓部大動脈瘤に対して分枝再建を伴うステン トグラフト内挿術を行った症例の周術期成績}

$\mathrm{KKR}$ 札幌医療センター 心臓・血管外科

上田 秀樹、大畑 俊裕、阿部 慎司

弓部大動脈瘤の治療に際して、近年人工心肺下の人 工血管置換術 (GR)から、分枝再建を伴うステントグ ラフト内挿術(TEVAR)へのパラダイムシフトがおき つつある。一方で、zone3 以下の TEVAR は良好な 成績が報告されているものの、頸部分枝の処理を要 する TEVAR は、脳合併症などの報告も多く、その 適応には議論の余地がある。今回、当院で行った頸 部分枝再建を伴う TEVAR を行った症例の周術期成 績について検討する。【対象】上記疾患に対して、当 院では原則的に GR での治療を目指すが、high risk 症例には elephant trunk 変法に準じた Hybrid 治療 または、debranching 法、 chimney 法、開空型ステ ントグラフトを組み合わせて TEVAR を行っている。 2005 年 12 月から 2012 年 7 月までに待機または緊急 的に治療を行った頸部血管の再建を伴う弓部大動脈 瘤症例 61 例のうち、TEVAR を行った high risk 症 例 25 例 (男 16 女 9、平均 $77 \pm 8$ 歳)を対象とした。 瘤の中枢側進展部位は zone0: 3 例、zone1: 2 例、 zone2: 8 例、zone3: 12 例であった。術前合併症をス コア化したJapan scoreの予想30-day operative mortality は $13 \pm 11 \%$ 、予想主要合併症発症率は 35 土15\%であった。【方法】debranching 法(Deb)を行っ た症例は 22 例で、 3 枝 Deb: 3 例、 2 枝 Deb: 10 例 (う ち 2 例は計画的に腕頭動脈に chimney graft 留置)、 1 枝 Deb: 9 例 (うち 3 例で開空型ステントグラフト使 用)であった。3 例で計画的に左鎖骨下動脈に chimney stent を留置することのみで分枝再建とした。周 術期に発症したStrokeの程度を modified Rankin scoreにて評価した。【結果】院内死亡は 1 例 (4\%)。 神経学的合併症は 5 例 (20\%) (不全対麻疩 1 例 (4\%)、 Stroke 発症 4 例 (16\%)) に認められた。Stroke 発症 例の modified Rankin score は 1 点、 4 点が各 1 例、 5 点が 2 例であった。神経学的合併症発症における 危険因子は、同発症症例とそれ以外の症例間で、脳 血管障害の既往のみが有意であり、(オッズ比 12.00 , CI $1.07-134.1, \mathrm{p}=0.022$ )、年齢、Japan score、性別、 使用機種、透析の有無、緊急手術か否かで有意差を 認めなかった。平均 $11 \pm 8$ ケ月の follow-upで、 type2 Endoleak に対して追加治療を必要とした症例 を 2 例認めたのみで、他に明らかな aortic eventを 認めていない。【結語】頸部分枝再建を伴う TEVAR は、mortalityの改善は得られたが、strokeの risk は 高いといわざるを得ず、特に脳血管障害の既往症例 は、GRの選択を含め、術式選択には、より慎重な対 応が必要と考えられた。

\section{PP-162 乞ำ \\ TEVAR 時における chimney 法による左鎖骨 下動脈温存の経験}

\author{
三重大学医学部附属病院 放射線診断科 \\ 2 三重大学医学部附属病院 心臓血管外科 \\ 高知医療センター 心臓血管外科
}

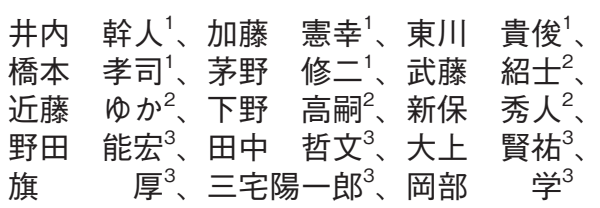

【目 的】近 年、 thoracic endovascular aortic repair (TEVAR)において、ステントグラフト近位端を弓部 大動脈領域 (Z0-Z2) に留置する症例が増えてきてい る。Z1、Z1では debranchを行うが、Z2では debranch を行わず左鎖骨下動脈を閉塞することも多い。 しかし、左鎖骨下動脈は前脊髄動脈への collateral source であることや、閉塞後に脳後方循環の盗血現 象や左腕の虚血などが生じるリスクもあり、温存す ることが考慮される。今回我々は、Z2 に近位端を留 置する症例で、chimney 法を用いた左鎖骨下動脈の 温存を行ってきたので、その結果を報告する。【対象】 対象は、企業製ステントグラフトの使用を開始した 2008 年 5 月から 2012 年 7 月までの約 4 年間に企業 製ステントグラフトを用いて TEVARを行った 161 例のうち、chimney 法を用いて左鎖骨下動脈の血流 を温存した 11 例である。年齢は 31 歳から 83 歳まで で、平均年齢は $66 \pm 14$ 歳、男性 5 例、女性は 6 例で あった。対象となった疾患は、胸部大動脈瘤が 8 例、 解離性大動脈瘤が 3 例であった。【方法】手術は全例 で全身麻酔、気管挿管下に、血管造影室で行った。 使用したデバイスは、TALENT が 1 例、TX2 が 10 例であった。左鎖骨下動脈の血流温存は、左上腕動 脈に6 Fr シースを挿入し、左鎖骨下動脈にbare metal stent を留置する方法をとった。【結果】ステン トグラフトの留置、左鎖骨下動脈への stent 留置は全 例で成功した。術後 30 日以内の死亡は認められな かった。術後早期合併症としては、1例で術中にA 型解離の発症を認め、上行大動脈人工血管置換術を 行った。エンドリーク、脊髄虚血は認められなかった。 全例生存中で、平均観察期間は $8 \pm 6$ ケ月 $(1 \sim 25$ ケ月 $)$ である。対象期間中に、近位端を Z2 に留置して左鎖 骨下動脈を閉塞した症例が 26 例あり、脊髄虚血は認 めなかったが、1 例で左腕の虚血症状のために腋窩 動脈バイパスが必要であった。Chimney 法を用いた 症例では、左腕の虚血や盗血現象などの症状は認め られていない。【結論】Chimney 法による左鎖骨下動 脈温存は、左上腕動脈からのアプローチで行える簡 便かつ低侵襲な方法である。今回の検討では脊髄虚 血に対する chimney 法の有用性は不明であるが、左 腕の虚血症状や盗血現象を回避するのに有用と考え られる。 
PP-163 文

2 debranching TEVAR: 当科における早期、 中期成績と合併症発生についての検討

\section{${ }^{1}$ いわき市立総合磐城共立病院 心臓血管外科 獨協医科大学越谷病院 心臓血管外科呼吸器外科 3 福島県立医科大学 心臓血管外科}

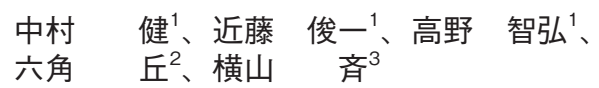

【はじめに】当院では弓部大動脈瘤の治療に TEVAR を積極的に導入しており、debranching TEVARも 治療の選択枝の一つとしている。今回、当院で施行 された 2 debranching TEVAR について早期、中期 の成績および術後合併症の発生について検討し、今 後の展望について考察した。【対象】2009 年 4 月から 2012 年 4 月の観察期間中 (3 年間) に TEVAR で治療 を行った 121 例中、 2 debranching TEVAR を行った 14 例を対象とした。debranch 手術はいずれの症例も リング付き人工血管を用いて Ax-Lt.CCA-Ax bypas を行った。Bypassの方法について、前半の 10 例は まず両 Ax bypassを行った後、単純遮断下にLt. CCA bypas を置いた。後半 4 例は両側 CCA の血流 低下防止の観点から、先に Lt.Ax Lt.CCA bypass を 行い、Lt.CCA の血流を絶やさず流したまま、最後に Rt.Ax bypass を行った。それぞれについて前半群、 後半群に分けて検討した。【結果】全体の平均年齢は 74.5 ( \pm 9.89 、前半 76.7 、後半 69.0$)$ 歳、 14 名全て男性 であった。真性瘤は 10 例、解離性は 4 例であった。 使用デバイスは東京医大式開空型 2 例、TALENT 2 例、TAG 9 例、TX2 2 例であった。初期成功率は 前半群、後半群共に 100\%であった。平均追跡期間 は 16 ヶ月 (7-36 ヶ月)で、現在までで術後死亡は前半 群の腹部に大動脈瘤を合併していた症例の破裂によ る死亡 1 例 $(7.1 \%)$ のみであり、その他胸部の大動脈 関連事故は認めていない。脳梗塞の発生は前、後半 ともに無し、対麻痺の発生は前半群で 1 例であった。 術後一過性に手指の疩れや脱力感を自覚した症例は 前半群では 5 例 (50\%)、後半群では 0 例であり、い ずれもリハビリによって症状の消退を認めている。 いずれの群も遠隔期で freedom from aneurysm related death は、100\%であり追加 TEVAR を要した 症例は 0 であった。【まとめ】前半群に対し、手技的 な工夫を加えた後半群では脳神経学的な合併症の発 生は無く、遠隔期にも新たな麻痺の発生は無かった。 当科の 2 debranching TEVAR の早期、中期成績は 良好であり、ステントグラフト関連の合併症につい て、遠隔期で新たに発生が認められた合併症は無かっ た。これらより、2 debranching TEVARは早期の合 併症発生を回避すれば長期成績は良く、脳神経学的 なトラブルについても遠隔期での発生は低い可能性 が示唆された。当科では、安全かつ低侵襲な手技と して debranching TEVAR を今後も積極的に適用し ていく方針である。

\section{PP-164 2 s \\ Squid capture 法で in-site graft fenestration を行う Zone O TEVAR}

\section{${ }^{1}$ 大分大学 心臓血管外科 \\ 年大分大学 放射線科}

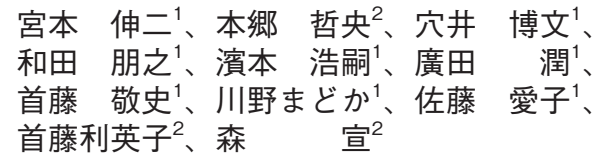

【目的】我々はかつて 7 例の弓部瘤に対して total debranch TEVAR を行ったが転院後に縦隔炎を起こした 症例を含めると術後比較的早期に全員死亡してしまっ たことからなんとか開胸を回避する方法として in-site graft fenestration(IGF)を考案した。IGFでは穿刺が 成功するかどうかがポイントとなるが今回確実に穿刺 する technique(Squid capture 法)を用いて IGFを行 う方法を呈示する。【対象】83歳、女性。133cm、 $32 \mathrm{~kg}_{0}$ COPD で在宅酸素療法中。CT で $76 \mathrm{~mm}$ 径の 弓部大動脈あり。開胸すらリスク高いと考え IGF TEVAR を選択した。【方法】全身麻酔下に総頸動脈 間、左総頸 - 鎖骨下動脈、左鎖骨下 - 大腿動脈バイ パスをダクロングラフトにて作成。鎖骨上で右鎖骨下 動脈に $6 \mathrm{~mm}$ の人工血管を吻合し conduit を作成。左 総頸動脈中枢は二重結紮、右総頸動脈中枢はブルドッ ク鉗子をかけ遮断し。右大腿動脈から $24 \mathrm{Fr}$ シース挿 入を試みるも上がらず、後腹膜経路で右総腸骨動脈に $10 \mathrm{~mm}$ 人工血管をかけそれを conduit としてシースを 挿入。鎖骨上の conduit から自作のスネアを挿入し、 腹部 conduit からガイドワイヤーを弓部大動脈内スネ アループを通過させ大動脈基部まで留置。そのガイド ワイヤーを用いて二本の Gore-TAG を Zone0 から 3 まで展開留置。スネアを絞りループ内で広がっている TAG をスネアシースに引き寄せシース断端が TAG 表面と密着するようにした上でシースから穿刺針を挿 入し穿刺。ガイドワイヤーを穿刺部位から TAG 内に 留置。バルーンで穿刺部位を拡張したのち Excluder 脚を挿入展開し更にその中に Palmatz stent を追加留 置。【結果】術後 7 日目に左鎖骨下動脈のコイル塞栓術 施行。その後の CT でエンドリークなし。脳障害等合 併症なく退院した。【考察】Squid capture 法は確実な 穿刺を可能にしこれにより IGF の適応が拡大できる と考える。

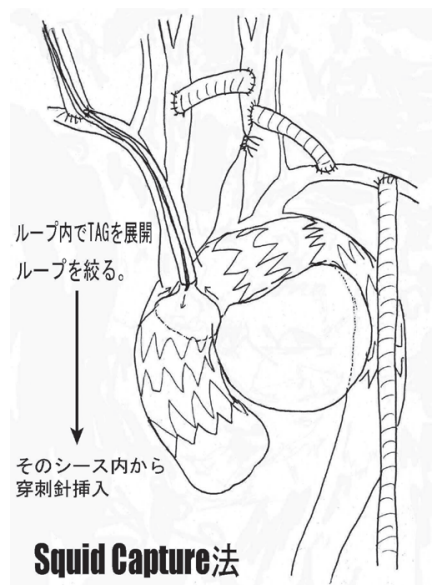


PP-165 خ 2

大動脈縮窄症の上行ー下行大動脈バイパス 術後合併症に対するステントグラフト治療

\author{
千葉県循環器病センター 心臟血管外科 \\ 浅野 宗一、林田 直樹、村山 博和、 \\ 松尾 浩三、鬼頭 浩之、平野 雅生、 \\ 大場 正直、弘瀬 伸行、椛沢 政司、 \\ 長谷川秀臣、渡邊 裕樹
}

【はじめに】大動脈縮窄症に対し上行 - 下行大動脈バ イパス術を行い、遠隔期に人工血管劣化・吻合部瘤 を併発した場合、再胸骨正中切開 +再開胸で手術侵 襲が過大となる場合が多い。我々はこれらの症例に 対しステントグラフト内挿術(TEVAR)を併用しなが ら比較的低侵襲で治療し得たので報告する。【症例 1】59 歳男性。1981 年(35 歳時)大動脈縮窄症・B 型大 動脈解離に対し、Cooly double velour graft $(\phi 16 \mathrm{~mm})$ にて上行 - 下行バイパス術＋下行置換術施行。2006 年に人工血管劣化による両人工血管の拡大を認め再 手術。左開胸をさけ胸骨正中切開のみ行い人工心肺 下に弓部 3debrach および右腋窩 - 大腿動脈バイパス を施行し、上行 - 下行バイパス人工血管を中枢側で 切離。上行〜弓部〜下行大動脈にステントグラフト 内挿 (東京医大方式)。右腋窩 - 大腿動脈バイパスは その後感染し 2011 年人工血管抜去。上下肢の圧較差 はなく経過順調。【症例 2】71 歳女性。1981 年(41歳 時) 大動脈縮窄症・上肢高血圧に対し、Cooly double velour graft $(\phi 16 \mathrm{~mm})$ にて上行 -下行バイパス術施 行。1994 年人工血管劣化による末梢側吻合部瘤に対 し前回人工血管をすべて除去し、Hemashield $(\phi 24 \mathrm{~mm})$ にて再置換。2009 年末梢側吻合部瘤に対し 人工血管〜下行大動脈にステントグラフト内挿 $(\mathrm{TAG}) 。 2012$ 年中枢側吻合部瘤に対し左開胸をさけ 上行大動脈人工血管置換を施行し経過順調。【症例 3】51 歳男性。1977 年(17 歳時) 大動脈縮窄症に対し、 他院にて上行 - 下行バイパス術施行 (人工血管不明)。 2012 年に末梢側吻合部瘤を認め、人工血管〜下行大 動脈にステントグラフト内挿(TALENT) し、弓部〜 左鎖骨下動脈にもステントグラフト内挿(Excluder 脚)を施行し、経過順調。【結果】3 例とも Endoleak はなく、劣化人工血管の縮小・吻合部瘤の縮小を認 めている。【結語】大動脈縮窄症に対する上行 - 下行 大動脈バイパス術後の人工血管劣化・吻合部瘤に対 し、TEAVAR を併用した治療を行った。TEVAR 併 用により再胸骨正中切開＋再開胸の大侵襲を避ける ことができた。かかる症例では 1 例ごとの open surgery・TEVAR、あるいは二期的治療などの入念な 治療計画をたてることが重要である。

\section{PP-166 年 \\ EVAR 後 Typell エンドリークによる破裂症 例、その対応は?}

\author{
心臓病センター榊原病院 心臓血管外科 \\ 平井雄喜、吉鷹 秀範、近沢 元太、 \\ 石田 敦久、平岡 有努、田中 恒有、 \\ 毛利 教生、水田 真司、松下弘、 \\ 大野司、鈴木 康太、永田智己、 \\ 都津川敏範、田村健太郎、坂口 太一
}

ステントグラフト内挿術の中期成績が発表される中、 エンドリークの発症率の高さが露呈されてきた。ス テントグラフト内挿術は低侵襲であるが、エンドリー クに対する対処が大きな課題である。我々は TypeII エンドリークによる瘤拡大に対する簡便な外科的治 療を提唱してきたが、今回、EVAR 後 TypeII エン ドリークによる腹部大動脈瘤 (AAA) 破裂に対し簡便 術式で救命した一例を経験したので報告する。症例 は 85 歳男性。既往に骨髄異形成症候群(MDS)、急 性心筋梗塞、慢性腎臓病あり。2010 年 3 月 $70 \mathrm{~mm}$ の AAA 発見。高齢、血小板減少、腎機能障害、巨大 瘤とハイリスクであったため EVAR 施行。術後 CT で明らかなエンドリークなく、術後 1 年後の CT に て瘤径拡大なく経過していた。2012 年 3 月、腹痛・ 胸痛あり。CT にて AAA 破裂、採血で急性心筋梗塞 (AMI)の診断。AAA 破裂を優先して治療する方針 となり緊急手術となった。経腹膜経路で瘤を切開す ると腰動脈 1 箇所より出血を認めた。同部位の縫合 止血施行した。TypeI、III、IV エンドリークは認め なかった。他部位の止血も確認後、瘤を縫縮し終了。 その後、AMI に対し PCI 施行。PCI 後、プラビック ス+バイアスピリン投与(DAPT) と MDSがからん で再出血、瘤内後壁からわずかに染み出る新鮮血の woozingにより再開腹止血を要したが、その後の術 後経過問題なく退院となった。術後 2 力月後の CT にて瘤内の血液再貯留はなく経過は良好であった。 EVAR 後の晚期エンドリーク治療に対しては経動脈 的塞栓術が一般的であるが、再発率も多い。人工血 管置換術による再手術が行われる場合もあるが手術 時間も長くなり、出血量も多い。我々は、TypeII 工 ンドリークによる瘤拡大症例に対して破裂も含めて 現在までに 7 例においての腰動脈および IMA の外科 的結禁及び出血点の止血のみを行ってきた。ステン トグラフト摘出を行わない本術式は簡便であり、手 術時間も約 1 時間と短く、出血量も少ない上、術後 の回復も早いことから、低侵襲と考える。DAPT や 血小板減少を伴うようなハイリスク症例にも施行で き、今後、エンドリーク治療のオプションになり得る。 今回はその具体的な術式をビデオを交えて提示した い。 


\section{PP-167 文 \\ 腹部大動脈瘤治療における Off-Label Use の 検討〜治療選択に変化をおこしうるか?}

\author{
京都府立医科大学 心臟血管外科 \\ 川尻英長、岡克彦、坂井修、 \\ 松代 卓也、大平卓、山本 経尚、 \\ 土肥 正浩、渡辺 太治、大川 和成、 \\ 神田 圭一、土井潔、夜久 均
}

企業製デバイスの導入以降、腹部大動脈瘤治療にお ける EVAR の比率は年々増加傾向にある。それに伴 いEVAR をどのような症例で行うかの基準が曖昧と なる傾向が見られている。そうした中で解剖学的に ステントグラフトが困難とされる症例に対する OffLabel Use がどこまで可能か、中期、遠隔期の成績 がどこまで期待できるかを知ることが今後の治療法 が従来手術と EVAR とどちらにシフトしていくかの 鍵となりうる。当科における Off-Label Use の基本 戦略として (1) Challenging neck に対しては、ネック に平行に留置する解剖学的 deployment を第一とし、 術中 typeIa エンドリークに対しては Aortic Cuff ない し Palmatz ステントを追加する。(2) 両側内腸骨動脈 塞栓は選択的塞栓を行い、末梢枝を温存する。(3)外 腸骨動脈 landing を要する症例には脚屈曲、狭窄予 防に metal stentを追加する。(4) Terminal aorta 狭 小例に対しては、脚内 Kissing stentを行う。以上を 踏まえて施行した Off-Label Use の症例につき検討を 行った。対象は当科で 2007 年 10 月から 2012 年 4 月 の間に施行した腹部大動脈ステントグラフト 114 例。 このうち Off-Label Use の 24 例 (OL 群) と IFU(遵 守)群 90 例で比較検討を行った。OL 群の内訳として challenging neck11 例(高度 屈 曲 Neck9 例、Short Neck2 例)、Terminal Aorta 狭小 5 例、両側内腸骨 動脈塞栓を要した 3 例、Access 狭小例 2 例、ネック の Shaggy aorta2 例であった。年齢は OL 群 : 78.3 7.5 歳、IFU 群 : $75.3 \pm 7.3$ 歳で両群間に有意差なし。 手術死亡は OL 群、IFU 群でともになし。KaplanMeier 法を用いた Aortic event 回避率(腸骨動脈領域 の event含 む) は 1 年 で OL 群 $94.4 \%$ 、IFU 群 $98.5 \%$ 、3 年で OL 群 $94.4 \%$ IFU 群 $96.0 \%$ であり、 両群間に有意差は見られず。（Log-Rank, $\mathrm{p}=0.46)$ 以上 の結果を考慮すると、Off-Label Use はハイリスク症 例で選択的に行っている傾向があるものの、比較的 安定した中期成績が得られている。10 年以上の遠隔 期成績は未知であるが、一定の治療戦略に基づいた 上での Off Label Use は今後の腹部大動脈瘤、腸骨 動脈瘤治療におけるパラダイムシフトを起こしうる のではないかと予想する。

\section{PP-168 宛 当院におけるEVARの治療成績と術後 en- doleak の解析}

\author{
山口大学大学院医学系研究科 器官病態外科学
}

\author{
佐村 誠、森景 則保、安楽由利子、 \\ 山下 修、村上 雅憲、末廣晃太郎、 \\ 濱野 公一
}

【目的】腹部大動脈瘤に対するステントグラフト治療 (EVAR) が広く普及し、遠隔期成績も明らかになっ てきた。今回、われわれの施設での EVARの治療成 績と EVAR 術後に経験した endoleak について検討 を行ったので報告する。【対象】2007 年 4 月から 2012 年 3 月までに、当院で施行した EVAR88 例を対象と した。年齢中央值は 76 歳 (27-90)、男性 74 例、女性 14 例であった。腹部大動脈瘤 64 例、孤立性腸骨動 脈瘤 15 例、腹部・腸骨動脈瘤合併 9 例であった。瘤 径中央值は 49.2mm (22.9-94.4)であった。【結果】術後 瘤径が $5 \mathrm{~mm}$ 以上縮小した症例は 30 例 $(34 \%)$ 、不変 は 44 例 (50\%)、 $5 \mathrm{~mm}$ 以上拡大した症例は 4 例 (4\%) であった。術後 endoleak を認めた症例が 30 例 (35\%) で、type Ib が 4 例、type II が 26 例であった。瘤径 拡大の症例は全例 endoleak を認めた症例であった (Ib 1 例、II 3 例)。Type Ib endoleak 認めた症例 は全例末梢側 graft migration によるものであり、内 腸骨動脈コイル塞栓と外腸骨動脈への延長を 3 例、 open repair を 1 例必要とした。Type II endoleakを 認めた症例で、瘤径が $5 \mathrm{~mm}$ 以上拡大した症例は 3 例、 $2 \mathrm{~mm}$ 以上の拡大傾向を認めた症例は 3 例、 $2 \mathrm{~mm}$ 以上の縮小傾向を認めた症例は 3 例、不変は 17 例で あった。 $5 \mathrm{~mm}$ 以上縮小した症例はなかった。 5 例に コイル塞栓を追加したが、 $5 \mathrm{~mm}$ 以上の拡大を認めた 3 例ではコイル塞栓後も拡大傾向であった。また、 Type II endoleak での瘤径拡大に関して、関連が報 告されている契煙歴、脂質異常症、スタチン内服の 有無で解析を行ったが、有意差はなかった。抗血小板、 抗凝固薬を 2 郕以上内服している症例では、有意差 を認めた (odds 比：11.3、 $\mathrm{P}=0.01)$ 。考察】当院での EVARの治療成績は妥当であった。瘤径拡大には endoleak の有無が重要な因子であった。Type Ib endoleak に関しては末梢側総腸骨動脈径の拡大に伴う migration であるため、術前総腸骨動脈の拡大が見ら れる症例では術後注意深い経過観察が必要であり、 また症例によっては末梢側 landing zone は外腸骨動 脈にするべきであると考える。また、瘤径拡大が $5 \mathrm{~mm}$ 以上の症例では、追加コイル塞栓では不十分で あり、他の治療介入を考慮すべきであると考える。 
PP-169 文

EVAR の中期成績と type 2 endoleak に対す る治療戦略

\author{
神戸大学 医学部付属病院 外科学講座 心臓血管 \\ 外科 \\ 竹歳 秀人、野村 佳克、小原 大見、 \\ 木下 史子、後竹 康子、宮原 俊介、 \\ 山中 勝弘、白坂 知識、中井 秀和、 \\ 井上武、南一司、岡田 健次、 \\ 大北裕
}

【背景と目的】腹部大動脈瘤 (AAA) に対する腹部大動 脈ステントグラフト内挿術(EVAR)の中期成績と、 その後に行った reintervention について検討した。 【対象および方法】2007 年 3 月から 2012 年 8 月までに 企業製デバイスを用いて当科にて行った EVAR157 例を対象とした。【結果】平均年齢は $76.8 \pm 76$ 歳。男 性 135 例 (85.9\%)、女性 22 例 (14.1\%)、平均追跡期 間は $16.7 \pm 14.7$ カ月であった。使用したデバイスは Excluder、69 例、Zenith、42 例、Zenith Flex、30 例、 Powerlink、14 例、Endurant、5例であった。生存 率は 1 年 $90.5 \% 、 2$ 年 $85.6 \% 、 4$ 年 $73.6 \%$ であった。 大動脈関連死亡は術直後に急死性大動脈解離を起こ した 1 例のみであった。 Reintervention 回避率は 1 年 $93.0 \% 、 2$ 年 $87.5 \% 、 4$ 年 $82.2 \%$ であった。Reintervention の原因は endoleak が 8 例 ( $1 \mathrm{a}$ が 1 例、 $1 \mathrm{~b}$ が 1 例、 2 が 6 例)、瘤径の拡大が 3 例、感染が 1 例、 下肢動脈塞栓が 1 例、破裂が 1 例、尿管漏が 1 例で あった。Type 2 endoleak に対しては全て IMA 塞栓 術を施行した。IMA 塞栓を要した 6 例の術前、IMA 入口部の径は平均 $3.41 \pm 0.39 \mathrm{~mm}$ (IMA 塞栓をしな かった群は $2.87 \pm 1.05 \mathrm{~mm}$ )であった。【結語】EVAR の術前、 reinterventionの回避を予測する因子として、 IMA を評価しておくことが重要な因子であると考え た。

\section{PP-170 㲾 \\ EVAR において中枢側ネックの血栓は治療適 応外となるのか}

\author{
九州大学病院 心臓血管外科 \\ 大石 恭久、牛島 智基、田ノ上禎久、 \\ 西田誉浩、中島 淳博、塩川 祐一、 \\ 富永 隆治
}

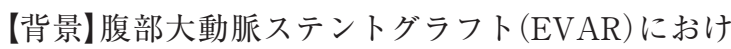
る instruction for use(IFU)では、中枢側ネックの血 栓が解剖学的禁忌のひとつとされている。特に Gore Excluder においては、厚さ $2 \mathrm{~mm}$ 以上、全周の $25 \%$ 以上と明確に定義されている。しかしながら IFU 外 の症例を経験することにより、果たして現在の IFU は正しいのかどうかという疑問が生じてきている。 【目的】EVAR 症例において、中枢側ネックの血栓が 腎機能に与える影響を観察することにより、現在の IFUを評価する。【方法】2010 年 10 月から現在まで 当科で行った EVAR 症例 35 例を対象とした。術前 CT から中枢側ネックに存在する血栓厚を計測した。 術後造影 CT 検査にて endoleak や塞栓所見の有無を 評価した。腎機能の評価として推算糸球体滤過量 (eGFR)の推移を算出した。【結果】平均年齢 75 歳。 29 例に Gore Excluder を、6 例に Medtronic Endurant を使用した。内腸骨動脈コイル塞栓を 13 例に併施し た。全例留置に成功したが、1 例を腸管壞死で失った。 手術時間は平均 144 分であった。中枢側からの endoleak 認めた症例は無かった。下行大動脈から腹 部にかけて高度動脈硬化病変( shaggy aorta)を有す るものが 7 例。CT上、中枢側 neckの血栓厚が $2 \mathrm{~mm}$ 以上のものが 20 例、 $3 \mathrm{~mm}$ 以上が 14 例、 $4 \mathrm{~mm}$ 以上が 5 例であった。術前 CKD stage 分類では、I が 1 例、II が 19 例、III が 13 例、IV が 2 例であった。 術後の最低 eGFR が術前值より10\%以上低下したも の 10 例を腎機能低下群とした。腎機能低下群と非低 下群における比較において表のような結果を得た。 【考察】中枢側ネックの血栓厚は、 $2 \mathrm{~mm}$ 以上になると 術後急性期の腎機能低下をきたす可能性が示唆され、 特に $3 \mathrm{~mm}$ 以上で顕著であった。しかしながら、死亡 例 1 例を除いて経過中に術前状態まで回復しており、 腎機能の面からは絶対的な禁忌とする指標とはなら ないのではないかと考えられた。

\begin{tabular}{|c|c|c|c|}
\hline & 腎機能低下群 & 腎機能非低下群 & pvalue \\
\hline 血栓厚 $(\mathrm{mm})$ & $3.2 \pm 1.6$ & $2.2 \pm 1.2$ & 0.064 \\
\hline 血栓厚 $2 \mathrm{~mm}$ 以上 & $8 / 10$ & $12 / 25$ & 0.084 \\
\hline 血栓厚 $3 \mathrm{~mm}$ 以上 & $7 / 10$ & $7 / 25$ & 0.022 \\
\hline Shaggy aorta & $4 / 10$ & $3 / 25$ & 0.061 \\
\hline 術前CKD stage & $2.5 \pm 0.5$ & $2.4 \pm 0.7$ & 0.811 \\
\hline 術前eGFR & $54.8 \pm 15.8$ & $59.0 \pm 17.4$ & 0.505 \\
\hline 術後塞栓 & $2 / 10$ & $1 / 25$ & 0.126 \\
\hline GFR変化率(\%) & $-25.0 \pm 16.0$ & $3.2 \pm 10.6$ & $<0.0001$ \\
\hline LVEF (\%) & $67.8 \pm 10.1$ & $63.1 \pm 13.0$ & 0.318 \\
\hline 手術時間(分) & $165.2 \pm 50.9$ & $135.0 \pm 29.4$ & 0.034 \\
\hline
\end{tabular}




\section{PP-171 ¿ \\ 当院における若年者の AAA に対する EVAR の検討}

\author{
心臓病センター榊原病院 心臓血管外科
}

水田 真司、吉鷹 秀範、坂口 太一、

津島 義正、石田 敦久、近沢 元太、

都津川敏範、田村健太郎、田中 恒有、

毛利 教生、松下弘、大野司、

永田 智己、平井 雄喜、鈴木 康太

【背景】 2007 年 4 月より腹部大動脈瘤に対する企業性 ステントグラフトが保険償還となり、当院でも 2007 年 5 月より腹部大動脈瘤に対する EVAR を開始して いる。高齢者などの開腹手術ハイリスク症例を中心 にその症例数を伸ばしているが、低侵襲で早期の社 会復帰が望めるという点は若年者にとっても魅力的 であり、安定した長期成績が得られれば若年者に対 しても治療の第一選択となりうると考えられる。【対 象と方法】 2007 年 5 月から 2012 年 7 月末までの当院 における AAA 治療総数は 654 例で、その内訳は開 腹手術 (OS) 群 431 例、ステントグラフト (SG) 群 223 例であった。このうち 60 歳以下の若年者に限ると OS 群 31 例、SG 群 6 例であった。今回我々は若年者 に対する EVAR の有用性と遠隔期成績について検討 した。【結果】手術時間は 245.3 分 (OS 群) vs120.6 分 (SG 群) と、SG 群で有意に短かった。平均 30.3 ヶ月 (6-58 ヶ月)の遠隔期成績では、周術期、遠隔期とも 両群で死亡症例は認めなかった。遠隔期において SG 群では問題となるエンドリークは認めず全例で瘤径 の縮小をみた。OS 群では周術期に 1 例でグラフト感 染による再手術を経験しているが、30 例では吻合部 仮性瘤などの合併症で追加手術となった症例は存在 しなかった。男性患者に対する性機能温存について は現在検討中である。【考察】本邦での EVARの遠隔 期成績については未だ明らかになっておらず、現時 点ではリスクのない症例についてはOSを第一選択 とすべきであると考えられる。一方、海外での遠隔 期成績では、術後の合併症累積発症率あるいは追加 治療率は SG 群で有意に高いものの、生存率では有 意な差はないという報告が散見される。当院の若年 者に対する EVAR の検討では遠隔期成績も含めて十 分満足のいく結果が得られており、若年者に対して も EVAR が第一選択となりうる可能性を示してい る。今後もさらに症例数を重ねて追加報告を行う予 定である。

\section{PP-172 六 \\ 腹部大動脈ステントグラフト内挿術において 内外腸骨動脈バイパスを併施した症例の検 討}

\author{
金沢大学 心肺・総合外科
}

$\begin{array}{llc}\text { 瀬口 } & \text { 龍太、大竹 } & \text { 裕志、木内 竜太、 } \\ \text { 新谷 } & \text { 佳子、西田 } & \text { 佑児、山口聖次郎、 } \\ \text { 富田 } & \text { 重之、渡邊 } & \text { 剛 }\end{array}$

【はじめに】両側総腸骨動脈領域に対する腹部大動脈 瘤ステントグラフト内挿術(EVAR)では、末梢側を外 腸骨動脈にランディングさせる必要のある症例がし ばしば存在する。こういった症例では両側の内腸骨 動脈の根部をステントグラフトでカバーすることに なる。両側の内腸骨動脈を閉塞させる治療法も報告 されているが、虚血による合併症は可能な限り少な い方が良い。そのため当科では片側の内外腸骨動脈 間に人工血管によるバイパスを確立し、内腸骨動脈 の血流を確保する治療を行っている。今回我々は、 内外腸骨動脈バイパスを併施下に EVAR を行った症 例を呈示し、その安全性と有用性を検討する。【方法】 2010 年 4 月から 2012 年 7 月にかけて当科で EVAR を行った 102 症例の内、内外腸骨動脈バイパスを併 施した 7 例 (平均年齢 $75.4 \pm 9.1$ 歳、男: 女比 $4: 3$ )を 検討した。術式としては内外腸骨動脈バイパスを EVAR に先行して行った。片側の下腹部に斜切開を 行い、後腹膜アプローチにて内外腸骨動脈を露出し た。外腸骨動脈に十分な Landing Zone を確保する ため、外腸骨動脈の遠位に人工血管 (Hemashield Platinum)の中枢側吻合を行い、内腸骨動脈との間に パイパスを確立した。バイパスの血流が良好なこと を確認した後、内腸骨動脈はパイパス吻合部よりも 近位で結紮し遮断した。対側の内腸骨動脈に関して は、瘤化を認めているものに対してはコイル塞栓を 施行し、瘤化を認めないものに対しては根部を結䅨 した。続いてステントグラフト内挿術を施行した。 メインボディのアクセス路としては、3 例で大腿動 脈、3 例で外腸骨動脈、 1 例で外腸骨動脈 conduit を使用した。術後抗凝固療法として、手術当日より 低分子ヘパリンの点滴を開始し、翌日よりアスピリ ンとワーファリンを併用した。【結果】平均手術時間 は $257 \pm 56$ 分、平均出血量は $285 \pm 226 \mathrm{ml}$ であった。 少量の TypeII エンドリークを 2 例で認めたが、術後 に瘤径の増大を認めた症例は 1 例も無かった。バイ パスは全例で開存し、下部消化管の血流も保たれて いた。明らかな殿筋跛行や勃起不全などの訴えはな かった。【まとめ】内外腸骨動脈バイパス術を併施し た EVAR は安全な術式であり、内腸骨動脈領域の虚 血による術後合併症の予防にも有用である。 


\section{PP -173}

腹部大動脈・腸骨動脈瘤破裂症例に対する 緊急ステントグラフト内挿術の検討

\section{東京医科歯科大学 血管外科}

$\begin{array}{cccc}\text { 工藤 } & \text { 敏文、葛井総太郎、西澤 } & \text { 真人、 } \\ \text { 猪狩 } & \text { 公宏、小泉 } \text { 伸也、内山 } & \text { 英俊、 } \\ \text { 豊福 } & \text { 崇浩、地引 } & \text { 政利、井上 } & \text { 芳徳 }\end{array}$

【目的】当科で経験した、腹部大動脈・腸骨動脈瘤破 裂症例に対する緊急ステントグラフト内挿術 (EVAR)につき検討を行う。【症例と結果】2011 年 8 月から 2012 年 7 月の 1 年間で、待期的手術を含め EVAR を 37 例行った。このうち 5 例 $(13 \%)$ が破裂症 例でありこれらを検討した。平均年齢は 71.6 歳 (62-79 歳)であり、男性 4 例、女性 1 例であった。破裂部位 は腹部大動脈瘤 3 例、総腸骨動脈瘤 1 例、内腸骨動 脈瘤 1 例であった。全例挿管全身麻酔下に EVAR を 施行した。使用デバイスは EXCLUDER 3 例、EPL 3 例であり、3 例で内腸骨動脈コイル塞栓(1 例は両側) を同時に行った。手術時間は平均 178 分(99-228 分)、 術中出血量は平均 $806 \mathrm{~g}(140-2200 \mathrm{~g})$ であった。動脈瘤 の形態は両側内腸骨動脈瘤症例を除き、全例 IFU 内 であった。総腸骨動脈瘤破裂によりショック状態で 緊急手術を行った症例では術後腹部コンパートメン 卜症候群予防のため開腹のまま ICUにて集中管理を 行ったが、術後広範な結腸・直腸壊死および DICを 来たし失った。他の 4 例では ICU 滞在平均 2.2 日 (2-4 日)、入院日数平均 16.2 日 (9-29 日)であり、術後合併 症なく退院し現在外来通院中である。術後の造影 CT では、4例ともにエンドリークを認めず、動脈瘤に対 する治療経過も良好である。【結語】当科における腹 部大動脈・腸骨動脈瘤破裂症例に対する緊急 EVAR の成績を検討した。循環動態が比較的安定しており、 かつ動脈瘤の形態が適している症例であれば、破裂 症例に対するステントグラフト内挿術は安全かつ効 果的に施行可能であることが示唆された。

\section{PP-174 is \\ 腎動脈 Debranch を視野に入れた後腹膜腔 鏡視下手術による小切開腎動脈再建術 2 例 の経験}

\author{
${ }^{1}$ 獨協医科大学越谷病院 心臓血管外科呼吸器外科 \\ 獨協医科大学越谷病院 外科

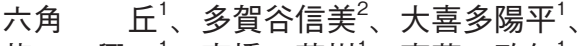
龍 興一 1 、高橋 英樹 ${ }^{1} 、$ 齊藤 政仁、
深井 隆太 ${ }^{1}$ 、入江 嘉仁、大矢 雅敏 ${ }^{2}$ 、
今関 隆雄 ${ }^{1}$

【はじめに】腎動脈 Debranch を要するステントグラ フト内挿術において、開腹手術による腎動脈血行再 建が行われている。今回我々は、腎動脈再建におい て低侵襲手術を得ることを目的に、鏡視下手術手技 を応用し後腹膜腔をバイパス経路とした外腸骨動脈 一腎動脈再建をおこなった 2 例 (右腎動脈瘤 1 例、胸 腹部大動脈瘤 1 例) を報告する。【方法】半側臥位にお き、前腋窩線上にある腎門部と内腸骨動脈分岐部レ ベルの中間点で後腹膜腔へ PDB バルーンを鈍的に挿 入する。バルーン拡張によって鈍的に後腹膜を剥離 せしめた後にカメラポートとなるブラントチップトラ カールに入れ替え、気腹圧を $10 \mathrm{cmH} 2 \mathrm{O}$ に設定しワー キングスペースを得る。この左右に鉗子操作用 $\phi 5 \mathrm{~mm}$ トラカールを刺入・留置する。超音波凝固切 開装置を用いて外腸骨動脈を露出せしめ、吻合部位 を選定する。尿管筋膜は腹膜から遊離せずに受動し、 Gerota筋膜を確認してこの腹側から腎門部へアプ ローチする。鏡視下に展開した腎門部直上に $5 \mathrm{~cm}$ の 小切開をおくことにより、腎動脈は直視下に吻合可 能となる。気腹が必要な時は小切開創にウンドプロ テクターと手術用グローブを装着したグローブ法で 再度気腹が可能となる。鏡視下に外腸骨動脈・グラ フト吻合をおこなう際の遮断は、遮断鉗子を小切開 創のグローブから外腸骨動脈においた。直視下に吻 合をおこなう際にも吻合部直上に $5 \mathrm{~cm}$ の小切開をお くことができる。外腸骨動脈・グラフト吻合の後に グラフト末梢側を腎門部へ誘導し、グラフト・腎動 脈吻合を直視下に行う。【鏡視下後腹膜手術の長所と 短所】鏡視下の操作をおこなうことにより、吻合部を 選定したうえで正確な位置に小切開創が得られるこ とが長所である。しかし、ワーキングスペースが限 られていることから、鉗子操作に難渋することもあ る。しかしながら、鏡視下に血管吻合が可能であれば、 婜門部小切開のみで血行再建が可能となり十分な低 侵襲手術を得ることができる。【まとめ】鏡視下手術 を後腹膜腔の血行再建術に応用することによって、 腸骨動脈をInflowとした腎動脈デブランチにおけ る、ステントグラフト内挿術に見合った低侵襲手術 が得られる。 


\section{PP-175 孤立性腸骨動脈瘤に対する血管内治療}

\author{
千葉県循環器病センター 心臓血管外科 \\ 長谷川秀臣、林田 直樹、平野 雅生、 \\ 浅野 宗一、鬼頭 浩之、大場 正直、 \\ 弘瀬 伸行、椛沢 政司、松尾 浩三、 \\ 村山 博和
}

【目的】最近では腸骨動脈瘤に対する血管内治療が増 加傾向にある。そこで当院での成績を検討した。【対 象と方法】2009 年から 2011 年にかけて当院で血管内 治療を受けた孤立性腸骨動脈瘤患者 8 例。患者は全 例男性で、平均年齢は 77 歳であった。 4 例が総腸骨 動脈瘤であり、そのうち 1 例は内腸骨動脈瘤を合併 していた。残り 4 例は内腸骨動脈瘤であった。孤立 性腸骨動脈瘤は腹部大動脈の最大径が $30 \mathrm{~mm}$ 以下の ものとした。腹部大動脈瘤手術の既往のある者は除 外した。なお、1例に開腹による両側総腸骨動脈瘤の 手術歴があった。9 個の瘤平均径は $37 \mathrm{~mm}$ であった。 術前評価および術後のフォローには CT Angiogram を用いた。治療は Y 字型ステントグラフト (Excluder, Zenith) 3 例 (総腸骨動脈瘤)に、腹部大動脈瘤用ス テントグラフトの脚を 2 例 (総腸骨動脈瘤 1 例、内腸 骨動脈瘤 1 例)、残り 3 例はコイル塞栓のみ(内腸骨 動脈瘤)で治療された。なお総腸骨動脈瘤に脚を用い る場合の中枢のランディングゾーンは長さ $10 \mathrm{~mm}$ 以 上とした。コイル塞栓術は内腸骨動脈瘤では全てに 用い、総腸骨動脈瘤では末梢ランディングゾーンの 短いものの同側の内腸骨動脈に施行された。術後の 平均観察期間は 14 か月であった。術後は半年に 1 度 の CTA で瘤径を観察した。【結果】周術期合併症は なかったが、Y 字型ステントグラフト 1 例のフォロー 中に慰筋跛行および TypeII エンドリークを認めた。 また、1例は術後 33 カ月に脳出血により死亡した。 瘤径の拡大した症例は無く、瘤径は平均 $35 \mathrm{~mm}$ まで 縮小が認められた。【結語】孤立性腸骨動脈瘤に対す る血管内治療は初期成績については安全で有効な治 療と考えられた。

\section{PP-176 文 \\ 中等度低体温循環停止法と逆行性脳潅流法 による A 型急性大動脈解離緊急手術の検討}

\author{
医療法人財団石心会狭山病院 心臓血管外科 \\ 塩見 大輔、高橋 亜弥、垣 伸明、 \\ 木山宏
}

【目的】A 型急性大動脈解離に対する手術は低体温法 で行われてきたが、近年中等度低体温法の安全性が 報告されている。当院では上行置換および hemiarch replacement に対して中等度低体温循環停止法と逆 行性脳潅流法を併用しており、従来の低体温循環停 止法と順行性脳潅流法併用との比較検討を行った。

【方法】心尖部送血法を導入した 2005 年 3 月から 2012 年 2 月の間に A 型急性大動脈解離に対して上行 および hemiarch replacementを施行した 50 例を対 象とした。深部体温が 28 度以上で循環停止し逆行性 脳潅流を併用した $\mathrm{M}$ 群 (23 例) と 25 度以下で循環停 止し順行性脳潅流を併用した L 群 (27 例)について検 討を行った。

【結果】男女比 (M 群 8:15、L 群 17: 10、 $\mathrm{p}=\mathrm{ns}$ ) に差 はなかったが、平均年齢 $(\mathrm{M}$ 群 $72.2 \pm 7.4$ 歳、L 群 $65.8 \pm 8.3$ 歳、 $\mathrm{p}<0.01)$ では有意差を認めた。術前心 タンポナーデ(M 群 6 例 $(26.1 \%) 、 \mathrm{~L}$ 群 6 例 $(22.2 \%) 、$ $\mathrm{p}=\mathrm{ns})$ 、術前心肺停止 (M 群 1 例 $(4.3 \%)$ 、 L 群 1 例 $(3.7 \%) 、 \mathrm{p}=\mathrm{ns})$ 、血栓閉塞型 $(\mathrm{M}$ 群 4 例 $(17.4 \%) 、 \mathrm{~L}$ 群 7 例 $(25.9 \%) 、 \mathrm{p}=\mathrm{ns})$ 、抗凝固薬内服 ( $\mathrm{M}$ 群 9 例 (39.1\%)、L 群 4 例 $(14.8 \%) 、 \mathrm{p}=\mathrm{ns})$ では有意差はな かった。術中最低深部体温は $\left(\mathrm{M}\right.$ 群 $26.3 \pm 1.7^{\circ} \mathrm{C} 、 \mathrm{~L}$ 群 $\left.23.1 \pm 0.9^{\circ} \mathrm{C} 、 \mathrm{p}<0.01\right)$ であった。手術時間 (M 群 296 \pm 83 分、L 群 $354 \pm 75$ 分、 $\mathrm{p}=0.013)$ 、体外循環時間 $(M$ 群 $155 \pm 36$ 分、L 群 $193 \pm 42$ 分、 $\mathrm{p}<0.01$ )、循環停

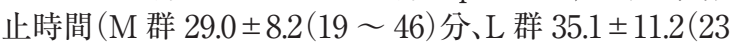
〜 65)分。 $\mathrm{p}=0.036)$ において有意に短縮を認めた。 合併症は出血再開胸 ( $\mathrm{M}$ 群 0 例、 $\mathrm{L}$ 群 2 例 $(7.4 \%) 、 \mathrm{p}$ $=\mathrm{ns})$ 、縦隔炎 ( $\mathrm{M}$ 群 0 例、 L 群 1 例 $(3.7 \%) 、 \mathrm{p}=$ $n s) 、$ 脳梗 塞( $\mathrm{M}$ 群 2 例 $(8.7 \%$ )、 L 群 2 例 (7.4\%)、 $\mathrm{p}=\mathrm{ns}) 、 \mathrm{CHDF}$ (M 群 0 例、 L 群 1 例 $(3.7 \%) 、 \mathrm{p}=\mathrm{ns})$ で有意差はなかった。M 群では低酸素に起因する恒 久的脳障害の発生はなかった。抜管可能例の平均挿 管期間 ( $\mathrm{M}$ 群 $4.6 \pm 5.2$ 日、 L 群 $7.2 \pm 9.6 、 \mathrm{p}=\mathrm{ns}$ )、入 院期 間 $(\mathrm{M}$ 群 $39.3 \pm 24.8$ 日、 $\mathrm{L}$ 群 $39.7 \pm 28.3$ 日、 $\mathrm{p}=$ ns) では有意差はなかったが、ICU 滞在期間 (M 群 5.7 \pm 1.2 日、L 群 $10.2 \pm 1.8$ 日、 $\mathrm{p}=0.048)$ は有意に短縮し た。在院死は M 群 1 例 (4.3\%)、L群 5 例 (18.5\%) で 有意差はなかった $(\mathrm{p}=0.20)$ 。

【考察】M 群では中等度低体温循環停止法により手術 時間と体外循環時間が短縮し、逆行性脳潅流法によ り手術操作が容易となり循環停止時間が短縮したと 考えられる。より少ない手術侵襲が早期 ICU 退室に つながったと考えられる。死亡率や合併症発生に差 は認められず安全性には問題がないと考えられる。 
PP-177 文

急性大動脈解離における急性肺障害の発生 機序に関する検討

\author{
秋田大学医学部外科学講座 心臓血管外科学分野 \\ 山浦 玄武、山本 文雄、山本 浩史、 \\ 石橋 和幸、佐藤 央、白戸 圭介 \\ 本川真美加、田中 郁信、張 春鵬
}

【目的】当科において急性大動脈解離に対して手術を 施行した症例の急性肺障害の原因を、その術前患者 因子、発症時の大動脈解離病変、酸化ストレスの発 生等を中心に探求した。【対象と方法】2001 年 2 月か ら 2012 年 8 月までの stanford A 型急性大動脈解離 手術症例 59 例 (男性 28 例 /女性 30 例、平均年齢 62.4 \pm 13.5 歳、34-85 歳)を対象とした。術前患者因子 と急性肺障害の指標として酸素化係数 $\left(\mathrm{PaO}_{2} / \mathrm{FiO}_{2}\right.$ : $\mathrm{P} / \mathrm{F}$ 比) や肺胞気動脈血酸素分圧 $\left(\mathrm{A}-\mathrm{aDO}_{2}\right)$ との関連 を検討した。また、術前 CT 検査における大動脈解 離の程度 (偽腔容積 : 大動脈横断面における偽腔部分 の面積の総和 $\times$ スライス厚) を測定し、急性肺障害の 指標との関連を検討した。さらに、最近の症例にお いて急性大動脈解離発症に伴う酸化ストレスを、活 性酸素・フリーラジカル代謝物 (d-ROMs) 測定によっ て定量し、関連を検討した。【結果】術前患者因子で は BMI と術前 $\mathrm{P} / \mathrm{F}$ 比及び術前 $\mathrm{A}-\mathrm{aDO}_{2}$ との間に有 意な相関関係があった $(\mathrm{n}=59$ 、それぞれ $\mathrm{P}=0.004$ 、 $\mathrm{R}=0.41$ 及び $\mathrm{P}=0.0003 、 \mathrm{R}=0.50)$ 。術前偽腔容積は、 術前 $\mathrm{P} / \mathrm{F}$ 比と負の相関傾向があり、術前 $\mathrm{A}-\mathrm{aDO}_{2}$ と 正の相関傾向があるも、有意な相関関係は得られな かった(それぞれ $\mathrm{P}=0.58 、 \mathrm{R}=0.20$ 及び $\mathrm{P}=0.67$ 、 $\mathrm{R}=0.15)$ 。術前 $\mathrm{d}-\mathrm{ROMs}$ 值では、術前 $\mathrm{P} / \mathrm{F}$ 比との間 に相関関係が得られなかったが、術前 $\mathrm{A}-\mathrm{aDO}_{2}$ との 間に強い相関関係が得られた $(\mathrm{n}=10 、 \mathrm{P}=0.012$ 、 $\mathrm{R}=0.75$ )。また BMI と d-ROMs 值との間にも強い相 関関係が示された $(n=10 、 \mathrm{P}=0.007 、 \mathrm{R}=0.79)$ 。【結論】 急性大動脈解離における急性肺障害の発生において、 BMI や d-ROMs 值の高值が増悪因子であった。急性 肺障害には肥満が大きなリスクファクターであり、 これには活性酸素・フリーラジカルの発生が関与し ている可能性が示唆された。
PP-178 公

急性 $A$ 型大動脈解離手術後遠隔期基部再手 術：GRF glue のホルマリンの影響

\author{
船橋市立医療センター 心臟血管外科 \\ 茂木 健司、松浦馨、桜井学、 \\ 榎本 吉倫、川村 知紀、高原 善治
}

我々は、急性 $\mathrm{A}$ 型大動脈解離手術において、大動脈 基部解離腔内の血液・凝血塊を可及的に除去、glue を塗布、大動脈弁交連直上の高さで内外にフェルト 帯で固定し、基部の断端形成を行っている。GRF glue を使い始めた当初(1996 年 4 月)は、添加するホ ルマリン量に特別な配慮をしなかった。ホルマリン の悪影響を考慮して、1999 年からホルマリン量を制 限して用いるように変更し、2008 年からは GRF glue の使用を中止し、Fibrin glue にかえた。【目的】急性 $\mathrm{A}$ 型大動脈解離手術における手術成績と遠隔期大動 脈基部再手術への、GRF glue の影響を調べた。【対 象・方法】1996 年 4 月から 2011 年 12 月までの、Bentall 手術を行った症例を除く連続 117 例を対象とし た。1996 年 4 月から 1999 年 5 月までのホルマリン添 加液量に配慮していない連続 24 例 (A 群) と、その後 のホルマリン添加液量を極力減量した連続 57 例 (B 群)、および Fibrin glue に変更した 2008 年 3 月以後 の連続 36 例 (C 群) に分けた。各群の年齢は $61.1 \pm$ 10.1 : 62.6 \pm 12.1 : 62.2 \pm 11.0 才 (A 群 : B 群 : C 群)、 男性比は $79: 47: 56 \%$ 、上行弓部全置換術比率は、 79.2 : $84.2: 88.9 \%$ 、CABG 同時施行症例数は 1 例 : 3 例：4例であった。各群間の手術成績と遠隔期生存 率および遠隔期大動脈基部再解離による基部拡大 · 大動脈弁逆流に対する基部再手術について検討した。 【結果】手術時間は $342 \pm 145: 300 \pm 74: 322 \pm 80$ 分、 体外循環時間は $169 \pm 48: 163 \pm 52: 172 \pm 42$ 分、大 動脈遮断時間は $75 \pm 15: 76 \pm 23: 89 \pm 26$ 分 $(p=0.006)$ 、 ICU 滞在日数は $1.9 \pm 1.4: 3.2 \pm 4.1: 3.5 \pm 6.7$ 日、入院 日数は $31 \pm 10: 38 \pm 36: 30 \pm 19$ 日、入院死亡は 6 例 (死 亡率 $5.1 \%$ ) で、各群 $8.3: 5.2: 2.8 \%$ で有意差は無かっ た。生存退院した A 群 22 例、B 群 54 例、C 群 35 例を対象に遠隔期成績を検討した。5 年生存率は 83\%、87\%、86\% (Kaplan-Meier 法、 $\mathrm{p}=0.7248$ Log Rank) で有意差は無いが、大動脈基部再手術は A 群 8 例、 B 群 2 例、 C 群 1 例 $(\mathrm{p}<0.001)$ であり、大動 脈基部再手術回避率は、Kaplan-Meier 法で $\mathrm{p}=0.0035$ (Log Rank) と有意に A 群で再手術が多い結果で あった。再手術までの期間は、術後 1〜 128 力月であっ た。 $\mathrm{B}$ 群 1 例 (術後 2 力月) と C 群 1 例 (術後 1 力月) の基部再手術については、初回手術時の glue 以外の 要因が推測された。【結語】遠隔期大動脈基部再解離 に関しては、添加するホルマリン添加液の使用法が 原因であることが示唆された。 
PP-179 㕣

急性 $A$ 型大動脈解離における送血路

\section{${ }^{1}$ 高知大学医学部外科学 心臓血管外科 \\ ${ }^{2}$ 広島大学病院 心臓血管外科}

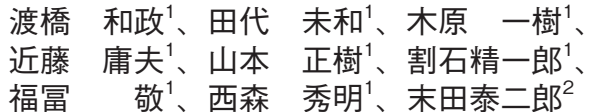

【目的】急性 $\mathrm{A}$ 型解離の治療では、偽腔送血を回避し つつ真腔送血により虚血臓器の灌流を回復すること が望ましいが、期待どおりの結果とは必ずしもなら ない。送血路と臓器灌流につき検討し、報告する。【力 法】1995 年以降の急性 $\mathrm{A}$ 型解離の手術症例のうち、 術中に経食道心エコー法(TEE)を含む灌流評価を行 いえた 110 症例(男性 53 例、 $22 \sim 87$ 歳)を対象とし た。27症例で術前より臓器虚血を認めた(脳 13 例、 冠動脈 5 例、四肢 14 例、腹部内臓 9 例、脊髄 1 例： 重複あり）。上行大動脈置換、大動脈基部置換、上行 弓部置換(オープンステント併施を含む)を 87 例、3 例、20例に行った。送血路は大腿動脈送血から腋窩 動脈送血に移行し、前者は 32 例 (うち8 例腋窩送血 併施)、後者は 78 例であった。術中灌流評価は、 TEE、両側前頭葉組織内酸素飽和度 $(r S O 2)$ モニター、 眼球ドプラ法を用いた。【成績】院内死亡は 10 例 (9.1\%)で、7 例はショックで大腿送血を行った症例 であった。大腿動脈送血 32 例中 4 例で偽腔送血のた め腋窩動脈送血に変更した。1例は高度血圧低下で 気付き TEEで診断した。1 例は送血開始数分後に右 冠動脈の閉塞、2 例は弓部〜上行大動脈の真腔虚脱 がTEE で判明した。他の 1 例では体外循環開始後に 右橈骨動脈圧が突然消失し、腕頭動脈の真腔虚脱が TEEで判明した。脳灌流は維持されており、他部位 で圧モニターし大動脈再建を行いその後真腔回復を 確認した。腋窩動脈送血の 78 例では、1例のみ偽腔 送血による右 rSO2 低下を認め、左腋窩動脈送血に 変更し rSO2 が回復した。他の 2 例は腕頭動脈の解 離のため右腋窩動脈送血のみで全身灌流ができず、 両側腋窩動脈送血とした。他の 1 例では腕頭〜右総 頚動脈閉塞があり左腋窩動脈送血を選択したが、右 rSO2 低下を認め両側送血とし回復を認めた。大腿動 脈・腋窩動脈送血の各 1 例で、真腔灌流にもかかわ らず左冠動脈、上腸間膜動脈、大腿動脈の灌流障害 が持続し選択的灌流を要した。【結論】腋窩動脈送血 では偽腔送血は起こりにくいが皆無ではないこと、 真腔灌流が必ずしも臓器灌流回復を保証しないこと、 症例ごとにどちらの腋窩動脈送血を選択すべきか異 なることが明らかとなった。これらの問題点の解決 策の一つとして術中灌流評価が重要と考えられる。
PP-180 幽

A 型大動脈解離に対する上行大動脈送血の 簡便性、コツ、注意点

川崎市立川崎病院 心臓血管外科

田口眞一、森厚夫、鈴木 亮、

【はじめに】A 型大動脈解離手術時の中心動脈送血と しての上行大動脈送血は簡便で、胸部正中創内のみ の操作でできる。当院では経食道エコーガイド下の みで実施しており、問題なく行えている。しかし、 若干の注意点も明らかになってきており、コッととも に報告することとした。【対象】2007 年 7 月からの 5 年間に実施した大動脈解離に対する手術 44 例の内、 $\mathrm{A}$ 型解離で上行大動脈送血を行ったのは 33 例であっ た。この内、セルジンガー法を使用して FemII カ ニューレを挿入した 29 例を対象とした。【方法】全例 経食道エコーガイド下のみで行った。セルジンガー 法で上行大動脈にカニューレを挿入した。大腿動脈 送血を行って減圧してからの挿入とした。【結果】 28 例で真腔送血を実施し得たが、真腔が狭小化してい た 1 例で、偽腔送血となった。上行大動脈送血によ る合併症はなかった。【コツ、注意点】1)針の刺入点： 多くの症例で真腔は上行大動脈左側に存在する。CT を良く見て刺入点を決める。2)針の刺入時：刺す時、 針はまず偽腔に刺入されて次にフラップを通って真 腔に刺入される。偽腔外壁とフラップを針が通る二 回の抵抗を感知する事が真腔送血にとって重要であ る。3) ガイドワイヤーの確認：ガイドワイヤーが下 行大動脈で真腔に挿入されている事を確認してカ ニューレを挿入する。4)ガイドワイヤーの偽腔内再 挿入：III 型逆行解離でガイドワイヤーが真腔からエ ントリーを通って、下行大動脈では再び偽腔に入っ た症例があった。カニューレを深く入れすぎない事 が真腔送血に重要である。5)偽腔拡張の可能性：III 型逆行解離で上行大動脈血栓化した症例において、 ガイドワイヤーのみが挿入されている状態の時に偽 腔が拡張した症例があった。この瞬間は上行大動脈 にあらたに小エントリーを作っている事になり注意 を要する。【まとめ】A 型大動脈解離手術で、セルジ ンガー法による上行大動脈送血は簡便な方法である が、実施に当たって具体的に考慮するべき点をいく つか報告する。 


\section{PP-181 is \\ New device を用いた大動脈解離に対するス テントグラフト治療の試み〜 CTAG の有用 性〜}

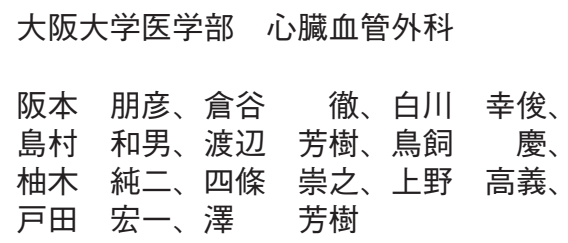

(背景) ステントグラフト治療 (TEVAR)の進歩に伴 い、最近ではこの術式が大動脈解離に対して日本循 環器学会ガイドライン上推奨治療となった。しかし 現在本邦で使用可能なデバイスのみでは弓部の急峻 な屈曲や大きな真腔口径差のため対応困難なことも 多い。近年 Comformable TAG thoracic endoprosthesis (CTAG) が急峻な屈曲に対応する追従性、対応 口径の拡大等により解離対応型デバイスの 1 つとし て注目されている。そこで我々は、CTAGを用いた 解離に対する TEVARの有効性を検討した。（対象、 方法) 2010 年 1 月〜 2012 年 5 月の TEVAR 症例 292 例中, 偽腔拡大傾向があり、従来のデバイスでは対応 不可能な大動脈解離 11 例を対象とした。男女比 $6: 5$, 平均年齢 56.6(42-71) 歳、発症から手術までは平均 22.6 ケ月 $(0.8 \sim 84$ ケ月)、手術適応は拡大傾向が 9 例、 ULP2 例、中枢側 landing は zone2:6 例、zone3: 5 例、 術式は Debranching TEVAR4 例、LSA chimney1 例、 simple TEVAR6 例であった。解離に対しては胸 部エントリーを全て閉鎖、中枢 landing は非解離部、 末梢 landing は下行大動脈直線部に留置する方針で、 退院時と術後 6 ケ月にCT で偽腔の血栓化および最 大径レベルでの瘤径の変化にて治療効果を評価した。 (結果、考察) 技術的成功 $100 \%$ 、全例に術後主要合 併症を認めず。早期死亡、病院死亡も認めず。1 例 に type1 endoleak 認めた。平均追跡期間は 12.3 ケ 月 (2-21 ケ月)、術後死亡なし。再手術は 2 例で末梢 からの吹き上がりに加え typela endoleakを認め瘤 の拡大を来たした症例と、ステント留置部末梢の melting に対し、追加 TEVAR を行った症例であっ た。(イベント回避率 $81.8 \% / 1$ 年) 退院時 CT で 10 例 (91\%)において偽腔の血栓化を認め、術後 6 ケ月後 の最大径レベルでの瘤径は術後 6 ヶ月以上を経過し た 8 例中全例で縮小を認めた。(結語) 大動脈解離に CTAG を使用した TEVAR は良好な早期、中期成績 であった。今後、新しいデバイスが導入されれば、 大動脈解離に対する TEVAR は、さらに適応拡大で きると思われる。

\section{PP-182 « \\ 臓器虚血を合併した急性 $\mathrm{A}$ 型大動脈解離の 検討}

\section{福島県立医科大学 心臓血管外科}

三澤 幸辰、佐戸川弘之、高瀬 信弥、

若松 大樹、黒澤 博之、瀬戸 夕輝、

五十嵐 崇、籠島 彰人、藤宮剛、

新城宏治、横山斉

【目的】術前安定状態にある急性 A 型大動脈解離に対 する緊急手術症例の早期成績は近年良好となってき た。しかし臓器虚血合併例では分枝動脈循環障害 (malperfusion)が時に予後を左右する。今回、教室 で経験した臓器虚血を合併した急性 $\mathrm{A}$ 型大動脈解離 緊急手術症例について検討した。【対象】2001 年 1 月 ～ 2012 年 6 月の急性 $\mathrm{A}$ 型大動脈解離緊急手術症例 137 例を対象とした。年齢は 37 ～87(平均 67) 歳、性 別は男性 61 例、女性 76 例であった。【結果】38 症例 で 47 蔵器に術前虚血を認めた。虚血臓器の内訳は四 肢 26 例、心 8 、脳 6、腎・春髄各 3、肝 1 であった。 術前からの腸管虚血例は認めなかった。複数臓器虚 血を 7 例で認めた。虚血臓器への術前対応は 38 例中 7 例で行った。内訳は重症虚血下肢灌流を先行 4 例、 心筋虚血による高度徐脈に対する体外式ペーシング 2 例、RCA に対する PCI 先行 1 例であった。手術術 式は上行・ヘミアーチ置換 85 例、全弓部置換 52 例 であった。同時手術として、CABG・四肢動脈バイ パスを各 11 例施行した。術後LOS は 5 例認め 4 例 を失った。術前心筋虚血合併 8 例中、虚血領域は RCA6 例、LAD1 例、LCA+RCA1 例であり、術後 LOS を生じたのは LAD 虚血が関与した 2 例であっ た。術前脳虚血 6 例中、術後一時的神経障害は 3 例 認めたが退院時には改善した。永久的神経障害は 1 例認め失った。術前単独腎虚血 2 例は術後腎梗塞と なったが、血液透析は必要としなかった。術後腸管 壊死は 4 例で認め、3 例は破裂例で内 2 例は術前 PCPS 導入例であった。1 例は腹部真腔狭小化例で あった。壞死腸管は 3 例が左側結腸であった。術前 重症下肢虚血の 1 例で MNMS を発症し失った。臓 器虚血に関連した入院死亡予測因子(単変量解析) は 臟器虚血合併 0.067 、複数臓器虚血 0.172 、心筋虚血 0.131 、術後 $\operatorname{LOS}<0.001$ 、脳虚血 0.505 、四肢虚血 0.301 、術後腸管壊死 $<0.001$ であった。多変量解析 では有意差は認めなかった。【結語】術後入院死亡に 影響した臓器虚血は術後腸管壊死のみであった。術 前腸管虚血を認めなくても、循環虚脱例や腹部真腔 狭小化例では術後腸管壊死に注意が必要で、術中開 腹による確認や注意深い経過観察が必要と考えられ た。心筋虚血合併例は RCA 領域に多く、術後 LOS の要因とならなかった。 
$\mathrm{PP}-183$ 方

術式別に見た Stanford A 型急性大動脈解離 に対する手術成績

神戸医療センター中央市民病院 心臓血管外科

左近 慶人、村下 貴志、中村 健、

小西 康信、福永 直人、金光ひでお、

小山 忠明、藤原 洋、岡田 行功

【目的】Stanford A 型急性大動脈解離においては、 main entry 切除を含めた上行置換術が基本的な術式 となるが、置換されない範囲における遠隔期の大動 脈関連イベントの発生率についての詳細な検討は少 ない。当院での早期・中期成績を術式別に検討した。 【対象】 2000 年 1 月から 2012 年 5 月までに当院で Stanford A 型急性大動脈解離に対して手術を施行し た 124 例を対象とした。平均年齢 $64.8 \pm 12.1$ 歳、男 性 67 例 (54\%)。術前ショック 30 例 $(24 \%) 、$ 臓器灌 流障害 34 例 $(27 \%)$ を認めた。術式は main entry 閉 鎖を基本術式とし、大動脈基部 +上行または弓部置 換 18 例 (15\%)、上行置換のみ 82 例 $(66 \%)$ 、弓部置 換 24 例 (19\%) であった。併施手術はCABG 13 例 (10\%)、大動脈弁形成 - 置換 5 例 $(4 \%)$ 、下肢への非 解剖学的バイパス 2 例 $(2 \%)$ などであった。遠隔フォ ローは外来または電話で行い、フォロー率は $96 \%$ 、 院内死亡群を除いた平均フォロー期間は $4.3 \pm 3.4$ 年 であった。【結果】院内死亡は基部置換群で $7 / 18$ (39\%)、上行置換群で 9/82(11\%)、弓部置換群で 5/24(21\%)であった。遠隔死亡は基部置換群では認 めず、上行置換群で 3 例 (いずれも非心臓・大動脈関 連)、弓部置換群で 1 例 (下行大動脈破裂) 認め、5 年 生存率は基部置換群 $61.1 \pm 11.5 \%$ 、上行置換群 $86.7 \pm$ 4.0\%、弓部置換群 $73.1 \pm 9.6 \%$ であった。遠隔期の大 動脈関連イベント (大動脈再手術、再解離、大動脈関 連死亡) は基部置換群で 1 例 (下行再解離)、上行置換 群で 9 例 (基部再手術 1 例、弓部以下の再手術 5 例、 下行再解離 3 例) 、弓部置換群で 1 例 (下行大動脈破 裂) 認め、 5 年回避率は基部置換群 $80.0 \pm 17.9 \%$ 、上 行置換群 $92.2 \pm 3.8 \%$ 、弓部置換群 $92.3 \pm 7.4 \%$ であっ た。遠隔期に大動脈関連イベントを起こした 11 例中 9 例は偽腔開存型であり、他 2 例は血栓閉塞型の再 解離であった。【結論】基部置換群は冠動脈の malperfusion を起こしている症例が多く手術成績が不良 であった。上行置換群と弓部置換群の大動脈関連イ ベント発生率の差はなかったが、イベント発生は偽 腔開存型に多く、より厳密な経過観察を要するもの と考えられた。

\section{PP-184 㝋 \\ 内視鏡下大伏在静脈グラフト採取術を用い た冠動脈バイパス術の早期成績}

\author{
長崎光晴会病院 循環器センター外科
}

麓英征、末永 悦郎、陣内 宏紀、
吉武秀一郎

【目的】内視鏡下静脈グラフト採取術 $(\mathrm{EVH})$ は美容性 に優れ術後創部合併症が軽減される一方、採取時の 静脈内膜損傷によるグラフトの質の低下が危惧され る。2006 年 5 月より $\mathrm{EVH}$ を導入。【対象と方法】 1998 年 1 月から 2011 年 12 月までの単独冠動脈バイ パス術 725 例中 526 例にて静脈グラフトを使用した。 それらを EVH 群(Endoscopic 群、以下 $\mathrm{E}$ 群 : 183 例 315 本)、切開採取群 (Open 群、以下 $\mathrm{O}$ 群: 343 例 504 本)に分け、術前術中術後因子を比較検討した。 【結果】E 群: 年齢 $70.2 \pm 9.6$ 歳 $(\mathrm{M} / \mathrm{F}=133: 50) 、 \mathrm{O}$ 群: 年歯令 $69.7 \pm 8.8$ 歳 $(\mathrm{M} / \mathrm{F}=221 / 122) 、 \mathrm{DM}(\mathrm{E}$ 群 : $48.6 \%$ 、 $\mathrm{O}$ 群 : $39.4 \%$ )、 HT (E 群 : $65.6 \%$ 、O 群 : $75.5 \%$ )、HL (E 群 : $53.6 \%$, O 群 : 43.7\%)、ASO(E 群 : $7.1 \% 、 O$ 群 : $6.4 \%$ )、脳梗塞 ( $\mathrm{E}$ 群: $3.8 \%$ 、 $\mathrm{O}$ 群 : $7.3 \%$ )、腎機能障 害( $\mathrm{E}$ 群: $9.8 \% 、 \mathrm{O}$ 群 : 8、7\%)、Euro-Score(E 群 : 6.4 \pm 9.9 、 $\mathrm{O}$ 群 : $4.5 \pm 4.4)$ 、無輸血 Index $(=\mathrm{Ht}$ 值 $\mathrm{x}$ 体重 $)$ (E: 2055 $\pm 540 、 O$ 群: $1970 \pm 516) 、$ 病変枝数 (E 群: 3.0 \pm 0.8 本、 $\mathrm{O}$ 群: $2.8 \pm 0.5$ 本)、 LMT 病変 $(\mathrm{E}$ 群: $43.7 \%$ 、 $\mathrm{O}$ 群: $34.9 \%$ )、低左心機能( $\mathrm{E}$ 群 : $3.3 \%$ 、 群 : $9.6 \%$ ) *.バイパス本数 ( $\mathrm{E}$ 群: $3.1 \pm 0.8$ 本、 $\mathrm{O}$ 群: $3.2 \pm 1.0$ 本)、 静脈使用本数 ( $\mathrm{E}$ 群: 1 本 63 例、 2 本 109 例、 3 本 10 例、 4 本 1 例、 $\mathrm{O}$ 群: 1216 例、 2100 例、326 例、 4 本 1 例)、LITA 使 用 率(E群: $96.7 \%$ Ｏ群: $95.9 \%$ )、 RITA 使用率( $\mathrm{E}$ 群: 59.5\%、O 群: $54.8 \%$ )、RA 使用 率( $\mathrm{E}$ 群: 0\%、O 群: 49\%)、手術時間( $\mathrm{E}$ 群: $223 \pm$ 45、 $\mathrm{O}$ 群: $277 \pm 58$ ) 分 * 、体外循環時間 ( $\mathrm{E}$ 群: $84 \pm 29$ 、 $\mathrm{O}$ 群: $114 \pm 32$ ) 分* 、大動脈遮断時間 ( $\mathrm{E}$ 群: $52 \pm 25$ 、 $\mathrm{O}$ 群 : $81 \pm 25$ ) 分 * ${ }^{*}$ CPK-MB 值( $\mathrm{E}$ 群 : $58 \pm 74 、 \mathrm{O}$ 群: $52 \pm 50) \mathrm{IU} / \mathrm{l}$. 術後挿管時間 (E 群: $243 \pm 476$ 、O 群: $204 \pm 140$ ) 分、術後 12 時間出血 (E 群: $264 \pm 143 、 O$ 群: $254 \pm 192) \mathrm{ml}$ 、無輸血率( $\mathrm{E}$ 群 : $68.3 \%$ 、O 群 : $71.7 \%$ )、 術後脳梗塞 ( $\mathrm{E}$ 群: $0.5 \%$ 、 $\mathrm{O}$ 群: $1.2 \%$ )、下肢創部合 併症 (E 群: $0.5 \%$ 、 $\mathrm{O}$ 群 : $3.4 \%$ )* 術後 7 日目での静 脈グラフト開存率 ( $\mathrm{E}$ 群 : $310 / 315=98.4 \%$ 、O 群 : 473/ $498=95.9 \%$ )、静脈グラフト閉塞部位( $\mathrm{E}$ 群: LAD 1 例、Dg 2 例、OM 2 例、\#14PL 2 例、\#4PL 1 例、O 群: LAD 2 例、Dg 6 例、OM 1 例、\#14PL 7 例、 \#3RCA 2 例、\#4PD 4 例、\#4PL 3 例、)、LITA 開存 率 (E 群 : $176 / 177=99.4 \% 、 O$ 群 : $329 / 329=100 \%$ )、 RIT A 開 存 率 (E 群: $108 / 109=99 \%$ Ｏ群： 186/188=98.9\%)、RA 開 存 率( $\mathrm{E}$ 群: N/A、O 群: $100 \%$ )であった。在院日数 ( $\mathrm{E}$ 群 : $23.2 \pm 16.6$ 日、O 群 : $18.5 \pm 12.9$ 日)、手術死亡(E 群 : $0 \% 、 \mathrm{O}$ 群 : $0.3 \%$ )*は $\mathrm{P}<0.05$ 。【結語】EVH は術後創部合併症が軽減され 手術全体時間への影響は少なかった。術後急性期で のグラフト開存率は従来の採取法と比べ劣ることな く熟練採取者による EVH は安全性であり術式の妥当 性が示唆された。 
$\mathrm{PP}-185$ 宛

当科での心拍動下冠動脈バイパス術におけ る PAS-port system を用いた中枢側吻合の 検討

\author{
心臓血管研究所付属病院 心臓血管外科 \\ 山部 剛史、門磨 義隆、高井 秀明、 \\ 田邊 大明
}

【目的】当科での PAS-port system を用いた off-pump CABGにおける中枢側吻合を検討しその成績を報告 する。【方法】2004 年 12 月から 2012 年 7 月までに当 科で施行した単独心拍動下冠動脈バイパス術におい て、中枢側吻合 (Ao-SVG 吻合)に PAS-port system を使用した 102 例 (平均年齢 : $73.3 \pm 8.0$ 、男性 : 81 例、 女性：21 例)について検討した。【成績】上行大動脈を in flow としたSVGの平均吻合箇所は 2.5 箇所であ り、術中に測定したSVGグラフトの平均流速は $82.6 \mathrm{ml} / \mathrm{min}$ であった。術中合併症では中枢側吻合部 出血を 18 例(17.6\%)に認め、うち 1 例は大動脈部分 遮断下に再吻合を要した。術後グラフト評価は 75 例 (73.5\%) で行われ、方法の内訳は CAG：53 例、 CTA：17 例、心筋シンチによる虚血評価：5 例であっ た。この内、中枢側吻合の閉塞を 2 例、狭窄を 2 例、 シンチでの評価不十分を 1 例に認め、開存率は 97.3\%であった。術後合併症では出血再開胸を 1 例、 呼吸不全を 5 例、SSI 5 例に認めたが脳梗塞は認 めず在院死亡も認めなかった。【結論】心拍動下冠動 脈バイパス時の PAS-port system を使用した中枢側 吻合は、吻合部出血を認めることがあるものの止血 は容易であった。術後のグラフト開存率も良好であ り、また大動脈部分遮断時に懸念される脳合併症の 発生も認めず安全な手技であると考えられた。

\section{PP-186 SYNTAX score は冠動脈バイパス術の成績 に影響するのか?}

\section{福島県立医科大学 心臓血管外科}

藤宮剛、佐戸川弘之、高瀬 信弥、

三澤 幸辰、若松 大樹、黒澤 博之、

瀬戸 夕輝、五十嵐 崇、籠島 彰人、

新城宏治、横山斉

【はじめに】SYNTAX study により多枝病変に対する CABG および PCI の遠隔成績につき報告がなされて いる。しかし、SYNTAX score で層別化し多枝病変 に対する CABG 成績の検討を行った報告は少ない。 今回、SYNTAX score が、CABG 術後の予後予測因 子となりうるか検討した。【対象と方法】当科で 2008 年 1 月から 2012 年 8 月までに施行した左主幹部病変 または三枝病変に対する CABG 58 例を対象とした。 男性 47 例、女性 11 例で、平均年齢は $68 \pm 10.6$ (38-87) 歳であった。SYNTAX score が 33 以上の H 群 (33 例) と 33 未満の L 群 (25 例) の成績に関し、後方視的 に検討した。【結果】術前患者背景では、PCI 既往 $(\mathrm{H}$ 群 11 例 (33\%)、L 群 2 例 $(8 \%): \mathrm{p}<0.05)$ や OMI (H 群 15 例 (45\%)、L群 4 例 (16\%): p < 0.05) が H 群 で有意に多かった。手術は OPCAB が H 群 : L 群そ れぞれ 32 例 (97\%): 22 例 (88\%) であった。前下行枝 (LAD)へのバイパスは内胸動脈(ITA)を第 1 選択と し、33 例 (97\%): 23 例 (95\%) で ITA-LAD バイパス を行った。吻合枝数(本) は $3.5 \pm 0.8: 3.4 \pm 1.0$ 、手術 時間 (分) は $345 \pm 53: 345 \pm 55$ で両群に有意差を認め ず、術中輸血量、術後抻管時間、ICU 滞在日数も有 意差は認めなかった。術後 30 日以内の死亡を $\mathrm{H}$ 群 : 1 例、 $\mathrm{L}$ 群 : 2 例に、在院死亡を $\mathrm{H}$ 群 : 1 例、 L 群 : 1 例に認めたが、両群に有意差はなかった。平均観察 期間は $17.8(1-53)$ カ月で、術後 4 年の累積全死亡率 $(\mathrm{H}$ 群 $6 \%$ 、L 群 $12 \%$ )、累積心臓死亡率 $(\mathrm{H}$ 群 $0 \%$ 、L 群 8\%)、累積 MACCE 発生率(H 群 14\%、L 群 8\%) に両群で有意差は認められなかった。【考察】CABG において SYNTAX score は早期・中期成績に影響し なかった。よって、PCI 成功率を左右する近位冠動 脈病変の複雑性はCABG 成績に影響せず、SYNTAX study の結果を指示するデータと考えられる。 また、ほぼ全例が OPCAB であった今回の成績は、 on-pump CABG が $85 \%$ を占める SYNTAX study 4 年のSYNTAX score $\geqq 33$ の High 群の成績(全死 亡: $17.7 \% 、 M A C C E: 33.2 \%)$ と比して良好であり、 OPCAB vs PCI の RCT 研究推進を支持すると思わ れる。 
PP-187 ¿

新たな LMT 治療 guideline に基づく $\mathrm{PCl}$ 推 奨 class II, class III 群への CABG の長期遠 隔成績

\section{東海大学医学部 外科学系心臓血管外科学}

長 泰則、志村信一郎、秋 顕、

古屋 秀和、小田桐重人、岡田 公章、

上田 敏彦

【背景】冠動脈血行再建の新たなガイドラインでは CABG は LMT 病変に対し class I で推奨、その一方 で PCI は LMT 単独または 1 枝病変 $( \pm 1 \mathrm{VD})$ かつ ostium or shaft lesion で class IIb 推 奨、 bifurcation で class IIb or III 推 奨、LMT +2 または 3 枝病変 (2,3VD)では class III 推奨 (PCI は非適応) となりつつ ある。当科では $50 \%$ 以上の狭窄を伴う LMT 症例に 一貫して CABG を選択、良好な長期グラフト開存と 遠隔成績のため心停止下で末梢側吻合を施行してき た。

【対象および方法】2000 年から 2009 年の CABG 580 例中、LMT 症例は 193 例 $(34.5 \%)$ たっった。 LMTに 施行した CABG 193 例を今後も PCI が行われるだろ う LMT $\pm 1 \mathrm{VD}$ 群 46 例と、CABG が行われるべき $\mathrm{LMT}+2,3 \mathrm{VD}$ 群 147 例の 2 群とし、後ろ向きに長期 遠隔成績を比較、MACCE、再血行再建の危険予測因 子から LMT に対する最適な治療戦略を検討した。

【結果】手術死亡は 5 例 $(2.6 \%) 、 4$ 例は ECG 変化を 伴った緊急症例、待機手術の 1 例は AAA 破裂で 失った。術中に発生した脳合併症はなし。1 年後の graft 開存率 ITA-LAD $96.2 \%$ 、他 $85.8 \%$ 。全体の 10 年生存率は $88.4 \%$ 、MACCE 回避率は 10 年で $72.7 \%$ であった。

$\pm 1 \mathrm{VD}$ 群、2,3VD 群に対する CABGの 10 年イベン 卜発生はいずれも $1 \mathrm{VD}$ 群で低く以下の通りであっ た。全死亡; $5.8 \%: 13.2 \%(\mathrm{p}=0.24) 、 \mathrm{CVA} ; 6.3 \%: 7.4 \%$ $(p=0.89) 、 M I ; 0 \%: 5.1 \%$ 、再血行再建 ; $8.0 \%: 9.7 \%$ $(\mathrm{p}=0.53) 、$ MACCE; $13.4 \%: 31.0 \%(\mathrm{p}=0.04)$ (Fig.1)。 多変量回帰分析で緊急手術 (HR、6.4)、LMT+2,3VD (HR、2.8)が MACCE、redo CABG (HR、8.1)が再血行 再建の有意な危険予測因子であった。

【結語】LMT に対し今後 PCIが行われるだろう LMT $\pm 1 \mathrm{VD}$ 群に対する心停止下 CABG は +2,3VD 群と比 較し有意に MACCE 発生率が低く、LMTへのPCI 治療に対する benchmark となり得た。ガイドライ ンに準拠することでより良好な長期遠隔成績が得ら れると予想されるが、回帰分析より ECG 変化を伴う 緊急症例や CABG 後症例に対しては PCI が有効な治 療戦略と考えられた。

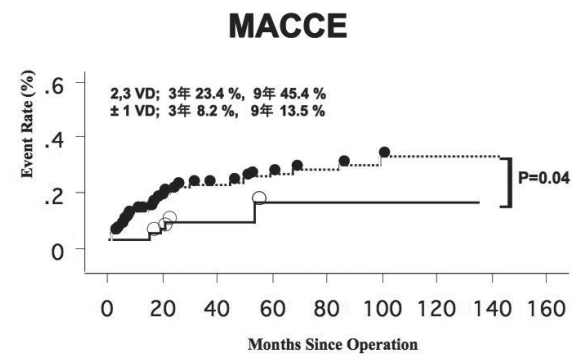

\section{PP-188 为 \\ 標準術式を OPCABで遂行した場合、on- pump CABG の遠隔期成績を超えられるか}

\section{福山循環器病院 心臓血管外科}

向井 省吾、尾畑 昇悟、森元 博信、
平岡 俊文、打田 裕明、山根 吉貴

【目的】従来我々は動脈グラフトを積極的に使用する OPCAB を冠動脈血行再建術(CABG)の基本術式と して取り組んできたが、薬剤溶出ステントの導入以 来、再建枝数の増加や患者背景の変化等により onpump beating CABGの頻度が増加しつつある。 OPCAB と On-pump CABG の治療成績を検討した。 【対象と方法】2002 年 4 月から 2010 年 12 月までの間 に筆者が行った CABG 単独施行例は 424 例であった が、このうち OPCAB で完遂できた 310 例と、onpump CABG を行った 101 例を比較検討した。心停 止下 $\mathrm{CABG}$ (7 例) は除外した。平均フォロー期間は $50.2 \pm 44.2$ か月、フォローアップ率は $94.2 \%$ であった。 【結果】患者背景は年歯 (Off-pump : On-pump $=68.1 \pm$ 8.8 歳: $69.9 \pm 8.6$ 歳)、男性 $(75 \%: 76 \%)$ 、糖尿病 $(35.4 \%: 40.6 \%)$ 、高血圧 $(52.9 \%: 59.4 \%)$ 、維持透析 (7.0\% : 6.9\%)では有意差はなかった。STS score で 計算した mortality は Off-pump 群 : On-pump 群 = $1.39 \pm 1.08 \%: 7.29 \pm 10.9 \%$ で、On-pump 群が高かっ た $(\mathrm{p}=0.02)$ 。緊急症例は $58.4 \%: 43.6 \%$ 、IABP 使用 $52.3 \%: 55.4 \%$ で有意差はなかった。再建枝数は 2.6 \pm 1.0 : $3.5 \pm 1.1$ で On-pump 群が多く $(\mathrm{p}<0.001)$ 、在 院死亡は 2 例 $(0.6 \%): 4$ 例 (4.0\%) で On-pump 群が 高かった $(\mathrm{p}<0.001)$ 。全グラフトの開存率は $95.9 \%$ で、使用グラフトの開存率 (Off-pump : On-pump) は ITA が $98.3 \%$ : 98.5\%、SVG93.3\%: $92.0 \%$ 、 RA96.1\%：97.0\%で、両群間に差は見られなかった。 Kaplan-Meier 法を用いた生存率は 5 年 91\%：90\%で 両群間に有意差はなかった。遠隔期合併症では Offpump 群死亡 $2.9 \%$ 、脳合併症 $2.0 \%$ 、創部治癒遷延 $2.3 \%$ な゙、On-pump 群死亡 $5.0 \%$ 、脳合併症 $4.0 \%$ 、 治癒遷延 $4.0 \%$ などであった。【結語】On-pump 群は 再建枝数が増加し、かつ MACE 回避率、在院死亡率 では Off-pump 群に劣っており、明らかな high risk group であるが、遠隔期の生存率に差はなかった。 $\mathrm{OPCAB}$ は術中循環動態の維持が可能な限り $\mathrm{CABG}$ の標準術式としての意義を持つ一方で、CABGの適 応が high riskにshiftしつつある現状では、Onpump CABG は送血路を確保できさえすれば安全な 術式であり high-risk 患者に対しても充分 benefit が あるといえる。 


\section{PP-189 « $\mathrm{PCI}$ の既往を有する単独 CABG の手術成績}

\author{
岐阜大学大学院医学系研究科 高度先進外科学分野
}

松野 幸博、島袋 勝也、石田成吏洋、

竹村 博文

【背景・目的】冠動脈疾患に対する PCI 治療の適応が 拡大され増加している今日、PCI の既往が CABG の 手術成績に与える影響に関してはしばしば議論の対 象となっている。これまでに PCI の既往は CABG 早 期死亡・心事故の独立した危険因子であるとの報告 も散見される。今回我々は、PCIの既往が単独 CABG の手術成績に与える影響につき検討を行った。 【対象・方法】2003 年 10 月から 2012 年 7 月までの全 CABG 290 例のうち、全ての合併手術施行を除く単 独 CABG 症例 197 例を対象とした。術前に PCI の既 往がない 139 例 (A 群; 435 バイパス) と既往がある 58 例(B 群; 164 バイパス)に分け、比較検討を行った。 【結果】平均年齢は A 群 $69.4 \pm 8.6$ 歳、B 群 $67.8 \pm 8.4$ 歳、PCI 平均回数 $1.7 \pm 1.2$ 回、DES 留置例 11 例 (19\%) であった。糖尿病の既往が A 群 63 例 (45.3\%)、B 群 32 例 $(55.2 \%$ )、術 前 LVEF は A 群 $59.0 \pm 13.8 \%$ 、B 群 $61.2 \pm 11.5 \%$ であり有意差は認めなかった。病変枝 数は $\mathrm{A}$ 群 $2.7 \pm 0.5 、 \mathrm{~B}$ 群 $2.6 \pm 0.6$ で、バイパス末梢吻 合数は $\mathrm{A}$ 群 $3.1 \pm 1.2 、 \mathrm{~B}$ 群 $2.8 \pm 1.2$ であり有意差はな いがA群で多い傾向を認めた。OPCABから Onpumpへ の conversion は A 群 12 例 $(8.6 \%) 、 B$ 群 7 例 (12.1\%)であり有意差はないが B 群で高い傾向を 認めた。術後早期造影でのグラフト開存率は A 群 98.2\%、B 群 95.7\%で、有意差はないが A 群で高い 傾向であった。術後主要合併症発生率は A 群 8 例 $(5.8 \%) 、 B$ 群 6 例 $(10.3 \%)$ であり有意差はないが B 群で高い傾向を認めた。手術死亡は A 群なし、B 群 1 例 (1.7\%)、在院死亡は A 群 4 例 $(2.9 \%) 、 B$ 群なし、 遠隔死亡(平均フォロー期間 : $59 \pm 29$ ヶ月)は A 群 15 例 (10.8\%)、B 群 4 例 (6.9\%) で、ともに有意差は認め なかった。MACE 回避率はA群 $98.4 \% 、 B$ 群 96.6\%、MACCE 回避率はA 群 98.4\%、B 群 $94.8 \%$ であり有意差はないものの B 群で低い傾向を認めた。 【結語】PCI 既往ありの群は病変枝数・バイパス枝数 が少ないにも関わらず、conversion 率および術後主 要合併症発生率が高く、早期グラフト開存率が低い 傾向を示し、また遠隔期成績では MACE/MACCE 回避率が低くなる傾向を認めた。PCI は低侵襲で治 療に伴うリスクは極めて低いものの、のちの CABG の治療効果を減弱させる可能性があることが示唆さ れ、今後の検討を要する。

\section{PP-190 药 OPCAB は周術期脳障害を回避できたか？}

\author{
福岡大学 医学部 心臟血管外科
}

$\begin{array}{lllll}\text { 峰松 } & \text { 紀年、田代 } & \text { 忠、和田 } & \text { 秀一、 } \\ \text { 西見 } & \text { 優、松村 } & \text { 仁、桑原 } & \text { 豪、 } \\ \text { 大住 } & \text { 真敬、藤井 } & \text { 満、清水 } & \text { 真行、 } \\ \text { 森田 } & \text { 裕一 } & & & \end{array}$

【目的】冠動脈バイパス術において、DES 全盛の現在 では、外科手術の成績を上げることが必須事項であ る。その中でも、脳神経合併症を回避することは極 めて重要な課題である。脳障害の観点から CABGに おける OPCAB の利点や問題点について検討する。 【方法】2001 年 1 月から 2011 年 12 月に施行した単独 冠動脈バイパス術は 902 例であった。OPCAB は 713 例であった。OPCAB での体外循環移行例は除外し た。脳梗塞の定義は、新規に出現した不可逆的な neurologic deficit として、TIA な゙の可逆的な脳虚 血症状は除外した。【結果】全 902 例のうち、周術期

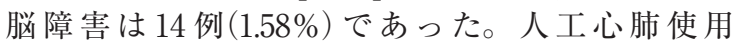
CABG で は 2 例 $(1.15 \%)$ で、OPCAB で は 12 例 $(1.68 \%)$ の発症を認めたが、有意な差は認めなった $(\mathrm{P}=0.746)$ 。人工心肺使用 $\mathrm{CABG}$ でも症例を検討す れば、周術期脳障害を回避できることが示された一 方で、内訳を見ると OPCAB 症例において高齢 $(68.6$ \pm 8.79 vs59.6 $\pm 14.8 ;$ p < 0.001) で、脳梗塞の既往があ り (16.3\%vs3.7\%; P < 0.001)、上行大動脈の性状不良 例が多く $(28.9 \% \mathrm{vs} 14.3 \% ; \mathrm{P}<0.001)$ 、頸動脈病変を 有している $(7.3 \% \mathrm{vs} 1.1 \% ; \mathrm{P}<0.001)$ ことか、脳障 害における OPCAB の有用性が推測された。それで は OPCAB において、周術期脳障害の原因となる因 子は何か? 脳梗塞発症群と非発症群を比較してみる と、高齢 $(72.8 \pm 4.57$ vs68.5 $\pm 8.83 ; \mathrm{p}=0.008)$ で、心機 能が低く $(\mathrm{EF}=51.5 \pm 14.5 \% \mathrm{vs} 60.1 \pm 14.2 \% ; \mathrm{p}=0.039)$ 、 脳梗塞の既往があり $(41.7 \%$ vs $15.8 \% ; \mathrm{P}<0.032)$ 、上 行大動脈の性状不良例を認めた $(58.3 \% \mathrm{vs} 28.4 \%$; $\mathrm{p}=0.047)$ 。中枢吻合に関しては、no touch 症例で 5 例、 device 使用などの中枢吻合施行症例で 7 例の脳梗塞

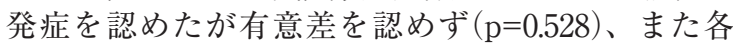
device ごとの比較においても有意差を認めなかった $(\mathrm{p}=0.660)$ 。OPCAB における周術期脳障害の原因と なる因子としては、脳梗塞の既往(relative risk 4.172, 95\%CI 1.285-13.546; P=0.017)、上行大動脈の性状 （relative risk 3.808, 95\%CI 1.183-12.259; $\mathrm{P}=0.025$ ) が 挙げられた。【考察】脳梗塞の観点から OPCAB は有 用な手術戦略であると考えられた。その OPCABに おいても脳梗塞の既往および上行大動脈の性状は重 要な因子であり、大動脈中枢吻合をはじめ、上行大 動脈の慎重な取り扱いが周術期脳障害の回避に有効 であると考えられた。 


\section{PP-191 文 \\ 頭頚部血管病変を有する CABG 患者への機 能的評価(SPECT)}

JA愛知豊田厚生病院 心臓血管外科

寺本 慎男、川口鎮

【はじめに】頸動脈狭窄や頭蓋内血管狭窄を有する患 者は高齢化の進行と共に増加傾向にある。近年 OPCAB の有用性や低侵襲性が取りあげられるなか、 人工心肺 $(\mathrm{CPB})$ 使用下での $\mathrm{CABG}(\mathrm{OnCAB})$ でも周術 期の神経学的合併症に差を認めなかったとする報告 も散見される。今回我々は頭澒部血管病変を有する $\mathrm{CABG}$ 症例を対象とし脳血流シンチグラフィ (SPECT) の有効性について検討した。【対象・方法】 2006 年 9 月 1 日から 2012 年 7 月 31 日まで当院で施 行された単独 $\mathrm{CABG}$ 症例 247 例のうち、術前に MRI を施行された 188 例を対象とした。頭頚部血管狭窄 所見を認めて SPECT 検査を施行されたものが 27 例 で、これをSPECT 群、MRIのみ施行された群を Control 群(161 例) として比較検討を行った。SPECT にて脳血流低下を認めない 23 例のうち、術中の Epiaortic echo で上行大動脈壁に問題がない 11 例は人 工心肺 $(\mathrm{CPB})$ を使用した。【結果】SPECT 群と Control 群で年齢、性別、DM、HT、HL 罹患率は両群 間に有意差を認めなかった。頭蓋内血管狭窄病変と 頸動脈狭窄病変の有病率は共に SPECT 群で有意に 高かった $\left({ }^{*} \mathrm{P}<0.01\right)$ 。病変枝数は SPECT 群 vs Control 群 : $2.6 \pm 0.6$ vs $2.5 \pm 0.7$ 、Euro SCORE(ES) : 5.2 \pm 2.7 vs $4.6 \pm 3.0$ で差がなかった。準緊急手術・緊急 手術は Control 群で 19 例(11.8\%) 認められ、RI 群は 全例定例手術症例であった。CPB 使用率：40.7 vs $54.0 \% 、 \mathrm{CPB}$ 時間ともに両群間で有意差は認めなかっ た。術直後から脳梗塞を発症したものは無かったが、 周術期の脳梗塞発症は Control 群で 4(Transient / Permanent :2/2) 例、SPECT 群で $1(: 1 / 0)$ 例認めた。 脳梗塞発症は術後平均 5.5 日 (1-12 日)であった。また $\mathrm{OPCAB}$ 群と $\mathrm{OnCAB}$ 群の比較では年齢 $\mathrm{OPCAB}$ 群 vs $\mathrm{OnCAB}$ 群 : $69 \pm 9$ vs $64 \pm 9\left(^{*}\right)$ 、 $\mathrm{ES}: 5.5 \pm 2.9$ vs 3.9 $\pm 2.9\left(^{*}\right)$ 、末梢吻合枝数 : $2.7 \pm 1.1$ vs $3.9 \pm 1.3\left(^{*}\right)$ で有 意差を認めたが、頭蓋内血管狭窄病変と頸動脈狭窄 病変の有病率はそれぞれ： 22.2 vs $16.3 \%$ 、18.9 vs $10.3 \%$ で有意差無く、脳梗塞発症も3(Transient/ Permanent :2/1)例 vs 2(:1/1)例で共に差を認めず、 手術操作が原因と思われる脳梗塞は認めなかった。 【結語】頭頚部血管狭窄病変を有していても $\mathrm{OPCAB}$ には固執せず、SPECT による機能的な評価にて脳潅 流が維持されている症例では $\mathrm{CPB}$ 使用も選択肢とで きるものと考えている。

\section{PP-192 文 \\ 慢性透析患者における CABG 症例と PCI 症 例の中期成績の検討}

\author{
$\mathrm{KKR}$ 札幌医療センター 心臓血管外科
}

大畑 俊裕、上田 秀樹、阿部 慎司

【目的】近年血液透析 (HD) 症例に対する手術症例は増 加している。また DES 登場以降 PCI の治療成績は向 上しているが、HD 症例における CABG と PCI の治 療成績の比較検討を行った報告は多くは認められな い。自施設における HD 症例に対する CABG と PCI の中期治療成績の比較検討を行ったので臨床的検討 を加え報告する。【対象及び方法】2005 年 1 月から 2012 年 7 月までに当院で HD 症例に対して行われた $\mathrm{CABG}$ 症例 22 例の内、単独 $\mathrm{CABG}(\mathrm{iCABG})$ 群 12 例 と弁膜症合併 (con.valve) 群 10 例、そして同時期に施 行された PCI 群 23 例を対象とした。年齢は平均 67.6 (43-80) 歳で、男女比は 33: 12 。平均観察期間は 28.1 ケ月であった。これら 3 群にて年齢、病変枝数、 LVEF、EuroSCORE II 及び遠隔生存率、MACE 回 避率、心不全死回避率を比較検討した。【結果】病院 死亡は con.valve 群にて 3 例 (30\%) で、死亡原因は LOS1 例、ARDS1 例、肝不全 1 例であった。con. valve 群は PCI 群に比し術前 EF 值は有意に低值を 示し $(47 \pm 16$ vs. $62 \pm 12, \mathrm{p}=0.0087)$ 、EuroSCOREII は 有意に高值を示した $(9.4 \pm 5.3$ vs.3.9 $\pm 3.1, \mathrm{p}=0.0008)$ 。 iCABG 群も PCI 群に比し有意に EuroSCOREII は高 值を示した $(8.2 \pm 7.9$ vs.3.9 $\pm 3.1, \mathrm{p}=0.025)$ 。手術死亡 も含む all cause death 一次エンドポイントとした 6 年生存率は $\mathrm{iCABG}$ 群 48\%、con.valve 群 $31 \%$,PCI 群 $31 \%$ であり、有意差を認めないものの $\mathrm{iCABG}$ 群 は高值を示した。MACE 回避率はそれぞれ $64 \%$, $71 \%, 37 \%$ であり PCI 群は有意に低值を示した $(\mathrm{p}=0.031)$ 。心不全死回避率は $100 \%, 100 \%, 50 \%$ で あった。全 HD 症例全体での導入後 6 年生存率が $53.4 \% 、 10$ 年生存率が $36.2 \%$ であることを考慮すれ ば、単独 $\mathrm{CABG}$ 群の中期成績は良好であると考えら れる。【まとめ】当院における HD症例に対する CABG と PCI の中期成績を検討した。単独 CABG 群 では PCI 群に比し、より多病変、 high riskであった にもかかわらず生存率では非劣勢を示し、MACE 回 避率では有意に低值を示した。弁膜症合併 CABG 群 では単独 CABG 群、PCI 群に比し有意に成績が不良 であった。HD 症例全体の遠隔成績から考慮すれば、 $\mathrm{HD}$ 合併冠疾患症例に対する $\mathrm{CABG}$ 手術成績は受け 入れうる範囲であると考えられた。 


\section{PP-193 称 \\ 急性心筋梗塞後の左室自由壁破裂、心室中 隔穿孔に対する手術成績の検討}

\author{
近森病院 ハートセンター 心臓血管外科 \\ 堀尾 直裕、佐野 俊和、手嶋 英樹、 \\ 池淵 正彦、入江 博之
}

【背景】急性心筋梗塞 (AMI) 後の機械的合併症である 左室自由壁破裂 (LVFWR)、心室中隔穿孔(VSP) は重 篤な合併症である。当院で外科的治療を実施した AMI 後の LVFWR およびVSP の治療成績を検討し た。【対象・方法】2001 年から 2012 年 6 月の間に、外 科的治療を実施した AMI 後の LVFWR および VSP について検討した。症例の内訳は LVFWR が 7 例、 VSP が 19 例 の合計 26 例 (男性 12 例、女性 14 例、 平均年齢 74 歳)であった。その間に当院に来院した AMI は 2638 例で、緊急 CAG は 2262 例であった。 また、単独 CABGは793例施行された。【結果】 LVFWR は Blow-out type が 2 例、Oozing type が 5 例であった。1 例は来院時 CPA であり、残りの 6 例 は shock 状態で来院した。5例で IABP が使用され、 2 例ではECMOが装着された。VSPはAnterior type が 14 例、Inferior type が 4 例、Posterior type が 1 例であった。 5 例が shock 状態で来院し、16 例 でIABPが使用された。手術手技はLVFWRでは フェルトを用いた縫合閉鎖が 2 例、直接縫合閉鎖が 2 例、パッチ閉鎖が 1 例、タココンブによる止血が 2 例であった。1 例では術後再破裂し、再手術となった。 VSP では infarct exclusion 法によるパッチ閉鎖が 16 例、直接縫合閉鎖が 1 例、パッチ閉鎖が 2 例であった。 2 例ではVSP が再発し、再手術となった。手術死亡 率 は LVFWR の $1 / 7$ 例 (14.3\%)、VSP の 3/19 例 (15.8\%)であった。LVFWR の死亡例は Blow-out type で来院時 CPA であり、ECMO が装着され手術施行し たが心拍再開せず術中死となった。VSP の死亡例は 術後低拍出量症候群で死亡した症例が 2 例あった。 もう 1 例は術後 8 日目に心室頻拍となり循環動態が 保てず死亡した。【まとめ】当院の AMI 後の LVFWR、VSP に対する外科的救命率はそれぞれ 85.7\%、84.2\%であった。AMI 合併症では、急激に循 環動態が悪化する場合が多く、早急に手術を施行す ることが重要であると考えられた。

\section{PP-194 is 左室形成術の適応と工夫}

\section{香川大学 心臟血管外科}

堀井 泰浩、山下 洋一、河野由美子、

北本 昌平、阪本 浩助

【はじめに】左室形成術の適応については、虚血性心 疾患に対する STICH trialの結果のみならず、確立 した一定の見解はないが、広範囲にわたる梗塞心筋 があり拡張して収縮力が低下している左室に対して は、その障害心筋を切除もしくはパッチ形成するこ とで左室機能を再構築することは可能である。障害 心筋の進展範囲を見極めることが肝要で、その上で その障害心筋部分を適切に形成する工夫についてビ デオで供覧したい。【術前検査】収縮力の著しく低下 した左室心筋において、残存心筋の Viability を検索 する方法としてドブタミン大量負荷エコーは有用で あるが、梗塞心筋など障害心筋の進展範囲に関して は遅延造影像 MRI 検査や PET 検査が必須となる。 梗塞心筋など左室壁に進展する線維化部分を見極め ることが可能となり、線維化心筋が広範囲に及んで いる場合には、左室形成術の良い適応となりうる。 【虚血性心筋症】現在の日本では、急性心筋梗塞に対 してカテーテル治療により早期再疎通がされている ことが多く、かつてのような完璧性心筋梗塞による 心室瘤形成は少数で、複数冠動脈領域や心内膜に線 維化心筋が散在していることがあり、その進展範囲 の同定に難渋することがある。その際に、体外循環 下で心拍動を維持することで左室収縮を用手的に検 索することは有用である。【非虚血性心筋症】梗塞心 筋が冠動脈領域に一致することはないが、拡張型心 筋症として著しい左室拡張を伴い左室機能の低下し ている症例では、線維化心筋が広範囲に及んでいる ことがある。その範囲は、たとえば左室後側壁乳頭 筋間に限局しているものや、前壁中隔部に局在して いるものや、また下壁に限局したものなど多岐にわ たる。その障害心筋の進展程度および範囲を同定し、 それに準じた適切な左室形成術を選択する必要があ る。前壁中隔に対するSAVE 手術、後側壁乳頭筋間 に対する Batista 手術、下壁に対する左室部分切除術 などさまざまな左室形成術につき紹介する。【まと め】筋梗塞後の梗塞心筋や局在する線維化心筋など の障害心筋の進展程度や範囲を同定し、その進展に 応じた左室形成術を適切に施行することで、左室拡 張の強い左室機能の低下した拡張型心筋症で、虚血 性のみならず非虚血性においても、左室機能を回復 して心不全を改善せしめる可能性がある。 


\section{PP-195 文 右冠動脈起始異常を合併した心臓手術の検 討}

国立循環器病研究センター 心臓血管外科

藤吉 俊毅、小林順二郎、藤田 知之、

秦広樹、島原 佑介、佐藤 俊輔

【背景・目的】右冠動脈起始異常 (ARCA) は希な先天 奇形で、動脈硬化病変の有無にかかわらず心筋虚血 や突然死の原因になり得る。発症頻度は ARCA が左 冠動脈起始異常 (ALCA)に比べて多いが、突然死は ALCA に多くみられる。そのため、ALCA は診断さ れた時点で治療適応となることが一般的であるが、 ARCA に対する手術適応は議論が分かれる。心臓手 術時にARCA を合併している患者に対する明確な治 療戦略もない。今回はARCA を合併した心臓手術に ついて検討した。【対象】1997 年から 2011 年までの間 に心臓手術を施行した患者の内、術前検査または術 中に ARCA と診断された 15 例 (平均 55.4 歳、男性 10 例) (基部置換 : 3 例、弁置換 : 8 例、ASD 閉鎖 : 2 例、OPCAB : 2 例)。【結果】全例とも ARCA は大動 脈 - 肺動脈間走行がみられ、6 例に大動脈壁内走行を

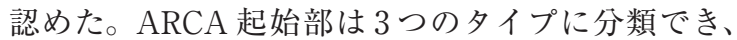
LCA の左側の左バルサルバあるいは ST junction レ ベルにあるタイプは 5 例であり、全例壁内走行であっ た。L-R 交連部の直上にある夕イプは 4 例でこれら はすべて L-R 交連部にRaphe をもつ二尖弁の AS で、 1 例に壁内走行を認めた。上行大動脈に起始部 があるタイプは 6 例で 3 例に壁内走行がみられた。 4 例 $(27 \%)$ に術前検査で RCA 領域の虚血所見を認め た。ARCAに対して予定手術を施行したのは 6 例 (40\%)であり、CABG のみ : 2 例、CABG+RCA closure:1 例、Transfer with reimplantation:3 例であっ た。全 15 例の内、術中に RCA 領域の虚血を来した のは $1(7 \%)$ 例で、AVR 施行後、閉胸時に胸部誘導 でST 上昇、血圧低下を認めたため緊急でRITARCA を施行し改善した。ARCA に対する手術の有無 にかかわらず、術後早期、遠隔期に RCA 領域の虚血 を起こした患者はいなかった。CAGBのみを施行し た 3 例は、術後早期グラフト開存は確認されたが遠 隔期評価を行った 2 例では、 2 例ともグラフトの閉塞 を認めた。【結論】ARCA は周術期に虚血を来す可能 性があり、手術介入が望ましいと考えられた。CABG のみは周術期の虚血を防ぐ backup にはなるが、遠 隔期にはグラフト閉塞の可能性が高く、どのような 手術を選択するかは今後の重要な課題である。

\section{PP-196 文 弓部大動脈瘤に対する total debranching TEVAR の短期成績}

\author{
獨協医科大学 \\ 武井祐介、井上 有方、桐谷ゆり子、 \\ 関雅浩、桑田 俊之、権重好、 \\ 柴崎 郁子、松下 恭、山田 靖之、 \\ 福田宏嗣
}

【背景・目的】胸部ステントグラフト内挿術は胸部下 行大動脈瘤のみならず、弓部大動脈瘤に対して適応 拡大され、近年 debranching TEVAR の良好な中期 成績が多数報告されている。当科においても弓部大 動脈瘤に対する外科的治療は全弓部置換が第一選択 ではあるが、高齢者や術前合併症の有無及び解剖学 的要因を検討し適応症例であれば積極的に debranching TEVAR を施行している。そのうちステン トグラフトの proximal landing zone が石丸分類にお いてZ Zone 0 に及ぶ場合、当科で施行可能な手技とし て total debranching TEVAR と chimney technique があり、開胸可能であれば前者を第一選択としてい る。当科における total debranching TEVAR の方法 と短期治療成績を報告する。

【方法】 2010 年より当科では、弓部大動脈瘤(慢性解 離及び破裂含む)に対して debranching TEVARを 開始し、2012 年 8 月時点で 37 症例を経験し、その内 Total debranching TEVAR は 4 症例である。当科 の total debranching TEVAR の方法は、胸骨正中切 開、左腋窩動脈露出、大腿動脈露出をまず施行する。 上行大動脈を partial clamp L Hemashield gold 12-8$8 \mathrm{~mm}$ の 3 分枝人工血管を上行大動脈に端側吻合、腕 頭動脈、左総頸動脈に端端吻合し最後に左腋窩動脈 に端側吻合する。ステントグラフトは Gore TAG を 用いて基本的に大腿動脈より挿入、脳梗塞予防目的 に腋窩動脈吻合部末梢側より左鎖骨下動脈起始部に バルーンを留置しステントグラフトを deploy する。 確認造影で左鎖骨下動脈からの typeII endoleak が認 められれば、同部位にコイル塞栓を施行する。全 4 症例において平均手術時間、術後在院日数、術後経過、 治療成績について検討した。

【結果】全 4 症例 (男性 3 人、女性 1 人)の平均年齢は $74 \pm 5$ 歳、術前合併症として陳旧性脳梗塞 2 例、未 梢動脈疾患 1 例、未期腎不全 1 例、COPD 1 例、担癌 症例 1 例であり術前平均 JACVSD 予測死亡+主要合 併症率 $35 \pm 16 \%$ であった。全 4 症例の primary success は 100\%であった。平均手術時間 $317 \pm 50$ 分、 平均術後在院日数 $15 \pm 7$ 日、手術関連合併症無く経 過し、平均術後観察期間は $7 \pm 7$ ヶ月であり全症例に おいて Endoleak を認めていない。

【考察・まとめ】当科における total debranching TEVAR の治療成績は良好であった。開胸可能であ り、かつ人工心肺を用いた全弓部置換術がハイリス クと推察される症例において、total debranching TEVAR は有用な方法であると考えられる。 


\section{PP-197 \\ 下行大動脈緊急症に対する外科治療成績： 企業製ステントグラフトが与える影響}

\section{弘前大学 胸部心臓血管外科}

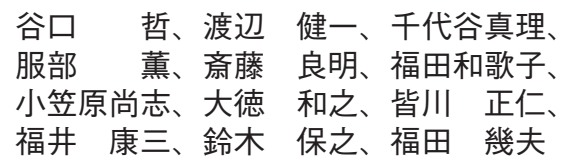

【目的】企業性ステントグラフトにより胸部下行大動 脈瘤の治療成績は向上したが、緊急手術例での治療 は未だ問題点が多い。緊急手術を施行した下行大動 脈疾患に対する治療成績に企業性ステントグラフト が与えた影響を検討する。【対象】1998 年より 2012 年 7 月までにおこなった胸部下行大動脈手術 115 例中、 緊急手術を行った 30 例を対象とした。企業性ステン トグラフト導入前 (2010 年前半まで、 $\mathrm{E}$ 群 19 例) は下 行置換術を第一選択とし(E-OR 群、 $\mathrm{n}=12$ )、人工心 肺手術困難症例と複数リスクを有する例に、Zステ ントによる自作 TEVAR(E-Z 群、 $\mathrm{n}=7$ )を施行した。 2010 年後半からは全例市販 SG による TEVARを 行った ( $\mathrm{L}$ 群、 $\mathrm{n}=11$ )。年齢は 59.3/75.7/70.2 歳、性別 (男：女) $8: 4 / 4: 3 / 9: 2(\mathrm{OR} / \mathrm{Z} / \mathrm{L})$ 、疾患の内訳は OR 群: 外傷性大動脈破裂 3、急性解離 (AAD) 5 、下 行大動脈瘤破裂 (rTAA) 4 例、 Z 群 : 外傷 $1 、 A A D 0 、$ rTAA6 例、L 群: 外傷 3、AAD2、rTAA6 例であっ た。【結果】人工肺ハイリスク例は企業性ステント グラフト導入前では $7 / 19(36.8 \%) 、$ 後期では $5 / 11$ (41.7\%)であり、差は認めなかった。ショック例は $\mathrm{E}$ 群 3 例 $15.8 \%$ (E-OR 群 8.3\%、Z 群 28.6\%)、 L 群 2 例 $18.2 \%$ と差は認めなかった。手術時間は $\mathrm{E}$ 群 354.8 分 (E-OR 群 461.0 分、 E-Z 群 203.0 分、 L 群 179.3 分と E-OR 群 vs L 群で短かったが(有意差あり、 $\mathrm{p}=0.00093) 、 \mathrm{E}-Z$ 群と L 群では差はなかった。術後 ICU 滞在期間は E 群 7.3 日 (E-OR7.9、E-Z6.3)、L 群 4.0 日、入院期間は E 群 29.2 日 (E-OR29.1、E-Z34.0)、 L 群 20.0 日と後期で短縮した。在院死亡は E-OR 群 0、E-Z 群 2(28.6\%) で typelendoleak による瘤破裂、 食道穿通による縦隔炎であった。 E-Z 群生存例の遠 隔期 open conversion 例は 2/5 例 (40\%) で、いずれ も rTAA 例であった。L 群の在院死亡は 1 例 (9.1\%) で AADの re-entry からの解離腔への血流による破 裂であった。遠隔期 open conversion 例は無く、 rTAA 例の合併症は認めなかった。【考察】企業性ス テントグラフトの導入により、下行大動脈緊急症に 対しては全例が対応可能となったが、 $\mathrm{AAD}$ 例では re-entry の処理による解離腔の減圧を配慮すべきで ある。選択バイアスがあるが Open repairの成績は 良好であり、下行大動脈緊急症に対して TEVARを bridge として使用すべき症例も存在すると思われる。 Z ステント使用例は注意深い遠隔期追跡が必要であ る。

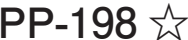 \\ 弓部大動脈瘤に対する治療戦略}

岐阜大学大学院 医学系研究科高度先進外科学

島袋 勝也、石田成吏洋、松野 幸博、

竹村 博文

【目的】当科における弓部大動脈瘤症例に対する手術 手技の選択と成績について検討した。【対象・方法】 2003 年 10 月から 2012 年 5 月までに経験した急性期 大動脈解離症例を除く弓部大動脈瘤 56 症例を対象と した。弓部人工血管置換術 (R- 群)を第一選択とし、 2010 年 9 月以降、80 歳以上や high risk 症例に対し ては debranching TEVAR(T-群)による治療を行っ ている。2011 年より弓部人工血管置換術適応症例に おいて瘤末梢側壁の性状が良好な症例に対しては open stent-graft 法を併用している。両群の手術およ び遠隔成績について比較検討した。【結果】R-群：T群は 46:10例であった。 R- 群: T- 群の平均年齢 72.2: 72.7 歳、男/女比 35/11: 8/2 であった。R- 群に 破裂性を 10 例、 T-群に外傷性を 2 例認めた。術式 は R- 群は䅡部 3 分枝再建 44 例、島状再建 2 例であっ た。 5 例に open sent-graft 法(すべて Th 7 以上)を 併用した。T-群は debranching TEVAR(DT)を 9 例 (Zone 0: 1 例、Zone1: 2 例、Zone 2: 6 例)に施行した。 $\mathrm{T}$ - 群の選択理由として外傷性 2 例、超高齢 2 例 (両 側反回神経麻痺を伴った 90 歳と維持透析中の 88 歳)、慢性 Stanford B 型解離による弓部動脈瘤部の entry 閉鎖 1 例、胸腹部大動脈瘤合併症例 1 例など であった。縦隔洞炎合併感染性動脈瘤破裂症例 1 例 に対してDTを選択した。術後呼吸器合併症に対し て気管切開を R- 群に 5 例、T-群に 1 例施行した。脳 神経合併症を $\mathrm{R}$-群に 3 例(小脳梗塞、左上肢不全麻 疩、不全片麻瘏) 認めたが退院後症状はすべて軽快し た。対麻痺症例は認めなかった。両群とも手術死亡 はなく、入院死亡を $\mathrm{R}$ - 群の破裂症例に 1 例(呼吸不 全)に認めたが両群に有意差は認めなかった。遠隔期 死亡を R- 群 (追跡期間 7-2337 日)に 8 例、 T- 群(追跡 期間 3-2337 日)に2 例認めたが動脈瘤関連死は認め なかった。R-群 1 年生存率 $87 \% 、 3$ 年 $78 \% 、 5$ 年 $62 \% 、 762 \%$ 、T-群 1 年 78\% であった。【考察】弓部 人工血管置換術の成績は良好であり第一選択と考え られた。Open stent-graft 法は末梢側トラブルの回避、 反回神経温存により手術時間の短縮、呼吸器合併症 の回避などのメリットがあり有用な併用術式となり 得ると考えられた。一方で長期成績は不明とはいえ ども高齢者や high risk 症例に対しては明らかに低侵 襲である TEVAR の選択は十分に妥当性のある治療 法と考えられた。慎重な術前評価により術式を選択 することで良好な手術および遠隔期成績が得られる と考える。 


\section{PP-199 它 \\ 胸部大動脈瘤治療戦略 OPEN /TEVAR/ HYBRID}

心臓病センター榊原病院

毛利 教生、吉鷹 秀範、坂口 太一、

津島 義正、都津川敏範、田村健太郎、

近沢 元太、石田 敦久

近年、ステントグラフトの登場により大血管の治療 は大きく変革し、その治療戦略は多岐にわたり、そ の適応は複雑化しつつある。本邦での診療ガイドラ インも 2011 年度から改訂されており、下行大動脈領 域に対する TEVARに関しては consensus を得つつ ある。弓部大動脈領域での TEVARについては、 conventional TAR, debranching TEVAR、hybrid などの治療法が存在し、その適応は controversial で ある。当院では 2009 年より TEVAR を導入、2011 年度までの 3 年間に 340 例の胸部大動脈疾患を加療 し、弓部大動脈瘤が 95 例存在する。その内訳は conventional TAR (OR) 75 例、 debranching TEVAR (SG) 15 例、hybrid TAR (HB) 5 例である。これらを 比較検討し、その適応の妥当性を検証した。(hybrid TAR は TAR+elephant trunkを行い、1 週間後に TEVAR施 行) (debranching TEVARでは2debranch 以上は開胸で上行大動脈に in flow 式）また、脳梗塞に注目し、大動脈を上行、弓部、腕 頭動脈基部、左総澒動脈基部、左鎖骨下動脈基部の 5 か所に分け、mobile plaque の有無と脳梗塞の関係 を検討した。患者背景は、3 群に明らかな差は認めな かった。手術時間は OR: 418min SG: 294min HB: 421min であった。脳梗塞は OR: 5/75 SG: 6/15 HB: 1/5であった。Mobile plaque の存在と脳梗塞の発生 については OR: 2/29 SG: 3/5 hybrid 0/1 であった。 SG は mobile plaque による脳梗塞の発症がほかの群 に比較し多かった。 mortality はOR: 8/75 SG: 3/15HB: 0/5 で hospital stay は OR: 29.6 日 SG 33.3 日 HB: 32.2 日であった。術前状態に差がないことを 考慮すると debranching TEVAR は、その侵襲性は 決して低くなく、Mobil plaque が存在した場合は高 率に脳梗塞を発症する可能性があり、現段階では、 conventional TAR、症例によっては TAR+elephant trunk+TEVAR が妥当な選択と考えられた。

\section{PP-200 文 \\ 胸部大動脈瘤に対する治療法一人工血管置 換術からステント内挿術へ}

\author{
信州大学医学部附属病院 心臓血管外科

$\begin{array}{lrrr}\text { 高野 } & \text { 環、福井 } & \text { 大祐、寺崎 } & \text { 貴光、 } \\ \text { 和田 } & \text { 有子、市村 } & \text { 創、毛原 } & \text { 啓、 } \\ \text { 大橋 } & \text { 伸朗、駒津 } & \text { 和宜、大津 } & \text { 義徳、 } \\ \text { 瀬戸達一郎、天野 } & \text { 純 } & \end{array}$

当科では 2009 年より胸部大動脈に対する TEVAR を開始し、2012 年 7 月現在、人工血管置換術の適応 は、若年者と解剖学的に TEVAR が困難な症例のみ になっている。胸部大動脈人工血管置換と TEVAR の患者背景、手術成績を評価し、何が TEVAR の適 応を広げたのかを検討した。く方法＞我々は、2005 年 1 月から 2012 年 7 月までに 260 例の胸部大動脈手 術を施行した。このうち急性大動脈解離 84 例と合併 手術施行例 20 例を除く大動脈瘤 156 例を対象とし、 TEVAR 導入前の 2005-2008 年に人工血管置換術を 施行した 73 症例 (S 群) と 2009-2012 年に TEVARを 施行した 83 症例 (E 群)との間で、症例の背景、術式、 挿管期間、ICU 滞在期間、術後合併症、入院期間、 院内死亡について retrospective に比較検討した。< 結果 $>\mathrm{S}$ 群の年齢は $73 \pm 9$ 歳、 $\mathrm{E}$ 群は $83 \pm 7$ 歳、 $\mathrm{E}$ 群で 10 歳高齢であった $(\mathrm{p}<0.01)$ 。瘤の部位は上行、 弓部、下行、胸腹部が $\mathrm{S}$ 群でそれぞれ 2.7、16.4、 72.6、6.9 \%、E 群では 1.2、20.5、74.7、3.6 \%だった。 破裂・仮性瘤は S 群で $32.9 \%$ 、 E 群で $14.5 \%$ ( p < 0.01 )。動脈瘤の診断から手術までの期間は $\mathrm{S}$ 群平均 13 ケ月、E 群 11 ヶ月で、 $\mathrm{S}$ 群の $53 \%$ では手術まで 6 ヶ

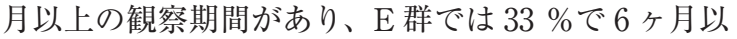
上観察されていた $(\mathrm{p}=0.08)$ 。術前に脳梗塞、未治 療または再発悪性腫瘍、血液透析、COPD、間質性 肺炎を S 群で $16.4 \%$ 、 群で $25.3 \%$ に認めた $(\mathrm{p}=$ 0.1 )。手術は S 群で全弓部置換 40 例、下行置換 24 例、 胸腹部 4 例、上行置換 2 例、その他 4 例、 $\mathrm{E}$ 群で、 TEVAR 45 例、TEVAR + bypass 19 例、TEVAR + chimney 7 例を施行した。S 群の $32.9 \%$ 、 E 群の $15.7 \%$ は緊急手術だった $(\mathrm{p}<0.05)$ 。院内死亡は S 群 12.3、 $\mathrm{E}$ 群 $4.8 \%(\mathrm{p}<0.01)$ 。手術時間、挿管期間、 ICU 滞在、入院日数は S 群でそれぞれ 623 分、 6.4 日、 7.6 日、46 日。E群でそれぞれ 190 分、2.0日、3.2 日、 18 日と全て $\mathrm{E}$ 群で短かった $(\mathrm{p}<0.01)$ 。術後合併症 は、S 群 $13.7 \%$ 、 E 群 $12.0 \%$ に認め、両群間で有意 差はなかった。＜考察＞TEVAR は、症例が高歯令で あり、術前合併症が多い傾向にもかかわらず、人工 血管置換と比べて死亡率は低く、合併症の発生も低 い傾向だった。人工血管置換では、破裂・仮性瘤が 多いために手術成績が悪かったと考えられるが、 TEVAR は手術時間、扦管期間、ICU 滞在、入院日 数は人工血管置換の $1 / 3$ と低侵襲であり、動脈瘤の 診断から早めの手術を行うことで、破裂や緊急手術 を減少させている可能性がある。低侵襲であること がTEVARの適応を拡大していると考えられた。 
PP-201 宛

ステントグラフト時代の下行大動脈 Open

Surgery

浜松医科大学 第一外科

高橋 大輔、椎谷 紀彦、山下 克司、

熟山 直己、大倉一宏

【目的】2009 年より本邦でも胸部大動脈瘤に対する企 業製ステントグラフトが使用可能となり、その適応 が急速に拡大している一方で、open surgeryにまわ る症例の背景も変化している。当科に打ける TEVAR 導入後の open surgery の症例像と成績を明 らかにする。

【対象と方法】2009 年から当科で治療した下行大動脈 疾患は 55 例で、open surgery 24 例、TEVAR31 例。 これらの背景因子を比較し、open surgeryにまわっ た要因、術式と成績を検討することで、TEVAR 時 代の open surgery の特徵を明らかにし、当科の治療 方針の妥当性を検討する。

【結果】open surgery は平均年齢 66.2 歳(35-86)、男 20 例、女 4 例、緊急 3 例、準緊急 2 例、待機 19 例。 囊状瘤 5 例、紡錘状 19 例、紡鍾状の最大瘤径は $58.3 \mathrm{~mm}$ 。解離性 11 例、非解離性 13 例。一方 TEVAR は、平均年齢 72 歳 (35-88)、男性 24 例、女 性 7 例、緊急 2 例、準緊急 2 例、待機 27 例。霊状瘤 16 例、紡錘状 15 例、紡錘状の最大瘤径は $58.0 \mathrm{~mm}$ 。 解離性 11 例、非解離性 20 例。解離性病変に TEVAR を適応した症例は ULP 部の慢性期囊状瘤が ほとんどであった。また広範胸部大動脈瘤に対する 弓部置換後の二期的 TEVAR が 10 例。すなわち open surgery では TEVARより襄状瘤が少なく、解 離性が多かった。open surgeryにまわった要因は、 偽腔開存型の解離性 10 例、 landing zone 不良 12 例 (長さ不足 $7 \cdot$ 屈曲 $3 \cdot$ 太 太さ2)、感染 3 例 (native 1 、 TEVAR 後 2、うち 1 例は AEFに対する TEVAR bridge 後)、65 歳未満の若年者 10 例。術式はいずれ も左開胸で、F-F バイパスによる部分体外循環下に 大動脈を遮断して手術したのが 20 例(左鎖骨下動脈 より中枢での大動脈遮断を要したもの 5 例)、低体温 循環停止にて手術したのが 4 例。Open surgery の在 院死亡 1 例 $(4.2 \%)$ 。 83 歳と超高齢、低肺機能、 shaggy aortaの広沉病変症例で、上行弓部置換 elephant trunk 後下行置換を施行し経過良好であった が、一時外泊中に肺炎を発症し、MOF となり失った。 術後脊髄障害、脳梗塞なし。一方 TEVAR では在院 死亡を認めなかったが、術後脊䯣障害 1 例、ステン トグラフト感染 1 例を認めた。

【結語】当科における TEVAR 導入後の open surgery は、 shaggy aorta、感染、TEVAR 後の再手術に加え、 偽胫開存型の慢性解離や広沉病変の若年者が主たる 対象であった。その手術成績は良好であり、低侵襲 治療に偏りがちな現代においても、遠隔成績を考慮 して応じた治療法を提供する当科の治療戦略は妥当 である。

\section{PP-202 玄 ステントグラフト導入前後の胸部大動脈瘤治 療}

船橋市立医療センター 心臟血管外科

櫻井学、茂木 健司、松浦馨、

榎本 吉倫、川村 知紀、高原 善治

【目的】ステントグラフト内挿術の普及により大動脈 瘤治療戦略は大きく変化しつつある。人工血管置換 術を基本とする治療指針はあるが低侵襲化の流れは ハイブリッド手術、デバイスの進化など共に未だ変 化し続けている。今回、当院に扔けるステントグラ フト導入前後の胸部人工血管置換術施行症例につき、 その変化を検討した。【対象と方法】2010 年 4 月から 当院ではステントグラフト治療を導入した。その前 後 2 年間 (2008 年 4 月から 2012 年 3 月) の待機的胸 部大動脈瘤手術を施行した 80 例中、人工血管置換術 を施行した 59 例につき検討した。ステントグラフト 導入前症例 $\mathrm{A}$ 群 33 例、導入後症例 B 群 26 例として 両群について術前因子(年齢、性別、リスクファク ター、合併症、病変部位、リスクスコア)、術中因子(術 式、手術時間、輸血)、術後因子 (ICU 滞在日数、術 後入院期間)につき検討した。 B 群期間中の TEVAR 症例は 21 例 (弓部 $/$ 下行 $/$ 胸腹部 $=4$ 例 $/ 13$ 例 $/ 4$ 例) (26.3\%) であった。【結果】在院死亡は A 群 : B 群 $=2$ 例 $: 0$ 例であった。平均年齢は $\mathrm{A}$ 群 $: \mathrm{B}$ 群 = 70.4 才 : 68.9 才(N.S.)。リスクファクターでは高コレ ステロール血症 $\mathrm{A}$ 群 : B 群 $=39.4 \%: 61.5 \%(\mathrm{p}=$ 0.09 )、術前腎機能障害 $(\mathrm{Cre}>1.5) \mathrm{A}$ 群: B 群 $=$ $12.1 \%: 34.6 \%(\mathrm{p}<0.05) 、$ 合併症発生の可能性あり の JAPAN SCORE が A 群 : B 群 $=25.1 \%: 29.9 \%$ (p $=0.06)$ と B 群がハイリスクの傾向を示した。他のリ スクファクターに関しては両群間に有意差は認めな かった。原因別において解離性大動脈瘤の割合が $\mathrm{A}$ 群 : B 群 $=9.1 \%: 34.6 \%(\mathrm{p}<0.05)$ と有意に B 群に 解離性瘤の割合が高かった。術式別では弓部/下行 $/$ 胸腹部の症例数は $\mathrm{A}$ 群: $\mathrm{B}$ 群 $=20$ 例 $/ 10$ 例 (30.3\%) /3 例 : 21 例 $/ 5$ 例 (23.8\%) /0 例と下行置換術 の割合が減少した。手術時間、ICU 滞在期間、術後 入院期間に関して両群間に有意差は認めなかった。 【考察】ステントグラフト導入後でも open surgeryに ハイリスクな症例がやや増加していたが在院死亡は 減少した。解離性大動脈瘤の手術割合が増加し、腎 機能障害症例がステントグラフト不適応症例として そのまま人工血管置換術になっていることがリスク 増の要因として考えられたが、open surgery の成績 は安定して扔りステントグラフト導入による臨床効 果の強調、そして今後の適応拡大を考えるならば、 解離性大動脈瘤と腎機能障害患者への対処などを克 服することが今後の課題と考えられた。 


\section{PP-203 2 ? \\ Closed circuit CPB を用いた Total debranch- ing TEVAR (Valiant)}

\author{
${ }^{1}$ いわき市立総合磐城共立病院 心臓血管外科 \\ 獨協医科大学 越谷病院 心臓血管外科・呼吸器 \\ 外科 \\ 3福島県立医科大学 心臓血管外科

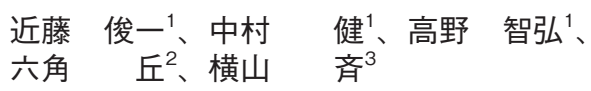

弓部大動脈瘤に対する完全弓部大動脈置換手術の成 績は、近年目覚ましく改善している。しかし、超高 齢者の弓部大動脈瘤に対する完全弓部置換手術の侵 襲は大きくその適応には、慎重にならざるを得ない。 我々は、そのような超高齢者の弓部大動脈瘤に対し、 胸部正中切開で閉鎖回路による人工心肺補助下に上 行大動脈加 total debranching $(14 \mathrm{~mm} \times 10 \mathrm{~mm} \times$ 10mm)を行い、Zone 0 から TEVARを行い良好な結 果を得ている。その、手術戦略およびビデオを供覧 する。症例は、87 歳 男性、開業医である。既往歴： 脳梗塞(麻痺なし) 現病歴: 7 年前から遠位弓部大動 脈瘤を指摘されていたが、手術についてはリスクが 高いため拒否していた。2012 年 5 月突然の胸部痛自 覚。改善がないため EMS call された。当院へ緊急搬 送となった。精査の結果、弓部大動脈に最大径 80mmの動脈瘤が見られた。幸い血管外への造影剤 の漏出は見られなかったため、ICUへ入院となった。 降圧、安静で程なく胸痛は消失した。弓部大動脈瘤 切迫破裂と診断した。積極的な治療は、完全弓部大 動脈置換手術もしくは、Valiant 46mm を用いた total debranching TEVARのみであった。相談の結果、 total debranching TEVAR を希望された。手術：胸 部正中切開の後、右腋窩動脈送血、右房 1 本脱血で 閉鎖回路人工心肺を開始した。人工心肺により十分 に減圧した後、上行大動脈に partial clamp を置いた。 上行大動脈を punch out L、Hemashield $14 \mathrm{~mm} \times$ $10 \mathrm{~mm} \times 10 \mathrm{~mm}$ の $14 \mathrm{~mm}$ 部分を end to sideに吻合 した。10mm 人工血管先端に選択的脳潅流カニュー ラ $12 \mathrm{Fr}$. を接続し、左鎖骨下動脈、腕頭動脈、左総 頸動脈の順に end to end に吻合した。左総頸動脈へ の吻合は、右腋窩動脈の送血回路に選択的脳潅流力 ニューラ $12 \mathrm{Fr}$.を接続し潅流しつつ行った。その後、 左外腸骨動脈アプローチで Valiant 4238-200 \& 4646200 を用いてZ0 から TEVARを行った。術後経過： 第一病日に抜管し、第二病日 ICU を退室した。まと め： closed circuit CPB を使用した on pump beating total debranching TEVAR は、安全で、低侵襲であっ た。

\section{PP-204 文 \\ 腎動脈上腹部大動脈遮断を必要とした腹部 大動脈瘤}

\author{
東京医科歯科大学 血管外科 \\ 地引 政利、葛井総太郎、西澤 真人、 \\ 猪狩 公宏、内山 英俊、小泉 伸也、 \\ 豊福 崇浩、工藤 敏文、井上 芳徳
}

はじめに: 腎動脈上・傍腎動脈腹部大動脈瘤や腎動 脈上腹部大動脈遮断を必要とする腹部大動脈瘤に対 して血管内治療は、本邦では一般的ではない。当科 で経験した症例について検討した。対象と方法： 1996 年 1 月から 2012 年 6 月において腎動脈上・傍腎 動脈腹部大動脈瘤や腎動脈上腹部大動脈遮断を必要 とした腹部大動脈瘤 76 例のうち維持透析 7 例、緊急 5 例を除く待機例 64 例 (男 56 例、女 8 例) $(70 \pm 8$ 歳) を対象とした。左腎静脈は流入静脈を切離し授動す るか左腎静脈を離断し術野を確保した。腎動脈遮断 前にマンニトールを $0.5 \mathrm{~g} / \mathrm{kg}$ 点滴静注し、30 分以上

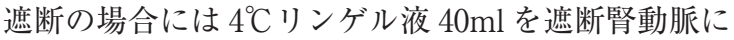
注入した。あらかじめ Y 型人工血管に $6 \mathrm{~mm}$ ePTFE を側端吻合しておき、中枢側吻合後、腎動脈を端々 吻合した。結果：左腎静脈離断は 26 例(平均断端圧 $29 \pm 14 \mathrm{mmHg}$ ) で、腎動脈再建 18 例 (両側 4 例、片側 14 例)であった。腎動脈遮断時間は腎動脈再建例； $60 \pm 48$ 分 (中央值 45 分)、再建なし例; $25 \pm 13$ 分 (中 央值 21 分)であった。術前後の腎機能は、再建なし例、 血清クレアチニン值 $0.97 \pm 0.3 \rightarrow 1.0 \pm 0.4 \mathrm{mg} / \mathrm{dl}$ 、 eGFR 值 $60 \pm 19 \rightarrow 58 \pm 20 \mathrm{ml} / \mathrm{min} / 1.73 \mathrm{~m} 2$ と術前後 で有意差を認めなかった。腎動脈再建例においても 術前後 eGFR 值 $56 \pm 26 \rightarrow 58 \pm 30 \mathrm{ml} / \mathrm{min} / 1.73 \mathrm{~m} 2$ (透 析移行例 2 例除く)で有意差を認めなかった。腎機能 増悪 (血清クレアチニン值上昇が $0.3 \mathrm{mg} / \mathrm{dl}$ 以上また は術前後クレアチニン比； 1.5 倍以上)を 9 例(再建 ; 5 例 (2 例は透析移行した)、再建なし； 4 例)に認め、 在院死 3 例 (再建例; 心不全 1 例、呼吸不全 : 1 例、 再建なし； S 状結腸癌穿孔 1 例) だった。腎動脈再建 後の透析移行 2 例は遮断時間が長いこと、術後合併 症の併発により腎機能の増悪となった。結語：腎動 脈上大動脈遮断を必要とする腹部大動脈瘤に対して、 本術式程度の単純な方法による腎保護で概ね満足す べき結果が得られた。 
PP-205 为

腹部大動脈瘤に対して開腹手術とステント治 療における術後血中エンドトキシン量の比較

\author{
順天堂大学 心臓血管外科 \\ 大石 淳実、土肥 静之、森田 照正、 \\ 稲葉 博隆、桑木 賢次、山本平、 \\ 松下 訓、松村 武史、嶋田 晶江、 \\ 横山 泰孝、黒田揮志夫、天野 篤
}

[背景]腹部大動脈に対する新たな侵襲的治療法とし て、従来の標準術式であった開腹による人工血管置 換術に代わり、ステントグラフト留置術の施行件数 が急速に増加している。一般的に開腹手術後には血 中エンドトキシン濃度が上昇することが知られてお り、その值と、術後の入院日数や合併症が関係する ことが報告されているが、今回我々は開腹手術と、 開腹操作を行わないステント留置術では血中エンド トキシン濃度に差が生じるのではないかと仮定し、 その血中濃度を経時的に比較するとともに、他の炎 症マーカーとの関係性を検証した。[対象と方法] 2012 年 4 月より、当院において腹部大動脈に対して 侵襲的治療を施行された症例を対象とし、開腹によ る人工血管置換術が行われた群を開腹群、ステント グラフト内挿術が行われた群をステント群とした。 開心術など他の手術との合併症例は除外した。術後 1、3、5 日目の血中エンドトキシン值 $(\mathrm{Et}) 、$ 体温、白 血球数 (WBC)、CRP、TNF- $\alpha$ を測定するとともに、 それぞれ術前值を基準值としてその変化率を記録し た。さらに年齢、性、BMI、内服薬、合併疾患、過 去に施行された手術の有無とその内容、行われた手 術と使用したデバイス、手術時間および術後経過を 記録し、両群間で比較検討した。[結果]開腹群では 腹部大動脈瘤が 4 例、閉塞性動脈硬化症が 3 例の計 7 例であり、ステント群は腹部大動脈瘤が 5 例であっ た。年齢および性別はそれぞれ平均 70.8 歳、6 6.2 歳 で両群間に差はなかった。また術前の Et、体温、 WBC、CRP、TNF- $\alpha$ に両群間に差は認めなかった。 体温、WBC、CRP は両群とも術後上昇したが、両群 間でその值および変化率に差はなかった。ステント 群では Et の変化も見られなかったが、開腹群におい ては、術後 3 日目に高くなる傾向があった。Etの変 化率は開腹群で有意に高值を示した $(\mathrm{p}<0.07)$ 。 TNF- $\alpha$ は両群とも変化は見られなかった。また使用 デバイス、術後合併症に差はなかったが、ステント 群において 1 例、内腸骨動脈切迫破裂が生じた。[結 語]開腹群の方がステント群より術後の Et の上昇を 示しており、腸管操作が関与しているものと考えら れた。開腹群においても病的意義と位置づけられて いる值までの Et の上昇は見られなかったが、エンド トキシン值を見てもステント治療はより低侵襲性で あることが示唆された。

\section{PP-206 宇 \\ 破裂性腹部大動脈瘤術後 open abdomen management $の$ 経験}

\author{
大阪赤十字病院 心臓血管外科 \\ 坂本 和久、伊藤 恵、中山 正吾
}

破裂性腹部大動脈瘤 (rAAA) は腹部コンパートメン 卜症候群 (ACS) 高危険群であり、術後 19\%に合併し その $2 / 3$ が死亡するとの報告もある。成績向上のた め 2011 年よりショックを伴う rAAA に対してシリコ ンエラストマーシートを用いた temporary abdominal closure (TAC)、膀胱内圧モニタリングのもと ACSを回避するべくopen abdomen management (OAM) を開始した。その初期成績を報告する。 strategy：PEA を来たした症例は肋間開胸下に下行 大動脈遮断を行った。手術は TACで終了し、術後 は膀胱内压をモニターし膀胱内圧 $12 \mathrm{mmHg}$ 以下、腹 腔内灌流圧を $60 \mathrm{mmHg}$ となる様に調節した。TAC 後の閉腹は用手的に仮閉鎖試験を行って決定した。 対象：2005年より 2012 年 3 月までにrAAA に対し て 29 例の緊急手術を行った。術前ショックの定義を SBP $80 \mathrm{mmHg}$ 以下で昇圧剂もしくは $1 \mathrm{~L}$ 以上の急速 輸液を必要としたものとしたところ、ショックを伴っ たものは 23 例で 2011 年以降方針に従い治療を行っ たもの 8 例を $\mathrm{O}$ 群、2011 年以前の症例 15 例を C 群 とした。患者背景 : 年齢 $\mathrm{O}$ 群 $70.1 \pm 11$ 歳、 C 群 70.7 \pm 14 歳、瘤径 $O$ 群 $83.6 \pm 7.4 \mathrm{~mm} 、 C$ 群 $70.9 \pm 14 \mathrm{~mm}$ 、 下行大動脈遮断症例は $\mathrm{O}$ 群 3/8: C 群 5/15、腎動脈 上遮断で中枢吻合を行ったものは O 群 2/8: C 群 1/15であった。腎動脈遮断時の腎保護は単純遮断で 行った。結果: 手術時間 O: $\mathrm{C}=198.8 \mathrm{~min} \pm 44: 300 \pm$ $10 \mathrm{~min}$ 、出 血 量 $\mathrm{O}: \mathrm{C}=3121 \pm 158 \mathrm{ml}: 4258 \pm 3839 \mathrm{ml}$ 、 濃厚赤血球輸血量 $\mathrm{O}: \mathrm{C}=8 \pm 4.7$ 単位: $12.8 \pm 8$ 単位で あった。手術時間は $\mathrm{O}$ 群で有意に短かった $(\mathrm{p}=0.016)$ 術後 24 時間以内の超早期死亡は $\mathrm{O}$ 群 3 例、C 群 1 例、その後の在院死亡は両群ともに認めなかった。 超早期死亡を除き術後の比較を行ったところ、ICU 滞在日数 $(\mathrm{O}: \mathrm{C}=13 \pm 8.9$ 日 : $14.5 \pm 12$ 日)、挿管時間 $(\mathrm{O}$ : $\mathrm{C}=9.6 \pm 7.6$ 日: $10.9 \pm 12$ 日)、術後 24 時間の $\mathrm{P} / \mathrm{F}$ 比 (O: $\mathrm{C}=220 \pm 50: 193 \pm 88$ ) は両群に有意差を認めな かったが、 $\mathrm{P} / \mathrm{F}$ 比 150 以下で抜管困難となった症例 $(\mathrm{O}: \mathrm{C}=1: 8)$ 、肺炎併発例 $(\mathrm{O}: \mathrm{C}=1: 7)$ 、一時的透析例 (O: $\mathrm{C}=0: 3)$ は $\mathrm{O}$ 群で少なかった。また $\mathrm{O}$ 群では腸管 運動は良好で全例 7 日以内に経腸栄養を開始できた。 $\mathrm{O}$ 群 の open abdomen time は 4.8 1.8 日 (2-6)) で、 TACに伴った感染や創合併症は認めなかった。考 察：OAM は鎮静、扦管管理が必要であり ICU 在室 時間、挿管時間の短縮にはつながらなかったが、続 発する合併症の減少にはつながると考えられた。結 語：OAM は合併症軽減に寄与しrAAAの治療成績 を改善する。 


\section{PP-207 六 炎症性腹部大動脈瘤・腸骨動脈瘤の治療成 績}

\section{神戸大学 心臓血管外科}

$\begin{array}{llll}\text { 後竹 } & \text { 康子、野村 } & \text { 佳克、木下 } & \text { 史子、 } \\ \text { 中井 } & \text { 秀和、小原 } & \text { 大見、竹歳 } & \text { 秀人、 } \\ \text { 山中 } & \text { 勝弘、宮原 } & \text { 俊介、白坂 } & \text { 知識、 } \\ \text { 坂本 } & \text { 敏仁、大村 } & \text { 篤史、井上 } & \text { 武、 } \\ \text { 南 } & \text { 一司、岡田 } & \text { 健次、大北 } & \text { 裕 }\end{array}$

【目的】当院における炎症性腹部大動脈瘤 - 腸骨動脈 瘤に対する治療成績を検討した。【対象】1999年 10 月から 2011 年 3 月までに当院で治療を行った炎症性 腹部大動脈瘤 (IAAA) 12 例 ·腸骨動脈瘤 (IIAA) 1 例 を対象とした。同時期に治療を行った腹部大動脈瘤 696 例 (open surgery 518 例、EVAR 178 例) の 1.8\% を占めた。平均年齢は $72.6 \pm 7.4$ 歳、男性が 12 例 (92.3\%)であった。術前 CT でマントルサインを認め、 炎症性瘤と診断可能であった症例は 8 例 $(61.5 \%) 、$ 術 前に破裂・切迫破裂を疑われた症例が 4 例 (30.7\%)、 非炎症性瘤と思われた症例が 1 例 $(7.6 \%)$ であった。 術前に水腎症を認めた 2 例中 1 例で術前に尿管ステ ントを留置した。術式は open surgery(OS)が10 例、 ステントグラフト内挿術(EVAR)が 3 例であった。8 例で病理診断を行い、全例が瘤壁の著しい線維性肥 厚と炎症細胞浸潤から炎症性瘤と診断された。術前 の平均 CRP は $1.60 \pm 2.69 \mathrm{mg} / \mathrm{dl}$ 。 IgG4 は 3 例で測定 しており、うち 2 例で $120,354 \mathrm{mg} / \mathrm{dl}$ と高值を認めた。 【結果】平均手術時間は $268 \pm 137$ 分、平均在院日数は $36.6 \pm 26.9$ 日であった。13 例中 6 例に術後合併症を 来した。内訳は労作性狭心症、脾損傷、人工血管左 脚血栓閉塞、腸管虚血、下肢末梢神経障害、術後イ レウスが 1 例ずつであった。OS 全例で瘤と腸管との 癒着を認め、 2 例で術中に明らかな瘤と尿管との癒着 を認めた。しかし、術中に尿管や腸管を損傷した症 例はなかった。手術死亡はなく、院内死亡は 2 例(急 性心不全、肝不全)であった。遠隔期の平均フォロー アップ期間は $30.9 \pm 33.7$ ヶ月。遠隔期の動脈関連合 併症としては、残存する腸骨動脈瘤に対して EVAR を行った症例が 1 例であった。遠隔期死亡 2 例を認 めたが、動脈関連合併症による死亡はなく、食道癌 1 例・脳挫傷 1 例であった。術後 3 ケ月の平均 CRP は $0.63 \pm 0.89 \mathrm{mg} / \mathrm{dl}$ と低下を認めた。術前マントルサイ ン陽性であった 8 例のうち、遠隔期に造影 CT を再 検した 3 例全てでマントルサイン㓌性となった。水 腎症については経過観察中だが、退院前の CT では 術前と比較して改善を認めなかった。【結語】当院に おける炎症性動脈瘤の治療成績は、周術期合併症を 除いては満足できるものであった。

\section{PP-208 2 腎動脈瘤に対する 3 手術例}

天理よろづ相談所病院 心臟血管外科

$\begin{array}{lll}\text { 五十嵐 仁、山中 } & \text { 一朗、仁科 健、 } \\ \text { 金光 尚樹、廣瀬 圭一、中塚 大介、 } \\ \text { 堀 裕貴、安水 大介、上田 裕一 }\end{array}$

【背景】腎動脈瘤は $20 \mathrm{~mm}$ を超えると破裂の危険性が あり、治療の対象となると言われている。近年、血 管内治療の進歩により腎動脈瘤に対してコイル塞栓 術、covered stent などの新しい治療も行なわれてい るが、未だ手術となる症例は少なくない。今回我々 は 3 例 4 瘤に対して、瘤切除・血行再建を行い、良 好な経過を得られたので、腎動脈瘤への到達経路・ 腎保護液・術式について若干の文献的考察を加えて 報告する。【症例 1】66 歳女性。強皮症による間質性 肺炎の精查中に、右側瘤径 $27 \mathrm{~mm}$ 、左側瘤径 $35 \mathrm{~mm}$ の両側腎動脈囊状瘤を指摘された、両側 Chevron 切 開にて approach し、両側腎動脈を露出。右側腎動脈 は腎保護液を注入し、囊状瘤を本幹ごと切除し、端 端吻合した。左側腎動脈は腎保護液を注入し、囊状 瘤を部分切除・閉鎖した。腎阻血時間はそれぞれ 20 分、10 分であった。【症例 2】85 歳男性。74歳時に遠 位弓部大動脈瘤に対して人工血管置換術を行った。 経過フォロー中に、左側腎動脈真性瘤の急速な拡大 を認め、瘤径 $63 \mathrm{~mm}$ であった。左側 Chevron 切開に て approach し、左側腎動脈を露出。腎保護液を注入 し真性瘤を切除し、採取していた大伏在静脈を用い て interpose した。腎阻血時間は35 分であった。【症 例 3】68 歳男性。他疾患の精査中に、瘤径 $22 \mathrm{~mm}$ の 右側腎動脈囊状瘤を指摘された。腰部斜切開にて後 腹膜経路で approach し、右側腎動脈を露出。腎保 護液を注入し、囊状瘤を部分切除・閉鎖した。㹂阻 血時間は 20 分であった。【考察】腎動脈への到達経路 として、泌尿器科的 approach である Chevron 切開・ 腰部斜切開を用いた。いずれの症例も良好な視野を 得ることができた。特に両側腎動脈瘤に対する両側 Chevron 切開は有用であった。また、腎保護液とし て $4^{\circ} \mathrm{C}$ 乳酸リンゲル液にマンニトール・ステロイドを 混合したものを用いた。平均腎阻血時間は 21.3 分で あったが、術後 $\mathrm{eGFR} \cdot \mathrm{BUN} \cdot \mathrm{Cre}$ の悪化を認める ことなく経過した。腎動脈瘤に対する血管内治療と して、コイル塞栓術では腎梗塞がほぼ必発である。 また、covered stent では国内では使用可能な device が限られており、遠隔成績も不明であることを考慮 すると、手術は未だ有用な治療であり、特に腎門部 における腎動脈瘤では第一選択と考えられる。【結 語】腎動脈瘤 3 例 4 瘤の手術を経験し、良好な結果を 得た。 
PP-209 宛

High Risk 胸腹部大動脈瘤に対する Debranching TEVAR の初期成績の検討

\section{1 日本医科大学附属病院 心臟血管外科 \\ ${ }^{2}$ 日本医科大学附属病院 放射線科}

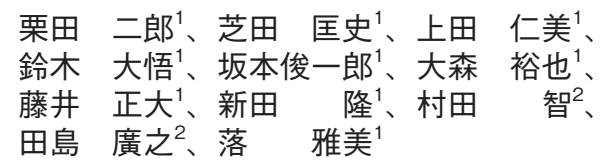

【背景】近年、胸腹部大動脈瘤の手術成績は向上して いるものの、依然として侵襲の高い手術である。術後、 長期管理から合併症を招き、難渋することも少なく ない。当院では 2009 年より再手術例、破裂例、低肺 機能などを合併した High Risk な胸腹部大動脈瘤に 対し、開腹下に腹部分枝再建バイパスを併施した Debranching TEVARを施行してきた。【対象】2009 年 4 月以降、腹部 4 分枝のいずれかに Debranching TEVAR を施行した 8 例を対象とした。年齢 $72.9 \pm 8.8$ 歳、Crawford Type1 1 例、Type2 2 例、Safi Type5 5 例。解離 1 例、炎症瘤 1 例、緊急 2 例 (破裂)、人 工血管置換術後(腹部大動脈瘤 2 例、胸部大動脈瘤 1 例)、透析症例 2 例、冠動脈バイパス術後 1 例。【方法】 まず開腹下に腸骨動脈領域から Landing Zone にか かる腹部分枝に人工血管を用いてバイパスした後に、 一期的あるいは二期的に TEVARを施行した。【結 果】手術死亡 2 例 ( 1 例は破裂瘤に対する上腸間膜動 脈へのバイパス症例で術後、対麻瘏および腸管虚血 による敗血性ショック、もう 1 例は Access route で ある外腸骨動脈からの出血および腸管虚血を伴った 多臟器不全)。遠隔期死亡 1 例(慢性腎不全のため術 後 1 年 4 只月後死亡)。脳梗塞 1 例、脊䯣障害 1 例。 エンドリーク Type2 1 例。【考察】Debranching TEVARの初期成績は概ね良好であったが、緊急破 裂症例と慢性解離症例の 2 例を失った。分枝血流の 評価のために Occlusion test を施行し、腹望動脈へ のバイパスを省略しえた症例もあったが、術後早期 グラフト閉塞により腸管虚血に陥った症例もあり、 確実な Access routeの確保や腹部分枝吻合部露出、 グラフト走行や吻合の工夫は今後の課題である。ま た、Debranching TEVAR の遠隔期の治療成績は不 明であり、graft 開存の確認、エンドリークの有無、 臓器症状の変化を十分観察する必要がある。しかし ながら、Debranching TEVARは、合併症を伴う High Risk 胸腹部大動脈瘤に対して従来の人工血管 置換術では耐術困難と判断される症例においても治 療範囲が広げられる可能性が示唆された。

\section{PP-210 㲾 左開胸手術における術中の肺保護と左心バ イパスによる酸素化の改善について}

\author{
1川崎幸病院 川崎大動脈センター 心臓血管外科 \\ 2 川崎幸病院 麻酔科 \\ ${ }^{3}$ 川崎市立川崎病院 麻酔科
}

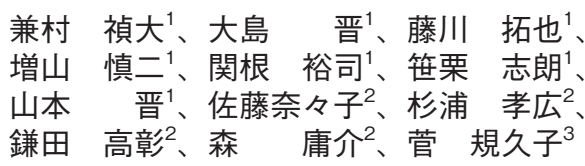

【目的】左開胸手術では、分離片肺換気が要求され術 中の肺保護と酸素化について難渋することが多い。 今回、当科における術中の外科的肺保護法と、補助 循環としての左心バイパス法による酸素化の改善に ついて検討した。【対象と方法】2009年 12 月から 2010 年 09 月までの 30 例。男性 23 例、女性 7 例。 年齢 $64.6 \pm 12.9$ 歳。術式は下行大動脈置換術 15 例、 胸腹部大動脈置換術 15 例 (うち 13 例で腹部分枝を再 建)。COPDを 5 例、喘息を 3 例に認めた $(1$ 例のみ 重複)。肺保護は、肺勒帯等に対する剥離操作を最小 限とし、肺全体をガーゼで覆い劧引し、術中は極力、 圧排を避け、分離換気終了時、加圧しながら表面に 水をかけリークの有無を確認した(動画を供覧予定)。 これに対し術後 3 日以内の左側の無気肺・気胸・肺 出血の有無を胸部レントゲン画像により retrospectiveに検討した。左心バイパスによる酸素化改善に ついては、右橈骨動脈に挿入した動脈圧ラインから 採血し、左心バイパス開始前 (pre- $\mathrm{PaO} 2$ )、左心バイ パス中 (LHB- $\mathrm{PaO} 2)$ 、左心バイパス終了後 (post$\mathrm{PaO} 2)$ の $\mathrm{PaO} 2$ の変化を検討した。【結果】手術時間 $383.3 \pm 131.2$ 分、左心バイパス時間 $102.2 \pm 46.4$ 分、 大動脈遮断時間 $75.9 \pm 29.5$ 分。癒着剥離のさいに損 傷し、左下葉切除を追加した症例を 1 例だけ認めた。 無気肺は 13 例(発症平均日数は術後 $1.3 \pm 1.5$ 日) に、 気胸は 1 例(術後 5 日目に両側発症)に認めたが、肺 出血は認めなかった。左心バイパスによる酸素化の 改善については、pre- $\mathrm{PaO} 2$ 269.5 $495.5 \mathrm{mmHg}$ 、 LHB- $\mathrm{PaO} 2427.5 \pm 78.2 \mathrm{mmHg}$ 、 post- $\mathrm{PaO} 2357.2 \pm$ $128.1 \mathrm{mmHg}$ であり、pre-群をコントロール群とし、 LHB- 群、post- 群において Student の t 検定 5\%で有 意であり、左心バイパス下において明らかな酸素化 の改善を認めた。【結語】左開胸手術時の当科の術野 での肺保護法は、周術期を通して呼吸器合併症に対 し有効と考えられる。また左開胸時の補助循環とし て、本邦では様々な理由から超低体温循環停止法、 部分体外循環法を使用が多いと考えられる。一般的 には人工肺を使用しない左心バイパス法は、前二者 と比して特に呼吸機能低下例で不適当と見なされて きた。しかし分離換気時でも $\mathrm{PaO} 2$ 值を低下させる のではなく逆に大きく改善させており、左開胸分離 換気が必要な大動脈置換術における補助循環として、 麻酔科医に十分な経験と技量があれば、手術全体を 簡素化出来ることと合わせて、極めて有用であるこ とが示唆された。 


\section{PP-211 々 \\ 当科における開心術術後胸部正中創手術部 位感染対策の変遷}

東京医科歯科大学 心臓血管外科

川口悟、水野 友裕、田村 清、

八丸 剛、渡邊 大樹、藤原 立樹、

藤田 修平、横山 賢司、荒井 裕国

【背景】近年の開心術患者の高齢化重症化に伴い、手 術部位感染 (surgical site infections：SSI) は重大な合 併症となっている。今回当院での SSI 対策の变遷に ついて報告する。【対象】当科で 2000 年頃より SSI の 流行があり、その度ガイドラインのより厳密な遂行 や運用の徹底を図る対策を行ってきた。手術直前の 除毛、フードの着用、黄色ブドウ球菌の術前鼻腔保 菌状態に対する除菌、予防的抗菌薬の皮切直前およ び 3 時間毎投与などが導入されていた。非流行期の I 期 (2007 年 1 月〜 12 月、 173 例)、対策に変更がない ものの SSI が流行した II 期 (2008 年 1 月〜 2010 年 8 月、 461 例)、感染対策チームの推奨で 3 時間毎の手 袋交換、アルコール手指消毒の徹底を開始、ドレー ピングに微生物シーラント(インテグシール)を導入 した III 期 $(2010$ 年 9 月〜 2012 年 4 月、262 例)に分 け各期の胸骨正中切開創の SSI の詳細を検討した。 【結果】I期表層 SSI(胸部正中皮下) 0 例 $(0 \%)$ 、深層 SSI (胸 骨 感染) 2 例 (1.2\%), 臓器 SSI(縦 隔炎) 0 例 (0\%)、全 SSI 2 例 (1.2\%)であったが、II 期では表層 4 例 $(0.87 \%)$ 、媣層 9 例 $(2.1 \%)$ 、臓器 $(0.70 \%)$, 全 SSI 16 例 (3.7\%) と増加傾向にあった。III 期では表層 1 例 $(0.38 \%) 、$ 深層 9 例 $(0.76 \%)$ 、臓器 $(2.7 \%)$ 、全 SSI 10 例 (3.8\%) と感染対策にも関わらず明らかな SSI の減 少は認めなかった。起因菌に関しては I 期-II 期では 18 例のうち、グラム陽性菌が11 例 (MRSA：4、 MRSE : 3、MSSA : 1、Corynebacterium : 3)であっ たが、III 期では全 SSI 10 例のうちグラム陰性桿菌 4 例 (緑膿菌 3 例、Acromobacter 1 例) と耐性グラム陰 性桿菌が増加、縦隔炎に至る重症例が多かった。耐 性菌対策として 2012 年 5 月以降さらに予防的抗菌薬 の使用を $\mathrm{ABPC} / \mathrm{SBT} 6$ 日間から CEZ3 日間に短縮し ている。検査室の協力で $\mathrm{CRP}$ より感染特異性の高い プロカルシトニンをモニターし抗菌剂の至適使用期 間を見定める工夫を開始している。【結語】当院 SSI 対策はガイドラインの遵守を基本とし、定期的なサー ベイランスを ICT の協力の元に行っている。施設毎 のマニュアルの作成とその運用の徹底が重要である と考える。

\section{PP-212 乞 当院における開心術後感染対策と正中創感 染における新たなる問題点}

\section{東京慈恵会医科大学附属病院 心臓外科}

\author{
儀武 路雄、坂本 吉正、長堀 隆一、 \\ 松村 洋高、木ノ内勝士、成瀬瞳、 \\ 中尾 充貴、橋本 和弘
}

当科の開心術における糖尿病合併率は、08 年 41.1 、 $09^{\prime}$ 年 $35.8 、 10^{\prime}$ 年 $41.1 、 11^{\prime}$ 年 $34.5 \%$ と高值を示して いる。さらに透析症例比率も各年、5.4、12.4、11.6、 $9.9 \%$ と高率化しており、易感染性症例が多いと言え る。SSI 発生は患者のみならず病院にとっても大きな 負担であり、感染対策室と共同で予防に取り組んで きた。下記対策によりいったんSSI 発生の減少が見 られ、効果があったと判断していたが、ごく最近従 来のパターンからは外れた縦隔炎が散発してきてお り、新たな問題点としてとらえている。【対象】当科 ではSSI 基本対策として a. 入院前鼻腔、 b. 術前シャ ワー浴、c. 手術室での剃毛、d. 術野消毒 : ベンクロ ジドアルコールにて前消毒＋イソジン消毒、e. 抗生 剂：CEZ、術当日は術直前及び 3 時間ごと、術後第 4 病日で終了。f. 術中 3 時間ごとの手袋交換と 2 重手 袋の一部併用、g. 閉創時、充分な洗浄とモノフィラ メント吸収糸による単結紮の多用、h. 持続的インス リン投与による血糖コントロール、i. ICU での感染対 策 ・歯科口腔ケアーチームの回診、j. 理学療法士指 導による早期の術後リハビリテーション開始等を 行っている。この対策が取られた 2010 年 1 月から本 年 3 月末までの、成人開心術 304 症例を対象とした。 【結果】この間、縦隔炎および感染の治療に際し胸骨 ワイヤーの一部抜去が必要となった症例は、11 例 (3.2\%)であった。この内 4 例が MRSA 感染であった。 さらに 1 例にMRSEを検出したが、残りの 6 例は MSSA、Ec. Fecalis 等の耐性菌以外の感染であった。 新たな傾向として、胸骨・皮膚所見にそしく、発熱 後の CT 検査で縦隔炎が診断されること、または 11 例中 5 例に見られたように退院時には明らかな創部 の問題が見られず、退院後に発症することが見られ た。共通の傾向としては一人暮らし、糖尿病を含め 病識の極めてそしい患者であり、退院後の指導が問 題となっている。幸い、感染制御部、形成外科等と の連携による迅速な治療を行ない、全例軽快退院と なっている。【結語】様々な対策により、減少傾向に あると思われていた縦隔炎であるが、新しい傾向が 見られ、更なる検討が必要となってきている。術前 においては、監視培養の強化(臍培養追加)、切開予 定部位のケアの見直し(シャワー・洗浄方法)、術後 に関しては、回診時手指衛生の再度獄底、患者自身 による創部管理の指導等の対策を行い、改善に努め ている。 


\section{PP-213}

\section{当院における開心術後縦隔炎の診断と治療 についての検討}

\author{
大阪大学大学院医学系医学科 心臓血管外科 \\ 芝本愛、戸田 宏一、宮川 繁、 \\ 西宏之、吉川 泰司、福嶌 五月、 \\ 吉岡 大輔、斉藤 哲也、上野 高義、 \\ 倉谷徹、澤芳樹
}

【背景・目的】胸骨正中切開後の縦隔炎は開心術にお ける重大な合併症の 1 つであるが、治療介入の判断 はしばしば困難である。当科では、発熱等の臨床症 状に加えて画像上縦隔に液貯留を認めるもの、術後 のドレーン・ペースメーカーワイヤー抜去時の培養 で菌が検出された症例に対しては縦隔炎を疑い、積 極的に外科治療を行ってきた。今回、外科治療を要 した縦隔炎症例を retrospectiveに検証した。

【対象・方法】 2002 年 1 月〜 2012 年 6 月に施行した開 心術 3397 例のうち、縦隔炎に対して手術を行なった 症例は 41 例で(発症率 $1.2 \%$ )、このうち VAD 装着患 者・小览症例を除く 27 症例を対象とした。これらの 症例に対して患者背景や起因菌、発症時期、開心術 後の炎症所見の推移、各種培養結果、術式、術後の 転帰を検討した。

【結果】平均年齢 $63 \pm 13$ 歳、男女比 19: 8。開心術の 内訳は CABG7 例、大血管 7 例、并膜症 5 例、複合 手術 8 例。（うち緊急手術 7 例、再手術 11 例。平均 手術時間 $499 \pm 185$ 分、体外循環時間 $213 \pm 123$ 分、 平均出血量 $3874 \pm 2783 \mathrm{ml}$ 、平均輸血量 $5117 \pm$ $3655 \mathrm{ml}$ 。) 糖尿病合併 9 例、維持透析 7 例、ITA 使用 9 例、肥満 $(B M I \geqq 25) 8$ 例、うっ血性心不全 (NYHA $\geqq 3) 5$ 例、low $\mathrm{EF}(\leqq 30 \%) 2$ 例、気管切開後 2 例、 ステロイド常用者 1 例であった。初回手術から縦隔 炎手術までは平均 $17 \pm 11$ 日で、8 14 日が 16 例と大 半を占めた。起因菌はブドウ球菌が 7 割以上であっ た。ほぼ全例で WBC/CRP は術後 2 年 4 日に一旦 peak 值を示し、その $2 \sim 5$ 日後に再上昇する傾向が見 られた。また 14 例で CT 上縦隔炎を疑う所見を認め た。血液培養陽性率は $12.8 \%$ (4 例)。ドレーン・ペー スメーカーワイヤーの陽性率は 44.4\% (12 例) であっ た。縦隔炎手術では大網充填を 25 例、腹直筋皮弁を 1 例に行い、 7 例で Vaccum Assisted Closure を併用 した。手術死亡 0 例。病院死亡は 3 例であったが、 いずれも縦隔炎に起因するものではなく、全症例で 縦隔炎は治癒した。

【結語】今回の検討では、縦隔炎患者では術後 2 週間 以内に 2 峰性の炎症所見の上昇を認める例が多かっ た。診断には CT およびドレーン等の培養結果が有 用であった。大網充填を標準術式とした早期外科的 介入を積極的に行うことにより、良好な治療成績を 得ることが出来た。

\section{PP-214 光 心臓血管手術後の手術部位感染に対する皮 下ドレーン留置の効果の検討}

\section{公立大学法人福島県立医科大学 心臓血管外科}

黒澤 博之、佐戸川弘之、高瀬 信弥、

三澤 幸辰、若松 大樹、瀬戸 夕輝、

五十嵐 崇、籠島 彰人、藤宮 剛、

新城宏治、横山斉

【背景と目的】心臓血管手術後の手術部位感染 (Surgical site infection：SSI)、特に深層 SSI の合併は余語 を著しく悪化させうる合併症である。当科では SSI 合併頻度が増加したことから、2010 年 2 月より皮下 ドレーン留置を導入した。今回は皮下ドレーン留置 前後でのSSI 発生率の変化を検討すること、また、 SSI に対する危険因子を検討することを目的とした。 【対象と方法】2007 年から 2011 年までに当科で胸骨 正中切開を伴う心臓血管手術を行った 483 例 (平均年 齢 $66 \pm 12$ 歳、男性 287 例、女性 196 例) を胸部正中 創閉創時に皮下ドレーンを留置した留置群(196 例) と 留置しなかった非留置群 (287 例)に分け、SSI の発生 率を後ろ向きに比較検討した。また、SSI 発生に対す る危険因子を検討した。【結果】2007 年から 2011 年 の全体での SSI 発生は 35 例 (7.2\%)、表層 SSI(S-SSI) 26 例 (5.4\%)、深層 SSI(D-SSI) 9 例 (1.9\%)であった。 留置群と非留置群に分け検討すると、周術期因子で は高血圧症 $(71.4 v s .59 .9 \% 、 \mathrm{p}=0.0094) 、$ 腎機能障害 $(\mathrm{Cr}$ $\geqq 1.5)(5.6 v s .13 .2 \% 、 \mathrm{p}=0.00025) 、$ 慢 性 透 析 (2.0vs.7.7\%、 $\mathrm{p}=0.00076)$ 、術後最高血糖值 $(226 \pm$

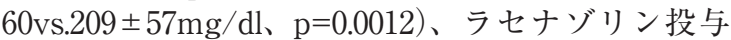
日数 $(5.3 \pm 2.1 \mathrm{vs} .4 .7 \pm 2.1$ 日、 $\mathrm{p}=0.0029)$ に有意差を認 めた。また SSI 発生率は 11 例 (5.6\%) vs.24 例 (8.4\%)、 S-SSI9 例 (4.6\%)vs.17 例 (5.9\%)、D-SSI2 例 (1.0\%) vs.7 例 $(2.4 \%)$ であり、両群間に差を認めなかった。 SSI 発生に対する危険因子は、多変量解析の結果、 高血圧症合併 $(\mathrm{OR}=2.8 、 1.1 \leqq \mathrm{OR} \leqq 7.0 、 \mathrm{p}=0.031)$ 、 腎機能障害 $(\mathrm{OR}=2.7 、 1.2 \leqq \mathrm{OR} \leqq 6.3 、 \mathrm{p}=0.019)$ 、閉 塞性換気障害 $(\mathrm{OR}=2.8 、 1.2 \leqq \mathrm{OR} \leqq 6.9 、 \mathrm{p}=0.019)$ が 有意であった。また、D-SSI に関しては、腎機能障害 $(\mathrm{OR}=6.4 、 1.6 \leqq \mathrm{OR} \leqq 25.7 、 \mathrm{p}=0.0088) 、 \mathrm{CPB}$ 時 間 $>240$ 分 $(\mathrm{OR}=6.3 、 1.0 \leqq \mathrm{OR} \leqq 38.6 、 \mathrm{p}=0.046)$ 、 術 後 $\mathrm{MaxCRP}>20(\mathrm{OR}=4.2 、 1.1 \leqq \mathrm{OR} \leqq 16.6$ 、 $\mathrm{p}=0.042$ ) が有意な危険因子としてあげられた。【結 語】皮下ドレーン留置導入前後でのSSI 発生率は 8.4\%から 5.6\%へ減少したが、統計学的な有意差を認 めなかった。多変量解析の結果、高血圧症合併、腎 機能障害 $(\mathrm{Cr} \geqq 1.5)$ 、閉塞性換気障害が SSI 発生に 対する有意な危険因子と考えられた。また、縦隔炎 に関しては、腎機能障害 $(\mathrm{Cr} \geqq 1.5) 、 C P B$ 時間 240 分以上、術後 CRP 20 以上が有意な危険因子となっ た。 


\section{PP-215 文 \\ 心臓血管外科手術後の無石胆囊炎のリスク 因子解析}

\section{山形大学医学部付属病院 第二外科学講座}

廣岡 秀人、内田 徹郎、吉村 幸浩、

金哲樹、前川 慶之、宮崎 良太、

水本 雅弘、安本匠、高橋愛、

貞弘 光章

【背景】無石胆囊炎は胆石を認めない胆囊炎として発 症し、集中治療室での管理を必要とするような重症 心臓手術後の患者で多く報告されている。【目的】今 回、我々は無石胆囊炎の臨床像を明らかにするため、 心臓血管外科手術後に発症した無石胆囊炎の術前・ 術中のリスク因子を解析したので報告する。【方法】 対象は 2007 年 1 月から 2011 年 12 月まで、当院で心 臓・大血管手術を施行された連続 586 例。無石胆囊 炎の罹患率、重篤度、起因菌、および在院死に対す る影響を解析した。術前因子として、ASA 分類、併 存疾患、採血デー夕、鼻腔保菌状態を、また術中因 子として術式、手術時間、体外循環時間、術中最低 体温などを評価しリスク因子の解析を行った。【結 果】586 例中、9 例 (1.53\%)の、経皮的ドレナージを必 要とした胆道感染症患者を無石胆囊炎と診断した。 発症時期は中央值 17.1 病日、死亡率は $17.4 \%(\mathrm{p}<$ 0.001、OR 8.80、95\%C.I. 2.1-36.8) であった。起因菌 は MSSA 1 例、Corynebacterium 1 例、Acinetobacter baumanii 1 例、Bacteroides vulgatus 1 例、 Krebsiella pneumonia1 例、Candida albicans1 例 で あり、残り 3 例では起因菌を同定できなかった。こ のうち 2 例が血液培養からも同種の菌が同定され、 敗血症を合併していた。単変量解析では胸部大動脈 手術 $(\mathrm{p}<0.05)$ 、 Alb 低值 $(\mathrm{p}<0.05)$ 、膠原病の既往 $(\mathrm{p}$ $<0.05)$ 、術前ステロイド内服歴 $(\mathrm{p}<0.01)$ が無石胆 囊炎のリスク因子となっており、多変量解析では独 立したリスク因子として胸部大動脈手術が挙げられ た $(\mathrm{p}<0.01 、 O R$ 5.4、95\%C.I. 2.1-13.5)。【考察】無石 胆囊炎は頻度は少ないものの、対応が遅れた場合胆 囊破裂、敗血症などへと重篤化する。重症患者では 鎮静・鎮痛により腹部所見がマスクされるため、術 前低栄養状態の患者や、膠原病の既往、ステロイド 投与歴のある患者で、胸部大動脈などの侵襲の過大 な手術後に不明熱、胆道系酵素上昇を認めた場合、 積極的に無石胆囊炎を疑い、速やかに適切な治療を 行う必要がある。
PP-216 is

術前口腔ケアは術後肺炎を予防できるのか？

大阪厚生年金病院 心臟血管外科

青山 孝信、藤井 弘通、髭 勝彰、

笹子 佳門

【背景】周術期口腔ケアは術後肺炎の発症頻度を減少 できるなど有用であるとされ、2012 年度からは周術 期口腔機能管理料として診療報酬が請求できるよう になった。当院は歯科を有する総合病院として、 2010 年 10 月から開心術の待機手術症例に歯科受診 による術前口腔ケアをすすめてきた。術前口腔ケア 導入前後での術後肺炎の発生率について検討した。

【対象】 2008 年 5 月から 2012 年 7 月までにおける待 機手術のうち、胸骨正中切開を行った心大血管手術 症例 241 例を対象とした。ただし術後 5 日以内に肺 炎を除く重篤な合併症 (LOS や虚血性腸炎など) で死 亡した症例は除外した。術後肺炎は画像上で明らか な肺炎像を認め抗生剂治療を要したものとした。術 前口腔ケアを施行していない群 145 例 (A 群 ; 男 / 女 $=91 / 54 、 67 \pm 12$ 歳) と施行した群 96 例 (B 群; 男 / 女 $=67 / 29 、 70 \pm 9$ 歳)の 2 群間で比較検討した。B 群 では術前歯科受診により口腔ケアのみならず必要が あれば抜歯等の治療を行った。また術後(挿管中およ び抜管後)の口腔ケアに関しては両群とも同様に施行 した。術前因子とその割合は糖尿病: 43/30(A 群 /B 群、\%、以下同様)、高血圧: 75/76、高脂血症： 50/51、高尿酸血症: 29/27、契煙歴: 57/56、透析: 18/7、ステロイド内服: $10 / 2$ であり、いずれも有意 差は無かった。

【結果】48時間以内の抜管症例は $\mathrm{A}$ 群 109 例 (75.2\%)、B 群 73 例 $(76.0 \%)$ であった。術後肺炎を 発症した症例は A 群 10 例 (7.9\%)、B 群 6 例 (6.3\%) であった。うち挿管中に肺炎を発症した症例は A 群 6 例 (4.1\%)、B 群 4 例 (4.2\%) であった。いずれも 2 群間に有意差は認めなかった。

【まとめ】周術期の口腔ケアは術後肺炎を減少させる と言われているが、今回の検討では術前口腔ケアは 術後肺炎の発症頻度には影響していなかった。本検 討の 2 群はともに術後口腔ケアを行っており、術後 肺炎には術後の口腔ケアがより関与している可能性 がある。しかし術前の歯科受診にて口腔ケアのみな らず治療を行うこともあり、感染性心内膜炎の原因 の一つである口腔からの感染を予防することにもな り得ると考えられ、今後も術前を含めた周術期口腔 ケアを継続していく方針である。 
PP-217 文

\section{超高齢者(85 歳以上)の心臓大血管手術の早 期、中期成績}

高松赤十字病院 心臓血管外科

西村 和修、榊原裕、村中 弘之、

黒川 俊嗣

【目的】近年高齢化社会を迎え、85 歳でも平均余命は 男 6.2 年、女 8.3 年(平成 22 年厚労省簡易生命表より) となっている。高齢者の手術における手術適応につ いては、救命の他にその患者のライフスタイルや QOL も考慮すべきであると考える。当院で施行した 超高齢者 (85 歳以上) 症例の術後 QOL について検討 した。【方法】2007 年 1 月から 2012 年 8 月までに当院 で施行した、 85 歳以上の心大血管手術 27 例 (28 手術) を対象とした。平均年齢 $87 \pm 2$ 歳 (最高齢 91 歳)、男 女 : $8 / 19$ 、術前 NYHA は 2 度 : $5 、 3$ 度 : $13 、 4$ 度 : 10。緊急／準緊急：10、待機：18。疾患のカテゴリー は虚血性 ( I ): 5、弁膜症 $(\mathrm{V}):$ : 18、疾患のカテゴリー は虚血性 ( I ): 5、弁膜症 $(\mathrm{V}): 12 、 \mathrm{~V}+\mathrm{I}$ : 6、大血管 $(\mathrm{A})$ : 5 。施行手術は単独 CABG: 4(うち OCPAB: 3 )、VSP 閉 鎖: 1、AVR: 14 (+CABG 含 む)、MVR \pm TAP: 3、 3 弁: 1、DAA に対する上行置換: 2 , 上行弓部置換 : 1, 弓部破裂； 1 , 仮性瘤に対するステント留置：1。 術前評価ポイントとしては、医学的条件以外、日常 生活自立度、認知症の有無、家族のサポートを重視 して適応を決定した。術後管理の注意として、甲状 腺機能、嬹下評価をルーチンに行っている。【成績】 早期手術成績は 30 日以内死亡 : 1 、在院死 : 4 でトー タル $18 \%$ の死亡率。手術時期別では緊急／準緊急： $3 / 10(30 \%)$ 、待機 : $2 / 18(11 \%)$ 。術後挿管時間 : 24 \pm 23 時間(中央值: 10 時間)、ICU 滞在日数 $4.6 \pm 1.9$ 日 (中央值 : 4 日) 、術後在院日数 $29.3 \pm 11.8$ 日 (中央值： 25 日)。主な合併症として、新たな Af：10、LOS: 7、 肺炎： 4 など。退院した 22 例の中期成績では脳出血 による遠隔死：1 があり、他はすべて生存。平均観察 期間 28 ケ月の時点で、NYHA 1 度: $12 、 2$ 度 : 6 、 寝たきり：2、不明：1であった。【結論】超高齢者の 手術成績は概ね良好であり、術後数年の QOL も満足 すべき結果であった。今後、適応拡大について、慎 重に検討する必要がある。

\section{PP-218 光 \\ 重症呼吸不全を合併した開心術における術 後呼吸管理の新しい選択枝}

\author{
名古屋掖済会病院 心臓血管外科 \\ 伊藤 英樹、平手 裕市、芦田 真一、 \\ 内田亘、帠井 真人
}

【はじめに】呼吸機能障害を合併する症例では、手術 死亡が増加し、肺や胸骨創部合併症などの増加によ り、術後管理に難渋することがある。我々は間質性 肺炎と肺気腫を基礎疾患に持ち、重症呼吸機能障害 を呈していた急性大動脈解離に緊急手術を施行した。 Proportional assist ventilation(PAV) と nasal high flow (NHF)を取り入れることで、困難と考えられた呼吸 器離脱が可能となり、気管切開を必要とせず、独歩 退院したので、その効用を含め報告する。【症例】68 歳男性。職歴に約 20 年間の家屋解体業があり、アス ベスト吸引歴あり。契煙歴は 20 本 / 日 $\times 50$ 年。背 部痛にて来院し、造影 CT にて急性大動脈解離 (StanfordA 型) と診断。肺野は気腫状変化と網状間質性陰 影を広範囲に認めた。来院時 room airにて $\mathrm{SpO}_{2} 70 \%$ 、経鼻 $4 \mathrm{~L} /$ 分での動脈血ガスにて $\mathrm{PaO}_{2}$ $52.5 \mathrm{mmHg} 、 \mathrm{Pco}_{2} 36.8 \mathrm{mmHg}_{\text {。 }}$ 残存肺機能で手術に 耐えうるか懸念されたが、緊急対応にて上行大動脈 置換 + 大動脈弁形成術を施行。右大腿送血、上下大 静脈脱血にて人工心肺確立。手術時間 264 分、人工 心肺時間 165 分、大動脈遮断時間 100 分、循環停止 時間 23 分。帰室後 PC/BiPAP で管理していたが、 肺コンプライアンスが悪く、高 PEEP が必要であっ た。その後も離脱条件を満たすに至らなかったので、 呼吸器設定をPAVに変更し、吸気努力に応じた換 気サポートを行う事で、自発呼吸の長所を活かし、 抻管時間 44 時間で抜管できた。抜管後はNHF を使 用する事で、低気道陽圧を供給し、喀痰排出を容易 にした。その後経過に問題なく、術後 46 日で独歩退 院した。【まとめ】重症呼吸機能障害を呈した急性大 動脈解離に緊急手術を施行し、耐術退院した。術後 管理に難渋すると予想されたが、PAVにて長期人工 呼吸管理とそれに伴う合併症を回避し、NHFにて抜 管後の呼吸状態を安定させた。PAV、NHF は呼吸機 能障害患者の術後管理ツールとして新しい選択枝と なりうる事が示唆された。

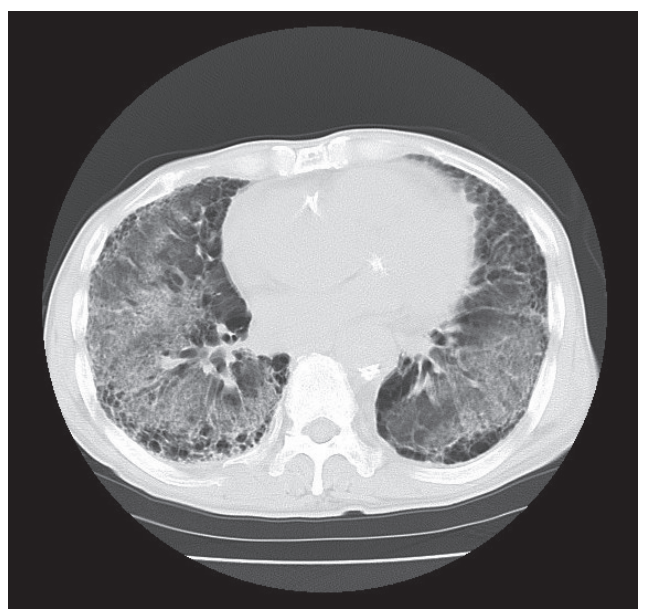




\section{PP-219 元 \\ 当院における早期回復・早期退院を目指した 周術期管理の工夫}

\author{
1社会保険紀南病院 心臓血管外科 \\ 2社会保険紀南病院 麻酔科 \\ 山本 淳平 ${ }^{1}$ 、樋口卓也 ${ }^{1}$ 、阪越 信雄 ${ }^{1}$ 、 \\ 中川 雅史 ${ }^{2}$
}

【はじめに】消化器外科領域では早期回復を目指した ERAS プログラムが導入されつつある。当科におい ても「フェンタニルを併用したレミフェンタニル主体 の Fast-track 麻酔」と「術翌日歩行訓練を含む早期り ハビリテーション」等を組み合わせた『心臓手術後の 回復力強化 (ERAC : Enhanced Recovery After Cardiac-surgery) プログラム』を実施している。これに関 連して昨年の本学会では、術翌日の ICU 内歩行訓練 が動脈血酸素濃度を増加させること、呼吸動態改善 に寄与する可能性があること、を報告した。今回は、 ERAC プログラムによる周術期管理が、実際に早期 の回復・退院に繋がっているか否かを検討した。【対 象】 2005 年 12 月から 2012 年 6 月までに当院で人工 心肺を使用した開心術 408 例のうち、大血管症例 · 感染性心内膜炎 - 重症脳障害例 - PCPS 挿入症例を 除外した 284 例を対象とした。これらをフェンタニ ル主体の麻酔を行った F 群 (64 例)、レミフェンタニ ル主体の麻酔を行った R 群(135 例)、ERAC 管理を 行った $\mathrm{E}$ 群(85 例)の 3 群に分けた。 $\mathrm{F}$ 群 $/ \mathrm{R}$ 群 $/ \mathrm{E}$ 群の平均年齢は 68 歳 $/ 70$ 歳 $/ 74$ 歳で、 $\mathrm{E}$ 群がやや 高齢であった。男女比・疾患・緊急手術の比率・術 前合併症等の術前状態に差はなかった。【方法】早期 回復の指標として各群における術翌日 ICU 退室率・ 術後 14 日以内の退院率 - 術後合併症発生率を比較検 討した。【結果】 $\mathrm{F}$ 群 $/ \mathrm{R}$ 群 $/ \mathrm{E}$ 群を比較すると、手 術室抜管例は $8 \% / 56 \% / 75 \%$ と R 群・ E 群で高值 であった。術翌日 ICU 退室率は 32\% / 49\% / 77\% であり、F 群に比べてオッズ比が R 群は $2.0(95 \% \mathrm{CI}$ 、 1.1 - 3.8)、E 群は 7.4(95\%CI、3.5 - 15.4)に増加した。 術後 14 日以内の早期退院率は $27 \% / 41 \% / 48 \%$ で あり、F 群に比べてオッズ比が R 群は 1.9 (95\%CI、0.97 - 3.7)、E群は 2.6(95\%CI、1.2 - 5.2)に増加した。 術後合併症の発生頻度、術後 30 日以内の再入院率は 各群間に差を認めなかった。【結語】ERAC プログラ ムによる周術期管理を行うことにより ICU 早期退室 率・早期退院率は上昇した。一方で、術後合併症や 早期再入院率は増加しなかった。ERAC プログラム は心臓手術後の回復力強化に有用である。

\section{PP-220 文 心臓血管手術後心房細動に対する adaptive servo-ventilation の効果}

\author{
1 広島大学病院 診療支援部 リハビリテーション \\ 部門 \\ ${ }^{2}$ 広島大学大学院 医歯薬保健学研究科応用生命 \\ 科学部門 外科学
}

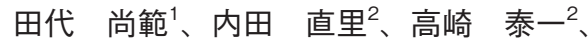
高橋 信也 ${ }^{2} 、$ 片山桂次郎 ${ }^{2} 、$ 倉岡 正嗣 ${ }^{2}$ 、
渡谷 啓介 2 、ジェコナイチョフ、黒崎 達也 ${ }^{2} 、$
今井 克彦2、末田泰二郎 ${ }^{2}$

【目的】心臓血管手術後心房細動 (Postoperative AF = POAF) は、最も頻度が高い合併症であり、周術期の 死亡率も悪化するとされる。POAF は、高齢、高血 圧などの術前因子の他に心房虚血などの手術因子、 術後容量負荷や後負荷など術後因子や炎症作用など により心房構造基質が変化し、自律神経系の不均衡 などがトリガー因子となって発症するものと考えら れている。NPPVの一方式である adaptive servoventilation(ASV) は、過剩な静脈還流量および左室 壁圧較差の軽減、虚脱肺胞の再拡張を認め、適切な 換気量を維持することで、呼吸仕事量を軽減し、交 感神経活性抑制効果が期待されている。本研究では、 弊害の少ない非薬物療法である ASV を使用し術後の 呼吸管理を行うことで、POAF の発症に影響を与え るか後方調查した。【方法】当院にて 2010 年 1 月から 2012 年 7 月までの間に虚血性心疾患、弁膜症、大血 管疾患にて心臓血管手術を受け、周術期リハビリテー ションを行った症例のうち、ASV 非導入 86 例をコ ントロール群、ASV 導入 52 例を ASV 群とし、2 群 間で比較した。術前より心房細動の症例や心房細動 に対する外科的治療が行われた症例、ステントグラ フト内挿術除症例、ASV が装着困難な症例は除外し た。ASVは 2011 年 8 月より導入し、Res Med 社製 AutosetCS ${ }^{\circledR}$ を用い、人工呼吸器離脱後より 1 日 30 分以上、術後 5 日間装着した。本人希望や医師が必 要と判断した場合には継続とした。データ収集は、 日本心臓血管外科手術データベース (JACVSD)より 後方調査した。【結果】年齢、性別、BMI、基礎疾患、 術前クレアチニンの項目において 2 群間で有意差は 認めなかった。ASV 群で $350.4 \pm 348.6$ 分 ASVを装 着しており、POAF 症例は、対象群 29/86 例 (33.7\%) に対し、ASV 群 $12 / 52$ 例 (23\%) と有意に減少した $(\mathrm{p}=0.001)$ 。また、炎症反応は、peak CRP が対象群 $17 \pm 8.4 \mathrm{mg} / \mathrm{dl}$ に対し、ASV 群 $12.6 \pm 6.2 \mathrm{mg} / \mathrm{dl}$ と 有意に低值であった $(\mathrm{p}<0.01)$ 。術後の在院日数は対 象群 $40 \pm 39.4$ 日、ASV 群 $28 \pm 13.3$ 日と ASV 群で有 意に短縮した $(\mathrm{p}=0.01)$ 。【結語】心臓血管手術後の ASV 管理は、POAF を減少し在院日数を短縮する効 果が示唆された。 
PP-221 咨

体外循環時ヘパリン抵抗性に対するアンチト ロンビン III 製剤使用の検討

東北大学 心臓血管外科

$\begin{array}{lrrr}\text { 河津 聡、神田 } & \text { 桂輔、鈴木 } & \text { 智之、 } \\ \text { 片平晋太郎、高橋 } & \text { 悟朗、増田 } & \text { 信也、 } \\ \text { 齋木 佳克、安達 } & \text { 理、秋山 } & \text { 正年、 } \\ \text { 熊谷紀一郎、本吉 } & \text { 直孝、川本 } & \text { 俊輔、 } \\ \text { 齋木 佳克 } & & & \end{array}$

【背景】体外循環使用時には抗凝固薬としてへパリン の使用が必須であり広く用いられている。しかし、 十分なへパリン投与にもかかわらず、体外循環に必 要な抗凝固作用が得られない症例も存在する。【目 的】ヘパリン抵抗性に対するアンチトロンビン III(以 下 ATIII) 製剤使用症例を対象とし、基礎疾患の背景 解析と ATIII 製剂使用の妥当性を評価する。【対象と 方法】当科における体外循環使用時の抗凝固療法プロ トコールは、体重あたり $0.25 \mathrm{ml}$ のヘパリン静注後 ACT が 400 秒を超えなかった症例に対してへパリン を追加投与する。追加投与後、予想される ACTより も低值の検査結果が得られた場合にへパリン抵抗性 があると判断する。対象症例は 2010 年 1 月から 2012 年 6 月までの期間における体外循環使用手術症例の 内、ATIII 製剂を使用した 26 例 (男性 23 例、女性 3 例) とした。【結果】術前診断は大動脈疾患が 12 例、 弁膜症 8、虚血性心疾患 3、心筋症が 3 例であった。 大動脈疾患の内訳は急性大動脈解離 1 例、慢性大動 脈解離 6、破裂、真性瘤切迫破裂 2、真性瘤が 3 例で あった。弁膜症症例では 8 例中 2 例が感染性心内膜 炎であった。術前の ATIII 值が低值のため初回へパ リン投与前にATIII 製剤を使用した症例は 6 例で、 初回へパリン投与後のへパリン抵抗性のため ATIII 製剤の投与を行った症例は 20 例であった。ACT 值 は術前の ATIII 值に関わらずATIII 製剂投与全症例 で有意に改善した。へパリン抵抗性症例を術前 ATIII 值域で 2 群に分けて検討すると、正常值症例 は 15 例、平均 $90.2(80 \sim 110)$ であり、低值症例は 5 例で平均 71.6(58〜 78) であった。ヘパリン抵抗性を 呈した今回の症例群で、術前 CRP 陽性 $(>0.3 \mathrm{mg} / \mathrm{dl})$ 患者が多く ATIII 正常群、低值群で陽性率がそれぞ れ $66.7 \%$ vs $80.0 \%$ 、平均值が 3.4 vs 2.3 であったが 統計学的有意差は検出されなかった。疾患別にみる とATIII 正常值群で大動脈解離症例が 6 例 $(40 \%)$ と 多く、逆にATIII 低值群には大動脈解離症例は含ま れていなかった。【結語】1)体外循環時へパリン抵抗 性に対しては、術前の ATIII 值に関わらずATIII 製 剂の投与が有効であった。2)ヘパリン抵抗性に関し ては背景にある炎症反応が関与している可能性があ る。3) 大動脈解離症例では術前 ATIII 值が正常值域 内であってもへパリン抵抗性となる症例が認められ る。

\section{PP-222 光 \\ 開心術術後の心房細動における Dexmedeto- midine の効果と実践}

\author{
1 公立陶生病院 心臓血管外科 \\ 2名古屋大学 心臓外科
}

$\begin{array}{ll}\text { 市原 } & \text { 利彦 }{ }^{1} \text { 、佐々木通雄 }{ }^{1} \text { 、新美 清章 }{ }^{1} 、 \\ \text { 野中 } & \text { 利通 }{ }^{1}\end{array}$

(背景) 開心術後にしばしば一過性を含め心房細動 (Af) が発症し、時として術後管理に難渋することが ある。術後の鎮静に $\alpha 2$ 拮抗効果のある Dexmedetomidine (DEX)を使用し、血圧、脈拍を同時にコント ロールしながら、管理している。今回この DEX が術 後 Af の発症に関与するかどうかを、血行動態を含め 検討した。(対象)人工心肺を用いた開心術で ICUに て管理した 46 例を対象とした。術後 DEX を積極的 に用ちいた D 群 16 名 (平均年歯令 64.4 歳) と、コント ロール 30 名 (平均年齢 67.7 歳) を C 群とした。両群 間に手術内容、体外循環時間、手術時間、麻酔時間、 出血量、術前合併症の有無には有意差は認めなかっ た。ICU 入室時の APACHE 2 スコアは D 群 $12.4 \pm$ 5.4、C 群 $9.4 \pm 3.7$ で、D 群の APACH 2 スコアが有 意に高かった $(\mathrm{p}=0.03)$ 。 DEX の投与方法は、ICU 入 室直後から中心静脈ラインが抜去されるまで、持続 注入し、徐脈、低血圧が生じた際は持続注入を中止 にした。DEXの平均投与期間は $4.2 \pm 1.0$ 日で平均投 与量は $0.28 \pm 0.07 \mu \mathrm{g} / \mathrm{kg} / \mathrm{hrl}$ であった。検討項目は、 Af の発生率、死亡率、病院滞在日数を検討した。両 群とも術中には塩酸ランジオロールを使用したが、 術後 ICUでは、DEX の効果が不明確になるので、 使用していない。(結果) D 群の 1 例、C 群の 16 例に 術後 4 日以内に Af の発症を発症し、D 群に少ない傾 向を認め(D 群 6\%、C 群 $27 \% 、 \mathrm{p}=0.096)$ 、病院滞在 日数も術前を含め、D 群により短い傾向を認めたが $(\mathrm{D}$ 群 $24.6 \pm 10.5$ 日、C 群 $44.9 \pm 41.7$ 日、 $\mathrm{p}=0.09$ )、両者 とも統計学的有意差は認めなかった。両群間に死亡 率の有意差は認められなかった。D群には投与中、 徐脈、血圧低下は認めなかった。(考察)開心術後高 齢者などには、しばしば術後 Afに遭遇することがあ る。術後状態が不安定な時期に不整脈は起こること が多い。D 群では術後 APACH スコアが悪いにも関 わらず ICUにおいて術後Afの発症を認めなかった ことは、DES の効果を応用し、術後管理を容易にす る一手段になりうると推察する。(結語) 開心術後の 術後早期の Af 発症の予防に、DEX 持続投与は鎮静 のみではなく、術後一過性の Af 発症を予防する可能 性があることが示唆されたので文献的考察も含め報 告する。 
PP-223 ๘

塩酸ランジオロールの周術期低容量持続投 与の有効性について

群馬県立小児医療センター 心臓血管外科

宮本 隆司、乾 明敏、吉井剛

【目的】短時間作用型 $\beta 1$ 選択的遮断薬の塩酸ランジオ ロール (商品名：オノアクト)を麻酔導入時から PICU 入室後 72 時間まで持続投与し、術中の酸素飽和度の 降下度、術後の血圧、心拍数及び心筋逸脱酵素など の推移を計測し、その有効性について検討した。【方 法】2007 年 6 月〜 2012 年 7 月でファロー四徵症 (ToF) 根治術を施行された 22 例のうち、塩酸ランジ オロール投与群 (L 群) 12 例と非投与群 (C 群) 10 例を 比較検討した。麻酔導入時より塩酸ランジオロール を $1 \mu \mathrm{g} / \mathrm{kg} / \mathrm{min}$ で投与を開始し最大 $10 \mu \mathrm{g} / \mathrm{kg} / \mathrm{min}$ ま で増量し PICU 入室後 72 時間で投与終了とした。術 前、術中、術後因子について両群を比較検討。（除外 基準)房室ブロック、喘息、平均動脈圧 $<60 \mathrm{mmHg}$ 、 心拍数 $<100 / \mathrm{min}$ の症状を伴う症例。【成績】年齢、 体重、性差などに両群で有意差を認めなかった。大 動脈遮断時間、人工心肺時間、手術時間、麻酔時間、 出血量、カテコラミン投与量に有意差は認められな かったが、手術開始から人工心肺装着時までの間の 酸素飽和度降下範囲は L 群にて有意に低值 $(12.6 \pm 7.8$ vs $24.2 \pm 6.5 、 \mathrm{p}<0.01)$ を示した。投与期間中の心拍 数・血圧に有意差は認められなかった。心筋逸脱酵 素においては、AST 值の PICU 入室後 24 時間 (156.5 \pm 54.8 vs $428.1 \pm 62.3 、 \mathrm{p}<0.01)$ と 48 時間 $(72.2 \pm 16.9$ vs $212.3 \pm 88.6 、 \mathrm{p}=0.03)$ と 72 時 間 $(42.5 \pm 12.1 \mathrm{vs}$ $264.2 \pm 166.8 、 \mathrm{p}<0.01)$ で、ALT 值の 72 時間 $(32.5 \pm$ 7.9 vs $203.4 \pm 178.5 、 \mathrm{p}=0.04)$ で、更に、CPK-MB 值 の 24 時間 $(53.6 \pm 38.7$ vs $113.7 \pm 52.2 、 \mathrm{p}<0.01)$ と 48 時間 $(23.4 \pm 7.5$ vs $47.5 \pm 23.4 、 \mathrm{p}<0.01)$ とで L 群が有 意に低值を示した。【考察】塩酸ランジオロール周術 期低容量持続投与にて酸素飽和度の降下範囲が抑制 され、無酸素発作の予防効果が認められた。また、 心筋逸脱酵素の上昇を抑制することが示され、周術 期の心筋保護効果が期待できる薬剤だと思われた。

\section{PP-224 is 術中止血困難症例に対する rFVIIa 製剤の有 用性の検討}

\author{
名古屋大学大学院医学研究科 心臓外科 \\ 荒木 善盛、藤田 山、野中 利道、 \\ 蒔苗永、徳田 順之、薦田さつき、 \\ 六鹿 雅登、藤本 和朗、成田 裕司、 \\ 大島 英揮、碓水 章彦
}

【目的】胸部大血管手術や心臓再手術での術中止血困 難例に対しては、従来の大量輸血療法に加えてフィ ブリノゲン製剤を投与するが、それでも止血困難な 場合は、欧米では頻用されている rFVIIa(遺伝子組 換え活性型血液凝固第 VII 因子製剂; ノボセブンR) を使用することも検討される。本邦においては rFVIIa は術中の止血目的では適応外使用であり、薬 品コストは高価であるため、その使用は限定的とな る。今回われわれは、術中止血困難例に対して rFVIIa を 2 例に使用したので、その効果を検討した。 【方法】症例 1 は 68 歳、男性。CABG の既往があり、 今回心膜炎と大動脈弁狭窄症に対して、心膜剥皮術 と大動脈弁置換術を行った。術中大動脈損傷を併発 し循環停止下に上行置換術を追加したが、ポンプ離 脱はできたものの、著明な出血傾向となった。症例 2 は 75 歳、男性。急性 A 型大動脈解離のため Bentall 手術を行ったが、冠動脈ボタンからの出血により右 心不全をきたし、長時間ポンプから人工心肺離脱困 難となり PCPS で手術を終了したが、著明な出血傾 向をきたした。大量輸血にもかかわらず凝固機能の 改善がえられず、 2 症例とも麻酔科との相談のもと rFVIIa 製椷を投与する方針とした。【結果】症例 1 で は、術中の最低血小板值 2 万 / $\mu \mathrm{l} 、$ フィブリノゲン值 $155 \mathrm{mg} / \mathrm{dl}$, に対して、赤血球 (RCC) 22 単位、新鮮凍 結血漿(FFP) 30 単位、血小板 (PC) 25 単位、フィブ リノゲン製剤 $6 \mathrm{~g}$ を投与したが、出血は軽減せず、 rFVIIa $5 \mathrm{mg}$ を投与したところ、出血傾向は著明に改 善し、その後は RCC8 単位、FFP20 単位、PC15 単 位を投与して手術を終了した。症例 2 は、術中の最 低血小板值 1.7 万 / $\mu$ 、、フィブリノゲン值 $60 \mathrm{mg} / \mathrm{dl}$, に 対して、RCC28 単位、FFP25 単位、PC30 単位を投 与したが出血は軽減せず、rFVIIa $5 \mathrm{mg}$ を投与したと ころ出血傾向は著明に改善し、その後は FFP10 単位、 PC15 単位の投与で手術は終了できた。【結語】 rFVIIa 製剂は、止血困難症例に対しての投与は適応 外使用となるが、止血効果は良好であった。今後は 実際の使用に向けて、投与後の塞栓症などの合併症 の併発とコスト軽減効果を検討する必要がある。 
PP-225 2

術後疼痛管理戦略における鎮痛補助薬リリ カの有効性

\author{
${ }^{1}$ 平塚共済病院 心臓センター 心臓血管外科 \\ 2小田原市立病院 心臓血管外科
}

半田 武巳 ${ }^{1} 、$ 高橋 政夫 ${ }^{1} 、$ 宮島 敬介 ${ }^{1}$ 、

石川 智啓 ${ }^{2}$

\section{【目的】}

我々の施設では、冠動脈バイパス術 $(100 \% O P C A B)$ の約 $80 \%$ は手術室抜管・約 10\% は当日抜管(術後 3 時間程度)、弁膜症など人工心肺使用症例では約 $70 \%$ は当日抜管(術後 3 時間程度)を行っている。早 期抜管の実践には術後疼痛管理が重要な因子であり、 当院での疼痛管理の工夫として

1. 胸骨動摇を防ぐために胸骨ピン・TORQ 併用での 胸骨固定

2. 閉創時皮下組織層へのアナペイン局所注入

3. 抜管前から翌朝までプレセデックス使用

4. 術直後からロキソニンテープの正中創周囲の貼付 を行っているが、経口鎮痛剤の内服には侵害受容性 疼痛治療薬であるロキソニンを使用していた。しか し、ロキソニン多用は潰瘍形成の危険性が高く、さ らにロキソニン単独ではコントロールしきれない疼 痛も存在するため、異なる作用機序の鎮痛剤を模索 し、末梢神経障害性疼痛治療薬として 2010 年に国内 承認されている鎮痛補助薬リリカの併用を行ったと ころロキソニン頓服量を大幅に減少させる事ができ た。そこで、当院の周術期疼痛管理戦略におけるリ リカ併用の位置付けについて報告を行う。

【方法】

胸骨正中切開による開心術後患者を対象とした。鎮 痛剂内服方法はリリカ・ロキソニン併用内服群(リ） ロ群) とロキソニン単独内服群 (ロ群)に無作為に分類 した。リ/ロ群ではリリカ $(75 \mathrm{mg}) 2 \mathrm{~T} /$ 分 2 で内服し、 ロキソニンは疼痛時頓服とした。ロ群ではロキソニ ン疼痛時頓服とした。頓服はVisual analog scale > 3 を基準とし、評価は 2 群間でのロキソニン使用量で 比較を行った。

【成績】

リ/口群 21 症例 (OPCAB 10 例 - 弁膜症等 11 症例)、 口群 25 例 (OPCAB12 例 - 弁膜症等 13 例) での検討 を行った。術後入院期間中のリ/ロ群でのロキソニ ン総頓服量は平均 $2.2 \pm 2.3$ 錠(術後平均入院期間 18.8 日)、口群では平均 $13.6 \pm 7.1$ 錠(術後平均入院期間 17.4 日)であった。さらに詳細に検討すると、CCU 滞 在期間中ではリ/口群平均 $1.7 \pm 1.8$ 錠 (平均滞在日数 3.7 日)、口群平均 $7.0 \pm 2.9$ 錠 (平均滞在日数 3.7 日) 頓 服されていた。一般病棟滞在期間中ではリ/ロ群平 均 $0.8 \pm 0.9$ 錠 (平均滞在日数 15.1 日)、口群平均 $5.4 \pm$ 4.9 錠 (平均滞在日数 13.6 日)頓服されていた。いずれ の期間でもリ/ロ群でのロキソニン頓服量が減少し ていた $(\mathrm{P}<0.01)$ 。

【結論】

鎮痛補助薬リリカの併用により、術後早期のロキソ ニン頓服量を大幅に減量する事が可能となった。周 術期疼痛管理戦略にリリカを加える事は妥当な選択 であると考えられた。
PP-226 究

\section{小児での circular LA resection による左房 縮小効果}

あいち小児保健医療総合センター

八神啓、村山 弘臣、長谷川広樹、

前田 正信

[目的]巨大左房は長期間僧帽弁疾患を罹患した結果 生じることが一般的であり、小児での報告例は少な い。われわれは、僧帽弁閉鎖不全症に続発した巨大 左房を生じた小児の 3 症例に対して、circular LA resection と僧帽弁形成術を施行した。その経過や左 房縮小効果について検討した。[対象および方法]3 歳女児、1 歳男児、1 12 歳女児で、それぞれ重度の僧 帽弁閉鎖不全症と巨大左房を罹患していた。そのう ち 2 症例は、巨大左房にて気管の圧迫症状を呈して いた。これらの 3 症例に対して僧帽弁形成術と併せ て、 circular LA resectionを施行した。造影 CTに よる左房断面積を積分することで左房容積を算出し、 術前術後の左房容積、胸部レントゲンでの心胸郭比 を比較し、経過と併せて検討した。[結果]各症例と も術後経過は合併症なくすべて良好であった。術前 術後の左房容積はそれぞれ $209 \mathrm{ml} \rightarrow 52 \mathrm{ml}$ 、 $147 \mathrm{ml} \rightarrow 34 \mathrm{ml} 、 133 \mathrm{ml} \rightarrow 29 \mathrm{ml}$ と各症例とも約 $25 \%$ に減少し、心胸郭比はそれぞれ、65\% $\rightarrow 60 \% 、 60 \%$ $\rightarrow 49 \% 、 63 \% \rightarrow 57 \%$ と減少していた。気管への圧迫 症状があった症例では、圧迫も解除されている。僧 帽弁逆流もすべて 1 度以下になっていた。[考察]circular LA resection は、右側左房切開にて左房を展 開し、上大静脈を離断することにより左房内腔の良 好な視野を得る。左房壁を、下大静脈背側付近から、 左肺静脈開口部と僧帽弁輪の間を切開してゆき、左 房の天井に至り、左心耳を含め、1〜2cm の帯状、 円周状に左房壁を切除し、縫合する手法である。左 房を全周性に効果的に切除、縮小することができ、 かつ、僧帽弁への視野も良好に確保できる利点があ る。われわれの経験では各症例とも左房容積は約 $25 \%$ に減少と効果的に LA volume reduction を施 行でき、合併症もなく良好な経過をたどった。小児 においても巨大左房を合併する僧帽弁疾患に対して、 circular LA resection は積極的に検討するべき手技 であると考える。 


\section{PP-227 文 可及的に房室弁形態を温存する Two-patch 法}

京都大学 心臟血管外科

$\begin{array}{lrlll}\text { 池田 } & \text { 義、中田 } & \text { 朋宏、武田 } & \text { 崇秀、 } \\ \text { 恒吉 } & \text { 裕史、南方 } & \text { 謙二、丸井 } & \text { 晃、 } \\ \text { 山崎 } & \text { 和裕、坂田 } & \text { 隆造 } & & \end{array}$

【目的】完全型房室中隔欠損 (CAVSD)の手術におい て、良好な遠隔期成績を得るためには共通房室弁を 変形させないことが重要であり、この観点から two patch 法が有利である。共通房室弁の形態を可及的 に温存するためにわれわれが行っている術式を供覧 する。【術式】右心房切開の後、まず水テストを行い 共通房室弁の形態を観察する。VSD 閉鎖後に心室中 隔の geometry が変化するので、この時点では共通 房室弁の左右分割位置のマーキングは行わない。 [VSD 閉鎖]VSD辺縁に半月状に trimmingした $0.4 \mathrm{~mm}$ 厚 EPTFE patch を結節綘合にて逢着する。 patchの高さはVSD の深さに合わせて慎重に調節す る。patchの直線部の長さは共通前尖と共通後尖の 幅の合計とし、前後長の縫縮は行わない。［僧帽弁形 成]LV に水を注入し、共通前後尖が VSD patch と交 差する部位で patch に仮固定する。再度水テストを 行い、僧帽弁 cleft の先端が前尖側と後尖側で正確に 揃っていることを確認する。満足な結果が得られる までこの操作をやり直すことが重要である。cleft の 先端を縫合し、逆流が認められなければ cleftを全長 にわたって結節縫合で閉鎖する。cleft 縫合後に弁中 央部からの逆流が残る場合には lateral leaflet と共通 前尖、後尖との交連部に弁輪縫縮を追加する。 $\mathrm{ASD}$ 閉鎖]U 字縫合をVSD patchの直線部から共通弁尖 を貫通し ASD 閉鎖用自己心膜に通して結紮する。 VSD patch と一緒に結紮することで、弁腹が縫縮さ れることを防ぐ。両端の糸から連続縫合にて自己心 膜を ASD 辺縁に逢着する。ASD 後縁の縫合ライン は房室結節の左側 (僧帽弁側)ではなく右側 (三尖弁 冠静脈洞)にとる。この後に三尖弁側の水テストを行 い、逆流があれば right superior leafletを心膜パッ 于の基部に逢着する。【対象】当院での連続 17 例。平 均手術時年齢 7.5 力月、平均体重 $4.9 \mathrm{~kg}$ 。Down 症 15 例、TOF 合併 2 例。【結果】右室低形成の 1 例が病院 死、PH 残存の 1 例が遠隔死。術後平均観察期間 5.7 年。MS、LVOTOによる再手術 1 例、MR による再 手術なし。最終来院時の心エコーにて MR は none: 3 例、 trivial: 8 例、 mild: 4 例であり、経時的な増悪傾 向も認めなかった。【結語】CAVSDに対する共通房 室弁の形態を可及的に温存した two-patch 法の遠隔 期成績は良好であった。

\section{PP-228 ¿ 2 \\ Restrictive VSD 合併症例における手術介入 の検討}

\author{
東京女子医科大学 心臟血管外科 \\ 豊田 泰幸、長嶋 光樹、平松 健司、 \\ 松村 剛毅、小沼 武司、立石 実、 \\ 中山 祐樹、山田有希子、加久 雄史、 \\ 早川美奈子、山崎 健二
}

【目的】Restrictive VSD 合併症例において VSD 拡大 を要する場合があるがその適切な手術介入に関して は明らかでない。【対象】1989 年 6 月より 2002 年 3 月 までに VSD 拡大術を併用した Rastelli、Jatene、ICR を施行された 89 例。手術時平均体重 $11.3 \pm 8.3 \mathrm{~kg}$ $\left(2.1^{\sim} 61.0 \mathrm{~kg}\right)$ 、日歯令中央值 911 日 $(16$ × 4577 日)。手術 死亡 10 例 (心肺離脱不可能 4 例、DIC2 例、CHF3 例、 shock1 例)、遠隔期死亡 15(DIC2、CHF7、感染 4、 肺塞栓 1 不明 1 )。男女比 50: 39。術後追跡期間中央值 2494 日(0 8204 日)。術式別(Rastelli 施行: TGA (24)、 $\operatorname{DORV}(20) 、 \mathrm{TAC}(3) 、 \mathrm{IAA}(1)$ - 計 48 例、Jatene 施行 : $\operatorname{DORV}(21) 、 T G A(2) 、 T a u s s i g-\operatorname{Bing}(2)$ - 計 25 例、 ICR 施 行: TOF (3)、DORV (12)、Taussig-Bing(1)計 16 例) に分類し手術時期、中遠隔期成績を検討し た。また全 89 例での手術時体重別生存率、手術時期 別生存率を検討した。【結果】Rastelli48 例中生存 33 例、死亡 15 例 (手術死亡 6 例、遠隔期死亡 9 例) 手術 時平均体重 $13.8 \pm 8.6 \mathrm{~kg}$ (生存 $15.0 \pm 9.3 \mathrm{~kg}$ 、死亡 11.01 $\pm 6.4 \mathrm{~kg}$ )、手術時日齢中央值 1277 日 (生存 1285 日、 死亡 888 日) Jatene25 例中生存 16 例、死亡 9 例 (手術 死亡 4 例、遠隔期死亡 5 例)、手術時平均体重は 5.9 $\pm 4.1 \mathrm{~kg}$ (生存 $6.7 \pm 4.8 \mathrm{~kg}$ 、死亡 $4.4 \pm 1.8 \mathrm{~kg}$ )、手術時 日齢中央值 112 日 (生存例 154 日死亡群 80 日)ICR16 例中生存 15 例、遠隔期死亡 1 例。手術時平均体重 $12.3 \pm 8.5 \mathrm{~kg}$ (生存 $12.4 \pm 8.8 \mathrm{~kg}$ 、死亡 $10.5 \mathrm{~kg}$ )、手術時 日齢中央值 1386 日 (生存 1338 日、死亡 4577 日)。全 症例のなかで心内導管再手術を要したのは Rastelli の 1 例 (DSO 施行例) で再手術後敗血症にて死亡。全 89 例の手術時体重別生存率 (5kg 毎に分類) は図 1 、 手術時期別生存率 (1 力月、3 力月、1 歳、3 歳で分類) を図 2 に示すがいずれも有意差は認めなかった。【結 果】手術介入を要する restrictive VSD 合併症例は DORV 等の複雑心奇形症例を多く認めた。適切な手 術介入に関して手術時体重、手術時期には有意差を 認めず基本的には原疾患によると推測された。
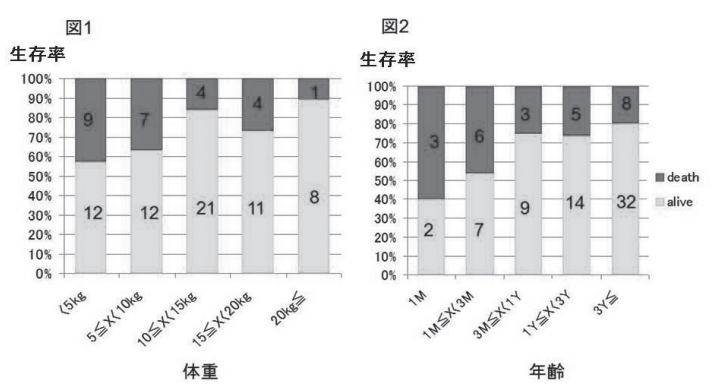
PP-229 究

上大静脈に流入する部分肺静脈還流異常症 に対する治療成績と新たな手術法

\section{福岡市立こども病院心臓血管外科}

$\begin{array}{llll}\text { 町田 } & \text { 大輔、中野 } & \text { 俊秀、帯刀 } & \text { 英樹、 } \\ \text { 檜山 } & \text { 和弘、柳瀬 } & \text { 豪、夷岡 } & \text { 徳彦、 } \\ \text { 松前 } & \text { 秀和、角 } & \text { 秀秋 } & \end{array}$

【背景】上大静脈 (SVC) 流入型部分肺静脈還流異常症 (PAPVD) に対する手術では上大静脈及び肺静脈 (PV) 還流に狭窄をきたさず、また洞結節機能を損傷 せずに修復する必要があるが、特に SVC 高位に PV が流入する症例では容易でないことが多い。【目的】 当院にて手術を施行したSVC 流入型 PAPVD 症例の 長期成績を検討するとともに、特に高位 SVC に流入 する症例に対する新たな手術法を紹介する。【対象・ 方法】当院にて 1983 年から 2012 年までに手術を施行 したSVC 流入型 PAPVD 症例 56 例を対象に後方視 的に検討した。【結果】観察期間は 7.8 年、手術時年齢、 体重はそれぞれ 6.2(0.1 14.3) 歳、19.2 (2.7 59.0) kg で あった。還流異常は右上葉枝のみ 19 例、右上葉・中 葉が 27 例、右全てが 10 例。右肺動脈より頭側で PV が SVCに流入する高位例は 39 例(70\%)であった。 手術方法は 1patch 法での rerouting が 27 例、SVC patch 拡大を加えた 2 patch 法が 7 例、心房 flap での rerouting が 4 例、Williams 法が 13 例で、新たな手 術法として modified ' double-decker' 法を 2 例に行っ た。本術式ではSVC 前壁を flap として SVC 内に縫 着、心房内パッチと併用し PV を左房へ reroute し、 flap の前面からパッチを用いて SVCから右房への reroute を行う。SVC 高位流入例でも大きく、発育 可能な SVC、PV 還流が確保でき、SVC-RA junction 部の縺合を避けられる点でより合併症回避が期待さ れる。同時手術を行った合併疾患はVSD4 例、TOF4 例、CoA/IAAcomplex2 例、PA/VSD/MAPCA1 例、 TR2 例でありVSD2 例と TR2 例を除きWilliams 法 で修復した。早期死亡はなく術後遠隔期死亡を 1 例 (PA/VSD/MAPCA 同時手術例)に認めた。術後の肺 静脈狭窄は心房 flap 法で 1 例認め Williams 法での再 手術を行った。上大静脈狭窄は Williams 法で 1 例認 めSVCstent 留置を行った。いずれも高位 SVC 流入 例であった。術後の洞機能不全は急性期に接合部調 律となり pacing を行ったものを 9 例認めたがいずれ も短期で改善し全例洞調律に回復した。ICU 退室時 $\mathrm{SVC}$ 圧は 5(2 9) $\mathrm{cmH} 2 \mathrm{O}$ 。いずれも術式間で差は認 めなかった。【考察】術後遠隔期成績は術式によらず 良好であるが、SVC 高位流入例で術後肺静脈・上大 静脈狭窄例を認めた。症例に合わせた術式の選択が 重要であり、術後合併症の観点から modified' double-decker' 法は特に高位 SVC に流入する症例で有 用であると考えられた。今後症例の蓄積と長期成績 の検討を要する。

\section{PP-230 \\ 小児ペースメーカ再手術症例の検討一心機 能保持の観点から}

\author{
兵庫県立こども病院 心臓血管外科
}

松久 弘典、大嶋 義博、圓尾 文子、 長谷川智巳、田中亜紀子、野田怜

【緒言】小児ペースメーカ再手術症例では基礎疾患、 手術歴等児の条件は様々で、アプローチ、リードの 選択に一定の見解は得られていない。当院では近年 再手術症例においても心機能保持の観点から左開胸、 左室電極を第一選択としている。【対象と方法】2000 年以降に施行されたペースメーカ移植術 59 例 72 手 術中、リード再移植を伴うシステム交換は 24 例、 27 手術であった。不整脈診断名は先天性房室ブロック： 8 例、後天性房室ブロック: 16 例、洞結節機能不全 : 2 例。年齢は $10.0 \pm 6.7$ 歳、前回リード移植後 4.8 年 (中 央值、6 ケ月 18 年)。手術適応はリード断線: 7 例、 闇值上昇: 6 例、心不全、心機能低下: 9 例、システ ム感染: 2 例、 twitching: 1 例、DDD へのアップグレー ド : 1 例。アプローチは左開胸 : 13 例、胸骨正中切開 : 5 例 (開心術時: 3 、再々手術: 2 )、正中小切開: 5 例 (緊 急: 2、心房リード追加 : 2、 twitching: 1)、経静脈リー ド : 3 例(感染: 2 、成人: 1 )。使用心室リードは suture on (steroid eluting): 13 例、 screw in: 11 例。心 室電極部位は右室 : 10 例、左室(体心室): 17 例。【結 果】早期死亡: 1 例 (無脾症、術前高度心不全、LOS)、 遠隔死亡: 1 例 (突然死)。リード性能 : 術後早期の閾 值上昇を 3 例(金属アレルギー: 1 例)に認め、全て screw in type であった。リード再移植回避生存率は 1 年 : $88 \pm 6 \% 、 5$ 年 : $78 \pm 9 \%$ 。各リードの最終 minimal energy threshold は screw in: $3.94 \pm 4.77 \mu \mathrm{J}$ 、 suture on: $0.80 \pm 0.33 \mu \mathrm{J}$ 、 transvenous: $0.64 \pm 0.61 \mu \mathrm{J}$ で あった (screw in- suture on 間で $\mathrm{p}<0.001)$ 心機能 : リード断線の為に緊急で右室リード移植を行った 2 例が心機能低下を来し、6 ケ月、3 年後に再々移植 (左 室リード)となった。心機能改善目的にて心室リード 移植を行った 7 例中 2 例に術前カテーテル電極によ るテストペーシングを行い、4 例に術中 TEEによる 心機能評価を行った。結果は 5 例に心機能、心不全 徵候の改善を認め、1 例が早期死亡、1 例が不変 $\rightarrow$ 遠 隔死であった。生存 22 例の最終 NYHA 心機能分類 は class I: 20 例、class II: 2 例。最終 L (S) VFS $=0.31$ \pm 0.11 。術前 - 最終フォローアップ時での L $(\mathrm{S}) \mathrm{VFS}$ の変化率は左室(体心室) ペーシング群: $+0.051 \pm$ 0.088、右室ペーシング群: $-0.006 \pm 0.092$ であった $(\mathrm{p}=0.11)$ 。【結語】小览ペースメーカ再手術症例にお いて、心機能保持の観点から左室電極留置を目指す 当院の方針は妥当と思われた。また再手術症例にお いても可能な限りステロイド溶出リードの使用が望 ましい。 


\section{$\mathrm{PP}-231$ 为 \\ グルタルアルデヒド処理自己心膜パッチによ る MICS-ASD 閉鎖術}

\author{
榊原記念病院 心臓血管外科 \\ 平岩 伸彦、田端 実、佐々木健一、
清水 篤、内室 智也、福井 艮啓、
高梨秀一郎
}

【目的】近年の心臓手術の低侵襲化に伴い、当院では 2009 年 7 月より右小開胸・胸腔鏡補助下での ASD 閉鎖術を導入している。 MICS に関連する pitfall を 検討するとともに、自己心膜パッチの有用性につき 報告する。【方法】2009 年 7 月から 2012 年 4 月まで に MICS-ASD 閉鎖術を施行した 35 例を対象とした。 全例 2 次孔欠損型で、卵円孔開存は除外した。対象 患者の平均年齢は $55 \pm 14$ 歳、男女比は $17: 18$ であっ た。皮膚切開長は平均 $5.5 \pm 1.0 \mathrm{~cm}$ で、ASD 閉鎖法と しては直接閉鎖 5 例、 $\mathrm{ePTFE}$ パッチ使用 16 例、自 己心膜パッチ(グルタルアルデヒド処理)使用 14 例で あった。合併手術は TAP5 例、Maze 手術 2 例、PV isolation2 例であった。これらの成績を検討した。【結 果】手術死亡および脳梗塞合併は認めなかった。正中 切開への conversion はなかった。 ePTFE パッチで 閉鎖した 2 症例で、術中経食道エコーにて針孔から の残存シャントを認め、beating 下に再度右房切開し 追加縫合を行った。これらは術直後の心エコー検査 でもごく少量の残存シャントを認めたが、遠隔期心 エコー検査では残存シャントは消失していた。また、 直接閉鎖した 1 例で、縫合部の離開を認め再手術と なり、自己心膜パッチで再度閉鎖した。2011 年 6 月 以降パッチ閉鎖時は自己心膜を使用しており、針孔 を含めた残存シャントや再発は経験していない。【考 察】胸腔鏡下での ePTFE パッチの使用は、ハレーショ ンのため辺縁やしわの確認が困難であり、手術器具 の可動制限ため針孔の拡大による残存シャントにつ ながりやすい。一方、自己心膜はグルタルアルデヒ ド処理によりその扱いも容易であり、ハレーション をおこさず、針孔の拡大も来しにくいというメリット を有する。現在、ASD 閉鎖術は Amplatzer Septal Occluder の使用が第一選択となっているため、外科 手術はリムの薄い症例が多く直接閉鎖では裂けやす い。小さな欠損孔でも直接閉鎖後の再発を経験した ため、現在は全ての症例でパッチ閉鎖をおこなって いる。【結語】MICS-ASD 閉鎖術における自己心膜 パッチは有用である。

\section{PP-232 is Intracardiac conduit による TCPC の検討}

\author{
静岡県立こども病院
}

井出雄二郎、太田 教隆、村田 眞哉、 登坂 有子、城 麻衣子、伊藤 弘毅、 杉本愛、小川 博永、坂本喜三郎

【背景】機能的単心室に対する根治手術は、心外導管 法(EC 法)による TCPC 法が一般的術式として確立 しているが、EC 法が必ずしも理想的な血流路となら ない解剖学的位置関係を持つ症例がある。【対象・方 法】2000 年 1 月 2012 年 4 月に、IC 法 (lateral tunnel 法は含まず)にて TCPC を施行した機能的単心室 連続 16 例を対象。診断は cTGA:7 例、無脾症候群 : 5 例 (3 例が総肺静脈還流異常を合併し、既に肺静脈 への手術介入後)、多脾症候群 : 1 例、Criss-Cross 心 : 1 例、他 2 例。1 15 例が BDGを終えた状態(2 例は IPAS 併設)、1 例が BTS 後。術前 UCG、CT、カテー テル検査の結果をもとに、EC 法では、「導管による 肺静脈圧迫」、「極端な左右肺血流不均衡とその後の 肺動静脈瘻の発生」「長く曲がった導管の配置デザ イン」が懸念されると判断した症例に対して IC 法を 選択した。その手術成績を、診療録をもとに後方視 的に検討した。【結果】16 例全例が Apico-caval juxta position (ACJP)。Bilateral SVC 合併が 4 例、肝静脈 の独立還流の合併はなし。術前カテーテル検査で、 $\mathrm{SVC}$ 圧 $=11(9-15) \mathrm{mmHg} 、 \mathrm{Rp}=1.4(0.5-2.2) 、 \mathrm{PAI}=196$ $(108-276) \mathrm{mm} 2 / \mathrm{m} 2 、 \mathrm{SaO} 2=86(80-94) \%$ 。IC 法施行 時の年齢・体重は 3.0 (1.6-11.5) 歳、 12.0 (8.7-28) $\mathrm{kg}_{0}$ 導管は 11 例で径 $16 \mathrm{~mm} 、 5$ 例で径 $18 \mathrm{~mm}$ を使用。術 前から不整脈治療を要していた 2 例で fenestration を併設。同時施行手術として、3 例で房室弁形成術、 5 例で心房間交通の拡大を施行。体外循環時間 $184 \pm$ 33 分、大動脈遮断時間 $73 \pm 23$ 分。合併症は、不整 脈 1 例 (後にアブレーション施行)、横隔神経麻痺 3 例(不全麻疩 2 例、要縫縮術 1 例)。術後の IVC 血流 の左右肺血流分布比は $\mathrm{R} / \mathrm{L}=0.94(0.26-7.55)$ 。平均入 院期間は 25 日。抗血栓療法は、抗血小板剤とワーファ リンを併用。術後平均 3.8 年の $\mathrm{f} / \mathrm{u}$ で、死亡・再手術 症例なし。肺動静脈瘻 - 肺静脈還流障害 - 脳梗塞の 発生はなし。また術後平均 1.1 年で行ったカテーテル 検査で、平均 Fontan 圧は $12.7 \pm 2.4 \mathrm{mmHg} 、$ C.I. $=3.5$ $\pm 0.85 \mathrm{~L} / \mathrm{min} / \mathrm{m} 2$ 。【結論】EC 法では「導管による肺静 脈圧迫」、極端な左右肺血流不均衡と肺動静脈瘻の 発生」「長く曲がった導管の配置デザイン」が懸念さ れる、ACJP の解剖学的位置関係を持つ症例に対し て、IC 法を行ってきた。平均 3.8 年の $\mathrm{f} / \mathrm{u}$ 期間で、 肺静脈還流障害・脳梗塞等の合併はなく、良好な Fontan 循環を維持できている。今後、成長に伴う心 臓容積の変化がどのような影響を及ぼすかを注意深 く観察していく必要がある。 
PP-233 ๘

当院における One and a half ventricle repair の中期遠隔期経過と適応の検討

\author{
順天堂大学 心臓血管外科 \\ 中西 啓介、川崎志保理、森田 照正、 \\ 稲葉 博隆、山本平、桑木 賢次、 \\ 土肥 静之、松下訓、松村 武史、 \\ 天野篤
}

【目的】One and a half ventricle repair $(1+1 / 2$ repair $)$ は、適応が確定していないことより、症例が少ない のが現状である。当施設で、1+1/2 repair を行った 3 症例の適応と中期遠隔期の経過に検討を加え報告す る。【対象】1996 年 7 月から 2006 年 1 月までに当院に て one and a half ventricle repair を施行された 3 症 例を対象とした。症例 1 は、純型肺動脈閉鎖に対し、 生後 1 力月時に左体肺動脈短絡術、Brock 術を施行 され、6歳時に bidirectional cavo pulmonary shunt を施行した。三尖弁輪径は $55 \%$ of normal に対して、 8 歳時に 1+1/2 repair を施行した。症例 2 は純型肺 動脈閉鎖 + critical AS。生直後に critical AS に対し て baloon 拡張術を施行し、生後 1 力月時に右体肺動 脈短絡術、生後 5 力月時に直視下肺動脈弁裂開術、 ASD 拡大術を施行した。1 歳 9 ヶ月時に三尖弁輪径 $57 \%$ of normalに対して $1+1 / 2$ repairを施行した。 症例 3 は、後天性両側肺動脈分岐部狭窄の成人例。 54 歳時に原因不明の大動脈炎症候群様の所見を有す る PS に対して、肺動脈形成術を施行するも、術後再 発。6 4 歳時に両側 PS、三尖弁閉鎖不全 4 度、心房 細動に対して、肺動脈に対する狭窄解除困難と判断 して、BCPS、左肺動脈パッチ拡大形成術、三尖弁輪 径成術 (Duran ring 33mm)、右側 MAZE、RA 縫縮 を施行した。【結果】全例で術後早期の人工呼吸器か らの離脱が可能であり、術後経過は良好であった。 追跡期間は、平均 11.3 年。症例 1 は、現在 NYHA1 度。 症例 2 は、手術に関係のない後遺症を認めるも現在 NYHA2 度。大動脈狭窄残存兼閉鎖不全に対する弁 置換待機中である。症例 3 は、術 5 年後に致死的不 整脈を認めたが、抗不整脈薬の内服により再発はな い。現在 NYHA2 度である。【考察】症例 $1 、 2$ とも右 室容積に関しては、biventricular repair と $1+1 / 2$ repair の境界に存在。症例 3 は正常右心室であった。 1+1/2 repair は、右室容積がある程度残存する症例 や、何らかの理由で PS 解除が困難な症例において、 良好な治療成績を得る事が可能な術式と考えられた。 【結語】右室容積に余裕があるも、他の理由により 1+1/2 repair を選択した 3 例の経過は良好であった。 右室容積の程度が、今後の $1+1 / 2$ repair の適応基準 になる可能性が示唆された。

\section{PP-234 㲾 中心肺動脈欠損や狭窄病変に対する治療戦 略}

\author{
埼玉医科大学国際医療センター 小児心臓外科 \\ 枡岡歩、鈴木 孝明、山岸 俊介、 \\ 宇野 吉雅、加藤木利行
}

【背景】中心肺動脈に狭窄性病変を有する患児に とって、左右均等な肺血管床の発達はその予後にとっ て重要な要因である。【目的】中心肺動脈久損また は狭窄を有する先天性心疾患患児の左右肺血管床発 達を含めた臨床成績を明らかにし、中心肺動脈欠損 もしくは狭窄病変への至適介入時期を明らかにする こと。【対象】 2007 年 4 月から 2012 年 3 月までに当 院にて手術介入した中心肺動脈欠損または狭窄を有 する症例 19 例(男女比 11: 8) を対象とした。疾患の内 訳 は、PA/VSD/MAPCA が 8 例、PA/IVS が 2 例、 中心肺動脈狭窄を合併した単心室症が 6 例、中心肺 動脈狭窄を合併した両大血管右室起始症が 2 例、 $\mathrm{PA} / \mathrm{TGA} / \mathrm{VSD}$ が 1 例であった。【結果】上記対象 症例のうち、初回手術介入時に中心肺動脈病変の修 復を行った症例は 14 例で、その手術方法は左右肺動 脈分岐部を含む狭窄部位を切除し、肺動脈を端々で 吻合したものが 8 例、右室流出路から主肺動脈をパッ チ形成術を施行した症例が 2 例、胸骨正中切開下に 一期的にUnifocalizationを施行した症例が 2 例、 Melbourne shunt を行った症例が 1 例であった。こ れらの症例ではカテーテルによる血管形成術が必要 であったが、中心肺動脈狭窄病変への再外科的介入 が必要となったのは 1 例のみであった。根治術(二心 室修復)に到達した症例は 5 例、BCPS 到達してい る症例は 2 例、いずれも左右肺動脈の発達に左右差 は認めていない。現在 $\mathrm{BCPC}(3$ 例 $)$ または根治術 (3 例)待機中である。1 例は BCPS 待機中に失っている (死因は不明)。一方、初回手術介入時に左右別々の 肺血流路作成を選択した症例は 5 例。肺血管床の発 達に左右差を認め、BCPS 時に Septation を施行し、 TCPC に到達した症例が 2 例、左右別々に肺血流路 を作成した後に、Unifocalizationを追加施行し、 TCPC に到達した症例が 1 例、BCPS 時に中心肺動 脈形成術を併施し、TCPC に到達した症例が 2 例で あった。【結語】初回手術時に中心肺動脈病変へ積 極的に介入した症例では、複数回のカテーテルイン ターベンションが必要となったが、いずれも左右肺 血管床の発達は良好であった。一方、左右別々の肺 血流路を用いた姑息手術を行った症例では、肺血管 床の発達に左右差を認めることが多く、複数回の中 心肺動脈病変への外科的介入が必要であった。左右 肺血管床の均等な発育を目指すためには、可能な限 り初回手術介入時に中心肺動脈狭窄解除や一期的 Unifocalization を行う事が重要ではないかと考えて いる。 
PP-235 ¿ 2

三尖弁低形成・肺動脈閉鎖症における無機 能右室に対する手術の工夫

北海道大学 循環器 - 呼吸器外科

浅井 英嗣、松居 喜朗、橘剛、

久保田 卓、大岡 智学、若狭哲、

新宮 康栄、内藤 裕嗣、飯島誠、

南田大郎、加藤 伸康、関 達也

[はじめに]: 三尖弁低形成・肺動脈閉鎖症では重症三 尖弁逆流 (TR)から拡大した右房・右室により左室機 能の低下、また静脈還流の悪化や右房 - 右室間での dumping (re-entrant circuit)などにより血行動態の悪 化をきたす。このような右房・右室に対し Sanoらの 報告では exclusion することにより心機能の改善を認 めたとの報告がある。当科では exclusion だけではな く内腔の縫縮を症例毎に追加、選択することで左室 の形態的な変化や冠動脈損傷を避ける工夫を行って いる。[対象]: 2002 年 4 月から 2012 年 8 月までに三 尖弁低形成・肺動脈閉鎖症における無機能右室に対 し右室の exclusion または内腔縫縮の手術介入を行っ た 3 例。症例 1 は冠動脈を避けて RV free wall を広 範に切除し断端を direct closure し三尖弁はfenestration をおいた自己心膜パッチにて閉鎖した。症例 2 は右室流出路を大きく切開し心尖部側から流出路に 向けて TSM と中隔を連続縫合後に free wall と中隔 を連続縫合で閉鎖し右室切開を閉鎖することで右室 内腔を処理、三尖弁は direct closure で閉鎖し前尖に fenestration をおいた。症例 3 は冠動脈を損傷せずま た内腔縫縮により左室形態を変化させないように free wall を exclusion し内腔を症例 2 と同様に縫縮 し切開断端を direct closure、三尖弁は direct closure で閉鎖、前尖にfenestration をおいた。症例 1 と 3 には同時に体肺動脈シャント手術を行った。手 術時年齢は 41.3 日 $(4 \sim 60)$ 、手術時体重は $2.87 \mathrm{~kg}$ $(2.54 \sim 3.2 \mathrm{~kg})$ であった。[結果]: 周術期死亡なし。 術後フォローアップ期間は 6.7 ヶ $(1 \sim 10$ ケ月)で 1 例は BDG 術後 TCPC 適応外となり他院フォローと なり不明、1 例は TCPC 待機中、 1 例は BDG 待機中

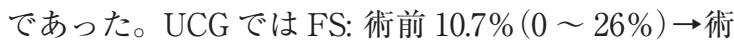
後 38.7\% (32 49\%)、LVDd: 術前 79.3\% N (72 88\%)

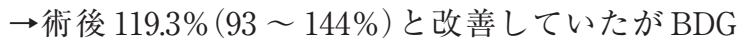
術後 TCPC 適応外となった症例 1 では右室からの圧 排は消失していたが心尖部が前方に屈曲した形態と なっており左室機能の悪化の原因であった可能性が ある。心臓カテーテル検査では RVEDV は全例で $0 \mathrm{ml}$ となっていた。[結論]: 当科で行った三尖弁低形 成・肺動脈閉鎖症における無機能右室に対する内腔 縫縮は冠動脈血流・左室形態を損ねる事なく、術後 の左室機能改善、CTR 減少に大きく寄与したと考え られる。無機能右室に対する手術介入の文献的考察 を加えて発表する。
PP-236

成人先天性心疾患に対する再右室流出路再 建例の検討

\author{
北海道大学 循環器 - 呼吸器外科
}

$\begin{array}{llll}\text { 浅井 英嗣、松居 } & \text { 喜朗、橘 } & \text { 剛、 } \\ \text { 久保田卓、大岡 } & \text { 智学、若狭 } & \text { 哲、 } \\ \text { 新宮 康栄、内藤 } & \text { 裕嗣、飯島 } & \text { 誠、 } \\ \text { 南田 } \text { 大郎、加藤 } & \text { 伸康、関 } & \text { 達也 }\end{array}$

【背景】右室流出路形成術後遠隔期の肺動脈弁逆流・ 狭窄 (PR・PS) は不可逆性の右心不全・不整脈の原因 となり、再右室流出路再建 (re-RVOTR) 法には生体 弁、機械弁、 homograft などが利用されるがその選 択は未だ議論されるところである。当科では 2007 年 1月以降 re-RVOTR の手術方針として 1: 10 歳以上か つ男性で $23 \mathrm{~mm}$ 以上、女性で $21 \mathrm{~mm}$ 以上の生体弁が 装着できる症例では人工血管と生体弁の conduit を、 2: 1 以外の症例では京都府立医大作成の e-PTFE3 弁 付き conduit を使用している。【目的】当科における re-RVOTR の手術方針・術式について検討する。【方 法】2007.1月〜 2012 年 1 月までに re-RVOTRを施行 した 15 例に関して後方視的に手術成績、UCG/心カ テーテル検査による術前後の血行動態・右心負荷を 評価した。【結果】15 例の原疾患は TOF: 10 例、PAVSD: 3 例、Truncus: 1 例、TGA: 1 例で再手術時年 齢は $18.6 \pm 14.5$ 歳で初回手術から $15.2 \pm 12.8$ 年後で あった。手術に至った主な理由はPS・右室圧負荷 : 7 例、 $\mathrm{PR}$ - 右室容量負荷: 8 例であった。人工血管と 生体弁の conduit 9 例に施行し、e-PTFE3 弁付き conduit を6例に施行した。手術成績は手術時間： $450 \pm 176$ 分、人工心肺時間: $219 \pm 119$ 分、出血量 : $872 \mathrm{ml}(27-3675 \mathrm{ml})$ 、無輸血手術を 5 例に施行し得た。 術後 LOS から周術期死亡が 1 例であった。しかし死 亡症例は手術介入を約 2 年前より推奨していたが本 人が希望せず手術介入時期が大幅に遅れた症例で あった。術前 / 後(中期遠隔期)での PR は $2.8 \pm 1.0$ か ら $0.9 \pm 0.7$ へ改善した。また術前/後(中期遠隔期) での PS は RVp/LVp が $0.84 \pm 0.2$ から $0.45 \pm 0.3$ へ改 善し、P弁位での flow は $3.8 \pm 0.6$ から $2.8 \pm 1.0$ へ改 善したが人工血管+生体弁 conduit の一例で術後退 院時にはPS が改善していたが中遠隔期で PS が徐々 に進行した症例があった。フォローアップ期間は 17 土14.7 ケ月であった。【結語】手術成績は良好であり 手術方針・術式は妥当であった。しかし中期遠隔期 に入り PS の再進行を認める症例があり今後の厳密な フォローアップが必要であることが示唆された。ReRVOTRの手術介入/手術手技に関する分権的考察 を加えて発表する。 
PP-237 它

ファロー四徵症修復術後長期遠隔期成績と 心室性不整脈及び肺動脈弁逆流の検討

\author{
新潟大学大学院医歯学総合研究科 呼吸循環外科学 \\ 分野 \\ 白石 修一、高橋昌、渡邊 マヤ、 \\ 土田 正則
}

【目的】ファロー四徴症修復術後 20 年以上を経過した 長期遠隔期での問題点と経右室切開法 ( RV 法)、肺動 脈弁輪切開法 (transanular patch: TAP 法)の術式別 の特徴について検討する。【方法】当院において 1964 年 7 月以降に行われたファロー四徴症心内修復術(肺 動脈閉鎖例・房室中隔欠損合併例などは除く) 387 例 のうち当院外来で 20 年以上経過観察可能であった 50 例を対象とした。術後観察期間は $30.6 \pm 7.5$ 年 (20-47 年)。手術時年齢 $6.2 \pm 5.1$ 歳。手術術式の内訳 は RV 法 19 例、 TAP 法 31 例。今回の検討対象例の うち RAPA 法はなし。【結果】心内修復手術時年齢は RV 法 $5.2 \pm 4.0$ 歳、TAP 法 $6.6 \pm 5.6$ 歳、術後経過観 察期間は RV 法 $31.2 \pm 8.5$ 年、TAP 法 $30.3 \pm 6.7$ 年で あり、共に有意差はなし。遠隔死亡を 3 例 $(\mathrm{RV}$ 法 1 例：小脳出血、TAP 法 2 例：突然死 2 例) に認めた。 遠隔期再手術として右室流出路再建術 3 例、大動脈 弁置換術 2 例を施行した。経過観察期間中に心室頻 拍・細動を 10 例( RV 法 1 例 (5.3\%)、TAP法 9 例 $(29.0 \%)$ ) に認めTAP法に多い傾向を示し $(\mathrm{p}=0.059)$ 、ICD 植え达み術を 6 例 $(\mathrm{RV}$ 法 1 例、 TAP 法 5 例) に行った。中等度以上の肺動脈弁逆流 (PR) は RV 法 3 例、TAP 法 15 例と TAP 法に多く $(\mathrm{p}=0.028)$ 、外来での BNP 值も RV 法 $25.0 \pm 17.0 \mathrm{pg} /$ $\mathrm{ml}$ 、TAP 法 $86.3+/-87.4 \mathrm{pg} / \mathrm{ml}$ と TAP 法で高值を 認めた $(\mathrm{p}=0.048)$ 。心電図上 $\mathrm{QRS}$ 幅は $\mathrm{RV}$ 法 $164+/$ $23 \mathrm{msec} 、 \mathrm{TAP}$ 法 $160 \pm 32 \mathrm{msec}$ QT $\pm 33 \mathrm{msec} 、 \mathrm{TAP}$ 法 $470 \pm 41 \mathrm{msec}$ と共に有意差は認 めなかった。また、心室頻拍・細動既往例では非既 往例に比べ心内修復手術時年齢が高く $(9.7 \pm 9.3$ 歳 vs $5.3 \pm 3.3$ 歳、 $p=0.018)$ 、術後遠隔期心エコー検査にお ける三尖弁逆流圧較差 $(40.5 \pm 10.9 \mathrm{mmHg}$ vs $30.9 \pm$ $9.9 \mathrm{mmHg} 、 \mathrm{p}=0.016)$ 及び BNP 值も高值を示し (126 $\pm 111 \mathrm{pg} / \mathrm{ml}$ vs $49 \pm 56 \mathrm{pg} / \mathrm{ml} 、 \mathrm{p}=0.021)$ 、心電図上 はQTc 時間の延長 $(488 \pm 32 \mathrm{msec}$ vs $458 \pm 39 \mathrm{msec})$ を認めた。また、心室性不整脈は外来経過観察期間 30 年以上の 24 例中 7 例と高率に認めた。【結語】 ファロー四徴症に対する RV 法後長期遠隔期におい て心室性不整脈の発生頻度及び肺動脈弁逆流は TAP 法と比較して少なく BNP も低值であった。術後長期 間経過例、手術時高年齢、BNP 高值、QTc 延長及び 三尖弁逆流圧較差高值の症例において心室性不整脈 の頻度が上昇するため、これらの症例では今後の慎 重な経過観察が必要である。

\section{PP-238 乞 当院における感染性心内膜炎の外科治療成 績}

岸和田徳洲会病院 心臓血管外科

$\begin{array}{lrlll}\text { 降矢 } & \text { 温一、東上 } & \text { 震一、松林 } & \text { 景二, } \\ \text { 頓田 } & \text { 央、川平 } & \text { 敏博、東 } & \text { 修平、 } \\ \text { 蔍岡 } & \text { 成年、平松 } & \text { 範彦 } & \end{array}$

【背景】感染性心内膜炎に対する治療成績は抗生剂の 開発や積極的かつ安定した外科治療の導入により著 しく向上してきている。今回我々はその長期成績も 含め感染性心内膜炎の外科治療の成績を調査、検討 したので報告する。【方法】2000 年 1 月から 2012 年 6 月までに当院で施行した感染性心内膜炎の手術症例 69 例を対象とした。感染性心内膜炎の診断は Duke 臨床的診断基準にて行った。当院での活動期感染性 心内膜炎の手術適応は、1) コントロール不良の心不 全症例、2)感染コントロール不良症例、3)可動性 vegetationの存在としている。全例で最低 3 週間の 抗生剤投与を原則とした。【患者背景】男女比 42 . 人 : 27 人、平均年齢 $58.0 \pm 14.8$ 歳、術前平均 EF60.1 \pm $13.1 \%$ 。活動期の症例は 44 例 $(63.7 \%)$ 。術前 PCPS 扦入例は 2 例。治療対象弁疾患としては、僧帽弁 39 例 $(56.5 \%$ )、大動脈弁 19 例 $(27.5 \%)$ 、僧帽弁 +大動 脈弁 11 例 (15.9\%) であり、その他三尖弁 2 例、先天 性心疾患 1 例であった。起因菌が同定された症例は 30 例 (43.7\%) で Streptococcus 16 例が最も多く、次 いで MRSA が 5 例、Staphylococcus 3 例であった。 【結果】術式は、僧房弁置換 28 術例、僧帽弁形成術 8 例、大動脈弁置換術 18 例、大動脈形成術 1 例、僧帽 弁置換術 + 大動脈弁形成術 2 例、僧帽弁形成術 + 大 動脈弁置換術 5 例、両弁置換術 4 例、その他 3 例で あった。平均人工心肺時間 $119.2 \pm 42.9$ 分、平均大動 脈遮断時間 $87.0 \pm 31.5$ 分であった。在院死亡例は 7 例 $(10.1 \%)$ あり、手術死亡は 2 例 $(2.8 \%)$ で術前にい ずれも EF10〜 15\%の PCPS 挿入を必要とした重症

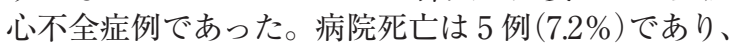
そのうち 4 例は術前敗血症状態の感染症コントロー ル困難例であった。これら 7 例を除外した長期成績 としては、1 年生存率が $94.6 \% 、 5$ 年生存率が $92.3 \%$ であった。また、術前 EF50\%以下であった症例は 9 例 (13.0\%)あり、いずれも活動期の症例でそのうちの 4 例が在院死亡例に該当した。【結論】当院における 過去 12 年間の感染性心内膜炎の外科治療成績につい て検討した。活動期感染性心内膜炎の外科治療につ いては、術前の心不全及び感染症の重症度が大きく 影響すると考えられる。心不全、感染症の程度が重 症化する前に外科的治療の介入をするのが適切であ り、その中でも特に心機能低下症例は死亡率が高く 注意を要する。 


\section{PP-239}

\section{活動期僧帽弁位感染性心内膜炎に対する僧 帽弁形成術：早期手術の特徵と成績}

\author{
${ }^{1}$ 長崎大学病院 心臓血管外科 \\ 長崎医療センター心臓血管外科 \\ 3佐世保総合病院 心臓血管外科
}

\begin{tabular}{|c|c|c|c|c|c|}
\hline E浦 & 崇1 & 江石 & 清行 ${ }^{1} 、$ & 中路 & 俊 ${ }^{1}$ \\
\hline 賓䐣 & 正好 ${ }^{2}$ & 橋詰 & 浩二 & 迫 & 史朗 ${ }^{3}$ \\
\hline & 殳子男 & 久田 & & 恒任 & 章 \\
\hline & 和好 1 & 橋本 & 亘 1 、 & 尾立 & 朋大 \\
\hline & 誠司 ${ }^{3}$ & 横 & 豪 1 & 田崎 & 雄一 \\
\hline
\end{tabular}

目的：活動期に僧帽弁形成術を行った感染性心内膜 炎症例 (IE) の病変、脳合併症、手術時期などの特徴 とその成績を明らかにすること。対象 : 1999 年 4 月 から 2012 年 7 月までに活動期僧帽弁位 IEする手術 51 例のうち形成術を行った 33 例 (65\%)を対象とし た。男性 26 例 $(79 \%$ )、平均年齢 $57 \pm 19$ 歳、大動脈 弁位 IE 合併 4 例 (12\%) であった。起因菌の同定は 29 例 (88\%) で可能で連鎖球菌属 15 例、ブドウ球菌 属 13 例、真菌 1 例であった。 $10 \mathrm{~mm}$ 以上の vegetation を 22 例 (67\%) に認め、塞栓歴は 17 例 (52\%)で あった。脳梗塞は 11 例 (33\%)、脳出血(SAH 含む) は 4 例、破裂性感染瘤は 1 例に認めた。IE の診断確 定から手術までは平均 $14 \pm 15$ 日、0-7 日が 13 例 (39\%)、8-14 日が 8 例 (24\%)、15-21 日が 7 例 (21\%)、 22 日以上が 5 例 (15\%)で 14 日以内が $64 \%$ であった。 緊急は 6 例 $(18 \%)$ だった。脳梗塞例での 2 週間以内 の早期手術は 4 例であった。術前 CRP は平均 $5.9 \pm$ $7.2 \mathrm{mg} / \mathrm{dl}$ で 0-7 日 $11.5 \pm 9.0 \mathrm{mg} / \mathrm{dl} 、 8-14$ 日 $3.3 \pm$ $2.2 \mathrm{mg} / \mathrm{dl} 、 15-21$ 日 $1.4 \pm 0.9 \mathrm{mg} / \mathrm{dl} 、 22$ 日 以上 $2.8 \pm$ $4.4 \mathrm{mg} / \mathrm{dl}$ であった。手術適応は塞栓予防が 24 例 (73\%、大動脈弁 vegetation 2 例含)、心不全治療／ 予防が 26 例 (79\%)、感染制御が 10 例 (30\%) であっ た。術前の MR は平均 $2.9 \pm 1.1$ 度で 3 度以上が 21 例 $(64 \%)$ 、病変は両尖 15 例 (46\%)、前尖 11 例 (33\%)、 後尖 7 例 $(21 \%)$ であった。手術は形成単独が 26 例 (79\%)、AVR などとの複合手術が 7 例、体外循環時 間は平均 $128 \pm 41$ 分、大動脈遮断時間は平均 $85 \pm 32$ 分であった。結果：病院死亡は 3 例 $(9 \%)$ に認め、内 2 例は緊急例で多蔵器不全と消化管出血(真菌)で 失った。他 1 例は複雑性尿路感染により失った。IE の再燃は認めず、CRP 陰性化 $(<1.0 \mathrm{mg} / \mathrm{dl} 、 18$ 例で の検討) までに要した術後日数の中央值は 19 日で あった。遠隔期心臓関連死は認めなかった。脳合併 症を有した 16 例で神経障害が悪化した症例はいな かったが、術後新たな脳梗塞を 2 例 $(6 \%)$ 、脳出血を 1 例 $(3 \%$ 、真菌)に生じた。中等度以上の MR 再燃は 4 例 (12\%) で前尖 2 例、両尖 2 例であった。術後 1 か 月での再燃 2 例、 5 か月 1 例、 4 年 1 例と早期再燃が 多かった。4 例中 3 例 (9\%)に再手術 (MVR)を行った。 結語: 早期手術の感染制御は良好であったが、真菌 に関連した IEの予後は不良であった。早期手術によ り形成術の可能性は高くなるが、広範な感染巣で組 織が脆弱な場合は術後早期の MR 再燃に注意する必 要がある。術前脳合併症 16 例に増悪を認めないが術 後に神経症状の出現を認めることがあるため神経症 状に注意を要する。

\section{PP-240 㲾 僧帽弁位感染性心内膜炎に対する外科治療 成績}

\author{
札幌医科大学 第2外科 \\ 中島 智博、橘一俊、宮木 靖子、 \\ 高木 伸之、樋上 哲哉
}

【背景】感染性心内膜炎は比較的稀な疾患ではあるが、 高い死亡率が報告されている。感染性心内膜炎に対 する治療は抗菌薬の発展、弁形成術の導入や、早期 手術の介入により変化を遂げている。今回我々は、 当院における僧帽弁感染性心内膜炎に対する手術方 法、手術成績について検討を行った。【対象】2007 年 01 月から 2012 年 07 月までの、当院における僧帽弁 位感染性心内膜炎に対する手術症例について検討を 行った。【結果】5 年間で 14 例の僧帽弁位感染性心内 膜炎の症例を手術治療した。平均年齢は $53.7 \pm 19.7$ 歳、男性 8 例、女性 6 例であった。1例は大動脈弁 位にも病贅を認めた。術前血液培養にて 7 例が陽性 であった。脳梗塞を術前に生じていた症例は 2 例で あった。手術は僧帽弁形成術 11 例、僧帽弁置換術 3 例であった。うち、1 例は僧帽弁形成術を施行したが 僧帽弁逆流を制御できずに置換術に移行した症例で あった。弁形成術方法は可及的に病贅を取り除き、 後尖弁輪に enhanced stay suture (後尖弁輪)を行い、 前尖に対しては当科独自の rough zone trimming 法 を行い、後尖に対しては四角切除術を行った。術後 心エコーでは僧帽弁逆流無し 10 例、mild3 例、moderate1 例、severe 0 例であった。また、術後結果は、 手術死亡 0 例、感染性脳動脈瘤破裂 1 例であったが 保存療法にて軽快した。【結論】現在までに術後再感 染症例、僧帽弁逆流制御不能症例は無く、僧帽弁位 感染性心内膜炎に対しても積極的に形成術を行うこ とは有用と考えられた。 
PP-241 文

僧帽弁位の感染性心内膜炎に対する MVP と MVR の違い

名古屋大学医学部附属病院 心臓外科

藤田山、碓水 章彦、野中 利通、

薦田さつき、徳田 順之、六鹿 雅登、

荒木 善盛、成田 裕司、大島 英揮

【目的】僧帽弁位における感染性心内膜炎(IE)の治療 法は、抗生剂治療で感染制御を行い、MVPを基本と してMVP 不能例に対して MVRを施行しているが、 両者を比較した研究は無い。本研究ではMVPおよ びMVRの短期的な成績について検討した。【対象】 当院で 2002 年から 2012 年にかけて僧帽弁位の IEに 対し MVPもしくは MVRを単独で施行した 22 例を 対象とした。男性 16 例、平均年齢 $52.6 \pm 19.1$ 歳。術前・ 術後の心エコーによる心機能を $\operatorname{MVP}(\mathrm{P}$ 群) 18 例、 $\operatorname{MVR}(\mathrm{R}$ 群) 4 例で検討した。【結果】術前の LVDd/ LVDs/EF/LAD は、P 群 は $54.9 \pm 5.0 / 33.7 \pm 4.9 / 69.6$ $\pm 7.1 / 41.6 \pm 5.4$ で、R 群は $51.7 \pm 9.4 / 28.7 \pm 3.6 / 72.2 \pm$ 14.1/41.2 \pm 8.6 。術後の LVDd/LVDs/EF/LAD は、P 群 は $47.4 \pm 5.1 / 32.9 \pm 5.3 / 58.0 \pm 10.5 / 33.5 \pm 9.1$ で、R 群は 47.2 $\pm 3.0 / 31.0 \pm 4.3 / 62.4 \pm 12.4 / 36.9 \pm 7.5$ であり、 両者に有意差は認めなかった。MRについては、術 前の $\mathrm{P}$ 群は $3.3 \pm 1.1 、 \mathrm{R}$ 群は $3.8 \pm 0.5$ 、術後の $\mathrm{P}$ 群は $0.8 \pm 1.1$ 、 $\mathrm{R}$ 群は $0.0 \pm 0.0$ であり、術後は $\mathrm{R}$ 群で $\mathrm{MR}$ が改善していた $(\mathrm{P}=0.005)$ 。手術時間 / 体外循環時間 /大動脈遮断時間について、P 群は $265 \pm 44$ 分 /145 \pm 27 分 $/ 98 \pm 22$ 分で、 $\mathrm{R}$ 群は $274 \pm 69$ 分 $/ 161 \pm 60$ 分 $/ 117 \pm 48$ 分であり、両者に有意差は認めなかった。 【結論】僧帽弁位 IEにおいても $80 \%$ 以上の症例で MVP が可能であった。両者の手術時間に有意な差は 無く、術後の心エコーによる心機能も有意な差は認 めなかった。今後は長期的な経過における評価が必 要であるが、IEにおいても MVPを施行する事によ り人工弁置換術の回避が可能である。

\section{PP-242 活動期感染性心内膜炎の外科治療}

神戸大学

$\begin{array}{lrrr}\text { 南 } & \text { 一司、木下 } & \text { 史子、後竹 } & \text { 泰子、 } \\ \text { 中井 } & \text { 秀和、小原 } & \text { 大見、竹歳 } & \text { 秀人、 } \\ \text { 山中 } & \text { 勝弘、宮原 } & \text { 俊介、白坂 } & \text { 知識、 } \\ \text { 野村 } & \text { 佳克、坂本 } & \text { 敏仁、大村 } & \text { 篤史、 } \\ \text { 井上 } & \text { 武、岡田 } & \text { 健次、大北 } & \text { 裕 }\end{array}$

活動期感染性心内膜炎は脳梗塞急性期や基部膿瘍な どの重症例も多く、一部の症例では再発をきたし治 療に難渋することも少なくない。基本的にはすべて 可及的早期手術で対応しており、その外科治療成績 および遠隔成績について検討した。[対象と方法］ 1999 年 10 月から 2012 年 8 月までに当科で施行した 活動期感染性心内膜炎手術 85 例 (男性 58 例、女性 27 例、平均年齢 $56.7 \pm 15.6$ 歳)。NVE: 73 例、PVE: 12 例。基部を含む大動脈弁位 34 例、僧帽弁位 39 例、 大動脈弁＋僧帽弁位 11 例、三尖弁位 2 例。患者背景 として糖尿病 12 例 $(14 \%) 、$ 高血圧 21 例 $(24 \%)$ 、腎 機能障害 10 例 $(11 \%)$ 。術前 NYHA3,4 度の急性心不 全は 36 例 $(42 \%)$ 。術前 $\mathrm{EF}$ は $59.5 \pm 11.6 \%$ 。脳梗塞 急性期 20 例 $(23 \%$ )、敗血症 19 例 $(22 \%$ )、塞栓症 28 例 $(33 \%)$ 。起因菌同定可能であったのは 46 例 $(54 \%)$ 。術 式は AVR17 例、MVR23 例、MVP16 例、AVR+MVR 7 例、AVR+MVP4 例、Ross6 例、基部置 換 11 例、 TVR1 例、TVP1 例。パッチによる弁輪再建を 20 例に 必要とした。[結果] 病院死亡は 6 例 $(7 \%)$ 。縦隔炎 2 例、敗血症 2 例、MOF 1 例、広範囲脳梗塞 1 例、脳 出血 1 例で失った。術後平均観察期間は $32.1 \pm 34.1$

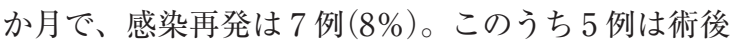
早期に再発を認め、再手術により救命可能であった のは 3 例であった。遠隔 5 年生存率は $77.6 \%$ 。[結論 $]$ 手術においては徹底した感染組織の debridement を 基本としており、基部置換や弁輪再建などの手技も 積極的に行っている。急性期をのりこえれば遠隔期 は比較的良好である。しかし、救命困難な重症例も 少なからずある。病院死亡例は高齢者低心機能、低 栄養、免疫不全患者などで sepsis、縦隔炎や PVEを 併発しており感染制御が困難であった。 
PP-243 $\lesssim$

急性期脳梗塞を合併した活動期感染性心内 膜炎に対する外科治療経験

\author{
広島市立広島市民病院 心臓血管外科 \\ 藤田 康文、吉田 英生、今井 章人、 \\ 井上 知也、鈴木登士彦、柚木 継二、 \\ 久持 邦和
}

診断技術の進歩による早期診断や抗生剂治療の進歩 により、感染性心内膜炎(IE)の治療成績は向上して いる。しかし、診断時には既に多くの合併症を引き 起こしている症例も見られ、特に急性期脳梗塞を有 する症例に対しては、手術時期の決定などに際して 決断に迷うことも少なくない。今回我々は、急性期 脳梗塞を合併した活動期感染性心内膜炎に対する外 科治療経験を報告する。対象は 1998 年 1 月から 2012 年 8 月までに当院で手術を行った IE 症例 35 例のう ち、術前に急性期脳梗塞を合併していた 4 例 (全例女 性)で、24歳から 64 歳であった。いずれも僧帽弁に 病贅を認め、1例は大動脈弁にも病贅を認めた。血 液培養陽性は 3 例で、溶連菌 2 例、ブドウ球菌 1 例 (MSSA)であった。3 例は小脳および大脳に多発性の 比較的小さな梗塞を認め、1 例は中大脳動脈第 2 分 枝より末梢に比較的大きな梗塞巣 2 つを認めた。い ずれも出血巣を認めず、脳梗塞の症状は軽度であり、 四肢麻痺などの重篤な症状を有さなかった。可動性 庞贅であり、再梗塞の危険が高いと判断したため、 発症後 2 日に 3 例、発症後 3 日に 1 例の手術を行っ た。手術は僧房弁形成術 1 例、僧房弁置換術 2 例、 二弁置換術(僧房弁 +大動脈弁) 1 例であった。いず れも術後に脳出血や再脳梗塞を生じることはなく、 全例生存退院され、日常生活に支障はない。以上の 結果から、術前に急性期脳梗塞を合併していても症 状が軽度でかつ脳出血を認めなければ、1)多発性で はあるが梗塞の範囲が小さい場合、あるいは、2)比 較的大きな脳梗塞ではあるが中大脳動脈第 2 分岐よ り末梢に存在する場合、に早期手術が可能と考えら れた。

\section{PP-244 is 僧帽弁位活動期感染性心内膜焱に対する弁 形成術}

\author{
札幌医科大学 外科学第二講座 \\ 宮木 靖子、宮木 靖子、橘一俊、 \\ 中島 智博、高木 伸之、樋上 哲哉
}

[背景]当科の僧帽弁位活動期感染性心内膜炎 (active IE) に対する手術は 2005 年 12 月までは全て弁置換術 で、過去 20 年の成績は感染を含めた心原死は 16 例 中 5 例 $(27.7 \%)$ であった。2006 年以降は、急性期 IE による僧帽弁逆流に対して僧帽弁形成を第一選択と する治療方針に変更した。[目的]当科の治療方針の 妥当性について検討する。[対象] 2006 年 1 月〜 2012 年 8 月までの IEに対して僧帽弁形成術を行った 15 例中、active IE 手術患者 11 例。[方法]年齢は 18 歳 〜 66 歳。僧帽弁単独の IE は 9 例。大動脈弁位も治 療を必要とした症例は 2 例。起因菌はMRSA2 例、 MSSA1 例、enterococcus 1 例、streptcoccus 4 例、 起因菌不明のものは 3 例。術前脳合併例は 4 例でそ のうち 2 例は意識障害を伴っていた。AVblock 合併 は 1 例、ショック状態の症例は 1 例。全例 $10 \mathrm{~mm}$ 以 上の可動性の尤贅を有した。破壊された弁尖は、前 尖のみ 3 例、後尖のみ 3 例、両尖は 5 例。術前の NYHA 分類では 1 例を除き 4 度、残りは 3 度であり、 全例緊急手術となった。[手術]弁輪部膿瘍による弁 輪部の破壊を伴ったものは 6 例、そのうち 5 例にお いて自己心膜パッチで弁輪形成した。手術方法とし ては、感染の及んだ範囲の弁尖を十分にデブリード マンし、後尖欠損に対しては、多くは矩形切除縫合 に準じた形成を行った。広範囲(後尖 $1 / 2$ )の欠損に対 しては sliding technique を用いた。交連部・前尖に 及ぶ久損に対しては自己心膜パッチを用い欠損部を 充填し、当科で行っている前尖術式「rough zone trimming 法(RZT)」の応用で弁形成を行った。RZT とは、腱索間を rough-zoneに限った帯状に trimming し縫合することで本来の coaptation line を左室 側に引き込み、新しく深い coaptation zone を作成す るというコンセプトに基づいている。［結果］全例で 僧帽弁形成を完遂。感染や弁関連の合併症は 1 例も 認めなかった。術後経過はおおむね良好で経過中に 肺炎にて 1 例失ったものの、他の 10 例は全例自宅退 院した。早期成績は全例、MR1 度以下で推移し、感 染の再燃を認めず、良好であった。中期遠隔期に 2 例 moderate MR に対して僧帽弁置換術を行ってい る。[考察] active IE では遠隔で逆流が多少生じても 弁形成で感染制御を図ることは重要であり、ことに 活動期の手術においては形成術の完遂は予後を規定 すると考えられる。[結語] active IEに対して僧帽弁 形成を第一選択とするわれわれの基本方針は妥当で ある。 
PP-245 宛

PCR 法にて確定診断を得るられた P. canes による難治性感染性心内膜炎の 1 治験例

\section{大和成和病院 心臓血管外科}

菊地 慶太、鈴木耕太郎、遠藤 由樹、

小坂 眞一、倉田篤

慢性化膿性扁桃腺炎を契機に発症した血液検査㓌性 菌による襄胞性感染性心内膜炎と感染性胸腹部大動 脈瘤を併発した症例に対して、段階的な手術と PCR 法による起因菌の同定により抗生剂治療を行い治療 しえた。本例は持続する不明熱の熱源の確定に難渋 し、かつ起因菌の同定に PCR 法を行い確定診断を得 ることができた極めて稀な症例であるため報告する。 症例：症例は 51 歳の男性。2010 年 5 月に化膿性扁 桃腺炎による発熱を繰り返したために 2011 年 11 月 に扁桃腺摘出術を施行。その後も 38 度以上の高熱と WBC15000 前後、CRP10 前後の炎症反応の上昇が長 期間持続したために 12 月 8 日に近医に入院、熱源の 精查が行われた。血液培養が繰り返し行われたが起 因菌は同定できず、また画像検査でも感染源と考え られる所見に乏しかったが、横隔膜直下腹部大動脈 に最大短径 $45 \mathrm{~mm}$ の Croford IV 型胸腹部大動脈瘤 を認めたために当院に紹介となった。画像上は多房 性の造影所見もあり感染性動脈瘤が疑われた。感染 原精査のため再度心エコー検査を行ったところ、弁 には問題なかったが左心室内に房状の可動性腫瘤が 認められた。非定型的ではあるが病状から膿瘍が疑 われ、2011 年 12 月 29 日に診断的な意味も含めて腫 瘤摘出術を行った。房状の腫瘤は左心室だけでなく 右心室にも多数認められ、すべて切除した。検体を 培養検査と PCR 検査に提出したところ、PCR 検査 にて Propionibacterium acnes(P.acnes) が検出され た。ペニシリン Gに感受性があり投薬を開始したと ころ炎症反応の低下があり解熱した。その後ペニシ リン Gの投与を継続し、炎症反応の改善を確認した のちの 2012 年 2 月 28 日に胸腹部大動脈人工血管置 換術を行った。この時人工血管はリファンピシンに 浸漬し吻合した。術後は 5 週間のペニシリン $\mathrm{G}$ 投与 を行い無熱と炎症反応の正常化を確認したのちに、 感受性のあるビクシリンとリファジンの経口投与に 切り替え、初回術後から 102 病日に軽快退院となっ た。まとめ：P.acnesによる感染性心内膜炎は極めて 稀でありまたその同定が困難である。自験例では手 術による検体を用いた PCR 法にて起因菌を同定し救 命しえた。血液検査陰性菌による感染性心血管疾患 の治療は、感受性のある抗生剂の投与が極めて大切 であるが、自験例の様にその診断に難渋することが ある。自験例では適切な判断に基づいた手術とそれ により得た検体が治療において極めて重要な要素で あると考えられたため報告する。

\section{PP-246 \\ 収縮性心膜炎に対する心膜切除範囲が血行 動態に与える影響}

\section{東北大学病院 心臓血管外科}

\author{
秋山 正年、河津聡、増田 信也、 \\ 高橋 悟朗、熊谷紀一郎、安達 理、 \\ 本吉 直孝、川本 俊輔、齋木 佳克
}

【目的】収縮性心膜炎の外科治療成績は全身状態や成 因などの術前背景だけではなく、心膜剥離範囲、合 併手術など術式により左右される。当科では心膜切 除範囲を、両横隔神経間＋横隔膜面 (A 群)、または これに左横隔神経後方左室面を加える(B 群)術式を 行ってきた。この 2 つ術式の治療成績を比較して、 外科的治療戦略について検討した。【方法】1982 年 9 月から 2012 年 8 月までに当科で経験した慢性収縮性 心膜炎症例のうち、心膜切除術のみ施行し、術前後 で心エコーまたは心臓カテーテル検査の比較が可能 な 20 例を対象とした。術式別に A 群 13 例(54.8歳、 男: 女 $6: 7$ 、特発性 7、開心術後 5、外傷性 1)B 群 7 例 (52.9 歳、7: 0、特発性 7 例)に分けた。画像診断で、 心膜石灰化は $\mathrm{B}$ 群 $(\mathrm{p}=0.03)$ 、胸水貯留は $\mathrm{A}$ 群 $(\mathrm{p}=$ 0.03)に有意に多かった。【成績】A 群 13 例には胸骨 正中切開、B 群には胸骨正中切開と左開胸で手術施 行。術後早期死亡 1 例 (25 日)、遠隔期死亡 1 例 (5 年)、 いずれも A 群。生存率は 1 年で $95 \% 、 10$ 年で $83 \%$ 。 術式別の主な血行動態を表に示す。左室駆出率 $(\mathrm{A}$ 群 $65 \rightarrow 68 \%$ 、B 群 $58 \rightarrow 58 、 \mathrm{p}=0.09)$ などに有意差は 認めなかった。心臓カテーテル検査では右房圧が B 群で有意に下がった。肺動脈楔入圧 $(\mathrm{A} ; 20 \rightarrow 14$ $\mathrm{mmHg} 、 \mathrm{~B} ; 20 \rightarrow 13 、 \mathrm{p}=0.5)$ や心係数 $(\mathrm{A} ; 2.3 \rightarrow 2.8$ $\left.\mathrm{L} / \mathrm{min} / \mathrm{m}^{2} 、 \mathrm{~B} ; 2.1 \rightarrow 2.4 、 \mathrm{p}=0.24\right)$ などに差はなかっ た。【結論】B群で左室径の有意な拡大、左室拡張期 流入血流速度の増加と、右房圧の有意な低下を認め た。両横隔神経間のみの心膜切除は正中切開で施行 可能だが、左室側の切除には工夫を要する。当科で は左開胸にて良好な視野で行っている。外科的な広 範囲の心膜切除で心膜に締めつけを可能なかぎり解 除することで左室の拡張能改善、右房圧減圧が得ら れる。

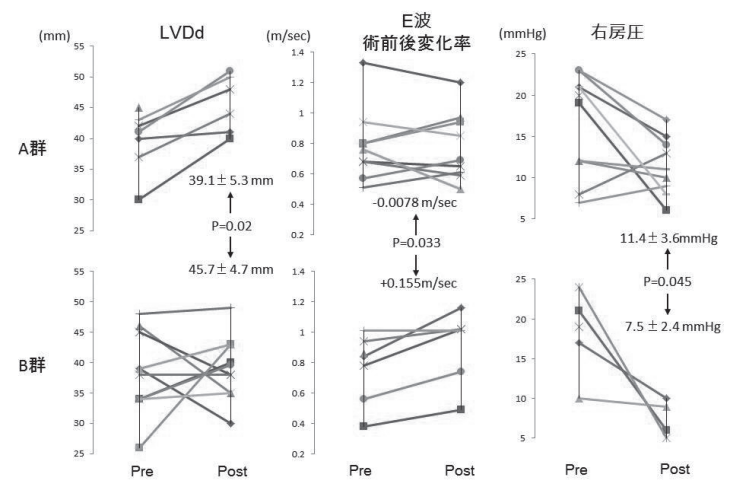


PP-247 年 収縮性心膜炎に対する治療成績の検討

\section{広島市立広島市民病院 心臓血管外科}

今井 章人、吉田 英生、井上 知也、 鈴木登士彦、藤田 康文、柚木 継二、 久持 邦和

【はじめに】収縮性心膜炎 (CP) は拡張障害を主体とす る疾患であり、外科的心膜切除のみが根本的治療で、 心膜切除に加え心外膜切開が必要となることも少な くない。タイミングが遅れて手術を行うと予後不良 とも言われ早期に診断を得ることが重要である。当 院では過去 25 年間にCP に対する手術症例を 14 例 経験したのでその治療成績を検討した。【対象】14 例 中男性 12 例女性 2 例で男性が $86 \%$ と圧倒的に多く、 年齢は $34 \sim 77$ 歳、平均 61.2 歳であった。原因は心 臓手術後 6 例 (43\%)、特発性 5 例 $(36 \%)$ 、結核性 2 例 (14\%)、中皮腫 1 例 $(7 \%)$ であった。術後の内訳は 冠動脈バイパス術 $(\mathrm{CABG})$ 後 3 例、弁置換術後 2 例、 心室中隔欠損閉鎖 $(V S D)$ 術後 1 例で、VSD 術後症例 は CP に対する再手術例であった。術後から症状発 現までの期間は二弁置換術後の 8 年 5 ケ月を除くと 3 ケ月〜 2 年と比較的早期に出現し、手術までの期間 は症状発現後 2 年以内に行われていた。術式は術前 の CT、心臓カテーテル、心エコー検査と術中所見で 心膜切除範囲を決定し、右房側・心室前面・横隔膜面・ 心尖部は通常の切除範囲、左室側面〜後面切除は必 要に応じて行ない、肥厚した心外膜は可及的に網目 状切開 (waffle technique)を行なった。【結果】体外循 環 $(\mathrm{CPB})$ 下に行なった症例は 9 例で、3 例は心内修 復のため心停止した。 8 例で左室側面の切除を行い、 その術野展開には内胸動脈剥離用開創器が有用であ り、心外膜切開にはハーモニックスカルペルが有用 であった。術後入院死亡はなく、入院日数は 13 171 日であったが、中皮腫症例は術後も腹水・胸水が 難治で、化学療法のため入院が 5 ケ月に及んだ。遠 隔死は 3 例ですべて他病因死であり疾患関連死亡は 認めていない。術後 NYHA は原疾患のためにあまり 改善しなかった中皮腫症例を除き、全て術前の 3 度 から $1 〜 2$ 度と改善した。【まとめ】CPに対する外科 的治療成績は概ね良好であった。病態にあわせて CPB を適宜使用し、可及的広範囲に心膜切除を行う ことが重要であり、視野展開には内胸動脈剥離用開 創器、心外膜切開にはハーモニックスカルペルが有 用であった。

\section{PP-248 \\ 人工心肺中のガス状微小塞栓に関する基礎 研究}

\author{
三重ハートセンター \\ 笹山 幸治、西村 善幸、神谷 賢一
}

【背景】Microbubble (MB) は、ガス状微小塞栓(Gaseous Microemboli: GME) を起因とする術後高次脳機 能障害の原因ともいわれ、心蔵血管外科手術では重 要な問題である。そこで、人工心肺 $(\mathrm{CPB})$ で発生し、 送血回路に混入する $\mathrm{MB}$ を実験で検討した。【方法】 臨床状況に近付けるため、実験回路の各構成品に臨 床使用可能な未開封新品を使用した。静脈血貯血槽

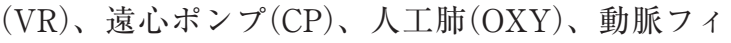
ルター $(\mathrm{AF})$ で模擬回路を作製した。実験直前に血小 板処理した牛血を用いて充填後、HCT: $25 \%$ 、血液温： $34{ }^{\circ} \mathrm{C} 、 \mathrm{PCO}_{2}: 40 \mathrm{mmHg} 、 \mathrm{PO}_{2}: 200 \mathrm{mmHg}$ に調整した。 心内血貯血槽(CX-CR40X) と静脈バブルトラップ （VBT160）を用いた模擬患者で除泡して、灌流量： $4.5 \mathrm{~L} /$ 分、送血圧: $200 \mathrm{mmHg}$ で循環し、血小板処理 開始から 10 時間で廃裹した。実験に使用した構成品 は、VR: VHK2001・CX-RR40、CP: ROTAFLOW、 OXY (AF 一 体 型): HMO71000 - FX25 - SYNTHE-

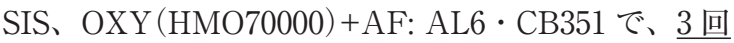
とも全て未開封新品を使用した。【実験 $\mathrm{A}$ 】脱血回路 から空気 $(200 \mathrm{~mL} / \mathrm{min})$ を混入し、VR夜面レベル (VRL) が $300 \mathrm{~mL}$ および $800 \mathrm{~mL}$ 時にVR outlet から 流出する MB を測定した。【実験 B】脱血回路から空 気 $(200-1,000 \mathrm{~mL} / \mathrm{min})$ を混入し、VRL が $800 \mathrm{~mL}$ 時に $\mathrm{CP} \cdot \mathrm{OXY} \cdot \mathrm{AF}$ outlet から流出する $\mathrm{MB}$ を測定した。 測 定に Hatteland 社製 CMD20 Microbubble Detec-

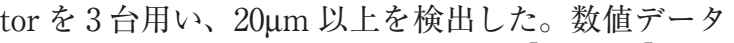
は、平均個数/minで表示した。【結果 A】VRL: 300mL 時の MB は、VHK2001: 471 個 •CX-RR40: 674 個、VRL: 800mL 時 は、VHK2001: 410 個・CX-RR40: 580 個であった。【結果 $\mathrm{B}$ 】脱血回路に $200 \mathrm{~mL} / \mathrm{min}$ と $600 \mathrm{~mL} / \mathrm{min}$ で送気し、送血回路に混入した $\mathrm{MB}$ は、 HMO71000: 10 個 と 249 個 - FX25: 8 個 と221 個 • SYNTHESIS: 0 個 と 1 個 -AL6: 0 個 と 114 個・ CB351: 0 個と79個であった (VRにCX-RR40を使 用)。【考察】脱血回路に混入した比較的大きな空気 は、VRの除泡剂で崩れて MB になる。MB の直径が 小さいほど気泡内部の沸点圧力が大きく浮力も小さ い。更に窒素を含むことから、血液に混入した $\mathrm{MB}$ は血液に溶け難い。従って、MB を除去するためには、 空気が通過できるOXYにより長く接触させるか、 $\mathrm{MB}$ より細かい AF で捕捉する必要がある。しかし、 長時間の異物接触や内部圧力損失の増大は、血液へ の影響が示唆され、今後の課題となった。【結語】 $\mathrm{CPB}$ 中に発生する MB は、全てを除去することが困 難である。術者は、脱血回路への空気混入を十分に 注意する必要がある。 
PP-249 گr

人工心肺回路内残血の処理法の比較検討

埼玉医科大学総合医療センター 心臓血管外科

松岡 貴裕、川島大、河田 光弘、

山火 秀明、今中 和人

人工心肺回路内残血を自己血回収装置で処理すると、 ヘパリンが除去されて止血に有益と言われている一 方、炎症の惹起などの問題も指摘されている。今回 我々は、通常の心臓手術において、自己血回収装置 と限外滤過とで血液検査や、術後出血量、輸血使用 量などの臨床経過にどのような影響が生じるかを比 較検討した。【対象】2011 年 2 月から 2012 年 6 月ま での間に当科で施行した、待機的な人工心肺使用下 の心臓手術 64 例を、無作為に自己血回収装置群 (S 群) 30 例と限外滤過群 (C 群) 34 例に振り分けた。再 手術、感染症例、大血管関連症例は除外した。C 群 では、自己血回収装置は使用しなかった。手術終了 後にそれぞれの方法で処理された血液を返血した。 人工心肺離脱時、ICU 帰室時、帰室後 6 時間、帰室 後 12 時間、術後一週間に血液検査を行い Hb、Hct、 TP、Alb、Fib、IL-6、CH50などの通常および炎症 関連の血液検査データ、また輸血使用量、術後 24 時 間の出血量、ICU 滞在日数などの臨床パラメーター を比較した。術前は Fib (S 群 $400 \mathrm{mg} / \mathrm{dl} 、 C$ 群 $351 \mathrm{mg} / \mathrm{dl} 、 \mathrm{p}=0.04)$ のみ $\mathrm{S}$ 群で有意に高值であった。 【結果】両群で処理血返血量 ( $\mathrm{S}$ 群 $531 \mathrm{ml} 、 \mathrm{C}$ 群 $578 \mathrm{ml}$ 、 $\mathrm{p}=0.44$ )、術後 24 時間の出血量 $(\mathrm{S}$ 群 $389 \mathrm{ml}$ 、C 群 $407 \mathrm{ml} 、 \mathrm{p}=0.60$ )、ICU 滞在日数 ( $\mathrm{S}$ 群 1.9 日、C 群 1.8 日、 $\mathrm{p}=0.78$ ) に有意差はなかった。手術室および ICU での総輸血使用量は、 $\mathrm{RCC}(\mathrm{S}$ 群 2.33 単位、C 群 3.23 単位、 $\mathrm{p}=0.37) 、 \mathrm{FFP}(\mathrm{S}$ 群 2.20 単位、C 群 2.64 単位、 $\mathrm{p}=0.66) 、 \mathrm{PC}(\mathrm{S}$ 群 0.66 単位、C 群 2.35 単位、 $\mathrm{p}=0.18)$ ともに両群で有意差はなかった。血液検査では、一 般に言われる IL-6 などの炎症系パラメーターには有 意差がなく、ICU 帰室時、ICU 帰室後 6 時間の $\mathrm{Hb}$ (帰 室時 : $\mathrm{S}$ 群 $9.7 \mathrm{~g} / \mathrm{dl} 、 \mathrm{C}$ 群 $8.9 \mathrm{~g} / \mathrm{dl} 、 \mathrm{p}=0.03 、 6$ 時間 : $\mathrm{S}$ 群 $11.1 \mathrm{~g} / \mathrm{dl} 、 \mathrm{C}$ 群 $10.1 \mathrm{~g} / \mathrm{dl} 、 \mathrm{p}=0.01$ ) が C 群で有意に 低值を示し、また帰室後 6 時間と帰室後 12 時間の $\mathrm{TP}(6$ 時間 : S 群 $5.51 \mathrm{~g} / \mathrm{dl} 、 \mathrm{C}$ 群 $5.80 \mathrm{~g} / \mathrm{dl} 、 \mathrm{p}=0.03 、 12$ 時間 : S 群 $5.58 \mathrm{~g} / \mathrm{dl} 、 \mathrm{C}$ 群 $5.96 \mathrm{~g} / \mathrm{dl} 、 \mathrm{p}=0.002)$ が $\mathrm{S}$ 群 で有意に低值であった。【結語】通常の心臟手術にお いては、自己血回収装置による輸血量節減効果もへ パリン除去による術後出血抑制も有意差を生じるほ どではなかった。むしろ低タンパク血症の補正の必 要性が増し、保険適応になってはいるが自己血回収 装置自体のコストが上乗せされるため、特に出血が 危惧される症例以外では必要性は低いかもしれない。
PP-250 乞

高齢者に対する Destination Therapy として の植込型補助人工心臓

\section{${ }^{1}$ 三井記念病院 心臓血管外科 \\ 東京大学重症心不全治療開発講座}

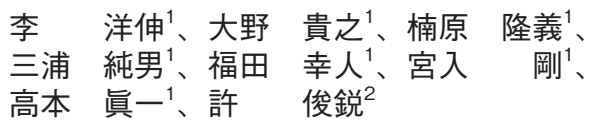

【背景】植込型補助人工心臓である Jarvik2000 は現在 本邦で保険適用承認申請中であるが、ポンプ容積 $25 \mathrm{ml}$ 、重量 $90 \mathrm{~g}$ と小型の軸流ポンプで、ポンプ自体 が左室内に埋込まれるためポケットの作成が不要で ある。体内ケーブルも細くドライブラインからの感 染を低減できる特徵を有する。欧米での良好な成績 も報告されてきており、7 年以上の補助例も報告され 高い耐久性を持つと考えられる。今回、われわれは Jarvik2000 を永久使用(Destination Therapy: DT) 目 的として使用したので報告する。【症例】78才男性。 低左心機能の虚血性心筋症 $(\mathrm{EF}=19 \% \mathrm{LVDd} /$ $\mathrm{Ds}=62 / 58 \mathrm{~mm}$ ) に対し、IABP 挿入下オフポンプ冠動 脈バイパス術 3 枝、CRTP 植込み術を施行。術翌日 に抜管し一般病棟にてリハビリテーションを進めて いたがカテコラミン依存状態(INTERMACS Profile 3) となり退院が困難となった。患者本人と家族の強 い希望により、術後44日目にDTとしての Jarvik2000 装着術を施行した。手術はFF バイパスによ る人工心肺補助下に左開胸で行った。下行大動脈に アウトフロー人工血管を端側吻合した後、左室心尖 部にポンプ装着用のカフを縫着した。心尖部心筋を punch outしてポンプを左室内に挿入、固定した。 装着術後 4 日目にカテコラミン補助不要となった。 抗凝固療法としては INR2.0-2.5 目標としワーファ リン調整を行った。リハビリテーションを進め、装 着術後 24 日目に医師、看護師同伴にて試験外泊した。 装着術後 91 日目に自宅退院し、日常生活に支障を来 すことない程度に回復した。しかし退院後 14 日目に 脳出血を発症し死亡した。【結論】Jarvik2000 装着に より術前 NYHA IV 度の心不全がI 度まで改善し患 者の QOL と ADL を向上させた。また短期間では あったが自宅での通常の生活が可能であった。高齢 化社会である我が国において、DTとしての植込型 補助人工心臓は重症心不全患者を救命し得る治療戦 略として有用であることが示唆された。 


\section{PP-251 为 \\ QGS からみた非虚血性拡張型心筋症におけ る左室壁収縮力低下の局在性}

\author{
北海道大学病院 循環器 - 呼吸器外科 \\ 久保田 卓、関達也、飯島誠、 \\ 内藤 祐嗣、新宮 康栄、若狭哲、 \\ 大岡 智学、橘剛、松居 喜郎
}

「背景」心拡大を伴った末期の非虚血性拡張型心筋症 (DCM)における左室壁収縮障害はさまざまな modalityによりその局在性が確認されている。しかし、比 較的簡便で定量的に局所的な壁収縮を評価できる Quantitative Gated SPECT(QGS) による wall thickening で DCM の局所壁運動を検討した報告はない。 「方法」2004 年から 2011 年 12 月までに DCM に対す る外科手術を行った症例のうち術前にQGS を施行し た 21 例を対象とした。QGSによる wall thickening は左室壁 level(basal、mid、distal)により標準值が異 なる。そこで日本人データーベースから算出された LV wall thickening の各 segment 平均值と標準偏差 を用いた $\mathrm{Z}$ score (平均值 $=0$ 、平均值 $-\mathrm{SD}=1.0$ 、 平均值 $-2 \mathrm{SD}=2.0$ )により $\mathrm{DCM}$ 症例の各 segment の thickening 值を是正した。そして、各 $\operatorname{area}(\mathrm{A}$ ：前 壁、AS：前壁中隔、IS: 下壁中隔、I：下壁、P：後壁、 $\mathrm{L}$ ：側壁)の mid と distal の值を合算し、各 area の值 とした。各症例内での area $Z$ score を更に算出し、0.8 以上を局所低下と定義し局在性を検討した。左室壁 area は 1way ANOVA もしくは Kruskal-Wallisによ り、またそれに続く各群間比較は post hocにより検 定した。「結果」DCM 症例の平均年齢は $57 \pm 12$ 歳、 $\mathrm{EF}$ は平均 $23.7 \pm 6.4 \% 、 \mathrm{EDV}$ は平均 $352 \pm 97 \mathrm{ml}$ で あった。症例毎の局在性は、A もしくは AS(AAS) が低下していた (AS 群)のが 6 例、 AAS と P 共に低 下していた $(\mathrm{AAS}+\mathrm{P}$ 群)のが 1 例、 $\mathrm{P}(\mathrm{P}$ 群)が 5 例、 その他(E 群)が 9 例であった。AS 群において、AAS は P およびLに比して優位に高值であった(AAS vs $\mathrm{P}: 9.9 \pm 0.9$ vs $7.9 \pm 1.5 \mathrm{p}=0.04$ 、vs $\mathrm{L}:$ vs $6.8 \pm 1.5 \mathrm{p}$ <0.01)。また、P群において、Pは AAS および IS に比して優位に高值であった(P vs AAS : 10.3 00.8 vs $7.7 \pm 1.5 \mathrm{p}<0.05$ 、vs IS : vs $7.3 \pm 1.0 \mathrm{p}<0.01)$ 。 群においては、Iが ISに比して優位に高值であった(I vs IS : $9.8 \pm 1.2$ vs $7.6 \pm 1.2 \mathrm{P}=0.01)$ 。「結論」DCM 症 例において QGS wall thickening から見た左室壁収 縮力は全体的に著明に低下はしているものの、その 中でも特に前壁中隔が低下している症例や、後側壁 が低下している症例を認め、左室収縮力低下の局在 性が確認された。左室形成を行う際は、前壁中隔の 形成だけではなく、後側壁に対する手技も積極的に 付加する必要がある症例が存在すると考えられた。

\section{PP-252 六 新たな胸骨固定補助材料(スーパーフィクソ ブ MX40)を用いた胸骨固定法}

\author{
社会医療法人財団 慈泉会 相澤病院 心臓血管外 \\ 科
}

恒元 秀夫、山浦 一宏

胸骨縦切開後の胸骨固定は、胸骨ワイヤーにより行 われているが、胸骨の脆弱性を伴った症例に対して は、ワイヤーによる胸骨の離断により、十分なワイ ヤーの締め付けが出来ず、強固な胸骨の固定は不可 能であった。今回、我々は、骨吸収性 Bio-Ceramic(スー パーフィクソブ MX40：以下 SF) を用いた新たな胸 骨固定法を考案した。また、人工骨を用いた胸骨固 定強度の測定を行い、FM を用いた胸骨固定の方が より強固となることを確認した。実際に SF を用いた 症例の結果について報告する。【対象】平成 22 年 4 月 〜平成 24 年 6 月の間に胸骨縦切開を施行した症例の うち、骨粗鬆症などにより胸骨の脆弱性を認め、SF を用いて胸骨を閉鎖した 33 例を対象とした(年齢： $70.1 \pm 8.2$ 歳、男女比 : $7: 26)$ 。方法 : 胸骨閉鎖の際、 $1.0 \times 3.0 \mathrm{~cm}$ の長方形の SF をプレジェットのように 胸骨ワイヤー(直径 $1 \mathrm{~mm}$ ) を通し、合計 5 力所の補強 を行い胸骨を閉鎖した。また、人工胸骨を用いて、 $\mathrm{SF}$ を用いて胸骨の固定を行った $\mathrm{F}$ 群とワイヤーのみ で固定を行った N 群に対して、ワイヤーによる胸骨 離断を認めるまでの締め付けトルクを比較検討した。 【結果】SFを用いた 33 例全例、胸骨の動摇は認めな かった。人工胸骨を用いた実験では、F 群の方が $\mathrm{N}$ 群よりワイヤーの締め付けトルクが約 38\%強かった。 【考察】人工胸骨を用いた実験結果より、胸骨の脆弱 性を呈する症例に対して、SF を用いて固定を行うと、 ワイヤーによる締め付けトルクが強いため、胸骨の 固定強度が増す事が確認された。臨床症例において も、胸骨動摇を認めた症例は無く、基礎的実験の結 果を童付ける結果であった。胸骨の強固な固定は、 炎症性骨膜反応による疼痛の軽減、早期離床、早期 リハビリが可能となり、術後在院日数の短縮に寄与 する可能性があると思われる。【結語】骨粗鬆症によ る胸骨の脆弱性を呈する胸骨縦切開症例に対して骨 吸収性 Bio-Ceramicにより作成されたSFを胸骨閉 鎖の補助材として用いることで、より強固な胸骨の 固定が得られ、術後疼痛の緩和、早期離床にも寄与 する可能性が有ると思われた。人工胸骨を用いた骨 粗鬆症シミュレーションモデルより、胸骨ワイヤー の締め付けトルクが SF を用いた場合、約 $38 \%$ 締め 付けトルクが増加し、胸骨固定強度の増強が得られ ることが確認された。 
PP-253 咨

\section{ゴム人工筋肉を用いた心筋補助装置の開発}

\section{弘前大学大学院医学研究科 胸部心臓血管外科学講} 座

齊藤 良明、鈴木 保之、大徳 和之、

皆川 正仁、福井 康三、福田 幾夫

【背景】重症心不全患者に対し広背筋を心臓周囲に巻 きつけ心補助を行う Dynamic Cardiomyoplasty は短 期間の心機能補助効果は良好であり、現存する人工 心臓の様に血液との異物反応もないため血栓塞栓、 全身炎症反応の合併症は少ない。しかしながら広背 筋による長期補助では、必ず筋肉疲労が生じ、有効 な補助が得られなくという問題が起こるため現在で はほとんど行われていない。そこで当科では人工筋 肉 (ゴム人工筋肉) を広背筋の代わりに使用して心周 囲を圧迫し補助を行うデバイスを開発している。【装 置と方法】ゴム人工筋肉 (FESTO 社製) は内径 $5 \mathrm{~mm}$ 、 長さ $10 \mathrm{~cm}$ 。人工筋肉のパフォーマンス: 最大収縮力 $150 \mathrm{~N}$ 、最大収縮率 $25 \%$ 、駆動 は圧縮空気( 0.1 $0.8 \mathrm{MPa})$ 。人工筋肉を 4 本使用し補助装置を作成し た(前後 2 本ずつで挟み込む形でサポートする。図 1)。 4 本の人工筋肉が収縮するのをサーボコントローラー で制御した。同時に $6 \times 8 \mathrm{~cm}$ の 1 方向弁付きのソフ トバッグと塩ビチューブを用いてシミュレーション 回路を作成し、内腔を水で満たし還流した。ソフト バッグ内圧、流出チューブ内圧、チューブ内拍出速度・ 流量を測定した。【結果】筋肉装置の動作はス ムーズで、収縮は強力であった。収縮時間、拡張時 間はサーボコントローラーで制御可能であり、さら に収縮頻度を 50-90回/分で設定しそれぞれの圧・ 流量を計測した。駆動用の圧縮空気圧は $0.8 \mathrm{MPa}$ と した。最大収縮期バッグ内圧・チューブ内圧はそれ ぞれ 110-160mmHg、110-140mmHg、最大拍出流速 は $2.9 \mathrm{~L} / \mathrm{min}$ であった。【結論】今回我々が使用したゴ 么人工筋肉は強力な収縮力を有し、心筋補助装置に 有用である可能性が示唆された。生体へ使用するた めに、現在形状・動作の改良、収縮同期のシステム 導入などをさらに進めている。

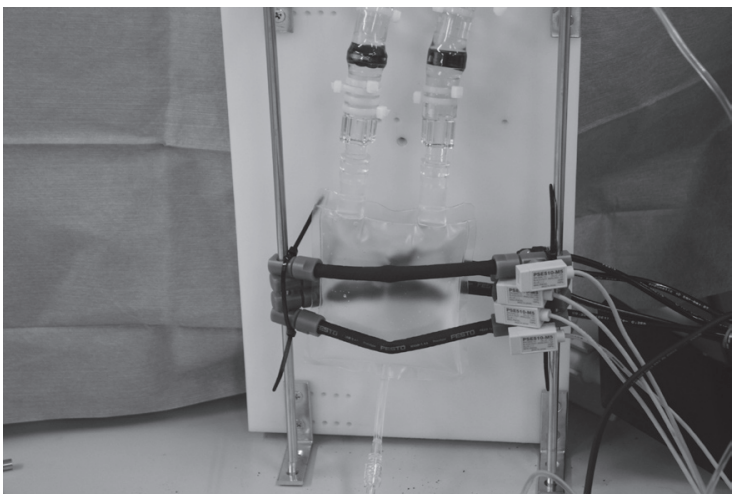

PP-254 乞ぇ

再冠動脈バイパス術における高周波心外膜 エコーの有用性

\section{滋賀医科大学医学部付属病院 心臓血管外科}

$\begin{array}{llll}\text { 内藤 } & \text { 志歩、木下 } & \text { 武、早川 } & \text { 真人、 } \\ \text { 高島 } & \text { 範之、畔柳 } & \text { 智司、乃田 } & \text { 浩光、 } \\ \text { 鈴木 } & \text { 友彰、浅井 } & \text { 徹 } & \end{array}$

目的：再 CABGにおいて、縦隔・心囊内の高度癒着 により標的血管の同定は困難を極め、手術時間延長、 出血リスクの増大、吻合の質の低下につながる。当 施設では 2011 年 7 月以降高周波心外膜エコー (Epicardial ultrasound、ECUS)を用い埋没冠動脈を確実 に同定し得ている。再冠動脈バイパス術に対しては 前回の吻合部位の評価、再手術における吻合の評価 にも特に有用であった。2011 年 7 月から 2012 年 4 月 までの再 CABG3 例における ECUS の有用性を検討 する。方法・血管：症例 $1: 71$ 歳男性。23 年前、胸 骨正中切開下に Ao-SVG-LAD を施行、労作性胸部不 快を契機に行なった冠動脈造影で、SVG 完全閉塞を 認めた。症例 $2: 75$ 歳男性。29 年前、胸骨正中切開 下にAo-SVG-LAD、Ao-SVG-OM を施行、狭心症再 発を契機に行なった冠動脈造影にて両 SVG 完全閉塞 を認めた。症例 $3: 78$ 歳男性。7 年前、胸骨正中切 開下にAo-SVG-LAD、Ao-SVG-RCA を施行、安静時 胸痛を契機に行なった冠動脈造影にて 3 枝完全閉塞、 Ao-SVG-RCA 完全閉塞とAo-SVG-LAD 高度狭窄を 認めた。症例 $1 、 2$ は待機手術、症例 3 は緊急手術と した。いずれの症例も再胸骨正中切開にて心囊に到 達した。心表面の癒着は高度で視診・触診による冠 動脈の同定は困難であったが、ECUSにより高度な 癒着組織に覆われた SVG と冠動脈の走行・内腔の状 態を正確に描出し、吻合に至適な冠動脈を露出する ことができた(図、癒着組織に埋没した前下行枝)。 $\mathrm{LAD}$ と $\mathrm{Dx}$ の区別は心室中隔壁や中隔枝の存在が目 印になった。動脈と静脈の区別においては、プラー クや石灰化の有無、静脈は軽度の圧迫で容易に内腔 が潰れてしまうことで区別できた。いずれの症例も オフポンプで完遂、完全血行再建を達成した。結語： ECUS は癒着組織に覆われたグラフトや冠動脈の走 行と内腔の性状を正確に評価にすることを非侵襲的 に可能にする、再手術症例で特に有用なデバイスで ある。

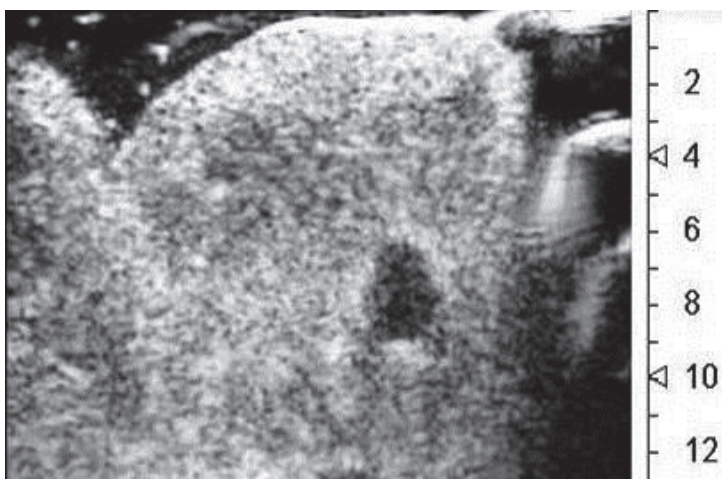




\section{PP-255}

980nmCW による血管内レーザー焼灼術 (EVLA) は患者が満足できる治療法か?

\author{
南和歌山医療センター \\ 小森 茂、東 康晴、内藤 古真、 \\ 清水 幸生、木下 貴裕
}

(はじめに)平成 23 年 1 月、一次性伏在静脈瘤に対し て 980nmCW レーザーによる EVLA が保険収載され た。患者負担は減少し、傷跡がほとんど残らないため、 一躍脚光を集めるものとなった。同年 10 月、当セン ターに導入以来し、症例数は増加の一途であるが、 治療効果の判定には時間を要す。今回は患者の満足 度を比較するために EVLA 前に治療経験のある症例 の満足度、早期成績を調べた。(対象と方法)平成 23 年 10 月から翌 8 月までの EVLA61 例のうち、以前 に侵襲的治療を受けた 12 例を対象とした。女性 9 例、 男性 3 例で、平均年齢は 65 歳 $(43-86)$ であった。 高位結紮後の再発が 2 例で硬化療法後の再発を 1 例 で認めた。EVLA 前の治療としてはストリッピング 手術 (ST) が 6 例、高位結紮術 (HL) が 5 例、硬化療 法が 1 例であった。下腿の瘤切除術は TLA 下スタブ アバルジョン法(stab)を行い、EVLA 8 例で、ST4 例で、HL 1 例で施行した。麻酔方法として EVLA は静脈麻酔下 TLA を施行した。ST は腰椎麻酔 4 例 (1 例は静脈麻酔補助下)、静脈麻酔下 TLA が 2 例で、 HL、硬化療法はいずれも局所麻酔であった。入院の 有無は、EVLA は 11 例が入院、1 例が外来、ST は 全例で入院、HL と硬化療法は日帰りが基本であるが、 1 例で入院加療を行った。EVLA の術後評価は CVT により翌朝の下肢静脈エコー検査で行った。患者満 足度評価項目としては 1 手術の時間、 2 手術中の痛 み、3 手術直後の痛み、 4 帰宅後の痛み、 5 帰宅後の ADL、6 現状、 7 現在の痛み、8 外観、9 費用の 9 項 目について 5 段階 (1 が不満、 3 が普通、 5 が大満足) で評価してもらい、次も受けるか? も返答してもらっ た。(結果)EVLA 後のエコーでは全例で GSV の閉塞 を確認し、EHIT などの重大な有害事象は認めなかっ た。満足度の平均としては、EVLA：4.3、ST：4.2、 HL : 2.2、硬化療法：1.2 であった。次も EVLA を選 択する方は $57 \%$ に留まった。麻酔別には静脈麻酔下 TLA：4.3、腰椎麻酔：4.1、局所麻酔：1.7 であった。 stabについてはあり :4.3、なし : 3.2 であった。(考察) EVLA は比較的患者満足度の高い治療と考えられる が、静脈麻酔下 TLA を行い、術中、術直後の疼痛 コントロールをしっかり行えば ST も患者満足度は高 く、TLA 下の stabによる下腿の静脈瘤切除は同時 に行えれば、より高い満足度が得られる事がわかっ た。

\section{PP-256 文 \\ 表面増強ラマン散乱(SERS) を用いた新たな 心筋組織イメージング}

\author{
1京都府立医科大学大学院 医学研究科 心臓血管 \\ 外科学 \\ 2京都府立医科大学大学院 医学研究科 細胞分子 \\ 機能病理学
}

\begin{tabular}{|c|c|c|c|c|c|}
\hline 山本 & 経尚 ${ }^{1}$ & 原田 & 義規 ${ }^{2}$ & 松代 & 卓也 ${ }^{1}$ 、 \\
\hline 大平 & 卓 ${ }^{1}$ & 川尻 & 英長 ${ }^{1}$ & 土肥 & 正浩 ${ }^{1} 、$ \\
\hline 辺 & 太治 ${ }^{1}$ & 大川 & 和成 ${ }^{1}$ & 坂井 & 修 \\
\hline 㡿 & 克彦 ${ }^{1}$ & 土井 & 潔 ${ }^{1}$ & 神田 & 圭一 \\
\hline 松 & 哲郎 & 5 & 均 & & \\
\hline
\end{tabular}

【目的】ヒト組織を生きたまま分子レベルで解明する ことは、術中ヒト心筋組織診断における究極の目標 である。現在、我々は、組織内生体分子の局在や機 能を無標識に観察・評価しうる方法の一つであるラ マン分光法に注目することで、新たな生体組織診断 法の開発を行っている。ラマン分光法は、単色光を 物質に照射し散乱光を分光器にて観察し、得られた スペクトルを解析することで物質の状態を分子レベ ルで評価できる方法である。しかし、古典的なラマ ン散乱のシグナルは非常に小さく、1 点のスペクトル を得るには長い時間がかかるため、共鳴ラマンなど 増強法を利用できる分子以外では組織イメージング を行うことは困難であった。今回、我々は表面増強 ラマン散乱 (Surface Enhanced Raman Spectroscopy; SERS) を用いることで、信号強度の改善を図った。 SERS は、金属ナノ粒子に光を照射することで発生す る表面プラズモン共鳴を利用したラマン散乱である。 金属ナノ粒子と標的分子が接することで、標的分子 のラマン散乱光強度が理論上 10 数桁増強する。ラッ ト心に対して生体毒性のない金ナノ粒子を用いるこ とにより新たな心筋イメージングが細胞レベルで可 能となった。【方法】心筋梗塞後 28 日目ラット心と正 常ラット心の $2 u m$ 切片作成し、標本上に金ナノ粒子 を滴下。高速ラマン顕微鏡を用いて心筋梗塞部・正 常心筋部を観察。得られたスペクトルを比較・検討 した。【結果】スペクトルの差に注目することで、ラッ 卜心の正常心筋部・梗塞部のイメージングが可能に なった。これは、今後、左室形成術時における切開 線決定など、新たな術中心筋組織診断法になりうる 可能性がある。 


\section{PP-257究 \\ 内視鏡的大伏在静脈グラフト採取連続 50 例 の検討}

公益財団法人天理よろづ相談所病院 心臓血管外科

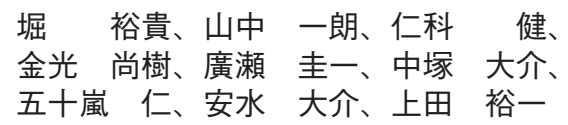

【目的】冠動脈バイパス術における静脈グラフト採取 部の創部合併症は、患者の $\mathrm{QOL}$ や術後の離床、入院 期間などに直結する。当院では術後の創部治癒遅延 を軽減するために冠動脈バイパス術 (CABG)に使用 する大伏在静脈グラフト採取は原則全例で内視鏡下 に採取(Endoscopic Vein graft Harvesting : EVH)す る方針に変更した。MICSなどの今後心臓血管外科 領域での低侵襲治療において、内視鏡操作のトレー ニングが重要となってきた昨今の状況を鑑みて、当 院では後期研修医が中心に EVH を施行、継続的に 評価を行なっている。静脈グラフト採取の方法を $\mathrm{EVH}$ に変更してからの短期的成績および創部合併 症、また採取する術者のラーニングカーブにつき検 討したため報告する。【対象及び方法】EVHによるグ ラフト採取を開始して 2011 年 1 月〜 2012 年 4 月ま での予定の CABG 連続 50 例を対象とした。平均年 齢 $69 \pm 9.9$ 歳、男性 30 例、女性 20 例。採取にはVirtuoSaph System(テルモ社)を使用し、大腿よりグラ フト採取を行った。採取したのは 2 人の心臓血管外 科後期研修医(卒後 3-6 年) であった。2 名共に dry lab、wet labのトレーニングを行った後、20-30 例採 取した医師が次にトレーニングする者を指導すると いう形で行った。採取したグラフトは執刀責任者が チェックし評価して、修復や枝の処置を加えた。術 後の早期グラフト開存率、quality 評価はCAGもし くは術後 1 週間前後の冠動脈 CT 㣮用いて行った。 また、グラフト採取のラーニングカーブについては、 開始から 5 例と最終 5 例の採取時間、修復箇所の数 の変化を評価した。【結果】大伏在静脈の採取時間は 平均 $41.2 \pm 13.5$ 分 / 本、(両下肢採取 11 例、 $22 \%$ ) 採 取後修復を要する箇所を $1.71 \pm 0.86$ 箇所に認めた。 術中計測による graft 血流量は平均 $69 \pm 40.7 \mathrm{ml} / \mathrm{min}$ 、 早期開存率は $97 \%(58 / 60$ 本)であった。また術後の 創部合併症は 1 例もなかった。グラフト採取のラー ニングカーブについては、個人差はあるものの採取 した医師のラーニングカーブは経験症例と共に時間、 quality 共に改善(平均 $34.5 \rightarrow 30.5$ 分 $/ 50.7 \rightarrow 40.2$ 分、平均 $1 \rightarrow 0.75$ 箇所 $/ 2.2 \rightarrow 0.67$ 箇所）した。【考 察及び結語】EVH は創部合併症の頻度が極めて低く、 美容上または入院治療のコストの面から非常に有用 であると思われた。短期成績も十分に満足できるも のであり、EVH がCABGの長期予後に与える影響 について今後フォローするとともに、グラフトの quality control のための指導体制を強化していく。

\section{PP-258 㫕 \\ メディカルクラークの活用と業務分担による 労務軽減対策}

\author{
宇治徳洲会病院 心臓血管外科 \\ 小林 \\ 豊
}

心臓血管外科医の人数は限られており、また疾患の 特性により業務が多岐に及ぶことは周知の事実であ る。電子カルテや電子オーダーリングシステムの導 入でより系統化された管理が可能となり業務量も減 量したものの依然その量は膨大であり、手術以外の 業務に忙殺され手術に注力できない状況が続いてい る。開心術はもとより末梢血管手術、緊急対応を主 たる業務とし、術前、術後管理から外来継続管理、 インフォームドコンセントの時間調整までを管理し 質を維持し続けることは至難の業である。このよう な背景のもと、2008 年度以降、国は急性期病院を対 象にメディカルクラーク (医師事務作業補助者：MC) の導入を後押ししている。当院でも医師の業務負担 軽減とそれによる治療の質の向上のため MC を活用 し、また各種業務を専門スタッフに分担するように チームを構成した。ルーチン化された検査や処方の オーダーを MCに一任し、医師は決定と確認のみを 行うことでオーダー業務から解放された。診断書を 含む書類関係においても、電子カルテに記載された サマリーをもとに MC が文章を起こし、医学的診断 が必要な事項を含めて最終確認を行うのみとした。 病棟管理においては基本方針の決定は朝のカンファ レンスにて MC を含む各種専門スタッフ同席の上で 決定し業務分担を行い、スタッフ間での調整も同時 に行った。各分野のスタッフには心臓外科知識を教 育し経験させていくことにより個々で判断可能な場 面が広がり、医師が他の業務中であっても直接の判 断や決定を迫られる場面は少なくなった。さらに医 師の不在の場面でも常に患者中心の医療を考えその 場で行動することができるため、患者満足度も高い。 $\mathrm{MC}$ や既存の各種専門スタッフを活用、役割分担す ることで、医師も含めた各職種での専門業務に集中 できる環境を構築することが可能であった。 


\section{PP-259 文 \\ 特定看護師導入による心臓血管外科医の労 務軽減についての検討}

\author{
愛媛大学医学部附属病院 心臓血管 - 呼吸器外科 \\ 流郷 昌裕、泉谷 裕則、八杉巧、 \\ 岡村達、鹿田 文昭、大倉 正寛、 \\ 中村 優貴
}

【背景】2009 年に厚生労働省が立ち上げた「チーム医 療の推進に関する検討会」の発足より 3 年が経過した 現在、日本外科学会など外科系関連 9 学会が要望す る「特定看護師」の確立、導入につき、議論がすすめ られている。【目的】当科において、特定看護師導入 により軽減されると思われる労務につき retrospectiveに検討した。【対象】当科入院患者のうち、成人 心臓血管外科手術目的にて入院した患者における、 2012 年 6 月 1 日〜 30 日の 1 カ月間の医療処置および これに付随する業務。【方法】2010年厚生労働省 「チーム医療推進のための看護業務検討 WG」(以下 WG)において選定された医療処置項目 (203 項目)の うち、現在当科で医師が施行しており、かつWG 調 査結果にて、看護師の回答から「今後看護師が実施可 能」が $50 \%$ 以上であった項目 (53 項目)につき、各々 所要時間を設定した上で、その総所要時間を算定し た。【結果】上記期間中の成人心臓血管外科入院患者 数は平均 17.1 人で、同期間の手術は計 16 件 (心臓・ 大血管手術 11 例、未梢血管手術 4 例、その他 1 例)、 総手術時間は 38 時間 20 分であった。上記期間中の 全入院患者につき、上記 53 項目の総所要時間を合計 すると 944.9 分で、平日 1 日あたり 45.0 分であった。 また上記 53 項目を、WG 調査結果に基づき、「検査 (動脈ライン採血、各種検査オーダーなど) 」「呼吸器 (酸素投与量調節、中止の決定など) 」「処置·創傷処置」 「日常生活関係(飲水・食事の指示など)」「手術(体位・ 消毒処置)」「薬剤の選択・使用」「その他(栄養士への 相談、リハビリ指示など)」の 7 つ大項目に分類し、 各々所要時間を算出したところ、最も所要時間の長 かった大項目は「処置」で計 261.2 分(総所要時間の $27.6 \%$ 、以下同じ)、以下所要時間の長い順に、「検査」 計 256.5 分 $(27.1 \%)$ 「薬剂の選択 - 使用」計 163.9 分 (17.3\%)「呼吸器」計 89.2 分 $(9.4 \%)$ 手 術」計 77 分 $(8.1 \%)$ 、「日常生活関係」77 分 $(8.1 \%)\lceil$ その他 $\rfloor 42$ 分 (4.4\%) であった。さらに、上記項目のうち、継続指示・ 処方、検査入力といった、医療知識や技術を必要と しない単純なオーダリングに関連する業務は 201.4 分 で総所要時間の $21.3 \%$ を占めた。【考察】以上の検討 より、特定看護師導入により、心臓血管外科医が日 常業務に忙殺されずに本来の業務に携わることがで きる一助となる可能性があると思われる。

\section{PP-260 穴 心臓血管外科治療への多職種によるチーム 医療}

\author{
JA長野厚生連佐久総合病院
}

竹村 隆広、新津 宏和、濱 元拓、

津田 泰利、白鳥 一明

【はじめに】地方病院では心臓外科医だけでなく、麻 酔科や ICU 等関連診療科の医師も少なく、心臓血管 外科手術医療のなかで他科医師から協力をえること は困難な場合が多い。当院では、治療、ケアの標準 化のためのクリニカルパス活用、多職種による周術 期管理などにより、医師の負担軽減に努めてきた。 当院における現在の取り組みを報告する。【当院での 取り組み】外来〜入院まで：心臓血管外科外来におい て説明が行われ手術が決定した場合、手術申し込み、 入院申し込み等の最低限必要な指示を医師が行った 後、外来ドクターアシスタント (DA)を通して術前検 査センター(看護師により構成)に連絡され、予約検 査を含めた検査のオーダーは同センター看護師によ り行われる。術前検査結果はセンター看護師により チェックされた後、麻酔科医師診を経て、追加が必 要な検査は術前検査センターより連絡、オーダーが 行われる。入院中の各オーダーは術前検査センター DAによりパス発行により行われる。紹介患者の場 合、連携パスにより標準化された術前検査は紹介病 院で行われ、デー夕は連携室経由で当院術前検査セ ンターに送られ同様に扱われている。入院後：必要 書類等は外来と共通の DA が作成し、承諾書等は医 師の説明後サインが行われる。術後 ICU 管理等は基 本的に心臓外科医師が行っているが、ICUでの内服 薬投与は標準化し、ICU 専任薬剤師が管理している。 一般病棟帰室後は医師と DA、薬剤師が毎日患者回 診を行っており、ワーファリンの投与量等は薬郕師 が管理し、また、追加の検査オーダー等は医師が口 頭で指示し、DA がオーダーを発行。退院時書類、 返書等も DA が管理し、必要に応じて医師に指示が 行われている。また、JACVSD, NCD の登録は専任 の診療情報管理士がデータマネージャーとして行っ ており、術前のデータは術前検査センター看護師の 協力により術前に登録され、患者説明時にJapan Score を示すことが可能になっている。また、退院時 の心リハ指示は理学療法士が行っている。【結論】多 職種によるそれぞれの専門性を生かした心臓血管外 科手術治療への関わりは、医療の質を向上するとも に、心臓血管外科医師の省力化に有用である。 
PP-261 宛

輸血量減少による医療費削減：ROTEM を用 いた周術期止血管理

\author{
弘前大学医学部 胸部心臓血管外科 \\ 小笠原尚志、皆川 正仁、千代谷真理、 \\ 服部薰、齊藤 良明、野村 阿南、 \\ 福田和歌子、渡辺 健一、近藤 慎浩、 \\ 谷口哲、大徳 和之、福井 康三、 \\ 鈴木 保之、福田 幾夫
}

【目的】止血は十分なフィブリノゲン重合体を形成し た上で血小板を投与することが重要である。そのた め術中の的確な凝固能モニタリングが不可欠である。 Rotational thromboelastometry (ROTEM)の使用が 周術期の止血管理に有用であるが輸血量減少による 医療費削減をもたらすかどうか検討した。【方法】対 象は成人人心肺使用症例とした。2011 年 1 月から 12 月末までの 121 例中 PCPS 症例を除外した 117 例; C 群と以降の ROTEM 使用症例 2012 年 7 月ま での 68 例中 PCPS 症例を除外した 66 例 ; R 群につ いて検討を行った。輸血管理について ROTEM の測 定結果による介入を行った。全血検体を用いたフィ ブリノゲン測定を中心に置き新鮮凍結血漿(FFP)に よるフィブリノゲンの補充を行い FIBTEM A10 值が $10 \mathrm{~mm}$ 以上を目指した (正常值 $7 \sim 23 \mathrm{~mm}$ 、測定 10 分後の血餅硬度でフィブリノゲン值と相関がある)。 【結果】術前因子では女性の割合 ; n $(\%)$ のみ有意差が 認められた $(\mathrm{P}=0.018)$ 。術中術後因子では大動脈遮断 時間 $(\mathrm{min}) ;$ mean $\pm \mathrm{SD}$ に有意差を認めた $(\mathrm{P}=0.047)$ 。 $\mathrm{R}$ 群の術中最終 FIBTEM 值 (A10) は $12.2 \pm 4.8 \mathrm{~mm}$ で あった。出血量 $(\mathrm{mL}) ; \operatorname{mean}(\mathrm{SD})$ は術中が $\mathrm{R}$ 群で有 意な減少が認められた $(\mathrm{P}<0.05)$ 。術中輸血量 $(\mathrm{ml})$; mean $\pm \mathrm{SD}$ はいずれの製剤においても有意な減少が 認められ、術中と術後 24 時間の総輸血量 $(\mathrm{ml})$; mean \pm SD においても同様な結果が得られた。あく まで単純計算ではあるが平均で RCC $353 \mathrm{ml}$ 、 FFP460ml、PC158ml の削減が見达まれる。医療費と いう観点からすると計 117,932 円となり ROTEM の ランニングコストを差し引くと年間心肺症例を 100 件とした場合 8,233,162 円の削減となった ROTEM リース代が 130,000 円/月、試薬等 20,000 円 / 件で 換算)。【結語】残念ながら ROTEM の保険点数は 微々たるものであるが(50 点/件)、それでもなお ROTEM の導入は輸血量減少による医療費削減につ ながる可能性がある。
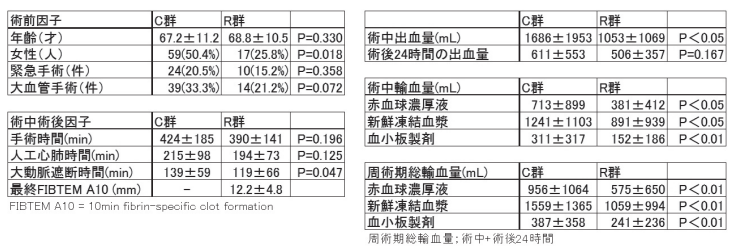

PP-262 超高齢者の心臓胸部大血管手術成績の検討

宮崎大学 循環呼吸・総合外科学

$\begin{array}{llll}\text { 長濱 } & \text { 博幸、松山 } & \text { 正和、遠藤 } & \text { 穣治、 } \\ \text { 西村 } & \text { 征憲、石井 } & \text { 廣人、中尾 } \text { 大伸、 } \\ \text { 阪口 } & \text { 修平、中村 } & \text { 都英 } & \end{array}$

【目的】近年、心臓外科領域において超高歯者に対す る手術症例が増加の一途をたどっている。手術適応 の判断に苦慮することも多く、その判断材料として 超高齢者に対する手術成績の不明な事が影響すると 思われる。今回、その超高齢者に対する手術成績を 評価した。【対象】2006 年 1 月から 2012 年 6 月 30 日 までの当科で施行した心臓胸部大血管手術症例で手 術時年齢が 80 歳以上の 62 例。【結果】男性 31 例、女 性 31 例。平均年齢 83.0 歳 (男性 83.1 歳、女性 82.9 歳)、 最高齢は 93 歳。症例の内訳は、虚血性心疾患 9 例、 弁疾患 12 例、虚血性心疾患 + 弁疾患 10 例、大動脈 疾患 + 弁疾患 4 例、大動脈疾患 25 例 (急性 A 型解離 5 例、慢性 B 型解離 2 例)、AMI 合併症 2 例。緊急 手術は 18 例 $(29 \%)$ 。平均入院期間は 31.5 日 \pm 25.0 。 術死 (30日内死亡) は 4 例 $(6.5 \%)$ で、86歳女性の VSP 症例、 82 歳女性の VSP 合併の左室破裂症例で 死因は LOS、86 歳男性の感染性弓部大動脈瘤破裂の 弓部置換症例で死因は敗血症、80 歳男性で心停止蘇 生後の $\mathrm{OPCAB}$ 症例で死因は MOF であり、全例緊 急手術症例であった。在院死は 2 例で、86 歳女性で $\mathrm{AVR}+\mathrm{MVP}+\mathrm{TAP}+\mathrm{CABG}$ で死因は脳梗塞、86 歳男 性で弓部置換症例で死因は間質性肺炎増悪であった。 TEVAR 症例 11 例に術死・在院死亡はなかった。遠 隔死亡は 9 例で、死因は肺炎 3 例、癌死 2 例、動脈 瘤関連死 2 例、敗血症 1 例、喘息 1 例である。Kaplan-Meier 法による生存曲線では、平均生存期間 $40.6 \pm 2.6$ ヶ月、 1 年生存率 $88.6 \%$ 、3 年生存率 $72.4 \%$ 、 5 年生存率 $46.0 \%$ であった。術死は緊急手術例に有意 に多く $(\mathrm{P}=0.001)$ 、緊急手術例と非緊急手術例の平均 生存期間は $21.8 \pm 3.7$ ヶ月と $44.8 \pm 2.5$ ケ月で、有意に 緊急例における生存率が悪かった $(\mathrm{P}=0.0137)$ 。しか し、術死を除く緊急手術例と非緊急手術例の 5 年生 存率は、 $41.3 \%$ と $48.4 \%$ で有意差は認めなかった。【ま とめ】1. 超高齢者における緊急手術成績は明らかに 不良であり、手術適応を考えるべきである。2. 術死 を除けば、超高齢者においても遠隔成績は良好であ る。3. 超高齢者の大動脈疾患では TEVARの適応 を考虑すべきである。 


\section{PP-263}

\section{5 歳以上超高齢者における心臓大血管 open surgery 症例の検討}

\author{
浜松医科大学 第一外科 \\ 鷲山 直己、椎谷 紀彦、山下 克司、 \\ 大倉一宏、高橋 大輔
}

【はじめに】超高齢者に対する心臓大血管手術は増加 の一途であるが、術後 QOL が保たれた生存の点で適 切な患者選択がなされているかが、社会的にも重要 である。 85 歳以上を超高齢者とし、80〜85 歳との 比較で心臓大血管 open surgery の現状を検討した。 【対象と方法】09 年〜 12 年 7 月までに心臓大血管手 術を受けた 80 歳以上症例は 73 例、うち 85 歳以上は 15 例。 85 歳以上 ( $\mathrm{A}$ 群、 $\mathrm{n}=15$ )、80 歳以上 85 歳未満 $(B$ 群、 $\mathrm{n}=58)$ の 2 群に分け risk 評価と成績を比較。A 群：胸部大動脈 4 例 (27\%)、弁膜症 6 例 (40\%)、単 独 CABG4 例 (27\%)、左室瘤 1 例 $(7 \%) 、 B$ 群：胸部 大動脈 27 例 (47\%)、弁膜症 16 例 (28\%)、単 独 CABG13 例 $(22 \%)$ 、左室瘤 1 例 $(2 \%)$ 、左房粘液腫 1 例 $(2 \%)$ 、緊急手術はA 群 4 例 $(27 \%) 、 B$ 群 14 例 $(24 \%)$ 。観察期間平均 18 ヶ月 $(1 \sim 42$ ヶ月)。【結果】 Japan SCORE (平均) はA 群 5.33(主要合併症 24.0)、 B 群 8.19(27.3)、A 群で低いが ns、術式別では A 群 : 胸部大動脈 4.88(27.6)、弁膜症 5.98(23.9)、単独 CABG 5.38(22.0)、B 群 : 胸部大動脈 11.24(34.3)、弁 膜症 6.64(22.2)、単独 CABG 4.62(21.8)。呼吸機能評 価(施行率 A 群 73\%、B 群 53\%) では A 群 :GOLD 0・ I 期 10 例 $(81 \%) 、$ II 期以上 1 例 $(9 \%) 、 B$ 群 : 0 - I 期 23 例 (74\%)、II 期以上 8 例 (26\%)、A 群で II 期以上 が少ないがns。A 群：30日死亡 1 例 $(6.7 \%)=$ 緊急 CABG 後 LOS、30 日以降の在院死亡なし、B 群 : 30 日死亡 1 例 $(1.7 \%)=$ 緊急 $C A B G$ 後 ARDS、30 日以 降の在院死亡 4 例 $=$ 胸部大動脈 2 (慢性期脳幹出血、 肺炎)、弁膜症 2 (肺炎、MOF) (ns)。自宅退院率は A 群 $87 \%$ 、B 群 $71 \%$ (ns)。自宅退院に関する単変量解 析では血清クレアチニン值 $(p=0.002)$ 、Japan SCORE $(p=0.004$ 、主要合併症 $p=0.026)$ で有意差を認めた。 遠隔期死亡は $\mathrm{A}$ 群 1 例 (消化管出血)、B 群 6 例 (肺 炎 3 例、脳出血 2 例、大動脈瘤破裂 1 例)、3 年生存 率は A 群 $86 \pm 9 \%$ 、 B 群 $70 \pm 10 \%$ 。中期死亡に関す る検討 (Cox regression、forward stepwise)では、Japan SCORE (主 要 合併症) $(\mathrm{p}=0.001$ 、Hazard ratio $1.109 、 95 \%$ CI $[1.044 、 1.179]) 、 B M I$ 低 值 $(p=0.022$ 、 0.696、[0.510、0.949］が独立予測因子であった。【結 語】85 歳以上では good risk 症例に手術が行われてお り、比較的良好な成績に繋がっていたと思われた。 Japan SCORE は高齢者自宅退院ならびに中期生存の 予測因子である。obesity paradox は心臓血管外科手 術にも見られる。

\section{PP-264 خ 85 歳以上超高齢者に対する心臓大血管手術 の検討}

\author{
獨協医科大学病院 心臓血管外科 \\ 権重好、山田 靖之、柴崎 郁子、 \\ 松下恭、井上 有方、桑田 俊之、 \\ 土屋豪、武井祐介、関雅浩、 \\ 桐谷ゆり子
}

はじめに：高齢化社会に伴い、開心術患者の適応年 齢が拡大している。今回我々は 85 歳以上の超高齢者 に対する開心術を対象に、治療方針の妥当性を検討 した。対象：2008 年 6 月から 2012 年 8 月までに当院 で施行した開心術 932 例中、85歳以上の 30 例を対 象とした。結果：平均年齢 $86.3 \pm 1.25$ 歳 (85-90)、男 女比 8：22、緊急症例 13 例 $(43.3 \%)$ 。術前診断は胸 部大動脈瘤 (TAA) 2 例、 TAA 破裂 2 例、急性大動 脈解離 (DAA) 5 例、大動脈弁狭窄症 (AS) 9 例、冠動 脈疾患 $(\mathrm{CAD}) 7$ 例、AS+CAD4 例、僧帽弁閉鎖不全 症 $(\mathrm{MR}) 1$ 例であり、施行手術は弓部全置換術 4 例、 上行置換術 4 例、下行置換術 1 例、大動脈弁置換術 $(\mathrm{AVR}) 9$ 例、冠動脈 バイパス術 $(\mathrm{CABG}) 7$ 例、 AVR+CABG4 例、僧帽弁形成術 (MVP) 1 例であった。 手術時間 $268 \pm 133$ 分、挿管時間 $64.7 \pm 115$ 時間、再 挿管は 3 例、気管切開を施行したのは 2 例であった。 術後 30 日死亡は 1 例、入院死亡は 4 例であった（表 1)。術後合併症として、新規透析導入は 2 例、縦隔 炎 1 例、乳び胸 1 例、ペースメーカー植込み 1 例で あった。術後 30 日で自宅退院したのは 12 人、入院 中は 14 人、転院は 3 人であった。考察 : 緊急症例 13 例中、大動脈疾患が 7 例 (TAA 破裂 2 例、DAA5 例) と多く、3 症例を失っている。一方で、TAA2 例を 含む待機症例 17 例においては、良好な成績である。 また、緊急症例において 30 日以内の自宅退院は 1 人 のみであるが、待機症例では自宅退院 11 人と術後経 過は良好であった。高齢を理由に手術を一度拒否さ れ、緊急で手術に至った 3 症例を経験した。超高齢 者であっても、定時症例においては良好な成績を見 込めることから、普段の診療において早期に診断、 専門医を受診し、十二分なインフォームドコンセン トの元、待機手術に備えるべきと考える。

\begin{tabular}{|c|c|c|c|c|c|}
\hline \multicolumn{6}{|c|}{ 表1 死亡症例 } \\
\hline 症例 & 診断 & 柴急 & 手術 & 原因 & 街㣪日数 \\
\hline 85歳 女性 & AS & 待楼 & AVR & 消化管唗死 & 31 \\
\hline 85歲 禺性 & CAD & 政急 & CABG 3枝 & 胆のう, 消化管穿孔 & 61 \\
\hline 87歳 男性 & TAA破裂 & 緊急 & 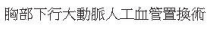 & 出血死 & 1 \\
\hline 86䠞 好性 & DAA & 慗急 & 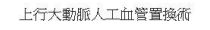 & 肺か心、檤梗军 & 56 \\
\hline 88歲 女性 & DAA & 缺急 & 上行大舫脈人下血管置撸秝 & 急性心筋梗塞、眪挭塞 & 62 \\
\hline
\end{tabular}




\title{
PP-265
}

\section{当院における超高齢者心臓大血管手術の現 況}

\section{山形大学医学部 第2外科}

\author{
金哲樹、内田 徹郎、前川 慶之、 \\ 宮崎 良太、水本 雅弘、廣岡 秀人、 \\ 安本 匠、吉村 幸浩、貞弘 光章
}

[背景］高齢化社会の進行と共に、心臓血管疾患を 持ち手術対象となる高齢者の絶対数が増加している ことは、日常診療にても明らかに感じられる。この 今後も増加傾向にあると考える高齢者の心臓血管手 術の意義について、当院での過去の症例を元に検討 したい。[方法］対象は、2007 年 1 月から 2011 年 12 月までに当院で行われた心臓血管手術患者 644 例 で、これを 80 歳以上 (A 群) と 80 歳未満(B 群) とに 分けた。男女比は全体で男：女が 445：119であった が、A 群では 45：40に対してB群は 400：159 とA 群で女性が多い傾向があった $(\mathrm{P}=0.0005)$ 。術式は 弁膜症が A 群 37.9\% に対してB群が $35.3 \%$ (P= 0.641)、虚血性心疾患が A 群 $11.8 \%$ に対して B 群 $25.0 \%(\mathrm{P}=0.007)$ 、胸部大動脈手術が $\mathrm{A}$ 群 $12.9 \%$ に 対して B 群が $15.6 \%(\mathrm{P}=0.530)$ と、虚血性心疾患にて $\mathrm{A}$ 群で少ない傾向があるものの、全体では術式傾向 の大きな差はなかった。術前 $\mathrm{EF}$ は A 群平均 $61.3 \%$ に対して B 群 $62.5 \%$ と有意差無いものの $(\mathrm{P}=0.545) 、$ 術前呼吸障害の合併率は A 群 58.3\% に対してB 群 $41.5 \%$ と有意差を持って $(\mathrm{P}=0.027) \mathrm{A}$ 群で多かった。 [結果] 術後感染死は A 群 $2.35 \%$ に対して B 群 $1.61 \%(\mathrm{P}=0.622)$ 、術後非感染死も A 群 $3.53 \%$ に対し て B 群 $3.58 \%(\mathrm{P}=0.982)$ と、感染・非感染を含めた術 死で両群間で有意差はなかった。術後の全体感染症 合併率については A 群 $40.0 \%$ に対してB 群 $22.4 \%$ $(\mathrm{P}=0.0004) 、 \mathrm{SSI}$ 合併率もA 群 $9.41 \%$ に対して B 群 $4.29 \%(\mathrm{P}=0.043)$ と感染症合併率は有意差を持って A 群で多かった。[考察］心臓血管手術の治療成績は、 近年の補助手段向上や術後管理の確立、手術手技の 工夫などにより日々改善してきている。それに応じ て高齢者に対する心臓血管手術の成績も良好なもの となってきている。もちろん高齢者というだけでも 十分な危険因子であることは間違いなく、またその 意志決定能力を含めた術前状態を峳密に把握し手術 の可否を検討することは重要である。しかしながら、 当院での検討からも 80 歳以上の超高齢者に対する心 蔵血管手術は十分許容できるものであり、もちろん 術前状態を十分評価してだが、積極的に行うべきも のと考える。 